Portland State University

PDXScholar

\title{
The Wildcat Creek Tuff, Eastern Oregon: Co-eruption of Crystal-poor Rhyolite and Fe-rich Andesite with Implication for Mafic Underpinnings to Voluminous A-type Rhyolites
}

Hillarie Jaye Sales

Portland State University

Follow this and additional works at: https://pdxscholar.library.pdx.edu/open_access_etds

Part of the Geology Commons

Let us know how access to this document benefits you.

\section{Recommended Citation}

Sales, Hillarie Jaye, "The Wildcat Creek Tuff, Eastern Oregon: Co-eruption of Crystal-poor Rhyolite and Ferich Andesite with Implication for Mafic Underpinnings to Voluminous A-type Rhyolites" (2018).

Dissertations and Theses. Paper 4352.

https://doi.org/10.15760/etd.6245

This Thesis is brought to you for free and open access. It has been accepted for inclusion in Dissertations and Theses by an authorized administrator of PDXScholar. Please contact us if we can make this document more accessible: pdxscholar@pdx.edu. 
The Wildcat Creek Tuff, Eastern Oregon:

Co-eruption of Crystal-poor Rhyolite and Fe-rich Andesite with Implication for Mafic Underpinnings to Voluminous A-type Rhyolites

\section{by}

Hillarie Jaye Sales

A thesis submitted in partial fulfillment of the requirements for the degree of

Master of Science

in Geology

Thesis Committee:

Martin J. Streck, Chair

Nancy A. Price

Richard C. Hugo

Portland State University 2018 


\begin{abstract}
The Wildcat Creek Tuff is a thin ( 3-12 m), rhyolite to andesitic ash-flow tuff with a minimal extent of $1500 \mathrm{~km}^{2}$ in Malheur county, eastern Oregon. The previously undated tuff yielded a single crystal, anorthoclase ${ }^{40} \mathrm{Ar} /{ }^{39} \mathrm{Ar}$ age of $15.49 \pm 0.02 \mathrm{Ma}$ and thus is closely related to mafic and silicic volcanism of the Columbia River Province. The tuff texturally stands out by its high proportion of co-mingled mafic inclusions appearing as dark, scoriaceous, and phenocryst-poor fragments, and their proportion dictate bulk tuff compositions ranging from rhyolite $\left(74 \% \mathrm{SiO}_{2}\right)$ to andesite $\left(59 \% \mathrm{SiO}_{2}\right)$. Glass analyses confirm rhyolite end member at 74-75 wt.\% $\mathrm{SiO}_{2}$ and two mafic members, one at 59-60 wt. $\% \mathrm{SiO}_{2}$ and the other at $56-57$ wt. $\% \mathrm{SiO}_{2}$. Rare plagioclase and even rarer pyroxene phenocrysts with compositions clustering at An60-74 and An35-45, and Mg17-19 and Mg80-84, respectively, similarly suggest two andesitic magmas with the $60 \%$ member being the dominant mafic composition. It has distinctly lower $\mathrm{TiO} 2$ and $\mathrm{CaO}$, slightly lower $\mathrm{FeO}$, and comparable $\mathrm{Al}_{2} \mathrm{O}_{3}, \mathrm{MgO}$, and alkalis.
\end{abstract}

Eruption of crystal-poor dacitic to basaltic-andesitic cognate components is also observed in other Miocene ash-flow tuffs from eastern Oregon, like the Rattlesnake, Dinner Creek, and the Devine Canyon Tuffs, as well as other less voluminous tuffs. However, the high proportion of mafic components in the Wildcat Creek tuff seems currently unrivaled. The co-eruption of intermediate magmas with rhyolite implies that mafic magmas were tapped from a common reservoir, and these magmas increased in 
proportion during the course of the eruption(s). This continued up to the point where nearly all deposited tuff material consisted of andesite. This is consistent with progressively deeper magma withdrawal, in turn implying that mafic magmas resided below the rhyolites as a discrete magma batch. Dacitic components of voluminous rhyolitic tuffs have been recently interpreted as remelted samples of a crystal mush after crystal-poor rhyolites where extracted. Dacitic Wildcat Creek Tuff samples do not bear any evidence of this. To the contrary, small negative Eu anomalies, normal $\mathrm{Ba}$ and $\mathrm{Sr}$ concentrations, and nearly aphyric nature are consistent with a large portion of mixing between Wildcat Creek Tuff rhyolites and regional mid Miocene, Fe-rich, and crystal poor basaltic andesite magmas that occur ubiquitously as lava flows. 


\section{ACKNOWLEDGEMENTS}

I would like to thank my advisor, Dr. Martin Streck, for his patience and guidance throughout this journey, and for sparking my love of volcanics. I would also like to thank my committee members. Dr. Nancy Price, thank you for your help and encouragement throughout this process. Dr. Richard Hugo, thanks for showing me the ropes in SEM.

I am so grateful for the help of my friends at PSU, especially Ellie. Without your brilliance and willingness to help I would have been lost. Love you, Brown Bear!

To my LabCor family, your understanding that "school comes first" allowed me to pursue my career while completing this crazy journey. Thanks for keeping me grounded, guys.

Most importantly, I would like to thank my boyfriend, Max, and my family for their love and support throughout this project. 


\section{TABLE OF CONTENTS}

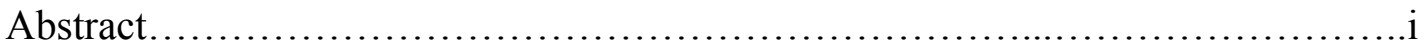

Acknowledgements.....................................................ii

List of Figures...................................................... vii

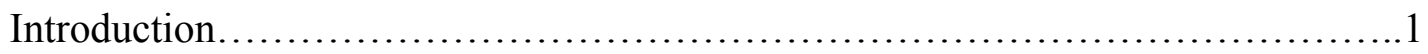

Background...............................................................

Select Prior Case Studies on Mafic Inclusions...........................6

Methods............................................................. 10

Sample Collection................................................. 10

Preparation and Analysis of Samples................................11

Results.................................................................. 14

Lithologic Characteristics........................................ 14

Petrographic Analysis............................................26

Glass Composition................................................43

Geochemical Analysis of Bulk Samples...............................46

Mineral Composition.............................................53

Isotopic Age Dating............................................. 55

Discussion............................................................ 57

Magmatic Components in the Wildcat Creek Tuff.......................57

Magma Mixing ..................................................64

Inclusions as Evidence for Magma Mixing........................68

Wildcat Creek Tuff in the Context of Nearby Units................69

Stratification of the Magma Reservoir.................................71 


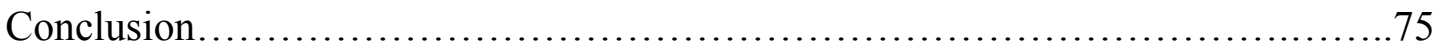

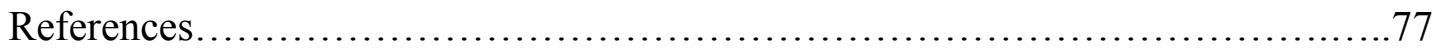

Appendix A: Field Site Locations................................................... 79

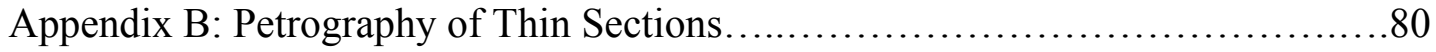

Appendix C: Bulk Geochemistry, XRF ...........................................

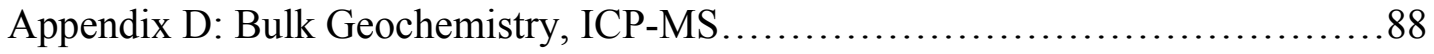

Appendix E: Glass Geochemistry, EMP ................................... 89

Appendix F: Feldspar Geochemistry, SEM.................................992

Appendix G: Pyroxene Geochemistry, SEM.................................... 94

Appendix H: SEM Spectra.................................................96

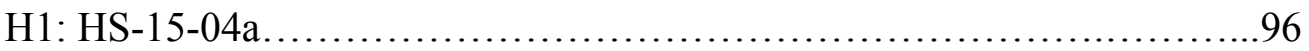

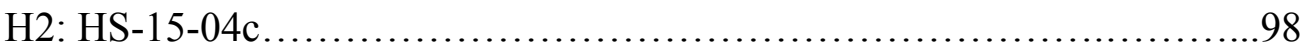

H3: HS-15-04d ................................................... 101

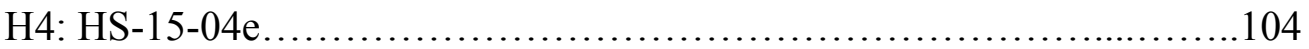

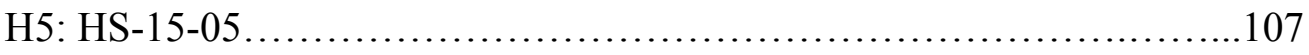

H6: MS-13-07...................................................... 111

H7: MS-14-03...................................................... 113

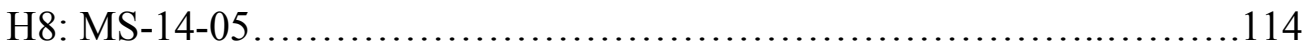

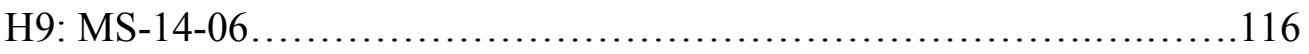

Appendix I: SEM and EMP Data for Feldspar Calculations.......................119

Appendix J: SEM and EMP Data for Pyroxene Calculations......................126

Appendix K: Major Element Comparison Plots..................................135

Appendix L: Major and Trace Element Comparison Plots..........................142 
Appendix M: Trace Element Comparison Plots................................ 144

Appendix N: Stratigraphic Column of Site 4................................... 152 


\section{LIST OF FIGURES}

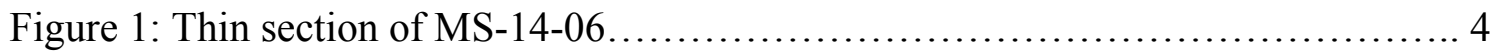

Figure 2: Modified map of the study area....................................... 5

Figure 3: Model of rhyolite extraction from crystal mush............................

Figure 4: Schematic of the Rattlesnake Tuff magma chamber.........................8

Figure 5: Geologic map of the Vale Quadrangle .................................... 10

Figure 6: Site location map of the Wildcat Creek Tuff...............................15

Figure 7: Site 1 of the Wildcat Creek Tuff........................................16

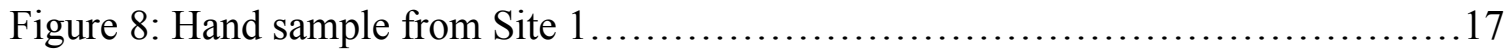

Figure 9: Site 4 of the Wildcat Creek Tuff........................................ 18

Figure 10: Hand sample of HS-15-04a............................................... 19

Figure 11: Site 4 of the Wildcat Creek Tuff, close-up of the contact with underlying

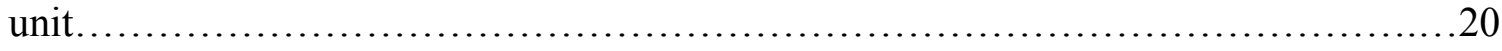

Figure 12: Site 4 of the Wildcat Creek Tuff, view of the contact showing erosion........21

Figure 13: Hand sample of HS-15-04c in the field...................................22

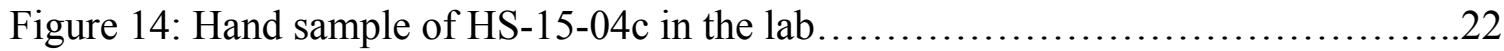

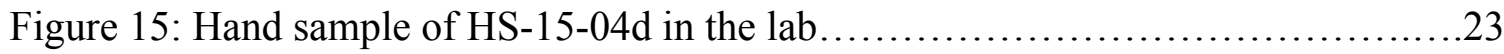

Figure 16: Site 5 of the Wildcat Creek Tuff, hand sample in the field...................24

Figure 17: Site 6 of the Wildcat Creek Tuff........................................25

Figure 18: Pyroxene mineral, P19 from sample HS-15-04c........................27

Figure 19: Feldspar mineral, F6 from sample HS-15-04c.........................28

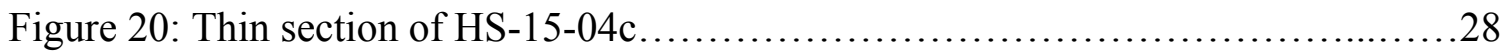

Figure 21: Feldspar mineral, F6 from sample HS-15-04d...........................29

Figure 22: Thin section of HS-15-04d .......................................... 30 
Figure 23: Pyroxene mineral, P4 from sample HS-15-04e........................ 31

Figure 24: Olivine mineral, P11 from sample HS-15-04e.......................... 32

Figure 25: Feldspar mineral, F5 from sample HS-15-04e..............................

Figure 26: Thin section of HS-15-04a...................................... 33

Figure 27: Pyroxene mineral, P5 from HS-15-04a........................... 34

Figure 28: Feldspar mineral, F6 from sample HS-15-04a......................... 35

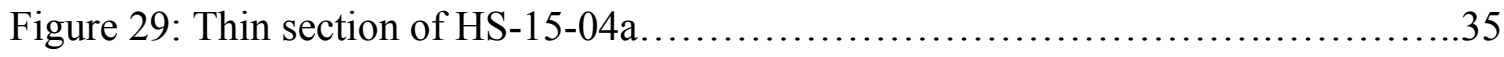

Figure 30: Feldspar mineral, F16 from sample HS-15-04............................ 37

Figure 31: Pyroxene mineral, P22 from sample HS-15-05...................... 37

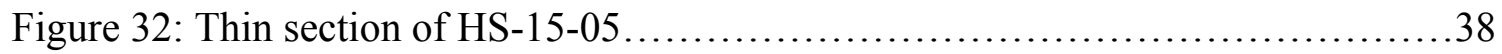

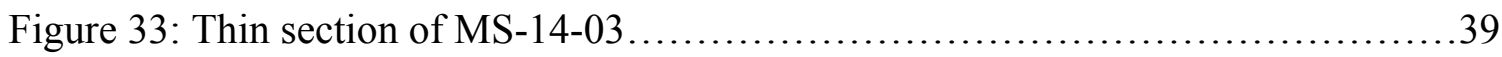

Figure 34: Pyroxene mineral, P17 from sample MS-14-06......................40

Figure 35: Feldspar mineral, F4 from sample MS-14-06......................41

Figure 36: Feldspar mineral, F3 from sample MS-14-06.......................41

Figure 37: Thin section of MS-14-06 showing glass analyses.....................42

Figure 38: Thin section of MS-14-05 ...................................43

Figure 39: Glass analyses from MS-14-06.................................44

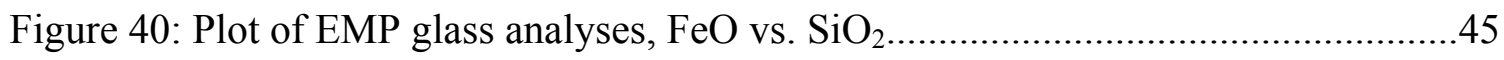

Figure 41: Total alkali-silica classification diagram $\ldots \ldots \ldots \ldots \ldots \ldots \ldots \ldots \ldots \ldots \ldots \ldots$

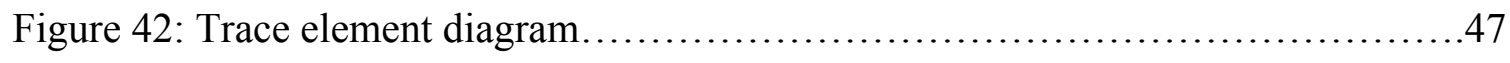

Figure 43: Rare earth element diagram......................................48

Figure 44: Major element variation diagram of $\mathrm{FeO}$ vs. $\mathrm{SiO}_{2} \ldots \ldots \ldots \ldots \ldots \ldots \ldots \ldots \ldots . \ldots 49$

Figure 45: Major element variation diagram of $\mathrm{TiO}_{2}$ vs. $\mathrm{SiO}_{2} \ldots \ldots \ldots \ldots \ldots \ldots \ldots \ldots$

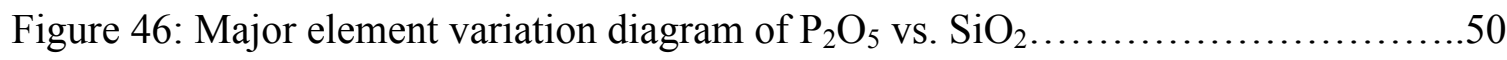

Figure 47: Major vs. trace element comparison plot of $\mathrm{Sr}$ vs. $\mathrm{SiO}_{2} \ldots \ldots \ldots \ldots \ldots \ldots \ldots$

viii 
Figure 48: Trace element comparison plot of Th vs. Nb.........................51

Figure 49: Glass composition analyses for mafic samples, $\mathrm{FeO}$ vs. $\mathrm{SiO}_{2} \ldots \ldots \ldots \ldots \ldots . .52$

Figure 50: Handpicked mafic material and mafic glass analyses, $\mathrm{FeO}$ vs. $\mathrm{SiO}_{2} \ldots \ldots \ldots . .52$

Figure 51: Ternary diagram showing feldspar minerals...........................54

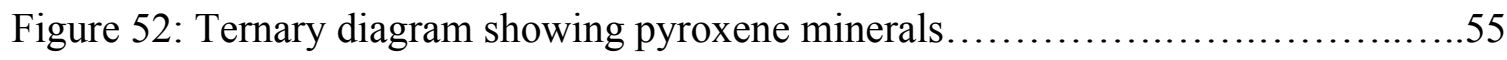

Figure 53: Plot of the ${ }^{40} \mathrm{Ar} /{ }^{39} \mathrm{Ar}$ isotopic age date analyses of the Wildcat Creek

Tuff................................................................. 56

Figure 54: Major element comparison plot of rhyolitic bulk samples and rhyolitic glass

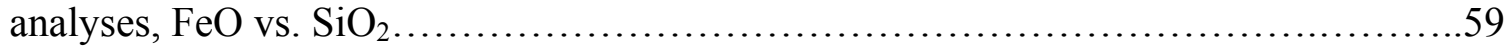

Figure 55: Pyroxene mineral, P3 from sample MS-14-06......................60

Figure 56: Pyroxene mineral P15 from MS-14-06...........................61

Figure 57a and 57b: EMP glass analyses for MS-14-05 and MS-14-06.............62

Figure 58: Averaged glass analyses by EMP and XRF, FeO vs. $\mathrm{SiO}_{2} \ldots \ldots \ldots \ldots \ldots \ldots$

Figure 59: Trace element diagram including plotted mixing calculations..............65

Figure 60: Trace element diagram, hypothetical mixture of samples HS-15-04c and HS-

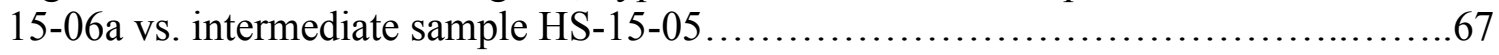

Figure 61: Trace element diagram, hypothetical mixture of samples HS-15-04e and MS-

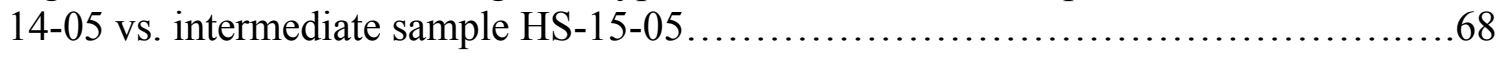

Figure 62: Rare earth element diagram of the Wildcat Creek Tuff vs. the Rattlesnake Tuff as a crystal cumulate.....................................................69

Figure 63: Trace element diagram of the Wildcat Creek Tuff and the Buchanan Tuff...70 


\section{INTRODUCTION}

Basaltic magmas are critical to the production of rhyolitic magmas, either as a material source of rhyolite production via fractional crystallization or as a heat source to partially melt the crust (Johnson, 1991). Mafic magmas are also important because they can maintain temperature for large batches of rhyolitic magmas stored under near surface conditions ( $\sim 3-6 \mathrm{~km})$ for long durations as essentially pure liquids ( $<5 \%$ phenocrysts), thus preventing solidification, which would produce granite. For these reasons, natural examples demonstrating a close temporal and spatial relationship of rhyolites and more mafic magmas are important for studying rhyolite evolution models. Examples of systems where intermediate magma co-erupted with rhyolites are mostly reported from ash-flow tuffs (e.g. Streck \& Grunder, 1999; Deering et al., 2011; Bachmann et al., 2014). The origin of these mafic components may vary as suggested by different interpretations. A mafic magma may underlie rhyolite and mixing may occur. Streck and Grunder (1999) described such a system where a dacite is produced due to the disturbance of the boundary between the rhyolite and basaltic-andesite that lie within the same magma chamber (see Fig. 4). Another example outlines intermediate magma formation in a zoned magma reservoir due to in-situ differentiation and re-melting of a crystal cumulate (Deering et al., 2011; Bachmann et al., 2014). In both cases, the system requires a recharge of hot mafic mama - in one case to provide the material source for mixing with rhyolites to produce dacitic magmas, and in the other case as thermal input for remobilization and melting of the crystal mush that will ultimately lead to crystalpoor dacitic magma. 
The mid-Miocene Wildcat Creek Tuff in Malheur County, Eastern Oregon is an ideal unit to investigate again the relationship between rhyolite and mafic magma, rhyolite petrogenesis, and the development of intermediate magma. The tuff contains abundant inclusions of dark, scoriaceous mafic material. The purpose of this study was to determine the origin of mafic inclusions in the Wildcat Creek Tuff and their petrogenetic relationship to the co-erupted rhyolites. It determined how the tuff was formed and the absolute age of the unit. This was accomplished by studying the composition and mineralogy of eruptive products found within the Wildcat Creek Tuff. 


\section{BACKGROUND}

The Wildcat Creek Tuff has been known to be a rhyolitic ash-flow tuff that erupted during the mid-Miocene and is part of a volcanic field in Malheur County, eastern Oregon (Hooper et al., 2000) (see Figure 2). No precise source area has been determined for the Wildcat Creek Tuff. Based on distribution of the tuff, a source near the center of its outcrop area is likely. This is located roughly where samples HS-15-05 and MS-14-03 were taken (see Table 1 for latitude/longitude). There was no radiometric age of the tuff and its age was only constrained by its stratigraphic position above the Littlefield Rhyolite (Cummings et al., 2000; Hooper et al., 2000). The tuff is characterized by abundant, dark scoriaceous inclusions ranging in size from the smallest at $<1 \mathrm{~mm}$ to the largest at $\sim 15 \mathrm{~mm}$. Although tuffs with similar mafic inclusions are preserved elsewhere (e.g., the Ammonia Tanks Tuff of Southwest Nevada (Deering et. al., 2011), the Carpenter Ridge Tuff of Colorado (Bachmann et. al., 2014), and the Rattlesnake Tuff of Eastern Oregon (Streck \& Grunder, 1999)), the high abundance ( 45 $\%$ vol) of mafic inclusions in the Wildcat Creek Tuff is exceptional (see Fig. 1). 


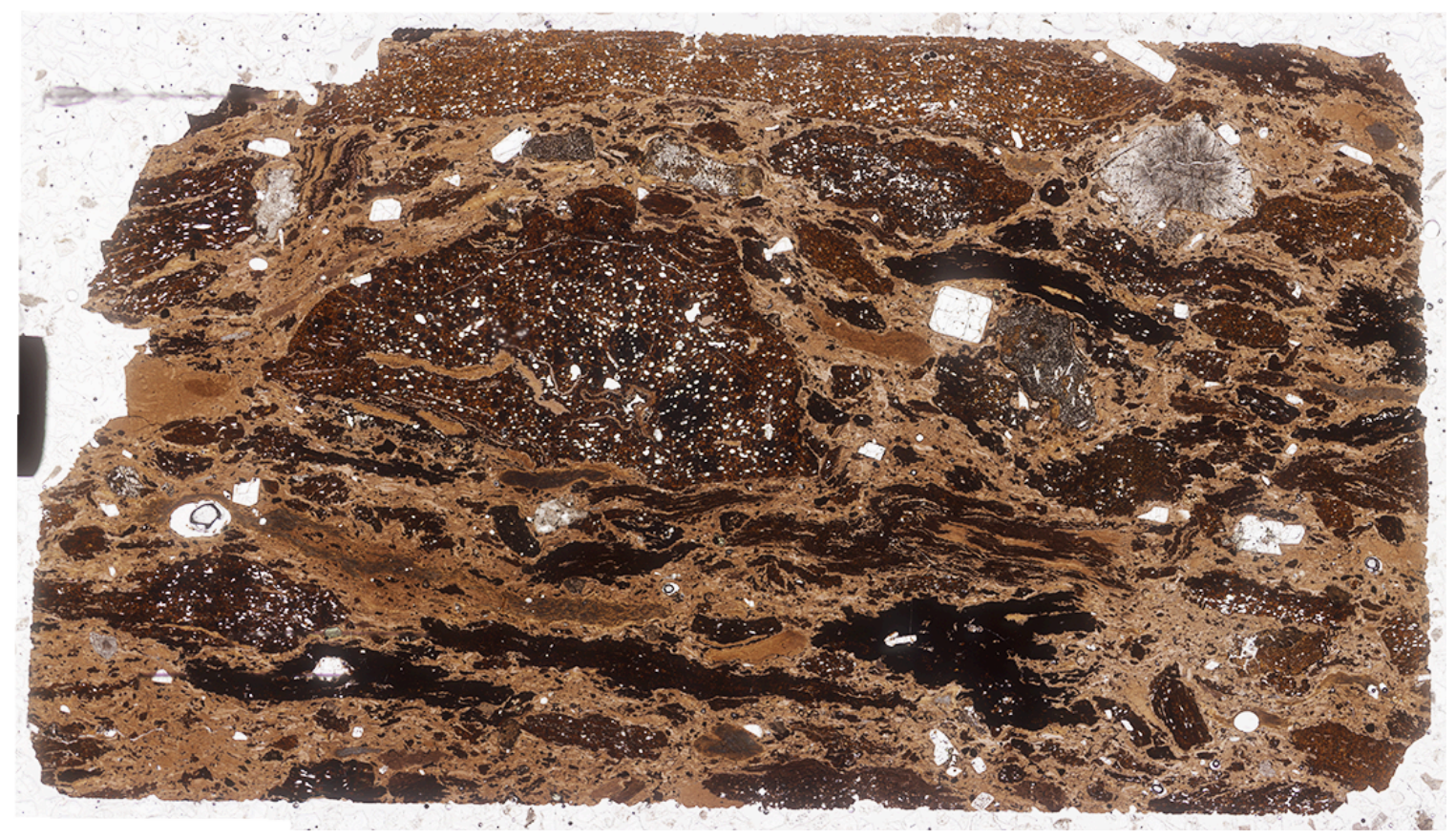

Figure 1. Sample MS1406 is characterized by bulk composition as trachydacite. This thin section scan (46mm in horizontal dimension), shown in plain light, displays one of the least welded samples of Wildcat Creek Tuff in the set, allowing for the analysis of individual components within the sample for silica content. The darkest sections of the sample are the most mafic. All of the scoriaceous inclusions are phenocryst-poor and darker than the surrounding groundmass. 


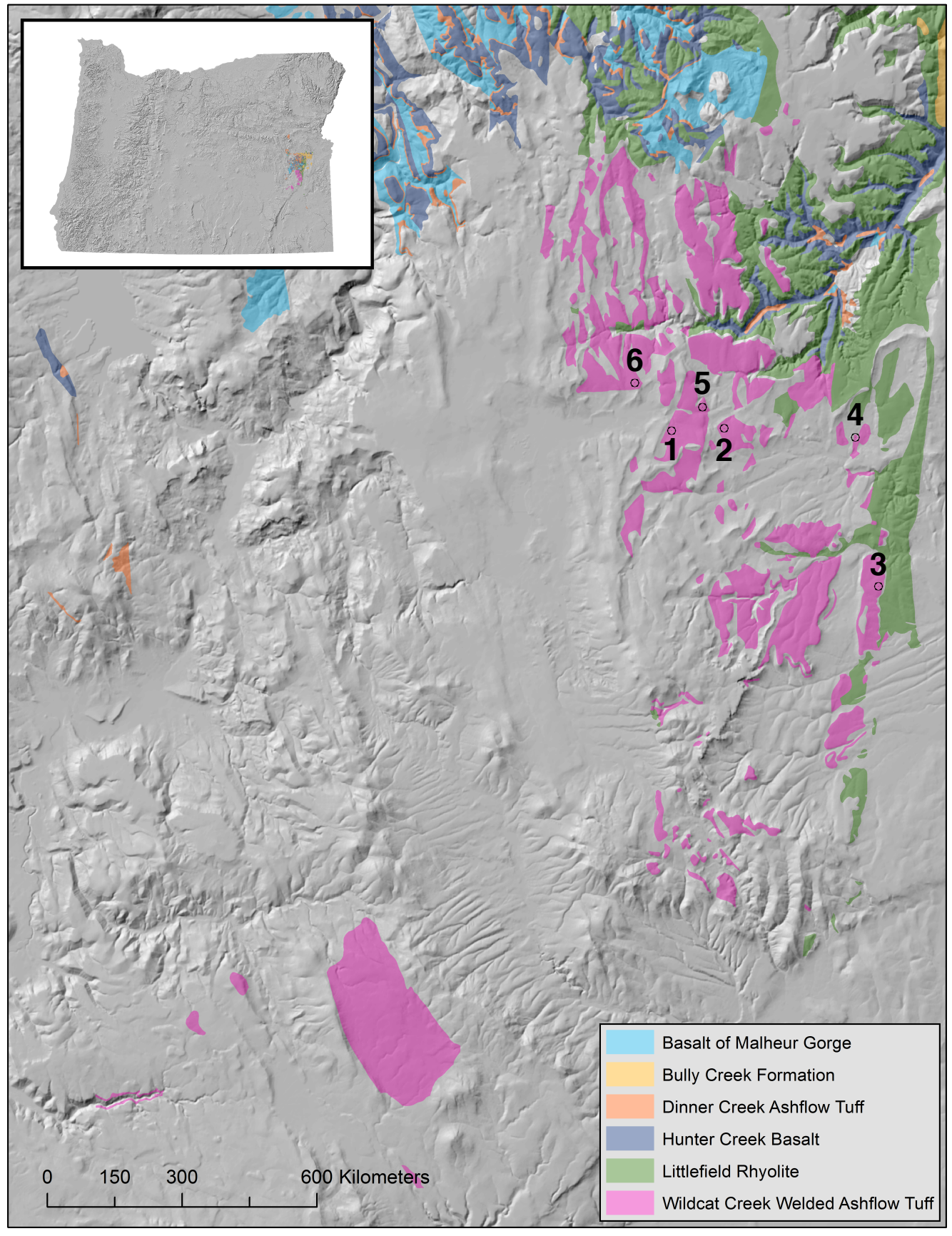

Figure 2. Modified map of the study area in Malheur County, Eastern Oregon (Webb, 2014). The Wildcat Creek Tuff (pink) was mapped by M.L. Ferns (1993) and J.P. Stimac (1988). Surrounding units, such as the Littlefield Rhyolite and the Hunter Creek Basalt, which may be of stratigraphic importance, or compositionally compared to the Wildcat Creek Tuff, have been included. Sample sites from fieldwork are noted. 
Select Prior Case Studies on Mafic Inclusions

The Ammonia Tanks rhyolitic tuff of the Southwest Nevada Volcanic Field displays compositional and thermal zoning that can be explained as a system where rhyolites were produced by extraction of interstitial liquid from a crystal mush (Deering et al., 2011). Once the melt was extracted, a crystal cumulate was left behind with only a small portion of melt (Deering et al., 2011). A late influx of hot mafic magma remobilized and remelted the crystal cumulate, allowing the cumulate to become eruptible, and this resulted in a phenocryst-poor dacitic magma that erupted along with rhyolites, forming mafic inclusions (Deering et al., 2011).

Similarly, Bachmann et al. (2014) considers the Carpenter Ridge rhyolite tuff to have been formed by in-situ differentiation and melt extraction from an upper-crustal mush zone. After extraction of the rhyolite from a crystal mush, a silicic crystal cumulate was again left behind below the rhyolite, recharged by mafic magma and remobilized (Bachmann et al., 2014). A zoned ignimbrite such as the Carpenter Ridge Tuff is likely to be the result of both mixing and fractionation, and mafic recharge is an important part of the remobilization process (Bachmann et al., 2014). 


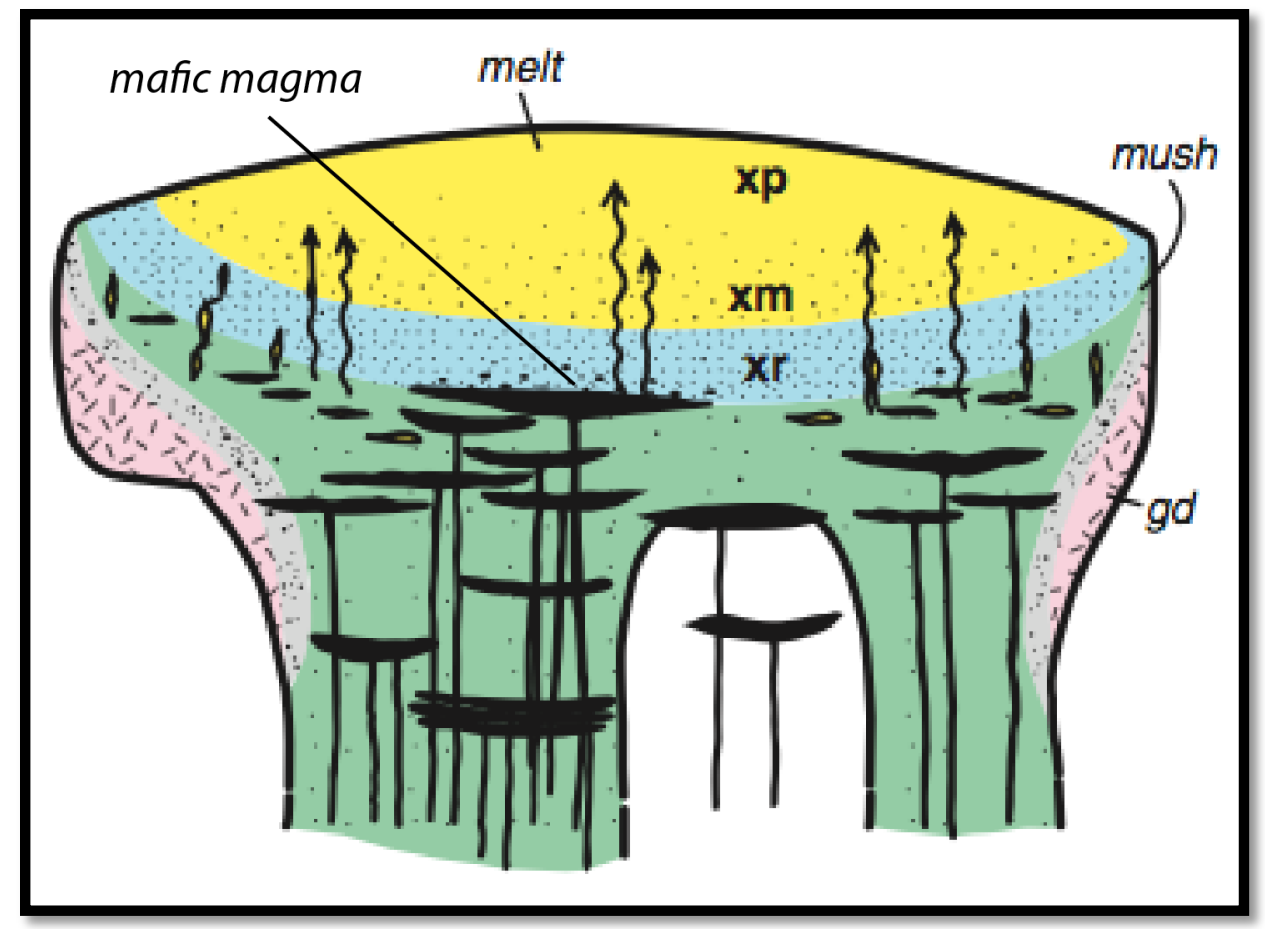

Figure 3. Modified figure from Hildreth \& Wilson (2007) shows the mush model of rhyolite melt extraction from a crystal mush. As the mafic recharge (black) accumulates beneath the silicic mush (blue), it remobilizes the crystal cumulate, decreasing crystallinity. Some mingling may occur between the recharged mafic magma and the rhyolite mush zone, but according to Deering et al. (2011) this process is secondary to in-situ differentiation and melt extraction. The crystal-poor area of the magma chamber is denoted by "xp"; the crystal-rich portion by "xr", and intermediate crystal content is represented by " $\mathrm{xm}$ ".

The Rattlesnake Tuff of Eastern Oregon contains mafic (basalt to basalticandesite) inclusions as well as dacite pumices (Streck \& Grunder, 1999). Components of the tuff indicate the magma chamber was zoned, highly silicic at the top and less so further at depth (Streck \& Grunder, 1999). Mafic inclusions have trace element enriched compositions that were the product of multiple cycles of mafic recharge and fractionation (Streck \& Grunder, 1999). Intermediate inclusions of dacite pumice are thought to be due to mixing of basaltic-andesite and high-silica rhyolite prior to eruption (Streck \& 
Grunder, 1999). Rhyolites create a density trap for mafic materials beneath, and the basalt thermally maintains the rhyolite, consequently allowing both members to differentiate inside the magma chamber (Streck \& Grunder, 1999).

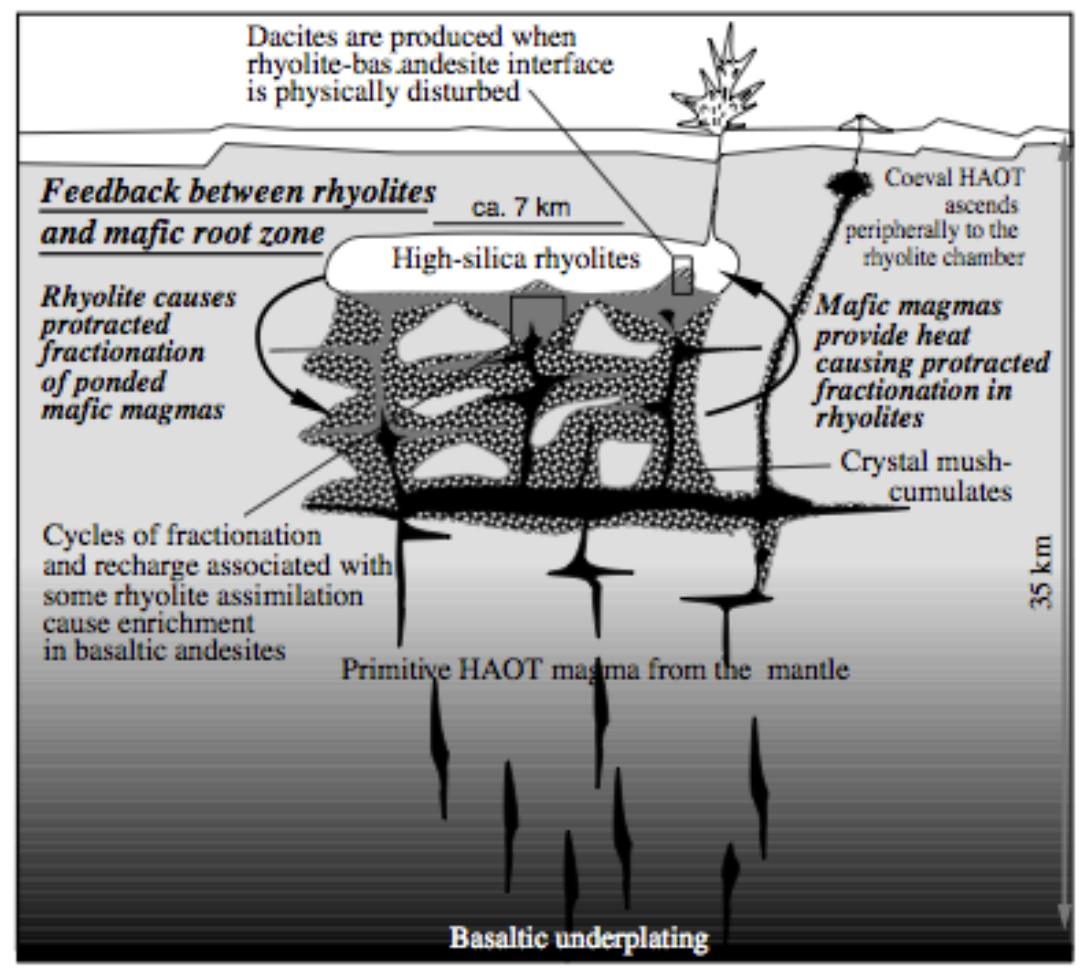

Figure 4. Schematic crossection of the Rattlesnake Tuff magma chamber, prior to eruption, identifying the mafic root zone and high-silica rhyolite lens. The production of dacite (the intermediate member of this system) is attributed to the disturbance of the boundary between the rhyolite and basaltic-andesite. Figure from Streck \& Grunder (1999).

All three studies envision the intrusion of hotter, mafic magma into the system before eruption, creating (1) chemical exchanges and mingling of rhyolite and basalt resulting in the creation of dacite inclusions (Streck \& Grunder, 1999), or (2) remobilization of a crystal cumulate through recharged hotter magmas, leading to melting 
of crystals and the generation of an intermediate magma composition (Deering et al., 2011; Bachmann et al., 2014). 


\section{METHODS}

\section{SAMPLE COLLECTION}

Fieldwork to collect samples for this study was undertaken in August 2015. The area covered, from east to west, includes $43^{\circ} 34^{\prime} 22.26^{\prime \prime} \mathrm{N}, 117^{\circ} 49^{\prime} 55.56^{\prime \prime} \mathrm{W}$ to $43^{\circ} 33^{\prime} 19.30^{\prime \prime} \mathrm{N}, 117^{\circ} 56^{\prime} 58.46^{\prime \prime} \mathrm{W}$. Ranging north to south it includes $43^{\circ} 35^{\prime} 41.52^{\prime \prime} \mathrm{N}$, $117^{\circ} 49^{\prime} 37.74^{\prime \prime} \mathrm{W}$ to $43^{\circ} 27^{\prime} 17.64 " \mathrm{~N}, 117^{\circ} 49^{\prime} 3.48^{\prime \prime} \mathrm{W}$. Samples of the Wildcat Creek Tuff were collected from outcrops at six locations around the field area, as determined by geologic maps of the area (See Fig. 5, below, and Table 1 in Appendix A).

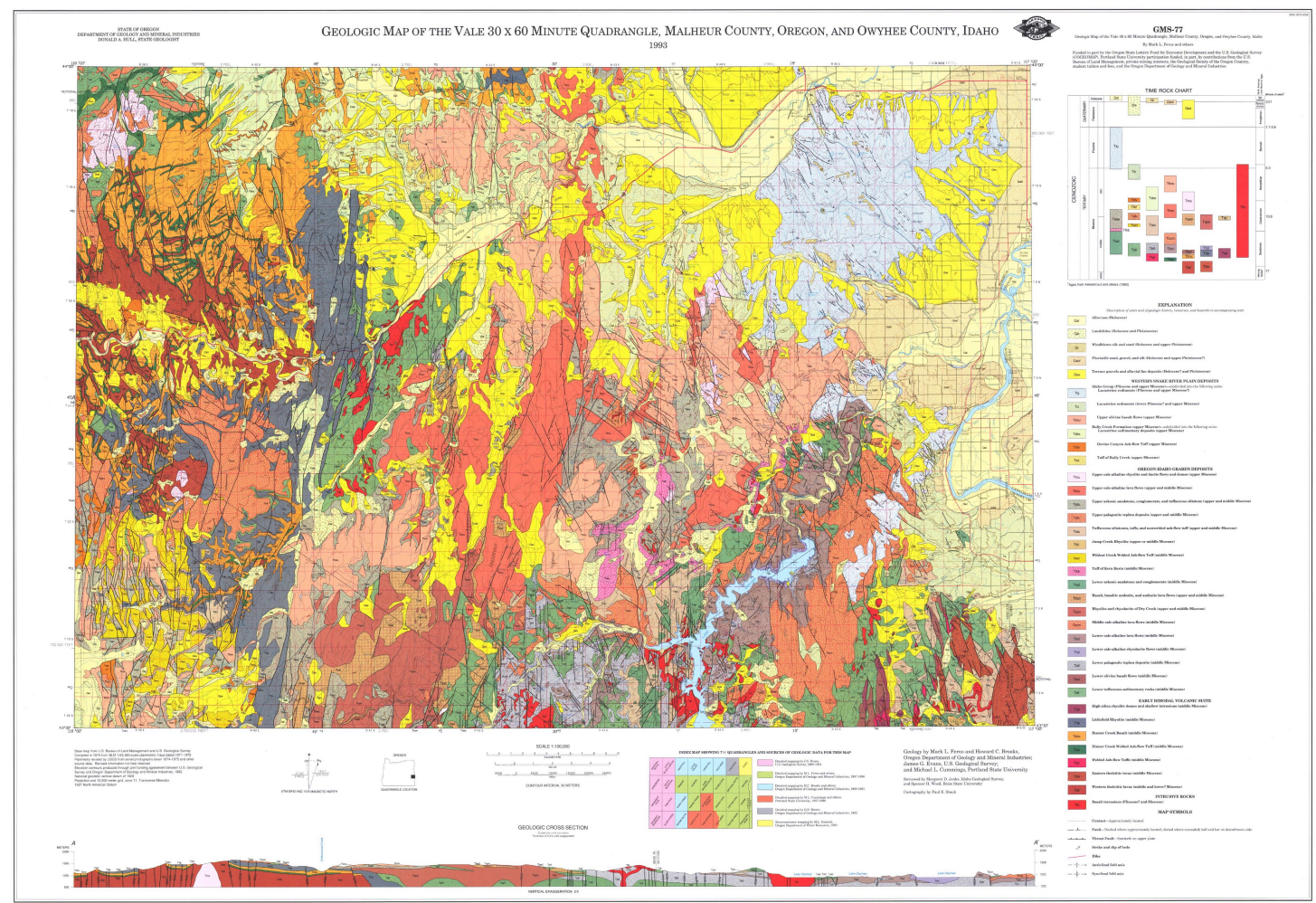

Figure 5. Geologic map of Malheur County, OR including the Wildcat Creek Tuff. On this map, the unit of interest is Ttwc and is yellow with orange dots. It falls into the category of Oregon-Idaho Graben Deposits emplaced during the mid-Miocene. (Ferns, 1993)

In addition, samples of underlying basalt and other, nearby units were collected for comparison. Field notes about the Wildcat Creek Tuff include lithological 
characteristics such as welding, devitrification, porosity, phenocryst abundance, and mafic inclusions. In total, seventeen samples from six sites were collected for this study. Three rock samples of the Wildcat Creek Tuff and one rock sample of the Buchanan Tuff, collected by Martin Streck in 2014 and 2013 respectively, were also included in this study for comparison. Sample locations for welded tuff includes Sites 5 and 6, located near $43.558350^{\circ},-117.904619^{\circ}$. The least welded samples were located at Site 4, located near $43.540133^{\circ},-117.822269^{\circ}$.

Samples were labeled with a unique identifier including initials, the year, and the site number. Notations were made regarding each site location and any additional information, including GPS coordinates. This information was recorded in a field notebook and each site was also plotted on Google Earth (Google Earth, 2014) for easy reference. All geographic data were collected using a Garmin eTrex 30.

A geologic map of the area was created using ArcGIS software (ESRI, 2014) (Fig. 2, above).

\section{PREPARATION AND ANALYSIS OF SAMPLES}

Eight rock samples were selected for bulk analysis (See Appendix B, Appendix C). These were individually chipped into a size fraction of approximately $0.5 \mathrm{~cm}$ using facilities at Portland State University. These samples were then taken to the Peter Hooper GeoAnalytical Laboratory of Washington State University (Pullman, WA), where further processing broke the samples down into rock powders and finally fused into glass beads and acid-dissolved solutions. Glass beads were used to analyze major and some traceelemental concentrations using the Thermal -ARL automated $\mathrm{x}$-ray fluorescence 
spectrometer (XRF) and the rock solutions were analyzed for trace elemental concentrations with the Agilent inductively coupled plasma mass spectrometer (ICP-MS). XRF data are available in Appendix B, and ICP-MS data are available in Appendix C. Additional samples were crushed further at Portland State University, using an iron mortar and pestle to achieve a size fraction of either $1.18 \mathrm{~mm}$ to $2.00 \mathrm{~mm}$ for larger grains, and $0.991 \mathrm{~mm}$ to $1.18 \mathrm{~mm}$ for smaller grains. The samples were then picked by hand using a binocular microscope to separate mafic inclusions from the otherwise felsic materials. The mafic material was then taken to the Peter Hooper Geoanalytical Lab at Washington State University for analysis separate from whole rock bulk composition. At Washington State University, approximately 12 grams of each sample were crushed into powder using a tungsten carbide ring mill. Three and a half grams of a flux agent, dilithium tetraborate $\left(\mathrm{Li}_{2} \mathrm{~B}_{4} \mathrm{O}_{7}\right)$, was then added to $1.25 \mathrm{~g}$ of rock powder for a 2:1 ratio (Flux agent: Sample). The rock-flux was mixed thoroughly, transferred to a carbon crucible, placed in a $1000^{\circ} \mathrm{C}$ muffle furnace, and fused into $15 \mathrm{~mm}$ glass beads. Once cool, these beads were then polished using isopropyl alcohol and sand paper to remove excess carbon. The glass beads were then re-crushed individually, ground into a powder, and fused again at $1000^{\circ} \mathrm{C}$ to ensure complete homogenization for both XRF and ICP-MS analysis. Staff at the WSU Peter Hooper GeoAnalytical Lab performed all XRF and ICPMS analyses. Analysis of 10 major elements and 19 trace elements was performed using XRF. Analysis of 23 additional trace elements was performed using ICP-MS.

While hand picking mafic material from the samples, feldspar phenocrysts were also hand selected from sample MS-14-5 in the size range of 600 to $991 \mu \mathrm{m}$. These were sent to New Mexico Tech where William McIntosh and his team conducted ${ }^{40} \mathrm{Ar} /{ }^{39} \mathrm{Ar}$ age 
dating experiments in the NMT Geochronology Research Laboratory. To determine the absolute age of the sample, the argon extraction method was conducted with a 50 watt $\mathrm{CO}_{2}$ laser. Individual feldspars were heated incrementally to release stored $\mathrm{Ar}$ that yielded then individual crystal age from which a average age was derived.

Thin sections were prepared and work at PSU consisted of cutting billets of each rock. These were sent to Spectrum Petrographics, a local petrographic company, for completing thin sections with a microprobe polish.

Petrographic analysis was completed at Portland State University using a Leica MZ 95 stereoscope and a Zeiss Primotech polarized light microscope. Detailed assessments of textures, mineral assemblages, phenocryst sizes, and proportions, were made. The thin sections were then carbon coated using an Electron Microscopy Sciences carbon evaporator, and scanning electron microscopy was conducted in the Center for Electron Microscopy and Nanofabrication located at Portland State University. The Zeiss Sigma VP FEG SEM was used to take back-scattered electron images and to determine composition of individual minerals within the samples. Specific sites in each thin section were selected for analysis, including minerals like feldspars and pyroxenes, and both mafic and felsic glass. The images and data were processed using AzTEC software at Portland State University.

Microprobe analysis was conducted remotely by using the electron microprobe at Oregon State University (Corvallis, Oregon). Feldspars, pyroxenes, and glass were analyzed on a Cameca SX-100 Electron Microprobe. Pyroxenes were analyzed with a sample current of $20 \mathrm{nA}$, a $2 \mu \mathrm{m}$ magnification beam, and $15 \mathrm{kV}$ voltage. Feldspars were analyzed with a sample current of $8 \mathrm{nA}$, a $5 \mu \mathrm{m}$ magnification beam, and $15 \mathrm{kV}$ voltage. 


\section{RESULTS}

\section{LITHOLOGIC CHARACTERISTICS}

Macroscopic analysis of the Wildcat Creek Tuff was performed while in the field in August 2015. The overall appearance of the unit is dark, ranging from black to brown, with some lighter outcrops where the felsic component of the system is more prevalent than the intermediate component. Site 4, in particular, stands out, as it shows the distinct contact with the underlying stratigraphic unit. Throughout the Wildcat Creek Tuff site locations, the most welded samples are located close to the bottom of the stratigraphic unit, while the least welded are near the top. Typically, the less welded portions of the unit are somewhat darker in color, ranging from reddish-brown dark grey and even to black. The more welded sites are lighter in color, both macro- and microscopically. This is somewhat contrary to increasing welding in vitric facies, but could be explained by crystallization of felsic groundmass crystals during devitrification. A map of the site locations is below (Fig. 6) 


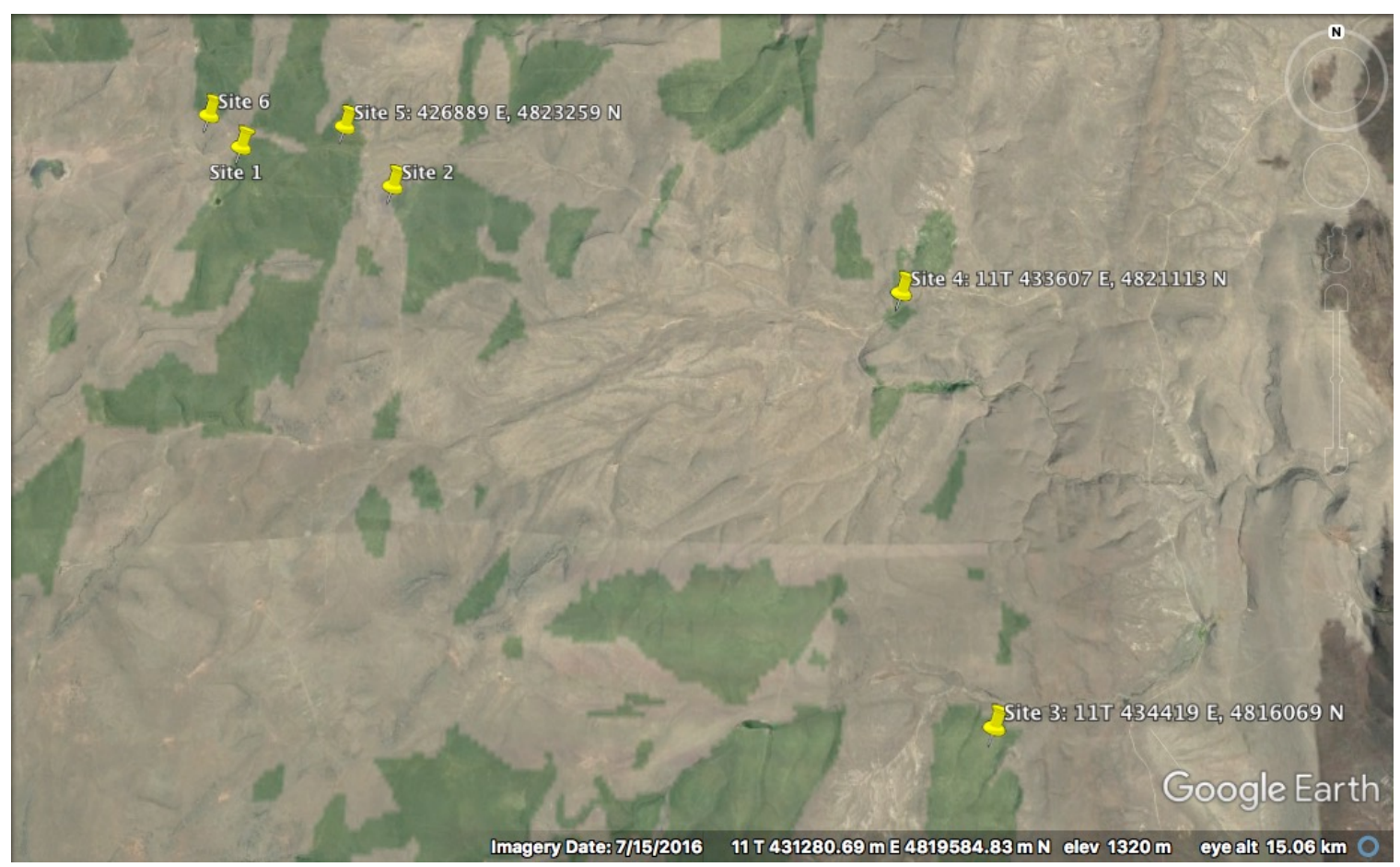

Figure 6. Site location map of the Wildcat Creek Tuff (green), including sites 1 through 6. The Google Earth image is overlain by a map showing the Wildcat Creek Tuff, created in Arc GIS. (Google Earth, 2014; ESRI, 2014)

\section{Site 1}

Located at $43.556356^{\circ},-117.920808^{\circ}$, Site 1 was the first Wildcat Creek Tuff location sampled during fieldwork. This outcrop was pre-selected and plotted in Google Earth. After a short hike of $\sim 0.25$ miles from Shumway Cutoff Road, several photographs were taken of the site and samples selected from the location (Figs. 7 and 8, below). The outcrop appears reddish-brown with many inclusions of scoria. In hand-sample once broken open, the rocks have both reddish-brown and dark grey components, fiamme, and angular clasts. 


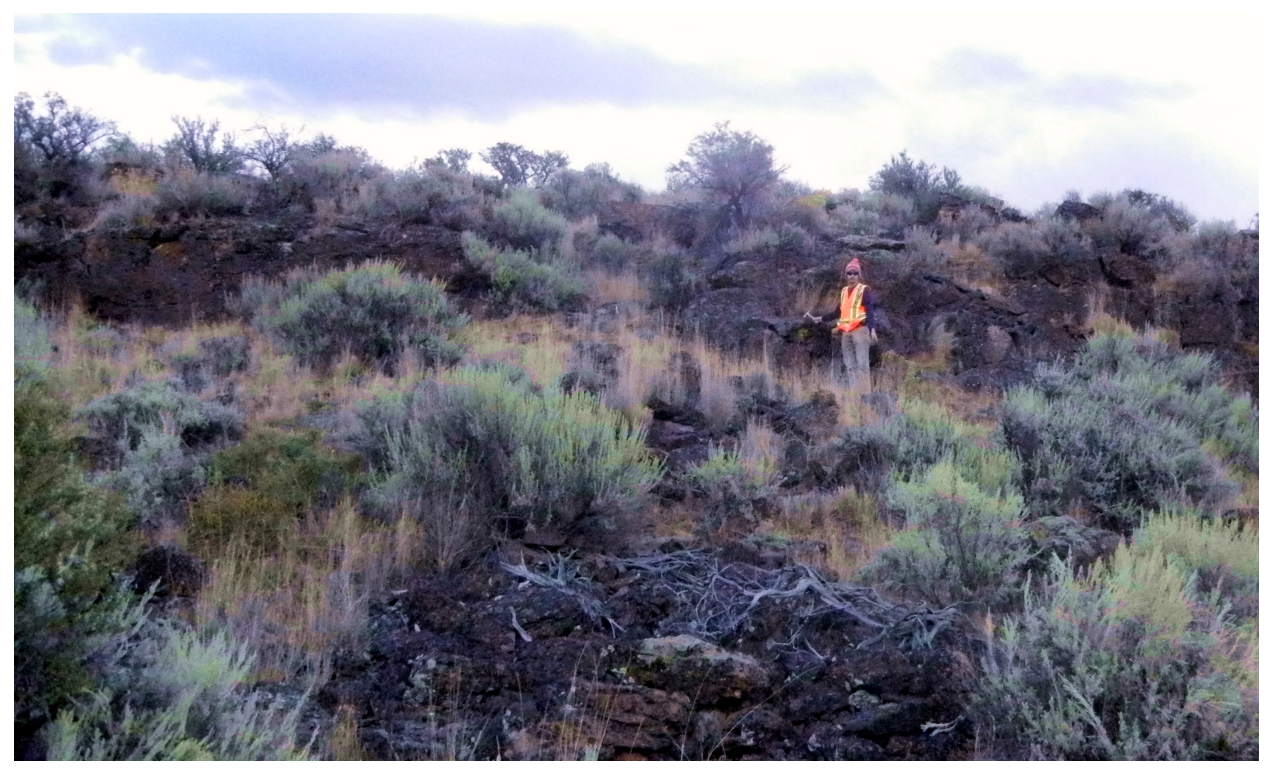

Figure 7. Site 1 of the Wildcat Creek Tuff. The darkest portion of the unit, located in the foreground of the photo, is not associated with the Wildcat Creek Tuff, but with the Littlefield Rhyolite that lies stratigraphically beneath it. Above, with geologist for scale, the Wildcat Creek Tuff rhyolite can be seen. It is reddish-brown to dark gray in color and phenocryst-poor. 


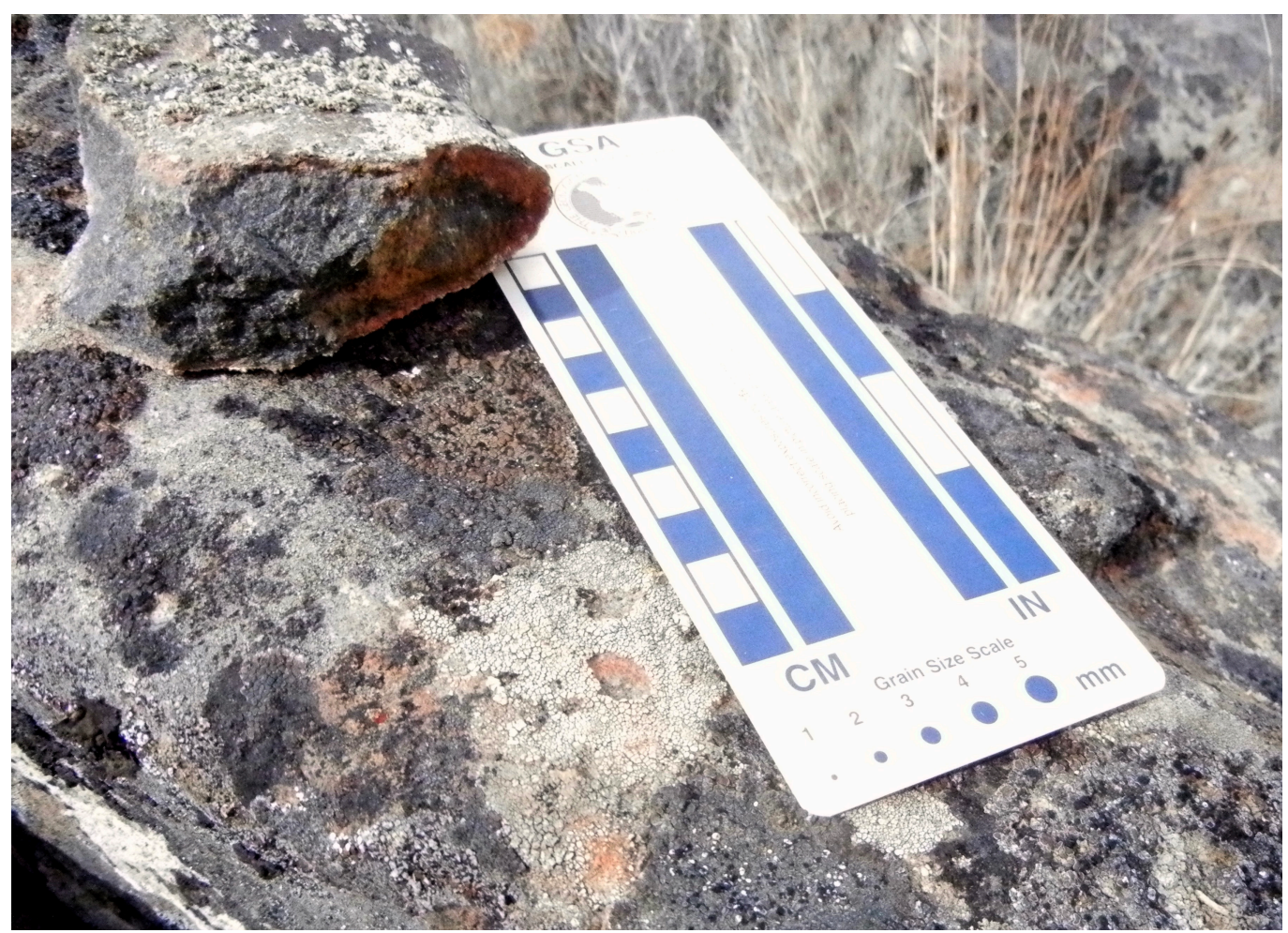

Figure 8. Hand sample obtained at Site 1 during fieldwork. A weathering rind is seen, but on the fresh face of the rock the color ranges from reddish-brown to dark grey. The rock is phenocrystpoor.

\section{Site 2}

Site 2 was located at $43.552022^{\circ},-117.898569^{\circ}$ on Monument Rock Road. This outcrop was pre-selected and plotted on Google Earth. Once fieldwork began at the site, the actual outcrop of the unit was difficult to locate. What little rock cropped out was dark grey to black in color and phenocryst-poor, resembling a basalt lava. In hand sample, however, the pyroclastic texture of the rock was apparent. This sample of the Wildcat Creek Tuff is similar to those located at Site 1, phenocryst poor and reddishbrown to dark grey in color. Obsidian was identified just below Site 2 as float. 
Site 3

Site 3 is located at $43.498144^{\circ},-117.804903^{\circ}$. Tabular, reddish rock was located below the Wildcat Creek Tuff outcrop near the top of the ridge. The outcropping portion of the WCT unit was dark grey to black in appearance and phenocryst-poor, containing red, vesicular pumice.

\section{Site 4}

Located at $43.540133^{\circ},-117.822269^{\circ}$, Site 4 is the best exposed and complete of all sites sampled during fieldwork. The full petrography of samples is described in Appendix A. The site is pictured in Fig. 9. Overall, the color variation of this outcrop ranges from light near the bottom of the unit to dark at the top, relating to changes in bulk composition. A full stratigraphic column of Site 4 can be seen in Appendix N.

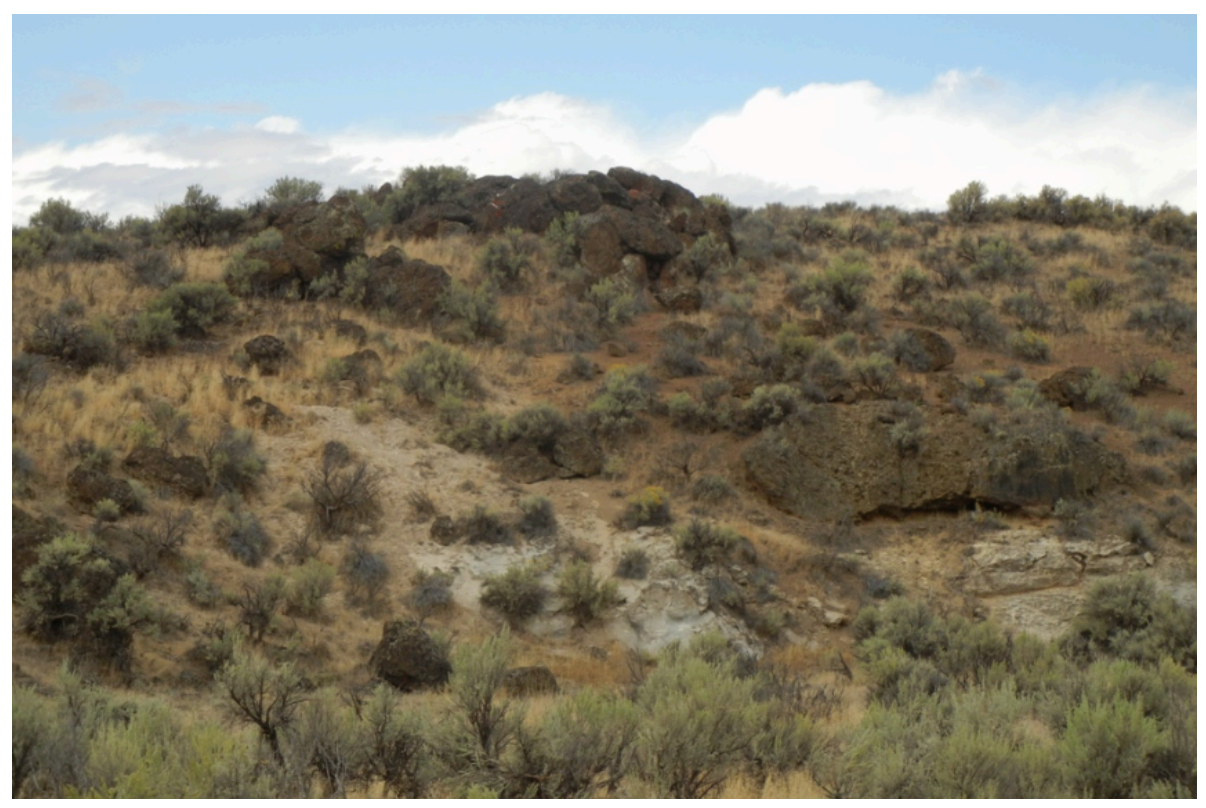

Figure 9. This outcrop of Wildcat Creek Tuff (WCT) was designated as Site 4. Near the center of the picture, a section of light-colored, ash-like material can be seen and this material was sampled as HS15-04f. The contact to the Wildcat Creek Tuff lies immediately above light tuffaceous layer (Fig. 5). 
Above the contact, the Wildcat Creek Tuff varies from densely welded near the bottom, to partially welded at the top of the cliff.

The first sample was taken immediately above the contact the underlying tan tuffaceous unit at an elevation of $1302 \mathrm{~m}$. Sample HS-15-04a contains black pumice up to 2 centimeters in length. Sample 04a is highly vesicular and displays low degree of welding, and it is phenocryst poor. This can be seen in hand sample, pictured below in Fig. 10 .

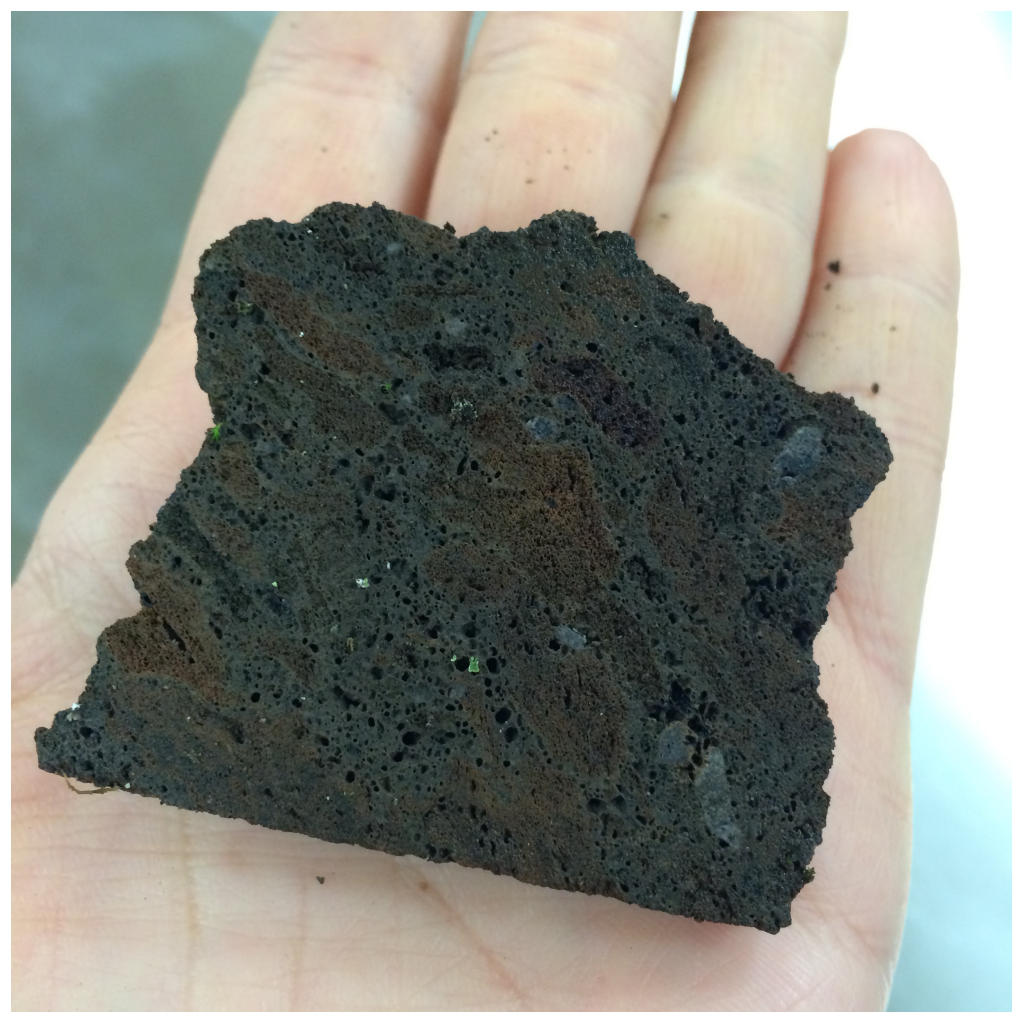

Figure 10. Hand sample of sample HS-15-04a shows the dark coloration, multiple colors of mafic scoria throughout the sample, suggesting compositional differences of magmas that comingled during eruption.

HS-15-04b was taken above the contact between the WCT and the underlying unit, taken at an elevation of $1305 \mathrm{~m}$, it is 3 meters above the contact.(see Figs. 10 and 11 , below). This part of the outcrop was somewhat eroded back, allowing observation of the 
contact in plane view. This section of the stratigraphic unit is highly welded and displays large, dark fiamme inside a red-to-brown matrix. Just below the contact, in the light material, HS-15-04f was sampled. This is a dacitic sample and it is much lighter than the surrounding rock.

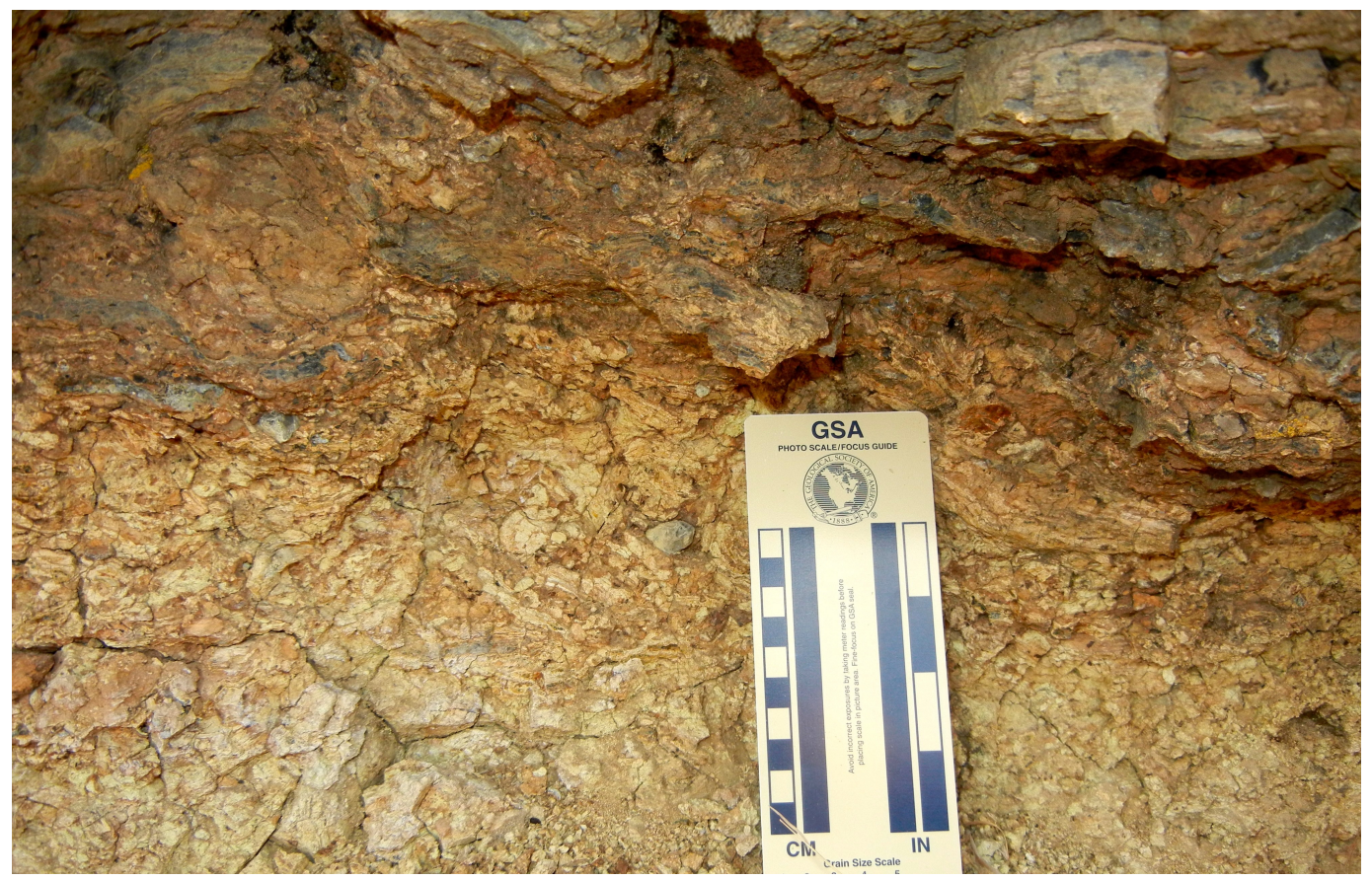

Figure 11. Image of the contact between the Wildcat Creek Tuff and the underlying tuffaceous unit at Site 4. In this close-up picture, a high degree of welding is visible with abundant fiamme above the contact. Dark grey to black fiamme can be seen, as well as a distinct color change between the two units. The light material at the bottom of the picture was sampled as HS-15-04f, while the dark red with black pumice, above, was sampled as HS-15-04b. 


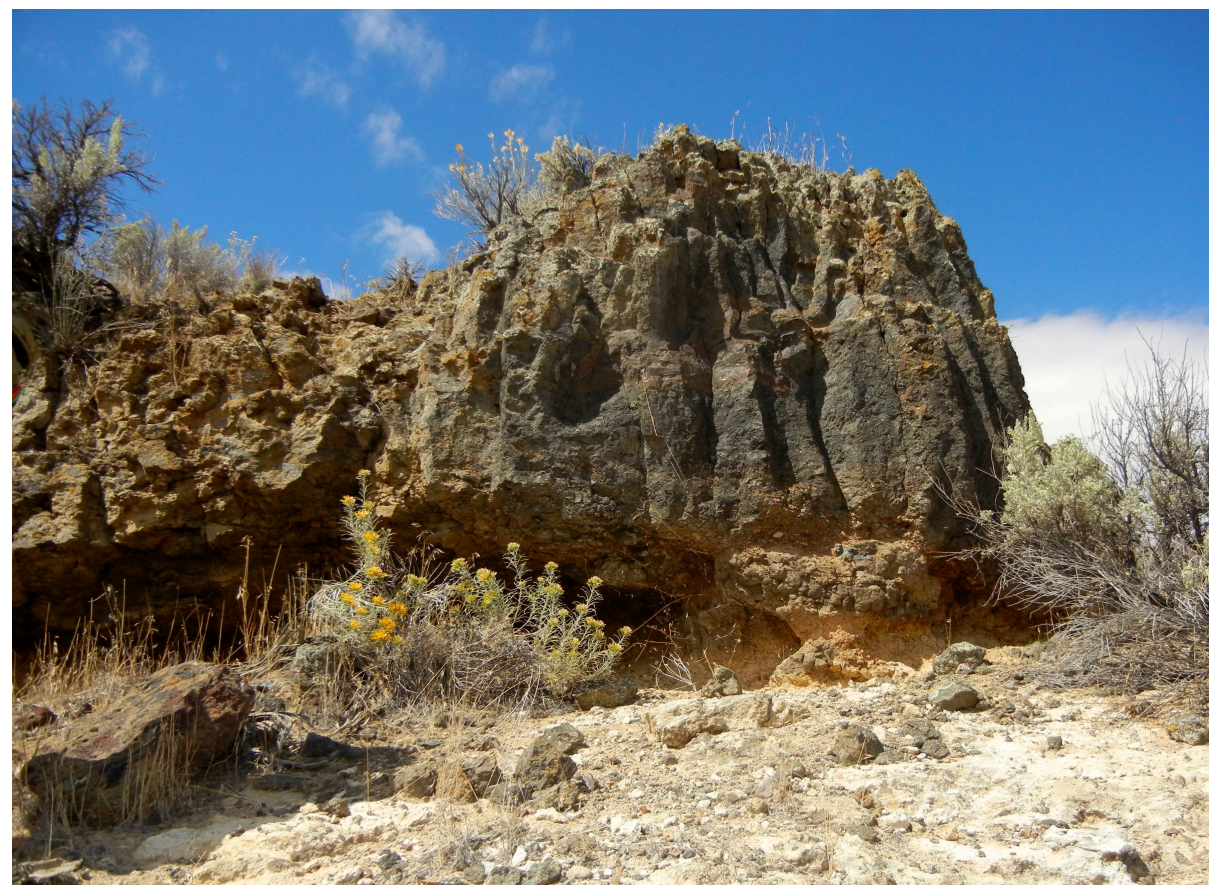

Figure 12. Another view of the contact between the Wildcat Creek Tuff (darker) and the underlying tuffaceous unit (lighter) at Site 4. The contact is eroded back exposing contact in plane view. The Wildcat Creek Tuff is red-brown to black in color, while the dacitic composition beneath is light grey to white with colorful inclusions of scoria.

Moving upwards in the stratigraphic unit, sample HS-15-04c was sampled $7 \mathrm{~m}$ above the base of the tuff. It is light grey to brown in hand sample, appearing mostly dark brown on the outcrop. It appears mostly phenocryst poor, with many colors of scoria. Few phenocrysts are visible to the naked eye. (See Figs. 13 and 14, below.) 


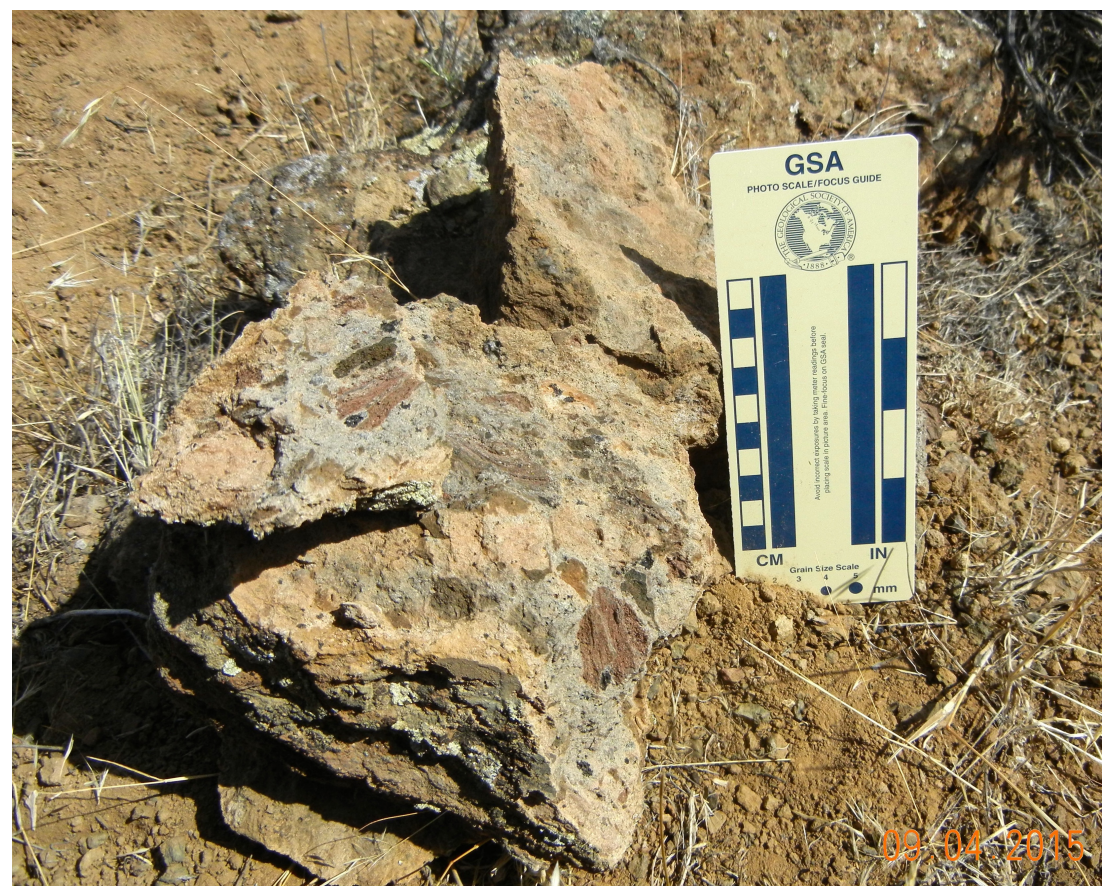

Figure 13. Sample HS-15-04c is light grey with many different sizes and colors of scoria.

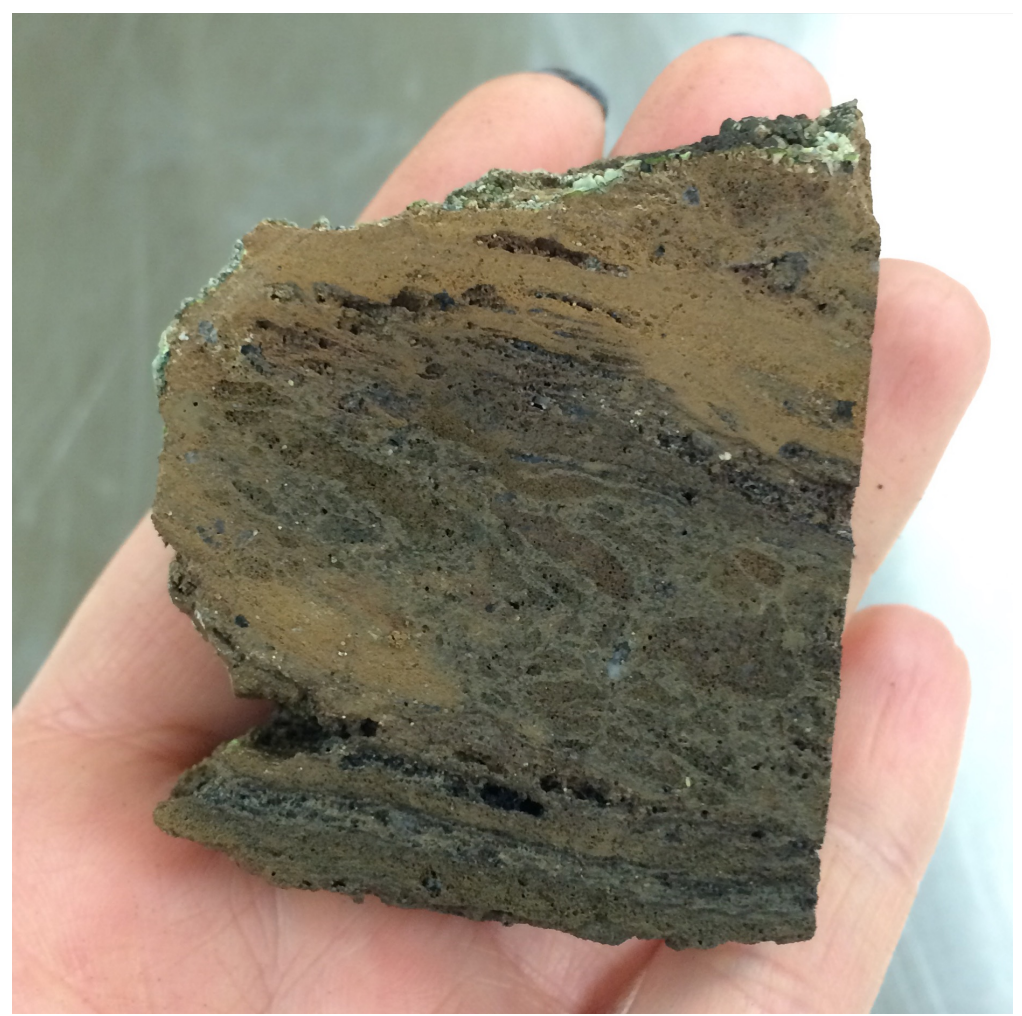

Figure 14. Sample HS-15-04c, in hand sample. Several colors of scoria are present amidst the felsic groundmass appearing as dark inclusions. The sample appears phenocryst poor. 
Sample HS-15-04e was taken below the top of the outcrop, $9 \mathrm{~m}$ above the contact. It again appears dark brown to light brown in hand sample with large brown pumice measuring up to $6 \mathrm{~cm}$. The matrix appears purple with no obvious phenocrysts.

Sample HS-15-04d was taken at the very top of the unit. The outcrop measures a total of 12 meters in thickness is continuous for roughly 80 meters. This sample appears black in the outcrop, and a swirl of red and black components in hand sample (Fig. 15, below). As with all other Wildcat Creek Tuff samples, it is phenocryst poor, and to the naked eye, this sample appears to be the most mafic, containing fewer crystals than any other taken from the same site.

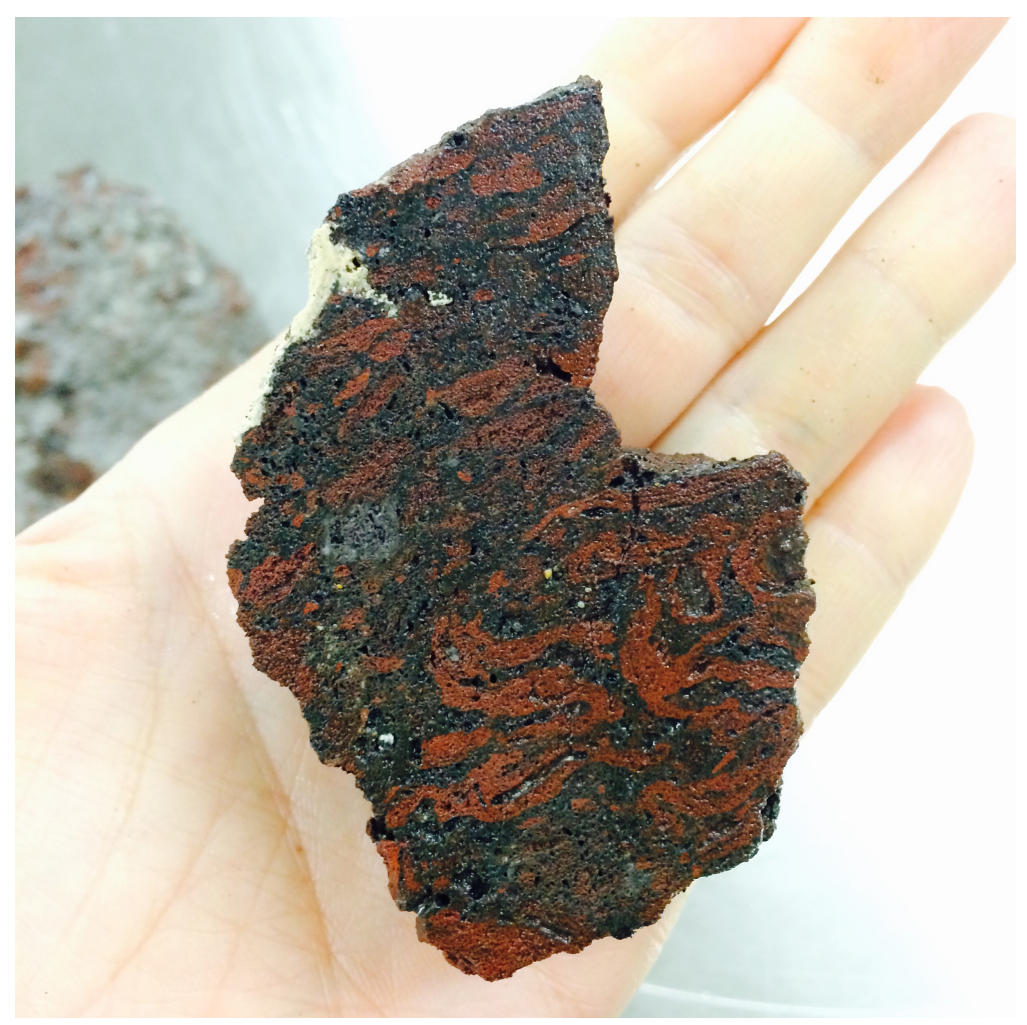

Figure 15. Swirls of red and black mingle in this sample of the Wildcat Creek Tuff. Sample HS-1504d is the least welded, showing the obvious contrast of mafic and felsic components. It is phenocryst poor. 


\section{Site 5}

Site 5 was pre-selected and plotted on Google Earth at $43.558350^{\circ},-117.904619^{\circ}$. It is where both samples HS-15-05 and MS-14-06 were taken. The unit is red colored and partially welded with black pumices, reddish-brown pumice, and some small white pumices that are not fully collapsed to fiamme. This section of the Wildcat Creek Tuff is also phenocryst-poor. Outcrop thickness is roughly $18 \mathrm{~m}$.

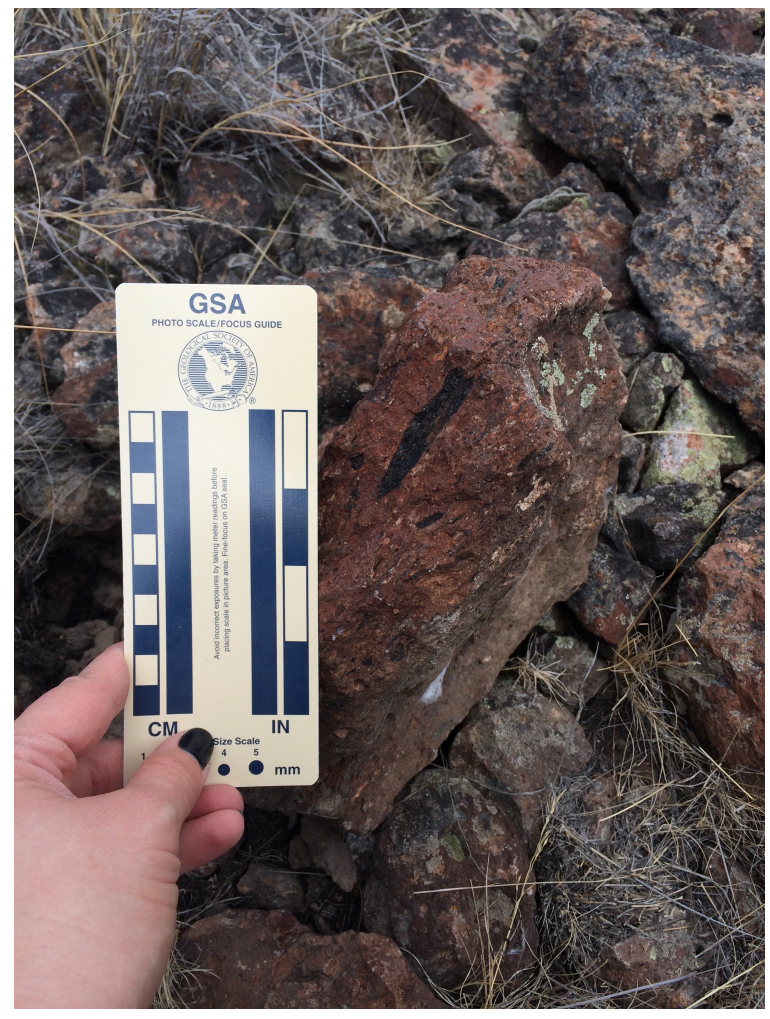

Figure 16. Site 5 Wildcat Creek Tuff samples and outcrop are red. The Tuff at this site is more welded than at site 4 based on the occurrence of fiamme versus pumice. This rock is sample HS-1505.

Site 6

Site 6 is located at $43.557389^{\circ},-117.925567^{\circ}$. The outcrop is red in color with abundant dark scoria scattered throughout. This site was comprised of rock that was 
highly welded. A view of the outcrop can be seen below in Fig. 17. Of all the sites, the tuff appears to be the most phenocryst-rich, although phenocryst content is below $10 \%$.

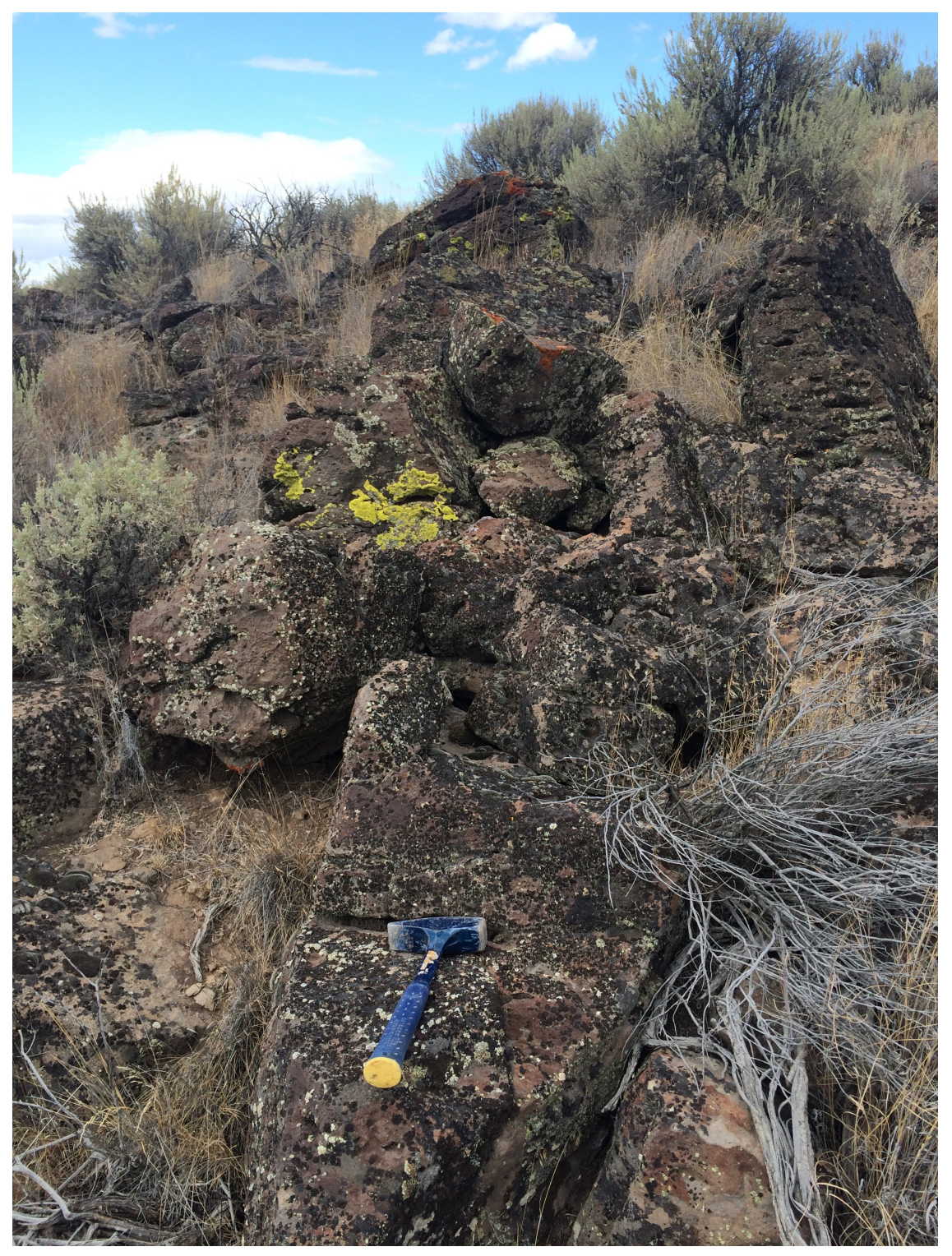

Figure 17. Site 6 from fieldwork to sample the Wildcat Creek Tuff is seen here. The rocks appear red with some dark scoriaceous inclusions.

\section{PETROGRAPHIC ANALYSIS}

Petrography was performed on the eight thin sections that were prepared from the total of twenty tuff samples collected from the Wildcat Creek Tuff outcrops. Criteria for 
the selection of samples for petrographic analysis are that they cover the range of observed lithofacies and geographic area. A full table of petrographic analyses can be found in Appendix A, including phenocryst abundance, major and minor phenocryst phases, and texture. Overall the samples are phenocryst poor, containing only $1 \%$ to $5 \%$ phenocrysts, and contain an abundance of mafic scoria comingled with rhyolite. The samples range from andesite to rhyolite.

All samples contain both feldspars and pyroxenes, and the scoria present in each sample differs in color, ranging from light brown to black, red, and even green. The rhyolite varies from light grey to dark reddish-brown, and the scoria is vesiculated and commonly displays mingling textures with the rhyolites. Furthermore, welded samples indicate rhyolitic tuff material and scoria have welded together. These data indicate that scoria represent a cognate component to the rhyolites and represent more mafic magmas, likely stored below rhyolitic magmas prior to eruption. Samples will be discussed form the most mafic to the most silicic samples (see Geochemistry below).

HS-15-04c

The sample is incipiently welded with a high abundance of mafic scoria nearing $45 \%$ to $50 \%$. Phenocryst abundance is approximately $4 \%$. This intermediate sample is the most mafic in the entire Wildcat Creek Tuff sample set, containing just $59.7 \% \mathrm{SiO}_{2}$. Pyroxenes are the most abundant phenocryst found in sample HS-15-04c. All of the pyroxenes in this sample are clinopyroxene. Few fayalitic olivine are also found. Both clinopyroxene and fayalite minerals are associated with the felsic portion of the sample. Pyroxenes appear subhedral as seen in Figure 18, below. 


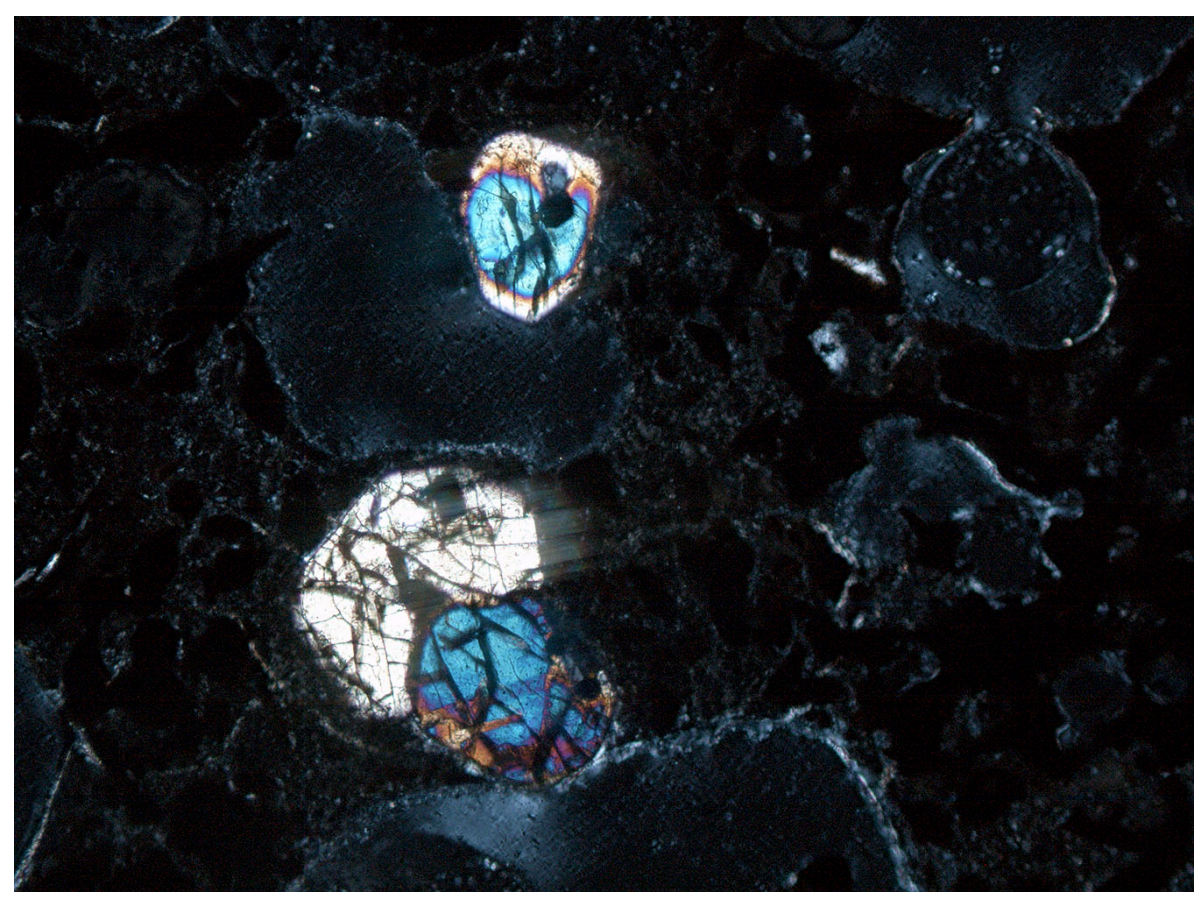

Figure 18. Mineral P19 from sample HS-15-04c, shown in crossed polars with 100x magnification in an optical microscope. This is a clinopyroxene, determined by the vibrant interference colors and the two directional cleavage at $89^{\circ}$.

Plagioclase feldspars are euhedral and pitted, while alkali-feldspar is more fractured and appears to be embedded in felsic material, though nearby mafic material tends to intrude. The sample is incipiently welded, which can be seen in Fig. 19, below.

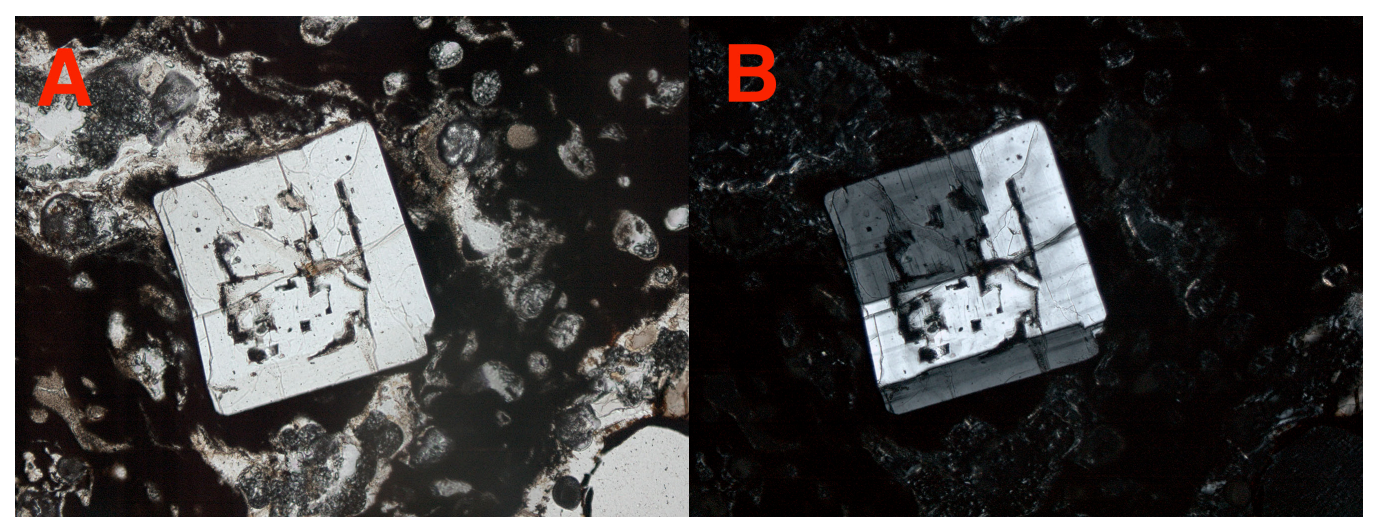

Figure 19. Plagioclase feldspar F6 from sample HS-15-04c is pictured in plain light (A) and polarized light (B), and magnified 100x in an optical microscope. It has a euhedral shape, polysynthetic 
twinning, obvious cleavage, and is pitted with melt inclusions. F6 is surrounded mainly by mafic material.

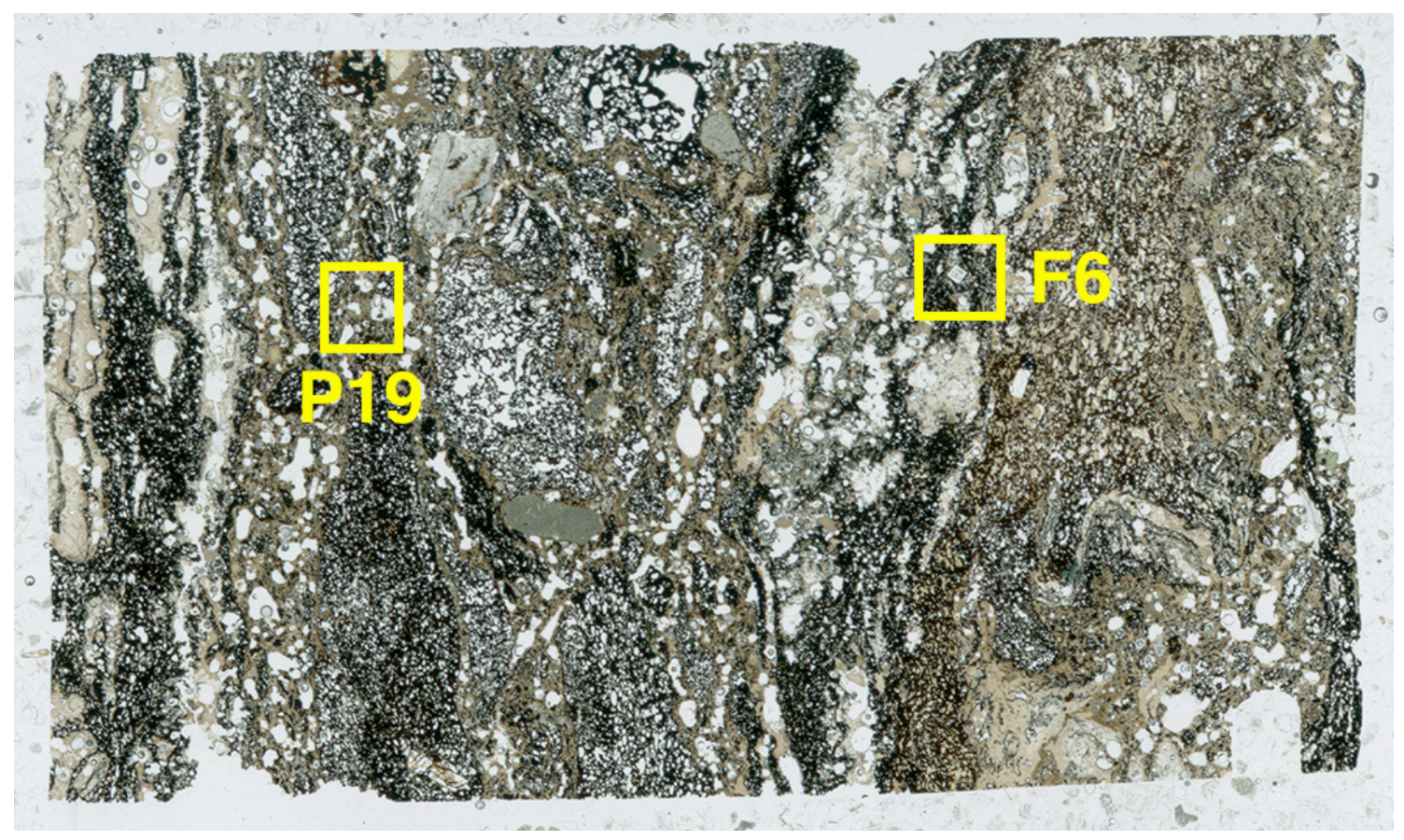

Figure 20. Thin section scan of HS-15-04c is shown in plain light with highlighted locations of pyroxene P19 and feldspar F6. Observable textural features include aphanitic rhyolite and intermediate scoria, strongly comingled, as well as high vesicularity indicating low degree of welding in this sample. See text for full description of the sample.

\section{HS-15-04d}

This trachyandesite sample was taken from the same outcrop as sample HS-15$04 \mathrm{c}$ (above). Silica content in this sample is $62.4 \%$ and is slightly higher than sample $04 \mathrm{c}$, and located vertically highest in the outcrop. Scoria proportionality is roughly $65 \%$, and this sample is the least welded. There is no true welding foliation within this sample, and it is phenocryst poor. Rare feldspar phenocrysts include rhyolitic anorthoclase and very few augite, clinopyroxene crystals associated with the felsic material within the magma. 
A few acicular feldspars are seen in Figure 21, below. These are phenocrysts belonging to the $\sim 60 \% \mathrm{SiO}_{2}$ icelandite that make up part of the mafic component of the magma system (see below, Fig. 21).

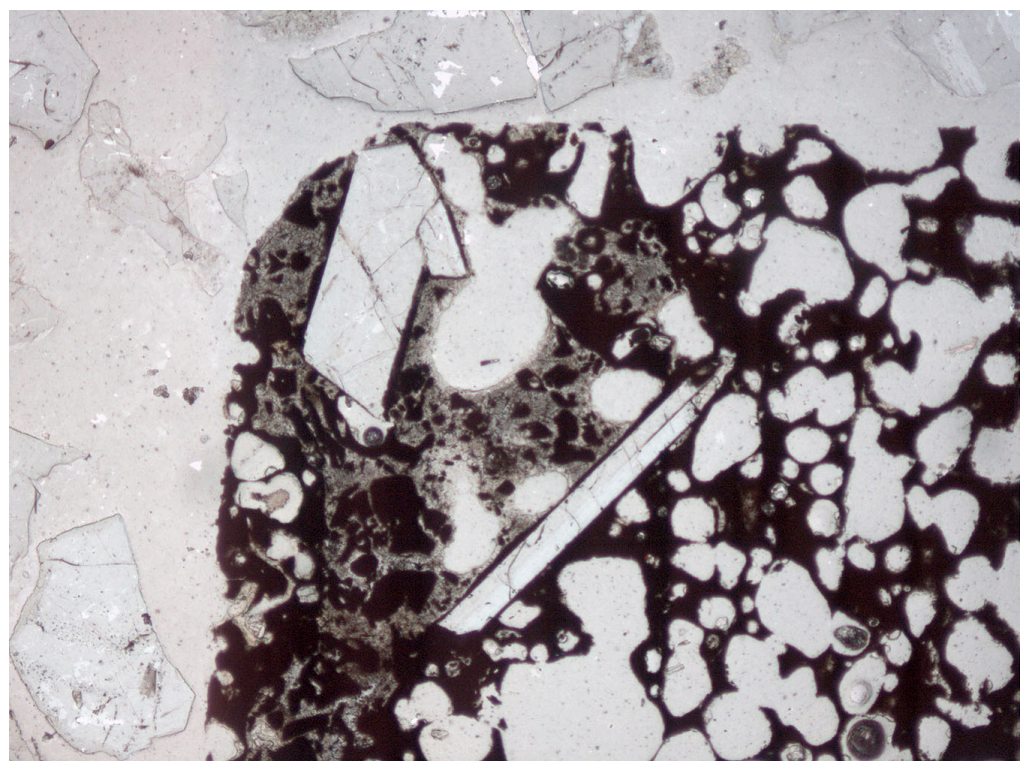

Figure 21. Plagioclase feldspar F6 from sample HS-15-04d is shown in plain light, magnified 50x in an optical microscope. It is embedded in an icelandite, appearing thin and needle-like compared to other feldspars in the sample. It is surrounded by mafic material, is euhedral in shape with cleavage. In polarized light, polysynthetic twinning is visible. 


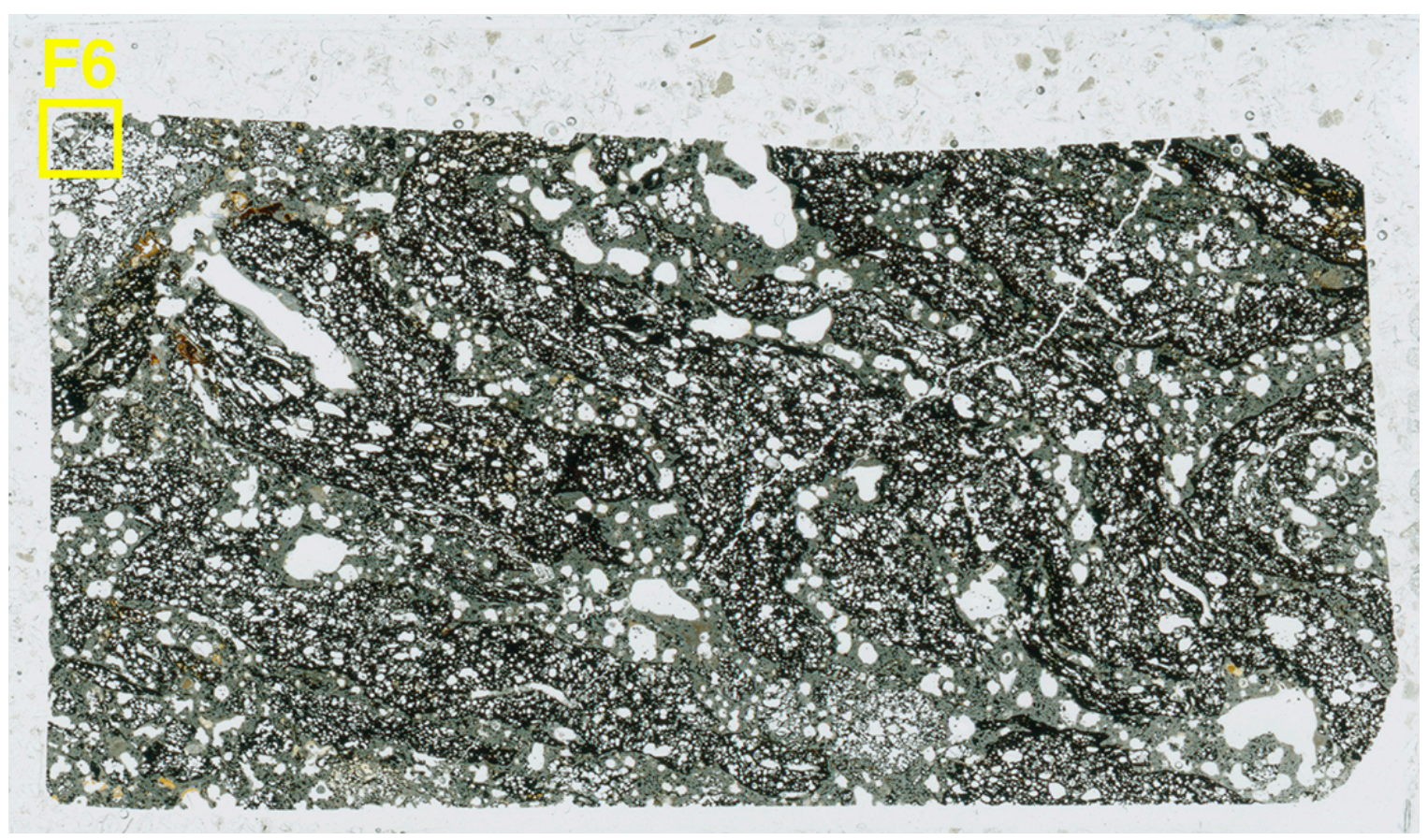

Figure 22. Plain light thin section scan of HS-15-04d shows the location of feldspar F6 (above in

Figure 21). The sample shows a high proportion of scoriaceous material, the darkest, black material in this image, roughly $65 \%$. The sample is highly vesicular, with no fiamme present, and is phenocryst-poor. A full description is in the text above.

HS-15-04e

Sample $04 \mathrm{e}$ is located $3 \mathrm{~m}$ vertically below sample $04 \mathrm{~d}$. Though it has an incipient degree of welding, a welding compaction direction can be observed (see Fig.26). Scoriaceous material accounts for approximately $70 \%$ of the sample. Scoria is dark and very phenocryst poor, while the rhyolitic glass in the sample is slightly lighter brown with abundant vesicles. Most of the pyroxenes in this sample are clinopyroxene associated with the rhyolite. There are a few fayalitic olivine specimens observed as a part of the rhyolite. The pyroxenes found in this sample are very fractured and subhedral in shape (see Fig. 23). Feldspar F5 is shown below (Fig. 24). It is euhedral, but broken, and inter-grown with pyroxenes which are anhedral in shape. 


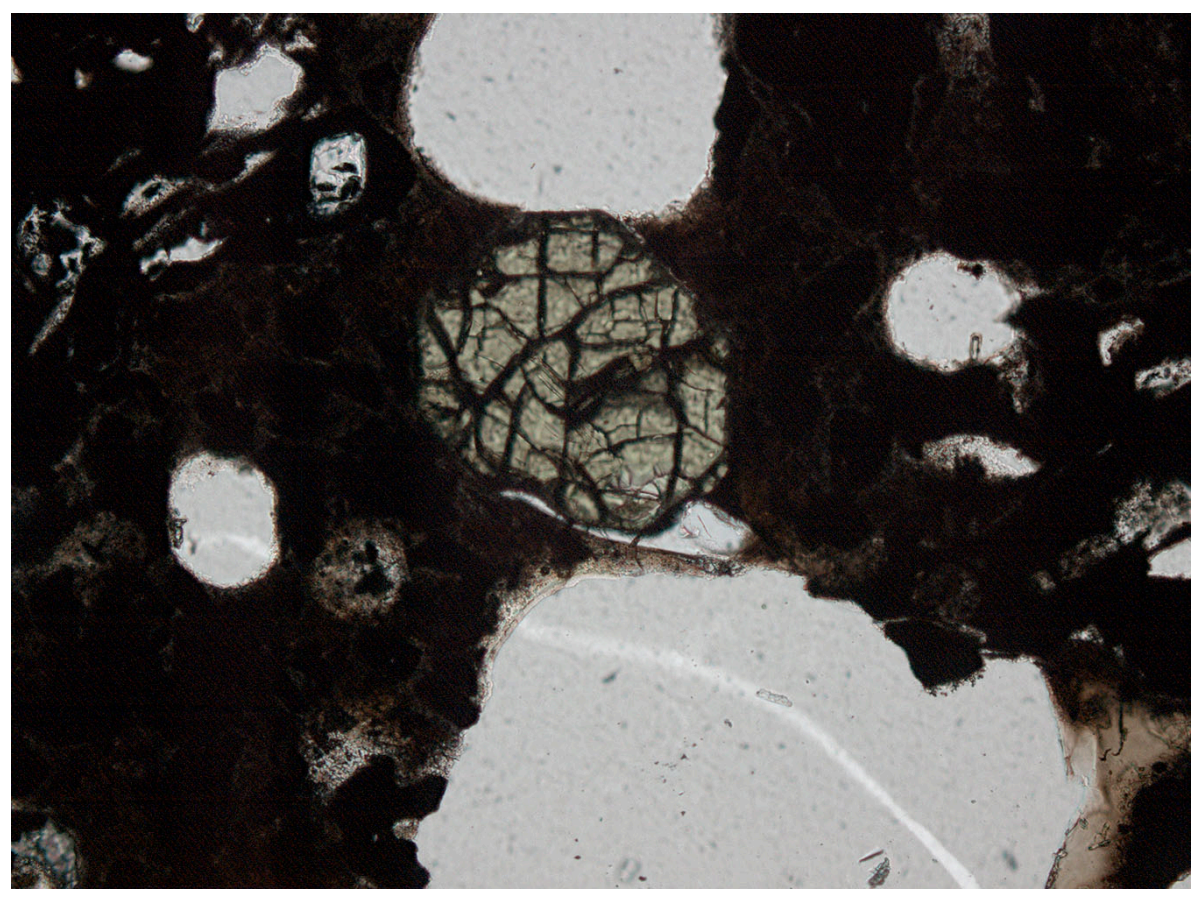

Figure 23. Clinopyroxene $\mathbf{P 4}$ from sample HS-15-04e is seen here surrounded by mafic material. It is magnified 100x and shown in plain light in this image taken by an optical microscope. 


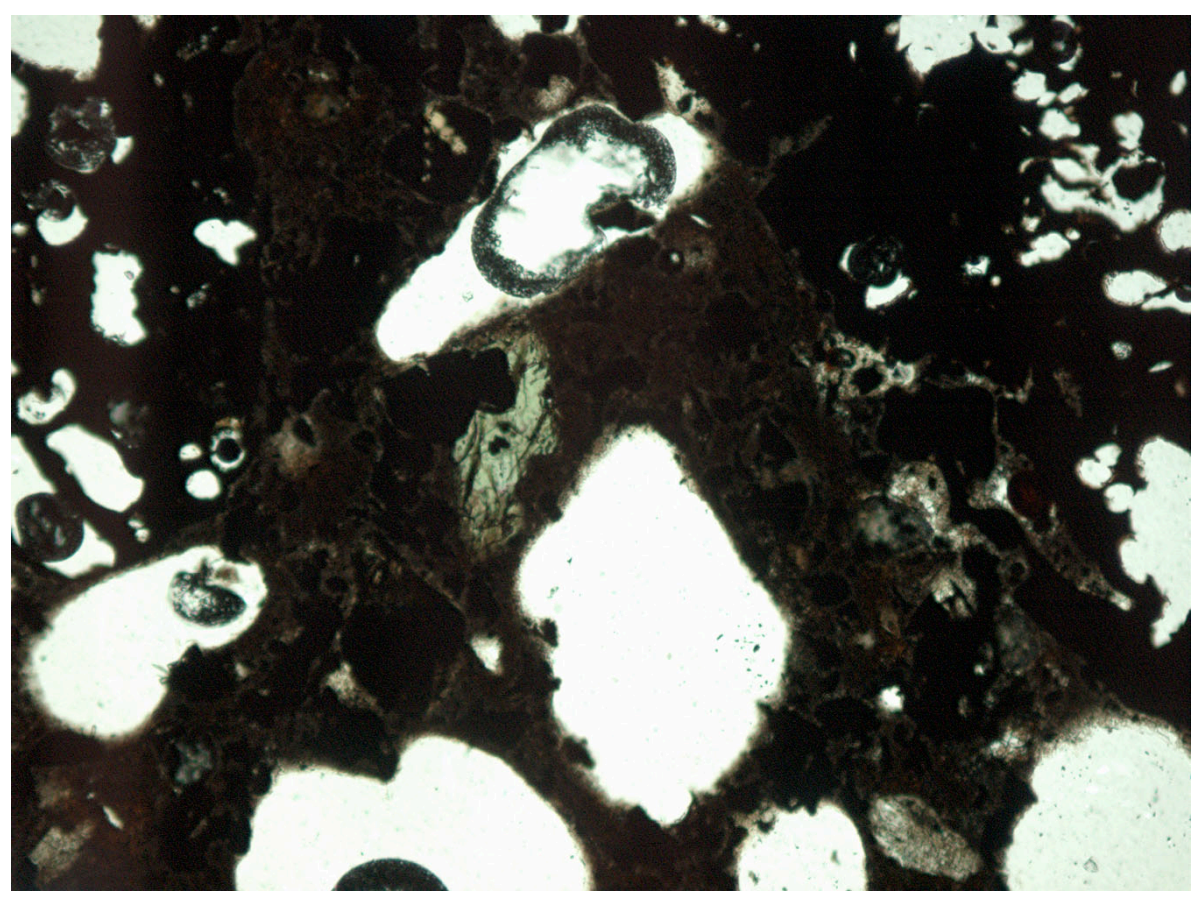

Figure 24. Fayalitic olivine, P11 from sample HS-15-04e, is seen here in the center of the photo in plain light, magnified 50x in an optical microscope. It is anhedral and fractured.

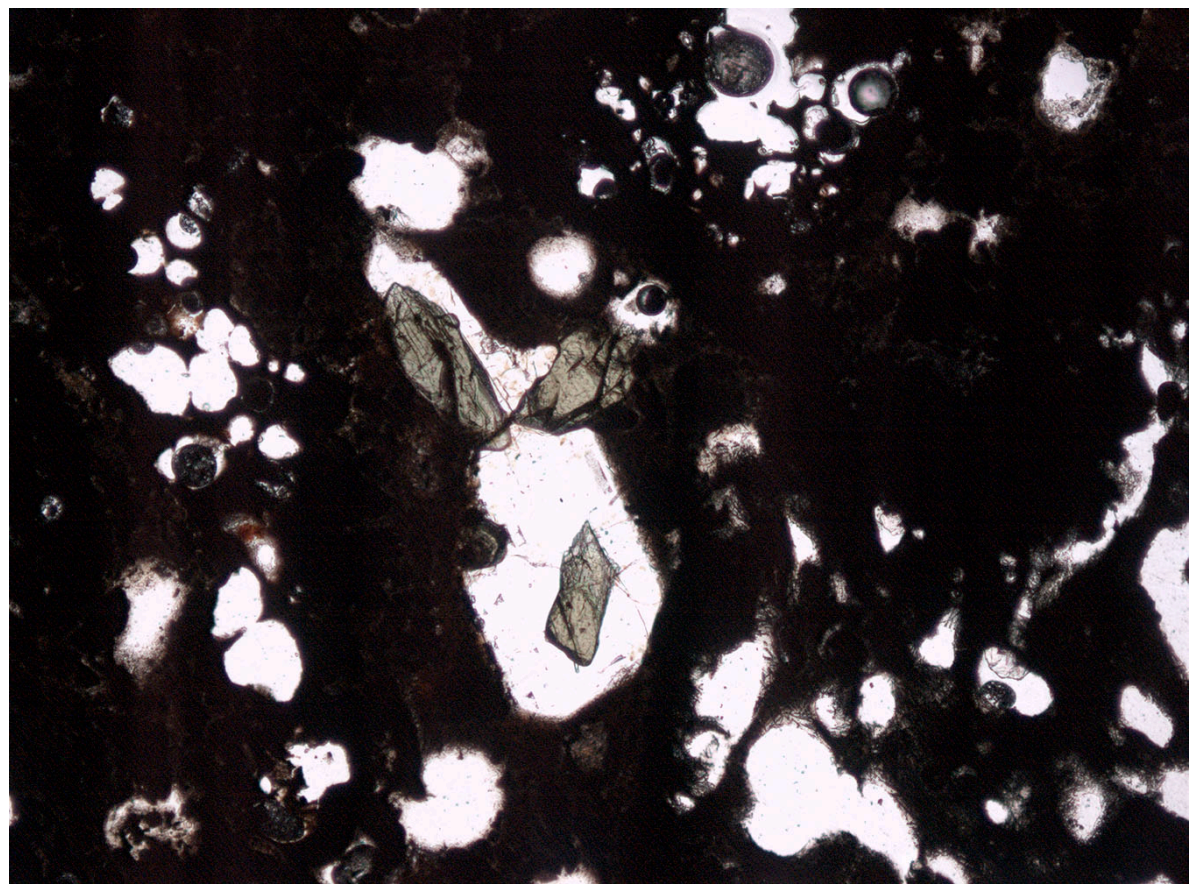

Figure 25. Plagioclase feldspar F5 from sample HS-15-04e is shown in plain light and magnified 50x in an optical microscope. It is surrounded by mafic material and contains intergrown pyroxenes P5. 


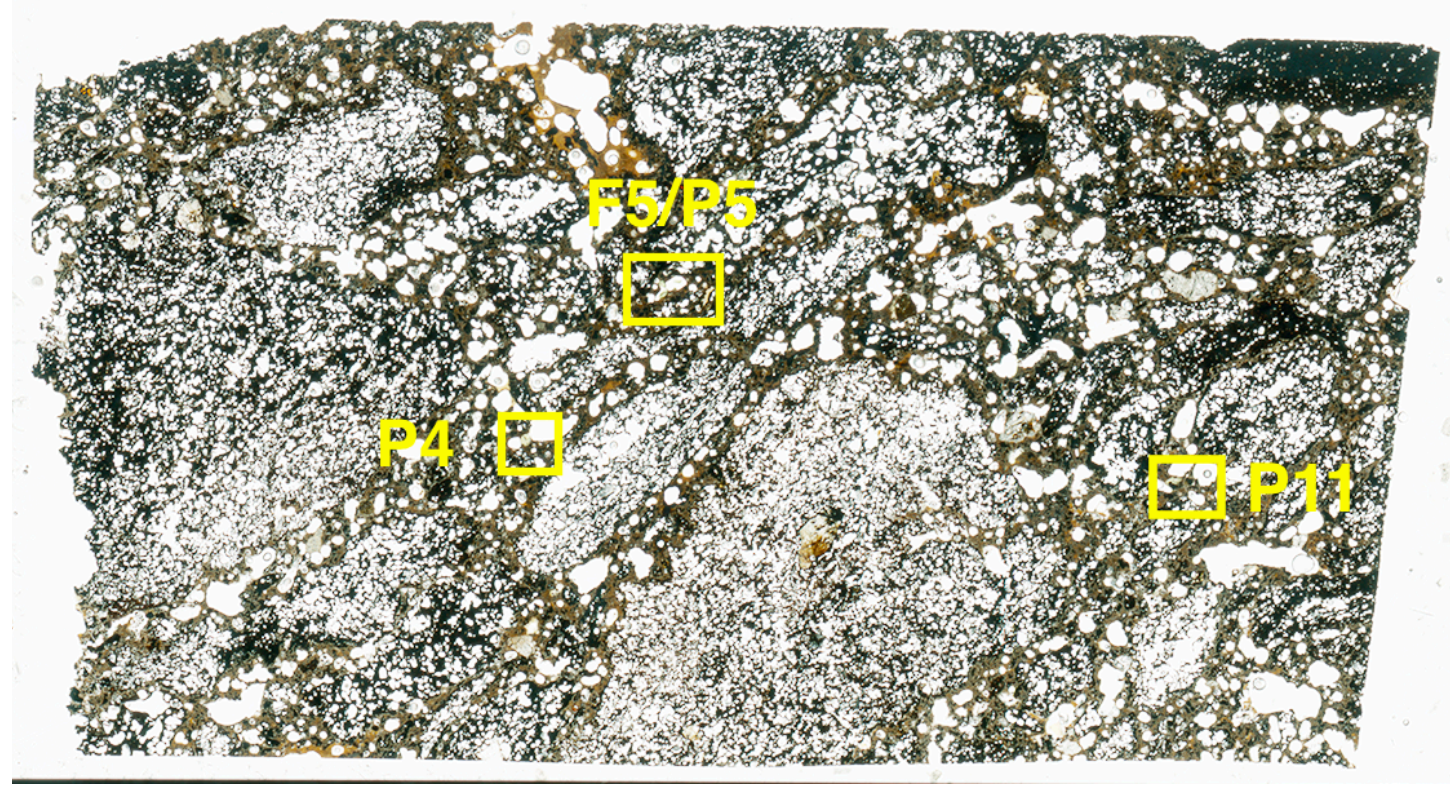

Figure 26. Thin section scan of HS-15-04e is shown in plain light with feldspar F5 and pyroxenes P4,

P5, and P11 noted. The minerals can be seen above in Figs. 22, 23, and 24. The sample has a very low degree of welding and contains a mixture of both mafic and felsic components. The felsic components are light to dark brown materials that are found between the very dark brown to black scoria clasts representing the mafic components. Welding compaction can be seen from the NW corner of the slide to the SE corner.

HS-15-04a

Located at the lowest point of the outcrop at Site 4, closest to the Littlefield Rhyolite, which is a slightly older unit positioned stratigraphically below the Wildcat Creek Tuff, is sample HS-15-04a. This sample contains a bulk silica composition of $63.47 \% \mathrm{SiO}_{2}$. This hand sample was selected from the bottom of the outcrop, just above a light colored, ash-like material located at site 4 . Scoriaceous material is more welded, the highest degree of welding in this outcrop, though no true direction can be distinguished. Very few pyroxenes can be found in this sample. Those that have been identified are 
euhedral to subhedral in shape, and are felsic-associated augite clinopyroxene as seen in Figure 27, below.

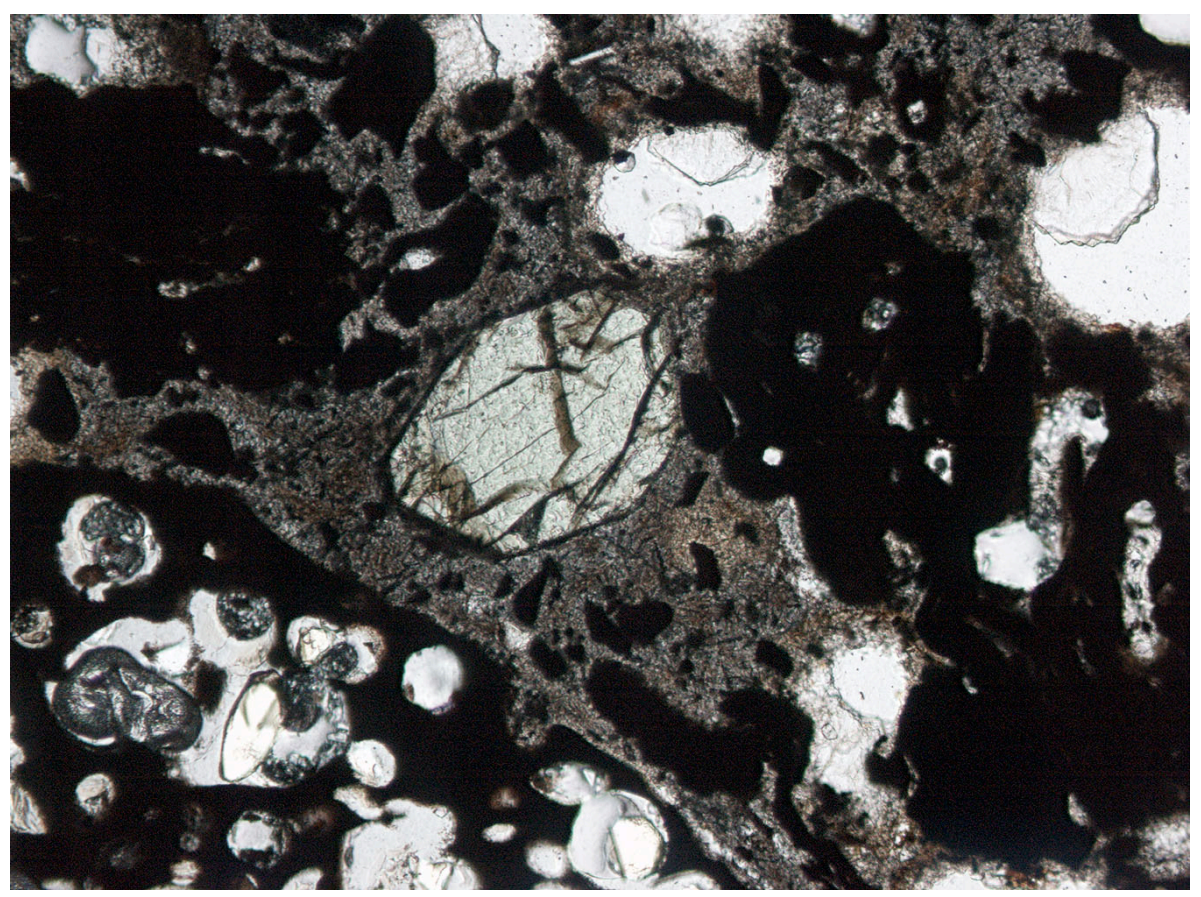

Figure 27. Euhedral, 8-sided pyroxene P5 from sample HS-15-04a as seen in plain light, magnified $100 \mathrm{x}$ in an optical microscope. It has cleavage in two directions, intersecting at $89^{\circ}$ and fractures. The mineral has high relief and a green tint. It is surrounded by felsic material and is thus, associated with the felsic component of the magma.

Rare feldspar phenocrysts are also euhedral to subhedral in shape, and primarily consist of anorthoclase, an alkali-feldspar associated with the rhyolite component of the magma system. Scoria proportionality of this sample is roughly $50 \%$, and can be seen as the darkest material in Figure 28, below. 


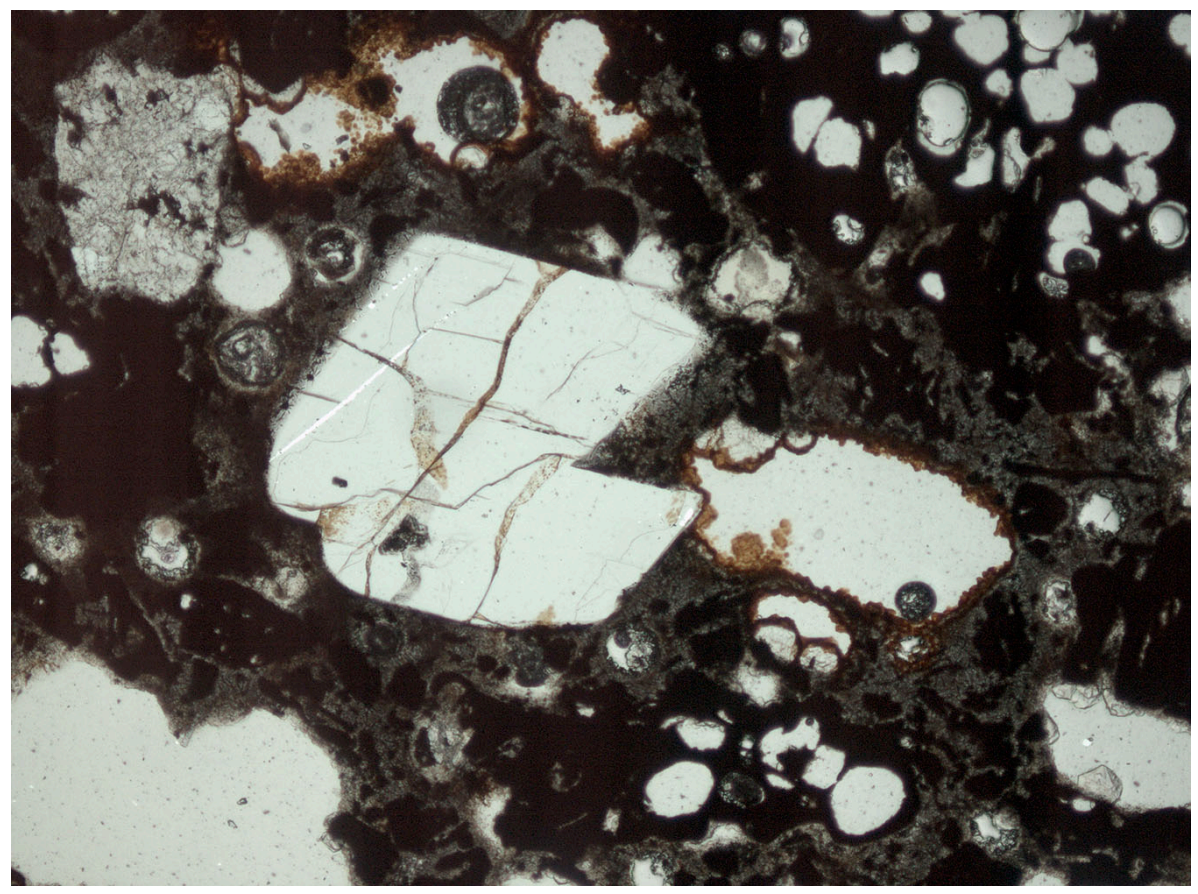

Figure 28. Feldspar F6 from sample HS-15-04a shown magnified 50x in plain light in an optical microscope. The feldspar is relatively low relief and surrounded by rhyolite material. It is subhedral to anhedral in shape and fractured.

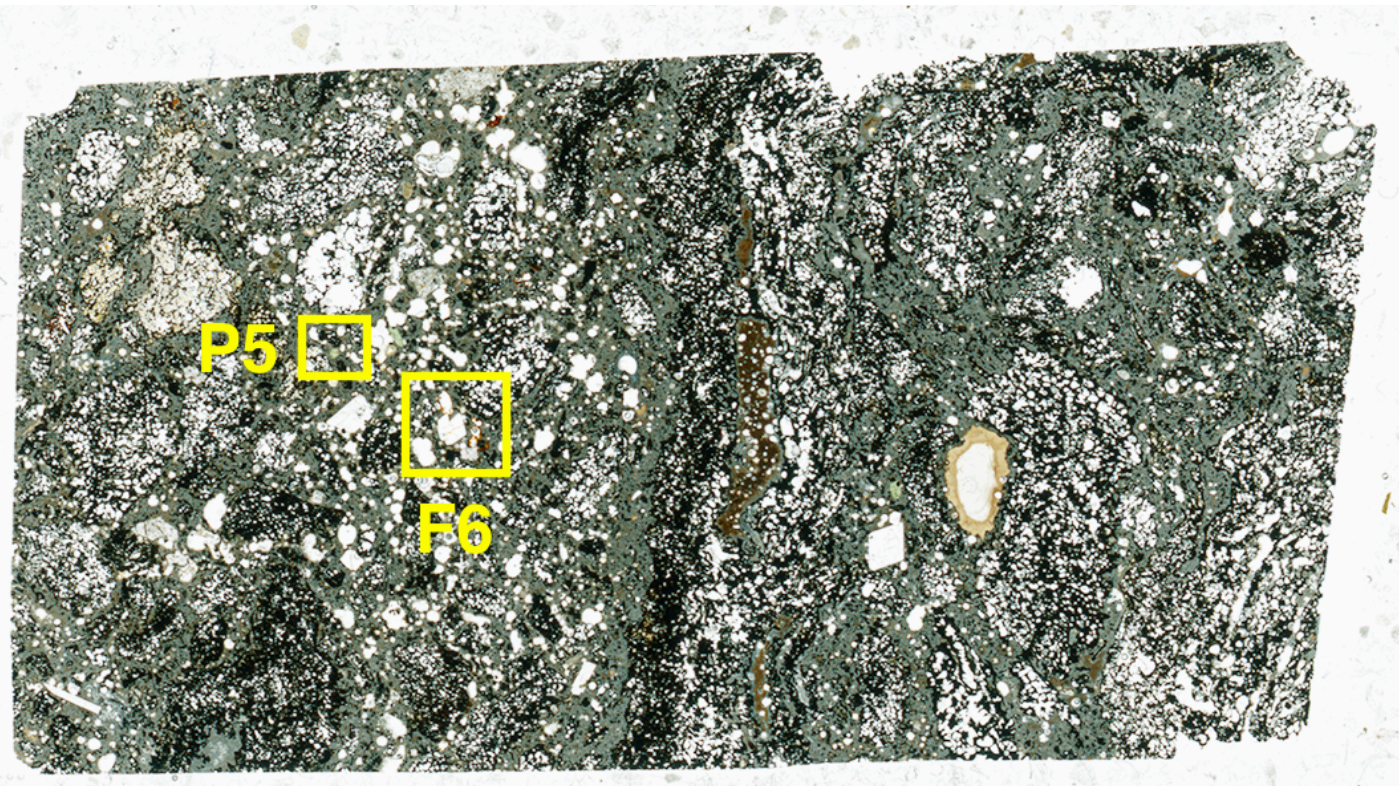

Figure 29. A thin section scan from sample HS-15-04a is shown in plain light. Pyroxene P5 and feldspar F6, as shown in Figures 26 and 27 above, are highlighted within the slide. The sample is the 
most welded of all those acquired from Site 4 and is positioned stratigraphically lowest in this outcrop.

HS-15-05

Sample HS-15-05 was taken from $43.558350^{\circ},-117.904619^{\circ}$. This trachydacite sample is partially welded, and contains $25 \%$ to $30 \%$ scoria. At $66.26 \% \mathrm{SiO}_{2}$ content in the bulk composition, it is the lightest color of the intermediate samples in the Wildcat Creek Tuff set. Slight welding foliation can be discerned as the phenocrysts and fiamme run generally in the same direction. The sample contains large lithic fragments and rare phenocrysts. The phenocrysts that are found in the sample consist largely of felsic alkalifeldspar and very few mafic pyroxenes. The feldspars are slightly fractured and with intergrown apatite and oxides, as seen below in Figure 30. Pyroxenes are highly altered, but present in felsic material as clinopyroxene. An example can be seen below in Figure 31. 


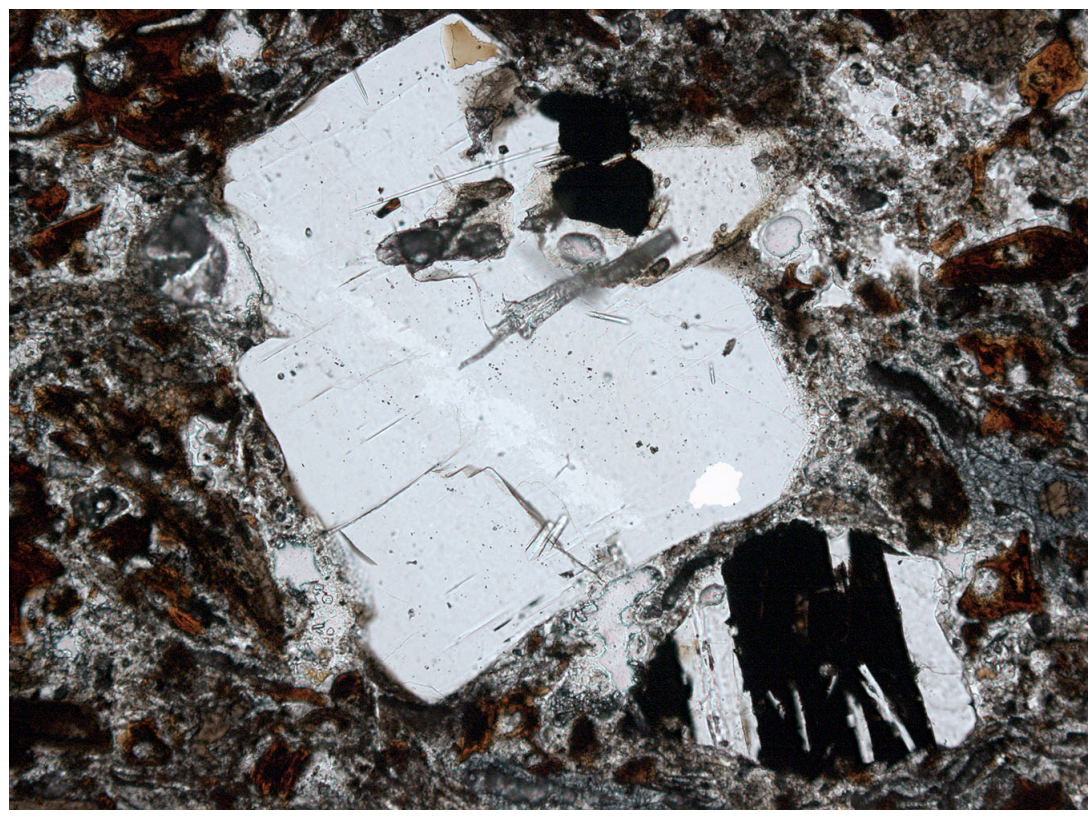

Figure 30. Feldspar F16 from sample HS-15-05 is seen in plain light, magnified 100x in a petrographic microscope. Inside the feldspar are needle-like minerals. These are apatite. Oxides minerals are found as inclusions as well, and the phenocryst are surrounded by a mixture of mafic and felsic material. The crystal has obvious cleavage and is subhedral to anhedral in shape. There is minimal cracking and pitting.

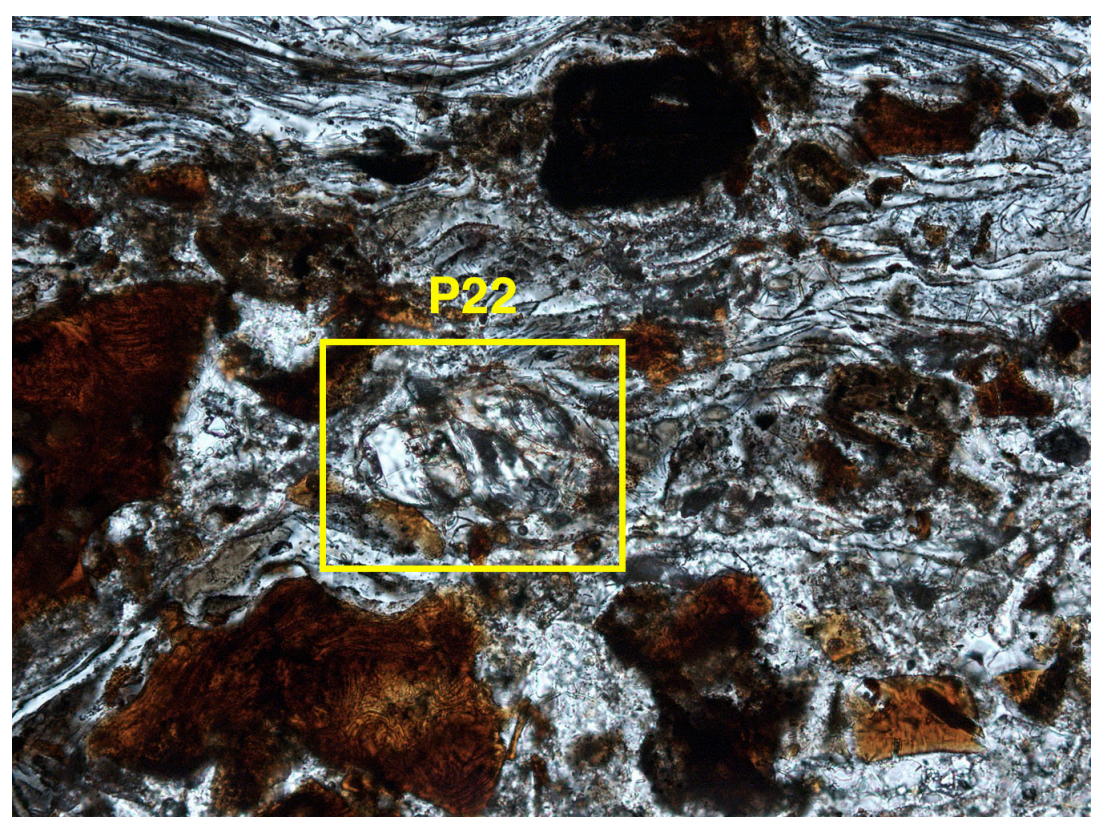


Figure 31. Clinopyroxene P22 from sample HS-15-05 is seen in plain light, magnified 200x in an optical microscope. The crystal is surrounded by felsic material and appears in high relief.

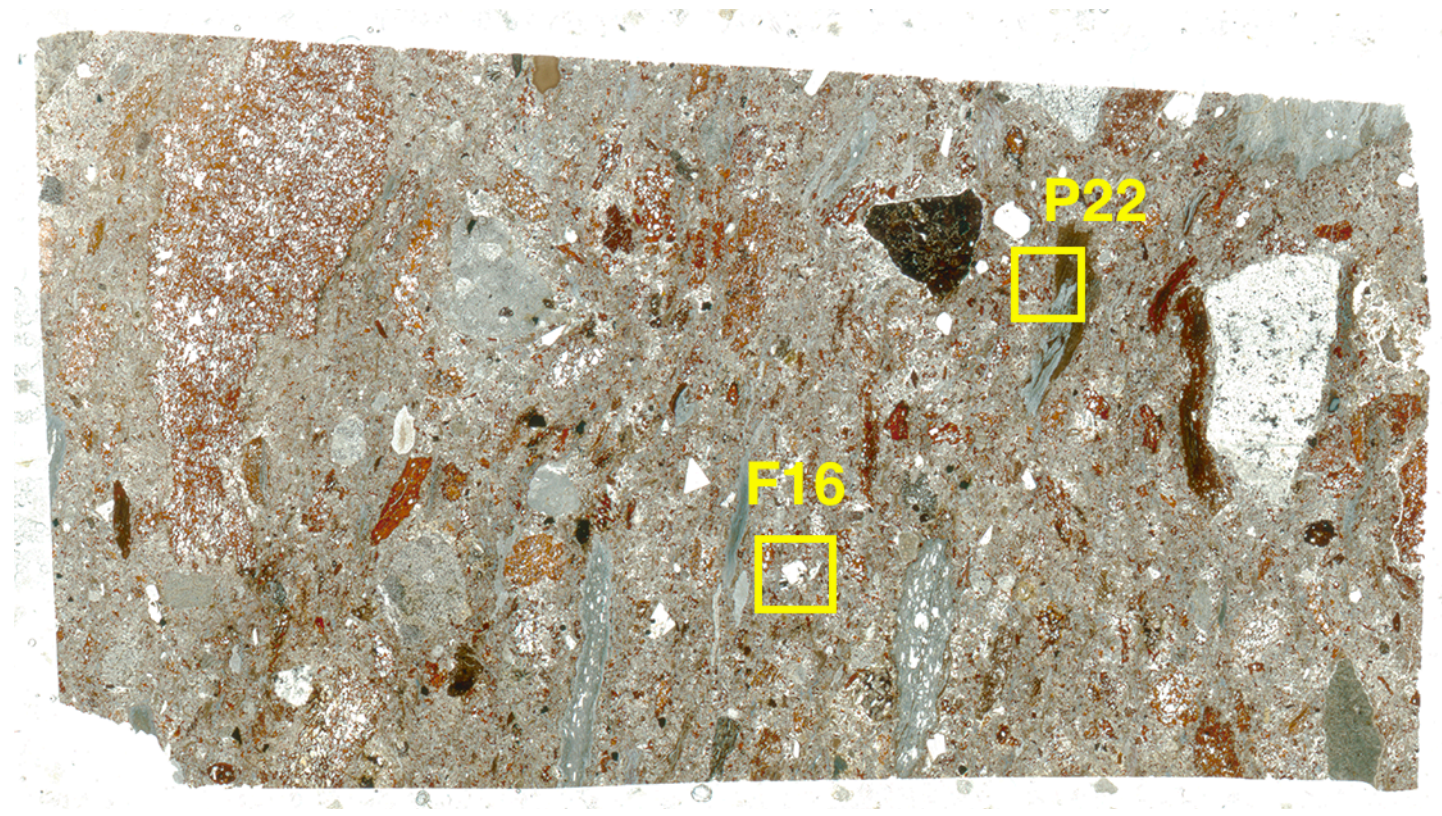

Figure 32. Thin section scan from sample HS-15-05 is seen in plain light. It is the most colorful and the lightest in overall color of the intermediate samples. Abundant fiamme of felsic glass, that are light grey, are seen throughout thin sections. Scoria of mafic composition is seen in light reddishbrown to dark reddish-brown. Lithic fragments are visible throughout the sample. Pyroxene P22, from Fig. 30 above, and feldspar F16, from Fig. 29 above, is noted. In hand sample, this sample is red in color, while in thin section, it appears very light brown and grey.

MS-14-03

Sample MS-14-03 was sampled from location $43.557967^{\circ},-117.905650^{\circ}$. It is a trachydacite with a silica content of $66.87 \%$, and it is lightly welded with an abundance of lithic fragments. Phenocryst abundance is approximately $4 \%$, while scoria abundance is roughly $40 \%$. In the Wildcat Creek Tuff sample set, this is an intermediate sample containing $66.87 \% \mathrm{SiO}_{2}$. Some welding foliation can be seen in that the sample is 
moderately welded. Very few phenocrysts are present, mostly notable are fiamme and scoriaceous inclusions. Plagioclase feldspars are fractured and pitted and are interspersed throughout mafic material. Few pyroxenes are present and they are mainly associated with felsic material, presenting as clinopyroxene.

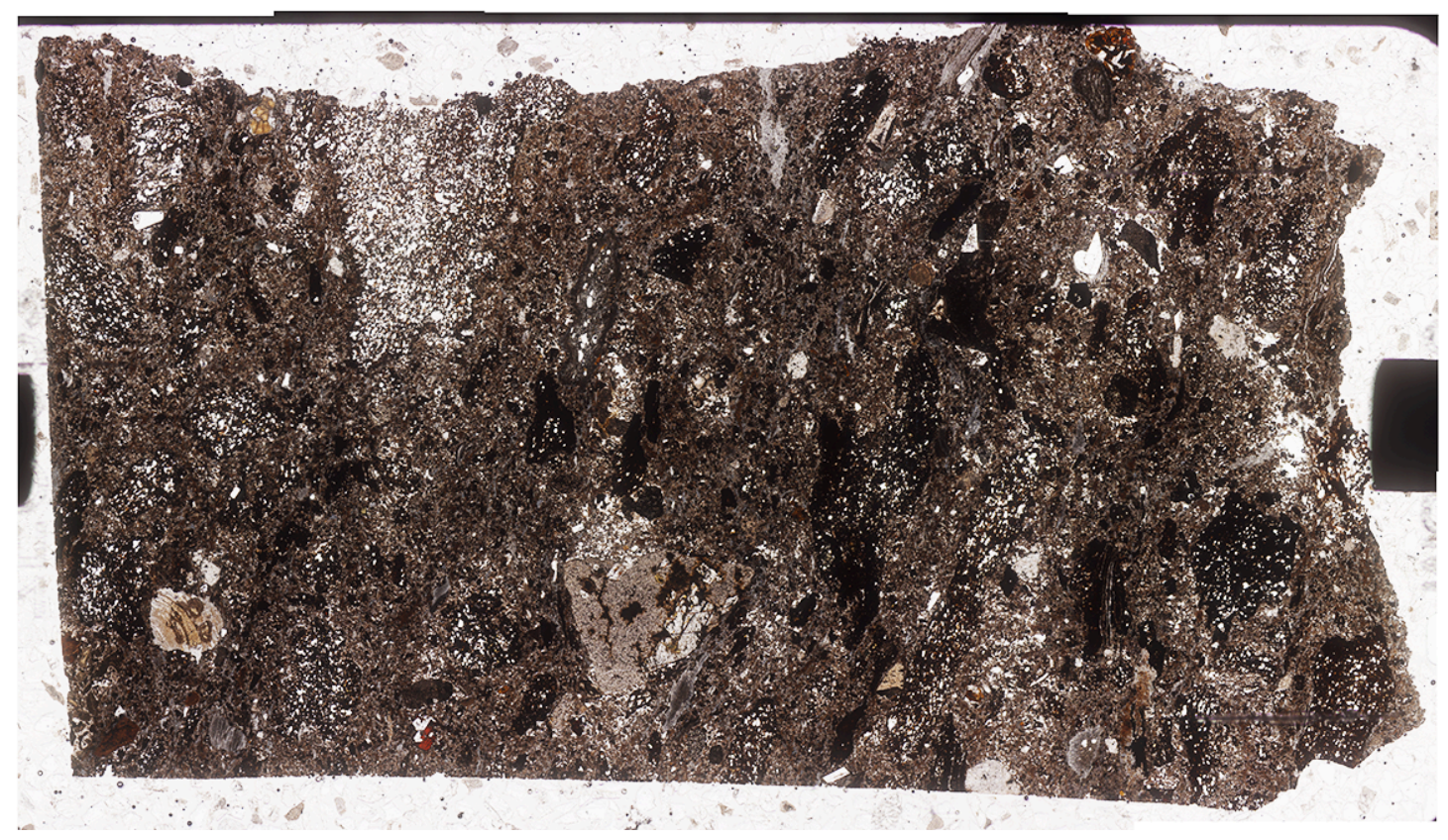

Figure 33. Thin section scan of sample MS-14-03, shown in plain light. This sample shows partial welding, abundant scoriaceous inclusions, fiamme, and very few phenocrysts.

MS-14-06

MS-14-06 was taken from location $43.572850^{\circ},-117.832100^{\circ}$. It is a trachydacite with a modal abundance of $\sim 5 \%$ phenocrysts. The texture is vitrophyric with $35 \%$ to $40 \%$ scoria. This sample has a moderate degree of welding, and pumices have partially collapsed to fiamme, but retained some vesicularity. There is a clear welding foliation visible. Phenocrysts mostly lack an apparent zonation. Some of the clinopyroxene 
crystals are associated with the rhyolitic portion of the sample. These are anhedral to subhedral and sometimes intergrown with the feldspars, as seen in Figure 34, below.

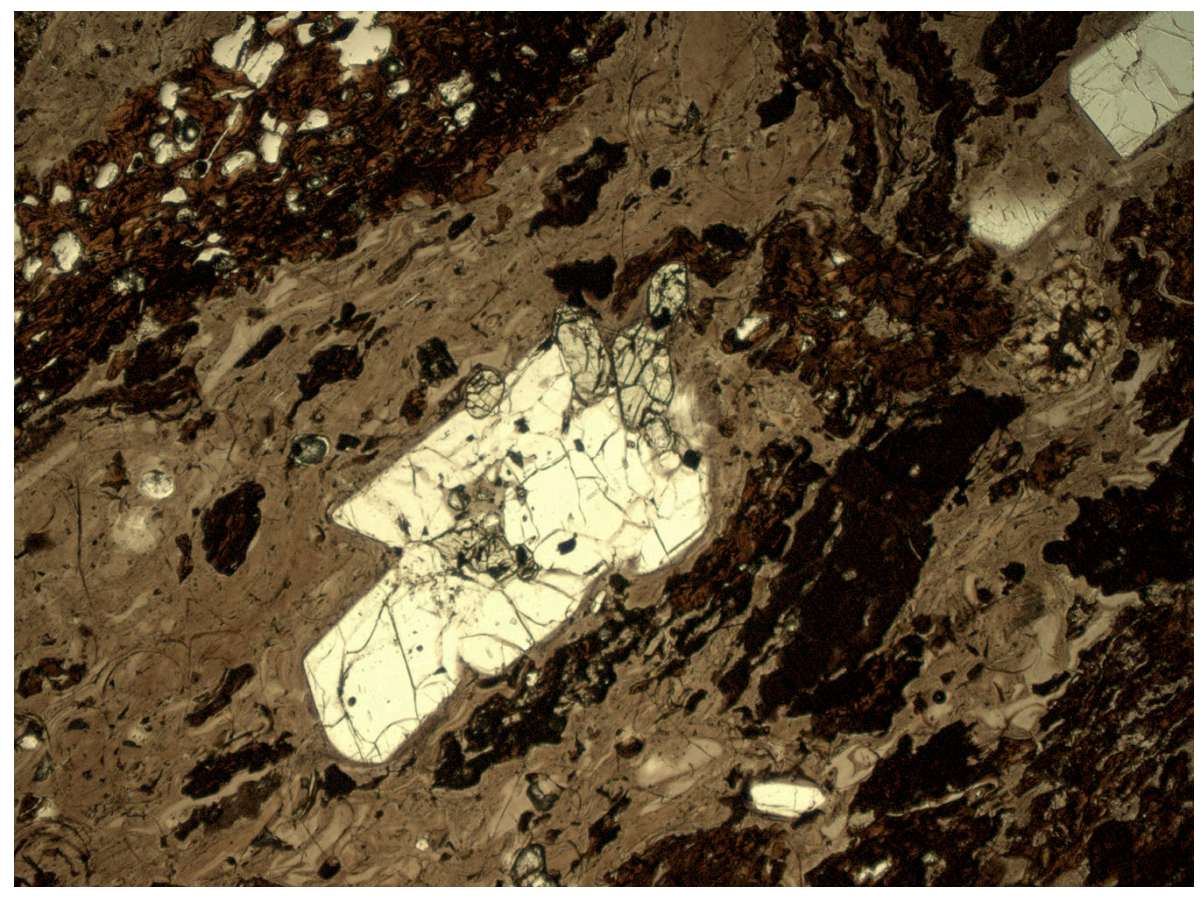

Figure 34. Pyroxenes $P 17$ from MS-14-06, magnified 25x in a petrographic microscope, are intergrown with alkali feldspar and surrounded by rhyolitic glass. The feldspar appears subhedral, as do the pyroxenes.

Feldspars are located in both the mafic and felsic constituents, with plagioclase associated with mafic material, seen in Figure 35, and alkali-feldspar in the rhyolite, as in Figure 36. 


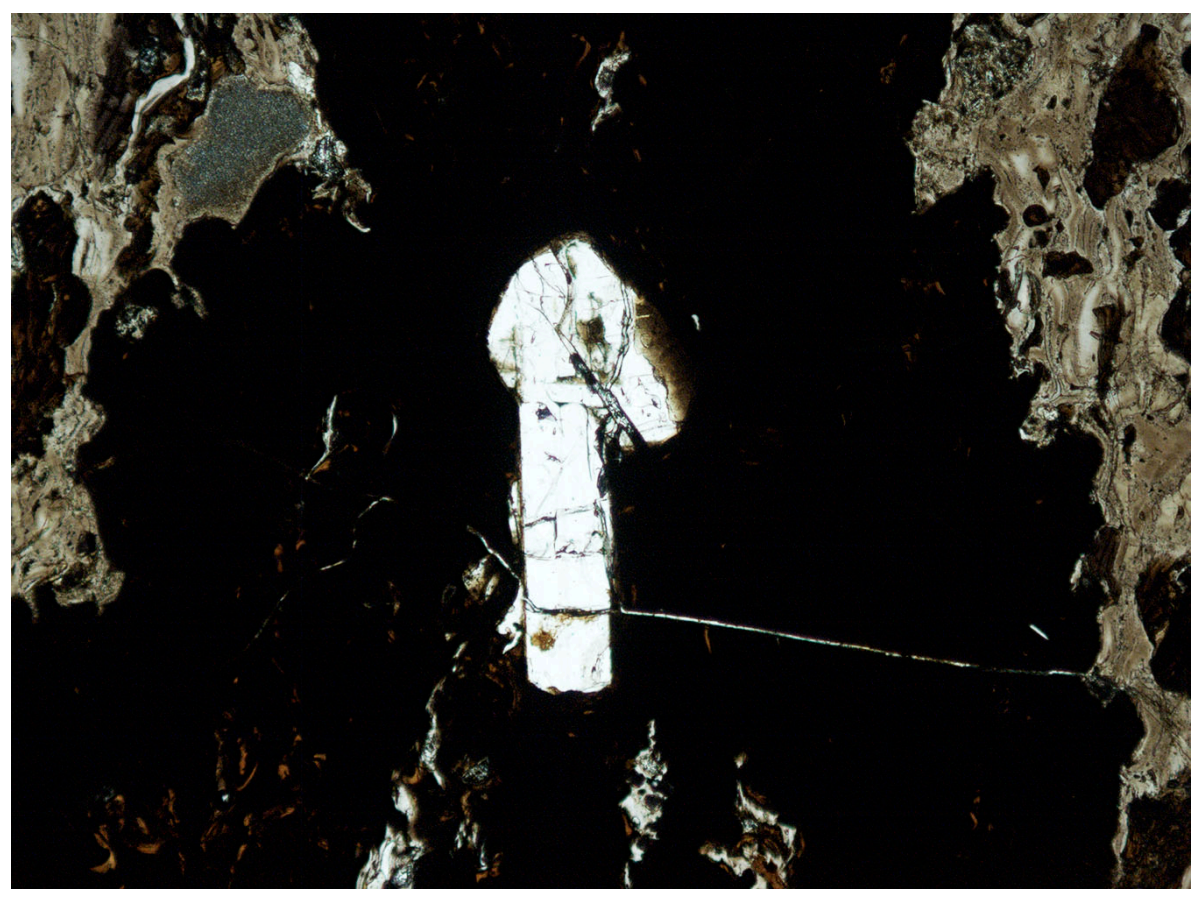

Figure 35. Intergrown plagioclase feldspar phenocrysts, F4, from sample MS-14-06, magnified 50x and shown in plain light in a petrographic microscope, are euhedral to subhedral and surrounded by dark, mafic material.

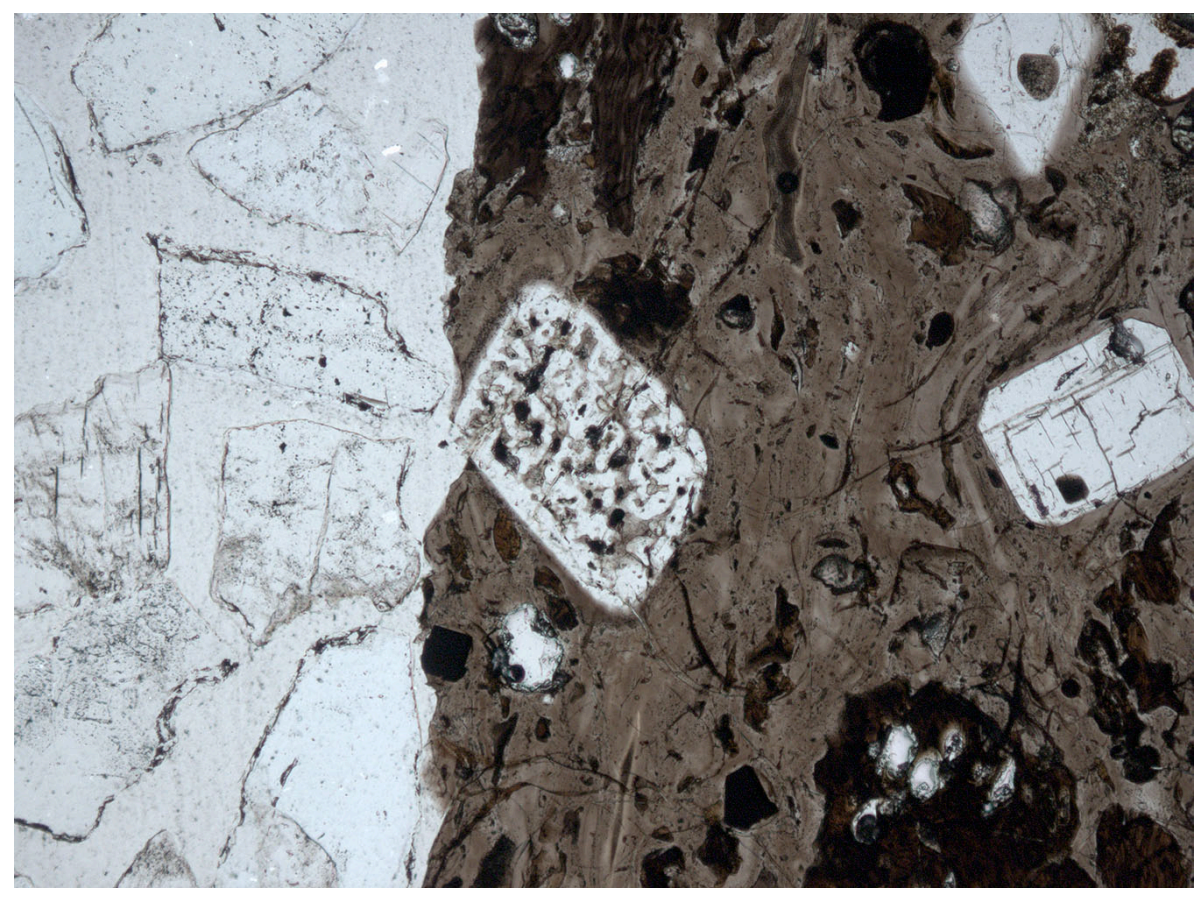


Figure 36. Two feldspar phenocrysts are shown. Alkali-feldspar F3, on the left, is surrounded by rhyolitic glass. It is magnified $50 x$ and shown in plain light in a petrographic microscope. The feldspar is subhedral in shape, but pitted and partially resorbed.

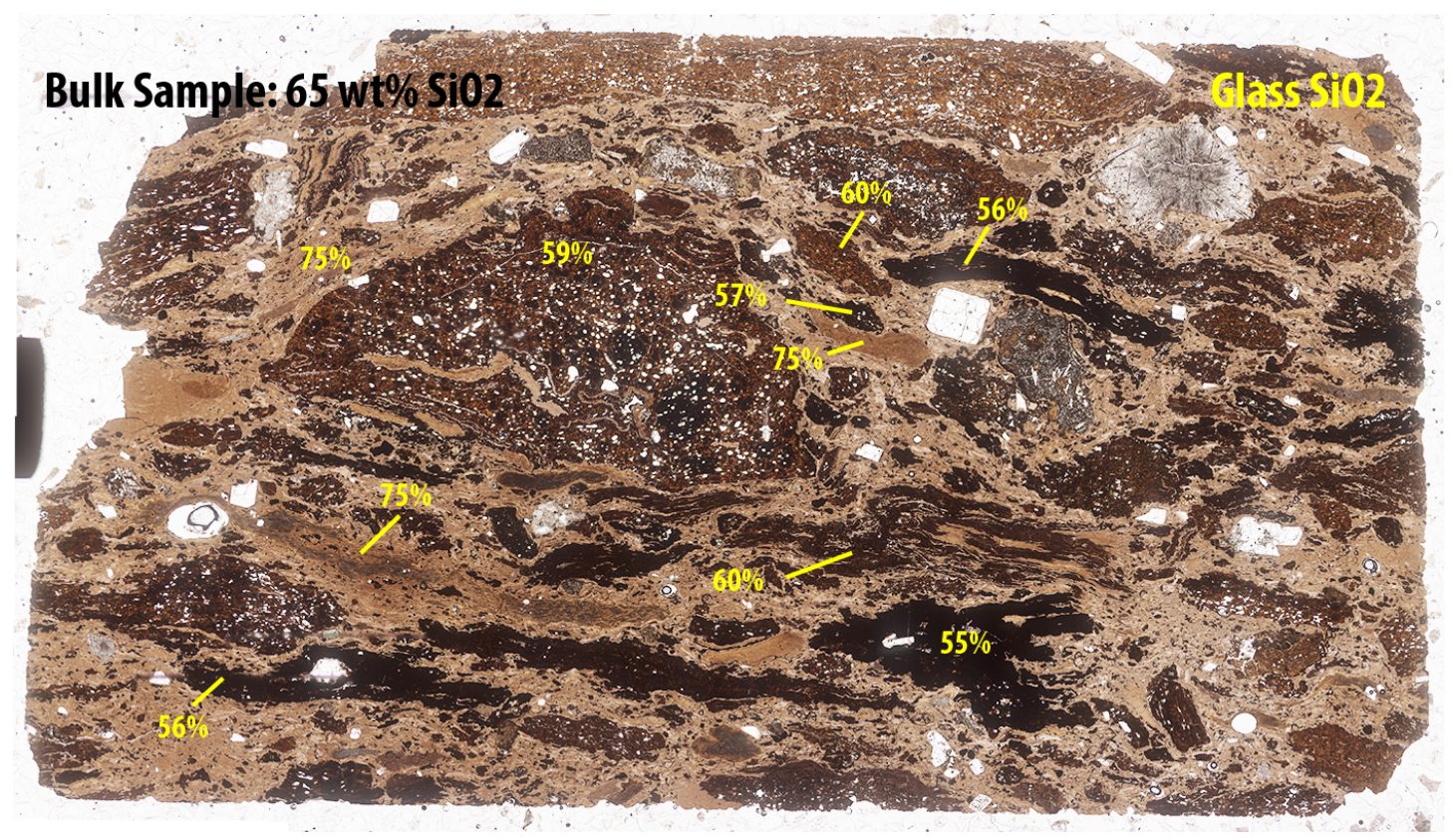

Figure 37. Scan of sample MS-14-06 is characterized by trachydacitic bulk composition with 65 wt\% SiO2. It is one of the glassiest samples of Wildcat Creek Tuff in the set, allowing for the analysis of individual components within the sample for silica content. The darkest glass of the sample is the most mafic, with $\sim 56$ wt\% SiO2, while the lighter glass ranges from 59 wt\% to 75 wt $\%$ SiO2. The largest scoriaceous inclusion measures $15 \mathrm{~mm}$ across. All of the scoriaceous inclusions are phenocryst-poor. Glass shards in the groundmass are mostly high silica rhyolite.

MS-14-05

Rhyolite sample MS1405 was taken from location $43.571700^{\circ},-117.834200^{\circ}$. This sample is a densely welded vitrophyre from the base of the outcrop with approximately $20 \%$ scoria. There are very few vesicles in this sample. There is clear welding compaction observable in thin section (Figure 38). The major minerals in this sample consist of feldspar and pyroxene with a modal abundance of 5\%. Fiamme and glass shards of rhyolitic glass can be seen throughout the sample. The most abundant 
mineral is alkali-feldspar, specifically anorthoclase and there are some pyroxene phenocrysts.

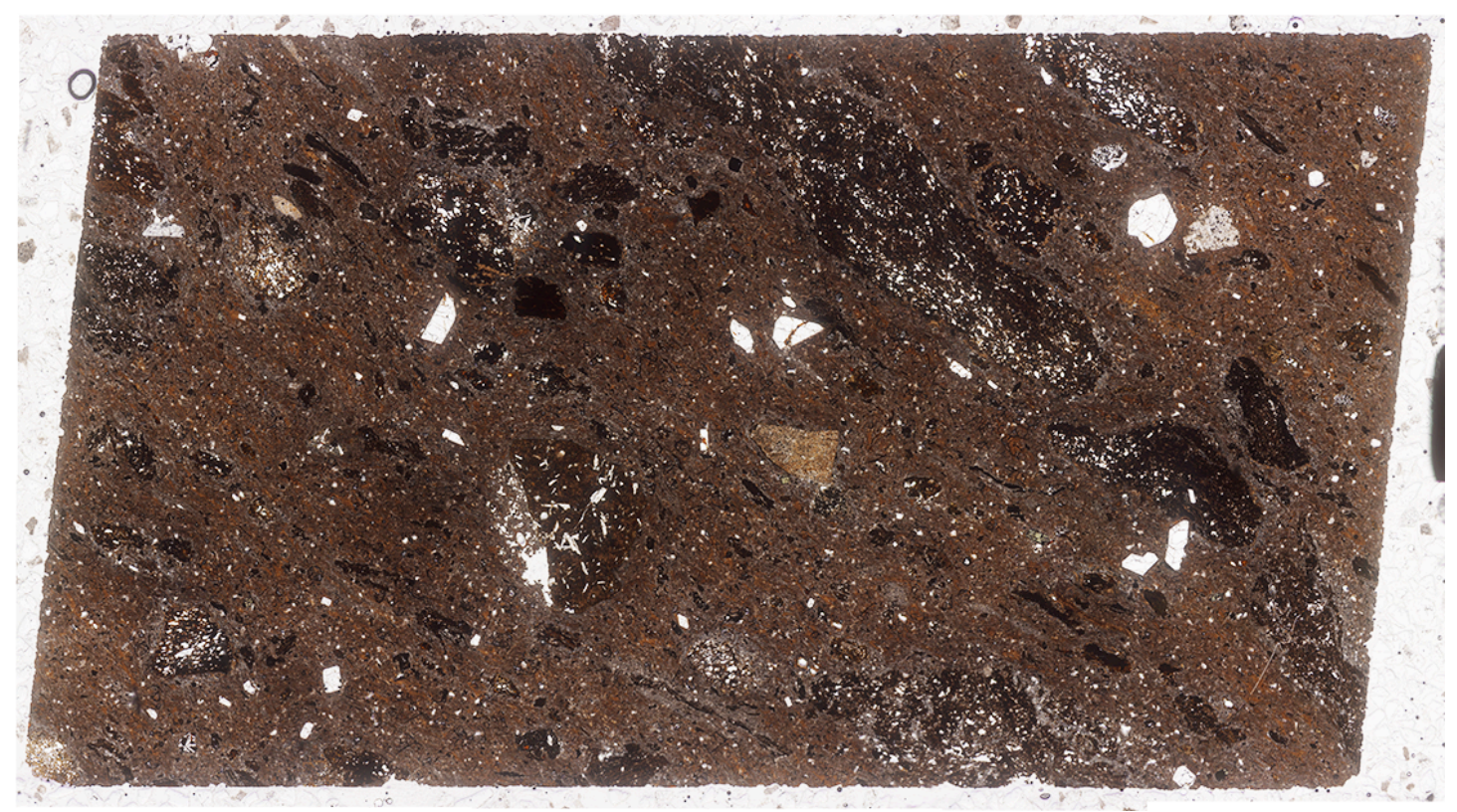

Figure 38. MS-14-05 thin section scan shown in plain light. A moderate degree of welding is apparent, as well as welding foliation. Some phenocrysts are present, mostly felsic-related alkalifeldspar, though few pyroxenes do exist in the sample.

\section{GLASS COMPOSITION}

Microprobe data were acquired for glass in two of the Wildcat Creek Tuff samples. Sample MS-14-05 is a rhyolite in bulk composition, and the $\mathrm{SiO}_{2}$ content of the two analyzed areas was averaged to $75 \%$ and $74 \%$. Sample MS-14-06 contained a mixture of rhyolitic glass and andesitic glass. Six sites were analyzed, G1 through G6 (Fig. 38 shows G1-G4). The comingled textures are evident in sample MS-14-06. (Fig. 37 in the previous sample). The EMP data confirmed that G1, the darkest in color, is the least silicic, and at $55 \% \mathrm{SiO}_{2}$ is basaltic-andesite. $\mathrm{G} 2$ a medium brown glass, yielded 
$60 \% \mathrm{SiO}_{2}$. G3, another dark, andesitic glass is $57 \% \mathrm{SiO}_{2}$. The last, $\mathrm{G} 4$, is the lightest glass analyzed by EMP and at $75 \% \mathrm{SiO}_{2}$ and it is therefore a rhyolite glass. The composition and complexities of the mingling textures are most obvious in this thin section, and the bulk composition reflects the mixture. It is an intermediate trachydacite with $66 \% \mathrm{SiO}_{2}$. All glass analyses are available in Appendix D, and the EMP glass is plotted in Figure 40.

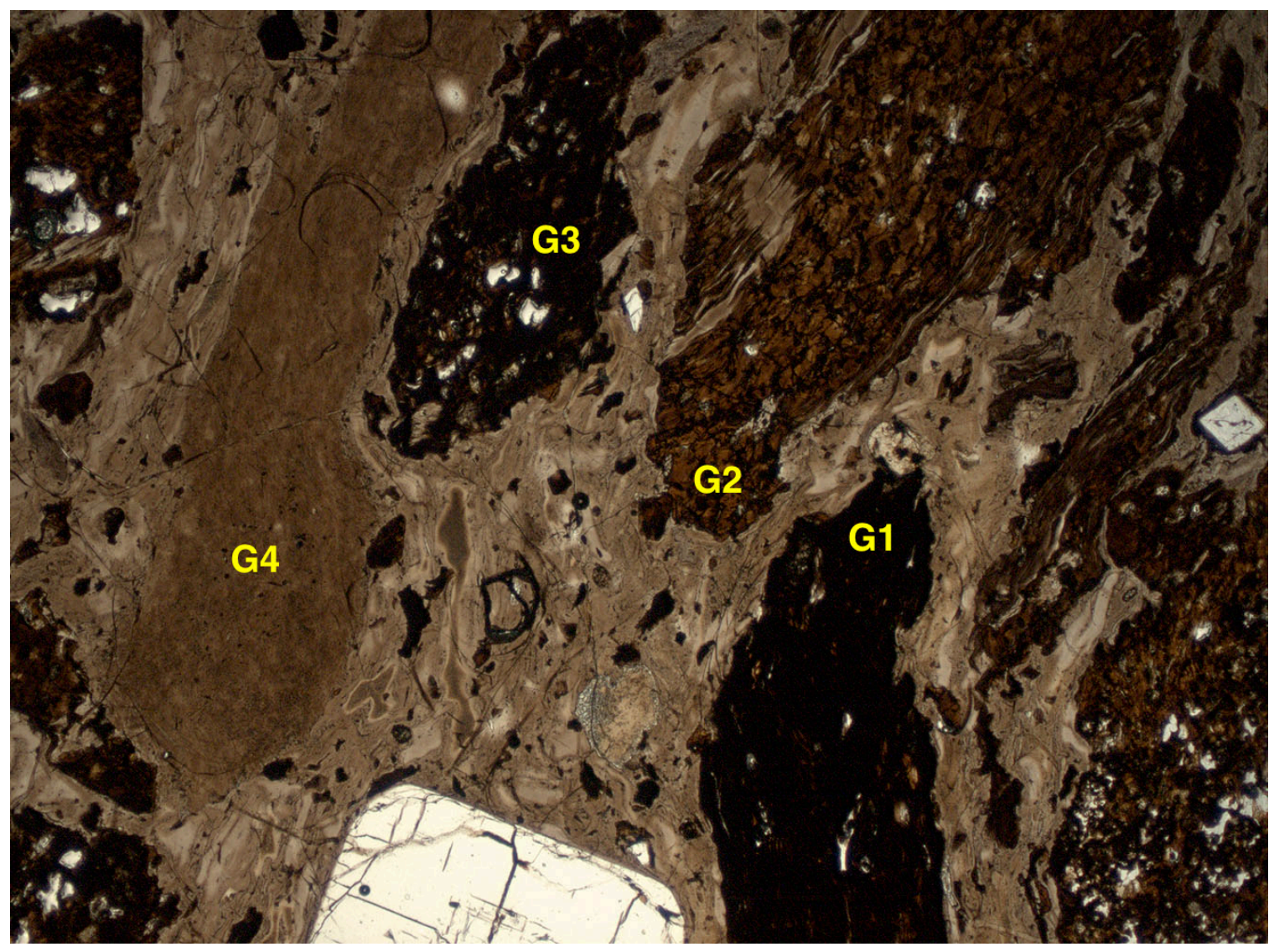

Figure 39. Magnified at 25x, this plain light image from a petrographic microscope of MS-14-06 shows the comingling textures of andesitic and rhyolitic glass. One of the least welded samples in the Wildcat Creek Tuff data set, the varied glass colors show andesite (G1, the darkest at $55 \% \mathrm{SiO}_{2}$ and G3 at $\left.57 \% \mathrm{SiO}_{2}\right)$, dacite ( $\mathrm{G} 2$ at $\left.60 \% \mathrm{SiO}_{2}\right)$, and rhyolite (G4, the lightest at $\left.74 \% \mathrm{SiO}_{2}\right)$. 


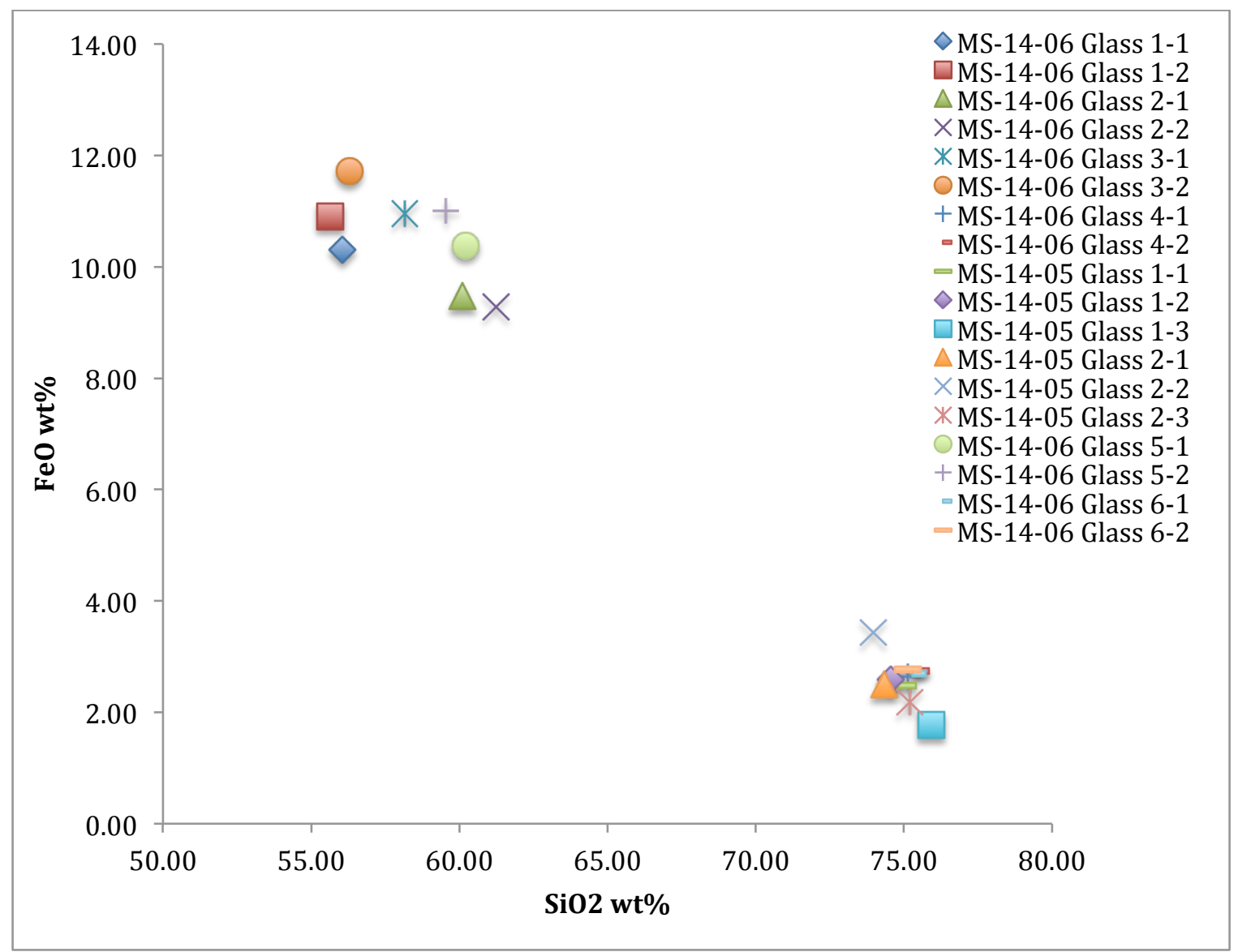

Figure 40. Plot of all EMP analyzed glass. Analysis of glass compositions by electron microprobe for two of the Wildcat Creek Tuff samples show that there is rhyolite glass present in the samples as well as mafic glass. The mafic glass falls into two categories: basaltic andesite ranging from $55 \%$ to $56 \%$ $\mathrm{SiO}_{2}(\mathrm{wt} \%)$ and andesite ranging from $58 \%$ to $61 \% \mathrm{SiO}_{2}(\mathrm{wt} \%)$. The silicic glass ranges from $74 \%$ $\mathrm{SiO}_{2}(\mathrm{wt} \%)$ to $76 \% \mathrm{SiO}_{2}(\mathrm{wt} \%)$ close to the rhyolite bulk composition. 


\section{GEOCHEMISTRY OF BULK SAMPLES}

The samples collected from the Wildcat Creek Tuff range from andesite to rhyolite. The most mafic rocks are trachyandesite and the most felsic are rhyolite. The silica content ranges from $\sim 60 \% \mathrm{SiO}_{2}$ in the most mafic sample, $\mathrm{HS}-15-04 \mathrm{e}$, to $\sim 74 \%$ $\mathrm{SiO}_{2}$ in the most rhyolitic sample, HS-15-06a. This can be seen in the Total Alkali Silica diagram of Fig. 41. Data of bulk analyses can be found in Appendices B and C.

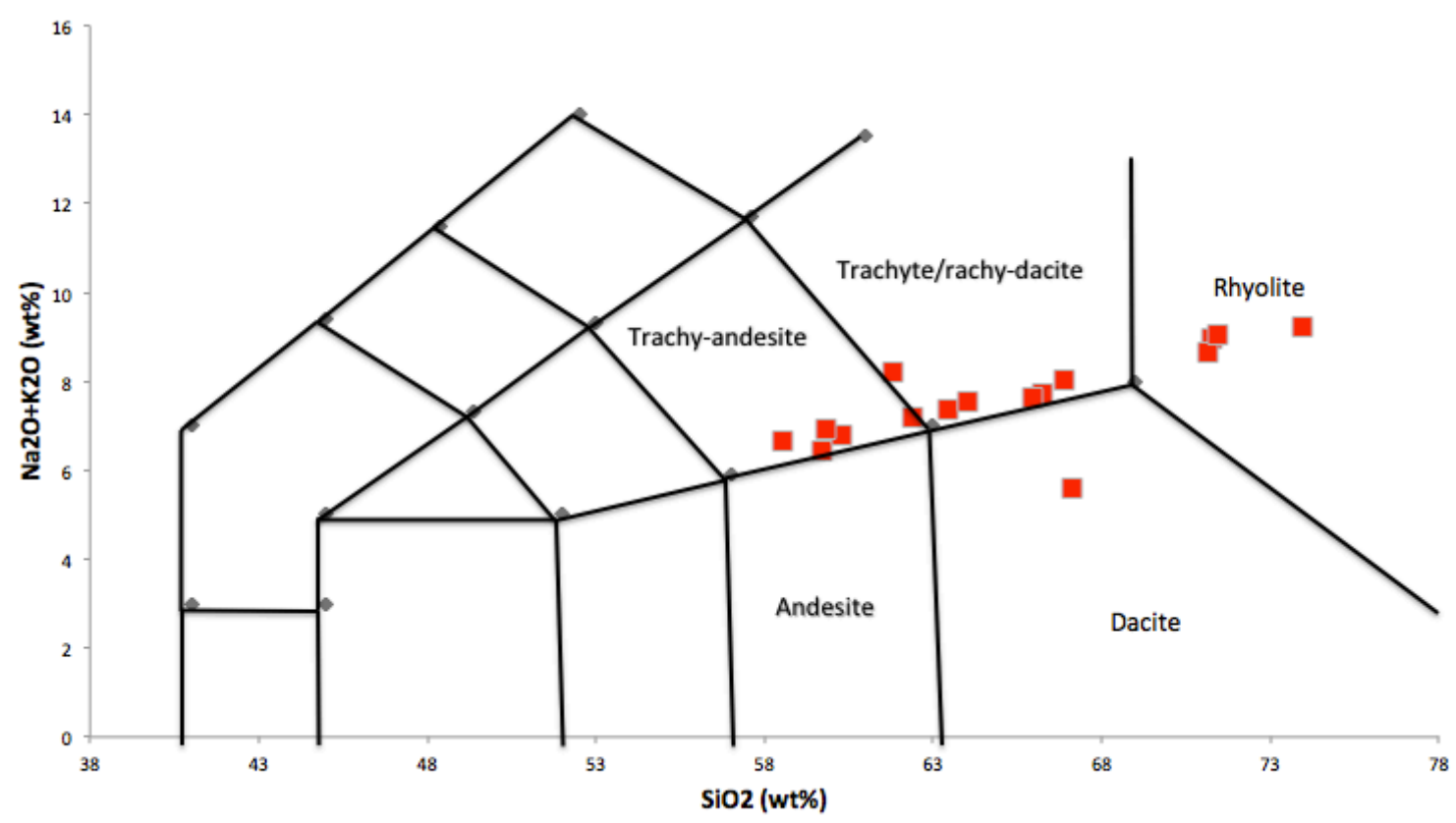

Figure 41. Total Alkali-Silica classification diagram (LeBas, 1986) for all Wildcat Creek Tuff samples. Samples range from trachyandesite to Rhyolite straddling the alkali/subalkalic boundary. One sample with a dacitic bulk composition falls off the trend. This outlier is sample HS154F.

Figure 42 shows the normalized trace element concentrations of the Wildcat Creek Tuff samples for which ICP-MS data were acquired. Although patterns are vertically offset there is an overall great similarity confirming they a sampling a single 
magma batch. All samples indicate a relative depletion at $\mathrm{Sr}, \mathrm{P}$, and $\mathrm{Ti}$ and all have a peak at lead and potassium. The range of $\mathrm{Sr}$ of all samples is from just $65 \mathrm{ppm} \mathrm{Sr}$ in sample HS-15-06a to $295 \mathrm{ppm}$ in sample HS-15-04e. The lowest level is associated with the highest silica rhyolitic sample, and the highest with the most mafic.

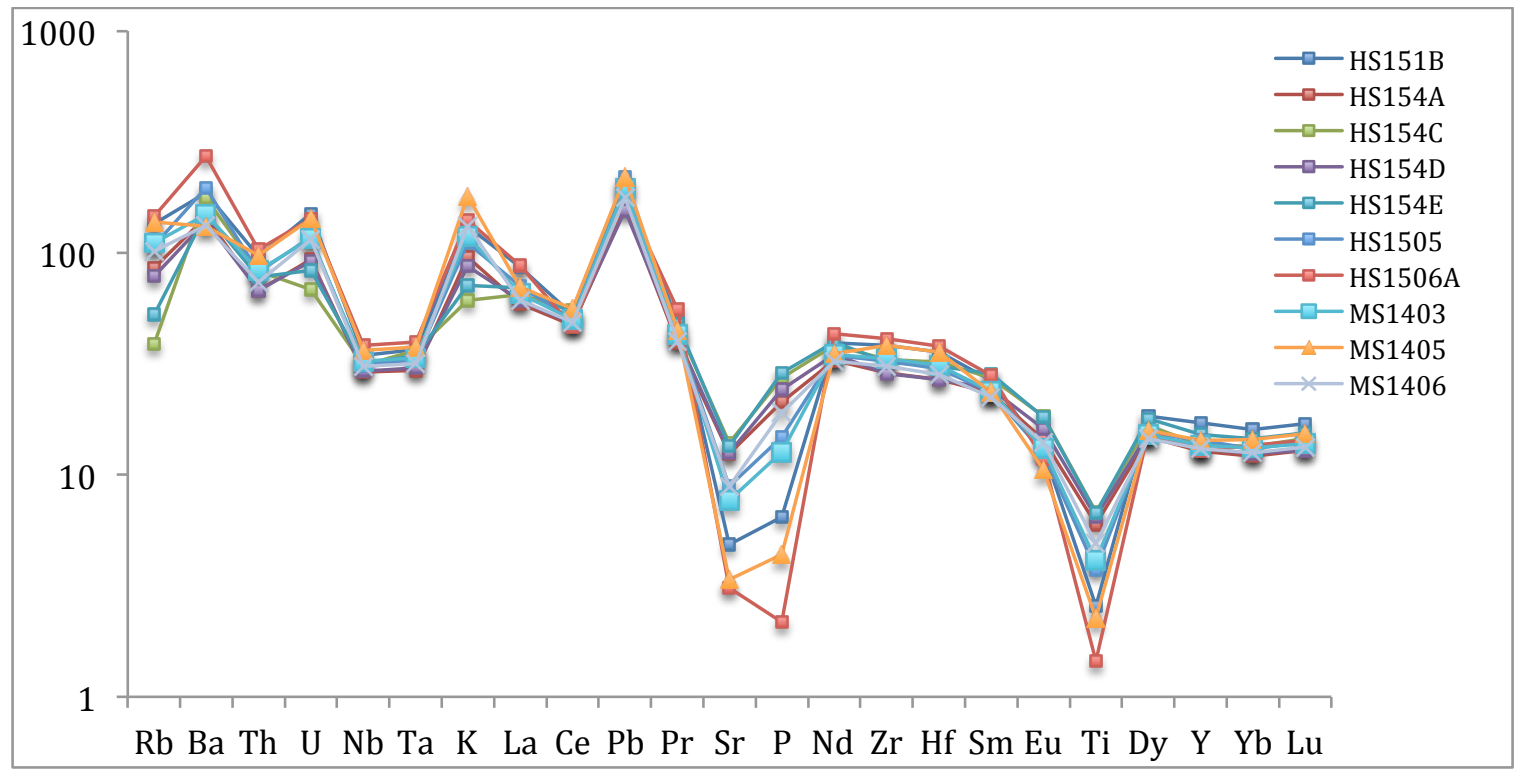

Figure 42. Primitive mantle normalized (Sun \& McDonough, 1989) incompatible trace element diagram displaying compositions of Wildcat Creek Tuff samples.

Rare earth elements were plotted for the Wildcat Creek Tuff samples (Fig. 43) to further illustrate elemental patterns of mafic and felsic components of the system using C1 chondrite normalization values (McDonough \& Sun, 1995). These include the most mafic samples, HS-15-04e, with $\sim 60 \% \mathrm{SiO}_{2}$, and HS-15-05, MS-14-03, and MS-14-06, all at $\sim 66 \% \mathrm{SiO}_{2}$ (Fig. 43). 


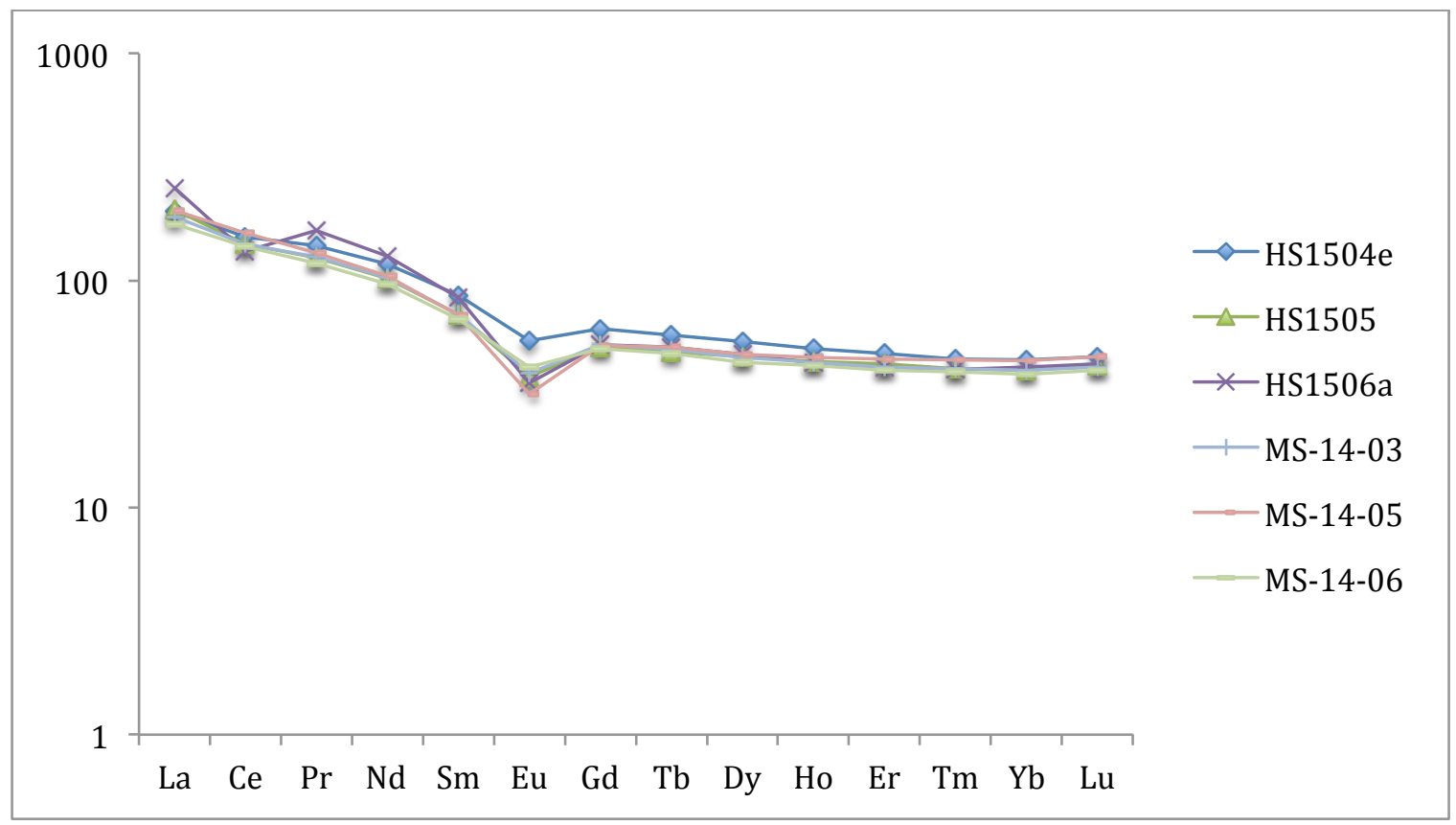

Figure 43. C1 chondrite normalized (McDonough \& Sun, 1995) Wildcat Creek Tuff samples. All samples show a general decrease in enrichment until Er, including a negative europium anomaly. This is similar to other rhyolites from eastern Oregon. HS-15-04e is the most mafic sample in the set, showing less depletion in all elements than the more silicic samples.

Major element variation diagrams were generated to determine patterns and trends in the data. All major elements $\left(\mathrm{TiO}_{2}, \mathrm{Al}_{2} \mathrm{O}_{3}, \mathrm{FeO}, \mathrm{MnO}, \mathrm{MgO}, \mathrm{CaO}, \mathrm{Na}_{2} \mathrm{O}, \mathrm{K}_{2} \mathrm{O}\right.$, and $\mathrm{P}_{2} \mathrm{O}_{5}$ ) were plotted against $\mathrm{SiO}_{2}$. Clear negative correlations are evident in plots of $\mathrm{FeO}$ and $\mathrm{TiO}_{2}$, and $\mathrm{P}_{2} \mathrm{O}_{5}$ versus $\mathrm{SiO}_{2}$, seen in figures 44,45 , and 46 , below. As silica increases, $\mathrm{FeO}, \mathrm{TiO}_{2}$, and $\mathrm{P}_{2} \mathrm{O}_{5}$ all decrease. Included in these diagrams are also Wildcat Creek Tuff data collected by Hooper et al. (2002). The full range of major element variation diagrams can be found in Appendix J. 


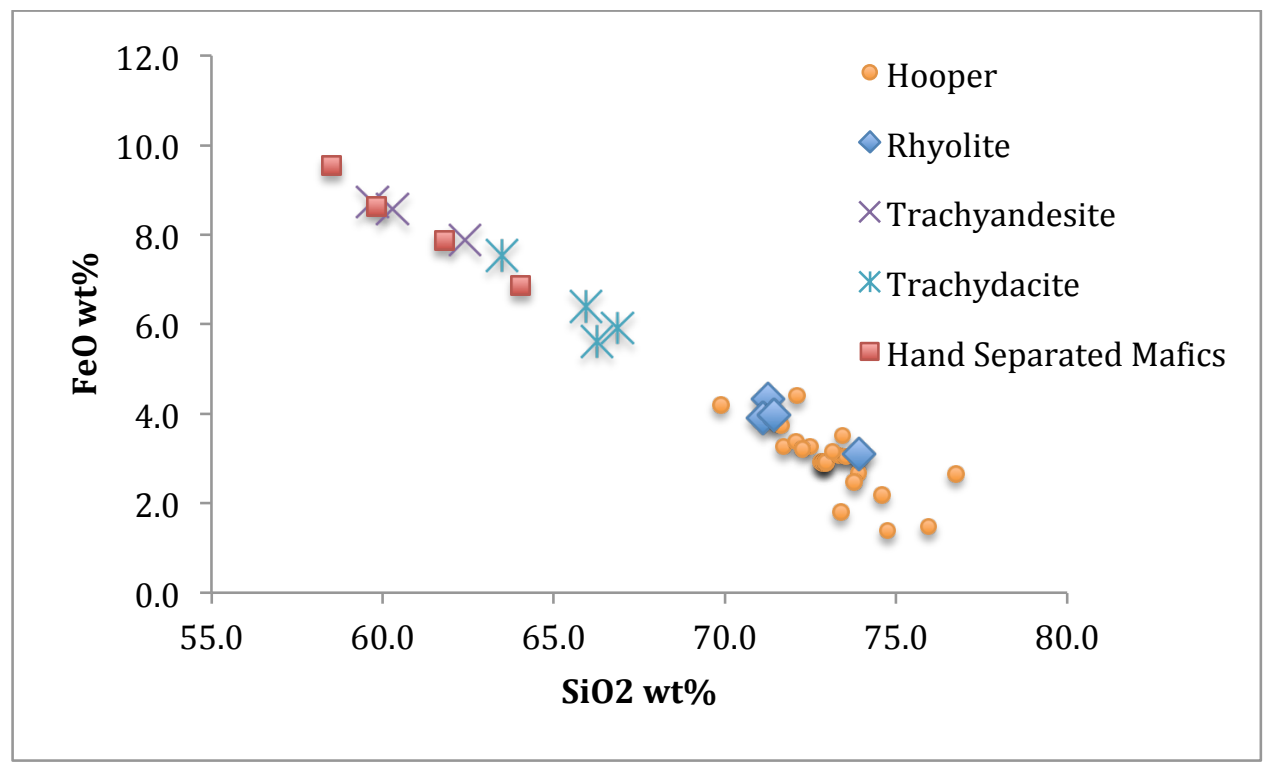

Figure 44. Major element variation diagram of $\mathrm{FeO}$ vs. $\mathrm{SiO}_{2}$. As silica content increases, iron content decreases, moving from the most mafic samples to the most rhyolitic. The orange circles are data by Hooper et. al. (2002).

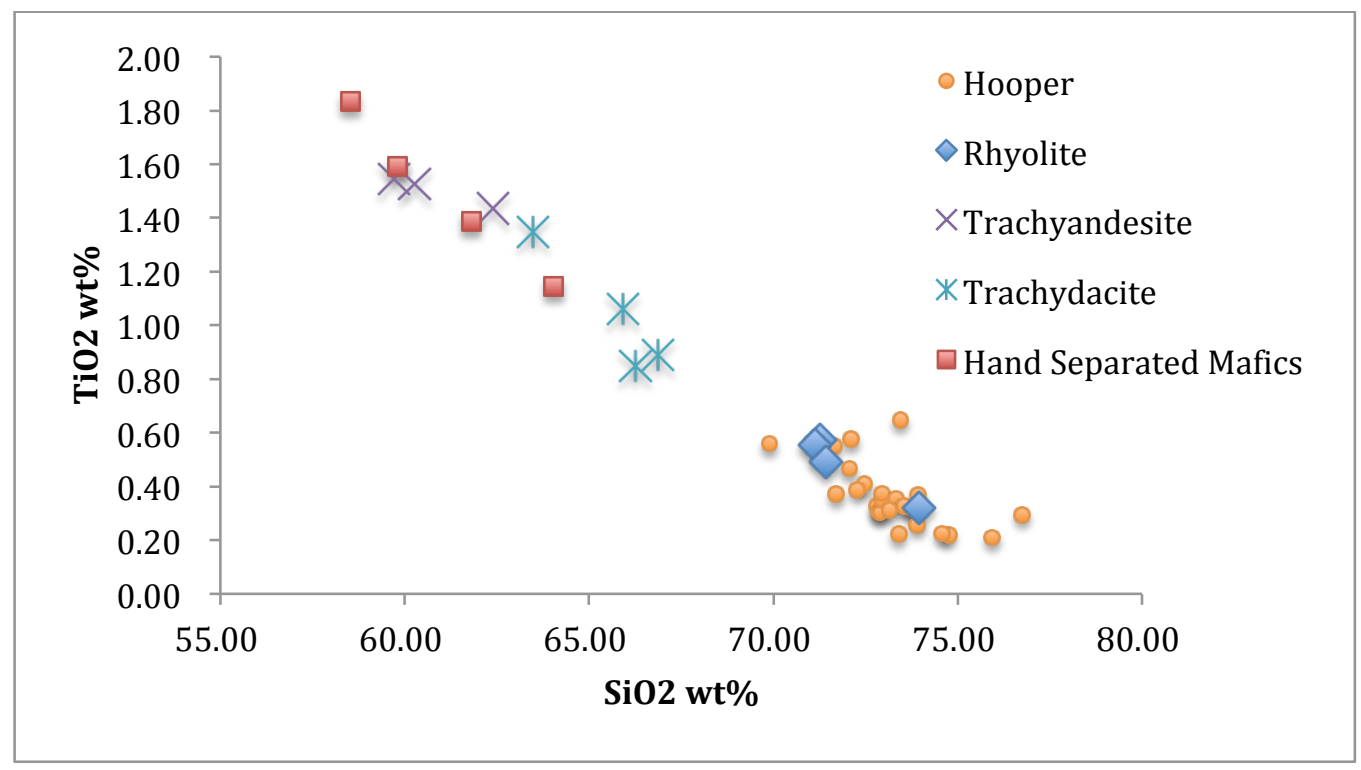

Figure 45. Major element variation diagram of $\mathrm{TiO}_{2}$ vs. $\mathrm{SiO}_{2}$. As silica increases $\mathrm{Ti}$ decreases in $\mathrm{Ti}$ from the most mafic to the most felsic sample. Orange circles are data by Hooper et. al. (2002). 


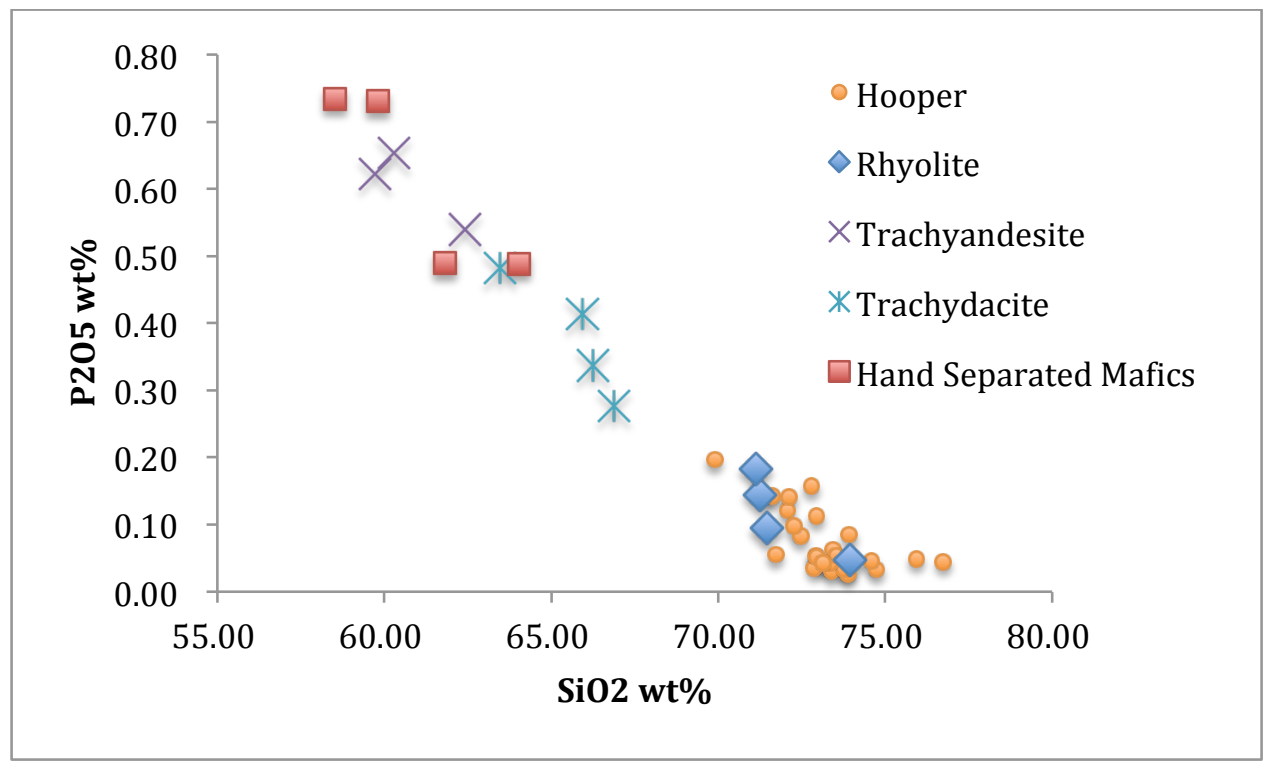

Figure 46. Major element comparison diagram featuring $\mathrm{P}_{2} \mathrm{O}_{5}$ vs. $\mathrm{SiO}_{2}$. As silica increases from least to most felsic, phosphorous decreases. Orange circles are data by Hooper et. al. (2002).

Major elements were also compared to some trace elements to further determine any patterns present in the data. The most linear correlation is between strontium and silica ( $\mathrm{Sr}$ vs. $\mathrm{SiO}_{2}$ ). Seen below in Fig. 47, $\mathrm{Sr}$ decreases as $\mathrm{SiO}_{2}$ increases.

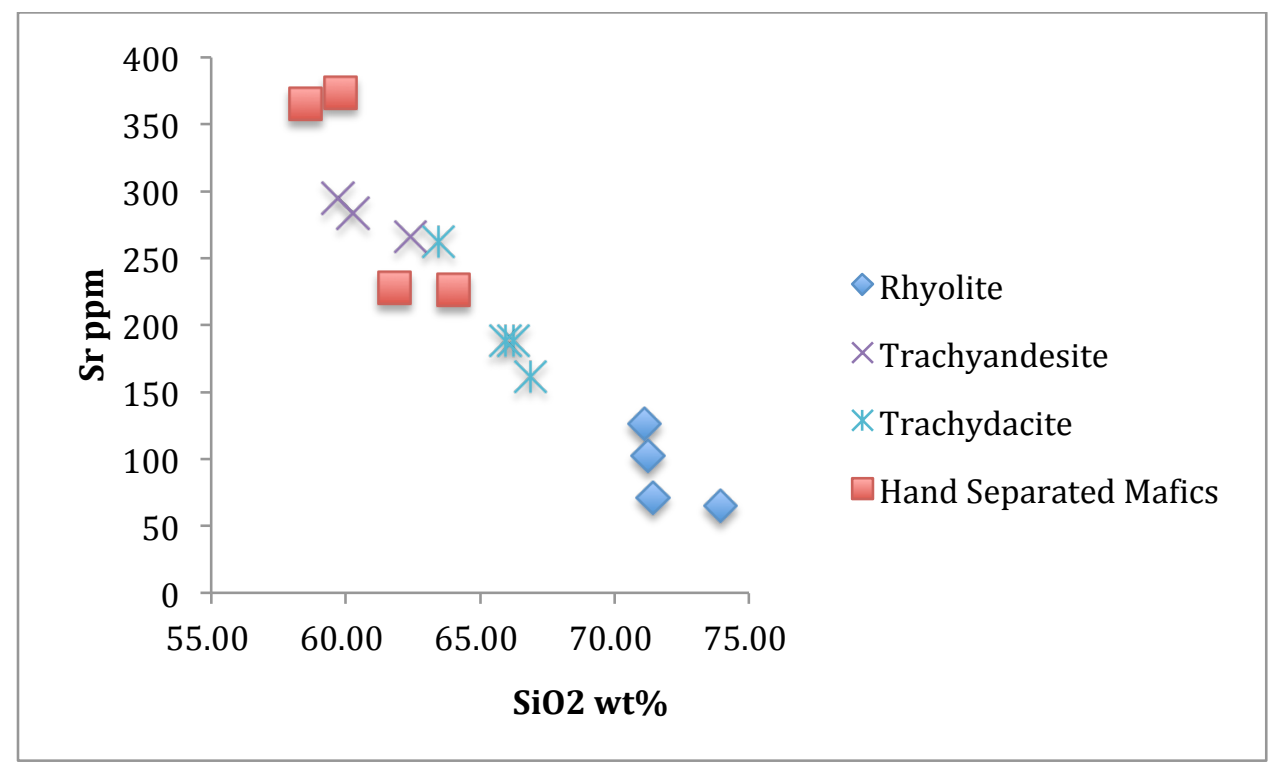

Figure 47.Sr vs. $\mathrm{SiO}_{2}$ plot featuring $\mathrm{Sr}$ plot. As silica increases from mafic to felsic, Sr decreases. The range of $\mathrm{Sr}$ is from 295ppm in an andesitic sample to as low as just 65ppm in a rhyolitic sample. 
Variations diagrams using trace elements were plotted for many combinations, all of which are available in Appendices K and L. Relationships were found to be especially linear in the case of Th vs. $\mathrm{Nb}$.

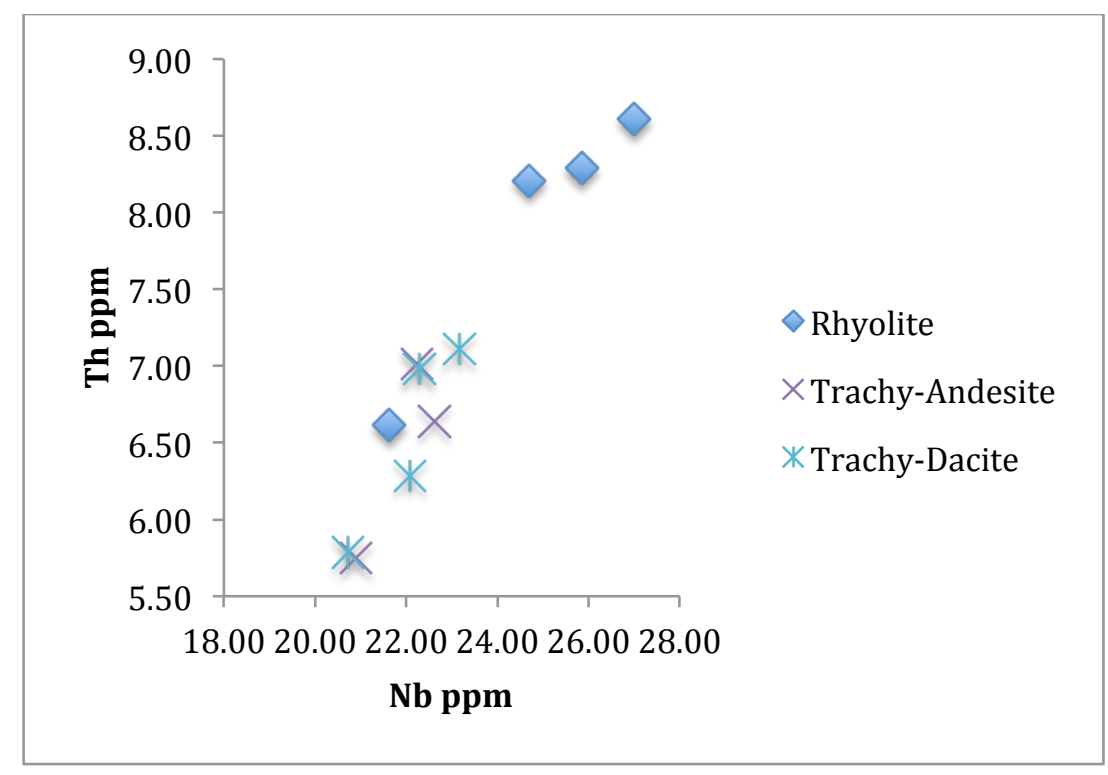

Figure 48. Trace element comparison plot of $\mathrm{Th}$ vs. Nb. There is a strong positive correlation to observe, as niobium increases so does thorium. The range includes trachyandesite at $20.9 \mathrm{ppm} \mathrm{Nb}$ and $5.75 \mathrm{ppm}$ Th to rhyolite at $27.01 \mathrm{ppm} \mathrm{Nb,8.61} \mathrm{ppm}$ Th.

The mafic end member of the system appears to be consist into two distinct types, one at $57 \% \mathrm{SiO}_{2}$ and the other at $60 \% \mathrm{SiO}_{2}$. Fig. 49 is used to illustrate this distinction. Basaltic andesite is higher in iron content than the more intermediate andesitic end member. Mafic material that was hand picked and analyzed by XRF was found to contain only slightly higher silica than the glass analyzed by EMP (Fig. 50). If separation was perfect and no rhyolite was part of the separated material, then the silica content of these "bulk scoria" samples can be use to estimate the approximate end member composition. 


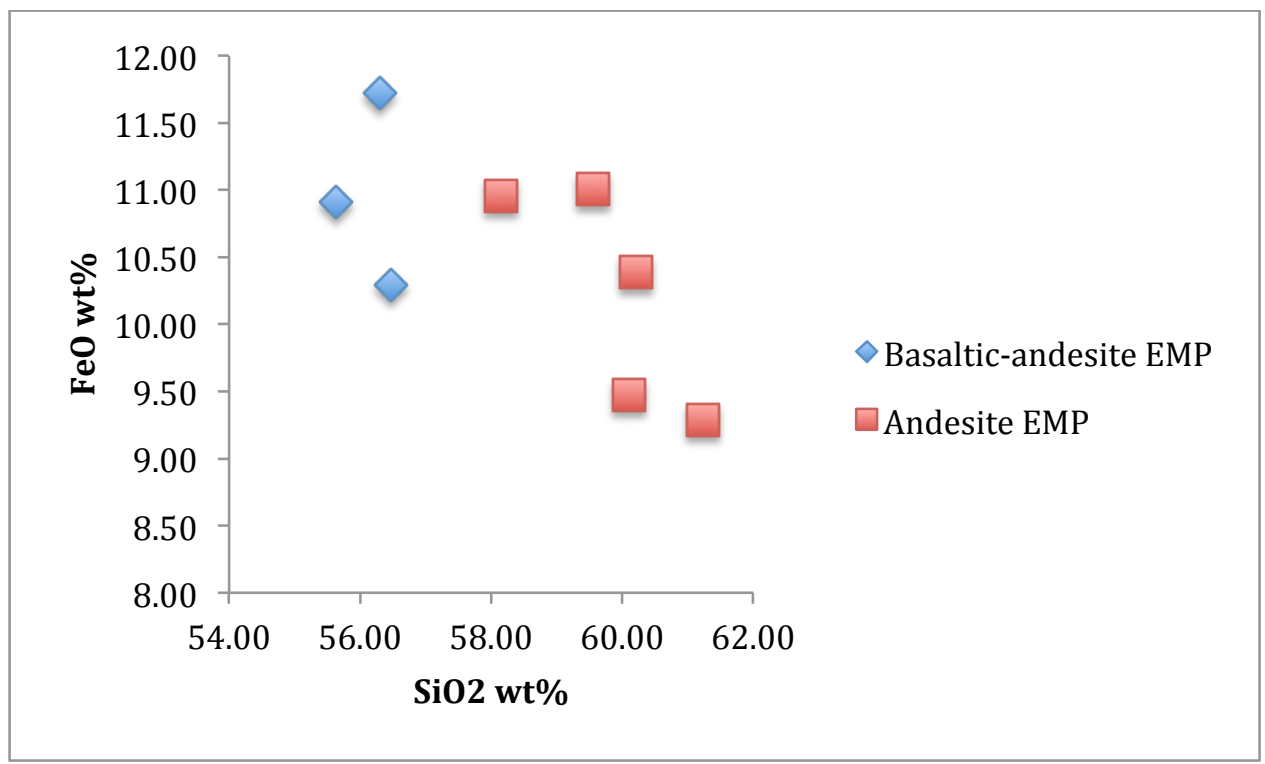

Figure 49. Composition of glass of the Wildcat Creek Tuff, plotted for only mafic samples. The mafic glass falls into two clusters. Basaltic-andesite is the most mafic, ranging from $55 \%$ to $56 \% \mathrm{SiO}_{2}$, while the andesitic glass falls between $58 \%$ and $61 \% \mathrm{SiO}_{2}$. These two compositions represent the mafic end member of the magma system. Basaltic andesite ranges from $10.03 \mathrm{wt} \% \mathrm{FeO}$ to $11.72 \mathrm{wt} \%$ FeO, while andesite falls short of that range at just $9.29 \mathrm{wt} \%$ to $11.01 \mathrm{wt} \% \mathrm{FeO}$.

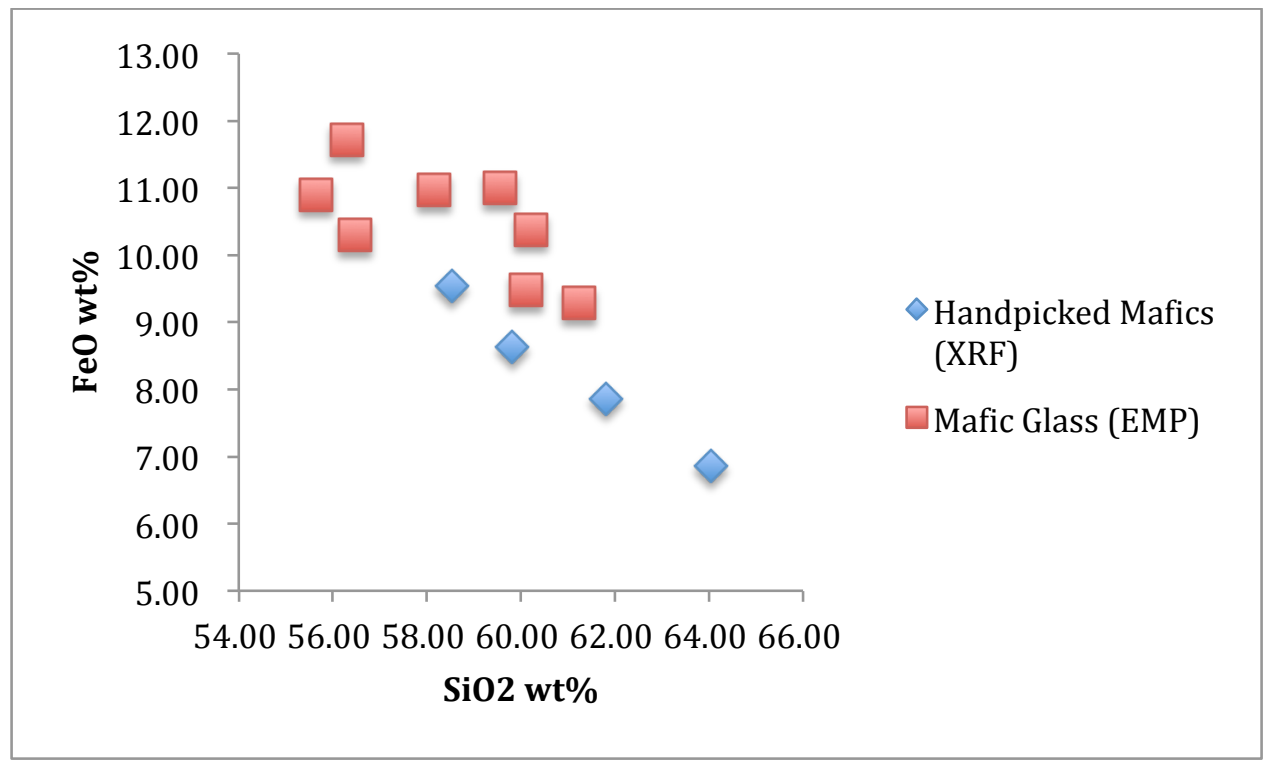

Figure 50. Plot of normalized mafic material, handpicked from four Wildcat Creek Tuff samples: HS-15-04a, HS-15-04c, HS-15-04d, HS-15-04e, analyzed by XRF. These samples (blue diamonds) are shown plotted against the mafic glass analyzed by EMP (red squares) from samples MS-14-05 and MS-14-06. The EMP analyzed glass falls into the basaltic-andesite to andesite category, while the 
handpicked mafic material is slightly more silicic andesite. Iron content varies, becoming lower as $\mathrm{SiO}_{2}$ content increases.

\section{MINERAL COMPOSITION}

Individual minerals were analyzed by both electron microprobe and scanning electron microscopy to aid in categorization and compositional identification. This included feldspars, pyroxenes, and occasionally Fe-Ti oxides. Glass composition of shards and pumices were analyzed by the electron microprobe. Tables of the full analyses can be found in Appendix D, and for SEM data in Appendix G, H, and I, sorted according to sample number. Feldspars fall into two major categories, including those associated with the mafic end member of the magma system, and those associated with the rhyolite. Alkali-feldspars ranging from mostly anorthoclase to sanidine belong to the felsic portion of the system and plagioclase feldspars are associated with the mafic portion of the system ranging from dacitic to andesitic. The spread can be seen below in the feldspar ternary diagram shown in Figure 51. Far fewer pyroxene minerals were found throughout the sample set, and they consist largely of clinopyroxene, those with high Fe belong to the rhyolitic portion while $\mathrm{Mg}$ richer are associated with mafic melt. Few fayalitic olivines were also identified in the rhyolitic samples. The pyroxene ternary diagram can be seen below in Figure 52. 


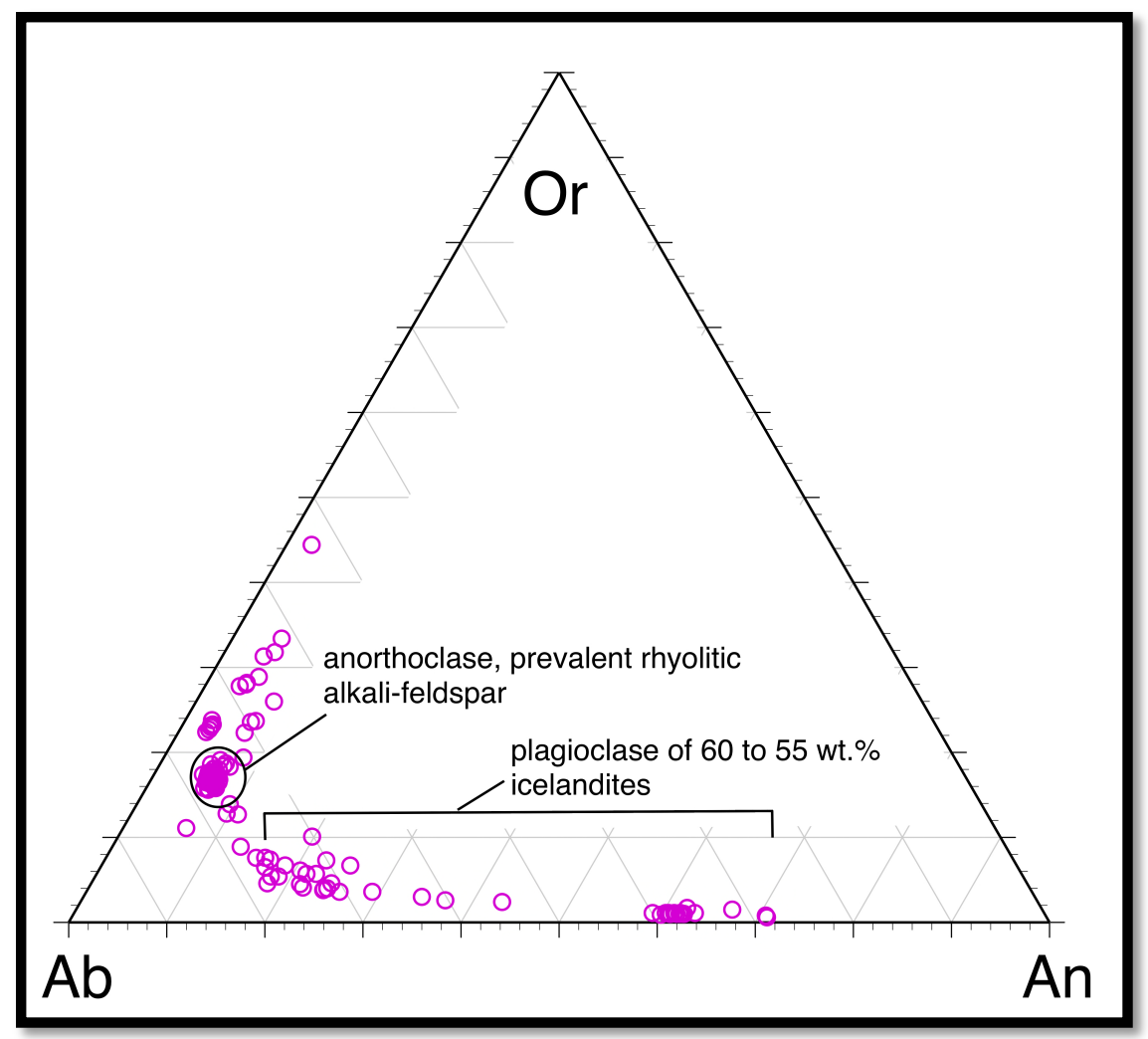

Figure 51. Ternary diagram showing feldspar minerals, based on EMP data. Alkali-feldspar is associated with the silica-rich rhyolitic end member of the magma system, where plagioclase is associated with the silica-poor trachyandesite end member. Far more phenocrysts occur in the rhyolitic portion of the tuff. 


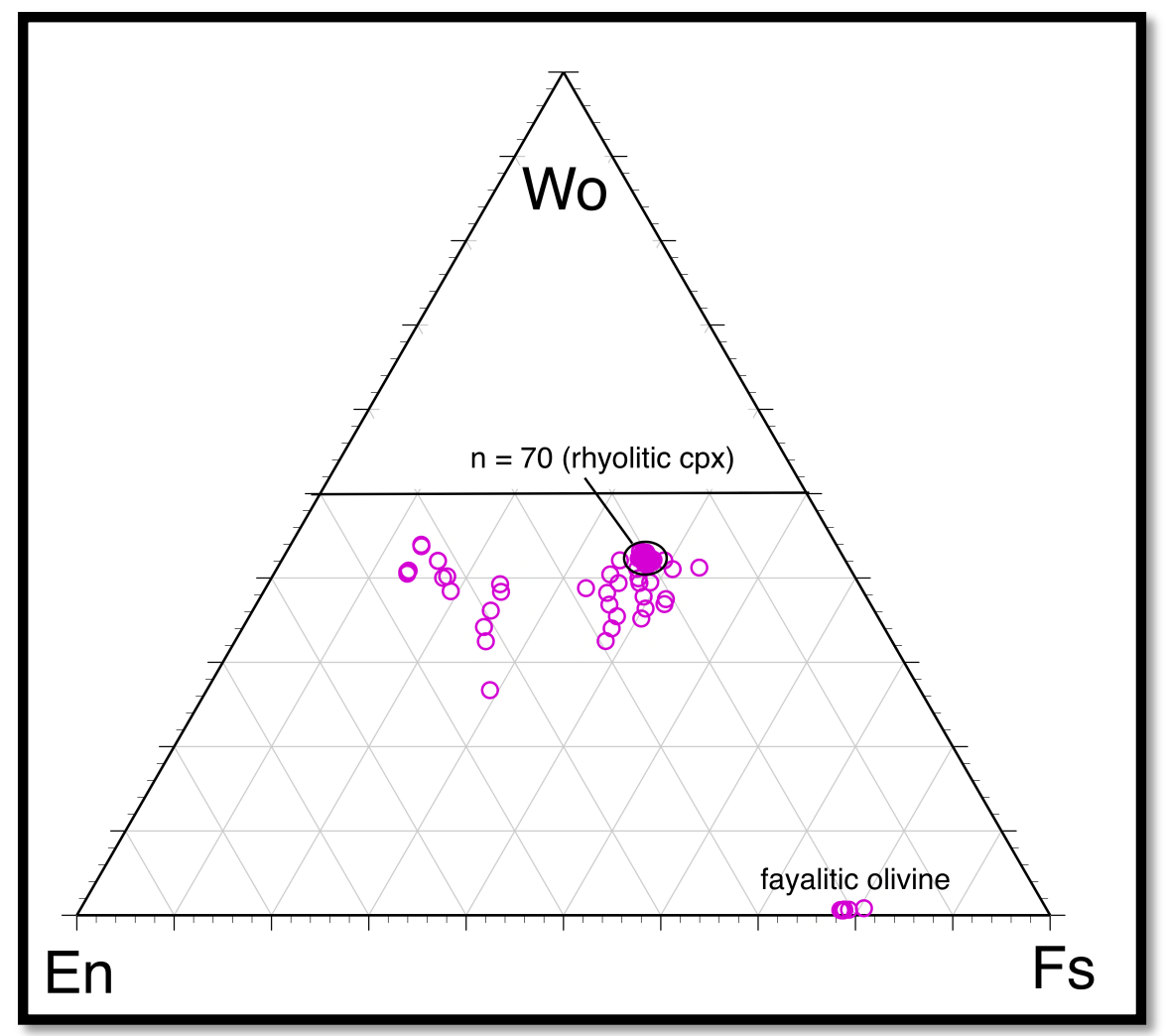

Figure 52. Ternary diagram of pyroxene minerals, based on EMP data. This diagram shows all analyzed pyroxenes for all samples within the set. Fe-rich clinopyroxene is associated with the rhyolitic end member. Fayalitic olivine crystals are associated with the silicic component of the magma system.

\section{ISOTOPIC AGE DATING}

${ }^{40} \mathrm{Ar} /{ }^{39} \mathrm{Ar}$ age dating was performed on sample MS-14-05 of the Wildcat Creek Tuff resulting in a single-crystal, anorthoclase ${ }^{40} \mathrm{Ar} /{ }^{39} \mathrm{Ar}$ age date of $15.49 \pm 0.02 \mathrm{Ma}$. The results are listed in Appendix M, and shown below in Figure 53. Isotopic ratios of Ar are used to constrain the final age date. 


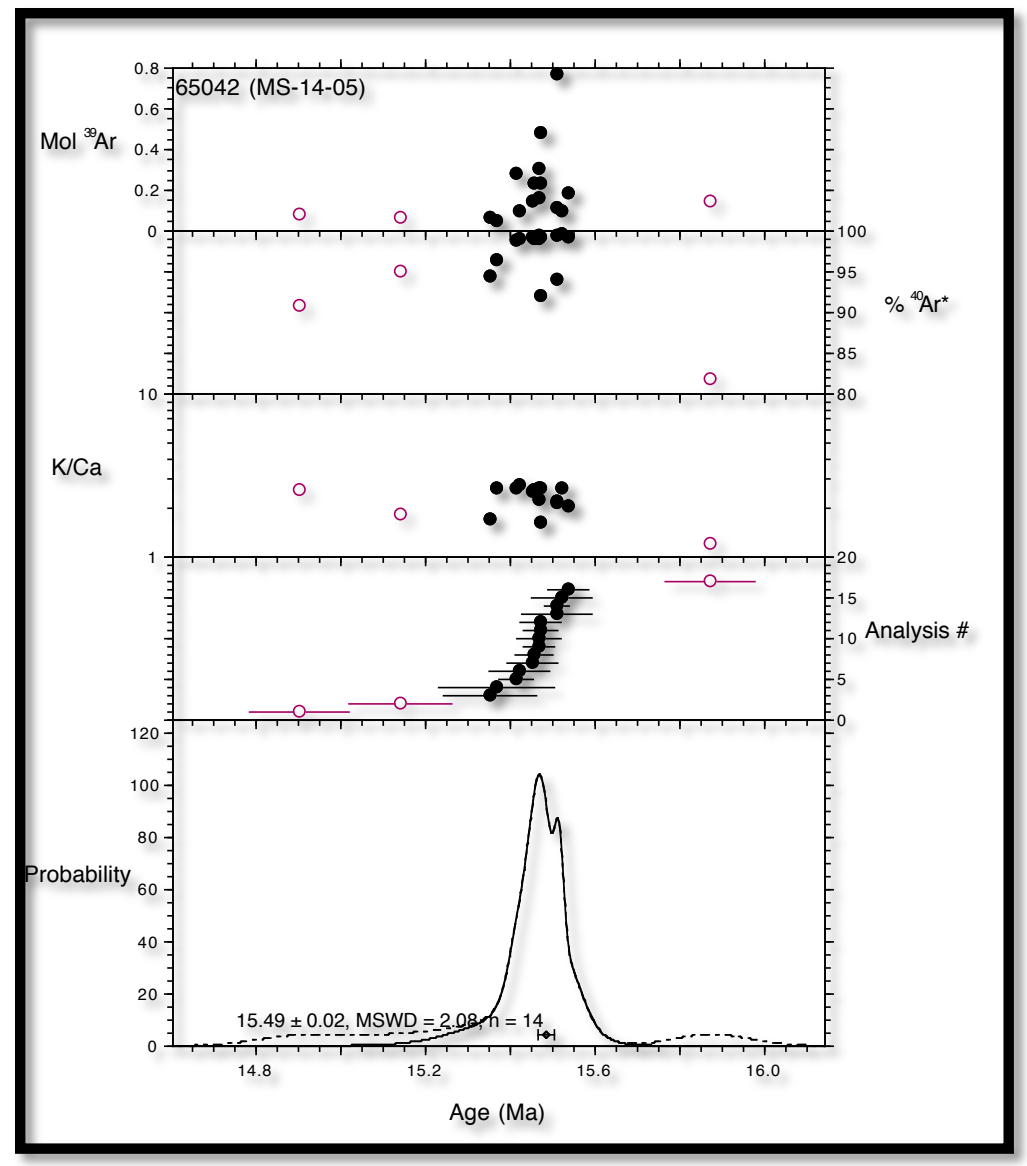

Figure 53. Age in millions of years for rhyolite sample MS1405 from the Wildcat Creek Tuff. This date of $\sim 15.5 \mathrm{Ma}$ was acquired by ${ }^{40} \mathrm{Ar} /{ }^{39} \mathrm{Ar}$ age dating. The curve at the bottom of this diagram indicates that the most probable age for this sample is 15.49+/- 0.02 Ma, (McIntosh, 2016). 


\section{DISCUSSION}

This discussion first considers the magmatic components of the Wildcat Creek Tuff (WCT), and then how compositionally intermediate WCT compositions can be explained by a two-component mixing model, and finally evaluating the results of this study in light of existing petrogenetic models of tuffs with similar mafic inclusions.

\section{MAGMATIC COMPONENTS IN THE WILDCAT CREEK TUFF}

Bulk composition of the Wildcat Creek Tuff range nearly continuously from 59 to 74 wt. $\% \mathrm{SiO}_{2}$. However, results of this study have shown that compositions of actual magmatic components are much more restricted than the range of bulk compositions would indicate. Based on glass analyses combined with mineral data indicate that magmatic components of the Wildcat Creek Tuff consist of rhyolite and andesite. Glass appearing next to select phenocrysts were analyzed to associate which mineral crystallized from which magma and mutual mineral inclusions were analyzed to cross correlate mineral compositions. For example, in sample MS-14-06 there are pyroxenes surrounded by rhyolite, andesite and basaltic andesite. Fe-rich augite, P3, (below, Fig. $55)$ is included in an anorthoclase alkali-feldspar phenocryst. Electron microprobe glass analyses for this sample are listed in Figures 56a and 56b, below, and the mineral analyses by both EMP and SEM can be found in Appendix G, H, and I. Pyroxene P15 from the same sample is seen below in Fig. 56. It is a fayalitic olivine enclosed within a mafic fiamme. The glass immediately surrounding the crystal however, is light colored rhyolitic glass. 
The rhyolite of the Wildcat Creek Tuff contains about $74 \% \mathrm{SiO}_{2}$ but no more than $5 \%$ phenocrysts. This rhyolite crystallized anorthoclase feldspar, Fe-rich augite, and FeTi oxide and \pm fayalitic olivine. The abundant scoria inclusions record the andesite. Based on glass analyses, the andesite, in fact, consist of a minimum of two magmatic components. One component is basaltic-andesite with approximately $56 \% \mathrm{SiO}_{2}$ and an andesitic component with roughly $60 \% \mathrm{SiO}_{2}$. Typical mineral phases for intermediate magmas include plagioclase feldspar, pyroxenes, hornblende, and oxides. The Wildcat Creek Tuff basaltic andesite and andesite are phenocryst-poor much like the rhyolitic end-member, containing no more than $1-2 \%$ phenocrysts dominated by clinopyroxene, plagioclase feldspar, and minor oxides.

Plagioclase feldspar ranges in composition from $\mathrm{An}_{70}$ to $\mathrm{An}_{20}$ with a distinct gap from $\mathrm{An}_{60}$ to $\sim \mathrm{An}_{40}$. It appears that high An plagioclase $\left(\mathrm{An}_{60-70}\right)$ crystallized from the basaltic andesite and lower An plagioclase $\left(\mathrm{An}_{20-40}\right)$ from the andesite. Both magmas crystallized augite. Crystals yielding slightly higher En and Wo components may have crystallized from basaltic andesite and those with higher Fs, from andesite. The small number of crystals to analyze makes this interpretation tentative.

Rhyolite glass analyses by EMP indicate a narrow range from 74 to $76 \mathrm{wt} \% \mathrm{SiO}_{2}$. This indicates that comingling of mafic magmas of the Wildcat Creek during eruption has lowered bulk samples to compositions of 70-71 wt.\%. A comparison of the XRF data for rhyolite samples and the EMP data for rhyolitic glass can be seen below in Fig. 54. 


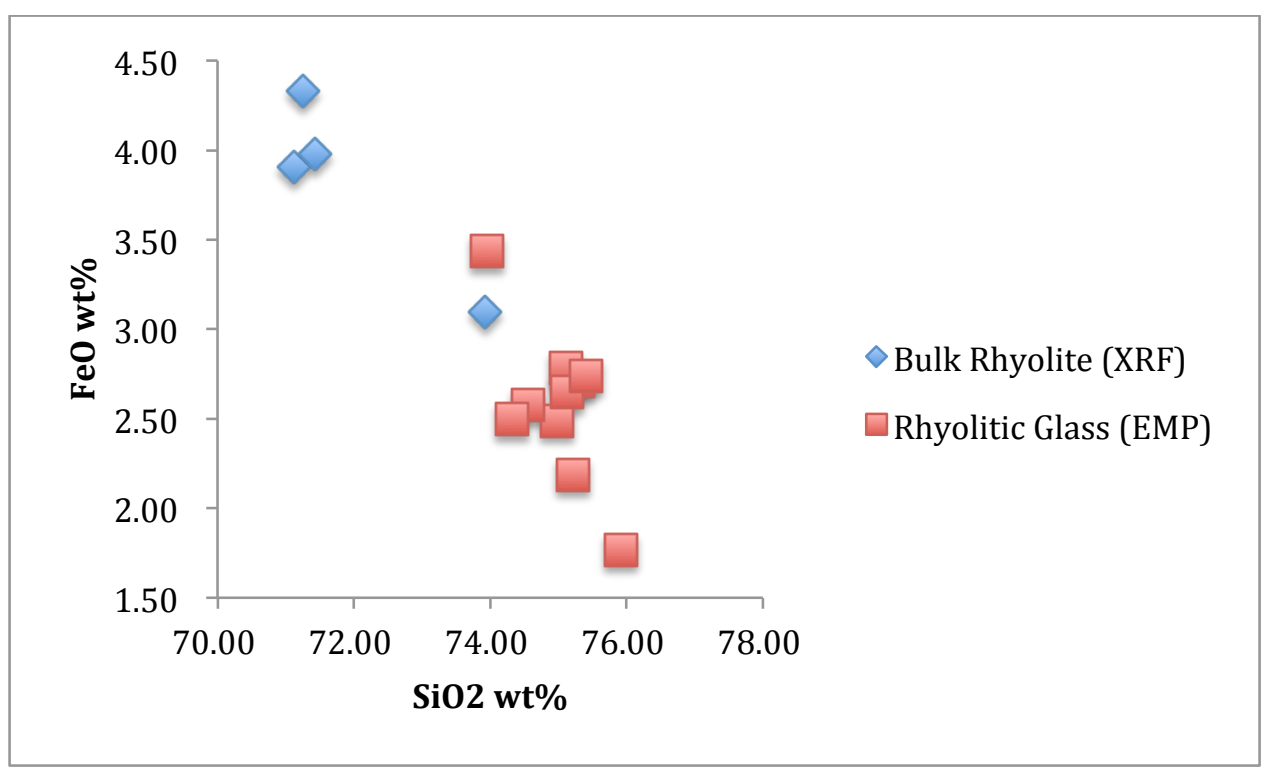

Figure 54. Comparison plot of rhyolitic samples of bulk composition HS-15-01b, HS-15-06a, MS-1307, and MS-14-05), as analyzed by XRF (blue diamonds) and rhyolitic glass analyses by EMP (red squares). The EMP analyses provide a range in silica content from $73 \%$ to $76 \%$, while the XRF bulk analyses range from $\sim 71 \%$ to $73 \% \mathrm{SiO}_{2}$ wt $\%$. The bulk samples are compositionally higher in $\mathrm{FeO}$ wt\%, but the full range is relatively small, only $1.77 \%$ to $4.33 \% \mathrm{FeO}$.

Visually, the rhyolite is lighter in color and contains more phenocrysts than the mafic components of each sample. Rhyolitic glass is light brown under the microscope in most samples. The most abundant phenocryst is anorthoclase alkali-feldspar although some sanidine crystals occur as well.

The mafic components of the magmatic system are darker in color than the rhyolite, ranging from middle to dark brown to nearly opaque under the microscope. Far fewer phenocrysts belong to basaltic andesite and andesite, but those present include clinopyroxene and plagioclase feldspar. 


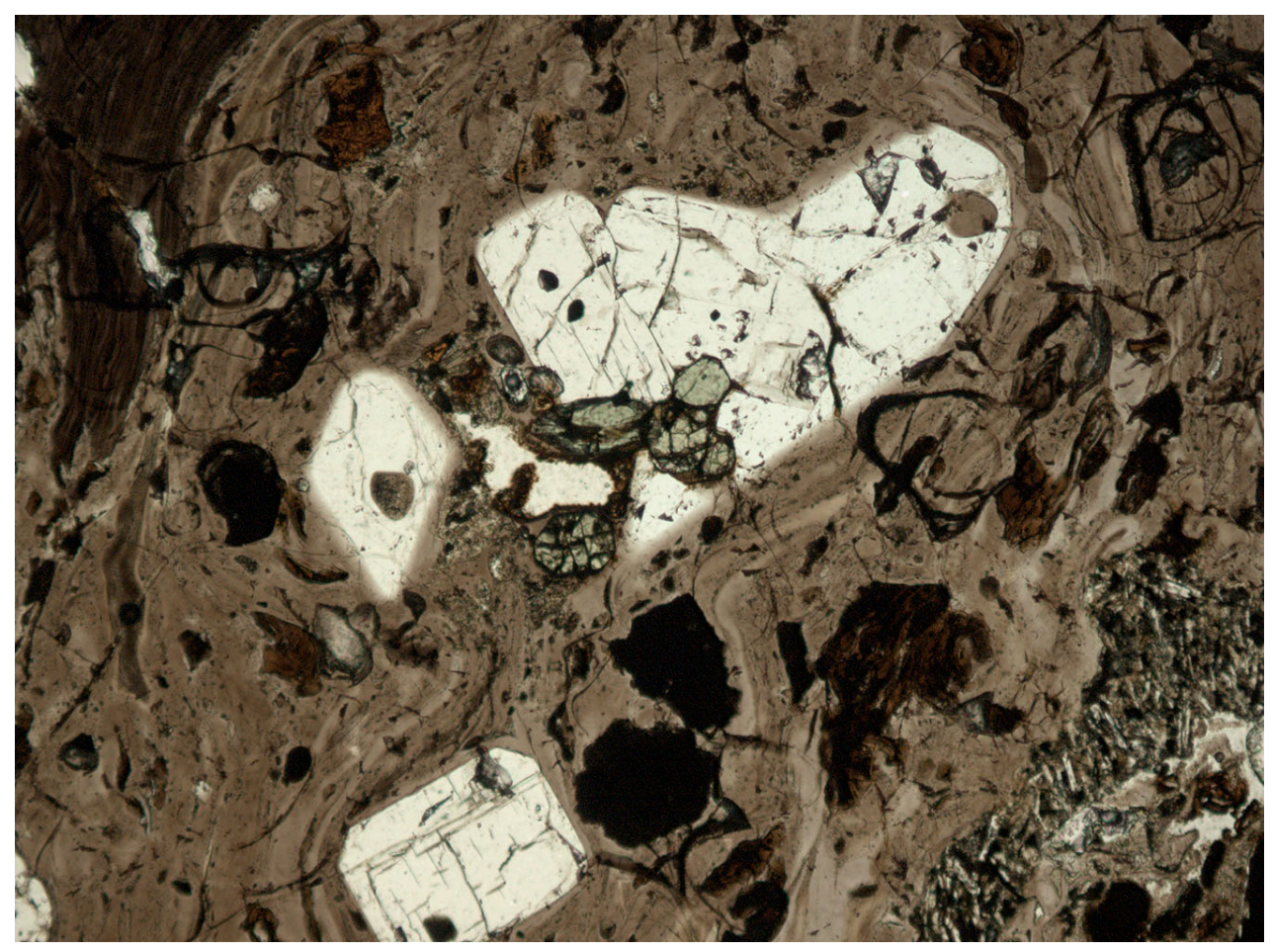

Figure 55. Pyroxenes $\mathbf{P 3}$ from sample MS-14-06 are intergrown with a large resorbed anorthoclase alkali-feldspar. The pyroxenes are subhedral and fractured Fe-augite. Both are associated with the rhyolitic magma. The image is taken in plain light from a petrographic microscope and magnified 100x. 


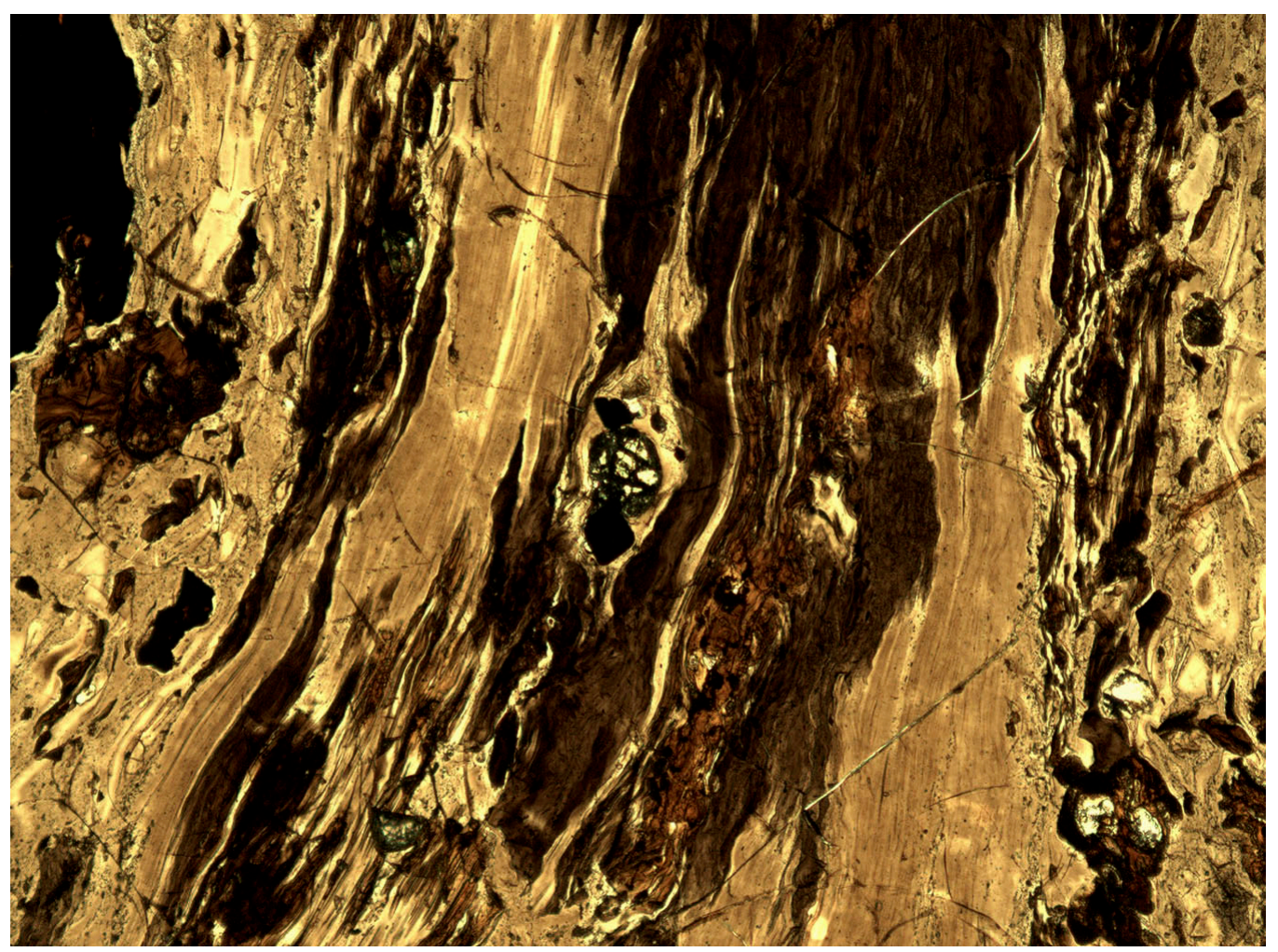

Figure 56. Pyroxene P15 from sample MS-14-06 is seen in the middle of a mafic fiamme. Dark, mafic material surrounds the subhedral to euhedral phenocryst, but the lighter, rhyolitic glass immediately surrounds the pyroxene. The image is taken in a petrographic microscope, in plain light, and magnified 100x. 


\begin{tabular}{|c|c|c|c|c|c|}
\hline $\begin{array}{c}\text { Sample } \\
\text { Glass\# } \\
\text { Glass Type }\end{array}$ & $\begin{array}{c}\text { MS-14-05 } \\
1-1 \\
\text { Rhyolite }\end{array}$ & $\begin{array}{c}\text { MS-14-05 } \\
1-2 \\
\text { Rhyolite }\end{array}$ & $\begin{array}{c}\text { MS-14-05 } \\
1-3 \\
\text { Rhyolite }\end{array}$ & $\begin{array}{c}\text { MS-14-05 } \\
2-1 \\
\text { Rhyolite }\end{array}$ & $\begin{array}{c}\text { MS-14-05 } \\
2-2 \\
\text { Rhyolite }\end{array}$ \\
\hline SiO2 & 74.98 & 74.55 & 75.93 & 74.32 & 73.95 \\
\hline Al2O3 & 13.20 & 13.00 & 13.29 & 13.44 & 13.17 \\
\hline $\mathrm{FeO}$ & 2.49 & 2.58 & 1.77 & 2.50 & 3.44 \\
\hline MgO & 0.02 & 0.04 & 0.02 & 0.07 & 0.06 \\
\hline $\mathrm{CaO}$ & 0.05 & 0.10 & 0.07 & 0.75 & 0.14 \\
\hline $\mathrm{Na2O}$ & 2.60 & 3.18 & 2.32 & 2.47 & 3.16 \\
\hline K2O & 6.58 & 6.47 & 6.53 & 6.35 & 5.99 \\
\hline $\mathrm{BaO}$ & 0.08 & 0.09 & 0.09 & 0.09 & 0.09 \\
\hline Total & 100.00 & 100.00 & 100.00 & 100.00 & 100.00 \\
\hline Sample & MS-14-05 & MS-14-06 & MS-14-06 & MS-14-06 & MS-14-06 \\
\hline Glass\# & $2-3$ & 5-1 & 5-2 & 6-1 & 6-2 \\
\hline Glass Type & Rhyolite & Andesite & Andesite & Rhyolite & Rhyolite \\
\hline SiO2 & 75.21 & 60.21 & 59.56 & 78.25 & 75.12 \\
\hline Al2O3 & 13.17 & 15.15 & 14.83 & 13.67 & 13.88 \\
\hline $\mathrm{FeO}$ & 2.19 & 10.38 & 11.01 & 2.71 & 2.78 \\
\hline MgO & 0.03 & 3.35 & 3.54 & 0.08 & 0.10 \\
\hline $\mathrm{CaO}$ & 0.14 & 6.63 & 6.50 & 0.40 & 0.46 \\
\hline $\mathrm{Na2O}$ & 2.82 & 1.62 & 2.03 & 3.66 & 3.56 \\
\hline K2O & 6.35 & 2.51 & 2.41 & 4.09 & 4.00 \\
\hline $\mathrm{BaO}$ & 0.09 & 0.13 & 0.12 & 0.11 & 0.10 \\
\hline Total & 100.00 & 100.00 & 100.00 & 102.97 & 100.00 \\
\hline
\end{tabular}

\begin{tabular}{|c|c|c|c|c|c|}
\hline $\begin{array}{c}\text { Sample } \\
\text { Glass\# } \\
\text { Glass Type }\end{array}$ & $\begin{array}{c}\text { MS-14-06 } \\
1-1 \\
\text { Basaltic Andesite }\end{array}$ & $\begin{array}{c}\text { MS-14-06 } \\
1-2 \\
\text { eBasaltic Andesite }\end{array}$ & $\begin{array}{c}\text { MS-14-06 } \\
2-1 \\
\text { Andesite }\end{array}$ & $\begin{array}{c}\text { MS-14-06 } \\
2-2 \\
\text { Andesite }\end{array}$ & $\begin{array}{c}\text { MS-14-06 } \\
\text { 3-1 } \\
\text { Andesite }\end{array}$ \\
\hline SiO2 & 56.47 & 55.64 & 60.10 & 61.24 & 58.16 \\
\hline TiO2 & 2.36 & 2.23 & 1.78 & 1.84 & 2.21 \\
\hline Al2O3 & 14.28 & 14.13 & 14.12 & 14.62 & 14.39 \\
\hline $\mathrm{FeO}$ & 10.30 & 10.91 & 9.47 & 9.29 & 10.96 \\
\hline MnO & 0.22 & 0.22 & 0.29 & 0.20 & 0.19 \\
\hline MgO & 3.99 & 3.91 & 3.10 & 2.75 & 3.50 \\
\hline $\mathrm{CaO}$ & 7.85 & 8.00 & 6.24 & 5.39 & 5.86 \\
\hline $\mathrm{Na2O}$ & 2.19 & 2.62 & 2.01 & 1.88 & 2.06 \\
\hline K2O & 2.28 & 2.25 & 2.86 & 2.75 & 2.68 \\
\hline Cr2O3 & 0.00 & 0.04 & 0.01 & 0.01 & 0.00 \\
\hline ZnO & 0.07 & 0.05 & 0.01 & 0.02 & 0.00 \\
\hline Total & 100.00 & 100.00 & 100.00 & 100.00 & 100.00 \\
\hline Sample & MS-14-06 & MS-14-06 & MS-14-06 & & \\
\hline Glass\# & $3-2$ & 4-1 & 4-2 & & \\
\hline Glass Type & Andesite & Rhyolite & Rhyolite & & \\
\hline SiO2 & 56.29 & 75.12 & 75.41 & & \\
\hline TiO2 & 2.25 & 0.30 & 0.25 & & \\
\hline Al2O3 & 14.04 & 13.28 & 13.41 & & \\
\hline $\mathrm{FeO}$ & 11.72 & 2.65 & 2.74 & & \\
\hline MnO & 0.27 & 0.12 & 0.16 & & \\
\hline MgO & 4.09 & 0.09 & 0.07 & & \\
\hline $\mathrm{CaO}$ & 7.20 & 0.82 & 0.67 & & \\
\hline $\mathrm{Na2O}$ & 1.82 & 2.90 & 3.01 & & \\
\hline K2O & 2.28 & 4.70 & 4.24 & & \\
\hline $\mathrm{Cr} 2 \mathrm{O} 3$ & 0.03 & 0.00 & 0.00 & & \\
\hline $\mathrm{ZnO}$ & 0.00 & 0.02 & 0.05 & & \\
\hline Total & 100.00 & 100.00 & 100.00 & & \\
\hline
\end{tabular}


Figures 57a and 57b. Tables of electron microprobe glass analyses for samples MS-14-05 and MS-1406. Most glass analyzed falls into the rhyolite category of 74-75\% $\mathrm{SiO}_{2}$, but some intermediate glass is andesitic at $60 \% \mathrm{SiO}_{2}$, and basaltic andesite at $56 \% \mathrm{SiO}_{2}$. FeO is higher in the intermediate andesitic glass and lower in silicic glass.

EMP glass analyses were plotted to determine the extent of the differences (Fig. $\mathrm{X})$ of the rhyolitic and andesitic end members of the magmatic system. Figure 58 shows the averaged XRF bulk data for Hooper's Wildcat Creek Tuff rhyolitic sample set (Hooper et. al., 2002) along with the EMP glass values of the samples used for this study. The table of these values is available in Appendix D.

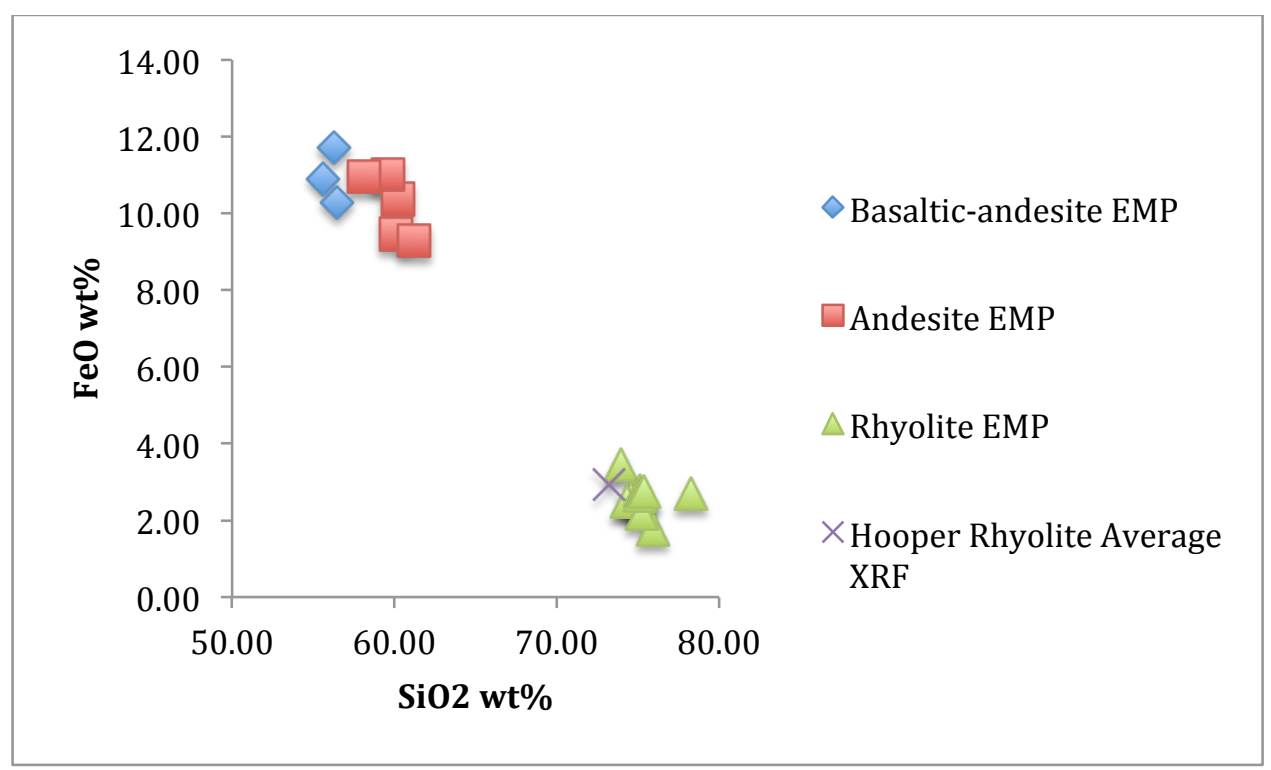

Figure 58. Averaged glass analyses by EMP and bulk analyses by XRF (Hooper et. al., 2002).

Hooper's samples are all rhyolitic in bulk composition, while samples of the Wildcat Creek Tuff of this study falls between basaltic-andesite and rhyolite. 


\section{MAGMA MIXING}

All magmatic components identified above were distinct magmas in the subsurface before eruption. During eruption, these magmas co-mingled to produce bulk tuff samples with variable compositions of dacite to low-silica rhyolite and spanning the compositional range between the rhyolite to andesite magmatic components. We can use mixing calculations to explore if bulk compositions could indeed be explained by mixing of the identified components, or whether additional components need to be considered. Given the linear array between the $60 \%$ and $56 \% \mathrm{SiO} 2$ component (see Figs. 57 and 58 , above, for glass compositions), we can simplify the mixing model from a threecomponent to a two-component magma system. This is desirable as it simplifies the calculations, and because we have only major elemental compositions for each of the two mafic components, but we lack the full suite of trace elements.

For modeling mixtures between rhyolite and andesite, I used a standard mixing equation (equation 1):

$$
m=A x+B(1-x)
$$

" $A$ " is the concentration of one element of mafic (andesite) end member , "B" is concentration of the element of the high silica (rhyolite) end member, " $\mathrm{x}$ " is the mixing proportion, and " $\mathrm{m}$ " is the concentration of the element in the resulting mixture. The mixing calculations were completed using two representative end member samples, the most silicic and the most intermediate. These are rhyolite HS-15-06a $\left(73.93 \% \mathrm{SiO}_{2}\right)$ and basaltic-andesite HS-15-04e $\left(60.28 \% \mathrm{SiO}_{2}\right)$. All samples in the WCT suite fall within the 
range of these two silica values, thus the two samples are an accurate representation of the extreme end members of the magmatic system. Figure 59 displays results for a $50 \%$ mixture along with two compositionally intermediate WCT dacites.

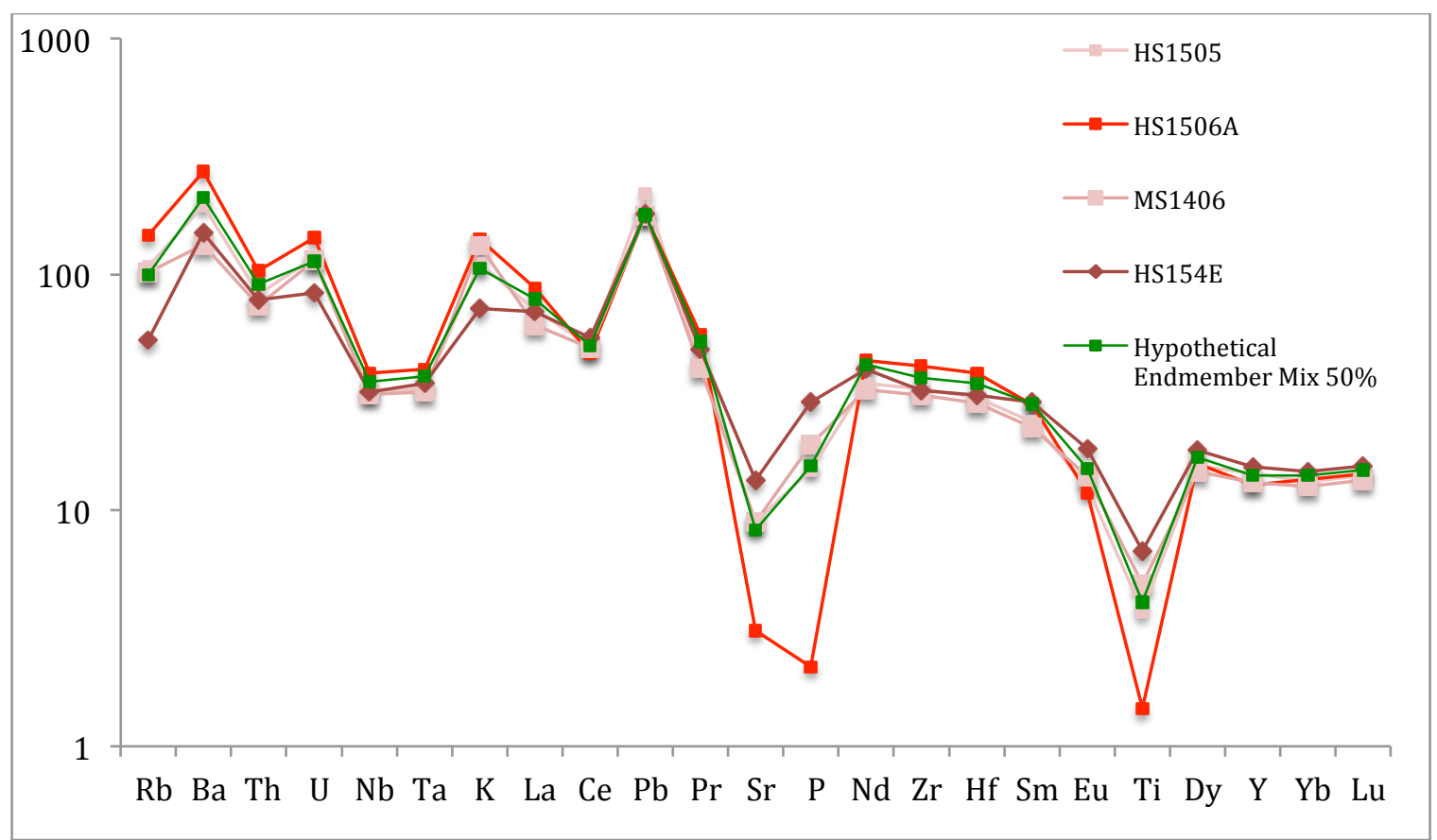

Figure 59. This mantle normalized (Sun \& McDonough, 1989) spider diagram shows trace element compositions for the sample with the highest SiO2 content, rhyolite HS-15-06a at $\sim 74 \%$, the sample with a very low $\mathrm{SiO} 2$ content, trachyandesite HS-15-04e at $\sim 60 \%$, and two trachydacite samples, MS14-06 and HS-15-05, both at $\sim 66 \%$ SiO2. The green line shows a $50 \%$ mixture of the two end members of this system. All samples dip at Ti and $\mathrm{Sr}$, peaking at Pb. HS-15-06a shows a $\mathrm{P}$ anomaly, dipping while the other samples all increase, and MS-14-06 shows a slight La anomaly, dipping further than the rest of the samples.

To further evaluate that mixing of these two end members yields results consistent with compositional data of all samples, I devised a two-step scenario. In step 1, the silica 
content of a sample was used to derive the proportion of mixing that produces exactly this silica value using the following rearranged mixing equation (equation 2):

$$
x=\frac{m-B}{A-B}
$$

where " $\mathrm{A}$ " is the mafic end member, " $\mathrm{B}$ " is the silicic end member, " $\mathrm{m}$ " is the concentration of the element in the mixture, and " $x$ " is the percent mixing. In the second step, this mixing proportion was used to calculate the resulting mixture for all trace elements shown in Figure 60. The calculated trace element concentration was then compared to those of the natural sample. The table of all values for these calculations can be found in Appendix C. Using the two end members of the system (HS-15-06a, rhyolite; HS-15-04c, basaltic andesite) as explained above, $m=\sim 46 \%$. That percentage was then applied to the end members and normalized according to primitive mantle values (Sun \& McDonough, 1989). These calculated trace element values were then plotted as seen below in Figure 60, the theoretical mixture is extremely close in composition to the actual dacitic sample, HS-15-05.

A second calculation was completed using samples MS-14-05 as the rhyolitic end member, and HS-15-04e as the basaltic andesite. The comparison was again made to sample HS-15-05 and the results are shown in Figure 61. 


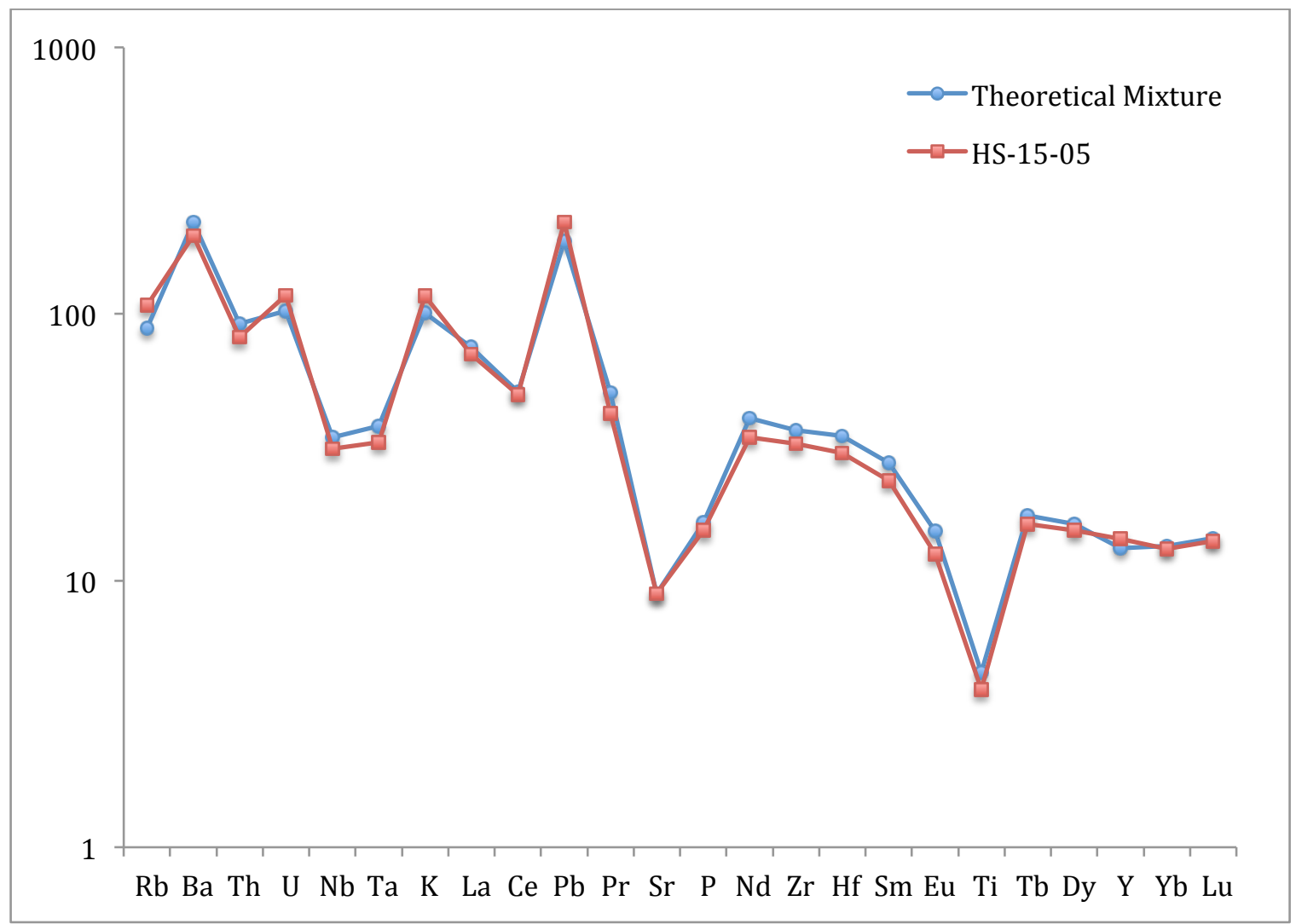

Figure 60. Plot of trace elements, normalized with primitive mantle values (Sun \& McDonough, 1989). In blue (circles) you see the calculated trace elements of the theoretical mixture, combining rhyolite HS-15-06a (bulk composition 74\% $\mathrm{SiO}_{2}$ ) with trachyandesite HS-15-04c (bulk composition $59 \% \mathrm{SiO}_{2}$ ). The values are very close to those of actual sample HS-15-05, a trachydacite that falls in the middle of the $\mathrm{SiO}_{2}$ range of Wildcat Creek Tuff samples at $66 \%$. Both plots dip at $\mathrm{Nb}$, $\mathrm{Ta}, \mathrm{Sr}$, and $\mathrm{Ti}$, and peak at $\mathrm{Pb}$. Minor differences occur between $\mathrm{Nd}$ and $\mathrm{Eu}$; the theoretical mixture is more enriched in these elements than the observed sample. 


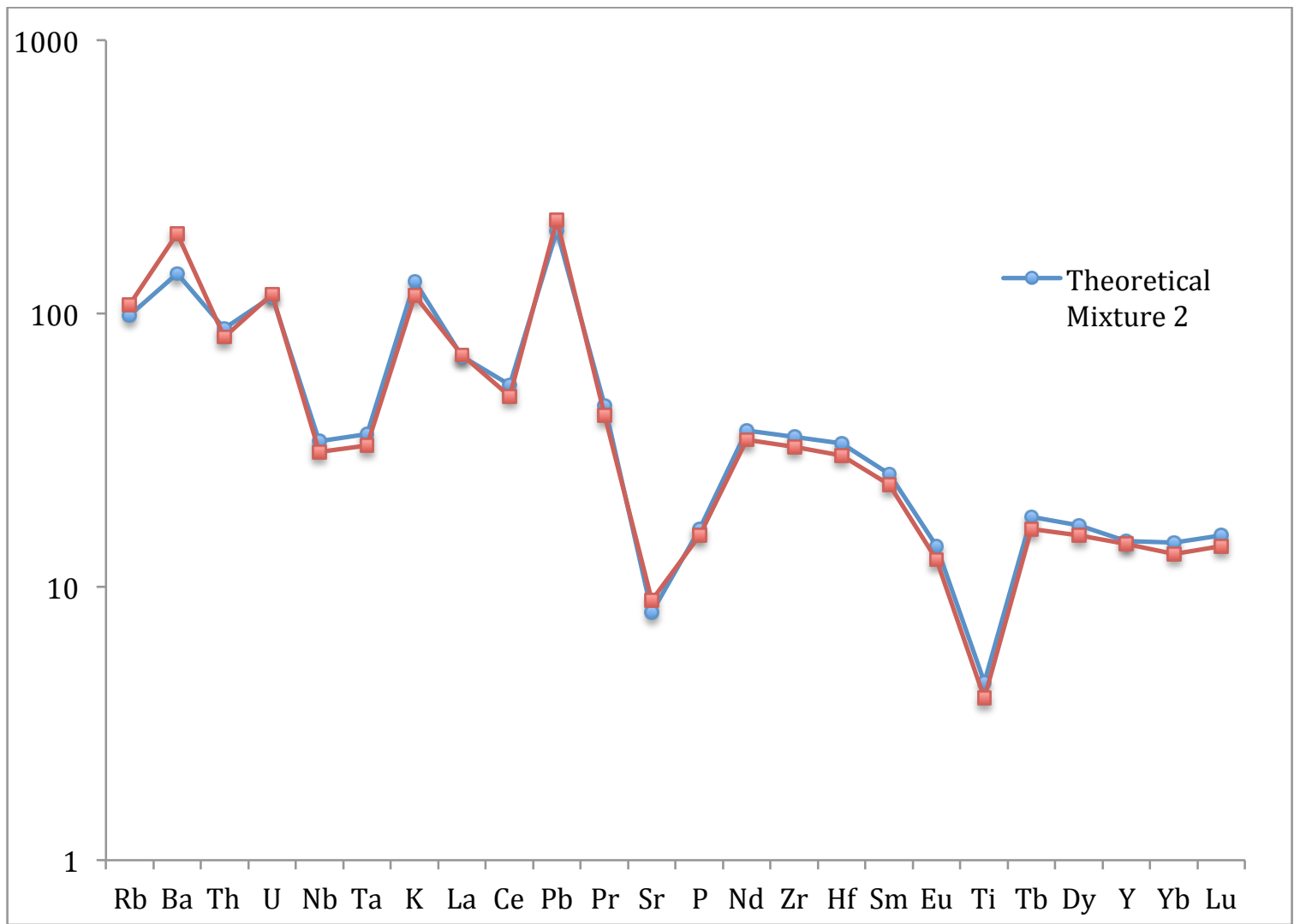

Figure 61. Plot of trace elements, normalized with primitive mantle values (Sun \& McDonough, 1989). In blue (circles) you see the calculated trace elements of the theoretical mixture, combining rhyolite MS-14-05 (bulk composition 71\% $\mathrm{SiO}_{2}$ ) with trachyandesite HS-15-04e (bulk composition $60 \% \mathrm{SiO}_{2}$ ). The values are very close to those of actual sample, again trachyandesite HS-15-05 with bulk composition $66 \%$. Both plots again dip at $\mathrm{Nb}$, $\mathrm{Ta}, \mathrm{Sr}$, and $\mathrm{Ti}$, and peak at $\mathrm{Pb}$. Minor differences occur between $\mathrm{Nd}$ and $\mathrm{Eu}$; the theoretical mixture is more enriched in these elements than the observed sample. In this example, the theoretical mixture is even closer to the natural, dacitic sample.

Inclusions as Evidence for Magma Mixing

When compared to the Rattlesnake Tuff of eastern Oregon, the andesites of the Wildcat Creek Tuff show a general trend of decreasing from La to Lu, with a slight negative Eu anomaly (Fig. 62, below). The cumulate model of the Rattlesnake Tuff shows a slight depletion from La to $\mathrm{Ce}$, but a large positive Eu anomaly, and again, a 
positive trend from $\mathrm{Yb}$ to $\mathrm{Lu}$. Although the Eu depletion in the WCT is small, it indicates a mixing of magmas, rather than being a crystal cumulate.

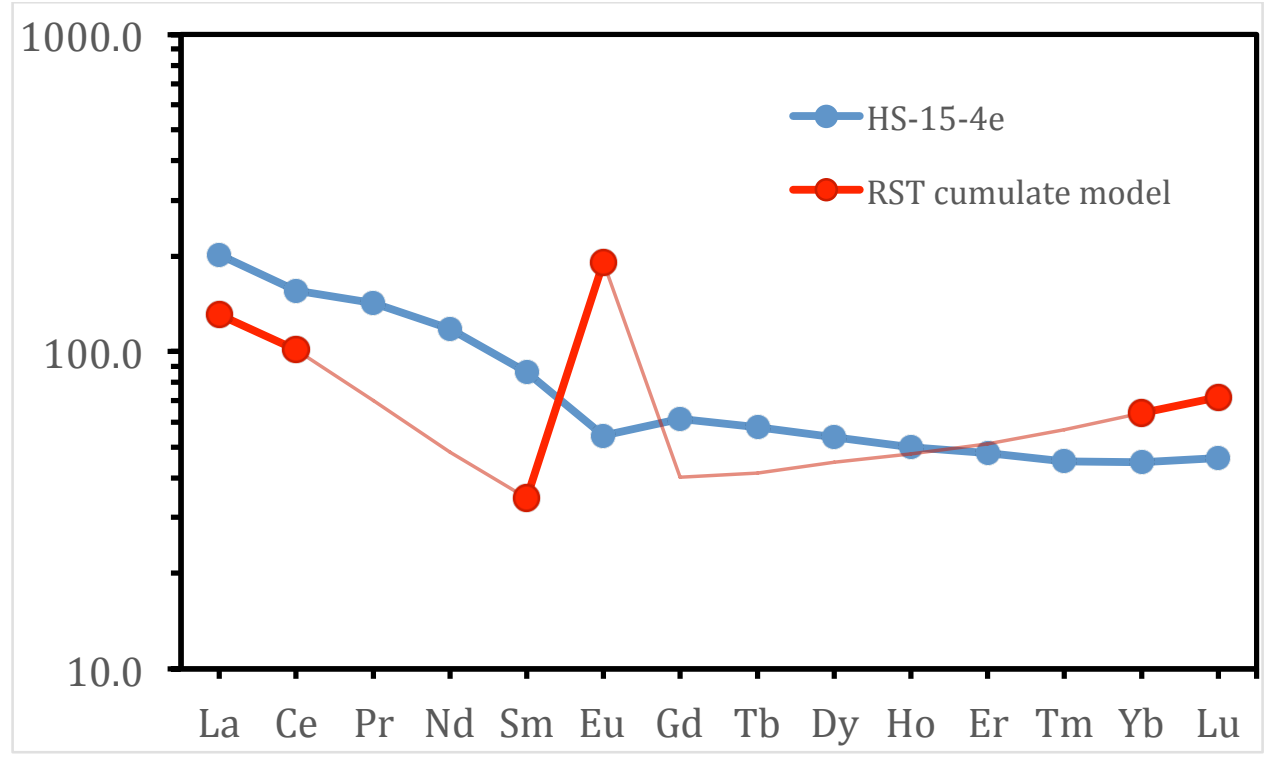

Figure 62. C1 chondrite normalized (Sun \& McDonough, 1989) REE plot comparing Wildcat Creek Tuff andesite sample HS-15-04e to Rattlesnake Creek Tuff crystal fractionation model E to D (Streck \& Grunder, 1997). The Rattlesnake Tuff model presents a crystal cumulate, while the Wildcat Creek Tuff samples do not follow the same patterns, presenting as a binary mixed magma system. Pr to Nd and Gd to Tm are interpolated for the RST cumulate model.

\section{Wildcat Creek Tuff in the Context of Nearby Units}

There is some lithological and compositional resemblance between the Wildcat Creek Tuff and the Tuff of Buchanan east of the town of Buchanan, OR roughly $50 \mathrm{~km}$ west of the main WCT outcrop area. Data from Large (2016) indicate that the two units share similarities in concentrations of trace elements (Fig. 63, below). The estimated age of the Tuff of Buchanan is $15.9 \mathrm{Ma}$ (Large, 2016) while the Wildcat Creek Tuff has an age of 15.5 Ma (this study). Large's data of the Buchanan rhyolites closely follows data collected for the Wildcat Creek Tuff. One sample of the Buchanan Tuff was included 
with the Wildcat Creek Tuff set. This is MS-13-07. The rhyolitic sample falls well within the Wildcat Creek Tuff trends, based on major elements and many trace elements, but falls off the trend in some elements, notably $\mathrm{Nb}, \mathrm{Zr}$, and $\mathrm{Th}$. This suggests that, although similar, the tuff of Buchanan is a distinct unit.

The Littlefield Rhyolite (LFR) underlies the Wildcat Creek Tuff. They outcrop together near $43.572850^{\circ},-117.832100^{\circ}$, in the northeast corner of the WCT unit, as mapped by Ferns for the Vale Quadrangle map (Ferns, 1993). Sample MS-14-06 was collected at this site, and it is one of the trachydacite samples. Single crystal ${ }^{40} \mathrm{Ar} /{ }^{39} \mathrm{Ar}$ ages place the LFR at 16.05 to $16.20 \mathrm{Ma}$ (Webb, 2017). Although rhyolites of the WCT are slightly younger, they may have evolved from residual magmas of the Littlefield Rhyolite.

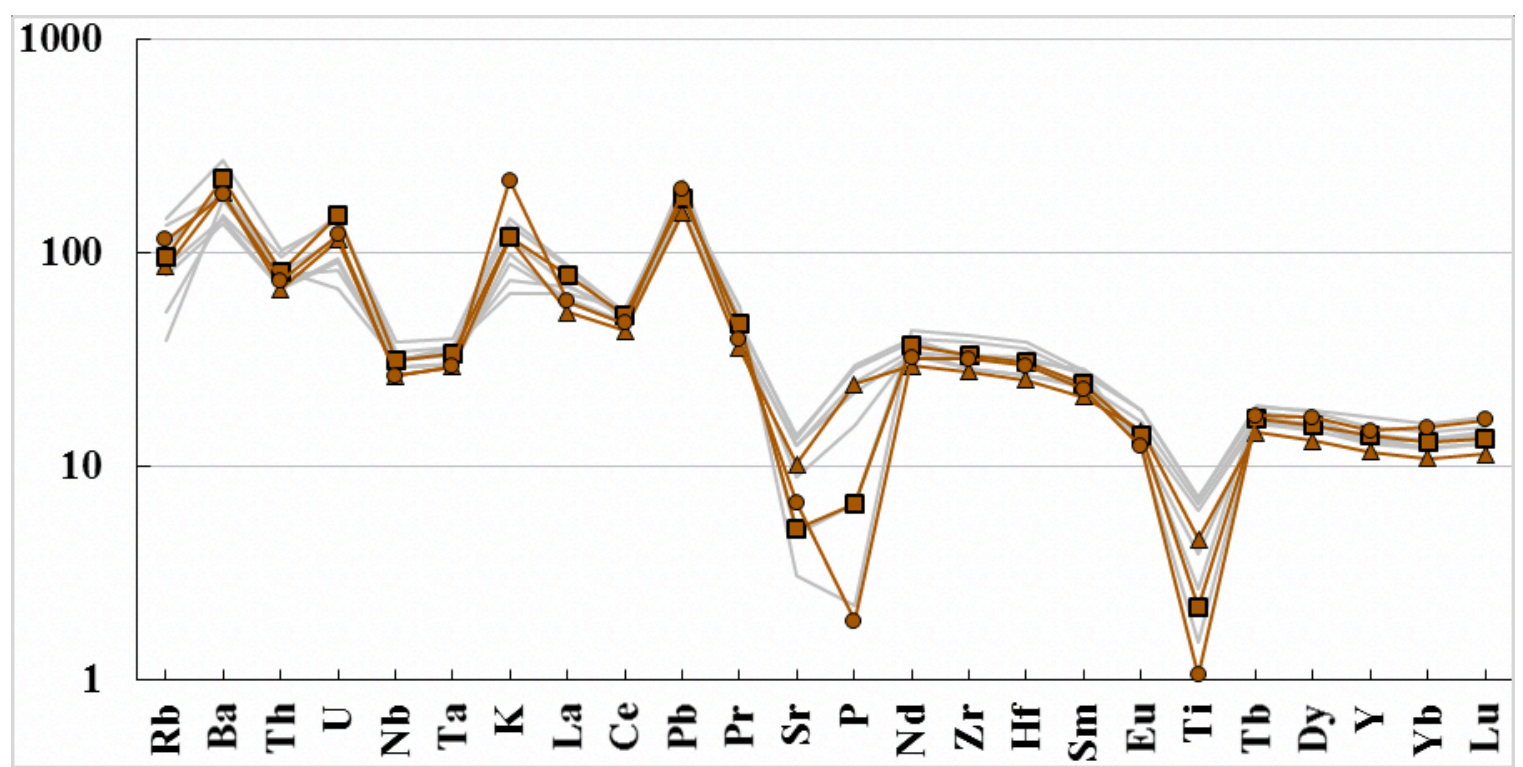

Figure 63. Multi-element diagram of Buchanan rhyolite samples (Large, 2016) overlain on Wildcat Creek Tuff samples (grayed). Concentrations normalized to primitive mantle values of Sun and McDonough (1989). 


\section{STRATIFICATION OF THE MAGMA RESERVOIR}

The formation of dacitic magma can occur by partial melting, fractional crystallization, magma mixing, or magma assimilation. In the case of the Wildcat Creek Tuff, it is likely that magma mixing occurred, due to the presence of mingling textures throughout the unit. The mafic inclusions in the Wildcat Creek Tuff are a window into the interaction of basaltic magmas with rhyolites where basalt serves as heat source in a bimodal system. Large tuffs with similar mafic inclusions are found in other areas, such as the Ammonia Tanks Tuff of Southwest Nevada (Deering et. al., 2011), the Carpenter Ridge Tuff of Colorado (Bachman et. al., 2014), and the Rattlesnake Tuff of Eastern Oregon (Streck \& Grunder, 1999).

The crystal mush method is proposed in the case of the Ammonia Tanks Tuff. The eruption created a large ignimbrite, roughly $900 \mathrm{~km}^{3}$, from a shallow, thermally and chemically zoned reservoir. The mixture of the two magmas is due to in-situ differentiation driven by crystal liquid separation (Deering et. al., 2011). The most silicic portion of the magma (rhyolite) rises to the top of the reservoir, leaving behind a crystal mush at $50 \%$ or greater crystallinity at the bottom (Deering et. al., 2011). After remelting the crustal mush with an overall dacitic composition, this magma and the differentiated magma erupted jointly, accounting for the chemical zonation and the mixture of rhyolite with a hotter, more mafic recharge magma (Deering et. al., 2011). The heating and the late recharge partially melted the crystals and triggered the eruption. Though this model 
partially fits this study, the Wildcat Creek Tuff samples contain a negative Eu anomaly that would not be present in a crystal cumulate.

Another large ignimbrite, the Carpenter Ridge Tuff of Colorado is strongly zoned. The lower zone is a phenocryst-poor rhyolite, and the upper zone is a more crystal-rich, less silicic, trachydacite (Bachman et. al., 2014). Variations in the major and trace elements imply in-situ differentiation due to interstitial melt extraction from the upper zone of the magma chamber (Bachman et. al., 2014). Inclusions of trachydacite are believed to be the remobilized crystal cumulate. Mafic clasts and high aluminum amphiboles points to a late recharge event (Bachman et. al., 2014). The mafic material mixed with the crystal cumulate and thermally remobilized the silicic crystal cumulate in the upper zone, creating a gradient in the crystal cumulate and masking the in-situ differentiation (Bachman et. al., 2014). The Carpenter Ridge Tuff provides information about in-situ crystal liquid separation and zoned magma chambers containing crystal rich lower zones and liquid, eruptible, upper zones. This is thought to be common in uppercrustal magma reservoirs, though may not account fully for the exceptional mixture of mafic material in the Wildcat Creek Tuff.

The Rattlesnake Tuff of eastern Oregon is known for mafic inclusions, providing insight into mafic processes beneath large, silicic magma chambers. Inclusions contain both rhyolitic and basaltic phenocrysts, supporting a mixing model of genesis for the unit (Streck \& Grunder, 1999). The low-density rhyolite trapped the hot, mafic magma below, causing fractionation along with the recharge of hot, mafic magma. This entered incompatible elements into the primitive magma, while the mafic root zone thermally maintained the rhyolite and promoted zonation and differentiation (Streck \& Grunder, 
1999). The authors envisioned a zoned magma chamber, silicic at the top and mafic at depth, similar to the Wildcat Creek Tuff. Both tuff units contain mafic inclusions that are trace element enriched due to mafic fractionation. In both units, the basaltic andesite mixed with rhyolite to create exceptional mingling textures and trace element analyses indicate mixing rather than a crystal cumulate.

The Wildcat Creek Tuff contains rhyolite, andesite, and basaltic andesite, comingled during eruption to create an intermediate-to-felsic unit. The eruption created a tuff that is partially-to-densely welded at the bottom and non-welded at the top, with the most rhyolitic samples appearing at the bottom of the unit. Rhyolite erupted first, having been at the top of the stratified reservoir. This created the lowest part of the unit, containing mafic, scoriaceous inclusions of andesite. As more magma continued to erupt, it became less silicic. The lower magma reservoir contained progressively hotter, andesitic magma, leading to phenocryst-poor, andesitic lava emplaced above the rhyolite, containing increasingly more mafic material. This is consistent with progressively deeper withdrawal, implying that the mafic magmas resided beneath the rhyolites.

The rhyolitic component of this unit is phenocryst-poor, but contains alkalifeldspar and glass at $74-75 \mathrm{wt} \% \mathrm{SiO}_{2}$. Few plagioclase feldspar phenocrysts are found in the andesitic component, along with fewer pyroxenes. Clinopyroxene is the primary phenocryst associated with the mafic portion of the magma. A few fayalitic olivine crystals are observed in the rhyolite. The presence of these crystals, along with multiple glass analyses, implies that two mafic end members are present within the system. These include an andesite with a bulk composition of $60 \% \mathrm{SiO}_{2}$, and a basaltic-andesite with a bulk composition of $56 \% \mathrm{SiO}_{2}$. The prevalent mafic component, andesite at $60 \mathrm{wt} \% \mathrm{SiO}_{2}$, 
contains lower $\mathrm{TiO}_{2}$ and $\mathrm{CaO}$, lower $\mathrm{FeO}$, and comparable $\mathrm{Al}_{2} \mathrm{O}_{3}, \mathrm{MgO}$, and alkalis.

Together, these mafic magmas range from dacite to basaltic-andesite components due to mixing.

The models of the Ammonia Tanks Tuff and the Carpenter Ridge Tuff imply that the dacitic components of the magmas were crystal mush, remelted after the extraction of rhyolitic magma. These models do not explain the observed features of the Wildcat Creek Tuff due to small $\mathrm{Eu}$ anomalies and normal concentrations of $\mathrm{Ba}$ and Sr. These features, along with the aphyric texture of the Wildcat Creek Tuff, suggest that magma mixing of rhyolite and a basaltic-andesite created this unit. 


\section{CONCLUSION}

The Wildcat Creek Tuff is a thin, but voluminous ignimbrite, formed in Malheur County, eastern Oregon. It is related to the silicic and mafic volcanism of the Columbia River Province, and this particular unit is due to the mixing and co-eruption of rhyolite with andesite. The andesite of the WCT unit is variable, and divided into two magmas, including basaltic andesite at $57 \% \mathrm{SiO}_{2}$ and andesite at $60 \% \mathrm{SiO}_{2}$. Glass analyses confirm the range of both intermediate and rhyolitic glass to be close in silica content to the bulk composition of each end member. The mixture of the two magma types, despite the variable mafic end member, can be considered a binary system. The andesite components of the system all contain patterns suggestive of magma mixing, such as a negative Eu anomaly and troughs in $\mathrm{Sr}$ and $\mathrm{Ti}$. The most abundant phenocryst phase in a cumulate is feldspar, and when melted, would lead to enrichment of Eu and Sr that have preferentially partitioned into feldspar. The Wildcat Creek Tuff is depleted in these trace elements, arguing for magma mixing, evolved from a basaltic parent, rather than a remelted crystal cumulate which would present a positive Eu anomaly. Fractional crystallization, in-situ differentiation, and the remelting of a crystal cumulate are often the factors in the creation of similar rhyolite tuffs containing mafic inclusions, but these scenarios are unlikely in the formation of this unit. It is likely that extensive magma mixing of hot, andesitic recharge with the rhyolitic magma created the eruption of the Wildcat Creek Tuff as we see it today. Previously dated by only stratigraphic constraints, the here obtained single-crystal, anorthoclase ${ }^{40} \mathrm{Ar} /{ }^{39} \mathrm{Ar}$ radiometric age date of 
15.49 $\pm 0.02 \mathrm{Ma}$ for the Wildcat Creek Tuff provides now a precise absolute age for this tuff . 


\section{REFERENCES}

Bachman, O., Deering, C. D., Lipman, P. W., \& Plummer, C. (2014). Building zoned ignimbrites by recycling silicic cumulates: insight from the 1,000 km3 Carpenter Ridge Tuff, CO. Contributions to Mineralogy and Petrology , 167.

Deering, C. D., Bachman, O., \& Vogel, T. A. (2011). The Ammonia Tanks Tuff: Erupting a melt-rich rhyolite cap and its remobilized crystal cumulate. Earth and Planetary Science Letters .

ESRI. (2014, April 15). ArcGIS 10.2.2.

Ferns, M. L. (1993). Geologic Map of the Vale 30x60 Quadrangle, Malheur County, Oregon, and Owyhee County, Idaho. Oregon Department of Geology and Mineral Industries.

Google Earth. (2014). Retrieved from Google Earth: http:/www.google.com/earth/

Hildreth, W., \& Wilson, C. (2007). Compositional Zoning of the Bishop Tuff. Journal of Petrology , 48, 951-999.

Hooper, P., Binger, G., \& Lees, K.R. (2002). Ages of the Steens and Columbia River flood basalts and their relationship to extension-related calc-alkalic volcanism in eastern Oregon. Geological Society of America Bulletin (114), 43-50.

Large, A. M. (2016). Silicic Volcanism at the Northern and Western Extent of the Columbia River Basalt Rhyolite Flare-up: Rhyolites of the Buchanan Volcanic Complex and Dooley Mountain Volcanic Complex, Oregon. Portland State University, Department of Geology.

LeBas, M. L. (1986). A chemical classification of volcanic-rocks based on the total alkali silica diagram. Journal of Petrology, 27 (3), 745-750.

McDonough, W., \& Sun, S. (1995). The composition of the Earth. Chemical Geology, $120,223-253$.

McDougall, I., \& Harrison, T. (1999). Geochronology and Thermochronology by the 40Ar/39Ar Method (2nd ed.). Oxford: Oxford University Press.

Stimac, J. (1988). Geology of the Stockade Mountain 15' Quadrangle, Malheur and Harney Counties, Oregon. Fort Hayes State University.

Streck, M. J., \& Grunder, A. L. (1997). Compositional Gradients and Gaps in High-silica Rhyolites of the Rattlesnake Tuff, Oregon. Journal of Petrology , 38 (1), 133-163. 
Streck, M. J., \& Grunder, A. L. (1999). Enrichment of basalt and mixing of dacite in the root zone of a large rhyolite chamber: inclusions and pumices from the Rattlesnake Tuff, Oregon. Contributions to Mineralogy and Petrology, 136, 193-212.

Sun, S., \& McDonough, W. (1989). Chemical and isotopic systematics of oceanic basalts; implications for mantle composition and processes. 42 , 313-345. London: Geological Society.

Webb, B. M. (2017). The Littlefield Rhyolite, Eastern Oregon: Distinct Flow Units and Their Constraings on Age and Storage Sites of Grande Ronde Basalt Magmas. Portland State University, Department of Geology. 


\section{APPENDIX A: Field Site Locations}

Table 1. GPS coordinates for each sample selected during fieldwork. Sample MS-13-07 is not included because GPS coordinates are not available. Stop number and satellite variations in GPS are not included for all MS- samples because these are not available.

\begin{tabular}{|c|c|c|c|c|c|c|c|c|}
\hline \multirow{2}{*}{$\begin{array}{l}\text { Stop } \\
1 \mathrm{a}\end{array}$} & \multirow{2}{*}{$\begin{array}{c}\text { Sample Numbe } \\
\text { HS-15-01a }\end{array}$} & \multirow{2}{*}{$\begin{array}{c}\text { Zone } \\
11 \mathrm{~T}\end{array}$} & \multirow{2}{*}{$\begin{array}{l}\text { Easting } \\
425572\end{array}$} & \multirow{2}{*}{$\begin{array}{l}\text { Northing } \\
4823081\end{array}$} & \multirow{2}{*}{$\begin{array}{c}\begin{array}{c}\text { GPS Variation } \\
(+/-)\end{array} \\
2 \mathrm{~m}\end{array}$} & \multirow{2}{*}{$\begin{array}{cc}\text { Lat } & \text { Long } \\
43^{\circ} 33.418^{\prime} \mathrm{N} 117^{\circ} 55.290^{\prime} \mathrm{W}\end{array}$} & \multicolumn{2}{|c|}{ Decimal Degrees } \\
\hline & & & & & & & $43.556972^{\circ}$ & $-117.921497^{\circ}$ \\
\hline $1 \mathrm{~b}$ & HS-15-01b & $11 T$ & 425627 & 4823012 & $2 m$ & $43^{\circ} 33.381^{\prime} \mathrm{N} 117^{\circ} 55.248^{\prime} \mathrm{W}$ & $43.556356^{\circ}$ & $-117.920808^{\circ}$ \\
\hline $1 \mathrm{c}$ & HS-15-01c & $11 \mathrm{~T}$ & 425639 & 4823006 & $2 m$ & $43^{\circ} 33.378^{\prime} \mathrm{N} 117^{\circ} 55.240^{\prime} \mathrm{W}$ & $43.556303^{\circ}$ & $-117.920658^{\circ}$ \\
\hline $1 d$ & HS-15-01d & $11 \mathrm{~T}$ & 425646 & 4823002 & $2 m$ & $43^{\circ} 33.376^{\prime} \mathrm{N} 117^{\circ} 55.234^{\prime} \mathrm{W}$ & $43.555950^{\circ}$ & $-117.920875^{\circ}$ \\
\hline $1 \mathrm{e}$ & HS-15-01e & $11 \mathrm{~T}$ & 425621 & 4822967 & $2 m$ & $43^{\circ} 33.357^{\prime} \mathrm{N} 117^{\circ} 55.252^{\prime} \mathrm{W}$ & $43.555950^{\circ}$ & $-117.920875^{\circ}$ \\
\hline $2 a$ & HS-15-02a & $11 \mathrm{~T}$ & 427218 & 4822511 & $2 m$ & $43^{\circ} 33.121^{\prime} \mathrm{N} 117^{\circ} 53.914^{\prime} \mathrm{W}$ & $43.552022^{\circ}$ & $-117.898569^{\circ}$ \\
\hline $2 b$ & HS-15-02b & $11 \mathrm{~T}$ & 427253 & 4822964 & $2 m$ & $43^{\circ} 33.365^{\prime} \mathrm{N} 117^{\circ} 54.040^{\prime} \mathrm{W}$ & $43.556083^{\circ}$ & $-117.900672^{\circ}$ \\
\hline 3 & HS-15-03a & $11 T$ & 435258 & 4816522 & $3 m$ & $43^{\circ} 29.889^{\prime} \mathrm{N} 117^{\circ} 48.294^{\prime} \mathrm{W}$ & $43.498144^{\circ}$ & $-117.804903^{\circ}$ \\
\hline $4 a$ & HS-15-04a & $11 \mathrm{~T}$ & 433568 & 4821127 & $9 \mathrm{~m}$ & $43^{\circ} 32.408^{\prime} \mathrm{N} 117^{\circ} 49.336^{\prime} \mathrm{W}$ & $43.540133^{\circ}$ & $-117.822269^{\circ}$ \\
\hline $4 b$ & HS-15-04b & $11 \mathrm{~T}$ & 433570 & 4821160 & $3 m$ & $43^{\circ} 32.426^{\prime} \mathrm{N} 117^{\circ} 49.335^{\prime} \mathrm{W}$ & $43.540431^{\circ}$ & $-117.822250^{\circ}$ \\
\hline $4 c$ & HS-15-04c & $11 \mathrm{~T}$ & 433558 & 4821158 & $3 m$ & $43^{\circ} 32.425^{\prime} \mathrm{N} 117^{\circ} 49.344^{\prime} \mathrm{W}$ & $43.540411^{\circ}$ & $-117.822397^{\circ}$ \\
\hline $4 d$ & HS-15-04d & $11 T$ & 433538 & 4821170 & $3 m$ & $43^{\circ} 32.431^{\prime} \mathrm{N} 117^{\circ} 49.359^{\prime} \mathrm{W}$ & $43.540519^{\circ}$ & $-117.822647^{\circ}$ \\
\hline $4 e$ & HS-15-04e & $11 T$ & 433551 & 4821164 & $3 m$ & $43^{\circ} 32.428^{\prime} \mathrm{N} 117^{\circ} 49.349^{\prime} \mathrm{W}$ & $43.540467^{\circ}$ & $-117.822486^{\circ}$ \\
\hline $4 f$ & HS-15-04f & $11 T$ & 433571 & 4821130 & $3 m$ & $43^{\circ} 32.410^{\prime} \mathrm{N} 117^{\circ} 49.334^{\prime} \mathrm{W}$ & $43.540161^{\circ}$ & $-117.822233^{\circ}$ \\
\hline 5 & HS-15-05 & $11 \mathrm{~T}$ & 426936 & 4823219 & $3 m$ & $43^{\circ} 33.501^{\prime} \mathrm{N} 117^{\circ} 54.278^{\prime} \mathrm{W}$ & $43.558350^{\circ}$ & $-117.904619^{\circ}$ \\
\hline 6 & HS-15-06a & $11 T$ & 425243 & 4823131 & $2 m$ & $43^{\circ} 33.443^{\prime} \mathrm{N} 117^{\circ} 55.535^{\prime} \mathrm{W}$ & $43.557389^{\circ}$ & $-117.925567^{\circ}$ \\
\hline \multirow[t]{4}{*}{6} & HS-15-06b & $11 T$ & 425243 & 4823197 & $2 m$ & $43^{\circ} 33.479^{\prime} \mathrm{N} 117^{\circ} 55.535^{\prime} \mathrm{W}$ & $43.557983^{\circ}$ & $-117.925586^{\circ}$ \\
\hline & MS-14-03 & $11 \mathrm{~T}$ & 426853 & 4823177 & & $43^{\circ} 33.478^{\prime} \mathrm{N} 117^{\circ} 54.339^{\prime} \mathrm{W}$ & $43.557967^{\circ}$ & $-117.905650^{\circ}$ \\
\hline & MS-14-05 & $11 \mathrm{~T}$ & 432639 & 4824642 & & $43^{\circ} 34.302^{\prime} \mathrm{N} 117^{\circ} 50.052^{\prime} \mathrm{W}$ & $43.571700^{\circ}$ & $-117.834200^{\circ}$ \\
\hline & MS-14-06 & $11 \mathrm{~T}$ & 432810 & 4824768 & & $43^{\circ} 34.371^{\prime} \mathrm{N} 117^{\circ} 49.926^{\prime} \mathrm{W}$ & $43.572850^{\circ}$ & $-117.832100^{\circ}$ \\
\hline
\end{tabular}


APPENDIX B: Petrography of Thin Sections

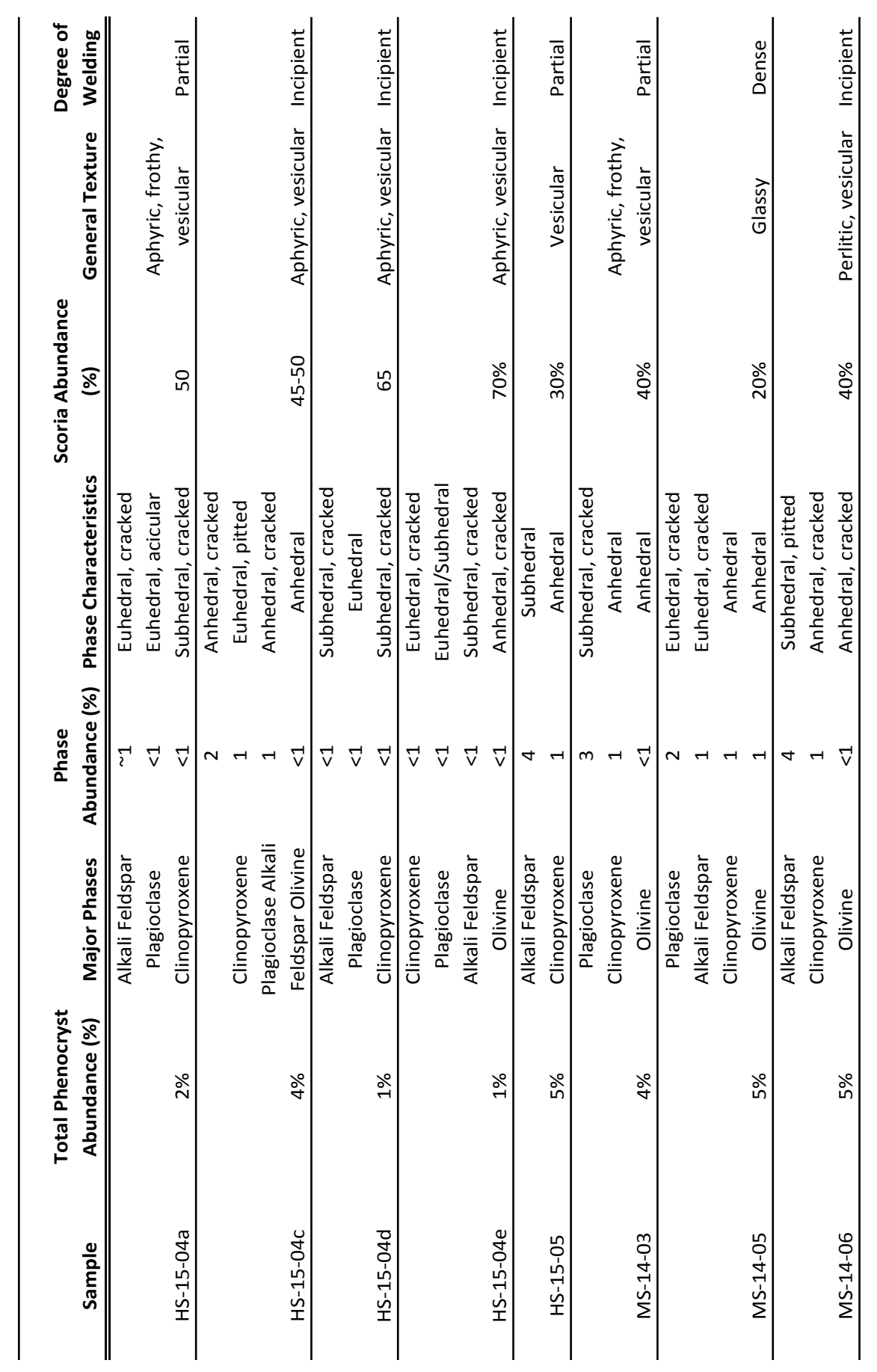


APPENDIX C: Bulk Geochemistry, XRF

\begin{tabular}{|c|c|c|c|c|c|c|c|c|}
\hline \multirow{2}{*}{$\begin{array}{c}\text { Data Set } \\
\text { Sample ID }\end{array}$} & \multicolumn{8}{|c|}{ Sales Wildcat Creek Tuff } \\
\hline & HS-15-01b & HS-15-04a & HS-15-04c & HS-15-04d & HS-15-04e & HS-15-04f & HS-15-05 & HS-15-06a \\
\hline Unit & WCT & WCT & WCT & WCT & WCT & WCT & WCT & WCT \\
\hline & \multicolumn{8}{|c|}{ Unnormalized Major Elements (Weight \%): } \\
\hline $\mathrm{SiO2}$ & 69.18 & 61.20 & 56.97 & 60.76 & 57.67 & 57.87 & 63.25 & 72.05 \\
\hline TiO2 & 0.56 & 1.30 & 1.47 & 1.40 & 1.46 & 0.38 & 0.81 & 0.31 \\
\hline Al2O3 & 13.09 & 13.31 & 16.07 & 13.81 & 15.42 & 16.61 & 12.61 & 12.50 \\
\hline $\mathrm{FeO}^{*}$ & 4.20 & 7.27 & 8.32 & 7.68 & 8.20 & 4.64 & 5.35 & 3.01 \\
\hline MnO & 0.19 & 0.19 & 0.23 & 0.21 & 0.23 & 0.13 & 0.16 & 0.16 \\
\hline MgO & 0.34 & 1.75 & 1.62 & 1.85 & 1.60 & 0.79 & 1.45 & 0.17 \\
\hline $\mathrm{CaO}$ & 0.68 & 3.85 & 3.97 & 4.15 & 3.96 & 0.93 & 4.14 & 0.21 \\
\hline $\mathrm{Na2O}$ & 4.74 & 4.19 & 4.31 & 4.35 & 4.36 & 1.61 & 4.01 & 4.75 \\
\hline K2O & 3.96 & 2.89 & 1.85 & 2.64 & 2.15 & 3.20 & 3.35 & 4.24 \\
\hline P2O5 & 0.14 & 0.46 & 0.59 & 0.53 & 0.63 & 0.04 & 0.32 & 0.05 \\
\hline Sum & 97.09 & 96.42 & 95.40 & 97.37 & 95.68 & 86.20 & 95.46 & 97.45 \\
\hline LOI \% & 1.91 & 1.85 & 3.92 & 1.83 & 2.98 & 12.38 & 3.66 & 1.57 \\
\hline \multicolumn{3}{|l|}{ XRF Data } & \multicolumn{6}{|c|}{ Normalized Major Elements (Weight \%): } \\
\hline $\mathrm{SiO2}$ & 71.25 & 63.47 & 59.71 & 62.40 & 60.28 & 67.14 & 66.26 & 73.93 \\
\hline TiO2 & 0.57 & 1.35 & 1.54 & 1.44 & 1.53 & 0.44 & 0.85 & 0.32 \\
\hline Al2O3 & 13.49 & 13.81 & 16.84 & 14.18 & 16.12 & 19.27 & 13.21 & 12.83 \\
\hline $\mathrm{FeO} *$ & 4.33 & 7.54 & 8.73 & 7.89 & 8.57 & 5.38 & 5.61 & 3.09 \\
\hline MnO & 0.19 & 0.20 & 0.24 & 0.21 & 0.24 & 0.15 & 0.17 & 0.16 \\
\hline MgO & 0.35 & 1.82 & 1.70 & 1.90 & 1.67 & 0.91 & 1.52 & 0.18 \\
\hline $\mathrm{CaO}$ & 0.70 & 3.99 & 4.16 & 4.26 & 4.14 & 1.08 & 4.34 & 0.22 \\
\hline $\mathrm{Na2O}$ & 4.89 & 4.34 & 4.51 & 4.47 & 4.56 & 1.87 & 4.20 & 4.87 \\
\hline K2O & 4.08 & 3.00 & 1.94 & 2.71 & 2.25 & 3.71 & 3.51 & 4.35 \\
\hline P2O5 & 0.15 & 0.48 & 0.62 & 0.54 & 0.65 & 0.04 & 0.34 & 0.05 \\
\hline Total & 100.00 & 100.00 & 100.00 & 100.00 & 100.00 & 100.00 & 100.00 & 100.00 \\
\hline
\end{tabular}




\begin{tabular}{|c|c|c|c|c|c|c|c|c|}
\hline \multirow{2}{*}{$\begin{array}{c}\text { Data Set } \\
\text { Sample ID } \\
\text { Unit } \\
\end{array}$} & \multicolumn{8}{|c|}{ Sales Wildcat Creek Tuff } \\
\hline & $\begin{array}{c}\text { HS-15-01b } \\
\text { WCT }\end{array}$ & $\begin{array}{c}\text { HS-15-04a } \\
\text { WCT }\end{array}$ & $\begin{array}{c}\text { HS-15-04c } \\
\text { WCT }\end{array}$ & $\begin{array}{c}\text { HS-15-04d } \\
\text { WCT }\end{array}$ & $\begin{array}{c}\text { HS-15-04e } \\
\text { WCT }\end{array}$ & $\begin{array}{c}\text { HS-15-04f } \\
\text { WCT }\end{array}$ & $\begin{array}{c}\text { HS-15-05 } \\
\text { WCT }\end{array}$ & $\begin{array}{c}\text { HS-15-06a } \\
\text { WCT }\end{array}$ \\
\hline XRF Data & \multicolumn{8}{|c|}{ Unnormalized Trace Elements (ppm): } \\
\hline $\mathbf{N i}$ & 8.06 & 9.85 & 12.04 & 12.74 & 11.84 & 3.68 & 13.33 & 7.46 \\
\hline $\mathrm{Cr}$ & 10.55 & 9.45 & 15.12 & 12.44 & 12.74 & 1.19 & 10.65 & 5.37 \\
\hline Sc & 10.45 & 20.60 & 24.18 & 22.69 & 23.58 & 8.46 & 13.93 & 6.77 \\
\hline $\mathbf{V}$ & 45.37 & 138.50 & 147.56 & 137.01 & 141.39 & 17.31 & 77.91 & 22.29 \\
\hline $\mathrm{Ba}$ & 1298.67 & 1012.21 & 1226.44 & 975.60 & 1049.13 & 523.47 & 1373.30 & 1870.30 \\
\hline $\mathbf{R b}$ & 89.45 & 55.22 & 25.87 & 51.84 & 34.43 & 59.70 & 70.55 & 95.12 \\
\hline $\mathrm{Sr}$ & 100.79 & 257.61 & 292.83 & 264.07 & 281.49 & 56.22 & 184.77 & 63.08 \\
\hline $\mathrm{Zr}$ & 427.03 & 316.43 & 359.56 & 316.13 & 353.20 & 628.32 & 358.35 & 450.86 \\
\hline$Y$ & 79.80 & 58.80 & 62.19 & 59.90 & 68.85 & 91.14 & 65.47 & 59.10 \\
\hline $\mathrm{Nb}$ & 25.97 & 21.29 & 21.49 & 21.39 & 23.08 & 39.00 & 23.18 & 27.86 \\
\hline Ga & 21.39 & 20.80 & 23.58 & 21.19 & 23.28 & 28.66 & 19.20 & 21.19 \\
\hline $\mathrm{Cu}$ & 11.84 & 21.79 & 23.58 & 24.38 & 24.97 & 7.36 & 19.40 & 9.25 \\
\hline $\mathrm{Zn}$ & 125.47 & 134.82 & 146.76 & 138.70 & 151.74 & 174.82 & 125.07 & 118.01 \\
\hline $\mathrm{Pb}$ & 14.43 & 11.54 & 13.43 & 11.54 & 12.94 & 22.39 & 15.02 & 13.93 \\
\hline La & 60.20 & 38.81 & 43.58 & 40.89 & 45.67 & 75.32 & 47.16 & 55.62 \\
\hline $\mathrm{Ce}$ & 91.64 & 80.79 & 94.23 & 81.89 & 96.71 & 140.20 & 86.96 & 75.02 \\
\hline Th & 8.26 & 5.77 & 7.26 & 6.27 & 6.07 & 12.54 & 7.06 & 8.06 \\
\hline
\end{tabular}




\begin{tabular}{|c|c|c|c|c|c|c|c|c|}
\hline \multirow{2}{*}{$\begin{array}{c}\text { Data Set } \\
\text { Sample ID }\end{array}$} & \multicolumn{4}{|c|}{ Streck Buchanan/Wildcat Creek Tuff } & \multicolumn{4}{|c|}{ Sales WCT Hand Selected Mafics } \\
\hline & MS-13-07 & MS-14-03 & MS-14-05 & MS-14-06 & HS1504a & HS1504c & HS1504d & HS1504e \\
\hline Unit & BT & WCT & WCT & WCT & WCT & WCT & WCT & WCT \\
\hline & \multicolumn{8}{|c|}{ "Unnormalized Major Elements (Weight \%): } \\
\hline $\mathrm{SiO2}$ & & & & & 57.13 & 62.31 & 59.33 & 57.78 \\
\hline TiO2 & & & & & 1.79 & 1.11 & 1.33 & 1.54 \\
\hline Al203 & & & & & 14.18 & 14.63 & 13.25 & 13.90 \\
\hline $\mathrm{FeO} *$ & & & & & 9.31 & 6.67 & 7.55 & 8.34 \\
\hline MnO & & & & & 0.21 & 0.20 & 0.21 & 0.18 \\
\hline MgO & & & & & 2.44 & 1.35 & 1.89 & 2.02 \\
\hline $\mathrm{CaO}$ & & & & & 5.33 & 3.21 & 4.06 & 5.46 \\
\hline $\mathrm{Na2O}$ & & & & & 4.84 & 4.21 & 3.75 & 3.83 \\
\hline K2O & & & & & 1.66 & 3.14 & 4.15 & 2.83 \\
\hline P2O5 & & & & & 0.72 & 0.47 & 0.47 & 0.71 \\
\hline Sum & & & & & 97.62 & 97.31 & 95.99 & 96.58 \\
\hline LOI \% & & & & & 1.64 & 2.48 & 3.60 & 2.57 \\
\hline XRF Data & \multicolumn{8}{|c|}{ Normalized Major Elements (Weight \%): } \\
\hline $\mathrm{SiO2}$ & 71.12 & 66.87 & 71.44 & 65.93 & 58.52 & 64.04 & 61.81 & 59.82 \\
\hline TiO2 & 0.55 & 0.89 & 0.49 & 1.06 & 1.83 & 1.14 & 1.39 & 1.59 \\
\hline Al2O3 & 13.42 & 13.59 & 13.36 & 13.76 & 14.53 & 15.03 & 13.81 & 14.39 \\
\hline $\mathrm{FeO}^{*}$ & 3.90 & 5.91 & 3.98 & 6.40 & 9.54 & 6.85 & 7.86 & 8.63 \\
\hline MnO & 0.07 & 0.17 & 0.15 & 0.18 & 0.21 & 0.20 & 0.22 & 0.19 \\
\hline MgO & 0.51 & 1.15 & 0.38 & 1.45 & 2.50 & 1.39 & 1.97 & 2.09 \\
\hline $\mathrm{CaO}$ & 1.60 & 3.11 & 1.04 & 3.15 & 5.46 & 3.30 & 4.23 & 5.65 \\
\hline $\mathrm{Na2O}$ & 3.72 & 4.46 & 3.63 & 3.67 & 4.96 & 4.32 & 3.90 & 3.97 \\
\hline K2O & 4.91 & 3.57 & 5.44 & 3.98 & 1.70 & 3.23 & 4.32 & 2.93 \\
\hline P2O5 & 0.18 & 0.28 & 0.10 & 0.41 & 0.73 & 0.49 & 0.49 & 0.73 \\
\hline Total & 95.48 & 97.11 & 95.93 & 96.37 & 100.00 & 100.00 & 100.00 & 100.00 \\
\hline
\end{tabular}




\begin{tabular}{|c|c|c|c|c|c|c|c|c|}
\hline \multirow{2}{*}{$\begin{array}{l}\text { Data Set } \\
\text { Sample ID }\end{array}$} & \multicolumn{4}{|c|}{ Streck Buchanan/Wildcat Creek Tuff } & \multicolumn{4}{|c|}{ Sales WCT Hand Selected Mafics } \\
\hline & MS-13-07 & MS-14-03 & MS-14-05 & MS-14-06 & HS1504a & HS1504c & HS1504d & HS1504e \\
\hline Unit & BT & WCT & WCT & WCT & WCT & WCT & WCT & WCT \\
\hline XRF Data & \multicolumn{8}{|c|}{ "Unnormalized Trace Elements (ppm): } \\
\hline $\mathrm{Ni}$ & 2.89 & 8.46 & 5.17 & 7.46 & 10.85 & 5.80 & 13.70 & 3.22 \\
\hline $\mathrm{Cr}$ & 3.88 & 12.54 & 8.66 & 12.84 & 15.28 & 12.40 & 12.30 & 2.61 \\
\hline Sc & 7.46 & 16.72 & 8.96 & 17.81 & 27.54 & 17.70 & 22.30 & 22.91 \\
\hline $\mathbf{v}$ & 26.47 & 83.78 & 33.33 & 90.35 & 165.72 & 102.20 & 152.40 & 103.82 \\
\hline $\mathrm{Ba}$ & 1539.66 & 1033.01 & 906.94 & 929.43 & 928.12 & 1142.40 & 909.00 & 1025.60 \\
\hline $\mathbf{R b}$ & 68.36 & 72.24 & 89.95 & 67.96 & 23.54 & 53.61 & 94.67 & 42.55 \\
\hline $\mathrm{Sr}$ & 123.18 & 161.29 & 70.65 & 188.06 & 365.32 & 226.10 & 227.90 & 374.16 \\
\hline $\mathrm{Zr}$ & 357.11 & 376.91 & 429.44 & 347.75 & 259.59 & 369.87 & 300.95 & 209.61 \\
\hline $\mathbf{Y}$ & 58.80 & 63.08 & 66.67 & 60.00 & 61.41 & 76.40 & 60.50 & 50.35 \\
\hline $\mathrm{Nb}$ & 21.99 & 24.08 & 26.57 & 23.68 & 18.69 & 23.40 & 20.80 & 14.77 \\
\hline Ga & 21.49 & 20.30 & 21.29 & 20.40 & 21.11 & 22.30 & 19.10 & 20.80 \\
\hline $\mathrm{Cu}$ & 2.89 & 15.82 & 7.16 & 18.81 & 29.25 & 18.10 & 29.90 & 4.82 \\
\hline $\mathrm{Zn}$ & 151.04 & 132.14 & 133.23 & 139.40 & 146.53 & 136.40 & 166.50 & 226.63 \\
\hline $\mathbf{P b}$ & 13.43 & 13.83 & 16.02 & 12.54 & 10.15 & 12.20 & 16.30 & 25.33 \\
\hline La & 38.51 & 42.69 & 46.27 & 40.20 & 39.60 & 49.10 & 37.80 & 31.46 \\
\hline $\mathrm{Ce}$ & 81.59 & 87.76 & 95.72 & 87.76 & 75.38 & 87.70 & 78.10 & 67.84 \\
\hline Th & 6.67 & 7.06 & 9.45 & 6.17 & 4.12 & 6.60 & 4.60 & 3.32 \\
\hline
\end{tabular}

\begin{tabular}{|c|c|c|c|c|c|c|c|c|c|c|c|c|c|c|}
\hline $\begin{array}{c}\text { Data Set } \\
\text { Sample ID }\end{array}$ & & \multicolumn{10}{|c|}{ Hooper et. al. (2002) } & \multicolumn{3}{|c|}{ Data Set } \\
\hline $\begin{array}{c}\text { Sample ID } \\
\text { Unit }\end{array}$ & $\begin{array}{c}\text { KL281 } \\
\text { WCT }\end{array}$ & $\begin{array}{c}\text { KL256 } \\
\text { WCT }\end{array}$ & $\begin{array}{l}\text { BB161 } \\
\text { WCT }\end{array}$ & $\begin{array}{l}\text { AL-82 } \\
\text { WCT }\end{array}$ & $\begin{array}{c}\text { MP-41B } \\
\text { WCT }\end{array}$ & $\begin{array}{l}\text { SK-43 } \\
\text { WCT }\end{array}$ & $\begin{array}{l}\text { SK46 } \\
\text { WCT }\end{array}$ & $\begin{array}{c}\text { SK-98A } \\
\text { WCT }\end{array}$ & $\begin{array}{l}\text { TP-115 } \\
\text { WCT }\end{array}$ & $\begin{array}{c}\text { TP-119 } \\
\text { WCT }\end{array}$ & $\begin{array}{c}\text { JJFB12 } \\
\text { WCT }\end{array}$ & $\begin{array}{c}\text { AYB424 } \\
\text { WCT }\end{array}$ & $\begin{array}{c}\text { Sample ID } \\
\text { Unit }\end{array}$ & $\begin{array}{c}\text { AYB425 } \\
\text { WCT }\end{array}$ \\
\hline \multicolumn{15}{|c|}{ Unnormalized Major Elements (Weight \%): } \\
\hline $\mathrm{SiO2}$ & & & & & & & & & & & & & $\mathrm{SiO2}$ & \\
\hline TiO2 & & & & & & & & & & & & & TiO2 & \\
\hline Al2O3 & & & & & & & & & & & & & Al2O3 & \\
\hline $\mathrm{FeO}^{*}$ & & & & & & & & & & & & & $\mathrm{FeO}^{*}$ & \\
\hline MnO & & & & & & & & & & & & & MnO & \\
\hline MgO & & & & & & & & & & & & & MgO & \\
\hline $\mathrm{CaO}$ & & & & & & & & & & & & & $\mathrm{CaO}$ & \\
\hline $\mathrm{Na2O}$ & & & & & & & & & & & & & $\mathrm{Na2O}$ & \\
\hline K2O & & & & & & & & & & & & & K2O & \\
\hline P2O5 & & & & & & & & & & & & & P2O5 & \\
\hline Sum & & & & & & & & & & & & & Sum & \\
\hline LOI \% & & & & & & & & & & & & & LOI \% & \\
\hline XRF Data & & \multicolumn{10}{|c|}{ Normalized Major Elements (Weight \%): } & \multicolumn{3}{|c|}{ XRF Data } \\
\hline $\mathrm{SiO2}$ & 73.40 & 73.44 & 72.48 & 73.90 & 72.80 & 71.63 & 72.86 & 74.75 & 71.71 & 72.07 & 74.59 & 72.11 & $\mathrm{SiO} 2$ & 69.89 \\
\hline TiO2 & 0.22 & 0.65 & 0.41 & 0.26 & 0.33 & 0.55 & 0.31 & 0.22 & 0.37 & 0.47 & 0.22 & 0.58 & TiO2 & 0.56 \\
\hline $\mathrm{Al} 2 \mathrm{O} 3$ & 13.79 & 13.96 & 13.22 & 12.66 & 13.49 & 13.55 & 13.40 & 13.67 & 14.17 & 13.48 & 13.43 & 13.33 & Al2O3 & 13.01 \\
\hline FeO* & 1.79 & 3.52 & 3.26 & 2.67 & 2.91 & 3.73 & 2.89 & 1.39 & 3.28 & 3.38 & 2.18 & 4.41 & $\mathrm{FeO}^{*}$ & 4.21 \\
\hline MnO & 0.07 & 0.10 & 0.11 & 0.12 & 0.12 & 0.15 & 0.11 & 0.04 & 0.15 & 0.13 & 0.08 & 0.19 & MnO & 0.15 \\
\hline MgO & 0.00 & 0.35 & 0.32 & 0.04 & 0.26 & 0.36 & 0.06 & 0.00 & 0.32 & 0.46 & 0.21 & 0.82 & $\mathrm{MgO}$ & 0.91 \\
\hline $\mathrm{CaO}$ & 0.59 & 1.31 & 0.83 & 0.47 & 0.77 & 0.74 & 0.58 & 0.45 & 0.74 & 1.10 & 0.92 & 1.34 & $\mathrm{CaO}$ & 3.33 \\
\hline $\mathrm{Na2O}$ & 5.08 & 1.58 & 3.65 & 5.29 & 3.41 & 5.02 & 4.05 & 4.30 & 3.83 & 3.89 & 4.18 & 2.52 & $\mathrm{Na2O}$ & 2.91 \\
\hline K2O & 5.04 & 5.03 & 5.63 & 4.57 & 5.75 & 4.12 & 5.71 & 5.15 & 5.38 & 4.90 & 4.14 & 4.56 & K2O & 4.83 \\
\hline P2O5 & 0.03 & 0.06 & 0.08 & 0.03 & 0.16 & 0.14 & 0.04 & 0.03 & 0.05 & 0.12 & 0.05 & 0.14 & P2O5 & 0.20 \\
\hline Total & 100.00 & 100.00 & 100.00 & 100.00 & 100.00 & 100.00 & 100.00 & 100.00 & 100.00 & 100.00 & 100.00 & 100.00 & Total & 100.00 \\
\hline
\end{tabular}




\begin{tabular}{lllllllllll}
\hline \multicolumn{10}{c}{ Hooper et. al. (2002) } \\
MP 12 & MP121 & AL72 & AL96 & AL174 & SC16 & SC22 & SC54 & SC108 & SK37 & SK81 \\
WCT & WCT & WCT & WCT & WCT & WCT & WCT & WCT & WCT & WCT & WCT \\
\hline \hline
\end{tabular}

Unnormalized Major Elements (Weight \%):

\begin{tabular}{cccccccccccc}
\multicolumn{10}{c}{ Normalized Major Elements (Weight \%): } \\
72.91 & 72.94 & 72.28 & 72.94 & 73.92 & 76.74 & 73.77 & 73.34 & 73.53 & 73.15 & 75.94 \\
0.30 & 0.35 & 0.39 & 0.37 & 0.37 & 0.29 & 0.32 & 0.36 & 0.33 & 0.31 & 0.21 \\
13.09 & 13.55 & 13.27 & 13.33 & 12.93 & 11.36 & 13.23 & 13.19 & 13.02 & 13.19 & 12.55 \\
2.91 & 2.89 & 3.22 & 2.92 & 2.99 & 2.66 & 2.46 & 3.06 & 3.05 & 3.16 & 1.49 \\
0.10 & 0.08 & 0.12 & 0.08 & 0.03 & 0.09 & 0.04 & 0.07 & 0.10 & 0.12 & 0.02 \\
0.13 & 0.10 & 0.27 & 0.14 & 0.29 & 0.29 & 0.32 & 0.41 & 0.23 & 0.18 & 0.35 \\
0.53 & 0.53 & 0.83 & 0.44 & 0.27 & 0.21 & 0.14 & 0.28 & 0.20 & 0.53 & 0.49 \\
3.66 & 3.89 & 3.73 & 5.39 & 4.95 & 4.51 & 5.23 & 4.98 & 5.08 & 3.91 & 4.53 \\
6.30 & 5.61 & 5.81 & 4.27 & 4.17 & 3.81 & 4.46 & 4.28 & 4.40 & 5.41 & 4.37 \\
0.05 & 0.05 & 0.10 & 0.11 & 0.08 & 0.04 & 0.03 & 0.04 & 0.05 & 0.04 & 0.05 \\
100.00 & 100.00 & 100.00 & 100.00 & 100.00 & 100.00 & 100.00 & 100.00 & 100.00 & 100.00 & 100.00 \\
\hline
\end{tabular}




\begin{tabular}{|c|c|c|c|c|c|c|c|c|c|c|}
\hline \multirow[b]{2}{*}{$\begin{array}{l}\text { MP } 12 \\
\text { WCT }\end{array}$} & \multirow[b]{2}{*}{$\begin{array}{c}\text { MP121 } \\
\text { WCT }\end{array}$} & \multicolumn{7}{|c|}{ Hooper et. al. (2002) } & \multirow[b]{2}{*}{$\begin{array}{l}\text { SK37 } \\
\text { WCT }\end{array}$} & \multirow[b]{2}{*}{$\begin{array}{l}\text { SK81 } \\
\text { WCT }\end{array}$} \\
\hline & & $\begin{array}{l}\text { AL72 } \\
\text { WCT }\end{array}$ & $\begin{array}{l}\text { AL96 } \\
\text { WCT }\end{array}$ & $\begin{array}{c}\text { AL174 } \\
\text { WCT }\end{array}$ & $\begin{array}{l}\text { SC16 } \\
\text { WCT }\end{array}$ & $\begin{array}{l}\text { SC22 } \\
\text { WCT }\end{array}$ & $\begin{array}{l}\text { SC54 } \\
\text { WCT }\end{array}$ & $\begin{array}{c}\text { SC108 } \\
\text { WCT }\end{array}$ & & \\
\hline \multicolumn{11}{|c|}{ Unnormalized Trace Elements (ppm): } \\
\hline 8.00 & 10.00 & 11.00 & 12.00 & 12.00 & 10.00 & 14.00 & 9.00 & 10.00 & 7.00 & 11.00 \\
\hline 1.00 & 5.00 & 8.00 & 3.00 & 5.00 & 5.00 & 3.00 & 5.00 & 7.00 & 2.00 & 0.00 \\
\hline 2.00 & 1.00 & 6.00 & 3.00 & 2.00 & 4.00 & 0.00 & 2.00 & 4.00 & 7.00 & 0.00 \\
\hline 1.00 & 10.00 & 17.00 & 28.00 & 16.00 & 24.00 & 16.00 & 29.00 & 24.00 & 4.00 & 11.00 \\
\hline 968.00 & 1191.00 & 1065.00 & 1064.00 & 925.00 & 853.00 & 859.00 & 972.00 & 1006.00 & 1051.00 & 950.00 \\
\hline 101.00 & 108.00 & 95.00 & 92.00 & 92.00 & 86.00 & 100.00 & 94.00 & 100.00 & 97.00 & 110.00 \\
\hline 33.00 & 49.00 & 53.00 & 47.00 & 50.00 & 42.00 & 29.00 & 45.00 & 38.00 & 38.00 & 36.00 \\
\hline 410.00 & 405.00 & 398.00 & 392.00 & 390.00 & 355.00 & 417.00 & 405.00 & 416.00 & 411.00 & 337.00 \\
\hline 69.00 & 65.00 & 73.00 & 75.00 & 66.00 & 51.00 & 54.00 & 47.00 & 53.00 & 69.00 & 65.00 \\
\hline 30.68 & 31.19 & 30.83 & 30.17 & 29.59 & 27.14 & 29.51 & 30.74 & 31.12 & 32.16 & 29.80 \\
\hline 22.00 & 21.00 & 24.00 & 25.00 & 22.00 & 18.00 & 22.00 & 22.00 & 22.00 & 22.00 & 18.00 \\
\hline 1.00 & 0.00 & 3.00 & 7.00 & 3.00 & 3.00 & 0.00 & 5.00 & 2.00 & 0.00 & 0.00 \\
\hline 122.00 & 117.00 & 127.00 & 121.00 & 120.00 & 106.00 & 121.00 & 95.00 & 125.00 & 125.00 & 64.00 \\
\hline 16.00 & 16.00 & 15.00 & 15.00 & 11.00 & 12.00 & 13.00 & 12.00 & 15.00 & 15.00 & 14.00 \\
\hline 58.00 & 51.00 & 44.00 & 60.00 & 47.00 & 46.00 & 50.00 & 47.00 & 37.00 & 67.00 & 50.00 \\
\hline 99.00 & 97.00 & 98.00 & 118.00 & 78.00 & 95.00 & 77.00 & 61.00 & 75.00 & 100.00 & 121.00 \\
\hline 7.00 & 8.00 & 7.00 & 7.00 & 7.00 & 6.00 & 6.00 & 6.00 & 7.00 & 8.00 & 10.00 \\
\hline
\end{tabular}


APPENDIX D: Bulk Geochemistry, ICP-MS

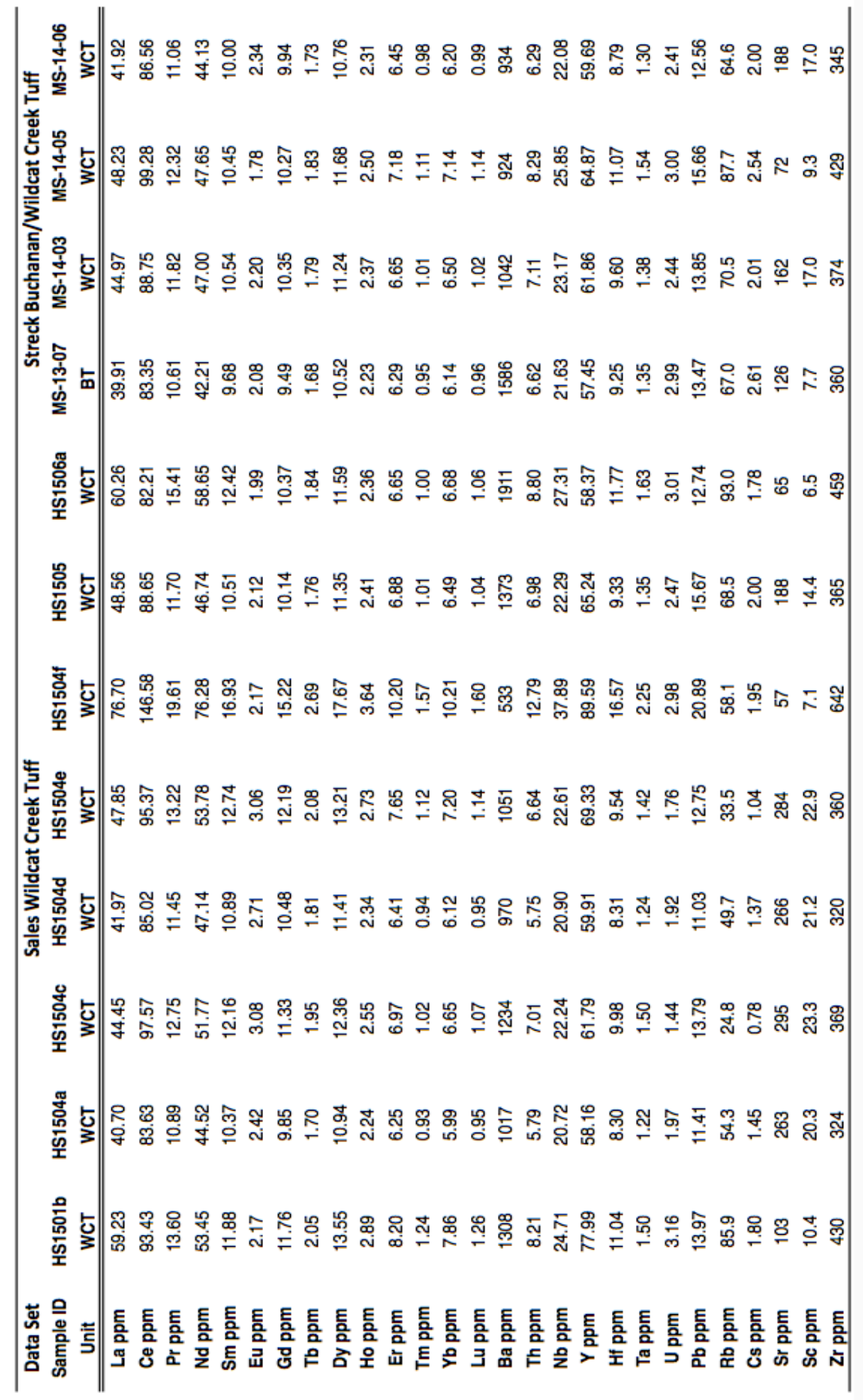


APPENDIX E: Glass Geochemistry, EMP

\begin{tabular}{|c|c|c|c|c|c|c|c|c|c|c|}
\hline \multirow{4}{*}{$\begin{array}{c}\text { Date } \\
\text { Sample } \\
\text { Site/Glass }\end{array}$} & \multicolumn{10}{|c|}{$\begin{array}{ll}\text { EMP Glass Values } \\
\end{array}$} \\
\hline & $12 / 2 / 1623: 23$ & $12 / 2 / 1623: 26$ & $12 / 2 / 1623: 29$ & $12 / 2 / 1623: 31$ & $12 / 2 / 1623: 34$ & 12/2/16 23:36 & $12 / 2 / 1623: 59$ & 12/3/16 0:02 & 12/3/160:04 & 12/3/16 0:07 \\
\hline & MS-14-05 & MS-14-05 & MS-14-05 & MS-14-05 & MS-14-05 & MS-14-05 & MS-14-06 & MS-14-06 & MS-14-06 & MS-14-06 \\
\hline & 20/1 & $20 / 1$ & $20 / 1$ & $20 / 2$ & $20 / 2$ & $20 / 2$ & $10 / 5$ & $10 / 5$ & $10 / 6$ & $10 / 6$ \\
\hline SiO2 & 70.58 & 69.74 & 70.24 & 69.19 & 69.24 & 69.89 & 56.41 & 56.29 & 73.67 & 73.49 \\
\hline $\mathrm{Al} 2 \mathrm{O} 3$ & 12.43 & 12.16 & 12.30 & 12.51 & 12.33 & 12.23 & 14.19 & 14.02 & 13.38 & 13.58 \\
\hline $\mathrm{FeO}$ & 2.34 & 2.41 & 1.63 & 2.33 & 3.22 & 2.03 & 9.73 & 10.41 & 2.65 & 2.72 \\
\hline $\mathrm{MgO}$ & 0.02 & 0.04 & 0.02 & 0.06 & 0.06 & 0.03 & 3.14 & 3.34 & 0.07 & 0.09 \\
\hline $\mathrm{CaO}$ & 0.05 & 0.09 & 0.06 & 0.70 & 0.13 & 0.13 & 6.21 & 6.15 & 0.39 & 0.45 \\
\hline $\mathrm{Na} 2 \mathrm{O}$ & 2.45 & 2.98 & 2.15 & 2.30 & 2.96 & 2.62 & 1.52 & 1.92 & 3.59 & 3.48 \\
\hline K2O & 6.19 & 6.05 & 6.04 & 5.91 & 5.61 & 5.90 & 2.35 & 2.28 & 4.00 & 3.92 \\
\hline BaO & 0.07 & 0.08 & 0.08 & 0.09 & 0.09 & 0.08 & 0.12 & 0.12 & 0.10 & 0.10 \\
\hline Total & 94.14 & 93.55 & 92.52 & 93.10 & 93.62 & 92.93 & 93.68 & 94.52 & 97.85 & 97.83 \\
\hline
\end{tabular}

\begin{tabular}{|c|c|c|c|c|c|c|c|c|}
\hline \multicolumn{9}{|c|}{ EMP Glass Values (cont'd) } \\
\hline Date & 2/24/17 21:40 & $2 / 24 / 1721: 43$ & $2 / 24 / 1721: 46$ & $2 / 24 / 1721: 49$ & $2 / 24 / 1721: 52$ & 2/24/17 21:54 & 2/24/17 21:57 & $2 / 24 / 1722: 00$ \\
\hline Sample & MS-14-06 & MS-14-06 & MS-14-06 & MS-14-06 & MS-14-06 & MS-14-06 & MS-14-06 & MS-14-06 \\
\hline Site/Glass & $11 / 1$ & $11 / 1$ & $11 / 2$ & $11 / 2$ & $11 / 3$ & $11 / 3$ & $11 / 4$ & $11 / 4$ \\
\hline $\mathrm{SiO2}$ & 55.90 & 55.68 & 59.83 & 59.50 & 57.39 & 55.49 & 74.01 & 74.09 \\
\hline $\mathrm{TiO} 2$ & 2.34 & 2.23 & 1.77 & 1.79 & 2.18 & 2.21 & 0.29 & 0.25 \\
\hline $\mathrm{Al} 2 \mathrm{O} 3$ & 14.13 & 14.14 & 14.06 & 14.21 & 14.20 & 13.84 & 13.08 & 13.18 \\
\hline $\mathrm{FeO}$ & 10.19 & 10.92 & 9.43 & 9.02 & 10.82 & 11.55 & 2.61 & 2.69 \\
\hline $\mathrm{MnO}$ & 0.21 & 0.22 & 0.29 & 0.20 & 0.19 & 0.27 & 0.11 & 0.16 \\
\hline $\mathrm{MgO}$ & 3.95 & 3.92 & 3.09 & 2.67 & 3.45 & 4.03 & 0.09 & 0.07 \\
\hline $\mathrm{CaO}$ & 7.78 & 8.01 & 6.21 & 5.24 & 5.78 & 7.09 & 0.80 & 0.66 \\
\hline $\mathrm{Na} 2 \mathrm{O}$ & 2.16 & 2.62 & 2.00 & 1.83 & 2.03 & 1.79 & 2.86 & 2.96 \\
\hline $\mathrm{K} 2 \mathrm{O}$ & 2.26 & 2.26 & 2.84 & 2.67 & 2.64 & 2.25 & 4.63 & 4.16 \\
\hline $\mathrm{Cr} 2 \mathrm{O} 3$ & 0.00 & 0.04 & 0.01 & 0.01 & 0.00 & 0.03 & 0.00 & 0.00 \\
\hline $\mathrm{ZnO}$ & 0.07 & 0.05 & 0.01 & 0.02 & 0.00 & 0.00 & 0.02 & 0.04 \\
\hline Total & 98.99 & 100.07 & 99.54 & 97.17 & 98.68 & 98.58 & 98.52 & 98.25 \\
\hline
\end{tabular}

\begin{tabular}{|c|c|c|c|c|c|c|c|c|c|c|}
\hline \multirow{4}{*}{$\begin{array}{c}\text { Date } \\
\text { Sample } \\
\text { Site/Glass }\end{array}$} & \multicolumn{10}{|c|}{ Normalized EMP Glass Values } \\
\hline & 12/2/16 23:23 & $12 / 2 / 1623: 26$ & $12 / 2 / 1623: 29$ & $12 / 2 / 1623: 31$ & $12 / 2 / 1623: 34$ & $12 / 2 / 1623: 36$ & 12/2/16 23:59 & $12 / 3 / 160: 02$ & $12 / 3 / 160: 04$ & $12 / 3 / 160: 07$ \\
\hline & MS-14-05 & MS-14-05 & MS-14-05 & MS-14-05 & MS-14-05 & MS-14-05 & MS-14-06 & MS-14-06 & MS-14-06 & MS-14-06 \\
\hline & $20 / 1$ & $20 / 1$ & $20 / 1$ & $20 / 2$ & $20 / 2$ & $20 / 2$ & $10 / 5$ & $10 / 5$ & $10 / 6$ & $10 / 6$ \\
\hline SiO2 & 74.98 & 74.55 & 75.93 & 74.32 & 73.95 & 75.21 & 60.21 & 59.56 & 75.28 & 75.12 \\
\hline Al203 & 13.20 & 13.00 & 13.29 & 13.44 & 13.17 & 13.17 & 15.15 & 14.83 & 13.67 & 13.88 \\
\hline $\mathrm{FeO}$ & 2.49 & 2.58 & 1.77 & 2.50 & 3.44 & 2.19 & 10.38 & 11.01 & 2.71 & 2.78 \\
\hline $\mathrm{MgO}$ & 0.02 & 0.04 & 0.02 & 0.07 & 0.06 & 0.03 & 3.35 & 3.54 & 0.08 & 0.10 \\
\hline $\mathrm{CaO}$ & 0.05 & 0.10 & 0.07 & 0.75 & 0.14 & 0.14 & 6.63 & 6.50 & 0.40 & 0.46 \\
\hline $\mathrm{Na} 2 \mathrm{O}$ & 2.60 & 3.18 & 2.32 & 2.47 & 3.16 & 2.82 & 1.62 & 2.03 & 3.66 & 3.56 \\
\hline K2O & 6.58 & 6.47 & 6.53 & 6.35 & 5.99 & 6.35 & 2.51 & 2.41 & 4.09 & 4.00 \\
\hline $\mathrm{BaO}$ & 0.08 & 0.09 & 0.09 & 0.09 & 0.09 & 0.09 & 0.13 & 0.12 & 0.11 & 0.10 \\
\hline Total & 100.00 & 100.00 & 100.00 & 100.00 & 100.00 & 100.00 & 100.00 & 100.00 & 100.00 & 100.00 \\
\hline
\end{tabular}

\begin{tabular}{|c|c|c|c|c|c|c|c|c|}
\hline \multicolumn{9}{|c|}{ Normalized EMP Glass Values (cont'd) } \\
\hline Date & 2/24/17 21:40 & 2/24/17 21:43 & 2/24/17 21:46 & 2/24/17 21:49 & 2/24/17 21:52 & 2/24/17 21:54 & 2/24/17 21:57 & 2/24/17 22:00 \\
\hline Sample & MS-14-06 & MS-14-06 & MS-14-06 & MS-14-06 & MS-14-06 & MS-14-06 & MS-14-06 & MS-14-06 \\
\hline Site/Glass & $11 / 1$ & $11 / 1$ & $11 / 2$ & $11 / 2$ & $11 / 3$ & $11 / 3$ & $11 / 4$ & $11 / 4$ \\
\hline $\mathrm{SiO} 2$ & 56.47 & 55.64 & 60.10 & 61.24 & 58.16 & 56.29 & 75.12 & 75.41 \\
\hline $\mathrm{TiO2}$ & 2.36 & 2.23 & 1.78 & 1.84 & 2.21 & 2.25 & 0.30 & 0.25 \\
\hline Al2O3 & 14.28 & 14.13 & 14.12 & 14.62 & 14.39 & 14.04 & 13.28 & 13.41 \\
\hline $\mathrm{FeO}$ & 10.30 & 10.91 & 9.47 & 9.29 & 10.96 & 11.72 & 2.65 & 2.74 \\
\hline MnO & 0.22 & 0.22 & 0.29 & 0.20 & 0.19 & 0.27 & 0.12 & 0.16 \\
\hline $\mathrm{MgO}$ & 3.99 & 3.91 & 3.10 & 2.75 & 3.50 & 4.09 & 0.09 & 0.07 \\
\hline $\mathrm{CaO}$ & 7.85 & 8.00 & 6.24 & 5.39 & 5.86 & 7.20 & 0.82 & 0.67 \\
\hline $\mathrm{Na} 2 \mathrm{O}$ & 2.19 & 2.62 & 2.01 & 1.88 & 2.06 & 1.82 & 2.90 & 3.01 \\
\hline $\mathrm{K} 2 \mathrm{O}$ & 2.28 & 2.25 & 2.86 & 2.75 & 2.68 & 2.28 & 4.70 & 4.24 \\
\hline $\mathrm{Cr} 2 \mathrm{O} 3$ & 0.00 & 0.04 & 0.01 & 0.01 & 0.00 & 0.03 & 0.00 & 0.00 \\
\hline $\mathrm{ZnO}$ & 0.07 & 0.05 & 0.01 & 0.02 & 0.00 & 0.00 & 0.02 & 0.05 \\
\hline Total & 100.00 & 100.00 & 100.00 & 100.00 & 100.00 & 100.00 & 100.00 & 100.00 \\
\hline
\end{tabular}




\begin{tabular}{cccccc}
\hline Sample & MS-14-05 & MS-14-05 & MS-14-05 & MS-14-05 & MS-14-05 \\
Glass\# & $\mathbf{1 - 1}$ & $\mathbf{1 - 2}$ & $\mathbf{1 - 3}$ & $\mathbf{2 - 1}$ & $\mathbf{2 - 2}$ \\
Glass Type & Rhyolite & Rhyolite & Rhyolite & Rhyolite & Rhyolite \\
\hline \hline SiO2 & 74.98 & 74.55 & 75.93 & 74.32 & 73.95 \\
Al2O3 & 13.20 & 13.00 & 13.29 & 13.44 & 13.17 \\
FeO & 2.49 & 2.58 & 1.77 & 2.50 & 3.44 \\
MgO & 0.02 & 0.04 & 0.02 & 0.07 & 0.06 \\
CaO & 0.05 & 0.10 & 0.07 & 0.75 & 0.14 \\
Na2O & 2.60 & 3.18 & 2.32 & 2.47 & 3.16 \\
K2O & 6.58 & 6.47 & 6.53 & 6.35 & 5.99 \\
BaO & 0.08 & 0.09 & 0.09 & 0.09 & 0.09 \\
Total & 100.00 & 100.00 & 100.00 & 100.00 & 100.00 \\
\hline & & & & & \\
Sample & MS-14-05 & MS-14-06 & MS-14-06 & MS-14-06 & MS-14-06 \\
Glass\# & $\mathbf{2 - 3}$ & $\mathbf{5 - 1}$ & $\mathbf{5 - 2}$ & $\mathbf{6 - 1}$ & $\mathbf{6 - 2}$ \\
Glass Type & Rhyolite & Andesite & Andesite & Rhyolite & Rhyolite \\
\hline \hline SiO2 & 75.21 & 60.21 & 59.56 & 75.28 & 75.12 \\
Al2O3 & 13.17 & 15.15 & 14.83 & 13.67 & 13.88 \\
FeO & 2.19 & 10.38 & 11.01 & 2.71 & 2.78 \\
MgO & 0.03 & 3.35 & 3.54 & 0.08 & 0.10 \\
CaO & 0.14 & 6.63 & 6.50 & 0.40 & 0.46 \\
Na2O & 2.82 & 1.62 & 2.03 & 3.66 & 3.56 \\
K2O & 6.35 & 2.51 & 2.41 & 4.09 & 4.00 \\
BaO & 0.09 & 0.13 & 0.12 & 0.11 & 0.10 \\
Total & 100.00 & 100.00 & 100.00 & 102.97 & 100.00 \\
\hline
\end{tabular}




\begin{tabular}{|c|c|c|c|}
\hline Sample & MS-14-06 & MS-14-06 & MS-14-06 \\
\hline Glass\# & 1-1 & 1-2 & 2-1 \\
\hline Glass Type & \multicolumn{2}{|c|}{ Basaltic AndesiteBasaltic Andesite } & Andesite \\
\hline $\mathrm{SiO2}$ & 56.47 & 55.64 & 60.10 \\
\hline TiO2 & 2.36 & 2.23 & 1.78 \\
\hline Al2O3 & 14.28 & 14.13 & 14.12 \\
\hline $\mathrm{FeO}$ & 10.30 & 10.91 & 9.47 \\
\hline MnO & 0.22 & 0.22 & 0.29 \\
\hline MgO & 3.99 & 3.91 & 3.10 \\
\hline $\mathrm{CaO}$ & 7.85 & 8.00 & 6.24 \\
\hline $\mathrm{Na2O}$ & 2.19 & 2.62 & 2.01 \\
\hline K2O & 2.28 & 2.25 & 2.86 \\
\hline Cr2O3 & 0.00 & 0.04 & 0.01 \\
\hline $\mathrm{ZnO}$ & 0.07 & 0.05 & 0.01 \\
\hline Total & 100.00 & 100.00 & 100.00 \\
\hline Sample & MS-14-06 & MS-14-06 & MS-14-06 \\
\hline Glass\# & 3-2 & 4-1 & 4-2 \\
\hline Glass Type & Andesite & Rhyolite & Rhyolite \\
\hline $\mathrm{SiO2}$ & 56.29 & 75.12 & 75.41 \\
\hline TiO2 & 2.25 & 0.30 & 0.25 \\
\hline Al2O3 & 14.04 & 13.28 & 13.41 \\
\hline $\mathrm{FeO}$ & 11.72 & 2.65 & 2.74 \\
\hline MnO & 0.27 & 0.12 & 0.16 \\
\hline MgO & 4.09 & 0.09 & 0.07 \\
\hline $\mathrm{CaO}$ & 7.20 & 0.82 & 0.67 \\
\hline $\mathrm{Na2O}$ & 1.82 & 2.90 & 3.01 \\
\hline K2O & 2.28 & 4.70 & 4.24 \\
\hline Cr2O3 & 0.03 & 0.00 & 0.00 \\
\hline ZnO & 0.00 & 0.02 & 0.05 \\
\hline Total & 100.00 & 100.00 & 100.00 \\
\hline
\end{tabular}


APPENDIX F: Feldspar Geochemistry, SEM

\begin{tabular}{|c|c|c|c|c|c|c|c|c|c|c|c|c|}
\hline \multirow[b]{2}{*}{ Sample } & \multirow[b]{2}{*}{ Site } & \multirow[b]{2}{*}{ Spectra } & \multirow[b]{2}{*}{ K (Atomic\%) } & \multirow[b]{2}{*}{$K(w t \%)$} & \multirow[b]{2}{*}{$\mathrm{Ca}$ (Atomic\%) } & \multirow[b]{2}{*}{$\mathrm{Ca}(w t \%)$} & \multirow[b]{2}{*}{$\mathrm{Na}$ (Atomic\%) } & \multirow{2}{*}{$\mathrm{Na}(\mathrm{wt} \%)$} & \multirow{2}{*}{$\begin{array}{l}\text { (High K) } \\
\text { Or }\end{array}$} & \multicolumn{2}{|c|}{ (High Ca) (High Na) } & \multirow{2}{*}{ Total } \\
\hline & & & & & & & & & & An & $\mathrm{Ab}$ & \\
\hline HS154a & 3 & 1 & 1.52 & 2.77 & 0.48 & 0.9 & 6.02 & 6.46 & 18.953 & 5.985 & 75.062 & 100 \\
\hline HS154a & 4 & 1 & 0.44 & 0.76 & 2.65 & 4.62 & 4.15 & 4.14 & 6.077 & 36.602 & 57.320 & 100 \\
\hline HS154a & 5 & 3 & 0.68 & 1.25 & 1.49 & 2.8 & 6.24 & 6.74 & 8.086 & 17.717 & 74.197 & 100 \\
\hline HS154a & 5 & 6 & 1.8 & 3.29 & 0.53 & 0.99 & 5.96 & 6.41 & 21.713 & 6.393 & 71.894 & 100 \\
\hline HS154a & 6 & 1 & 1.51 & 2.75 & 0.54 & 1 & 6.16 & 6.6 & 18.392 & 6.577 & 75.030 & 100 \\
\hline HS154a & 6 & 2 & 1.53 & 2.79 & 0.57 & 1.07 & 6.15 & 6.6 & 18.545 & 6.909 & 74.545 & 100 \\
\hline HS1505 & 2 & 1 & 0.28 & 0.51 & 3.08 & 5.71 & 5.35 & 5.7 & 3.215 & 35.362 & 61.424 & 100 \\
\hline HS1505 & 2 & 3 & 0.2 & 0.38 & 2.76 & 5.38 & 4.83 & 5.4 & 2.567 & 35.430 & 62.003 & 100 \\
\hline HS1505 & 3 & 4 & 3.08 & 5.87 & 0 & 0 & 3.32 & 3.71 & 48.125 & 0.000 & 51.875 & 100 \\
\hline HS1505 & 3 & 6 & 0.83 & 1.59 & 0.27 & 0.53 & 4.23 & 4.8 & 15.572 & 5.066 & 79.362 & 100 \\
\hline HS1505 & 3 & 7 & 0.17 & 0.32 & 3.63 & 7.06 & 3.95 & 4.4 & 2.194 & 46.839 & 50.968 & 100 \\
\hline HS1505 & 4 & 1 & 1.59 & 2.9 & 0.51 & 0.54 & 6.23 & 6.66 & 19.088 & 6.122 & 74.790 & 100 \\
\hline HS1505 & 4 & 2 & 1.55 & 2.81 & 0.58 & 1.07 & 6.26 & 6.68 & 18.474 & 6.913 & 74.613 & 100 \\
\hline HS1505 & 5 & 1 & 0 & 0 & 5.68 & 10.95 & 1.99 & 2.2 & 0.000 & 74.055 & 25.945 & 100 \\
\hline HS1505 & 5 & 2 & 0 & 0 & 5.39 & 10.45 & 2.2 & 2.45 & 0.000 & 71.014 & 28.986 & 100 \\
\hline HS1505 & 7 & 2 & 0.76 & 1.39 & 1.91 & 3.57 & 5.93 & 6.35 & 8.837 & 22.209 & 68.953 & 100 \\
\hline HS1505 & 9 & 1 & 1.41 & 2.7 & 0.48 & 0.94 & 5.44 & 6.15 & 19.236 & 6.548 & 74.216 & 100 \\
\hline HS1505 & 10 & 1 & 3.67 & 6.71 & 0 & 0 & 1.16 & 1.25 & 75.983 & 0.000 & 24.017 & 100 \\
\hline HS1505 & 11 & 1 & 1.45 & 2.78 & 0.45 & 0.89 & 5.53 & 6.23 & 19.515 & 6.057 & 74.428 & 100 \\
\hline HS1505 & 11 & 2 & 0.95 & 2.22 & 0.14 & 0.34 & 0.68 & 0.94 & 53.672 & 7.910 & 38.418 & 100 \\
\hline HS154D & 1 & 1 & 2.14 & 4.14 & 0.39 & 0.77 & 4.57 & 5.21 & 30.141 & 5.493 & 64.366 & 100 \\
\hline HS154D & 2 & 1 & 0.29 & 0.57 & 0.11 & 0.23 & 0.37 & 0.43 & 37.662 & 14.286 & 48.052 & 100 \\
\hline HS154D & 2 & 2 & 4.17 & 7.98 & 0.24 & 0.48 & 2.24 & 2.52 & 62.707 & 3.609 & 33.684 & 100 \\
\hline HS154D & 3 & 2 & 3.38 & 6.42 & 0 & 0 & 3.73 & 4.16 & 47.539 & 0.000 & 52.461 & 100 \\
\hline HS154D & 4 & 1 & 0.24 & 0.47 & 1.52 & 3.02 & 1.36 & 1.54 & 7.692 & 48.718 & 43.590 & 100 \\
\hline HS154D & 5 & 3 & 3.53 & 6.72 & 0 & 0 & 3.39 & 3.79 & 51.012 & 0.000 & 48.988 & 100 \\
\hline HS154D & 6 & 1 & 0.13 & 0.24 & 4.54 & 8.98 & 2.63 & 2.98 & 1.781 & 62.192 & 36.027 & 100 \\
\hline HS154D & 6 & 2 & 0.1 & 0.18 & 4.34 & 8.17 & 3.34 & 3.6 & 1.285 & 55.784 & 42.931 & 100 \\
\hline
\end{tabular}

\begin{tabular}{|c|c|c|c|c|c|c|c|c|c|c|c|c|}
\hline \multirow[b]{2}{*}{ Sample } & \multirow[b]{2}{*}{ Site } & \multirow[b]{2}{*}{ Spectra } & \multirow[b]{2}{*}{ K (Atomic\%) } & \multirow[b]{2}{*}{ K (wt\%) } & \multirow[b]{2}{*}{ Ca (Atomic\%) } & \multirow[b]{2}{*}{$\mathrm{Ca}$ (wt\%) } & \multirow[b]{2}{*}{$\mathrm{Na}$ (Atomic\%) } & \multirow{2}{*}{\multicolumn{2}{|c|}{$\begin{array}{ll} & \text { (High K) } \\
\mathrm{Na}(w \mathrm{t} \%) & \text { Or } \\
\end{array}$}} & \multirow{2}{*}{$\begin{array}{l}\text { (High Ca) } \\
\text { An }\end{array}$} & \multicolumn{2}{|l|}{ (High Na) } \\
\hline & & & & & & & & & & & $\mathbf{A b}$ & Total \\
\hline HS154D & 6 & 3 & $\begin{array}{ll} & 0.11\end{array}$ & 0.2 & 3.99 & 7.87 & 2.93 & 3.31 & 1.56472 & 56.75676 & 41.67852 & 100 \\
\hline HS154D & 6 & 4 & 0.12 & 0.23 & 4.6 & 9.08 & 2.65 & 3 & 1.62822 & 62.4152 & 35.95658 & 100 \\
\hline HS154D & 9 & 1 & 1.29 & 2.52 & 0.44 & 0.88 & 5.15 & 5.94 & 18.75 & 6.395349 & 74.85465 & 100 \\
\hline HS154D & 9 & 4 & 1.38 & 2.68 & 0.46 & 0.92 & 5.36 & 6.11 & 19.1667 & 6.388889 & 74.44444 & 100 \\
\hline HS154D & 10 & 1 & 2.48 & 4.79 & 0.39 & 0.76 & 4.23 & 4.8 & 34.9296 & 5.492958 & 59.57746 & 100 \\
\hline HS154D & 11 & 1 & 0.17 & 0.33 & 2.92 & 5.84 & 4.09 & 4.69 & 2.36769 & 40.66852 & 56.96379 & 100 \\
\hline HS154D & 11 & 2 & 0.16 & 0.31 & 3.22 & 6.37 & 4.05 & 4.6 & 2.15343 & 43.33782 & 54.50875 & 100 \\
\hline HS154E & 1 & 3 & 2.55 & 4.87 & 0.37 & 0.72 & 3.68 & 4.13 & 38.6364 & 5.606061 & 55.75758 & 100 \\
\hline HS154E & 1 & 4 & 2.5 & 4.77 & 0.27 & 0.53 & 2.95 & 3.31 & 43.7063 & 4.72028 & 51.57343 & 100 \\
\hline HS154E & 2 & 5 & 2.64 & 5.08 & 0.3 & 0.59 & 3.83 & 4.34 & 38.9956 & 4.431315 & 56.57312 & 100 \\
\hline HS154E & 3 & 1 & 3.9 & 7.01 & 0.32 & 0.59 & 3.78 & 3.99 & 48.75 & 4 & 47.25 & 100 \\
\hline HS154E & 4 & 4 & 1.78 & 3.45 & 0.56 & 1.12 & 4.46 & 5.09 & 26.1765 & 8.235294 & 65.58824 & 100 \\
\hline HS154E & 5 & 1 & 1.36 & 2.59 & 0.53 & 1.04 & 5.57 & 6.22 & 18.2306 & 7.104558 & 74.66488 & 100 \\
\hline HS154E & 6 & 1 & 1.51 & 2.75 & 0.59 & 1.1 & 6.27 & 6.72 & 18.0406 & 7.048984 & 74.91039 & 100 \\
\hline HS154E & 6 & 3 & 3.07 & 5.81 & 0.28 & 0.54 & 1.3 & 1.45 & 66.0215 & 6.021505 & 27.95699 & 100 \\
\hline HS154E & 7 & 2 & 1.26 & 2.42 & 0.58 & 1.15 & 5.42 & 6.13 & 17.3554 & 7.988981 & 74.65565 & 100 \\
\hline HS154E & 8 & 3 & 0.23 & 0.41 & 3.48 & 6.45 & 4.96 & 5.27 & 2.65283 & 40.13841 & 57.20877 & 100 \\
\hline HS154E & 9 & 1 & 1.6 & 2.91 & 0.57 & 1.06 & 6.23 & 6.65 & 19.0476 & 6.785714 & 74.16667 & 100 \\
\hline HS154E & 9 & 2 & 1.59 & 2.88 & 0.55 & 1.03 & 6.28 & 6.7 & 18.8836 & 6.532067 & 74.58432 & 100 \\
\hline HS154E & 10 & 1 & 0.1 & 0.18 & 5 & 9.55 & 2.82 & 3.09 & 1.26263 & 63.13131 & 35.60606 & 100 \\
\hline HS154E & 10 & 2 & 0.1 & 0.19 & 5.15 & 9.83 & 2.76 & 3.03 & 1.24844 & 64.29463 & 34.45693 & 100 \\
\hline HS154C & 1 & 1 & 1.4 & 0.74 & 0.52 & 0.28 & 5.03 & 1.56 & 20.1439 & 7.482014 & 72.3741 & 100 \\
\hline HS154C & 1 & 2 & 1.34 & 0.69 & 0.7 & 0.37 & 5.06 & 1.55 & 18.8732 & 9.859155 & 71.26761 & 100 \\
\hline HS154C & 3 & 7 & 0 & 0 & 8.46 & 3.79 & 0.34 & 0.09 & 0 & 96.13636 & 3.863636 & 100 \\
\hline HS154C & 3 & 8 & 1.24 & 0.65 & 0.59 & 0.32 & 5.4 & 1.66 & 17.1508 & 8.160443 & 74.6888 & 100 \\
\hline HS154C & 4 & 11 & 1.3 & 0.69 & 0.47 & 0.25 & 5.35 & 1.67 & 18.2584 & 6.601124 & 75.14045 & 100 \\
\hline HS154C & 5 & 17 & 1.37 & 0.71 & 0.43 & 0.23 & 5.26 & 1.6 & 19.4051 & 6.090652 & 74.50425 & 100 \\
\hline HS154C & 6 & 21 & 0.18 & 0.09 & 2.89 & 1.52 & 4.32 & 1.31 & 2.43572 & 39.1069 & 58.45737 & 100 \\
\hline
\end{tabular}




\begin{tabular}{|c|c|c|c|c|c|c|c|c|c|c|c|c|}
\hline \multirow[b]{2}{*}{ Sample } & \multirow[b]{2}{*}{ Site } & \multirow[b]{2}{*}{ Spectra } & \multirow[b]{2}{*}{ K (Atomic\%) } & \multirow[b]{2}{*}{$K(w t \%)$} & \multirow[b]{2}{*}{ Ca (Atomic\%) } & \multirow[b]{2}{*}{$\mathrm{Ca}(w \mathrm{t} \%)$} & \multirow[b]{2}{*}{$\mathrm{Na}$ (Atomic\%) } & \multirow{2}{*}{$\mathrm{Na}(w t \%)$} & \multirow{2}{*}{\multicolumn{2}{|c|}{$\begin{array}{ll}\text { (High K) } & \text { (High Ca) } \\
\text { Or } & \text { An } \\
\end{array}$}} & \multicolumn{2}{|c|}{ (High Na) } \\
\hline & & & & & & & & & & & $\mathbf{A b}$ & Total \\
\hline HS154C & 6 & 22 & $2 \quad 0.16$ & 0.08 & 3.26 & 1.68 & 4.12 & $2 \quad 1.22$ & 2.122 & 43.236 & 54.642 & 100 \\
\hline MS137 & 1 & 1 & 0.27 & 0.1 & 1.03 & 0.38 & 0 & 0 & 20.769 & 79.231 & 0.000 & 100 \\
\hline MS137 & 1 & 2 & 0.3 & 0.11 & 1.21 & 0.46 & 0 & 0 & 19.868 & 80.132 & 0.000 & 100 \\
\hline MS137 & 1 & 3 & 0.29 & 0.11 & 1.06 & 0.42 & 0 & 0 & 21.481 & 78.519 & 0.000 & 100 \\
\hline MS137 & 2 & 5 & 1.29 & 0.55 & 0.29 & 0.13 & 6.52 & 1.65 & 15.926 & 3.580 & 80.494 & 100 \\
\hline MS137 & 2 & 6 & 0.59 & 0.25 & 0.68 & 0.03 & 4.68 & 1.19 & 9.916 & 11.429 & 78.655 & 100 \\
\hline MS137 & 2 & 7 & 0.51 & 0.25 & 0 & 0.3 & 5.32 & 1.19 & 8.748 & 0.000 & 91.252 & 100 \\
\hline MS137 & 3 & 8 & 1.24 & 0.55 & 0.3 & 0.14 & 6.53 & 1.7 & 15.366 & 3.717 & 80.917 & 100 \\
\hline MS137 & 3 & 9 & 1.25 & 0.54 & 0.26 & 0.11 & 6.53 & 1.65 & 15.547 & 3.234 & 81.219 & 100 \\
\hline MS137 & 3 & 10 & 0.28 & 0.1 & 1.13 & 0.41 & 0 & 0 & 19.858 & 80.142 & 0.000 & 100 \\
\hline MS137 & 6 & 14 & 1.39 & 0.6 & 0.23 & 0.1 & 6.41 & 1.62 & 17.310 & 2.864 & 79.826 & 100 \\
\hline MS137 & 6 & 15 & 1.43 & 0.61 & 0.21 & 0.09 & 6.47 & 1.63 & 17.633 & 2.589 & 79.778 & 100 \\
\hline MS137 & 7 & 16 & 1.13 & 0.47 & 0.31 & 0.13 & 6.54 & 1.62 & 14.160 & 3.885 & 81.955 & 100 \\
\hline MS137 & 7 & 17 & 2.84 & 1.82 & 0.24 & 0.1 & 2.02 & 0.5 & 55.686 & 4.706 & 39.608 & 100 \\
\hline MS137 & 7 & 18 & 1.24 & 0.52 & 0.3 & 0.13 & 6.52 & 1.6 & 15.385 & 3.722 & 80.893 & 100 \\
\hline MS137 & 8 & 19 & 1.34 & 0.54 & 0.24 & 0.1 & 6.5 & 1.54 & 16.584 & 2.970 & 80.446 & 100 \\
\hline MS137 & 8 & 20 & 1.25 & 0.48 & 0.29 & 0.11 & 6.49 & 1.46 & 15.567 & 3.611 & 80.822 & 100 \\
\hline MS137 & 8 & 21 & 1.19 & 0.51 & 0.3 & 0.13 & 6.49 & 1.62 & 14.912 & 3.759 & 81.328 & 100 \\
\hline MS137 & 9 & 22 & 1.14 & 0.49 & 0.33 & 0.14 & 6.64 & 1.68 & 14.057 & 4.069 & 81.874 & 100 \\
\hline MS143 & 1 & 1 & 1.72 & 0.89 & 0.18 & 0.1 & 2.95 & 0.9 & 35.464 & 3.711 & 60.825 & 100 \\
\hline MS143 & 2 & 2 & 1.3 & 0.69 & 0.47 & 0.25 & 5.07 & 1.58 & 19.006 & 6.871 & 74.123 & 100 \\
\hline MS143 & 2 & 3 & 1.18 & 0.62 & 0.46 & 0.25 & 5.58 & 1.72 & 16.343 & 6.371 & 77.285 & 100 \\
\hline MS143 & 2 & 4 & 1.27 & 0.7 & 0.43 & 0.24 & 5.09 & 1.66 & 18.704 & 6.333 & 74.963 & 100 \\
\hline MS143 & 3 & 5 & 0.08 & 0.04 & 5.01 & 2.57 & 2.76 & 0.81 & 1.019 & 63.822 & 35.159 & 100 \\
\hline MS143 & 3 & 7 & 0.07 & 0.04 & 6.37 & 3.33 & 1.5 & 0.45 & 0.882 & 80.227 & 18.892 & 100 \\
\hline MS143 & 3 & 8 & 0.1 & 0.05 & 4.9 & 2.58 & 2.65 & 0.8 & 1.307 & 64.052 & 34.641 & 100 \\
\hline MS143 & 3 & 10 & 0.08 & 0.04 & 5.07 & 2.64 & 2.56 & 0.76 & 1.038 & 65.759 & 33.204 & 100 \\
\hline MS143 & 4 & 11 & 0.57 & 0.26 & 1.03 & 0.49 & 0.08 & 0.02 & 33.929 & 61.310 & 4.762 & 100 \\
\hline
\end{tabular}

\begin{tabular}{|c|c|c|c|c|c|c|c|c|c|c|c|c|}
\hline \multirow[b]{2}{*}{ Sample } & \multirow[b]{2}{*}{ Site } & \multirow[b]{2}{*}{ Spectra } & \multirow[b]{2}{*}{ K (Atomic\%) } & \multirow[b]{2}{*}{$K(w t \%)$} & \multirow[b]{2}{*}{$\mathrm{Ca}$ (Atomic\%) } & \multirow[b]{2}{*}{$\mathrm{Ca}(\mathrm{wt} \%)$} & \multirow[b]{2}{*}{$\mathrm{Na}$ (Atomic\%) } & \multirow{2}{*}{$\mathrm{Na}(w t \%)$} & \multirow{2}{*}{$\begin{array}{l}\text { (High K) } \\
\text { Or }\end{array}$} & \multicolumn{2}{|c|}{ (High Ca) (High Na) } & \multirow{2}{*}{ Total } \\
\hline & & & & & & & & & & An & $\mathrm{Ab}$ & \\
\hline MS143 & 4 & 13 & $\begin{array}{ll}3 & 0.37\end{array}$ & 0.17 & 1.86 & 0.89 & 0.39 & 0.11 & 14.122 & 70.992 & $\quad 14.885$ & 100 \\
\hline MS143 & 5 & 14 & 0.31 & 0.16 & 1.76 & 0.94 & 5.15 & 1.58 & 4.294 & 24.377 & 71.330 & 100 \\
\hline MS143 & 6 & 16 & 1.33 & 0.7 & 0.44 & 0.24 & 5.22 & 1.62 & 19.027 & 6.295 & 74.678 & 100 \\
\hline MS143 & 6 & 17 & 1.54 & 0.69 & 0.64 & 0.29 & 6.33 & 1.67 & 18.096 & 7.521 & 74.383 & 100 \\
\hline MS143 & 7 & 18 & 0.42 & 0.32 & 1.07 & 0.84 & 3.19 & 1.44 & 8.974 & 22.863 & 68.162 & 100 \\
\hline MS143 & 7 & 19 & 0.58 & 0.3 & 1.82 & 0.97 & 4.85 & 1.47 & 8.000 & 25.103 & 66.897 & 100 \\
\hline MS143 & 7 & 20 & 0.55 & 0.28 & 1.8 & 0.93 & 4.86 & 1.44 & 7.628 & 24.965 & 67.406 & 100 \\
\hline MS145 & 2 & 5 & 1.3 & 0.67 & 0.45 & 0.24 & 5.39 & 1.64 & 18.207 & 6.303 & 75.490 & 100 \\
\hline MS145 & 2 & 7 & 1.28 & 0.69 & 0.54 & 0.3 & 5.52 & 1.75 & 17.439 & 7.357 & 75.204 & 100 \\
\hline MS145 & 3 & 8 & 0.03 & 0.02 & 8.43 & 3.86 & 0.36 & 0.09 & 0.340 & 95.578 & 4.082 & 100 \\
\hline MS145 & 3 & 10 & 0 & 0 & 25.13 & 10.7 & 0.09 & 0.02 & 0.000 & 99.643 & 0.357 & 100 \\
\hline MS145 & 4 & 11 & 0 & 0 & 8.03 & 3.85 & 0.29 & 0.08 & 0.000 & 96.514 & 3.486 & 100 \\
\hline MS145 & 4 & 12 & 0 & 0 & 7.87 & 3.81 & 0.25 & 0.07 & 0.000 & 96.921 & 3.079 & 100 \\
\hline MS146 & 3 & 9 & 1.55 & 0.68 & 0.58 & 0.26 & 6.32 & 1.62 & 18.343 & 6.864 & 74.793 & 100 \\
\hline MS146 & 4 & 14 & 0.13 & 0.07 & 4.84 & 2.49 & 2.81 & 0.83 & 1.671 & 62.211 & 36.118 & 100 \\
\hline MS146 & 4 & 15 & 0.11 & 0.06 & 4.85 & 2.53 & 2.73 & 0.82 & 1.430 & 63.069 & 35.501 & 100 \\
\hline MS146 & 4 & 17 & 0.86 & 0.42 & 3.43 & 1.73 & 0.82 & 0.24 & 16.830 & 67.123 & 16.047 & 100 \\
\hline MS146 & 5 & 19 & 1.36 & 0.75 & 0.44 & 0.25 & 5.08 & 1.63 & 19.767 & 6.395 & 73.837 & 100 \\
\hline MS146 & 5 & 20 & 1.33 & 0.63 & 0.52 & 0.25 & 5.32 & 1.47 & 18.550 & 7.252 & 74.198 & 100 \\
\hline MS146 & 5 & 21 & 0.83 & 0.43 & 11.77 & 6.31 & 1.45 & 0.45 & 5.907 & 83.772 & 10.320 & 100 \\
\hline MS146 & 6 & 23 & 1.35 & 0.7 & 0.29 & 0.02 & 5.44 & 1.66 & 19.068 & 4.096 & 76.836 & 100 \\
\hline MS146 & 7 & 24 & 0.03 & 0.02 & 8 & 3.84 & 0.28 & 0.08 & 0.361 & 96.270 & 3.369 & 100 \\
\hline MS146 & 7 & 25 & 0.04 & 0.02 & 5.8 & 2.95 & 2.01 & 0.59 & 0.510 & 73.885 & 25.605 & 100 \\
\hline MS146 & 7 & 26 & 0.13 & 0.05 & 6.62 & 2.86 & 0.27 & 0.07 & 1.852 & 94.302 & 3.846 & 100 \\
\hline MS146 & 7 & 27 & 0 & 0 & 7.3 & 3.6 & 0.11 & 0.03 & 0.000 & 98.516 & 1.484 & 100 \\
\hline MS146 & 7 & 28 & 0.14 & 0.07 & 4.57 & 2.33 & 2.88 & 0.84 & 1.845 & 60.211 & 37.945 & 100 \\
\hline MS146 & 8 & 31 & 0.95 & 0.48 & 2.56 & 1.33 & 1.28 & 0.38 & 19.833 & 53.445 & 26.722 & 100 \\
\hline MS146 & 8 & 32 & 1.32 & 0.7 & 1.61 & 0.86 & 1.96 & 0.61 & 26.994 & 32.924 & 40.082 & 100 \\
\hline MS146 & 8 & 33 & 1.64 & 0.89 & 1.17 & 0.65 & 2 & 0.64 & 34.096 & 24.324 & 41.580 & 100 \\
\hline
\end{tabular}


APPENDIX G: Pyroxene Geochemistry, SEM

\begin{tabular}{|c|c|c|c|c|c|c|c|c|c|}
\hline Sample & Site & Spectra & Ca (Atomic\%) & Mg (Atomic\%) & Fe (Atomic\%) & $\begin{array}{l}\text { High Ca } \\
\text { Wo }\end{array}$ & $\begin{array}{l}\text { High Mg } \\
\text { En }\end{array}$ & $\begin{array}{l}\text { High Fe } \\
\text { Fs }\end{array}$ & Total \\
\hline HS154a & 2 & 1 & 8.85 & 9.32 & 4.62 & 38.83 & 40.90 & 20.27 & 100 \\
\hline HS154a & 3 & 5 & 9.43 & 4.46 & 8.55 & 42.02 & 19.88 & 38.10 & 100 \\
\hline HS154a & 4 & 3 & 3.13 & 1.84 & 4.68 & 32.44 & 19.07 & 48.50 & 100 \\
\hline HS154a & 5 & 1 & 9.61 & 4.48 & 8.74 & 42.09 & 19.62 & 38.28 & 100 \\
\hline HS154a & 5 & 2 & 9.57 & 4.45 & 8.75 & 42.03 & 19.54 & 38.43 & 100 \\
\hline HS154a & 7 & 1 & 9.52 & 4.47 & 8.56 & 42.22 & 19.82 & 37.96 & 100 \\
\hline HS154a & 7 & 6 & 9.41 & 4.41 & 8.64 & 41.90 & 19.63 & 38.47 & 100 \\
\hline HS1505 & 5 & 4 & 3.72 & 3.23 & 4.09 & 33.70 & 29.26 & 37.05 & 100 \\
\hline HS1505 & 6 & 3 & 7.59 & 7.12 & 4.46 & 39.59 & 37.14 & 23.27 & 100 \\
\hline HS1505 & 8 & 1 & 0.93 & 11.08 & 1.69 & 6.79 & 80.88 & 12.34 & 100 \\
\hline HS1505 & 8 & 2 & 0.73 & 9.92 & 1.22 & 6.15 & 83.57 & 10.28 & 100 \\
\hline HS1505 & 8 & 3 & 0.54 & 9.93 & 1.22 & 4.62 & 84.94 & 10.44 & 100 \\
\hline HS154d & 7 & 1 & 8.02 & 3.72 & 7.19 & 42.37 & 19.65 & 37.98 & 100 \\
\hline HS154d & 7 & 2 & 8.24 & 3.79 & 7.19 & 42.87 & 19.72 & 37.41 & 100 \\
\hline HS154e & 2 & 4 & 6.37 & 0.96 & 9.64 & 37.54 & 5.66 & 56.81 & 100 \\
\hline HS154e & 4 & 1 & 7.85 & 3.69 & 7.05 & 42.23 & 19.85 & 37.92 & 100 \\
\hline HS154e & 4 & 3 & 8.2 & 3.49 & 7.28 & 43.23 & 18.40 & 38.38 & 100 \\
\hline HS154e & 5 & 3 & 8.19 & 3.81 & 7.59 & 41.81 & 19.45 & 38.74 & 100 \\
\hline HS154e & 5 & 4 & 8.31 & 3.77 & 7.67 & 42.08 & 19.09 & 38.84 & 100 \\
\hline HS154e & 5 & 5 & 8.66 & 4.02 & 7.75 & 42.39 & 19.68 & 37.93 & 100 \\
\hline HS154e & 5 & 6 & 8.55 & 3.94 & 7.39 & 43.01 & 19.82 & 37.17 & 100 \\
\hline HS154e & 8 & 1 & 8.58 & 3.61 & 8.37 & 41.73 & 17.56 & 40.71 & 100 \\
\hline HS154e & 11 & 4 & 8.67 & 3.99 & 7.66 & 42.67 & 19.64 & 37.70 & 100 \\
\hline HS154c & 2 & 3 & 4.7 & 1.91 & 21.54 & 16.70 & 6.79 & 76.52 & 100 \\
\hline HS154c & 2 & 4 & 8.58 & 3.72 & 7.85 & 42.58 & 18.46 & 38.96 & 100 \\
\hline HS154c & 3 & 7 & 8.46 & 3.8 & 7.61 & 42.58 & 19.12 & 38.30 & 100 \\
\hline HS154c & 7 & 25 & 8.18 & 3.89 & 7.57 & 41.65 & 19.81 & 38.54 & 100 \\
\hline HS154c & 7 & 27 & 8.36 & 3.91 & 7.58 & 42.12 & 19.70 & 38.19 & 100 \\
\hline HS154c & 9 & 33 & 8.42 & 3.8 & 7.52 & 42.65 & 19.25 & 38.10 & 100 \\
\hline
\end{tabular}




\begin{tabular}{|c|c|c|c|c|c|c|c|c|c|}
\hline Sample & Site & Spectra & Ca (Atomic\%) & $\mathrm{Mg}$ (Atomic\%) & $\mathrm{Fe}$ (Atomic\%) & $\begin{array}{l}\text { High Ca } \\
\text { Wo }\end{array}$ & $\begin{array}{l}\text { High Mg } \\
\text { En }\end{array}$ & $\begin{array}{l}\text { High Fe } \\
\text { Fs }\end{array}$ & Total \\
\hline HS154c & 10 & 36 & $\begin{array}{ll}6 & 8.6\end{array}$ & 3.91 & 7.5 & 42.98 & $\begin{array}{ll}8 & 19.54\end{array}$ & 37.48 & 3100 \\
\hline HS154c & 10 & 37 & 8.35 & 3.79 & 7.57 & 42.36 & 19.23 & 38.41 & 100 \\
\hline MS137 & 4 & 11 & 8.59 & 0 & 9 & 48.83 & 0.00 & 51.17 & 100 \\
\hline MS143 & 3 & $\mathrm{~s}$ & 0.42 & 11.01 & 8.7 & 2.09 & 54.69 & 43.22 & 100 \\
\hline MS143 & 4 & 11 & 1.03 & 1.58 & 7.57 & 10.12 & 15.52 & 74.36 & 100 \\
\hline MS143 & 4 & 13 & 1.86 & 1.48 & 6.61 & 18.69 & 14.87 & 66.43 & 100 \\
\hline MS145 & 3 & $\varepsilon$ & 8.43 & 3.9 & 7.68 & 42.13 & 19.49 & 38.38 & 100 \\
\hline MS145 & 4 & 11 & 8.03 & 3.68 & 7.34 & 42.15 & 19.32 & 38.53 & 100 \\
\hline MS145 & 4 & 12 & 7.87 & 3.64 & 7 & 42.52 & 19.67 & 37.82 & 100 \\
\hline MS145 & 5 & 13 & 8.23 & 3.91 & 7.44 & 42.03 & 19.97 & 38.00 & 100 \\
\hline MS145 & 5 & 14 & 8.32 & 3.83 & 7.47 & 42.41 & 19.52 & 38.07 & 100 \\
\hline MS146 & 3 & $\varepsilon$ & 8.44 & 3.73 & 7.36 & 43.22 & 19.10 & 37.69 & 100 \\
\hline MS146 & 3 & 10 & 7.95 & 3.41 & 7.78 & 41.54 & 17.82 & 40.65 & 100 \\
\hline MS146 & 3 & 12 & 19.21 & 1.09 & 2.6 & 83.89 & 4.76 & 11.35 & 100 \\
\hline MS146 & 3 & 13 & 8.37 & 3.98 & 7.64 & 41.87 & 19.91 & 38.22 & 100 \\
\hline MS146 & 5 & 18 & 7.82 & 3.97 & 7.69 & 40.14 & 20.38 & 39.48 & 100 \\
\hline MS146 & 7 & 24 & 8 & 8.32 & 3.39 & 40.59 & 42.21 & 17.20 & 100 \\
\hline MS146 & 7 & 26 & 6.62 & 2.48 & 6.94 & 41.27 & 15.46 & 43.27 & 100 \\
\hline MS146 & 7 & 27 & 7.3 & 8.15 & 3.94 & 37.65 & 42.03 & 20.32 & 100 \\
\hline MS146 & 8 & 29 & 8.14 & 3.7 & 7.45 & 42.20 & 19.18 & 38.62 & 100 \\
\hline
\end{tabular}




\section{APPENDIX H: SEM Spectra}

H1. HS-15-04a

\begin{tabular}{|c|c|c|c|c|c|c|c|c|c|c|c|c|c|c|c|}
\hline \multicolumn{4}{|c|}{$\begin{array}{c}\text { Site } 1 \\
\text { Spectra } 1\end{array}$} & \multicolumn{4}{|c|}{$\begin{array}{c}\text { Site } 1 \\
\text { Spectra } 2\end{array}$} & \multicolumn{4}{|c|}{$\begin{array}{c}\text { Site } 2 \\
\text { Spectra } 1\end{array}$} & \multicolumn{4}{|c|}{$\begin{array}{c}\text { Site } 2 \\
\text { Spectra 2 }\end{array}$} \\
\hline $\mathrm{Na}$ & $5.41 \mathrm{Na}$ & 5.76 & 0.07 & $\mathrm{Na}$ & $3.96 \mathrm{Na}$ & 4.05 & 0.06 & $\mathrm{Na}$ & $0.32 \mathrm{Na}$ & 0.31 & 0.04 & $\mathrm{~F}$ & $4.49 \mathrm{~F}$ & 3.38 & 0.13 \\
\hline Al & $9.57 \mathrm{Al}$ & 11.96 & 0.09 & $\mathrm{Mg}$ & $1.05 \mathrm{Mg}$ & 1.14 & 0.04 & $\mathrm{Mg}$ & $9.32 \mathrm{Mg}$ & 9.55 & 0.08 & $\mathrm{Mg}$ & $0.17 \mathrm{Mg}$ & 0.16 & 0.03 \\
\hline $\mathrm{Si}$ & $27.22 \mathrm{Si}$ & 35.41 & 0.14 & $\mathrm{Al}$ & $7.52 \mathrm{Al}$ & 9.03 & 0.08 & $\mathrm{Al}$ & $0.31 \mathrm{Al}$ & 0.35 & 0.04 & $\mathrm{Si}$ & $0.2 \mathrm{Si}$ & 0.22 & 0.03 \\
\hline $\mathrm{Ba}$ & $0.17 \mathrm{Ba}$ & 1.1 & 0.14 & $\mathrm{Ca}$ & $2.16 \mathrm{Ca}$ & 3.85 & 0.07 & $\mathrm{Mn}$ & $0.27 \mathrm{Mn}$ & 0.62 & 0.08 & $\mathrm{Ca}$ & $27.36 \mathrm{Ca}$ & 43.36 & 0.18 \\
\hline \multirow[t]{3}{*}{ Total } & 100 Total & 100 & & $\mathrm{Ti}$ & $0.6 \mathrm{Ti}$ & 1.29 & 0.07 & $\mathrm{Fe}$ & $4.62 \mathrm{Fe}$ & 10.86 & 0.17 & Total & 100 Total & 100 & \\
\hline & & & & $\mathrm{Fe}$ & $2.91 \mathrm{Fe}$ & 7.23 & 0.15 & Total & 100 Total & 100 & & & & & \\
\hline & & & & Total & 100 Total & 100 & & & & & & & & & \\
\hline
\end{tabular}

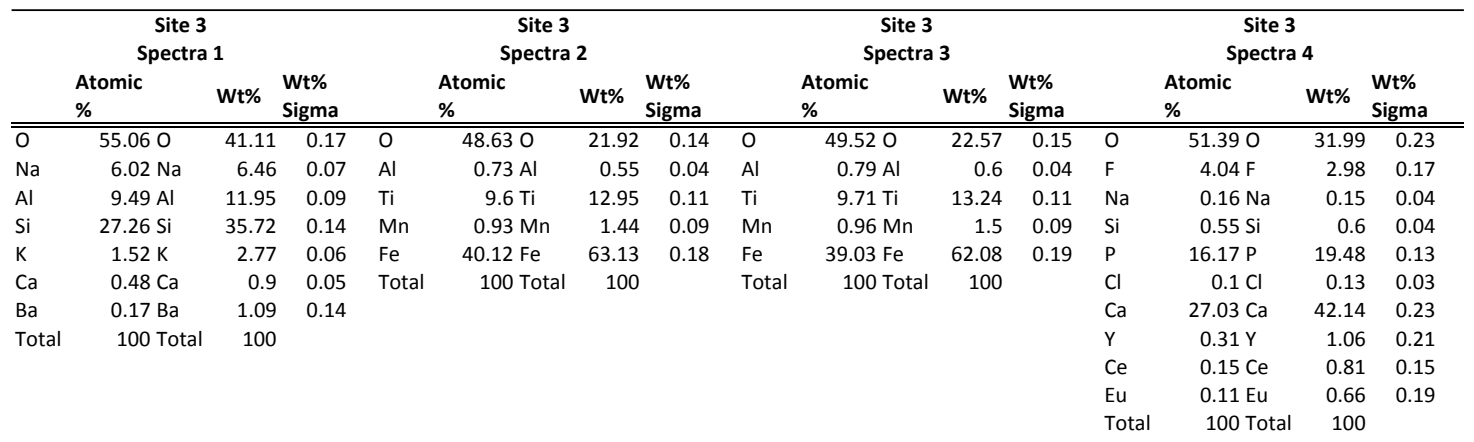

\begin{tabular}{|c|c|c|c|c|c|c|c|c|c|c|c|c|c|c|c|}
\hline \multicolumn{4}{|c|}{$\begin{array}{c}\text { Site } 3 \\
\text { Spectra } 5\end{array}$} & \multicolumn{4}{|c|}{$\begin{array}{c}\text { Site } 3 \\
\text { Spectra } 6\end{array}$} & \multicolumn{4}{|c|}{$\begin{array}{c}\text { Site } 3 \\
\text { Spectra } 7\end{array}$} & \multicolumn{4}{|c|}{$\begin{array}{c}\text { Site } 3 \\
\text { Spectra } 8\end{array}$} \\
\hline Mg & $4.46 \mathrm{Mg}$ & 4.29 & 0.06 & $\mathrm{Al}$ & $0.7 \mathrm{Al}$ & 0.53 & 0.04 & $\mathrm{Al}$ & $0.78 \mathrm{Al}$ & 0.6 & 0.04 & $\mathrm{Al}$ & $0.8 \mathrm{Al}$ & 0.61 & 0.04 \\
\hline $\mathrm{Al}$ & $0.31 \mathrm{Al}$ & 0.33 & 0.04 & $\mathrm{Ti}$ & $9.5 \mathrm{Ti}$ & 12.83 & 0.11 & $\mathrm{Ti}$ & $9.55 \mathrm{Ti}$ & 13.1 & 0.11 & $\mathrm{Ti}$ & $9.1 \mathrm{Ti}$ & 12.37 & 0.11 \\
\hline $\mathrm{Si}$ & $23.46 \mathrm{Si}$ & 26.09 & 0.13 & $\mathrm{Mn}$ & $1.02 \mathrm{Mn}$ & 1.58 & 0.09 & $\mathrm{Mn}$ & $0.94 \mathrm{Mn}$ & 1.48 & 0.09 & $\mathrm{Mn}$ & $0.86 \mathrm{Mn}$ & 1.33 & 0.09 \\
\hline $\mathrm{Mn}$ & $0.77 \mathrm{Mn}$ & 1.67 & 0.1 & & & & & & & & & & & & \\
\hline $\mathrm{Fe}$ & $8.55 \mathrm{Fe}$ & 18.91 & 0.19 & & & & & & & & & & & & \\
\hline Total & 100 Total & 100 & & & & & & & & & & & & & \\
\hline
\end{tabular}

\begin{tabular}{|c|c|c|c|c|c|c|c|c|c|c|c|c|c|c|c|}
\hline \multicolumn{4}{|c|}{$\begin{array}{c}\text { Site } 4 \\
\text { Spectra } 1\end{array}$} & \multicolumn{4}{|c|}{$\begin{array}{c}\text { Site } 4 \\
\text { Spectra } 2\end{array}$} & \multicolumn{4}{|c|}{$\begin{array}{c}\text { Site } 4 \\
\text { Spectra } 3\end{array}$} & \multicolumn{4}{|c|}{$\begin{array}{c}\text { Site } 5 \\
\text { Spectra } 1\end{array}$} \\
\hline & $\begin{array}{l}\text { Atomic } \\
\%\end{array}$ & $\mathbf{W t} \%$ & $\begin{array}{l}\text { Wt\% } \\
\text { Sigma }\end{array}$ & & $\begin{array}{l}\text { Atomic } \\
\%\end{array}$ & $\mathbf{W t} \%$ & $\begin{array}{l}\text { Wt\% } \\
\text { Sigma }\end{array}$ & & $\begin{array}{l}\text { Atomic } \\
\%\end{array}$ & $\mathbf{W t} \%$ & $\begin{array}{l}\text { Wt } \% \\
\text { Sigma }\end{array}$ & & $\begin{array}{l}\text { Atomic } \\
\%\end{array}$ & $\mathbf{W t} \%$ & $\begin{array}{l}\text { Wt\% } \\
\text { Sigma }\end{array}$ \\
\hline$\overline{0}$ & 54.590 & 37.95 & 0.17 & 0 & 57.130 & 29.51 & 0.2 & 0 & 53.380 & 36.78 & 0.17 & $\overline{0}$ & $52.24 \mathrm{O}$ & 32.86 & 0.18 \\
\hline $\mathrm{Na}$ & $4.15 \mathrm{Na}$ & 4.14 & 0.06 & $\mathrm{Mg}$ & $0.98 \mathrm{Mg}$ & 0.77 & 0.04 & $\mathrm{Na}$ & $4.33 \mathrm{Na}$ & 4.28 & 0.07 & $\mathrm{Mg}$ & $4.48 \mathrm{Mg}$ & 4.29 & 0.06 \\
\hline $\mathrm{Mg}$ & $1.93 \mathrm{Mg}$ & 2.04 & 0.05 & $\mathrm{Al}$ & $0.16 \mathrm{Al}$ & 0.14 & 0.04 & $\mathrm{Mg}$ & $1.84 \mathrm{Mg}$ & 1.93 & 0.05 & $\mathrm{Al}$ & $0.27 \mathrm{Al}$ & 0.29 & 0.04 \\
\hline $\mathrm{Al}$ & $7.01 \mathrm{Al}$ & 8.22 & 0.07 & $\mathrm{Si}$ & $0.54 \mathrm{Si}$ & 0.49 & 0.03 & Al & $7.47 \mathrm{Al}$ & 8.68 & 0.08 & $\mathrm{Si}$ & $23.63 \mathrm{Si}$ & 26.09 & 0.13 \\
\hline $\mathrm{Si}$ & $22.99 \mathrm{Si}$ & 28.05 & 0.13 & $\mathrm{Ca}$ & $0.18 \mathrm{Ca}$ & 0.23 & 0.04 & $\mathrm{Si}$ & $23.21 \mathrm{Si}$ & 28.08 & 0.13 & $\mathrm{Ca}$ & $9.61 \mathrm{Ca}$ & 15.14 & 0.11 \\
\hline$P$ & $0.27 \mathrm{P}$ & 0.36 & 0.04 & $\mathrm{Ti}$ & $19.69 \mathrm{Ti}$ & 30.45 & 0.17 & $P$ & $0.31 \mathrm{P}$ & 0.42 & 0.04 & Sc & $0.14 \mathrm{Sc}$ & 0.25 & 0.07 \\
\hline K & $0.44 \mathrm{~K}$ & 0.76 & 0.04 & v & $0.26 \mathrm{~V}$ & 0.42 & 0.09 & K & $0.6 \mathrm{~K}$ & 1.01 & 0.05 & $\mathrm{Ti}$ & $0.11 \mathrm{Ti}$ & 0.2 & 0.05 \\
\hline $\mathrm{Ca}$ & $2.65 \mathrm{Ca}$ & 4.62 & 0.07 & $\mathrm{Mn}$ & $0.26 \mathrm{Mn}$ & 0.47 & 0.08 & $\mathrm{Ca}$ & $3.13 \mathrm{Ca}$ & 5.4 & 0.08 & $\mathrm{Mn}$ & $0.78 \mathrm{Mn}$ & 1.69 & 0.1 \\
\hline $\mathrm{Ti}$ & $1.81 \mathrm{Ti}$ & 3.77 & 0.08 & $\mathrm{Fe}$ & $20.81 \mathrm{Fe}$ & 37.53 & 0.21 & $\mathrm{Ti}$ & $1.05 \mathrm{Ti}$ & 2.16 & 0.07 & $\mathrm{Fe}$ & $8.74 \mathrm{Fe}$ & 19.19 & 0.19 \\
\hline $\mathrm{Fe}$ & $4.16 \mathrm{Fe}$ & 10.1 & 0.16 & Total & 100 Total & 100 & & $\mathrm{Fe}$ & $4.68 \mathrm{Fe}$ & 11.26 & 0.17 & Total & 100 Total & 100 & \\
\hline Total & 100 Total & 100 & & & & & & Total & 100 Total & 100 & & & & & \\
\hline
\end{tabular}




\begin{tabular}{|c|c|c|c|c|c|c|c|c|c|c|c|c|c|c|c|}
\hline \multicolumn{4}{|c|}{$\begin{array}{c}\text { Site } 5 \\
\text { Spectra } 2\end{array}$} & \multicolumn{4}{|c|}{$\begin{array}{c}\text { Site } 5 \\
\text { Spectra } 3\end{array}$} & \multicolumn{4}{|c|}{$\begin{array}{c}\text { Site } 5 \\
\text { Spectra } 4\end{array}$} & \multicolumn{4}{|c|}{$\begin{array}{c}\text { Site } 5 \\
\text { Spectra } 5\end{array}$} \\
\hline $\mathrm{Mg}$ & $4.45 \mathrm{Mg}$ & 4.25 & 0.06 & $\mathrm{Na}$ & $6.24 \mathrm{Na}$ & 6.74 & 0.07 & Al & $0.73 \mathrm{Al}$ & 0.55 & 0.04 & Al & $0.77 \mathrm{Al}$ & 0.61 & 0.04 \\
\hline $\mathrm{Al}$ & $0.32 \mathrm{Al}$ & 0.34 & 0.04 & Al & $10.5 \mathrm{Al}$ & 13.29 & 0.09 & $\mathrm{Ti}$ & $8.48 \mathrm{Ti}$ & 11.4 & 0.11 & $\mathrm{Ti}$ & $9.18 \mathrm{Ti}$ & 12.95 & 0.11 \\
\hline $\mathrm{Si}$ & $23.67 \mathrm{Si}$ & 26.16 & 0.13 & $\mathrm{Si}$ & $26.18 \mathrm{Si}$ & 34.5 & 0.14 & $\mathrm{Mn}$ & $0.83 \mathrm{Mn}$ & 1.27 & 0.09 & $\mathrm{Mn}$ & $0.71 \mathrm{Mn}$ & 1.14 & 0.09 \\
\hline $\mathrm{Mn}$ & $0.82 \mathrm{Mn}$ & 1.78 & 0.1 & $\mathrm{Fe}$ & $0.11 \mathrm{Fe}$ & 0.28 & 0.09 & & & & & & & & \\
\hline $\mathrm{Fe}$ & $8.75 \mathrm{Fe}$ & 19.23 & 0.19 & Total & 100 Total & 100 & & & & & & & & & \\
\hline Total & 100 Total & 100 & & & & & & & & & & & & & \\
\hline \multicolumn{4}{|c|}{$\begin{array}{c}\text { Site } 5 \\
\text { Spectra } 6\end{array}$} & \multicolumn{4}{|c|}{$\begin{array}{c}\text { Site } 6 \\
\text { Spectra } 1\end{array}$} & \multicolumn{4}{|c|}{$\begin{array}{c}\text { Site } 6 \\
\text { Spectra 2 }\end{array}$} & \multicolumn{4}{|c|}{$\begin{array}{c}\text { Site } 6 \\
\text { Spectra } 3\end{array}$} \\
\hline $\mathrm{Na}$ & $5.96 \mathrm{Na}$ & 6.41 & 0.07 & $\mathrm{Na}$ & $6.16 \mathrm{Na}$ & 6.6 & 0.07 & $\mathrm{Na}$ & $6.15 \mathrm{Na}$ & 6.6 & 0.07 & $\mathrm{Na}$ & $3.47 \mathrm{Na}$ & 3.46 & 0.06 \\
\hline Al & $9.46 \mathrm{Al}$ & 11.94 & 0.09 & Al & $9.65 \mathrm{Al}$ & 12.13 & 0.09 & $\mathrm{Al}$ & $9.59 \mathrm{Al}$ & 12.09 & 0.09 & $\mathrm{Mg}$ & $2.97 \mathrm{Mg}$ & 3.13 & 0.05 \\
\hline $\mathrm{Si}$ & $26.96 \mathrm{Si}$ & 35.43 & 0.14 & $\mathrm{Si}$ & $27.06 \mathrm{Si}$ & 35.39 & 0.15 & $\mathrm{Si}$ & $27.07 \mathrm{Si}$ & 35.52 & 0.14 & $\mathrm{Al}$ & $6.36 \mathrm{Al}$ & 7.44 & 0.07 \\
\hline K & $1.8 \mathrm{~K}$ & 3.29 & 0.07 & $\mathrm{~K}$ & $1.51 \mathrm{~K}$ & 2.75 & 0.06 & K & $1.53 \mathrm{~K}$ & 2.79 & 0.06 & $\mathrm{Si}$ & $22.69 \mathrm{Si}$ & 27.59 & 0.13 \\
\hline $\mathrm{Ca}$ & $0.53 \mathrm{Ca}$ & 0.99 & 0.05 & $\mathrm{Ca}$ & $0.54 \mathrm{Ca}$ & 1 & 0.05 & $\mathrm{Ca}$ & $0.57 \mathrm{Ca}$ & 1.07 & 0.05 & $P$ & $0.24 \mathrm{P}$ & 0.32 & 0.04 \\
\hline $\mathrm{Ba}$ & $0.1 \mathrm{Ba}$ & 0.63 & 0.13 & $\mathrm{Fe}$ & $0.14 \mathrm{Fe}$ & 0.35 & 0.09 & $\mathrm{Ba}$ & $0.13 \mathrm{Ba}$ & 0.86 & 0.14 & $K$ & $0.43 \mathrm{~K}$ & 0.73 & 0.04 \\
\hline \multirow[t]{5}{*}{ Total } & 100 Total & 100 & & $\mathrm{Ba}$ & $0.15 \mathrm{Ba}$ & 0.97 & 0.14 & Total & 100 Total & 100 & & $\mathrm{Ca}$ & $3.91 \mathrm{Ca}$ & 6.79 & 0.08 \\
\hline & & & & Total & 100 Total & 100 & & & & & & $\mathrm{Ti}$ & $0.73 \mathrm{Ti}$ & 1.51 & 0.07 \\
\hline & & & & & & & & & & & & $\mathrm{Mn}$ & $0.15 \mathrm{Mn}$ & 0.36 & 0.08 \\
\hline & & & & & & & & & & & & $\mathrm{Fe}$ & $4.5 \mathrm{Fe}$ & 10.89 & 0.17 \\
\hline & & & & & & & & & & & & Total & 100 Total & 100 & \\
\hline
\end{tabular}

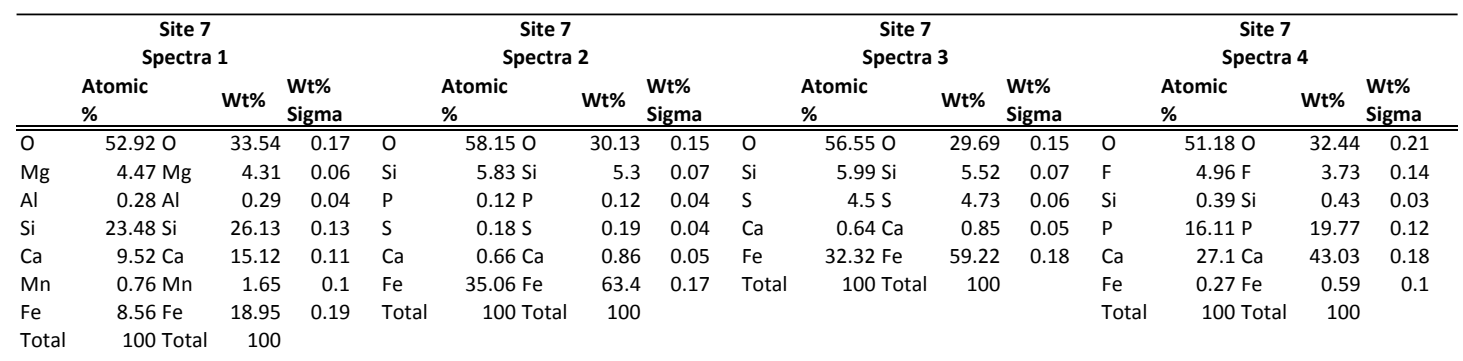

\begin{tabular}{|c|c|c|c|c|c|c|c|c|c|c|c|c|c|c|c|}
\hline \multicolumn{4}{|c|}{$\begin{array}{c}\text { Site } 7 \\
\text { Spectra } 5\end{array}$} & \multicolumn{4}{|c|}{$\begin{array}{c}\text { Site } 7 \\
\text { Spectra } 6\end{array}$} & \multicolumn{4}{|c|}{$\begin{array}{c}\text { Site } 7 \\
\text { Spectra } 7\end{array}$} & \multicolumn{4}{|c|}{$\begin{array}{c}\text { Site } 7 \\
\text { Spectra } 8\end{array}$} \\
\hline & $\begin{array}{l}\text { Atomic } \\
\%\end{array}$ & Wt\% & $\begin{array}{l}\text { Wt\% } \\
\text { Sigma }\end{array}$ & & $\begin{array}{l}\text { Atomic } \\
\%\end{array}$ & $\mathbf{W t} \%$ & $\begin{array}{l}\text { Wt\% } \\
\text { Sigma }\end{array}$ & & $\begin{array}{l}\text { Atomic } \\
\%\end{array}$ & $\mathbf{W t} \%$ & $\begin{array}{l}\text { Wt\% } \\
\text { Sigma }\end{array}$ & & $\begin{array}{l}\text { Atomic } \\
\%\end{array}$ & Wt\% & $\begin{array}{l}\text { Wt } \% \\
\text { Sigma }\end{array}$ \\
\hline$\overline{\mathrm{O}}$ & 51.530 & 24.11 & 0.15 & 0 & 52.620 & 33.23 & 0.18 & 0 & 51.430 & 23.91 & 0.15 & 0 & 49.710 & 30.96 & 0.22 \\
\hline $\mathrm{Al}$ & $0.7 \mathrm{Al}$ & 0.55 & 0.04 & $\mathrm{Mg}$ & $4.41 \mathrm{Mg}$ & 4.23 & 0.06 & Al & $0.8 \mathrm{Al}$ & 0.63 & 0.04 & $\mathrm{~F}$ & $5.45 \mathrm{~F}$ & 4.03 & 0.17 \\
\hline $\mathrm{Si}$ & $0.64 \mathrm{Si}$ & 0.52 & 0.04 & $\mathrm{Al}$ & $0.34 \mathrm{Al}$ & 0.36 & 0.04 & $\mathrm{Ti}$ & $8.82 \mathrm{Ti}$ & 12.28 & 0.11 & $\mathrm{Na}$ & $0.14 \mathrm{Na}$ & 0.12 & 0.04 \\
\hline $\mathrm{Ti}$ & $9.27 \mathrm{Ti}$ & 12.99 & 0.11 & $\mathrm{Si}$ & $23.6 \mathrm{Si}$ & 26.16 & 0.13 & $\mathrm{Mn}$ & $0.56 \mathrm{Mn}$ & 0.89 & 0.09 & $\mathrm{Si}$ & $0.48 \mathrm{Si}$ & 0.52 & 0.03 \\
\hline $\mathrm{Mn}$ & $0.51 \mathrm{Mn}$ & 0.82 & 0.09 & $\mathrm{Ca}$ & $9.41 \mathrm{Ca}$ & 14.89 & 0.11 & $\mathrm{Fe}$ & $38.39 \mathrm{Fe}$ & 62.3 & 0.19 & $P$ & $16.24 \mathrm{P}$ & 19.58 & 0.12 \\
\hline $\mathrm{Fe}$ & $37.35 \mathrm{Fe}$ & 61.01 & 0.19 & $\mathrm{Ti}$ & $0.13 \mathrm{Ti}$ & 0.25 & 0.05 & Total & 100 Total & 100 & & $\mathrm{Cl}$ & $0.16 \mathrm{Cl}$ & 0.22 & 0.03 \\
\hline \multirow[t]{4}{*}{ Total } & 100 Total & 100 & & $\mathrm{Mn}$ & $0.85 \mathrm{Mn}$ & 1.84 & 0.1 & & & & & $\mathrm{Ca}$ & $26.93 \mathrm{Ca}$ & 42.03 & 0.2 \\
\hline & & & & $\mathrm{Fe}$ & $8.64 \mathrm{Fe}$ & 19.04 & 0.19 & & & & & $\mathrm{Fe}$ & $0.73 \mathrm{Fe}$ & 1.58 & 0.11 \\
\hline & & & & Total & 100 Total & 100 & & & & & & $\mathrm{Ce}$ & $0.17 \mathrm{Ce}$ & 0.95 & 0.15 \\
\hline & & & & & & & & & & & & Total & 100 Total & 100 & \\
\hline
\end{tabular}




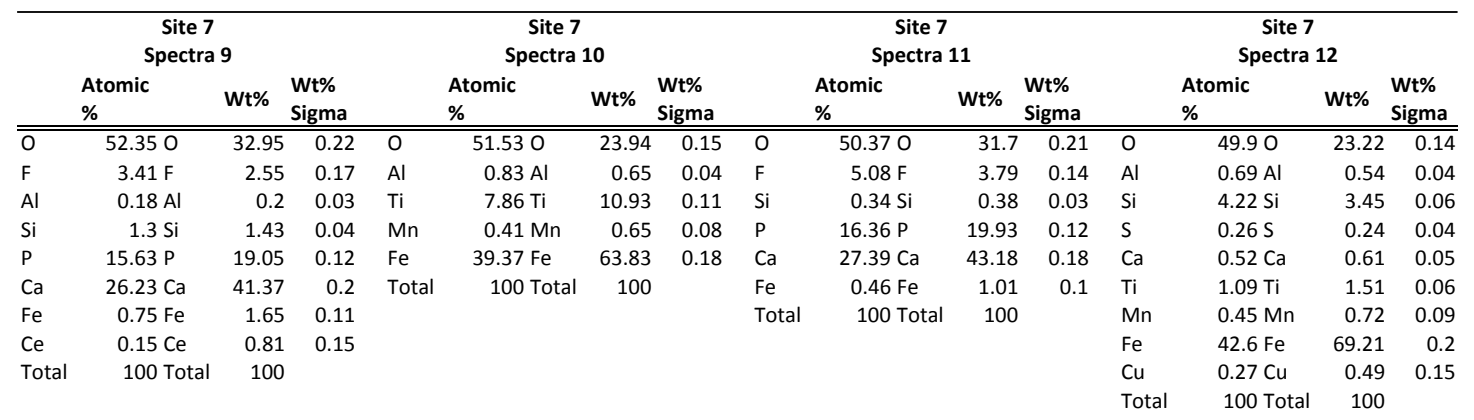

\section{H2. HS-15-04c}

\begin{tabular}{|c|c|c|c|c|c|c|c|c|c|c|c|c|c|c|}
\hline \multicolumn{5}{|c|}{ Site 1} & \multicolumn{5}{|c|}{ Site 1} & \multicolumn{5}{|c|}{ Site 2} \\
\hline Spectra 1 & Atomic \% & Spectrum 1 & Wt\% & Wt\% Sigma & Spectrum 2 & Atomic $\%$ & Spectrum 2 & Wt\% & Wt\% Sigma & Spectrum 3 & Atomic \% & Spectrum 3 & $\mathbf{W t} \%$ & Wt\% Sigma \\
\hline $\mathrm{Na}$ & 5.858374 & $\mathrm{Na}$ & 1.56 & 0.02 & $\mathrm{Na}$ & 5.859873 & $\mathrm{Na}$ & 1.55 & 0.02 & $\mathrm{Na}$ & 0.25413 & $\mathrm{Na}$ & 0.05 & 0.02 \\
\hline $\mathrm{Mg}$ & 0 & $\mathrm{Mg}$ & 0 & 0 & $\mathrm{Mg}$ & 0 & $\mathrm{Mg}$ & 0 & 0 & $\mathrm{Mg}$ & 2.206307 & $\mathrm{Mg}$ & 0.49 & 0.02 \\
\hline $\mathrm{Si}$ & 26.48498 & $\mathrm{Si}$ & 8.63 & 0.05 & $\mathrm{Si}$ & 26.61262 & $\mathrm{Si}$ & 8.57 & 0.05 & $\mathrm{Si}$ & 13.04147 & $\mathrm{Si}$ & 3.34 & 0.03 \\
\hline $\mathrm{P}$ & 0 & $\mathrm{P}$ & 0 & 0 & $P$ & 0 & $\mathrm{P}$ & 0 & 0 & $\mathrm{P}$ & 0 & $\mathrm{P}$ & 0 & 0 \\
\hline $\mathrm{s}$ & 0 & $\mathrm{~s}$ & 0 & 0 & $\mathrm{~s}$ & 0 & $\mathrm{~s}$ & 0 & 0 & $\mathrm{~s}$ & 0 & $\mathrm{~s}$ & 0 & 0 \\
\hline $\mathrm{Ti}$ & 0 & $\mathrm{Ti}$ & 0 & 0 & $\mathrm{Ti}$ & 0.138969 & $\mathrm{Ti}$ & 0.08 & 0.02 & $\mathrm{Ti}$ & 0.60067 & $\mathrm{Ti}$ & 0.26 & 0.02 \\
\hline $\mathrm{Cr}$ & 0 & $\mathrm{Cr}$ & 0 & 0 & $\mathrm{Cr}$ & 0 & $\mathrm{Cr}$ & 0 & 0 & $\mathrm{Cr}$ & 0 & $\mathrm{Cr}$ & 0 & 0 \\
\hline $\mathrm{Mn}$ & 0 & $\mathrm{Mn}$ & 0 & 0 & $\mathrm{Mn}$ & 0 & $\mathrm{Mn}$ & 0 & 0 & $\mathrm{Mn}$ & 0.935659 & $\mathrm{Mn}$ & 0.47 & 0.03 \\
\hline $\mathrm{Fe}$ & 0.174703 & $\mathrm{Fe}$ & 0.11 & 0.03 & $\mathrm{Fe}$ & 0.15055 & $\mathrm{Fe}$ & 0.1 & 0.03 & $\mathrm{Fe}$ & 24.8816 & $\mathrm{Fe}$ & 12.66 & 0.11 \\
\hline $\mathrm{Ni}$ & 0 & $\mathrm{Ni}$ & 0 & 0 & $\mathrm{Ni}$ & 0.057904 & $\mathrm{Ni}$ & 0.04 & 0.04 & $\mathrm{Ni}$ & 0 & $\mathrm{Ni}$ & 0 & 0 \\
\hline $\mathrm{Ba}$ & 0.128116 & $\mathrm{Ba}$ & 0.21 & 0.05 & Total & 100 & Total & 24.48 & & Total & 100 & Total & 26.96 & \\
\hline Total & 100 & Total & 24.83 & & & & & & & & & & & \\
\hline
\end{tabular}

\begin{tabular}{|c|c|c|c|c|c|c|c|c|c|c|c|c|c|c|}
\hline \multicolumn{5}{|c|}{ Site 2} & \multicolumn{5}{|c|}{ Site 2} & \multicolumn{5}{|c|}{ Site 3} \\
\hline Spectrum 4 & Atomic \% & Spectrum 4 & $\mathbf{W t} \%$ & Wt\% Sigma & Spectrum 5 & Atomic \% & Spectrum 5 & $\mathbf{W t} \%$ & Wt\% Sigma & Spectrum 6 & Atomic \% & Spectrum 6 & $\mathbf{W t} \%$ & Wt $\%$ Sigma \\
\hline $\mathrm{Na}$ & 0.483363 & $\mathrm{Na}$ & 0.11 & 0.01 & $\mathrm{~F}$ & 3.85929 & $\mathrm{~F}$ & 0.67 & 0.04 & $\mathrm{Na}$ & 0.170242 & $\mathrm{Na}$ & 0.03 & 0.02 \\
\hline $\mathrm{Mg}$ & 4.181655 & $\mathrm{Mg}$ & 1 & 0.02 & $\mathrm{Na}$ & 0.159381 & $\mathrm{Na}$ & 0.03 & 0.01 & $\mathrm{Mg}$ & 0.488026 & $\mathrm{Mg}$ & 0.09 & 0.01 \\
\hline $\mathrm{Si}$ & 23.67356 & $\mathrm{Si}$ & 6.57 & 0.04 & Al & 0.273224 & $\mathrm{Al}$ & 0.07 & 0.01 & $\mathrm{Si}$ & 0.090796 & $\mathrm{Si}$ & 0.02 & 0.01 \\
\hline $\mathrm{P}$ & 0 & $\mathrm{P}$ & 0 & 0 & $\mathrm{Si}$ & 0.899362 & $\mathrm{Si}$ & 0.23 & 0.01 & $\mathrm{P}$ & 0 & P & 0 & 0 \\
\hline $\mathrm{s}$ & 0.044964 & $\mathrm{~s}$ & 0.01 & 0.01 & $\mathrm{P}$ & 16.54144 & $\mathrm{P}$ & 4.68 & 0.03 & $\mathrm{~s}$ & 0 & $\mathrm{~s}$ & 0 & 0 \\
\hline $\mathrm{Cr}$ & 0 & $\mathrm{Cr}$ & 0 & 0 & $\mathrm{Ti}$ & 0.045537 & $\mathrm{Ti}$ & 0.02 & 0.02 & $\mathrm{Cr}$ & 0 & $\mathrm{Cr}$ & 0 & 0 \\
\hline $\mathrm{Mn}$ & 0.708183 & $\mathrm{Mn}$ & 0.38 & 0.03 & $\mathrm{Cr}$ & 0 & $\mathrm{Cr}$ & 0 & 0 & $\mathrm{Mn}$ & 0.964703 & $\mathrm{Mn}$ & 0.39 & 0.03 \\
\hline $\mathrm{Fe}$ & 8.824191 & $\mathrm{Fe}$ & 4.87 & 0.07 & $\mathrm{Mn}$ & 0 & $\mathrm{Mn}$ & 0 & 0 & $\mathrm{Fe}$ & 40.02951 & $\mathrm{Fe}$ & 16.32 & 0.11 \\
\hline $\mathrm{Ni}$ & 0 & $\mathrm{Ni}$ & 0 & 0 & $\mathrm{Fe}$ & 0.387067 & $\mathrm{Fe}$ & 0.2 & 0.03 & $\mathrm{Ni}$ & 0.102145 & $\mathrm{Ni}$ & 0.04 & 0.04 \\
\hline Total & 100 & Total & 25.11 & & $\mathrm{Ni}$ & 0 & $\mathrm{Ni}$ & 0 & 0 & Total & 100 & Total & 26.02 & \\
\hline
\end{tabular}

\begin{tabular}{|c|c|c|c|c|c|c|c|c|c|c|c|c|c|c|}
\hline \multicolumn{5}{|c|}{ Site 3} & \multicolumn{5}{|c|}{ Site 3} & \multicolumn{5}{|c|}{ Site 3} \\
\hline 0 & $\overline{52.05916}$ & 0 & 8.2 & 0.07 & 0 & $\overline{c 5.27518}$ & 0 & 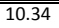 & 0.08 & $\mathrm{Na}$ & 0 & $\mathrm{Na}$ & 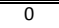 & 0 \\
\hline $\mathrm{Na}$ & 0.386803 & $\mathrm{Na}$ & 0.09 & 0.01 & $\mathrm{Na}$ & 6.165791 & $\mathrm{Na}$ & 1.66 & 0.02 & $\mathrm{Mg}$ & 0 & $\mathrm{Mg}$ & 0 & 0 \\
\hline $\mathrm{Mg}$ & 4.323094 & $\mathrm{Mg}$ & 1.03 & 0.02 & $\mathrm{Mg}$ & 0 & $\mathrm{Mg}$ & 0 & 0 & Al & 0.112962 & Al & 0.02 & 0.01 \\
\hline $\mathrm{Si}$ & 23.6405 & $\mathrm{Si}$ & 6.53 & 0.04 & $\mathrm{Si}$ & 26.77552 & $\mathrm{Si}$ & 8.79 & 0.05 & $\mathrm{P}$ & 0.098842 & $P$ & 0.02 & 0.01 \\
\hline $\mathrm{P}$ & 0 & $\mathrm{P}$ & 0 & 0 & $\mathrm{P}$ & 0 & P & 0 & 0 & $\mathrm{~s}$ & 49.46343 & $\mathrm{~s}$ & 10.29 & 0.06 \\
\hline $\mathrm{s}$ & 0 & s & 0 & 0 & $\mathrm{~s}$ & 0 & $\mathrm{~s}$ & 0 & 0 & $\mathrm{~K}$ & 0 & $\mathrm{~K}$ & 0 & 0 \\
\hline $\mathrm{Cr}$ & 0 & $\mathrm{Cr}$ & 0 & 0 & $\mathrm{Cr}$ & 0 & $\mathrm{Cr}$ & 0 & 0 & $\mathrm{Mn}$ & 0 & $\mathrm{Mn}$ & 0 & 0 \\
\hline $\mathrm{Mn}$ & 0.830489 & $\mathrm{Mn}$ & 0.45 & 0.03 & $\mathrm{Mn}$ & 0 & $\mathrm{Mn}$ & 0 & 0 & $\mathrm{Fe}$ & 49.33635 & $\mathrm{Fe}$ & 17.88 & 0.14 \\
\hline $\mathrm{Fe}$ & 8.657565 & $\mathrm{Fe}$ & 4.76 & 0.07 & $\mathrm{Fe}$ & 0.079927 & $\mathrm{Fe}$ & 0.05 & 0.03 & $\mathrm{Ni}$ & 0.197684 & $\mathrm{Ni}$ & 0.08 & 0.05 \\
\hline $\mathrm{Ni}$ & 0.102389 & $\mathrm{Ni}$ & 0.06 & 0.04 & $\mathrm{Ni}$ & 0 & $\mathrm{Ni}$ & 0 & 0 & Total & 100 & Total & 28.53 & \\
\hline Total & 100 & Total & 25.04 & & $\mathrm{Ba}$ & 0.137018 & $\mathrm{Ba}$ & 0.23 & 0.05 & & & & & \\
\hline & & & & & Total & 100 & Total & 25.03 & & & & & & \\
\hline
\end{tabular}




\begin{tabular}{|c|c|c|c|c|c|c|c|c|c|c|c|c|c|c|}
\hline \multicolumn{5}{|c|}{ Site 3} & \multicolumn{5}{|c|}{ Site 4} & \multicolumn{5}{|c|}{ Site 4} \\
\hline Spectrum 10 & Atomic \% & Spectrum 10 & $\mathbf{W t} \%$ & Wt\% Sigma & Spectrum 11 & Atomic \% & Spectrum 11 & $\mathbf{W t} \%$ & Wt\% Sigma & Spectrum 12 & Atomic \% & Spectrum 12 & $\mathbf{W t} \%$ & Wt\% Sigma \\
\hline 0 & 599.62264 & 0 & 7.63 & 0.05 & 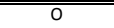 & 55.45089 & 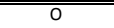 & 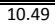 & 0.08 & 0 & 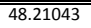 & 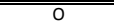 & $\begin{array}{l}5.77 \\
\end{array}$ & 0.05 \\
\hline $\mathrm{Na}$ & 0.080046 & $\mathrm{Na}$ & 0.02 & 0.01 & $\mathrm{Na}$ & 6.145893 & $\mathrm{Na}$ & 1.67 & 0.02 & $\mathrm{Na}$ & 0.14771 & $\mathrm{Na}$ & 0.03 & 0.02 \\
\hline $\mathrm{Mg}$ & 0.297313 & $\mathrm{Mg}$ & 0.06 & 0.01 & $\mathrm{Mg}$ & 0 & $\mathrm{Mg}$ & 0 & 0 & $\mathrm{Mg}$ & 0.53403 & $\mathrm{Mg}$ & 0.1 & 0.01 \\
\hline $\mathrm{Al}$ & 1.02916 & $\mathrm{Al}$ & 0.22 & 0.05 & $\mathrm{Al}$ & 9.350948 & $\mathrm{Al}$ & 2.98 & 0.03 & $\mathrm{Al}$ & 0.806727 & $\mathrm{Al}$ & 0.16 & 0.01 \\
\hline $\mathrm{Si}$ & 13.02459 & $\mathrm{Si}$ & 2.93 & 0.03 & $\mathrm{Si}$ & 26.75474 & $\mathrm{Si}$ & 8.89 & 0.05 & $\mathrm{Si}$ & 0.056812 & $\mathrm{Si}$ & 0.01 & 0.01 \\
\hline $\mathrm{P}$ & 0.125786 & $\mathrm{P}$ & 0.03 & 0.01 & $\mathrm{P}$ & 0 & $\mathrm{P}$ & 0 & 0 & $\mathrm{P}$ & 0 & $\mathrm{P}$ & 0 & 0 \\
\hline $\mathrm{s}$ & 0 & $\mathrm{~s}$ & 0 & 0 & $\mathrm{~s}$ & 0 & $\mathrm{~s}$ & 0 & 0 & $\mathrm{~s}$ & 0 & $\mathrm{~s}$ & 0 & 0 \\
\hline $\mathrm{K}$ & 0.057176 & $\mathrm{~K}$ & 0.02 & 0.01 & $\mathrm{~K}$ & 1.493395 & $\mathrm{~K}$ & 0.69 & 0.02 & $\mathrm{~K}$ & 0 & K & 0 & 0 \\
\hline $\mathrm{Ca}$ & 1.223556 & $\mathrm{Ca}$ & 0.39 & 0.02 & $\mathrm{Ca}$ & 0.53992 & $\mathrm{Ca}$ & 0.25 & 0.02 & $\mathrm{Ca}$ & 0 & $\mathrm{Ca}$ & 0 & 0 \\
\hline $\mathrm{Ti}$ & 0.080046 & $\mathrm{Ti}$ & 0.03 & 0.01 & $\mathrm{Ti}$ & 0 & $\mathrm{Ti}$ & 0 & 0 & $\mathrm{Ti}$ & 9.873878 & $\mathrm{Ti}$ & 3.54 & 0.04 \\
\hline $\mathrm{Cr}$ & 0 & $\mathrm{Cr}$ & 0 & 0 & $\mathrm{Cr}$ & 0 & $\mathrm{Cr}$ & 0 & 0 & $\mathrm{Cr}$ & 0 & $\mathrm{Cr}$ & 0 & 0 \\
\hline $\mathrm{Mn}$ & 0.057176 & $\mathrm{Mn}$ & 0.02 & 0.02 & $\mathrm{Mn}$ & 0 & $\mathrm{Mn}$ & 0 & 0 & $\mathrm{Mn}$ & 0.988524 & $\mathrm{Mn}$ & 0.41 & 0.03 \\
\hline $\mathrm{Fe}$ & 24.40252 & $\mathrm{Fe}$ & 10.91 & 0.09 & $\mathrm{Fe}$ & 0.114877 & $\mathrm{Fe}$ & 0.08 & 0.03 & $\mathrm{Fe}$ & 39.38189 & $\mathrm{Fe}$ & 16.44 & 0.12 \\
\hline $\mathrm{Ni}$ & 0 & $\mathrm{Ni}$ & 0 & 0 & $\mathrm{Ni}$ & 0 & $\mathrm{Ni}$ & 0 & 0 & $\mathrm{Ni}$ & 0 & $\mathrm{Ni}$ & 0 & 0 \\
\hline $\mathrm{Br}$ & 0 & $\mathrm{Br}$ & 0 & 0 & $\mathrm{Ba}$ & 0.149339 & $\mathrm{Ba}$ & 0.23 & 0.05 & Total & 100 & Total & 26.46 & \\
\hline Total & 100 & Total & 22.26 & & Total & 100 & Total & 25.28 & & & & & & \\
\hline
\end{tabular}

\begin{tabular}{|c|c|c|c|c|c|c|c|c|c|c|c|c|c|c|}
\hline \multicolumn{5}{|c|}{ Site 4} & \multicolumn{5}{|c|}{$\begin{array}{l}\text { Site } 4 \\
\end{array}$} & \multicolumn{5}{|c|}{ Site 4} \\
\hline Spectrum 13 & Atomic \% & Spectrum 13 & $\mathbf{W t} \%$ & Wt\% Sigma & Spectrum 14 & Atomic \% & Spectrum 14 & $\mathbf{W t} \%$ & Wt\% Sigma & Spectrum 15 & Atomic \% & Spectrum 15 & $\mathbf{W t} \%$ & Wt\% Sigma \\
\hline $\mathrm{F}$ & 4.139508 & $\mathrm{~F}$ & 0.76 & 0.04 & $\mathrm{~F}$ & 4.070957 & $\mathrm{~F}$ & 0.74 & 0.04 & $\mathrm{~F}$ & 4.01953 & $\mathrm{~F}$ & 0.71 & 0.06 \\
\hline $\mathrm{Al}$ & 0.04574 & $\mathrm{Al}$ & 0.01 & 0.01 & $\mathrm{Al}$ & 0.0796 & $\mathrm{Al}$ & 0.02 & 0.01 & $\mathrm{Al}$ & 0.124901 & $\mathrm{Al}$ & 0.03 & 0.01 \\
\hline $\mathrm{Si}$ & 0.365923 & $\mathrm{Si}$ & 0.1 & 0.01 & $\mathrm{Si}$ & 0.352513 & $\mathrm{Si}$ & 0.09 & 0.01 & $\mathrm{Si}$ & 0.476893 & $\mathrm{Si}$ & 0.12 & 0.01 \\
\hline P & 16.3179 & $\mathrm{P}$ & 4.89 & 0.04 & $\mathrm{P}$ & 16.64771 & $\mathrm{P}$ & 4.91 & 0.04 & $\mathrm{P}$ & 15.82832 & $\mathrm{P}$ & 4.57 & 0.04 \\
\hline $\mathrm{Ti}$ & 0 & $\mathrm{Ti}$ & 0 & 0 & $\mathrm{Ti}$ & 0 & $\mathrm{Ti}$ & 0 & 0 & $\mathrm{Ti}$ & 0.533666 & $\mathrm{Ti}$ & 0.24 & 0.02 \\
\hline $\mathrm{Cr}$ & 0 & $\mathrm{Cr}$ & 0 & 0 & $\mathrm{Cr}$ & 0 & $\mathrm{Cr}$ & 0 & 0 & $\mathrm{Cr}$ & 0 & $\mathrm{Cr}$ & 0 & 0 \\
\hline $\mathrm{Mn}$ & 0 & $\mathrm{Mn}$ & 0 & 0 & $\mathrm{Mn}$ & 0.125085 & $\mathrm{Mn}$ & 0.06 & 0.03 & $\mathrm{Mn}$ & 0.249801 & $\mathrm{Mn}$ & 0.13 & 0.03 \\
\hline $\mathrm{Fe}$ & 0.171527 & $\mathrm{Fe}$ & 0.09 & 0.03 & $\mathrm{Fe}$ & 0.295656 & $\mathrm{Fe}$ & 0.16 & 0.03 & $\mathrm{Fe}$ & 2.100602 & $\mathrm{Fe}$ & 1.09 & 0.05 \\
\hline $\mathrm{Ni}$ & 0 & $\mathrm{Ni}$ & 0 & 0 & $\mathrm{Ni}$ & 0 & $\mathrm{Ni}$ & 0 & 0 & $\mathrm{Ni}$ & 0 & $\mathrm{Ni}$ & 0 & 0 \\
\hline \multirow[t]{2}{*}{ Total } & 100 & Total & 24.62 & & Total & 100 & Total & 24.41 & & $\mathrm{Ce}$ & 0.238447 & $\mathrm{Ce}$ & 0.31 & 0.05 \\
\hline & & & & & & & & & & Total & 100 & Total & 24.57 & \\
\hline
\end{tabular}

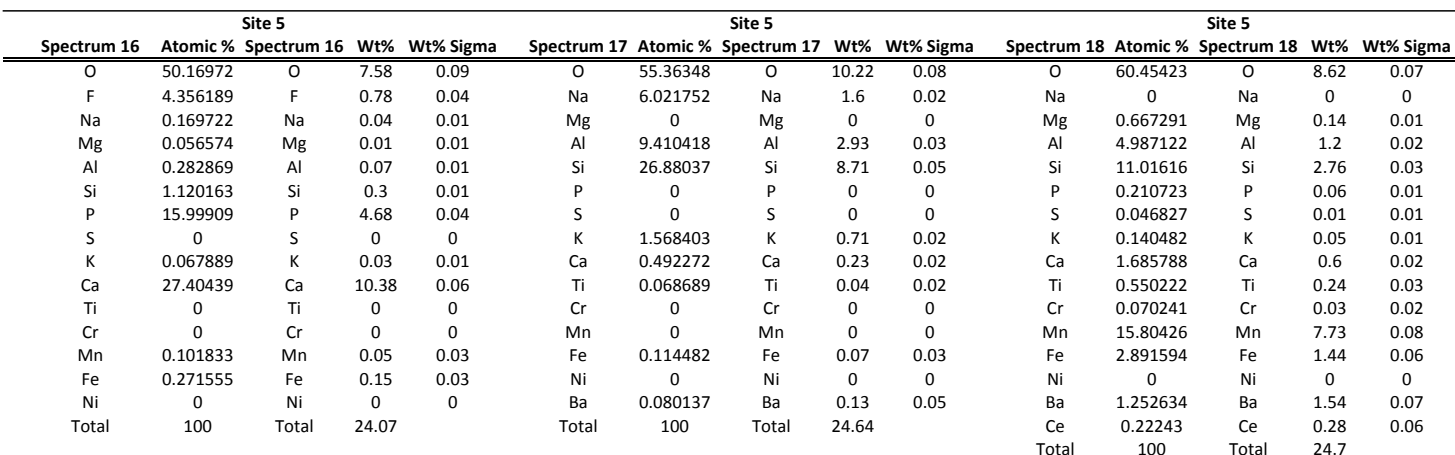

\begin{tabular}{|c|c|c|c|c|c|c|c|c|c|c|c|c|c|c|}
\hline \multicolumn{5}{|c|}{$\begin{array}{ll}\text { Site } 5 \\
\end{array}$} & \multicolumn{5}{|c|}{ Site 5} & \multicolumn{5}{|c|}{ Site 6} \\
\hline Spectrum 19 & Atomic \% & Spectrum 19 & $\mathbf{W t} \%$ & Wt\% Sigma & Spectrum 20 & Atomic \% & Spectrum 20 & $\mathbf{W t} \%$ & Wt\% Sigma & Spectrum 21 & Atomic \% & Spectrum 21 & $\mathbf{W t} \%$ & Wt\% Sigma \\
\hline 0 & $=01.3896$ & 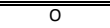 & 9.86 & 0.08 & 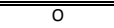 & $=61.96852$ & $\begin{array}{ll}0 \\
\end{array}$ & 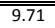 & 0.07 & 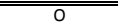 & $\begin{array}{l}55.37143 \\
\end{array}$ & 0 & 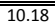 & $\begin{array}{l}0.07 \\
\end{array}$ \\
\hline $\mathrm{Na}$ & 0.093262 & $\mathrm{Na}$ & 0.02 & 0.01 & $\mathrm{Na}$ & 0 & $\mathrm{Na}$ & 0 & 0 & $\mathrm{Na}$ & 4.937143 & $\mathrm{Na}$ & 1.31 & 0.02 \\
\hline $\mathrm{Mg}$ & 0.524598 & $\mathrm{Mg}$ & 0.13 & 0.01 & $\mathrm{Mg}$ & 0.610759 & $\mathrm{Mg}$ & 0.15 & 0.01 & $\mathrm{Mg}$ & 0.045714 & $\mathrm{Mg}$ & 0.01 & 0.01 \\
\hline $\mathrm{Al}$ & 6.283516 & $\mathrm{Al}$ & 1.7 & 0.02 & $\mathrm{Al}$ & 6.037115 & $\mathrm{Al}$ & 1.59 & 0.02 & $\mathrm{Al}$ & 12.04571 & $\mathrm{Al}$ & 3.73 & 0.03 \\
\hline $\mathrm{Si}$ & 16.69387 & $\mathrm{Si}$ & 4.71 & 0.03 & $\mathrm{Si}$ & 16.22034 & $\mathrm{Si}$ & 4.46 & 0.03 & $\mathrm{Si}$ & 23.90857 & $\mathrm{Si}$ & 7.72 & 0.04 \\
\hline $\mathrm{p}$ & 0.209839 & $\mathrm{P}$ & 0.07 & 0.01 & $\mathrm{P}$ & 0.199671 & $\mathrm{P}$ & 0.06 & 0.01 & $\mathrm{p}$ & 0 & $\mathrm{P}$ & 0 & 0 \\
\hline $\mathrm{s}$ & 0.046631 & $\mathrm{~s}$ & 0.02 & 0.01 & s & 0 & $\mathrm{~s}$ & 0 & 0 & s & 0 & s & 0 & 0 \\
\hline $\mathrm{K}$ & 0.163208 & K & 0.06 & 0.01 & $\mathrm{~K}$ & 0.15269 & $\mathrm{~K}$ & 0.06 & 0.01 & K & 0.205714 & $\mathrm{~K}$ & 0.09 & 0.01 \\
\hline $\mathrm{Ca}$ & 1.445558 & $\mathrm{Ca}$ & 0.58 & 0.02 & $\mathrm{Ca}$ & 1.632605 & $\mathrm{Ca}$ & 0.64 & 0.02 & $\mathrm{Ca}$ & 3.302857 & $\mathrm{Ca}$ & 1.52 & 0.03 \\
\hline $\mathrm{Ti}$ & 1.28235 & $\mathrm{Ti}$ & 0.62 & 0.03 & $\mathrm{Ti}$ & 1.127555 & $\mathrm{Ti}$ & 0.53 & 0.03 & $\mathrm{Ti}$ & 0 & $\mathrm{Ti}$ & 0 & 0 \\
\hline $\mathrm{Cr}$ & 0.058289 & $\mathrm{Cr}$ & 0.03 & 0.02 & $\mathrm{Cr}$ & 0 & $\mathrm{Cr}$ & 0 & 0 & $\mathrm{Cr}$ & 0 & $\mathrm{Cr}$ & 0 & 0 \\
\hline $\mathrm{Mn}$ & 5.560737 & $\mathrm{Mn}$ & 3.07 & 0.06 & $\mathrm{Mn}$ & 6.600893 & $\mathrm{Mn}$ & 3.55 & 0.06 & $\mathrm{Mn}$ & 0.08 & $\mathrm{Mn}$ & 0.05 & 0.02 \\
\hline $\mathrm{Fe}$ & 5.910469 & $\mathrm{Fe}$ & 3.32 & 0.07 & $\mathrm{Fe}$ & 4.991778 & $\mathrm{Fe}$ & 2.73 & 0.06 & $\mathrm{Fe}$ & 0.102857 & $\mathrm{Fe}$ & 0.06 & 0.03 \\
\hline $\mathrm{Ni}$ & 0 & $\mathrm{Ni}$ & 0 & 0 & $\mathrm{Ni}$ & 0.070472 & $\mathrm{Ni}$ & 0.04 & 0.04 & $\mathrm{Ni}$ & 0 & $\mathrm{Ni}$ & 0 & 0 \\
\hline $\mathrm{Ba}$ & 0.174866 & $\mathrm{Ba}$ & 0.24 & 0.07 & $\mathrm{Ba}$ & 0.387597 & $\mathrm{Ba}$ & 0.52 & 0.06 & Total & 100 & Total & 24.67 & \\
\hline $\mathrm{Ce}$ & 0.163208 & $\mathrm{Ce}$ & 0.23 & 0.06 & Total & 100 & Total & 24.04 & & & & & & \\
\hline Total & 100 & Total & 24.66 & & & & & & & & & & & \\
\hline
\end{tabular}




\begin{tabular}{|c|c|c|c|c|c|c|c|c|c|c|c|c|c|c|}
\hline \multicolumn{5}{|c|}{ Site 6} & \multicolumn{5}{|c|}{ Site 7} & \multicolumn{5}{|c|}{ Site 7} \\
\hline Spectrum 22 & Atomic \% & Spectrum 22 & Wt\% & Wt\% Sigma & Spectrum 23 & Atomic \% & Spectrum 23 & Wt\% & Wt\% Sigma & Spectrum 24 & Atomic \% & Spectrum 24 & Wt $\%$ & Wt\% Sigma \\
\hline $\mathrm{Na}$ & 4.705345 & $\mathrm{Na}$ & 1.22 & 0.02 & $\mathrm{Na}$ & 0.114626 & $\mathrm{Na}$ & 0.02 & 0.02 & $\mathrm{~F}$ & 4.700125 & $\mathrm{~F}$ & 0.86 & 0.04 \\
\hline $\mathrm{Mg}$ & 0 & $\mathrm{Mg}$ & 0 & 0 & $\mathrm{Mg}$ & 0.469968 & Mg & 0.09 & 0.01 & $\mathrm{Na}$ & 0 & $\mathrm{Na}$ & 0 & 0 \\
\hline $\mathrm{Si}$ & 23.88077 & $\mathrm{Si}$ & 7.54 & 0.04 & $\mathrm{Si}$ & 0.103164 & $\mathrm{Si}$ & 0.02 & 0.01 & $\mathrm{Al}$ & 0 & $\mathrm{Al}$ & 0 & 0 \\
\hline $\mathrm{P}$ & 0 & $\mathrm{P}$ & 0 & 0 & $\mathrm{P}$ & 0 & $\mathrm{P}$ & 0 & 0 & $\mathrm{Si}$ & 0.489359 & $\mathrm{Si}$ & 0.13 & 0.01 \\
\hline s & 0 & $\mathrm{~s}$ & 0 & 0 & $\mathrm{~s}$ & 0 & $\mathrm{~s}$ & 0 & 0 & $P$ & 16.01229 & $P$ & 4.75 & 0.04 \\
\hline $\mathrm{K}$ & 0.182732 & K & 0.08 & 0.01 & $\mathrm{~K}$ & 0 & $\mathrm{~K}$ & 0 & 0 & $\mathrm{~s}$ & 0 & $\mathrm{~s}$ & 0 & 0 \\
\hline $\mathrm{Cr}$ & 0.045683 & $\mathrm{Cr}$ & 0.02 & 0.02 & $\mathrm{Cr}$ & 0 & $\mathrm{Cr}$ & 0 & 0 & $\mathrm{Ca}$ & 27.50654 & $\mathrm{Ca}$ & 10.57 & 0.06 \\
\hline $\mathrm{Mn}$ & 0 & $\mathrm{Mn}$ & 0 & 0 & $\mathrm{Mn}$ & 0.859697 & $\mathrm{Mn}$ & 0.36 & 0.03 & $\mathrm{Ti}$ & 0.182087 & $\mathrm{Ti}$ & 0.08 & 0.02 \\
\hline $\mathrm{Fe}$ & 0.228415 & $\mathrm{Fe}$ & 0.14 & 0.03 & $\mathrm{Fe}$ & 38.91564 & $\mathrm{Fe}$ & 16.49 & 0.12 & $\mathrm{Cr}$ & 0 & $\mathrm{Cr}$ & 0 & 0 \\
\hline $\mathrm{Ni}$ & 0 & $\mathrm{Ni}$ & 0 & 0 & $\mathrm{Ni}$ & 0 & $\mathrm{Ni}$ & 0 & 0 & $\mathrm{Mn}$ & 0.113804 & $\mathrm{Mn}$ & 0.06 & 0.03 \\
\hline \multirow[t]{3}{*}{ Total } & 100 & Total & 24.32 & & Total & 100 & Total & 26.56 & & $\mathrm{Fe}$ & 0.944577 & $\mathrm{Fe}$ & 0.51 & 0.04 \\
\hline & & & & & & & & & & $\mathrm{Ni}$ & 0 & $\mathrm{Ni}$ & 0 & 0 \\
\hline & & & & & & & & & & Total & 100 & Total & 24.67 & \\
\hline
\end{tabular}

\begin{tabular}{|c|c|c|c|c|c|c|c|c|c|c|c|c|c|c|}
\hline \multicolumn{5}{|c|}{$\begin{array}{l}\text { Site } 7 \\
\end{array}$} & \multicolumn{5}{|c|}{ Site 7} & \multicolumn{5}{|c|}{ Site 7} \\
\hline Spectrum 25 & Atomic \% & Spectrum 25 & $\mathbf{W t} \%$ & Wt $\%$ Sigma & Spectrum 26 & Atomic \% & Spectrum 26 & Wt $\%$ & Wt\% Sigma & Spectrum 27 & Atomic \% & Spectrum 27 & $\mathbf{W t} \%$ & Wt $\%$ Sigma \\
\hline $\mathrm{Na}$ & 0.3771 & $\mathrm{Na}$ & 0.09 & 0.01 & $\mathrm{~F}$ & 3.898286 & $\mathrm{~F}$ & 0.68 & 0.06 & $\mathrm{Na}$ & 0.405771 & $\mathrm{Na}$ & 0.09 & 0.01 \\
\hline $\mathrm{Mg}$ & 4.445206 & $\mathrm{Mg}$ & 1.1 & 0.02 & $\mathrm{Na}$ & 0.067212 & $\mathrm{Na}$ & 0.01 & 0.01 & $\mathrm{Mg}$ & 4.407124 & $\mathrm{Mg}$ & 1.08 & 0.02 \\
\hline $\mathrm{Si}$ & 23.3459 & $\mathrm{Si}$ & 6.7 & 0.04 & $\mathrm{Al}$ & 0.100818 & $\mathrm{Al}$ & 0.02 & 0.01 & $\mathrm{Si}$ & 23.2642 & $\mathrm{Si}$ & 6.61 & 0.04 \\
\hline P & 0 & $\mathrm{P}$ & 0 & 0 & $\mathrm{Si}$ & 0.526493 & $\mathrm{Si}$ & 0.14 & 0.01 & P & 0 & $\mathrm{P}$ & 0 & 0 \\
\hline $\mathrm{s}$ & 0 & $\mathrm{~s}$ & 0 & 0 & $\mathrm{P}$ & 16.82536 & $\mathrm{P}$ & 4.79 & 0.04 & $\mathrm{~s}$ & 0 & $\mathrm{~s}$ & 0 & 0 \\
\hline K & 0 & $\mathrm{~K}$ & 0 & 0 & s & 0 & $\mathrm{~s}$ & 0 & 0 & K & 0 & K & 0 & 0 \\
\hline $\mathrm{Cr}$ & 0 & $\mathrm{Cr}$ & 0 & 0 & $\mathrm{Ti}$ & 0 & $\mathrm{Ti}$ & 0 & 0 & $\mathrm{Cr}$ & 0 & $\mathrm{Cr}$ & 0 & 0 \\
\hline $\mathrm{Mn}$ & 0.788481 & $\mathrm{Mn}$ & 0.44 & 0.03 & $\mathrm{Cr}$ & 0 & $\mathrm{Cr}$ & 0 & 0 & $\mathrm{Mn}$ & 0.676285 & $\mathrm{Mn}$ & 0.37 & 0.03 \\
\hline $\mathrm{Fe}$ & 8.65044 & $\mathrm{Fe}$ & 4.94 & 0.08 & $\mathrm{Mn}$ & 0.067212 & $\mathrm{Mn}$ & 0.03 & 0.03 & $\mathrm{Fe}$ & 8.543733 & $\mathrm{Fe}$ & 4.83 & 0.07 \\
\hline $\mathrm{Ni}$ & 0 & $\mathrm{Ni}$ & 0 & 0 & $\mathrm{Fe}$ & 0.313655 & $\mathrm{Fe}$ & 0.16 & 0.03 & $\mathrm{Ni}$ & 0 & $\mathrm{Ni}$ & 0 & 0 \\
\hline \multirow[t]{3}{*}{ Total } & 100 & Total & 25.84 & & $\mathrm{Ni}$ & 0 & $\mathrm{Ni}$ & 0 & 0 & Total & 100 & Total & 25.5 & \\
\hline & & & & & $\mathrm{Ce}$ & 0.212837 & $\mathrm{Ce}$ & 0.27 & 0.05 & & & & & \\
\hline & & & & & Total & 100 & Total & 23.84 & & & & & & \\
\hline
\end{tabular}

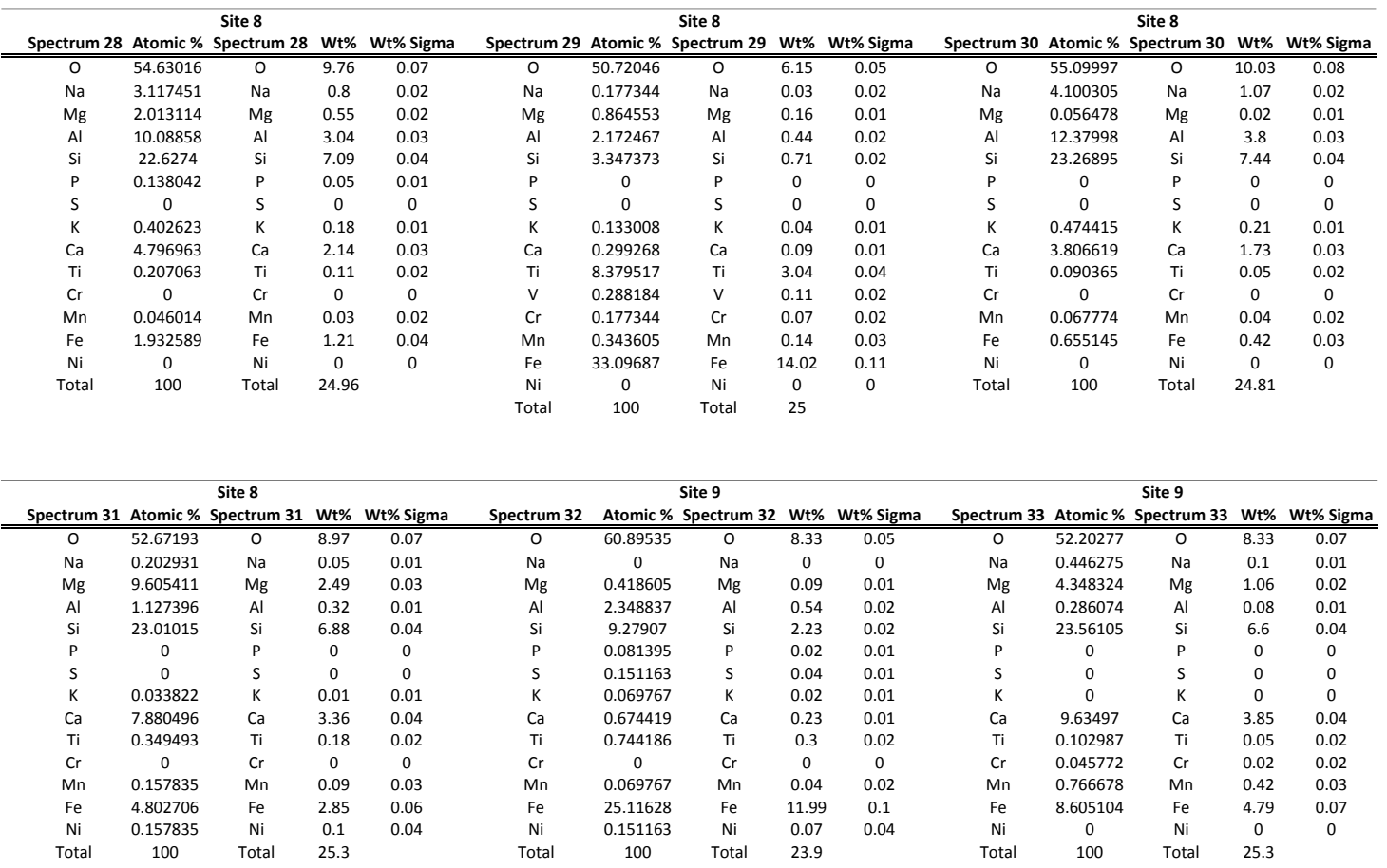




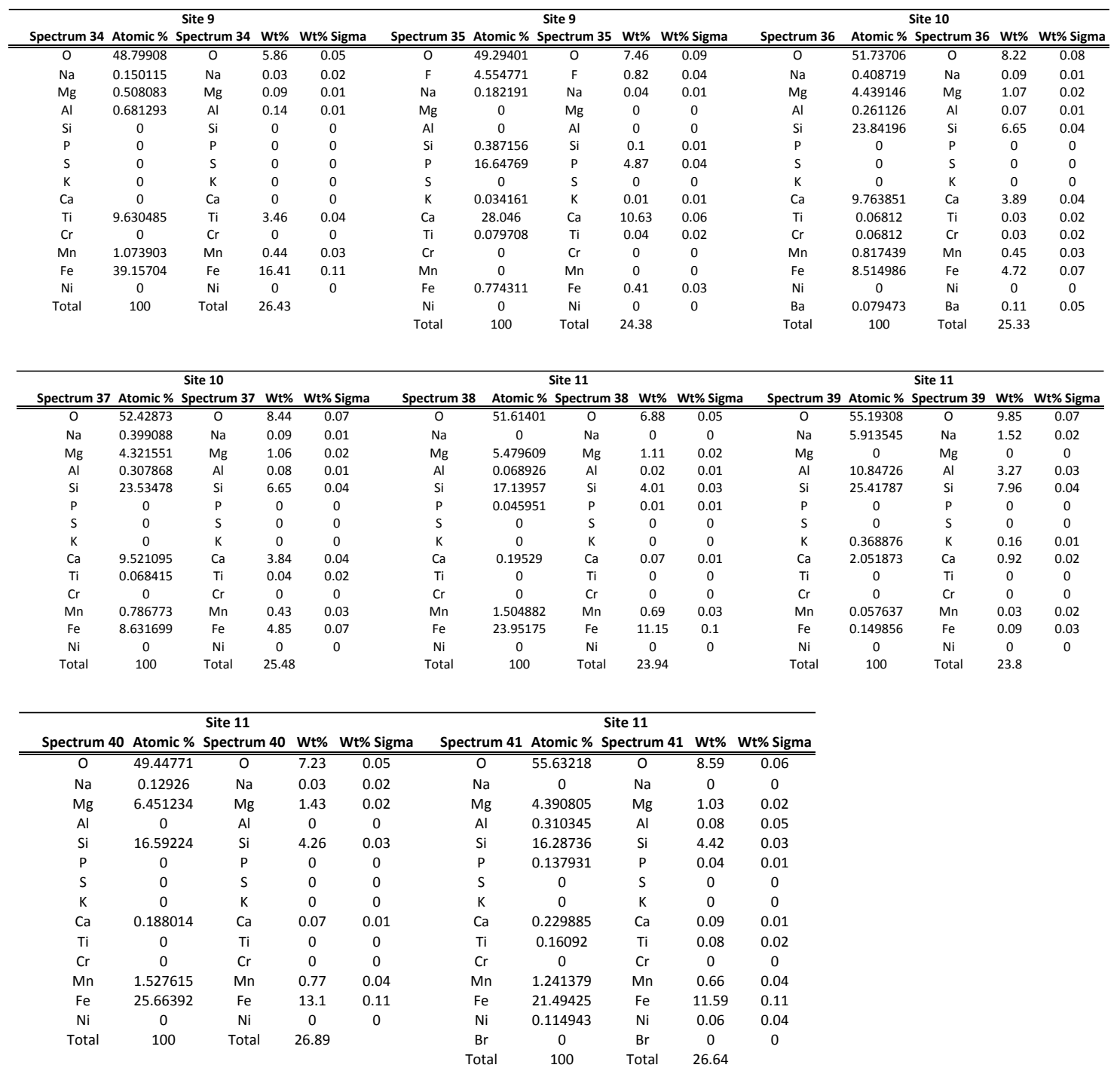

\section{H3. HS-15-04d}

\begin{tabular}{|c|c|c|c|c|c|c|c|c|c|c|c|c|c|c|}
\hline \multicolumn{5}{|c|}{ Site 1} & \multicolumn{5}{|c|}{ Site 1} & \multicolumn{5}{|c|}{ Site 2} \\
\hline 0 & 55.37622 & 0 & 41.26 & 0.25 & 0 & 59.03173 & 0 & 39 & 0.22 & 0 & 59.9856 & 0 & 45.125 & 0.26 \\
\hline $\mathrm{Na}$ & 5.306549 & $\mathrm{Na}$ & 5.681 & 0.07 & $\mathrm{Mg}$ & 1.084893 & $\mathrm{Mg}$ & 1.0941 & 0.04 & $\mathrm{Na}$ & 0.444071 & $\mathrm{Na}$ & 0.4786 & 0.03 \\
\hline $\mathrm{Si}$ & 27.02044 & $\mathrm{Si}$ & 35.34 & 0.21 & $\mathrm{Si}$ & 22.82343 & $\mathrm{Si}$ & 26.471 & 0.15 & $\mathrm{Si}$ & 34.94959 & $\mathrm{Si}$ & 46.149 & 0.26 \\
\hline $\mathrm{K}$ & 2.484905 & $\mathrm{~K}$ & 4.5142 & 0.07 & $\mathrm{~K}$ & 0.678058 & $\mathrm{~K}$ & 1.0941 & 0.04 & $\mathrm{~K}$ & 0.348056 & K & 0.6345 & 0.04 \\
\hline $\mathrm{Ca}$ & 0.452856 & $\mathrm{Ca}$ & 0.8396 & 0.05 & $\mathrm{Ca}$ & 1.044209 & $\mathrm{Ca}$ & 1.7294 & 0.05 & $\mathrm{Ca}$ & 0.132021 & $\mathrm{Ca}$ & 0.256 & 0.04 \\
\hline
\end{tabular}




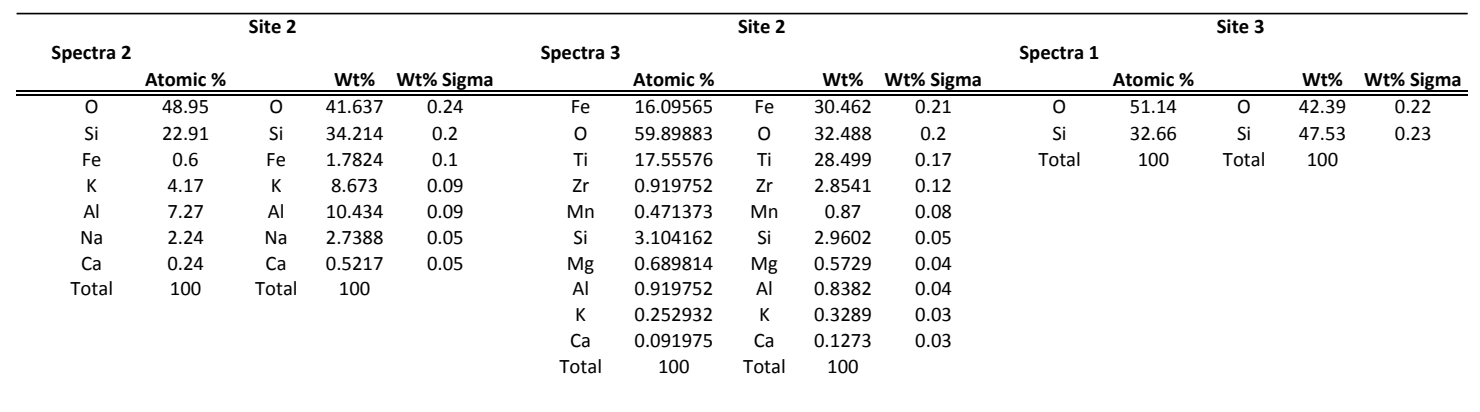

\begin{tabular}{|c|c|c|c|c|c|c|c|c|c|c|c|c|c|c|}
\hline \multicolumn{5}{|c|}{ Site 3} & \multicolumn{5}{|c|}{ Site 3} & \multicolumn{5}{|c|}{$\begin{array}{ll}\text { Site } 4 \\
\end{array}$} \\
\hline Spectra 2 & & & & & \multicolumn{3}{|c|}{$\begin{array}{l}\text { Spectra } 3 \\
\text { Atomic \% }\end{array}$} & & & \multicolumn{5}{|c|}{ Spectra 1} \\
\hline 0 & 54.88212 & 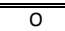 & 40.731 & 0.24 & 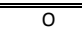 & "54.58294 & 0 & 26.165 & $\begin{array}{l}0.15 \\
\end{array}$ & 0 & (55.42344 & 0 & 38.852 & $\begin{array}{l}0.23 \\
\end{array}$ \\
\hline $\mathrm{Al}$ & 9.019128 & Al & 11.293 & 0.09 & $\mathrm{Si}$ & 0.43591 & $\mathrm{Si}$ & 0.3724 & 0.03 & $\mathrm{Mg}$ & 3.038711 & $\mathrm{Mg}$ & 3.2269 & 0.05 \\
\hline $\mathrm{Si}$ & 28.19173 & $\mathrm{Si}$ & 36.736 & 0.21 & $\mathrm{Ti}$ & 5.914232 & $\mathrm{Ti}$ & 8.4912 & 0.09 & $\mathrm{Al}$ & 7.636412 & $\mathrm{Al}$ & 9.0261 & 0.08 \\
\hline $\mathrm{K}$ & 3.758897 & K & 6.8204 & 0.08 & $\mathrm{Mn}$ & 0.471254 & $\mathrm{Mn}$ & 0.7768 & 0.08 & $\mathrm{Si}$ & 24.52107 & $\mathrm{Si}$ & 30.177 & 0.17 \\
\hline \multirow[t]{3}{*}{ Total } & 100 & Total & 100 & & $\mathrm{Fe}$ & 38.15975 & $\mathrm{Fe}$ & 63.843 & 0.21 & $\mathrm{~K}$ & 0.317083 & $\mathrm{~K}$ & 0.5495 & 0.04 \\
\hline & & & & & & & & & & $\mathrm{Fe}$ & 5.139384 & $\mathrm{Fe}$ & 12.58 & 0.16 \\
\hline & & & & & & & & & & Total & 100 & Total & 100 & \\
\hline
\end{tabular}

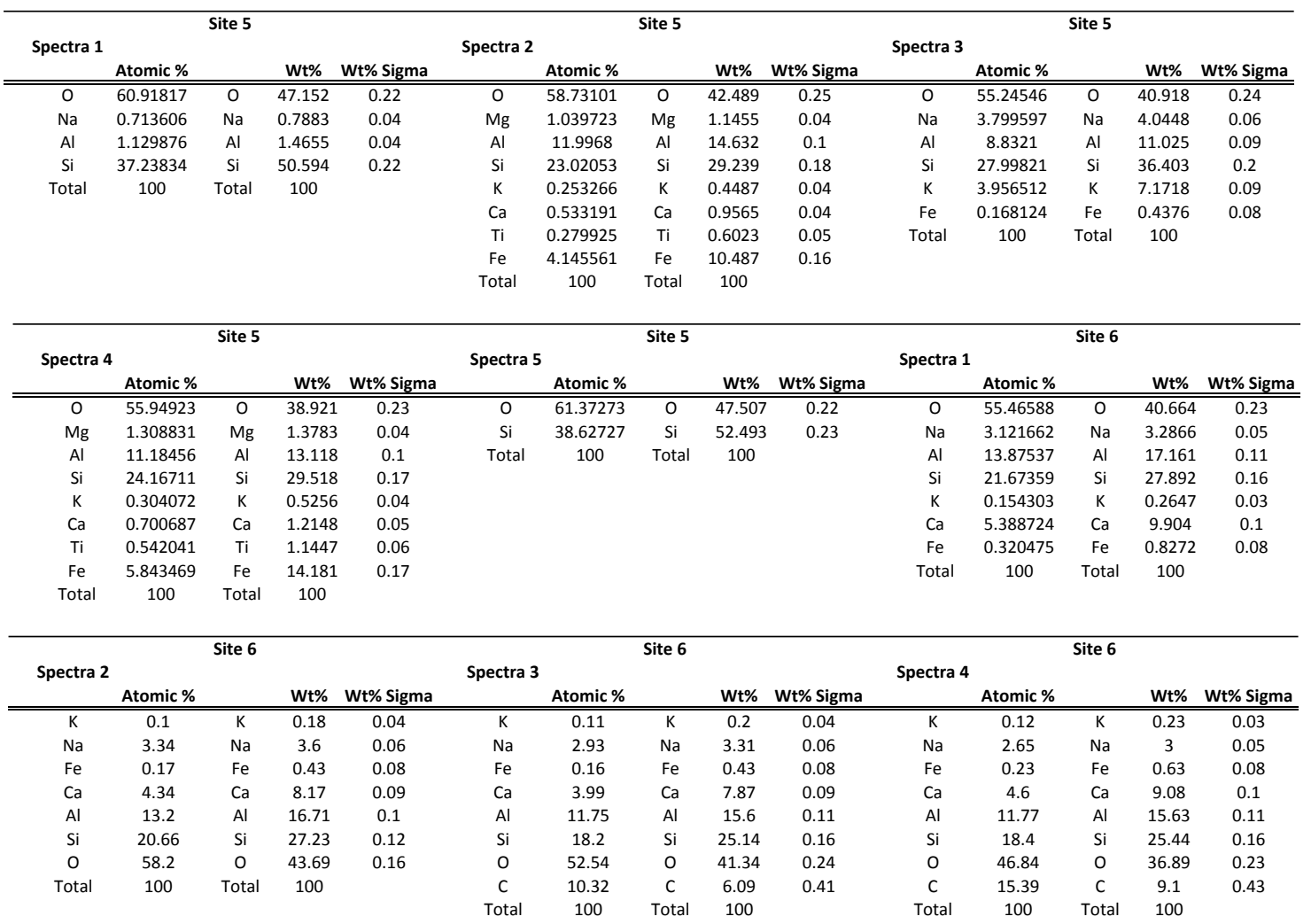




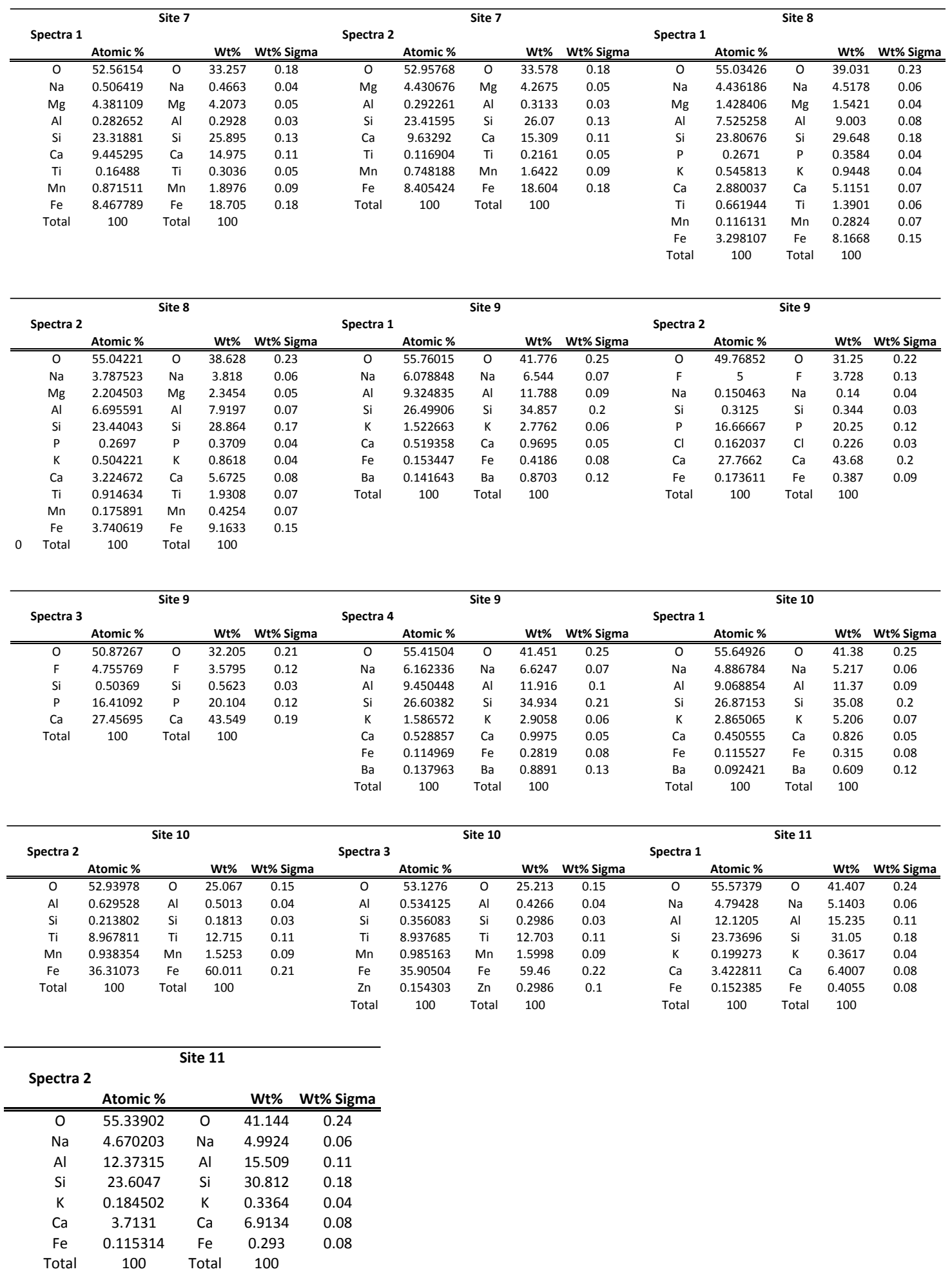




\section{H4. HS-15-04e}

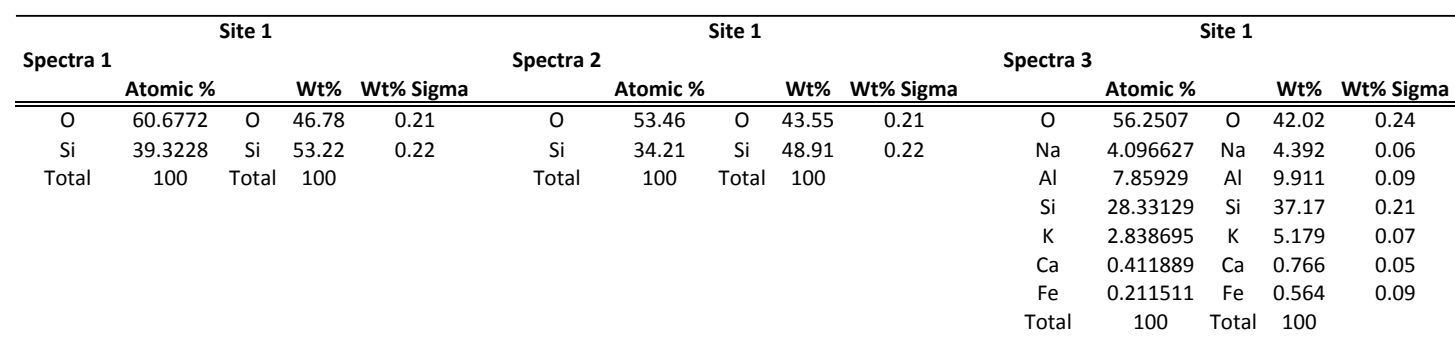

\begin{tabular}{|c|c|c|c|c|c|c|c|c|c|c|c|c|c|c|}
\hline \multicolumn{5}{|c|}{ Site 1} & \multicolumn{5}{|c|}{ Site 1} & \multicolumn{5}{|c|}{ Site 2} \\
\hline \multirow[t]{2}{*}{ Spectra 4} & \multirow{2}{*}{\multicolumn{2}{|c|}{ Atomic \% }} & \multirow[b]{2}{*}{ Wt\% } & \multirow[b]{2}{*}{ Wt\% Sigma } & \multirow[t]{2}{*}{ Spectra 5} & \multirow[b]{2}{*}{ Atomic \% } & \multirow{2}{*}{\multicolumn{2}{|c|}{$\mathbf{W t} \%$}} & \multirow[b]{2}{*}{ Wt\% Sigma } & \multirow[t]{2}{*}{ Spectra 1} & \multirow{2}{*}{ Atomic \% } & & \multirow[b]{2}{*}{$\mathbf{W t} \%$} & \multirow[b]{2}{*}{ Wt\% Sigma } \\
\hline & & & & & & & & & & & & & & \\
\hline 0 & 56.59876 & 0 & 42.3 & 0.25 & 0 & 61.09832 & 0 & 47.22 & 0.22 & 0 & 55.61259 & 0 & 39.33 & 0.23 \\
\hline $\mathrm{Al}$ & 6.698406 & Al & 8.449 & 0.08 & Total & 100 & Total & 100 & & $\mathrm{Mg}$ & 1.74538 & $\mathrm{Mg}$ & 1.88 & 0.04 \\
\hline $\mathrm{Si}$ & 30.14836 & $\mathrm{Si}$ & 39.55 & 0.22 & & & & & & $\mathrm{Al}$ & 7.209674 & $\mathrm{Al}$ & 8.606 & 0.08 \\
\hline $\mathrm{K}$ & 2.767936 & $\mathrm{~K}$ & 5.057 & 0.07 & & & & & & $\mathrm{Si}$ & 23.04358 & $\mathrm{Si}$ & 28.61 & 0.17 \\
\hline \multirow{6}{*}{ Total } & 100 & Total & 100 & & & & & & & $\mathrm{~K}$ & 0.593201 & $\mathrm{~K}$ & 1.021 & 0.04 \\
\hline & & & & & & & & & & $\mathrm{Ca}$ & 3.582021 & $\mathrm{Ca}$ & 6.339 & 0.08 \\
\hline & & & & & & & & & & $\mathrm{Ti}$ & 0.604609 & $\mathrm{Ti}$ & 1.279 & 0.06 \\
\hline & & & & & & & & & & $\mathrm{Mn}$ & 0.125485 & $\mathrm{Mn}$ & 0.29 & 0.07 \\
\hline & & & & & & & & & & $\mathrm{Fe}$ & 3.285421 & $\mathrm{Fe}$ & 8.101 & 0.15 \\
\hline & & & & & & & & & & Total & 100 & Total & 100 & \\
\hline
\end{tabular}

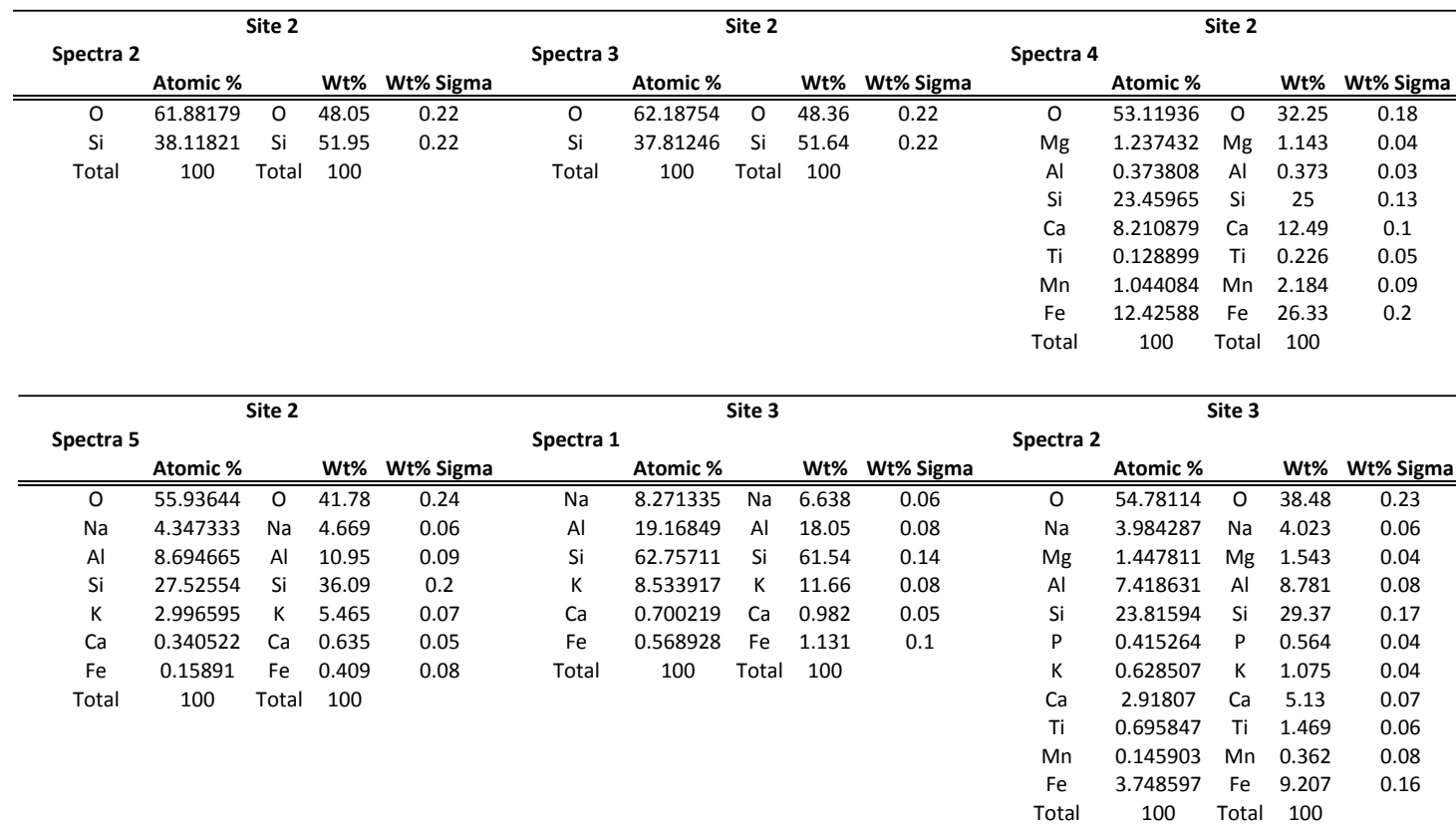




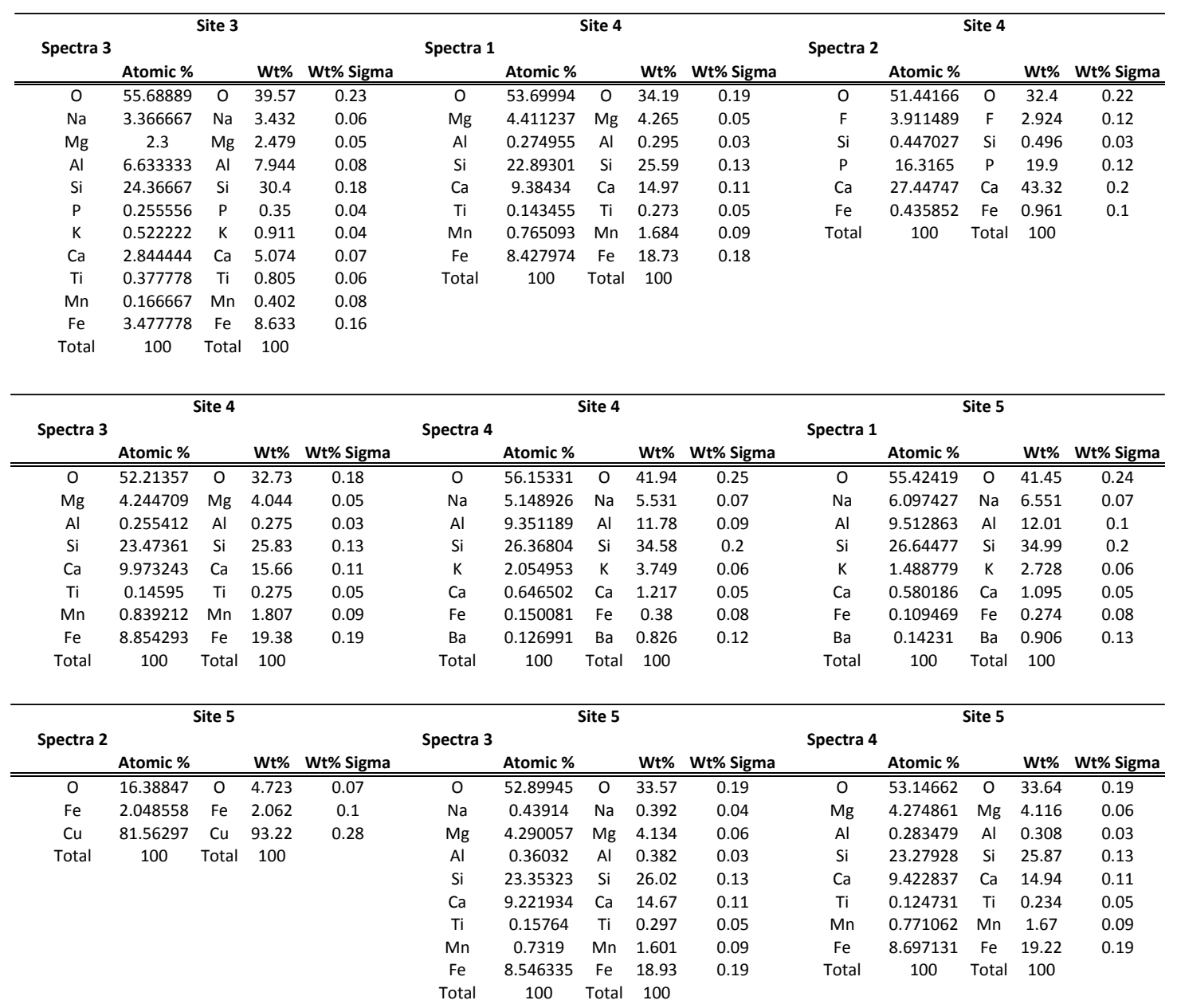

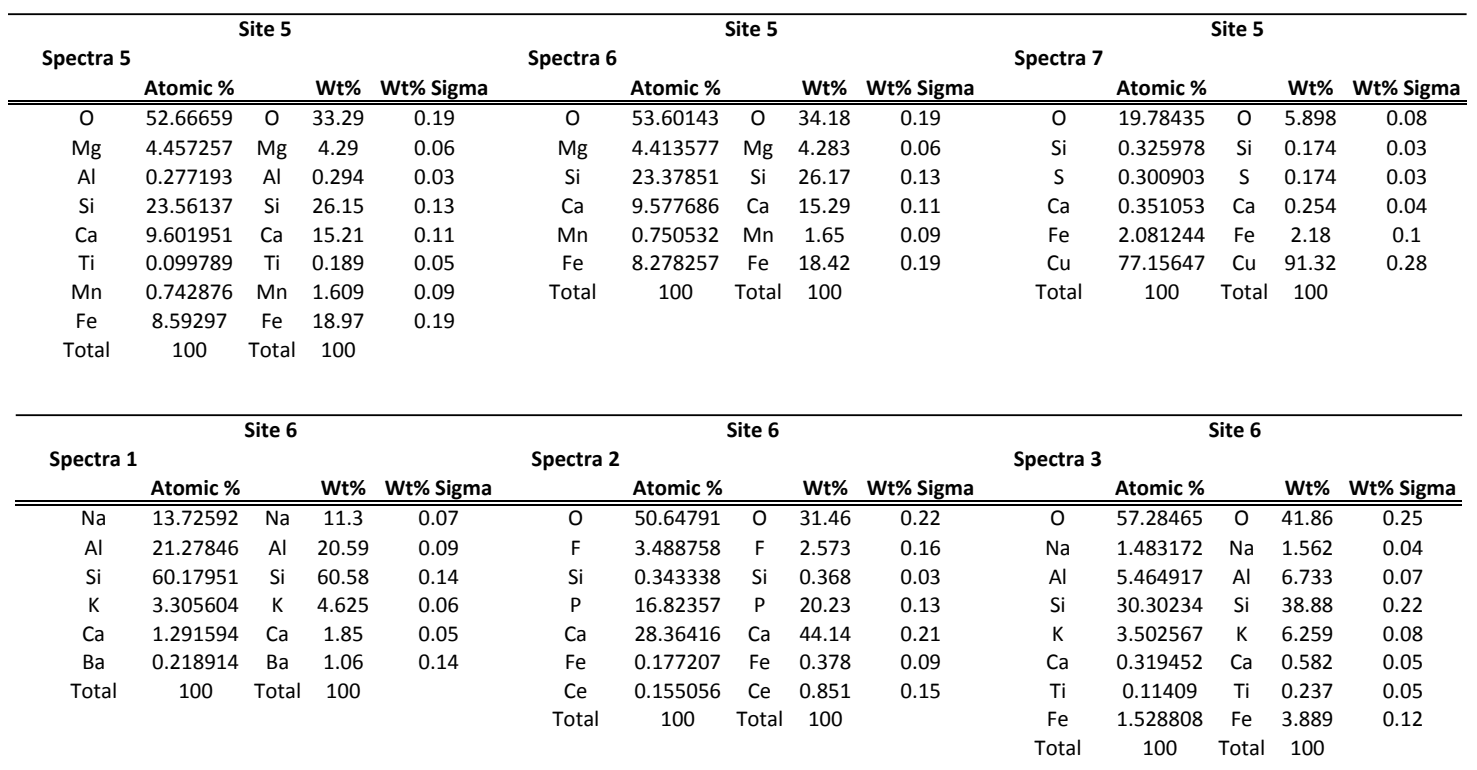




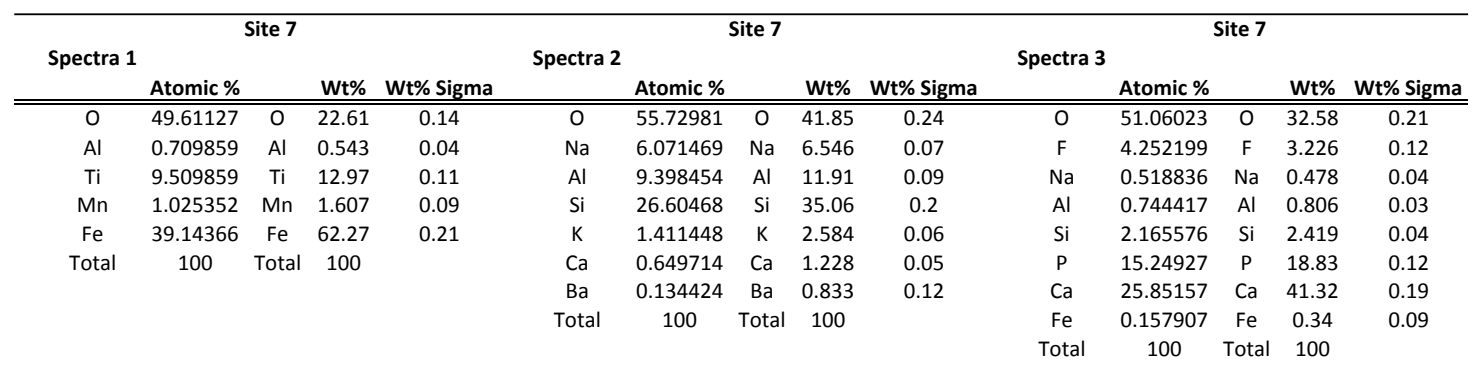

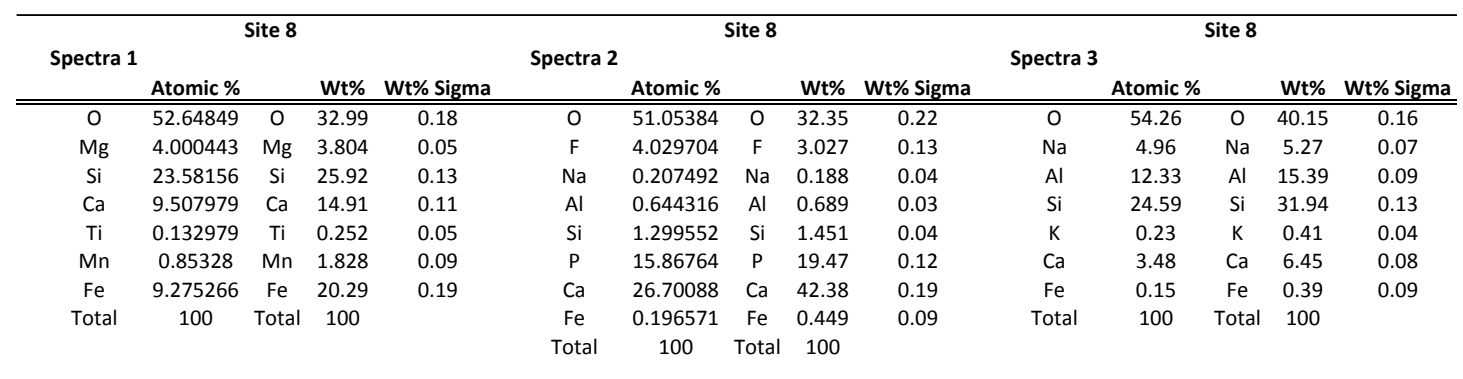

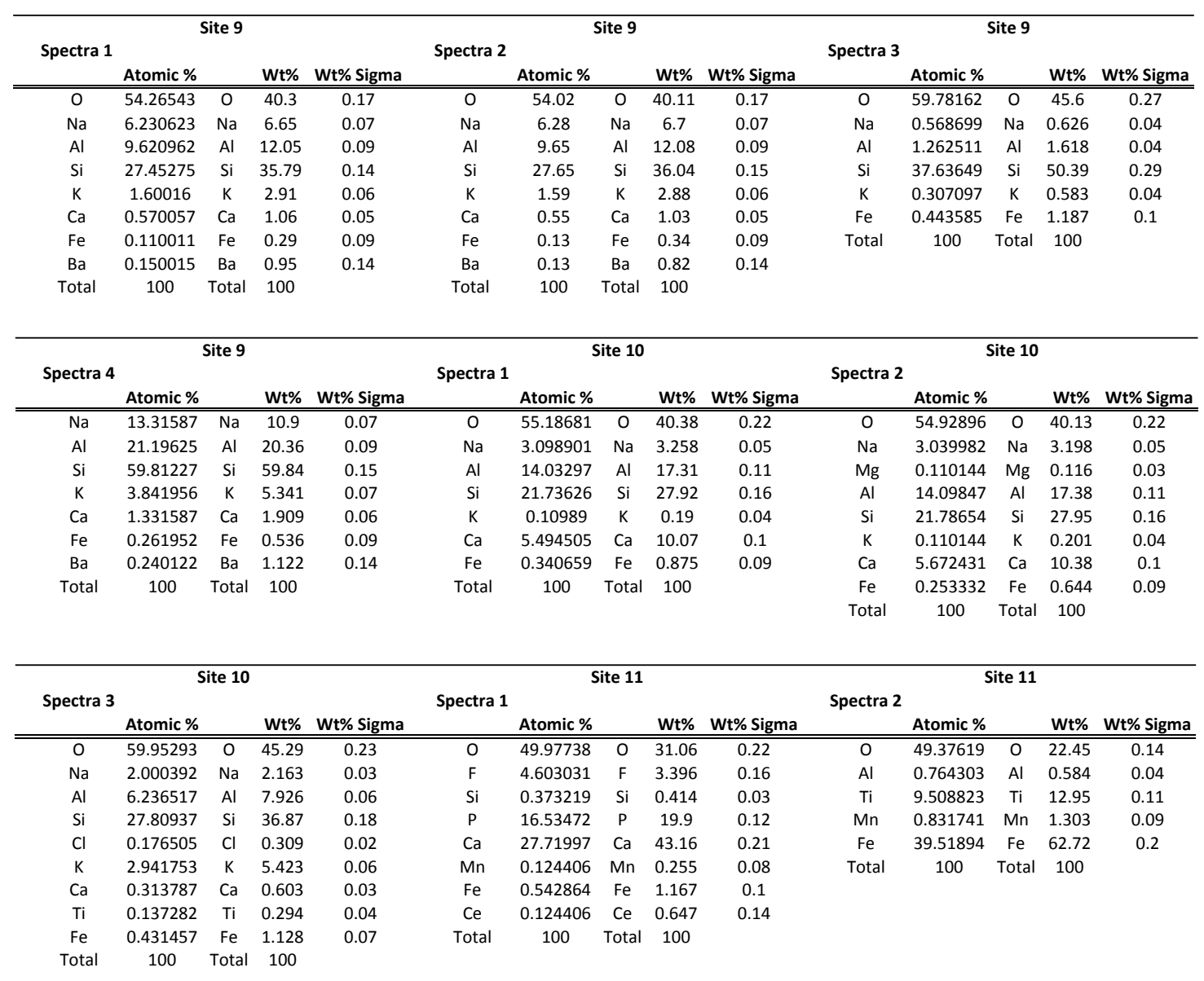




\begin{tabular}{|c|c|c|c|c|c|c|c|c|c|c|c|c|c|c|}
\hline \multicolumn{5}{|c|}{ Site 11} & \multicolumn{5}{|c|}{ Site 11} & \multicolumn{5}{|c|}{ Site 11} \\
\hline \multirow[t]{2}{*}{ Spectra 3} & \multirow{2}{*}{\multicolumn{2}{|c|}{ Atomic \% }} & \multirow[b]{2}{*}{ Wt\% } & \multirow[b]{2}{*}{ Wt $\%$ Sigma } & \multirow[t]{2}{*}{ Spectra 4} & & & \multirow[b]{2}{*}{ Wt\% } & \multirow[b]{2}{*}{ Wt\% Sigma } & \multirow[t]{2}{*}{ Spectra 5} & \multirow{2}{*}{\multicolumn{2}{|c|}{ Atomic \% }} & \multirow[b]{2}{*}{ Wt\% } & \multirow[b]{2}{*}{ Wt\% Sigma } \\
\hline & & & & & & Atomic \% & & & & & & & & \\
\hline 0 & "50.28921 & 0 & 23.26 & 0.15 & 0 & "52.6652 & 0 & 33.38 & 0.19 & 0 & "50.24981 & 0 & 31.26 & 0.22 \\
\hline $\mathrm{Al}$ & 0.941363 & Al & 0.733 & 0.04 & $\mathrm{Na}$ & 0.473568 & $\mathrm{Na}$ & 0.43 & 0.04 & $\mathrm{~F}$ & 4.607527 & $\mathrm{~F}$ & 3.407 & 0.16 \\
\hline $\mathrm{Si}$ & 0.703187 & $\mathrm{Si}$ & 0.565 & 0.04 & $\mathrm{Mg}$ & 4.394273 & $\mathrm{Mg}$ & 4.225 & 0.06 & $\mathrm{Si}$ & 0.488509 & $\mathrm{Si}$ & 0.526 & 0.03 \\
\hline $\mathrm{Ca}$ & 0.249518 & $\mathrm{Ca}$ & 0.283 & 0.04 & Al & 0.27533 & $\mathrm{Al}$ & 0.294 & 0.03 & $P$ & 16.39836 & $P$ & 19.76 & 0.12 \\
\hline $\mathrm{Ti}$ & 8.699104 & $\mathrm{Ti}$ & 12.04 & 0.11 & $\mathrm{Si}$ & 23.2489 & $\mathrm{Si}$ & 25.86 & 0.14 & $\mathrm{Ca}$ & 27.43422 & $\mathrm{Ca}$ & 42.77 & 0.21 \\
\hline $\mathrm{Mn}$ & 0.91868 & $\mathrm{Mn}$ & 1.455 & 0.09 & $\mathrm{Ca}$ & 9.548458 & $\mathrm{Ca}$ & 15.16 & 0.11 & $\mathrm{Fe}$ & 0.677251 & $\mathrm{Fe}$ & 1.483 & 0.1 \\
\hline $\mathrm{Fe}$ & 38.19893 & $\mathrm{Fe}$ & 61.67 & 0.21 & Sc & 0.121145 & Sc & 0.21 & 0.06 & $\mathrm{Ce}$ & 0.144332 & $\mathrm{Ce}$ & 0.799 & 0.15 \\
\hline \multirow[t]{4}{*}{ Total } & 100 & Total & 100 & & $\mathrm{Ti}$ & 0.110132 & $\mathrm{Ti}$ & 0.21 & 0.05 & Total & 100 & Total & 100 & \\
\hline & & & & & $\mathrm{Mn}$ & 0.726872 & $\mathrm{Mn}$ & 1.583 & 0.09 & & & & & \\
\hline & & & & & $\mathrm{Fe}$ & 8.436123 & $\mathrm{Fe}$ & 18.65 & 0.19 & & & & & \\
\hline & & & & & Total & 100 & Total & 100 & & & & & & \\
\hline
\end{tabular}

\section{H5. HS-15-05}

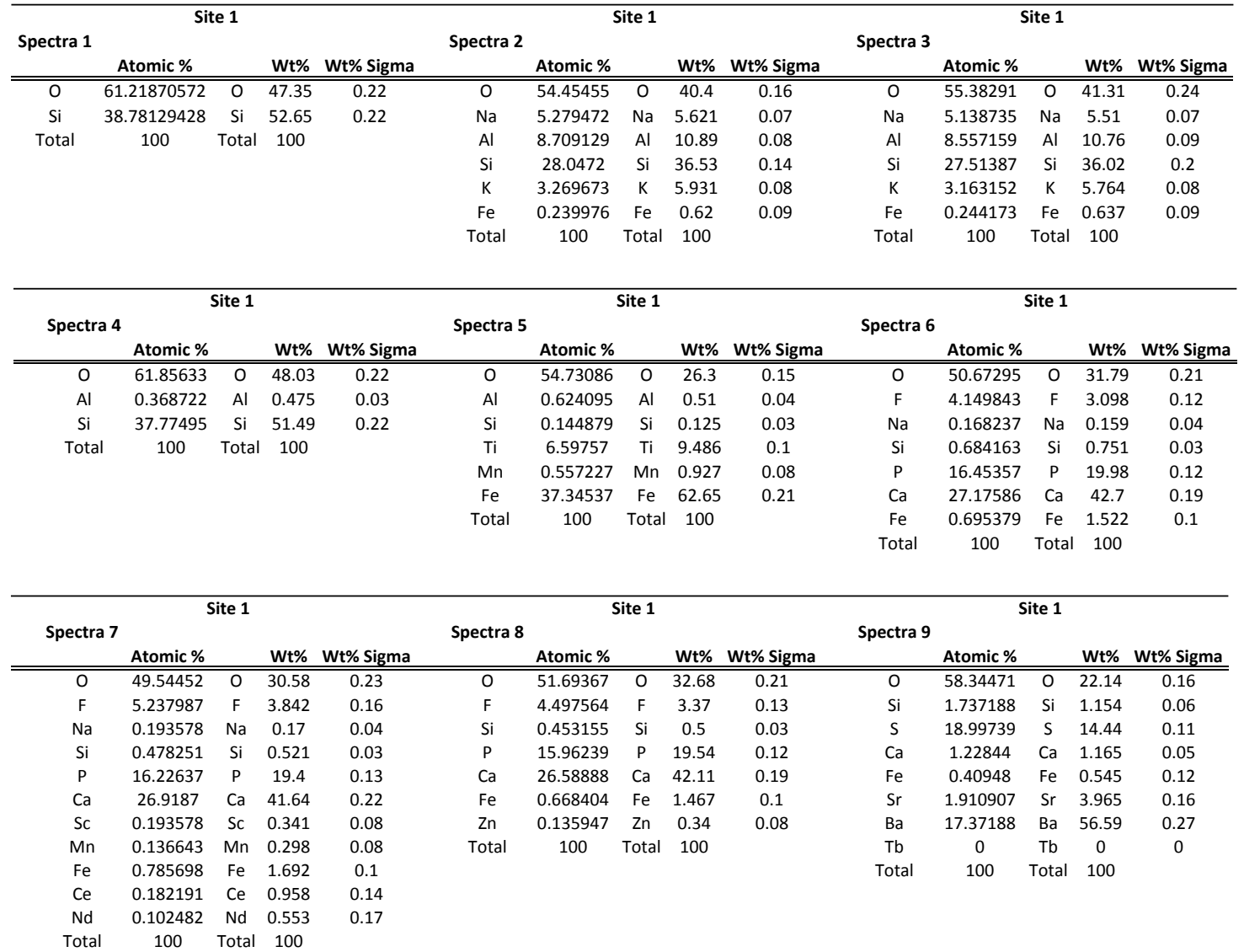




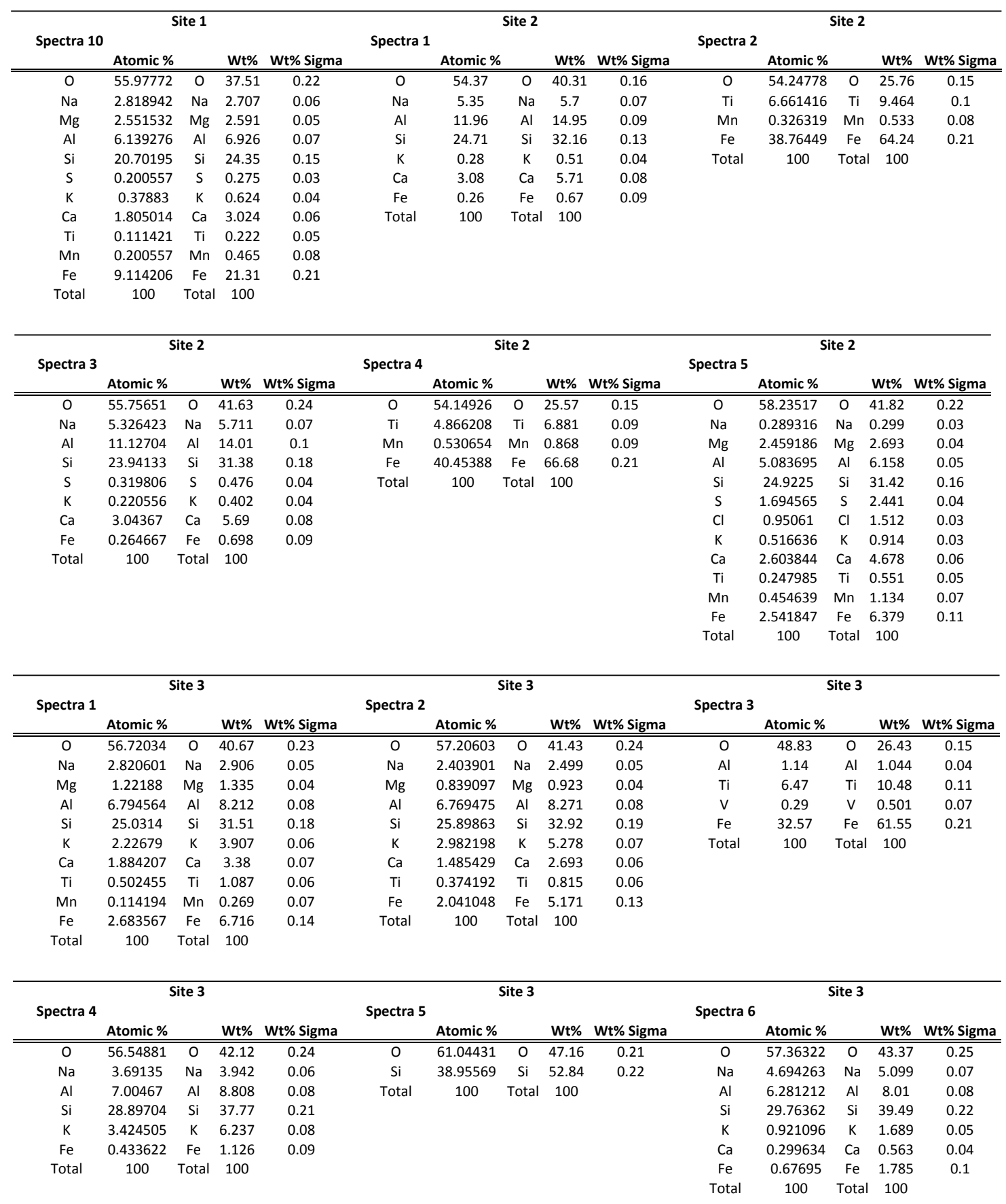




\begin{tabular}{|c|c|c|c|c|c|c|c|c|c|c|c|c|c|c|}
\hline \multicolumn{5}{|c|}{ Site 3} & \multicolumn{5}{|c|}{ Site 3} & \multicolumn{5}{|c|}{ Site 4} \\
\hline Spectra 7 & Atomic \% & & Wt\% & Wt\% Sigma & \multicolumn{5}{|l|}{ Spectra 8} & \multicolumn{5}{|l|}{ Spectra 1} \\
\hline 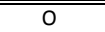 & "55.54936 & 0 & 41.16 & 0.23 & 0 & 55.16891 & 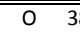 & 38.88 & 0.23 & 0 & 54.42 & 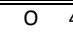 & "40.48 & 0.17 \\
\hline Al & 12.40379 & $\mathrm{Al}$ & 15.5 & 0.11 & $\mathrm{Mg}$ & 3.547622 & $\mathrm{Mg}$ & 3.794 & 0.06 & $\mathrm{Al}$ & 9.65 & Al & 12.1 & 0.09 \\
\hline $\mathrm{Si}$ & 23.12326 & $\mathrm{Si}$ & 30.08 & 0.17 & $\mathrm{Al}$ & 7.761835 & $\mathrm{Al}$ & 9.222 & 0.08 & $\mathrm{Si}$ & 27.35 & $\mathrm{Si}$ & 35.71 & 0.15 \\
\hline $\mathrm{K}$ & 0.189626 & $\mathrm{~K}$ & 0.341 & 0.04 & $\mathrm{Si}$ & 21.62468 & $\mathrm{Si}$ & 26.76 & 0.16 & $\mathrm{~K}$ & 1.59 & $\mathrm{~K}$ & 2.9 & 0.06 \\
\hline \multirow{5}{*}{ Total } & 100 & Total & 100 & & $\mathrm{Ca}$ & 3.999548 & $\mathrm{Ca}$ & 7.053 & 0.08 & $\mathrm{Ba}$ & 0.15 & $\mathrm{Ba}$ & 0.93 & 0.14 \\
\hline & & & & & $\mathrm{Ti}$ & 0.463224 & $\mathrm{Ti}$ & 0.972 & 0.06 & Total & 100 & Total & 100 & \\
\hline & & & & & $\mathrm{Mn}$ & 0.112982 & $\mathrm{Mn}$ & 0.289 & 0.07 & & & & & \\
\hline & & & & & $\mathrm{Fe}$ & 3.717094 & $\mathrm{Fe} \quad 9$ & 9.137 & 0.16 & & & & & \\
\hline & & & & & Total & 100 & Total 1 & 100 & & & & & & \\
\hline 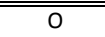 & 54.26 & 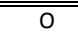 & 40.27 & $\begin{array}{l}0.17 \\
\end{array}$ & 0 & 2054.204 & 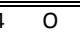 & 26.262 & 20.16 & 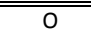 & 55.631 & 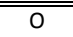 & "40.635 & $\begin{array}{ll}35 & 0.2\end{array}$ \\
\hline $\mathrm{Na}$ & 6.26 & $\mathrm{Na}$ & 6.68 & 0.07 & $\mathrm{Al}$ & 0.3372 & $\mathrm{Al}$ & 0.2822 & 0.03 & $\mathrm{Na}$ & 2.241 & $\mathrm{Na}$ & 2.3519 & 0.05 \\
\hline Al & 9.65 & $\mathrm{Al}$ & 12.08 & 0.09 & $\mathrm{Si}$ & 0.1686 & $\mathrm{Si}$ & 0.1359 & 0.03 & $\mathrm{Al}$ & 15 & $\mathrm{Al}$ & 18.473 & 0.11 \\
\hline $\mathrm{Si}$ & 27.43 & $\mathrm{Si}$ & 35.74 & 0.15 & $\mathrm{Ti}$ & 13.59 & $\mathrm{Ti}$ & 19.709 & 0.13 & $\mathrm{Si}$ & 20.541 & $\mathrm{Si}$ & 26.342 & 0.14 \\
\hline $\mathrm{K}$ & 1.55 & $\mathrm{~K}$ & 2.81 & 0.06 & $\mathrm{Mn}$ & 0.3822 & $\mathrm{Mn}$ & 0.6479 & 0.08 & $\mathrm{Ca}$ & 6.3964 & $\mathrm{Ca}$ & 11.706 & 0.1 \\
\hline $\mathrm{Ca}$ & 0.58 & $\mathrm{Ca}$ & 1.07 & 0.05 & $\mathrm{Fe}$ & 31.317 & $\mathrm{Fe}$ & 52.963 & 0.21 & $\mathrm{Fe}$ & 0.1914 & $\mathrm{Fe}$ & 0.4918 & 0.08 \\
\hline $\mathrm{Fe}$ & 0.11 & $\mathrm{Fe}$ & 0.28 & 0.09 & Total & 100 & Total & 100 & & Total & 100 & Total & 100 & \\
\hline $\mathrm{Ba}$ & 0.17 & $\mathrm{Ba}$ & 1.07 & 0.14 & & & & & & & & & & \\
\hline Total & 100 & Total & 100 & & & & & & & & & & & \\
\hline
\end{tabular}

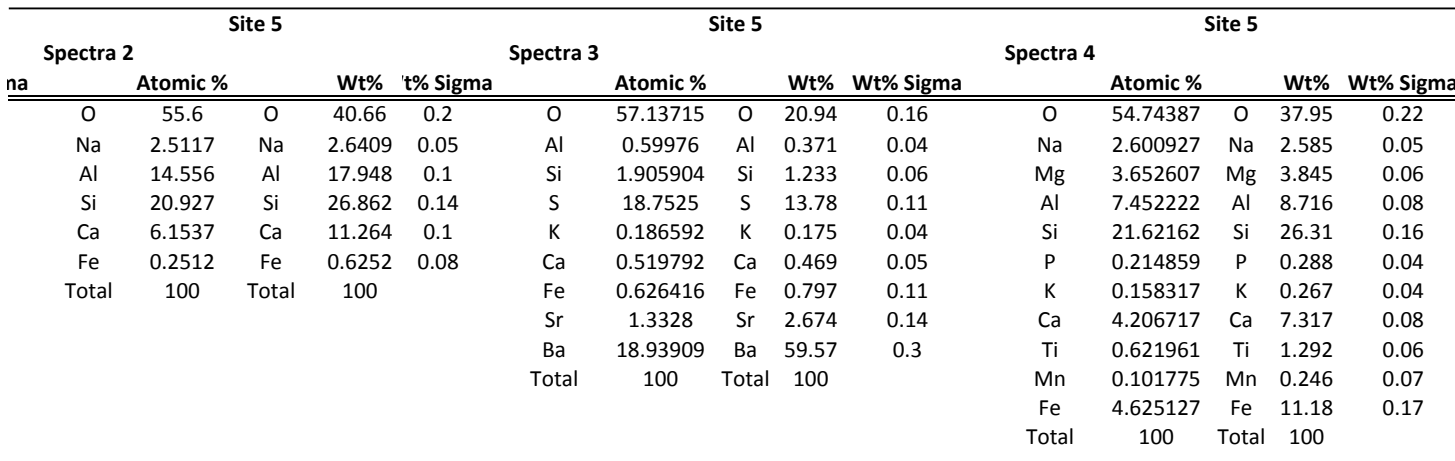

\begin{tabular}{|c|c|c|c|c|c|c|c|c|c|c|c|c|c|c|}
\hline \multicolumn{5}{|c|}{ Site 6} & \multicolumn{5}{|c|}{ Site 6} & \multicolumn{5}{|c|}{ Site 6} \\
\hline Spectra 1 & & & & & Spectra & & & & & Spectra & & & & \\
\hline 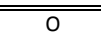 & 58.12045 & "O & 42.51 & 0.24 & "O & 52.68215 & $\bar{O} \mathrm{O}$ & 35.48 & 0.19 & "O & 53.40421 & $\bar{O} \mathrm{O}$ & 35.77 & 0.21 \\
\hline $\mathrm{Mg}$ & 1.398682 & $\mathrm{Mg}$ & 1.552 & 0.04 & $\mathrm{Mg}$ & 9.241679 & $\mathrm{Mg}$ & 9.459 & 0.08 & $\mathrm{Mg}$ & 8.052477 & $\mathrm{Mg}$ & 8.197 & 0.07 \\
\hline $\mathrm{Al}$ & 7.085886 & $\mathrm{Al}$ & 8.74 & 0.08 & $\mathrm{Al}$ & 2.024477 & $\mathrm{Al}$ & 2.306 & 0.05 & $\mathrm{Al}$ & 2.838724 & $\mathrm{Al}$ & 3.209 & 0.05 \\
\hline $\mathrm{Si}$ & 25.06069 & $\mathrm{Si}$ & 32.18 & 0.18 & $\mathrm{Si}$ & 22.0748 & $\mathrm{Si}$ & 26.09 & 0.13 & $\mathrm{Si}$ & 20.71929 & $\mathrm{Si}$ & 24.36 & 0.14 \\
\hline $\mathrm{Ca}$ & 1.826378 & $\mathrm{Ca}$ & 3.355 & 0.07 & $\mathrm{Mn}$ & 0.183004 & $\mathrm{Mn}$ & 0.418 & 0.08 & $\mathrm{Ti}$ & 0.904773 & $\mathrm{Ti}$ & 1.812 & 0.07 \\
\hline $\mathrm{Ti}$ & 0.624205 & $\mathrm{Ti}$ & 1.368 & 0.06 & $\mathrm{Fe}$ & 4.66659 & $\mathrm{Fe}$ & 10.96 & 0.16 & $\mathrm{Fe}$ & 5.044108 & $\mathrm{Fe}$ & 11.78 & 0.17 \\
\hline $\mathrm{Fe}$ & 1.525835 & $\mathrm{Fe}$ & 3.898 & 0.12 & Total & 100 & Total & 100 & & Total & 100 & Total & 100 & \\
\hline
\end{tabular}




\begin{tabular}{|c|c|c|c|c|c|c|c|c|c|c|c|c|c|c|}
\hline \multicolumn{5}{|c|}{ Site 6} & \multicolumn{5}{|c|}{ Site 6} & \multicolumn{5}{|c|}{ Site 7} \\
\hline \multirow[t]{2}{*}{ Spectra 4} & & & & & Spectra & & & & & Spectra 1 & & & & \\
\hline & Atomic \% & & Wt\% & Wt\% Sigma & & Atomic \% & & $\mathbf{W t} \%$ & Wt\% Sigma & & Atomic \% & & $\mathbf{W t} \%$ & Wt\% Sigma \\
\hline 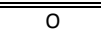 & $\begin{array}{l}57.08174 \\
\end{array}$ & 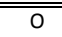 & 40.39 & 0.23 & 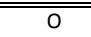 & 54.0707 & 0 & 26.28 & 0.15 & 0 & 40.93797 & 0 & 31.54 & 0.21 \\
\hline $\mathrm{Na}$ & 1.891466 & $\mathrm{Na}$ & 1.92 & 0.05 & $\mathrm{Mg}$ & 0.729761 & $\mathrm{Mg}$ & 0.536 & 0.04 & $\mathrm{~F}$ & 5.582497 & $\mathrm{~F}$ & 4.179 & 0.13 \\
\hline $\mathrm{Mg}$ & 1.441117 & $\mathrm{Mg}$ & 1.557 & 0.04 & $\mathrm{Al}$ & 1.881414 & $\mathrm{Al}$ & 1.545 & 0.04 & $\mathrm{Si}$ & 0.383444 & $\mathrm{Si}$ & 0.424 & 0.03 \\
\hline $\mathrm{Al}$ & 6.766494 & $\mathrm{Al}$ & 8.075 & 0.08 & $\mathrm{Si}$ & 0.216648 & $\mathrm{Si}$ & 0.189 & 0.03 & $\mathrm{P}$ & 16.49938 & $P$ & 20.18 & 0.12 \\
\hline $\mathrm{Si}$ & 24.0599 & $\mathrm{Si}$ & 29.9 & 0.17 & $\mathrm{Ti}$ & 6.72748 & $\mathrm{Ti}$ & 9.787 & 0.1 & $\mathrm{Ca}$ & 27.59671 & $\mathrm{Ca}$ & 43.67 & 0.19 \\
\hline $\mathrm{K}$ & 2.251745 & $\mathrm{~K}$ & 3.893 & 0.06 & v & 0.216648 & v & 0.336 & 0.07 & Total & 100 & Total & 100 & \\
\hline $\mathrm{Ca}$ & 2.364332 & $\mathrm{Ca}$ & 4.203 & 0.07 & $\mathrm{Cr}$ & 0.125428 & $\mathrm{Cr}$ & 0.2 & 0.06 & & & & & \\
\hline $\mathrm{Ti}$ & 0.562936 & $\mathrm{Ti}$ & 1.205 & 0.06 & $\mathrm{Mn}$ & 0.159635 & $\mathrm{Mn}$ & 0.273 & 0.08 & & & & & \\
\hline $\mathrm{Mn}$ & 0.112587 & $\mathrm{Mn}$ & 0.277 & 0.07 & $\mathrm{Fe}$ & 35.87229 & $\mathrm{Fe}$ & 60.85 & 0.22 & & & & & \\
\hline $\mathrm{Fe}$ & 3.467687 & $\mathrm{Fe}$ & 8.576 & 0.15 & Total & 100 & Total & 100 & & & & & & \\
\hline Total & 100 & Total & 100 & & & & & & & & & & & \\
\hline
\end{tabular}

\begin{tabular}{|c|c|c|c|c|c|c|c|c|c|c|c|c|c|c|}
\hline \multicolumn{5}{|c|}{ Site 7} & \multicolumn{5}{|c|}{ Site 7} & \multicolumn{5}{|c|}{ Site 7} \\
\hline \multirow{2}{*}{ Spectra 2} & \multirow{2}{*}{\multicolumn{2}{|c|}{ Atomic \% }} & \multirow[b]{2}{*}{ Wt\% } & \multirow[b]{2}{*}{ Wt\% Sigma } & \multirow[t]{2}{*}{ Spectra 3} & \multirow{2}{*}{\multicolumn{3}{|c|}{ Atomic \% }} & \multirow[b]{2}{*}{ Wt\% Sigma } & \multirow[t]{2}{*}{ Spectra 4} & \multirow[b]{2}{*}{ Atomic \% } & \multirow{2}{*}{\multicolumn{2}{|c|}{ Wt\% }} & \multirow[b]{2}{*}{ Wt\% Sigma } \\
\hline & & & & & & & & & & & & & & \\
\hline 0 & 54.3 & 0 & 40.48 & 0.16 & 0 & 50.16356 & 0 & 31.46 & 0.22 & 0 & 67.90777 & 0 & "53.11 & 0.26 \\
\hline $\mathrm{Na}$ & 5.93 & $\mathrm{Na}$ & 6.35 & 0.07 & $\mathrm{~F}$ & 5.267908 & $\mathrm{~F}$ & 3.922 & 0.16 & $\mathrm{Na}$ & 1.339773 & $\mathrm{Na}$ & 1.514 & 0.04 \\
\hline $\mathrm{Al}$ & 10.94 & $\mathrm{Al}$ & 13.76 & 0.09 & $\mathrm{Si}$ & 0.541455 & $\mathrm{Si}$ & 0.604 & 0.03 & $\mathrm{Mg}$ & 0.342733 & $\mathrm{Mg}$ & 0.412 & 0.02 \\
\hline $\mathrm{Si}$ & 26 & $\mathrm{Si}$ & 34.03 & 0.14 & $\mathrm{P}$ & 16.28878 & $\mathrm{P}$ & 19.78 & 0.12 & $\mathrm{Al}$ & 6.496339 & $\mathrm{Al}$ & 8.563 & 0.06 \\
\hline $\mathrm{K}$ & 0.76 & $\mathrm{~K}$ & 1.39 & 0.05 & $\mathrm{Ca}$ & 27.58037 & $\mathrm{Ca}$ & 43.33 & 0.2 & $\mathrm{Si}$ & 20.40816 & $\mathrm{Si}$ & 28.01 & 0.15 \\
\hline $\mathrm{Ca}$ & 1.91 & $\mathrm{Ca}$ & 3.57 & 0.07 & $\mathrm{Ce}$ & 0.157924 & $\mathrm{Ce}$ & 0.901 & 0.14 & K & 0.732201 & $\mathrm{~K}$ & 1.407 & 0.04 \\
\hline $\mathrm{Fe}$ & 0.16 & $\mathrm{Fe}$ & 0.41 & 0.09 & Total & 100 & Total & 100 & & $\mathrm{Ca}$ & 0.685465 & $\mathrm{Ca}$ & 1.341 & 0.04 \\
\hline \multirow[t]{3}{*}{ Total } & 100 & Total & 100 & & & & & & & $\mathrm{Ti}$ & 0.12463 & $\mathrm{Ti}$ & 0.292 & 0.04 \\
\hline & & & & & & & & & & $\mathrm{Fe}$ & 1.962923 & $\mathrm{Fe}$ & 5.351 & 0.11 \\
\hline & & & & & & & & & & Total & 100 & Total & 100 & \\
\hline
\end{tabular}

\begin{tabular}{|c|c|c|c|c|c|c|c|c|c|c|c|c|c|c|}
\hline \multicolumn{5}{|c|}{ Site 8} & \multicolumn{5}{|c|}{ Site 8} & \multicolumn{5}{|c|}{ Site 8} \\
\hline Spectra 1 & & & & & Spectra 2 & & & & & Spectra 3 & & & & \\
\hline 0 & "47.40671 & 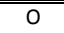 & 33.92 & 0.22 & 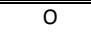 & "50.68904 & 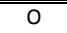 & 37.35 & 0.23 & 0 & 50.12967 & 0 & 36.69 & 0.22 \\
\hline $\mathrm{Mg}$ & 13.00164 & $\mathrm{Mg}$ & 14.15 & 0.11 & $\mathrm{Mg}$ & 11.76753 & $\mathrm{Mg}$ & 13.18 & 0.1 & $\mathrm{Mg}$ & 12.87604 & $\mathrm{Mg}$ & 14.33 & 0.1 \\
\hline $\mathrm{Al}$ & 6.395212 & $\mathrm{Al}$ & 7.718 & 0.08 & $\mathrm{Al}$ & 6.482924 & $\mathrm{Al}$ & 8.055 & 0.08 & $\mathrm{Al}$ & 6.2889 & $\mathrm{Al}$ & 7.768 & 0.07 \\
\hline $\mathrm{Si}$ & 21.68505 & $\mathrm{Si}$ & 27.24 & 0.17 & $\mathrm{Si}$ & 20.75494 & $\mathrm{Si}$ & 26.84 & 0.16 & $\mathrm{Si}$ & 19.38537 & $\mathrm{Si}$ & 24.91 & 0.15 \\
\hline $\mathrm{Ca}$ & 1.091293 & $\mathrm{Ca}$ & 1.968 & 0.06 & $\mathrm{Ca}$ & 0.874775 & $\mathrm{Ca}$ & 1.62 & 0.05 & $\mathrm{Mn}$ & 0.103734 & $\mathrm{Mn}$ & 0.267 & 0.07 \\
\hline $\mathrm{Mn}$ & 0.129078 & $\mathrm{Mn}$ & 0.306 & 0.08 & $\mathrm{Fe}$ & 1.461953 & $\mathrm{Fe}$ & 3.761 & 0.12 & $\mathrm{Fe}$ & 1.58195 & $\mathrm{Fe}$ & 4.035 & 0.11 \\
\hline $\mathrm{Fe}$ & 1.983103 & $\mathrm{Fe}$ & 4.952 & 0.13 & Total & 100 & Total & 100 & & Total & 100 & Total & 100 & \\
\hline Total & 100 & Total & 100 & & & & & & & & & & & \\
\hline
\end{tabular}

\begin{tabular}{|c|c|c|c|c|c|c|c|c|c|c|c|c|c|c|}
\hline \multicolumn{5}{|c|}{ Site 8} & \multicolumn{5}{|c|}{ Site 8} & \multicolumn{5}{|c|}{ Site 9} \\
\hline \multirow[t]{2}{*}{ Spectra 4} & \multirow{2}{*}{\multicolumn{2}{|c|}{ Atomic \% }} & \multirow[b]{2}{*}{ Wt\% } & \multirow[b]{2}{*}{ Wt\% Sigma } & \multirow[t]{2}{*}{ Spectra 5} & \multirow{2}{*}{ Atomic \% } & \multirow{2}{*}{\multicolumn{2}{|c|}{$\mathbf{W t} \%$}} & \multirow[b]{2}{*}{ Wt\% Sigma } & \multirow[t]{2}{*}{ Spectra 1} & \multirow{2}{*}{ Atomic \% } & \multirow{2}{*}{\multicolumn{2}{|c|}{ Wt\% }} & \multirow[b]{2}{*}{ Wt\% Sigma } \\
\hline & & & & & & & & & & & & & & \\
\hline 0 & 51.65813 & 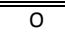 & 31.3 & 0.19 & 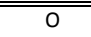 & 51.25342 & 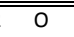 & 23.3 & 0.13 & 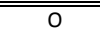 & 55.67435 & 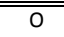 & 401.79 & 0.25 \\
\hline $\mathrm{Mg}$ & 5.014829 & $\mathrm{Mg}$ & 4.622 & 0.06 & Al & 0.307657 & $\mathrm{Al}$ & 0.23 & 0.04 & $\mathrm{Na}$ & 6.058581 & $\mathrm{Na}$ & 6.544 & 0.07 \\
\hline $\mathrm{Al}$ & 4.691291 & $\mathrm{Al}$ & 4.785 & 0.06 & $\mathrm{Si}$ & 0.524157 & $\mathrm{Si}$ & 0.419 & 0.04 & $\mathrm{Al}$ & 9.388573 & $\mathrm{Al}$ & 11.87 & 0.1 \\
\hline $\mathrm{Si}$ & 19.89755 & $\mathrm{Si}$ & 21.17 & 0.13 & $\mathrm{Fe}$ & 47.91477 & $\mathrm{Fe}$ & 76.05 & 0.19 & $\mathrm{Si}$ & 26.65107 & $\mathrm{Si}$ & 35.1 & 0.21 \\
\hline $\mathrm{Cl}$ & 0.202211 & $\mathrm{Cl}$ & 0.266 & 0.03 & Total & 100 & Total & 100 & & $\mathrm{~K}$ & 1.570331 & $\mathrm{~K}$ & 2.873 & 0.06 \\
\hline $\mathrm{K}$ & 1.482879 & $\mathrm{~K}$ & 2.19 & 0.05 & & & & & & $\mathrm{Ca}$ & 0.534581 & $\mathrm{Ca}$ & 1 & 0.05 \\
\hline $\mathrm{Ca}$ & 0.606633 & $\mathrm{Ca}$ & 0.915 & 0.04 & & & & & & $\mathrm{Ba}$ & 0.122508 & $\mathrm{Ba}$ & 0.819 & 0.13 \\
\hline $\mathrm{Ti}$ & 0.121327 & $\mathrm{Ti}$ & 0.232 & 0.05 & & & & & & Total & 100 & Total & 100 & \\
\hline $\mathrm{Mn}$ & 0.18873 & $\mathrm{Mn}$ & 0.382 & 0.07 & & & & & & & & & & \\
\hline $\mathrm{Fe}$ & 16.13642 & $\mathrm{Fe}$ & 34.14 & 0.23 & & & & & & & & & & \\
\hline \multirow[t]{2}{*}{ Total } & 100 & Total & 100 & & & & & & & & & & & \\
\hline & \multirow{2}{*}{\multicolumn{3}{|c|}{ Site 9}} & & \multicolumn{5}{|c|}{ Site 9} & \multicolumn{5}{|c|}{ Site 10} \\
\hline \multirow[t]{2}{*}{ Spectra 2} & & & & & Spectra 3 & & & & & Spectra 1 & & & & \\
\hline & Atomic \% & & $\mathrm{Wt} \%$ & Wt\% Sigma & & Atomic \% & & $\mathbf{W t} \%$ & Wt\% Sigma & & Atomic \% & & Wt\% & Wt\% Sigma \\
\hline $\bar{O}$ & 52.5867 & 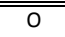 & 24.59 & 0.13 & $\bar{O}$ & 53.8874 & $\bar{O}$ & 25.55 & 0.15 & 0 & 58.49 & 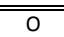 & 43.74 & 0.17 \\
\hline $\mathrm{Al}$ & 0.625355 & Al & 0.494 & 0.03 & $\mathrm{Si}$ & 0.163189 & $\mathrm{Si}$ & 0.138 & 0.03 & $\mathrm{Na}$ & 1.16 & $\mathrm{Na}$ & 1.25 & 0.05 \\
\hline $\mathrm{Si}$ & 1.691302 & $\mathrm{Si}$ & 1.389 & 0.04 & $\mathrm{Ti}$ & 7.250262 & $\mathrm{Ti}$ & 10.28 & 0.1 & $\mathrm{Al}$ & 6.22 & $\mathrm{Al}$ & 7.85 & 0.07 \\
\hline $\mathrm{Ca}$ & 0.142126 & $\mathrm{Ca}$ & 0.172 & 0.03 & $\mathrm{Mn}$ & 0.594475 & $\mathrm{Mn}$ & 0.964 & 0.08 & $\mathrm{Si}$ & 30.09 & $\mathrm{Si}$ & 39.51 & 0.15 \\
\hline $\mathrm{Mn}$ & 0.241615 & $\mathrm{Mn}$ & 0.379 & 0.07 & $\mathrm{Fe}$ & 38.10467 & $\mathrm{Fe}$ & 63.07 & 0.21 & $\mathrm{~K}$ & 3.67 & $\mathrm{~K}$ & 6.71 & 0.08 \\
\hline $\mathrm{Fe}$ & 44.71291 & $\mathrm{Fe}$ & 72.98 & 0.21 & Total & 100 & Total & 100 & & $\mathrm{Mn}$ & 0.1 & $\mathrm{Mn}$ & 0.27 & 0.08 \\
\hline \multirow[t]{2}{*}{ Total } & 100 & Total & 100 & & & & & & & $\mathrm{Fe}$ & 0.26 & $\mathrm{Fe}$ & 0.67 & 0.1 \\
\hline & & & & & & & & & & Total & 100 & Total & 100 & \\
\hline
\end{tabular}




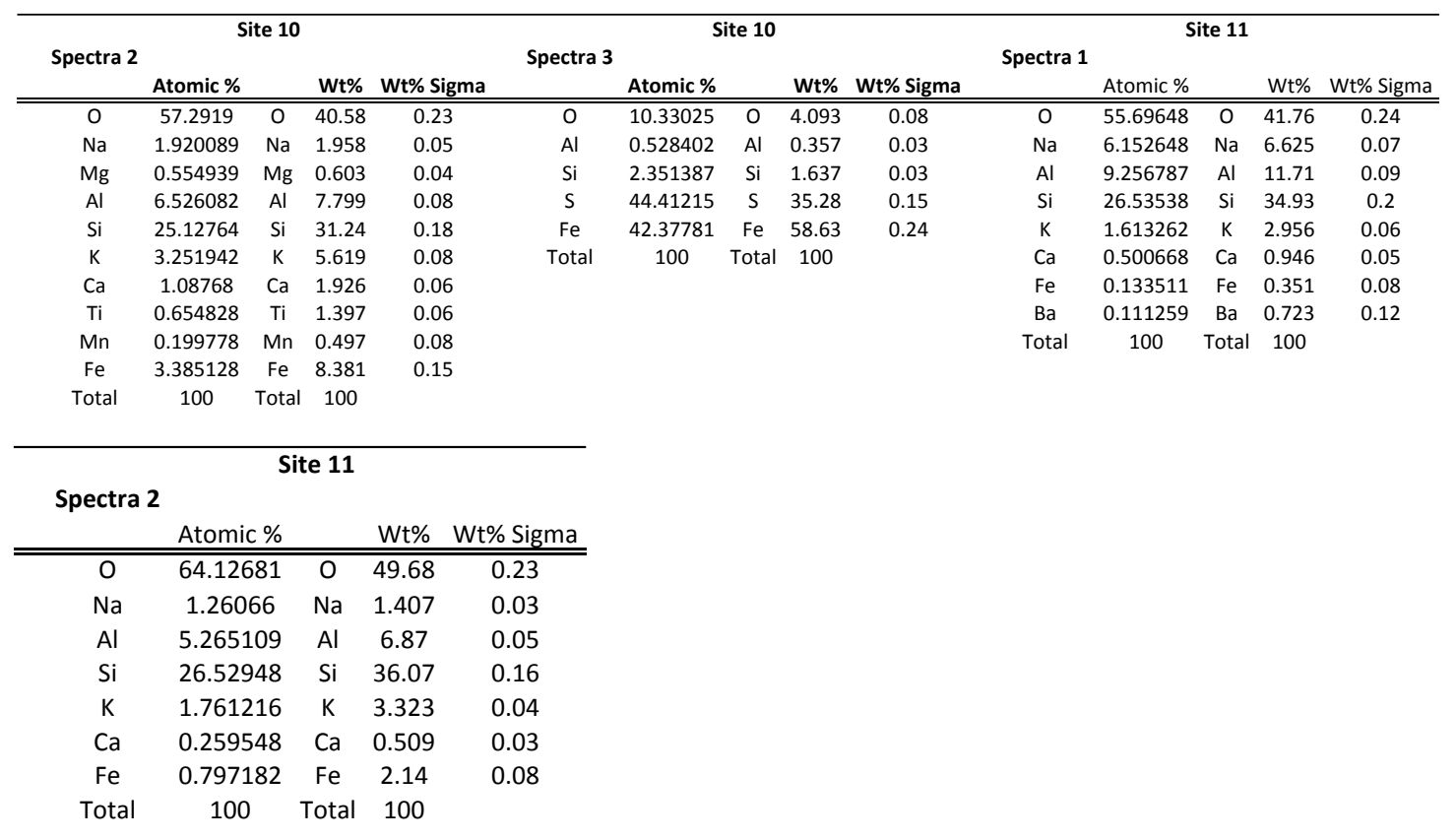

H6. MS-13-07

\begin{tabular}{|c|c|c|c|c|c|c|c|c|c|c|c|c|c|c|}
\hline \multicolumn{5}{|c|}{$\begin{array}{cc}\text { Site } 1 \\
\end{array}$} & \multicolumn{5}{|c|}{$\begin{array}{l}\text { Site } 1 \\
\end{array}$} & \multicolumn{5}{|c|}{ Site 1} \\
\hline Spectrum $1 \mathrm{~A}$ & Atomic \% S & Spectrum 1 & Wt\% W & Wt\% Sigma & Spectrum 2 & Atomic \% & Spectrum 2 & Wt\% & Wt\% Sigma & Spectrum 3 & Atomic \% & Spectrum 3 & $\mathbf{W t} \%$ & Wt\% Sigma \\
\hline 0 & 61.9 & 0 & 9.19 & 0.06 & 0 & 62.43 & 0 & 9.43 & 0.06 & 0 & 63.06 & 0 & 9.96 & 0.06 \\
\hline $\mathrm{Mg}$ & 1.61 & $\mathrm{Mg}$ & 0.36 & 0.01 & $\mathrm{Mg}$ & 1.6 & $\mathrm{Mg}$ & 0.37 & 0.01 & $\mathrm{Mg}$ & 1.58 & $\mathrm{Mg}$ & 0.38 & 0.01 \\
\hline Al & 4.45 & Al & 1.11 & 0.02 & Al & 4.24 & Al & 1.08 & 0.02 & $\mathrm{Al}$ & 4.4 & $\mathrm{Al}$ & 1.17 & 0.02 \\
\hline $\mathrm{Si}$ & 25.39 & $\mathrm{Si}$ & 6.62 & 0.04 & Si & 24.76 & $\mathrm{Si}$ & 6.56 & 0.04 & $\mathrm{Si}$ & 24.31 & Si & 6.74 & 0.04 \\
\hline $\mathrm{K}$ & 0.27 & $\mathrm{~K}$ & 0.1 & 0.01 & $\mathrm{~K}$ & 0.3 & $\mathrm{~K}$ & 0.11 & 0.01 & $\mathrm{~K}$ & 0.29 & $\mathrm{~K}$ & 0.11 & 0.01 \\
\hline $\mathrm{Ca}$ & 1.03 & $\mathrm{Ca}$ & 0.38 & 0.02 & $\mathrm{Ca}$ & 1.21 & $\mathrm{Ca}$ & 0.46 & 0.02 & $\mathrm{Ca}$ & 1.06 & $\mathrm{Ca}$ & 0.42 & 0.02 \\
\hline $\mathrm{Ti}$ & 0.17 & $\mathrm{Ti}$ & 0.08 & 0.02 & $\mathrm{Ti}$ & 0.21 & $\mathrm{Ti}$ & 0.1 & 0.02 & $\mathrm{Ti}$ & 0.16 & $\mathrm{Ti}$ & 0.08 & 0.02 \\
\hline $\mathrm{Fe}$ & 5.18 & $\mathrm{Fe}$ & 2.69 & 0.05 & $\mathrm{Fe}$ & 5.25 & $\mathrm{Fe}$ & 2.77 & 0.06 & $\mathrm{Fe}$ & 5.14 & $\mathrm{Fe}$ & 2.83 & 0.06 \\
\hline Total & 100 & Total & 20.53 & & Total & 100 & Total & 20.86 & & Total & 100 & Total & 21.69 & \\
\hline \multicolumn{5}{|c|}{ Site 1} & \multicolumn{5}{|c|}{ Site 2} & \multicolumn{5}{|c|}{ Site 2} \\
\hline Spectrum & 4 Atomic $\%$ & \% Spectrum 4 & $4 \mathrm{Wt} \%$ & $\%$ Wt\% Sigma & Spectrum & 5 Atomic \% & Spectrum 5 & $5 \mathrm{Wt} \%$ & Wt\% Sigma & Spectrum 6 & 6 Atomic \% & \% Spectrum 6 & $6 \mathrm{Wt} \%$ & Wt $\%$ Sigma \\
\hline $\begin{array}{ll}0 \\
\end{array}$ & $\begin{array}{l}57.23 \\
\end{array}$ & 0 & 9.56 & $\begin{array}{ll}6 & 0.07\end{array}$ & 0 & $\begin{array}{l}57.81 \\
\end{array}$ & 0 & 10.18 & $\begin{array}{ll}8 & 0.07 \\
\end{array}$ & 0 & $\begin{array}{l}59.92 \\
\end{array}$ & 0 & 10.58 & \begin{tabular}{|l|l|}
3 & 0.07 \\
\end{tabular} \\
\hline $\mathrm{Na}$ & 5.53 & $\mathrm{Na}$ & 1.33 & 0.02 & $\mathrm{Na}$ & 6.52 & $\mathrm{Na}$ & 1.65 & 0.02 & $\mathrm{Na}$ & 4.68 & $\mathrm{Na}$ & 1.19 & 0.02 \\
\hline $\mathrm{Mg}$ & 0.67 & $\mathrm{Mg}$ & 0.17 & 0.01 & $\mathrm{Al}$ & 8.8 & $\mathrm{Al}$ & 2.61 & 0.03 & $\mathrm{Al}$ & 5.42 & $\mathrm{Al}$ & 1.61 & 0.02 \\
\hline $\mathrm{Al}$ & 7.24 & $\mathrm{Al}$ & 2.04 & 0.02 & $\mathrm{Si}$ & 25.17 & $\mathrm{Si}$ & 7.78 & 0.04 & $\mathrm{Si}$ & 26.89 & $\mathrm{Si}$ & 8.33 & 0.04 \\
\hline $\mathrm{Si}$ & 23.3 & $\mathrm{Si}$ & 6.83 & 0.04 & K & 1.29 & $\mathrm{~K}$ & 0.55 & 0.02 & $\mathrm{~K}$ & 0.59 & K & 0.25 & 0.01 \\
\hline P & 0.23 & $P$ & 0.07 & 0.01 & $\mathrm{Ca}$ & 0.29 & $\mathrm{Ca}$ & 0.13 & 0.01 & $\mathrm{Ca}$ & 0.68 & $\mathrm{Ca}$ & 0.3 & 0.02 \\
\hline $\mathrm{s}$ & 0.86 & $\mathrm{~s}$ & 0.29 & 0.01 & $\mathrm{Ba}$ & 0.11 & $\mathrm{Ba}$ & 0.17 & 0.04 & $\mathrm{Fe}$ & 1.82 & $\mathrm{Fe}$ & 1.12 & 0.04 \\
\hline $\mathrm{K}$ & 0.35 & $\mathrm{~K}$ & 0.14 & 0.01 & Total & 100 & Total & 23.07 & & Total & 100 & Total & 23.39 & \\
\hline $\mathrm{Ca}$ & 1.78 & $\mathrm{Ca}$ & 0.75 & 0.02 & & & & & & & & & & \\
\hline $\mathrm{Ti}$ & 0.45 & $\mathrm{Ti}$ & 0.22 & 0.03 & & & & & & & & & & \\
\hline $\mathrm{Fe}$ & 1.64 & $\mathrm{Fe}$ & 0.96 & 0.04 & & & & & & & & & & \\
\hline $\mathrm{Ba}$ & 0.73 & $\mathrm{Ba}$ & 1.05 & 0.06 & & & & & & & & & & \\
\hline Total & 100 & Total & 23.41 & & & & & & & & & & & \\
\hline \multicolumn{5}{|c|}{ Site 2 } & \multicolumn{5}{|c|}{ Site 3} & \multicolumn{5}{|c|}{$\begin{array}{ll}\text { Site } 3 \\
\end{array}$} \\
\hline Spectrum 7 & 7 Atomic \% & $\%$ Spectrum 6 & $6 \mathrm{Wt} \%$ & Wt\% Sigma & Spectrum 8 & 8 Atomic \% & Spectrum 8 & $3 \mathrm{Wt} \%$ & Wt $\%$ Sigma & Spectrum 9 & 9 Atomic \% & \% Spectrum 9 & 9 Wt\% & Wt\% Sigma \\
\hline 0 & 60.44 & 0 & 10.58 & $\begin{array}{ll}8 & 0.07\end{array}$ & 0 & 58.71 & 0 & 10.66 & $\begin{array}{ll}6 & 0.07\end{array}$ & $\mathrm{O}$ & 57.97 & 0 & 10.2 & 0.07 \\
\hline $\mathrm{Na}$ & 5.32 & $\mathrm{Na}$ & 1.19 & 0.02 & $\mathrm{Na}$ & 6.53 & $\mathrm{Na}$ & 1.7 & 0.02 & $\mathrm{Na}$ & 6.53 & $\mathrm{Na}$ & 1.65 & 0.02 \\
\hline Al & 5.58 & Al & 1.61 & 0.02 & $\mathrm{Al}$ & 8.58 & $\mathrm{Al}$ & 2.63 & 0.03 & Al & 8.95 & $\mathrm{Al}$ & 2.65 & 0.03 \\
\hline $\mathrm{Si}$ & 27.78 & $\mathrm{Si}$ & 8.33 & 0.04 & $\mathrm{Si}$ & 24.51 & $\mathrm{Si}$ & 7.81 & 0.04 & $\mathrm{Si}$ & 24.89 & $\mathrm{Si}$ & 7.68 & 0.04 \\
\hline K & 0.51 & K & 0.25 & 0.01 & K & 1.24 & $\mathrm{~K}$ & 0.55 & 0.02 & $\mathrm{~K}$ & 1.25 & $\mathrm{~K}$ & 0.54 & 0.02 \\
\hline $\mathrm{Fe}$ & 0.26 & $\mathrm{Ca}$ & 0.3 & 0.02 & $\mathrm{Ca}$ & 0.3 & $\mathrm{Ca}$ & 0.14 & 0.01 & $\mathrm{Ca}$ & 0.26 & $\mathrm{Ca}$ & 0.11 & 0.01 \\
\hline $\mathrm{Sn}$ & 0.11 & $\mathrm{Fe}$ & 1.12 & 0.04 & $\mathrm{Ba}$ & 0.13 & $\mathrm{Ba}$ & 0.2 & 0.04 & $\mathrm{Ba}$ & 0.15 & $\mathrm{Ba}$ & 0.23 & 0.04 \\
\hline Total & 100 & Total & 23.39 & & Total & 100 & Total & 23.7 & & Total & 100 & Total & 23.07 & \\
\hline
\end{tabular}




\begin{tabular}{|c|c|c|c|c|c|c|c|c|c|c|c|c|c|c|c|}
\hline \multicolumn{5}{|c|}{ Site 3} & \multicolumn{5}{|c|}{$\begin{array}{c}\text { Site } 4 \\
\end{array}$} & \multicolumn{6}{|c|}{ Site 4} \\
\hline Spectrum 10 & Atomic \% & Spectrum 10 & $\mathbf{W t} \% \quad \mathbf{W t} \%$ & Wt\% Sigma & Spectrum $11 \mathrm{~A}$ & Atomic \% & Spectrum 11 & $\mathbf{W t} \%$ & Wt\% Sigma & \multicolumn{2}{|c|}{ Spectrum 12} & Atomic \% & Spectrum 12 & \multirow{2}{*}{$\begin{array}{l}\text { Wt\% } \\
7.14\end{array}$} & \multirow{2}{*}{$\begin{array}{c}\text { Wt\% Sigma } \\
0.07\end{array}$} \\
\hline $\begin{array}{l}0 \\
\end{array}$ & $\begin{array}{l}64.32 \\
\end{array}$ & $\begin{array}{l}0 \\
\end{array}$ & $=9.25 \quad 0$ & " & $\begin{array}{l}0 \\
\end{array}$ & " 59.41 & $\begin{array}{l}0 \\
0\end{array}$ & "8.15 & 0.06 & $\begin{array}{ll}0 \\
\end{array}$ & & " & $\begin{array}{l}0 \\
\end{array}$ & & \\
\hline $\mathrm{Mg}$ & 1.59 & $\mathrm{Mg}$ & 0.35 & 0.01 & $\mathrm{Si}$ & 22.42 & $\mathrm{Si}$ & 5.4 & 0.03 & $\mathrm{Ti}$ & & 18.87 & $\mathrm{Ti}$ & 6.31 & 0.05 \\
\hline $\mathrm{Al}$ & 4.22 & $\mathrm{Al}$ & 1.02 & 0.02 & $\mathrm{Ca}$ & 8.59 & $\mathrm{Ca}$ & 2.95 & 0.03 & $\mathrm{Mn}$ & & 0.7 & $\mathrm{Mn}$ & 0.27 & 0.02 \\
\hline $\mathrm{Si}$ & 23.78 & $\mathrm{Si}$ & 6 & 0.03 & $\mathrm{Ti}$ & 0.11 & $\mathrm{Ti}$ & 0.05 & 0.02 & $\mathrm{Fe}$ & & 16.57 & $\mathrm{Fe}$ & 6.46 & 0.07 \\
\hline $\mathrm{K}$ & 0.28 & K & 0.1 & 0.01 & $\mathrm{Mn}$ & 0.47 & $\mathrm{Mn}$ & 0.22 & 0.03 & Total & & 100 & Total & 20.18 & \\
\hline $\mathrm{Ca}$ & 1.13 & $\mathrm{Ca}$ & 0.41 & 0.02 & $\mathrm{Fe}$ & 9 & $\mathrm{Fe}$ & 4.31 & 0.06 & & & & & & \\
\hline $\mathrm{Ti}$ & 0.17 & $\mathrm{Ti}$ & 0.07 & 0.01 & Total & 100 & Total & 21.07 & & & & & & & \\
\hline $\mathrm{Fe}$ & 4.52 & $\mathrm{Fe}$ & 2.27 & 0.05 & & & & & & & & & & & \\
\hline Total & 100 & Total & 19.47 & & & & & & & & & & & & \\
\hline & & Site 4 & & & & & Site 6 & & & & & & Site 6 & & \\
\hline Spectrum 13 & Atomic \% & Spectrum 13 & $\mathbf{W t} \% \quad \mathbf{W t} \%$ & t $\mathrm{t} \%$ Sigma & Spectrum $14 \mathrm{~A}$ & Atomic \% & Spectrum 14 & $\mathbf{W t} \%$ & Wt $\%$ Sigma & Spectrur & $\mathrm{m} 15$ At & Atomic \% & Spectrum 15 & $\mathbf{W t} \%$ & Wt\% Sigma \\
\hline 0 & 62.91 & 0 & $8.94 \quad 0$ & 0.06 & 0 & 57.92 & 0 & 10.18 & 0.07 & 0 & & 57.97 & 0 & 10.19 & 0.07 \\
\hline Mg & 1.96 & $\mathrm{Mg}$ & 0.42 & 0.01 & $\mathrm{Na}$ & 6.41 & $\mathrm{Na}$ & 1.62 & 0.02 & $\mathrm{Na}$ & & 6.47 & $\mathrm{Na}$ & 1.63 & 0.02 \\
\hline $\mathrm{Al}$ & 3.33 & $\mathrm{Al}$ & 0.8 & 0.02 & Al & 8.84 & $\mathrm{Al}$ & 2.62 & 0.02 & $\mathrm{Al}$ & & 8.94 & $\mathrm{Al}$ & 2.65 & 0.03 \\
\hline $\mathrm{Si}$ & 23.91 & $\mathrm{Si}$ & 5.97 & 0.03 & $\mathrm{Si}$ & 25.07 & $\mathrm{Si}$ & 7.74 & 0.04 & $\mathrm{Si}$ & & 24.79 & $\mathrm{Si}$ & 7.65 & 0.04 \\
\hline K & 0.29 & $\mathrm{~K}$ & 0.1 & 0.01 & K & 1.39 & $\mathrm{~K}$ & 0.6 & 0.02 & $\mathrm{~K}$ & & 1.43 & $\mathrm{~K}$ & 0.61 & 0.02 \\
\hline $\mathrm{Ca}$ & 1.32 & $\mathrm{Ca}$ & 0.47 & 0.02 & $\mathrm{Ca}$ & 0.23 & $\mathrm{Ca}$ & 0.1 & 0.01 & $\mathrm{Ba}$ & & 0.2 & $\mathrm{Ba}$ & 0.3 & 0.04 \\
\hline $\mathrm{Ti}$ & 0.43 & $\mathrm{Ti}$ & 0.18 & 0.02 & $\mathrm{Ba}$ & 0.15 & $\mathrm{Ba}$ & 0.22 & 0.04 & $\mathrm{Ca}$ & & 0.21 & $\mathrm{Ca}$ & 0.09 & 0.01 \\
\hline $\mathrm{Fe}$ & 5.86 & $\mathrm{Fe}$ & 2.91 & 0.06 & Total & 100 & Total & 23.08 & & Tota & & 100 & Total & 23.12 & \\
\hline Total & 100 & Total & 19.79 & & & & & & & & & & & & \\
\hline & & Site 7 & & & & & Site 7 & & & & & & Site 7 & & \\
\hline Spectrum 16 & Atomic \% & Spectrum 16 & $\mathbf{W t} \% \quad \mathbf{W t} \%$ & Vt\% Sigma & Spectrum $17 \mathrm{~A}$ & Atomic \% & Spectrum 17 & $\mathbf{W t} \%$ & Wt\% Sigma & Spectrun & n 18 At & Atomic \% & Spectrum 18 & $\mathrm{Wt} \% \mathrm{~V}$ & Wt\% Sigma \\
\hline $\begin{array}{ll}0 \\
\end{array}$ & $\begin{array}{l}57.77 \\
\end{array}$ & $\begin{array}{ll}0 \\
\end{array}$ & 9.93 & $\begin{array}{l}0.07 \\
\end{array}$ & $\begin{array}{l}0 \\
\end{array}$ & $\begin{array}{l}61.66 \\
\end{array}$ & $\begin{array}{l}0 \\
\end{array}$ & "10.65 & 0.07 & $\begin{array}{ll}0 \\
\end{array}$ & & (57.86 & 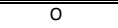 & $\begin{array}{l}9.91 \\
\end{array}$ & 0.07 \\
\hline $\mathrm{Na}$ & 6.54 & $\mathrm{Na}$ & 1.62 & 0.02 & $\mathrm{Na}$ & 2.02 & $\mathrm{Na}$ & 0.5 & 0.02 & $\mathrm{Na}$ & & 6.52 & $\mathrm{Na}$ & 1.6 & 0.02 \\
\hline $\mathrm{Al}$ & 9.01 & $\mathrm{Al}$ & 2.61 & 0.02 & $\mathrm{Al}$ & 5.35 & $\mathrm{Al}$ & 1.56 & 0.02 & $\mathrm{Al}$ & & 9.03 & $\mathrm{Al}$ & 2.61 & 0.03 \\
\hline $\mathrm{Si}$ & 25.09 & $\mathrm{Si}$ & 7.57 & 0.04 & $\mathrm{Si}$ & 27.39 & $\mathrm{Si}$ & 8.3 & 0.04 & $\mathrm{Si}$ & & 24.86 & $\mathrm{Si}$ & 7.48 & 0.04 \\
\hline $\mathrm{K}$ & 1.13 & $\mathrm{~K}$ & 0.47 & 0.02 & $\mathrm{~K}$ & 2.84 & $\mathrm{~K}$ & 1.2 & 0.02 & $\mathrm{~K}$ & & 1.24 & $\mathrm{~K}$ & 0.52 & 0.02 \\
\hline $\mathrm{Ca}$ & 0.31 & $\mathrm{Ca}$ & 0.13 & 0.01 & $\mathrm{Fe}$ & 0.51 & $\mathrm{Fe}$ & 0.31 & 0.03 & $\mathrm{Ca}$ & & 0.3 & $\mathrm{Ca}$ & 0.13 & 0.01 \\
\hline $\mathrm{Ba}$ & 0.15 & Ba & 0.23 & 0.04 & $\mathrm{Ca}$ & 0.24 & $\mathrm{Ca}$ & 0.1 & 0.01 & $\mathrm{Ba}$ & & 0.18 & $\mathrm{Ba}$ & 0.27 & 0.04 \\
\hline Total & 100 & Total & 22.56 & & Total & 100 & Total & 22.62 & & Total & & 100 & Total & 22.52 & \\
\hline & & Site 8 & & & & & Site 8 & & & & & & Site 8 & & \\
\hline Spectrum 19 & Atomic \% & Spectrum 19 & $\mathbf{W t} \% \mathbf{W t} \%$ & Vt\% Sigma & Spectrum $20 \mathrm{~A}$ & Atomic \% & Spectrum 20 & $\mathbf{w}$ t\% & Wt\% Sigma & Spectru & $\mathrm{m} 21 \mathrm{At}$ & Atomic \% & Spectrum 21 & $\mathbf{W t} \%$ & Wt $\%$ Sigma \\
\hline 0 & $\begin{array}{c}58.01 \\
\end{array}$ & 0 & $\begin{array}{lll}9.55 & 0\end{array}$ & 0.06 & 0 & 57.93 & 0 & $\begin{array}{c}9.08 \\
\end{array}$ & 0.06 & 0 & & 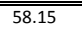 & $\begin{array}{l}0 \\
\end{array}$ & 10.09 & 0.07 \\
\hline $\mathrm{Na}$ & 6.5 & $\mathrm{Na}$ & 1.54 & 0.02 & $\mathrm{Na}$ & 6.49 & $\mathrm{Na}$ & 1.46 & 0.02 & $\mathrm{Na}$ & & 6.49 & $\mathrm{Na}$ & 1.62 & 0.02 \\
\hline $\mathrm{Al}$ & 8.84 & $\mathrm{Al}$ & 2.45 & 0.02 & $\mathrm{Al}$ & 9.01 & Al & 2.38 & 0.02 & Al & & 8.97 & $\mathrm{Al}$ & 2.62 & 0.03 \\
\hline $\mathrm{Si}$ & 24.93 & $\mathrm{Si}$ & 7.2 & 0.04 & $\mathrm{Si}$ & 24.91 & $\mathrm{Si}$ & 6.86 & 0.04 & $\mathrm{Si}$ & & 24.79 & $\mathrm{Si}$ & 7.55 & 0.04 \\
\hline K & 1.34 & K & 0.54 & 0.02 & K & 1.25 & K & 0.48 & 0.02 & K & & 1.19 & K & 0.51 & 0.02 \\
\hline $\mathrm{Ca}$ & 0.24 & $\mathrm{Ca}$ & 0.1 & 0.01 & $\mathrm{Ca}$ & 0.29 & $\mathrm{Ca}$ & 0.11 & 0.01 & $\mathrm{Ca}$ & & 0.3 & $\mathrm{Ca}$ & 0.13 & 0.01 \\
\hline $\mathrm{Ba}$ & 0.13 & $\mathrm{Ba}$ & 0.18 & 0.04 & $\mathrm{Ba}$ & 0.12 & $\mathrm{Ba}$ & 0.16 & 0.03 & $\mathrm{Ba}$ & & 0.11 & $\mathrm{Ba}$ & 0.16 & 0.04 \\
\hline Total & 100 & Total & 21.56 & & Total & 100 & Total & 20.53 & & Tota & & 100 & Total & 22.69 & \\
\hline & & Site 9 & & & & & Site 10 & & & & & & Site 10 & & \\
\hline Spectrum 22 & Atomic \% & Spectrum 22 & Wt $\% \quad$ Wt $\%$ & $t \%$ Sigma & Spectrum $23 \mathrm{~A}$ & Atomic \% & Spectrum 23 & $\mathbf{W t} \%$ & Wt\% Sigma & Spectrur & m 24 At & Atomic \% & Spectrum 24 & $\mathbf{W t} \%$ & Wt\% Sigma \\
\hline 0 & 58.04 & 0 & $\begin{array}{ll}10.2 \quad 0 \\
\end{array}$ & $\begin{array}{c}0.07 \\
\end{array}$ & 0 & 66.39 & 0 & $\begin{array}{l}7.53 \\
\end{array}$ & 0.07 & 0 & & 263.51 & 0 & 9 & 0.06 \\
\hline $\mathrm{Na}$ & 6.64 & $\mathrm{Na}$ & 1.68 & 0.02 & $\mathrm{Ti}$ & 18.18 & $\mathrm{Ti}$ & 6.17 & 0.04 & $\mathrm{Mg}$ & & 1.52 & $\mathrm{Mg}$ & 0.33 & 0.01 \\
\hline Al & 8.96 & Al & 2.66 & 0.03 & $\mathrm{Fe}$ & 14.67 & $\mathrm{Fe}$ & 5.81 & 0.07 & $\mathrm{Al}$ & & 4.8 & Al & 1.15 & 0.02 \\
\hline $\mathrm{Si}$ & 24.77 & $\mathrm{Si}$ & 7.64 & 0.04 & $\mathrm{Mn}$ & 0.56 & $\mathrm{Mn}$ & 0.22 & 0.02 & $\mathrm{Si}$ & & 24.27 & $\mathrm{Si}$ & 6.04 & 0.03 \\
\hline K & 1.14 & $\mathrm{~K}$ & 0.49 & 0.02 & $\mathrm{Si}$ & 0.19 & $\mathrm{Si}$ & 0.04 & 0.01 & $\mathrm{Ca}$ & & 0.93 & $\mathrm{Ca}$ & 0.33 & 0.01 \\
\hline $\mathrm{Ca}$ & 0.33 & $\mathrm{Ca}$ & 0.14 & 0.01 & Total & 100 & Total & 19.76 & & $\mathrm{Fe}$ & & 4.61 & $\mathrm{Fe}$ & 2.28 & 0.05 \\
\hline $\mathrm{Ba}$ & 0.12 & $\mathrm{Ba}$ & 0.19 & 0.04 & & & & & & K & & 0.24 & $\mathrm{~K}$ & 0.08 & 0.01 \\
\hline Total & 100 & Total & 22.98 & & & & & & & $\mathrm{Ti}$ & & 0.11 & $\mathrm{Ti}$ & 0.05 & 0.01 \\
\hline & & & & & & & & & & Tota & & 100 & Total & 19.26 & \\
\hline & & & e 10 & & & & & & Site & & & & & & \\
\hline Spectrum & n 25 Ato & omic \% Spe & ectrum 25 & Wt\% & Wt\% Sigma & Spe & ectrum 26 & Atom & ic \% Spec & trum 26 & $\mathrm{Wt} \%$ & Wt\% & o Sigma & & \\
\hline 0 & & 51.88 & 0 & 7.94 & 0.05 & & 0 & 58.8 & & 0 & 8.8 & & 0.08 & & \\
\hline $\mathrm{Mg}$ & & 1.78 & $\mathrm{Mg}$ & 0.35 & 0.01 & & $\mathrm{~F}$ & 4.6 & & $\mathrm{~F}$ & 0.83 & & 0.04 & & \\
\hline Al & & 4.53 & $\mathrm{Al}$ & 0.98 & 0.02 & & $P$ & 14.5 & & $P$ & 4.21 & & 0.03 & & \\
\hline $\mathrm{Si}$ & & 25.31 & $\mathrm{Si}$ & 5.7 & 0.03 & & $\mathrm{Ca}$ & 21.4 & & $\mathrm{Ca}$ & 8.03 & & 0.05 & & \\
\hline $\mathrm{Ca}$ & & 1.22 & $\mathrm{Ca}$ & 0.39 & 0.01 & & $\mathrm{Si}$ & 0.3 & & $\mathrm{Si}$ & 0.1 & & 0.01 & & \\
\hline $\mathrm{Fe}$ & & 4.88 & $\mathrm{Fe}$ & 2.19 & 0.05 & & $\mathrm{Fe}$ & 0.1 & & $\mathrm{Fe}$ & 0.08 & & 0.02 & & \\
\hline $\mathrm{K}$ & & 0.24 & $\mathrm{~K}$ & 0.08 & 0.01 & & Total & 10 & & otal & 22.06 & & & & \\
\hline $\mathrm{Ti}$ & & 0.16 & $\mathrm{Ti}$ & 0.06 & 0.01 & & & & & & & & & & \\
\hline Total & & 100 & Total & 17.68 & & & & & & & & & & & \\
\hline
\end{tabular}




\section{H7. MS-14-03}

\begin{tabular}{|c|c|c|c|c|c|c|c|c|c|c|c|}
\hline \multicolumn{4}{|c|}{$\begin{array}{c}\text { Site } 1 \\
\end{array}$} & \multicolumn{4}{|c|}{ Site 2} & \multicolumn{4}{|c|}{ Site 2} \\
\hline Spectrum 1 & Atomic \% Spectrum 1 & Wt\% & Wt\% Sigma & Spectrum 2 & Atomic \% Spectrum 2 & Wt\% & Wt\% Sigma & Spectrum 3 & Atomic \% Spectrum 3 & $\mathbf{W t} \%$ & Wt\% Sigma \\
\hline $\mathrm{Na}$ & $3.532934 \mathrm{Na}$ & 3.7831 & 0.02 & $\mathrm{Na}$ & $5.940942 \mathrm{Na}$ & 6.3864 & 0.02 & $\mathrm{Na}$ & $6.622359 \mathrm{Na}$ & 7.1816 & 0.02 \\
\hline $\mathrm{Mg}$ & $0 \mathrm{Mg}$ & 0 & 0 & $\mathrm{Mg}$ & $0 \mathrm{Mg}$ & 0 & 0 & $\mathrm{Mg}$ & $0.047472 \mathrm{Mg}$ & 0.0418 & 0.01 \\
\hline $\mathrm{Si}$ & $30.56287 \mathrm{Si}$ & 39.933 & 0.04 & $\mathrm{Si}$ & $27.07992 \mathrm{Si}$ & 35.53 & 0.05 & $\mathrm{Si}$ & $25.20769 \mathrm{Si}$ & 33.403 & 0.04 \\
\hline $\mathrm{P}$ & $O P$ & 0 & 0 & $P$ & $O P$ & 0 & 0 & $\mathrm{P}$ & $O P$ & 0 & 0 \\
\hline $\mathrm{s}$ & OS & 0 & 0 & $\mathrm{~s}$ & os & 0 & 0 & $\mathrm{~s}$ & os & 0 & 0 \\
\hline $\mathrm{Cr}$ & $0 \mathrm{Cr}$ & 0 & 0 & $\mathrm{Cr}$ & $0 \mathrm{Cr}$ & 0 & 0 & $\mathrm{Cr}$ & $0 \mathrm{Cr}$ & 0 & 0 \\
\hline $\mathrm{Mn}$ & $0 \mathrm{Mn}$ & 0 & 0 & $\mathrm{Mn}$ & $0 \mathrm{Mn}$ & 0 & 0 & $\mathrm{Mn}$ & $0.047472 \mathrm{Mn}$ & 0.1253 & 0.02 \\
\hline $\mathrm{Fe}$ & $0.91018 \mathrm{Fe}$ & 2.396 & 0.04 & $\mathrm{Fe}$ & $0 \mathrm{Fe}$ & 0 & 0 & $\mathrm{Fe}$ & $0.154284 \mathrm{Fe}$ & 0.4175 & 0.03 \\
\hline $\mathrm{Ni}$ & $0 \mathrm{Ni}$ & 0 & 0 & $\mathrm{Ni}$ & $0 \mathrm{Ni}$ & 0 & 0 & $\mathrm{Ni}$ & $0 \mathrm{Ni}$ & 0 & 0 \\
\hline \multirow[t]{2}{*}{ Total } & 100 Total & 100 & & $\mathrm{Ba}$ & $0.152332 \mathrm{Ba}$ & 1.0105 & 0.05 & $\mathrm{Ba}$ & $0.106812 \mathrm{Ba}$ & 0.6681 & 0.05 \\
\hline & & & & Total & 100 Total & 100 & & Total & 100 Total & 100 & \\
\hline
\end{tabular}

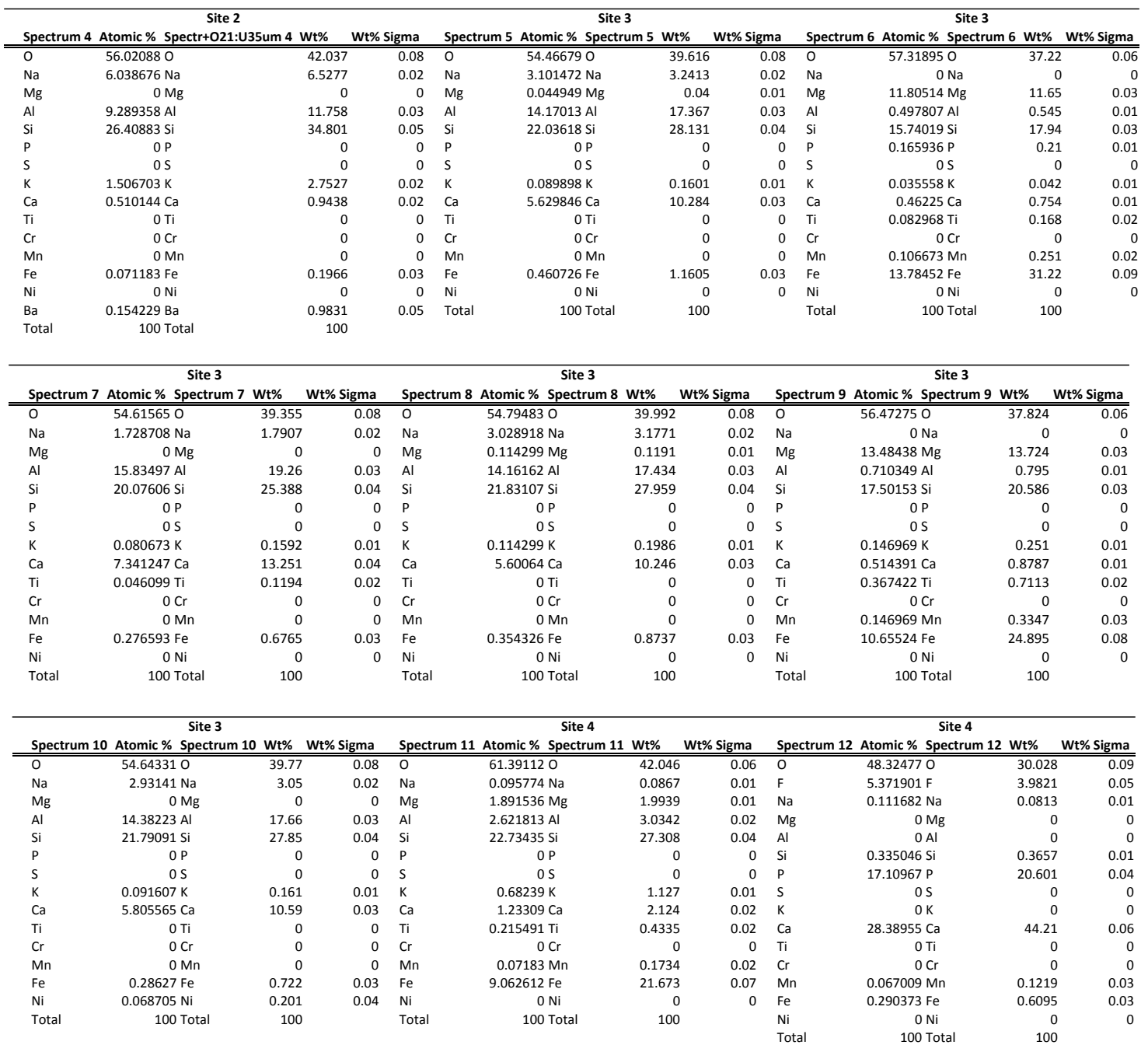




\begin{tabular}{|c|c|c|c|c|c|c|c|c|c|c|c|}
\hline \multicolumn{4}{|c|}{ Site 4} & \multicolumn{4}{|c|}{ Site 5} & \multicolumn{4}{|c|}{ Site 5} \\
\hline Spectrum 13 & Atomic \% Spectrum 13 & Wt\% & Wt\% Sigma & Spectrum 14 & Atomic \% Spectrum 14 & $\mathbf{W t} \%$ & Wt\% Sigma & Spectrum 15 & Atomic \% Spectrum 15 & $\mathbf{W t} \%$ & Wt\% Sigma \\
\hline $\mathrm{Na}$ & $0.485075 \mathrm{Na}$ & 0.4835 & 0.01 & $\mathrm{Na}$ & $5.937968 \mathrm{Na}$ & 6.4045 & 0.02 & $\mathrm{~F}$ & $3.906956 \mathrm{~F}$ & 2.895 & 0.04 \\
\hline $\mathrm{Mg}$ & $1.840796 \mathrm{Mg}$ & 1.8901 & 0.01 & $\mathrm{Mg}$ & $0 \mathrm{Mg}$ & 0 & 0 & $\mathrm{Na}$ & $0.101626 \mathrm{Na}$ & 0.0827 & 0.01 \\
\hline $\mathrm{Si}$ & $26.35572 \mathrm{Si}$ & 31.253 & 0.04 & $\mathrm{Si}$ & $25.38914 \mathrm{Si}$ & 33.563 & 0.04 & $\mathrm{Al}$ & $0.045167 \mathrm{Al}$ & 0.0414 & 0.01 \\
\hline $\mathrm{P}$ & $O P$ & 0 & 0 & $\mathrm{P}$ & $O P$ & 0 & 0 & $\mathrm{Si}$ & $0.395212 \mathrm{Si}$ & 0.4136 & 0.01 \\
\hline $\mathrm{s}$ & os & 0 & 0 & $\mathrm{~s}$ & $0 \mathrm{~s}$ & 0 & 0 & $\mathrm{P}$ & $16.70054 \mathrm{P}$ & 20.223 & 0.04 \\
\hline $\mathrm{K}$ & $0.460199 \mathrm{~K}$ & 0.7473 & 0.01 & $\mathrm{~K}$ & $0.357431 \mathrm{~K}$ & 0.6486 & 0.01 & $\mathrm{~s}$ & $0 \mathrm{~S}$ & 0 & 0 \\
\hline $\mathrm{Cr}$ & $0 \mathrm{Cr}$ & 0 & 0 & $\mathrm{Cr}$ & $0 \mathrm{Cr}$ & 0 & 0 & $\mathrm{Ti}$ & $0 \mathrm{Ti}$ & 0 & 0 \\
\hline $\mathrm{Mn}$ & $0.136816 \mathrm{Mn}$ & 0.3077 & 0.02 & $\mathrm{Mn}$ & $0 \mathrm{Mn}$ & 0 & 0 & $\mathrm{Cr}$ & $0 \mathrm{Cr}$ & 0 & 0 \\
\hline $\mathrm{Fe}$ & $8.221393 \mathrm{Fe}$ & 19.385 & 0.07 & $\mathrm{Fe}$ & $0.06918 \mathrm{Fe}$ & 0.1621 & 0.03 & $\mathrm{Mn}$ & $0.135501 \mathrm{Mn}$ & 0.2895 & 0.03 \\
\hline $\mathrm{Ni}$ & $0 \mathrm{Ni}$ & 0 & 0 & $\mathrm{Ni}$ & $0 \mathrm{Ni}$ & 0 & 0 & $\mathrm{Fe}$ & $0.203252 \mathrm{Fe}$ & 0.4549 & 0.03 \\
\hline \multirow[t]{2}{*}{ Total } & 100 Total & 100 & & Total & 100 Total & 100 & & $\mathrm{Ni}$ & $0 \mathrm{Ni}$ & 0 & 0 \\
\hline & & & & & & & & Total & 100 Total & 100 & \\
\hline
\end{tabular}

\begin{tabular}{|c|c|c|c|c|c|c|c|c|c|c|c|}
\hline \multicolumn{4}{|c|}{ Site 6} & \multicolumn{4}{|c|}{ Site 6} & \multicolumn{4}{|c|}{ Site 7} \\
\hline Spectrum 16 & Atomic \% Spectrum 16 & Wt\% & Wt\% Sigma & Spectrum 17 & Atomic \% Spectrum 17 & Wt\% & Wt\% Sigma & Spectrum 18 & Atomic \% Spectrum 18 & Wt\% & Wt $\%$ Sigma \\
\hline 0 & 55.449910 & 41.503 & 0.08 & 0 & 53.630 & 9.81 & 0.08 & 0 & 55.368420 & 401.476 & 0.08 \\
\hline $\mathrm{Na}$ & $6.052876 \mathrm{Na}$ & 6.5086 & 0.02 & $\mathrm{Na}$ & $6.33 \mathrm{Na}$ & 1.67 & 0.02 & $\mathrm{Na}$ & $5.596491 \mathrm{Na}$ & 6.0025 & 0.02 \\
\hline Mg & $0 \mathrm{Mg}$ & 0 & 0 & $\mathrm{Mg}$ & $0 \mathrm{Mg}$ & 0 & 0 & $\mathrm{Mg}$ & $0 \mathrm{Mg}$ & 0 & 0 \\
\hline Al & $9.438776 \mathrm{Al}$ & 11.892 & 0.03 & Al & $9.72 \mathrm{Al}$ & 3 & 0.03 & Al & $10.47368 \mathrm{Al}$ & 13.256 & 0.03 \\
\hline Si & $26.75093 \mathrm{Si}$ & 35.155 & 0.05 & Si & $27.75 \mathrm{Si}$ & 8.91 & 0.05 & $\mathrm{Si}$ & $25.70175 \mathrm{Si}$ & 33.806 & 0.04 \\
\hline $\mathrm{P}$ & $O P$ & 0 & 0 & $\mathrm{P}$ & $O P$ & 0 & 0 & $\mathrm{P}$ & $O P$ & 0 & 0 \\
\hline s & os & 0 & 0 & $\mathrm{~s}$ & os & 0 & 0 & s & os & 0 & 0 \\
\hline K & $1.542208 \mathrm{~K}$ & 2.8124 & 0.02 & $\mathrm{~K}$ & $1.54 \mathrm{~K}$ & 0.69 & 0.02 & $\mathrm{~K}$ & $0.736842 \mathrm{~K}$ & 1.3339 & 0.02 \\
\hline $\mathrm{Ca}$ & $0.510204 \mathrm{Ca}$ & 0.9642 & 0.02 & $\mathrm{Ca}$ & $0.64 \mathrm{Ca}$ & 0.29 & 0.02 & $\mathrm{Ca}$ & $1.877193 \mathrm{Ca}$ & 3.5015 & 0.02 \\
\hline $\mathrm{Ti}$ & $0 \mathrm{Ti}$ & 0 & 0 & $\mathrm{Ti}$ & $0.07 \mathrm{Ti}$ & 0.04 & 0.02 & $\mathrm{Ti}$ & $0 \mathrm{Ti}$ & 0 & 0 \\
\hline $\mathrm{Cr}$ & $0.034787 \mathrm{Cr}$ & 0.0804 & 0.02 & $\mathrm{Cr}$ & $0 \mathrm{Cr}$ & 0 & 0 & $\mathrm{Cr}$ & $0 \mathrm{Cr}$ & 0 & 0 \\
\hline $\mathrm{Mn}$ & $0 \mathrm{Mn}$ & 0 & 0 & $\mathrm{Mn}$ & $0.04 \mathrm{Mn}$ & 0.03 & 0.02 & $\mathrm{Mn}$ & $0.070175 \mathrm{Mn}$ & 0.1667 & 0.02 \\
\hline $\mathrm{Fe}$ & $0.092764 \mathrm{Fe}$ & 0.2411 & 0.03 & $\mathrm{Fe}$ & $0.09 \mathrm{Fe}$ & 0.06 & 0.03 & $\mathrm{Fe}$ & $0.175439 \mathrm{Fe}$ & 0.4585 & 0.03 \\
\hline $\mathrm{Ni}$ & $0 \mathrm{Ni}$ & 0 & 0 & $\mathrm{Ni}$ & $0.1 \mathrm{Ni}$ & 0.07 & 0.04 & $\mathrm{Ni}$ & $0 \mathrm{Ni}$ & 0 & 0 \\
\hline Ва & $0.127551 \mathrm{Ba}$ & 0.8437 & 0.05 & $\mathrm{Ba}$ & $0.08 \mathrm{Ba}$ & 0.13 & 0.05 & Total & 100 Total & 100 & \\
\hline Total & 100 Total & 100 & & Total & 100 Total & 24.7 & & & & & \\
\hline
\end{tabular}

\begin{tabular}{|c|c|c|c|c|c|c|c|c|c|c|c|}
\hline \multicolumn{4}{|c|}{ Site 7} & \multicolumn{4}{|c|}{ Site 7} & \multicolumn{4}{|c|}{ Site 7} \\
\hline Spectrum 19 & Atomic \% Spectrum 19 & $\mathbf{W t} \%$ & Wt\% Sigma & Spectrum 20 & Atomic \% Spectrum 20 & $\mathbf{w t} \%$ & Wt\% Sigma & Spectrum 21 & Atomic \% Spectrum 21 & Wt\% & Wt $\%$ Sigma \\
\hline $\mathrm{Na}$ & $5.585627 \mathrm{Na}$ & 5.9562 & 0.02 & $\mathrm{Na}$ & $5.608771 \mathrm{Na}$ & 6.043 & 0.02 & $\mathrm{~F}$ & $5.093339 \mathrm{~F}$ & 3.7948 & 0.05 \\
\hline $\mathrm{Mg}$ & $0 \mathrm{Mg}$ & 0 & 0 & $\mathrm{Mg}$ & $\mathrm{OMg}$ & 0 & 0 & $\mathrm{Na}$ & $\mathrm{ONa}$ & 0 & 0 \\
\hline $\mathrm{Si}$ & $25.44052 \mathrm{Si}$ & 33.225 & 0.05 & $\mathrm{Si}$ & $25.42412 \mathrm{Si}$ & 33.4 & 0.04 & $\mathrm{Al}$ & $0.103711 \mathrm{Al}$ & 0.1251 & 0.01 \\
\hline $\mathrm{P}$ & $O P$ & 0 & 0 & $\mathrm{P}$ & $O P$ & 0 & 0 & $\mathrm{Si}$ & $0.553123 \mathrm{Si}$ & 0.6255 & 0.01 \\
\hline s & os & 0 & 0 & $\mathrm{~s}$ & os & 0 & 0 & $\mathrm{P}$ & $16.4554 \mathrm{P}$ & 19.975 & 0.04 \\
\hline $\mathrm{K}$ & $0.667972 \mathrm{~K}$ & 1.2156 & 0.02 & $\mathrm{~K}$ & $0.634737 \mathrm{~K}$ & 1.175 & 0.02 & $\mathrm{~s}$ & $0 S$ & 0 & 0 \\
\hline $\mathrm{Cr}$ & $0 \mathrm{Cr}$ & 0 & 0 & $\mathrm{Cr}$ & $0 \mathrm{Cr}$ & 0 & 0 & $\mathrm{Ti}$ & $0 \mathrm{Ti}$ & 0 & 0 \\
\hline $\mathrm{Mn}$ & $0 \mathrm{Mn}$ & 0 & 0 & $\mathrm{Mn}$ & $0 \mathrm{Mn}$ & 0 & 0 & $\mathrm{Cr}$ & $\mathrm{OCr}$ & 0 & 0 \\
\hline $\mathrm{Fe}$ & $0.184268 \mathrm{Fe}$ & 0.4862 & 0.03 & $\mathrm{Fe}$ & $0.184651 \mathrm{Fe}$ & 0.462 & 0.03 & $\mathrm{Mn}$ & $0 \mathrm{Mn}$ & 0 & 0 \\
\hline $\mathrm{Ni}$ & $0 \mathrm{Ni}$ & 0 & 0 & $\mathrm{Ni}$ & $0 \mathrm{Ni}$ & 0 & 0 & $\mathrm{Fe}$ & $0.253515 \mathrm{Fe}$ & 0.5421 & 0.03 \\
\hline $\mathrm{Ba}$ & $0.080617 \mathrm{Ba}$ & 0.4862 & 0.05 & Total & 100 Total & 100 & & $\mathrm{Ni}$ & $0 \mathrm{Ni}$ & 0 & 0 \\
\hline Total & 100 Total & 100 & & & & & & Total & 100 Total & 100 & \\
\hline
\end{tabular}

H8. MS-14-05

\begin{tabular}{|c|c|c|c|c|c|c|c|c|c|c|c|c|c|c|}
\hline \multicolumn{5}{|c|}{ Site 1} & \multicolumn{5}{|c|}{ Site 1} & \multicolumn{5}{|c|}{ Site 1} \\
\hline $\mathrm{Na}$ & 0 & $\mathrm{Na}$ & 0 & 0 & $\mathrm{Na}$ & 6.371744 & $\mathrm{Na}$ & 1.74 & 0.02 & $\mathrm{Na}$ & 0.221911 & $\mathrm{Na}$ & 0.04 & 0.02 \\
\hline $\mathrm{Mg}$ & 0 & $\mathrm{Mg}$ & 0 & 0 & $\mathrm{Mg}$ & 0 & $\mathrm{Mg}$ & 0 & 0 & $\mathrm{Mg}$ & 0 & $\mathrm{Mg}$ & 0 & 0 \\
\hline $\mathrm{Si}$ & 38.99725 & $\mathrm{Si}$ & 13.38 & 0.05 & $\mathrm{Si}$ & 27.41141 & $\mathrm{Si}$ & 9.13 & 0.05 & $\mathrm{Si}$ & 0.256949 & $\mathrm{Si}$ & 0.05 & 0.01 \\
\hline $\mathrm{P}$ & 0 & $\mathrm{P}$ & 0 & 0 & P & 0 & P & 0 & 0 & P & 0 & P & 0 & 0 \\
\hline $\mathrm{s}$ & 0 & $\mathrm{~s}$ & 0 & 0 & $\mathrm{~s}$ & 0 & $\mathrm{~s}$ & 0 & 0 & s & 0 & s & 0 & 0 \\
\hline K & 0.023932 & K & 0.01 & 0.01 & K & 1.431589 & K & 0.66 & 0.02 & $\mathrm{~K}$ & 0 & K & 0 & 0 \\
\hline $\mathrm{Cr}$ & 0 & $\mathrm{Cr}$ & 0 & 0 & $\mathrm{Cr}$ & 0 & $\mathrm{Cr}$ & 0 & 0 & $\mathrm{Cr}$ & 0 & $\mathrm{Cr}$ & 0 & 0 \\
\hline $\mathrm{Mn}$ & 0 & $\mathrm{Mn}$ & 0 & 0 & $\mathrm{Mn}$ & 0 & $\mathrm{Mn}$ & 0 & 0 & $\mathrm{Mn}$ & 0.875964 & $\mathrm{Mn}$ & 0.35 & 0.03 \\
\hline $\mathrm{Fe}$ & 0 & $\mathrm{Fe}$ & 0 & 0 & $\mathrm{Fe}$ & 0.340296 & $\mathrm{Fe}$ & 0.22 & 0.03 & $\mathrm{Fe}$ & 42.04625 & $\mathrm{Fe}$ & 17.25 & 0.12 \\
\hline $\mathrm{Ni}$ & 0.05983 & $\mathrm{Ni}$ & 0.04 & 0.04 & $\mathrm{Ni}$ & 0 & $\mathrm{Ni}$ & 0 & 0 & $\mathrm{Ni}$ & 0 & $\mathrm{Ni}$ & 0 & 0 \\
\hline Total & 100 & Total & 25.35 & & Total & 100 & Total & 25.1 & & Total & 100 & Total & 25.89 & \\
\hline
\end{tabular}




\begin{tabular}{|c|c|c|c|c|c|c|c|c|c|c|c|c|c|c|c|}
\hline \multicolumn{5}{|c|}{ Site 1} & \multicolumn{5}{|c|}{$\begin{array}{ll}\text { Site 2 } \\
\end{array}$} & \multicolumn{6}{|c|}{ Site 2} \\
\hline Spectrum 4 A & Atomic \% Spe & jpectrum 4 & $\mathbf{W t} \%$ & Wt\% Sigma & Spectrum 5 & Atomic $\% \mathrm{~s}$ & Spectrum 5 & $\mathbf{W t} \%$ & Wt\% Sigma & & Spectrum 6 & Atomic \% & Spectrum 6 & $\mathbf{W t} \%$ & Wt\% Sigma \\
\hline $\begin{array}{ll}0 & 5\end{array}$ & 55.08393 & 0 & 8.41 & 0.06 & 0 & 055.31094 & 0 & 10.35 & 0.08 & & 0 & "50.14308 & 0 & $=7.68$ & 0.09 \\
\hline $\mathrm{Na}$ & 1.151079 & $\mathrm{Na}$ & 0.25 & 0.02 & $\mathrm{Na}$ & 6.116659 & $\mathrm{Na}$ & 1.64 & 0.02 & & $\mathrm{~F}$ & 4.292318 & $\mathrm{~F}$ & 0.78 & 0.04 \\
\hline $\mathrm{Mg}$ & 0 & $\mathrm{Mg}$ & 0 & 0 & $\mathrm{Mg}$ & 0 & $\mathrm{Mg}$ & 0 & 0 & & $\mathrm{Na}$ & 0.110059 & $\mathrm{Na}$ & 0.02 & 0.01 \\
\hline $\mathrm{Al}$ & 0.443645 & $\mathrm{Al}$ & 0.11 & 0.01 & $\mathrm{Al}$ & 9.418974 & $\mathrm{Al}$ & 2.97 & 0.03 & & $\mathrm{Mg}$ & 0 & $\mathrm{Mg}$ & 0 & 0 \\
\hline $\mathrm{Si}$ & 23.66906 & $\mathrm{Si}$ & 6.35 & 0.04 & $\mathrm{Si}$ & 26.90649 & $\mathrm{Si}$ & 8.84 & 0.05 & & $\mathrm{Al}$ & 0 & $\mathrm{Al}$ & 0 & 0 \\
\hline $\mathrm{P}$ & 0.059952 & $\mathrm{P}$ & 0.02 & 0.01 & $\mathrm{P}$ & 0 & $P$ & 0 & 0 & & $\mathrm{Si}$ & 0.198107 & $\mathrm{Si}$ & 0.05 & 0.01 \\
\hline $\mathrm{S}$ & 0 & $S$ & 0 & 0 & S & 0 & S & 0 & 0 & & $P$ & 16.93815 & $P$ & 5.02 & 0.04 \\
\hline K & 0.059952 & K & 0.02 & 0.01 & K & 1.475261 & $\mathrm{~K}$ & 0.67 & 0.02 & & $\mathrm{~s}$ & 0 & $\mathrm{~s}$ & 0 & 0 \\
\hline $\mathrm{Ca}$ & 0.263789 & $\mathrm{Ca}$ & 0.1 & 0.01 & $\mathrm{Ca}$ & 0.510667 & $\mathrm{Ca}$ & 0.24 & 0.02 & & $\mathrm{~K}$ & 0.05503 & $\mathrm{~K}$ & 0.02 & 0.01 \\
\hline $\mathrm{Ti}$ & 3.369305 & $\mathrm{Ti}$ & 1.54 & 0.03 & $\mathrm{Ti}$ & 0 & $\mathrm{Ti}$ & 0 & 0 & & $\mathrm{Ca}$ & 28.10918 & $\mathrm{Ca}$ & 10.79 & 0.06 \\
\hline $\mathrm{Cr}$ & 0 & $\mathrm{Cr}$ & 0 & 0 & $\mathrm{Cr}$ & 0 & $\mathrm{Cr}$ & 0 & 0 & & $\mathrm{Ti}$ & 0 & $\mathrm{Ti}$ & 0 & 0 \\
\hline $\mathrm{Mn}$ & 0.57554 & $\mathrm{Mn}$ & 0.3 & 0.03 & $\mathrm{Mn}$ & 0 & $\mathrm{Mn}$ & 0 & 0 & & $\mathrm{Cr}$ & 0 & $\mathrm{Cr}$ & 0 & 0 \\
\hline $\mathrm{Fe}$ & 15.2518 & $\mathrm{Fe}$ & 8.13 & 0.09 & $\mathrm{Fe}$ & 0.170222 & $\mathrm{Fe}$ & 0.11 & 0.03 & & $\mathrm{Mn}$ & 0 & $\mathrm{Mn}$ & 0 & 0 \\
\hline $\mathrm{Ni}$ & 0.071942 & $\mathrm{Ni}$ & 0.04 & 0.04 & $\mathrm{Ni}$ & 0 & $\mathrm{Ni}$ & 0 & 0 & & $\mathrm{Fe}$ & 0.154083 & $\mathrm{Fe}$ & 0.08 & 0.03 \\
\hline Total & 100 & Total & 25.27 & & $\mathrm{Ba}$ & 0.090785 & $\mathrm{Ba}$ & 0.14 & 0.05 & & $\mathrm{Ni}$ & 0 & $\mathrm{Ni}$ & 0 & 0 \\
\hline & & & & & Total & 100 & Total & 24.96 & & & Total & 100 & Total & 24.44 & \\
\hline & & Site 2 & & & & & Site 3 & & & & & & Site 3 & & \\
\hline Spectrum $7 \mathrm{~A}$ & Atomic \% Sp & Spectrum 7 & Wt\% & Wt $\%$ Sigma & Spectrum 8 & 8 Atomic \% & Spectrum 8 & $\mathbf{W t} \%$ & Wt\% Sigma & & Spectrum 9 & Atomic \% & Spectrum 9 & $\mathbf{W t} \%$ & Wt\% Sigma \\
\hline $\begin{array}{lll} & 0\end{array}$ & (55.50023 & 0 & $\begin{array}{ll}10.8 \\
\end{array}$ & $\begin{array}{l}0.08 \\
\end{array}$ & 0 & (252.9155 & 0 & $\begin{array}{l}8.63 \\
\end{array}$ & $\begin{array}{l}0.07 \\
\end{array}$ & & 0 & $\begin{array}{l}48.40727 \\
\end{array}$ & 0 & 5.79 & 0.05 \\
\hline $\mathrm{Na}$ & 6.247171 & $\mathrm{Na}$ & 1.75 & 0.02 & $\mathrm{Na}$ & 0.40291 & $\mathrm{Na}$ & 0.09 & 0.01 & & $\mathrm{Na}$ & 0.162168 & $\mathrm{Na}$ & 0.03 & 0.02 \\
\hline $\mathrm{Mg}$ & 0 & $\mathrm{Mg}$ & 0 & 0 & $\mathrm{Mg}$ & 4.364857 & $\mathrm{Mg}$ & 1.08 & 0.02 & & $\mathrm{Mg}$ & 0.382254 & $\mathrm{Mg}$ & 0.07 & 0.01 \\
\hline $\mathrm{Al}$ & 9.461295 & $\mathrm{Al}$ & 3.11 & 0.03 & $\mathrm{Al}$ & 0.257415 & $\mathrm{Al}$ & 0.07 & 0.01 & & $\mathrm{Al}$ & 0.625507 & $\mathrm{Al}$ & 0.13 & 0.01 \\
\hline $\mathrm{Si}$ & 26.44862 & $\mathrm{Si}$ & 9.03 & 0.05 & $\mathrm{Si}$ & 23.13374 & $\mathrm{Si}$ & 6.63 & 0.04 & & $\mathrm{Si}$ & 0.115835 & $\mathrm{Si}$ & 0.03 & 0.01 \\
\hline $\mathrm{P}$ & 0 & $P$ & 0 & 0 & $P$ & 0 & $P$ & 0 & 0 & & $P$ & 0 & $P$ & 0 & 0 \\
\hline s & 0 & $\mathrm{~s}$ & 0 & 0 & $\mathrm{~s}$ & 0.044768 & $\mathrm{~s}$ & 0.02 & 0.01 & & $\mathrm{~s}$ & 0 & $\mathrm{~s}$ & 0 & 0 \\
\hline $\mathrm{K}$ & 1.448619 & $\mathrm{~K}$ & 0.69 & 0.02 & $\mathrm{~K}$ & 0.033576 & $\mathrm{~K}$ & 0.02 & 0.01 & & $\mathrm{~K}$ & 0.046334 & $\mathrm{~K}$ & 0.01 & 0.01 \\
\hline $\mathrm{Ca}$ & 0.611136 & $\mathrm{Ca}$ & 0.3 & 0.02 & $\mathrm{Ca}$ & 9.434807 & $\mathrm{Ca}$ & 3.86 & 0.04 & & $\mathrm{Ca}$ & 0 & $\mathrm{Ca}$ & 0 & 0 \\
\hline $\mathrm{Ti}$ & 0 & $\mathrm{Ti}$ & 0 & 0 & $\mathrm{Ti}$ & 0.100727 & $\mathrm{Ti}$ & 0.05 & 0.02 & & $\mathrm{Ti}$ & 9.556354 & $\mathrm{Ti}$ & 3.42 & 0.04 \\
\hline $\mathrm{Cr}$ & 0.067904 & $\mathrm{Cr}$ & 0.05 & 0.02 & $\mathrm{Cr}$ & 0 & $\mathrm{Cr}$ & 0 & 0 & & $\mathrm{Cr}$ & 0 & $\mathrm{Cr}$ & 0 & 0 \\
\hline $\mathrm{Mn}$ & 0 & $\mathrm{Mn}$ & 0 & 0 & $\mathrm{Mn}$ & 0.716284 & $\mathrm{Mn}$ & 0.4 & 0.03 & & $\mathrm{Mn}$ & 1.065678 & $\mathrm{Mn}$ & 0.44 & 0.03 \\
\hline $\mathrm{Fe}$ & 0.067904 & $\mathrm{Fe}$ & 0.04 & 0.03 & $\mathrm{Fe}$ & 8.595411 & $\mathrm{Fe}$ & 4.9 & 0.07 & & $\mathrm{Fe}$ & 39.6386 & $\mathrm{Fe}$ & 16.55 & 0.12 \\
\hline $\mathrm{Ni}$ & 0 & $\mathrm{Ni}$ & 0 & 0 & $\mathrm{Ni}$ & 0 & $\mathrm{Ni}$ & 0 & 0 & & $\mathrm{Ni}$ & 0 & $\mathrm{Ni}$ & 0 & 0 \\
\hline $\mathrm{Ba}$ & 0.147125 & $\mathrm{Ba}$ & 0.25 & 0.05 & Total & 100 & Total & 25.75 & & & Total & 100 & Total & 26.47 & \\
\hline Total & 100 & Total & 26.02 & & & & & & & & & & & & \\
\hline & & Site 3 & & & & & Site 4 & & & & & & Site 4 & & \\
\hline Spectrum 10 & Atomic \% Sp & pectrum 10 & $w_{t} \%$ & Wt\% Sigma & Spectrum 11 & Atomic $\% \mathrm{~S}$ & Spectrum 11 & $\mathrm{Wt}_{\mathrm{t}} \%$ & Wt $\%$ Sigma & & jpectrum 12 & Atomic \% & Spectrum 12 & $\mathbf{W t} \%$ & Wt\% Sigma \\
\hline ב & $\begin{array}{l}49.32912 \\
\end{array}$ & 0 & "7.44 & $\begin{array}{l}0.09 \\
\end{array}$ & $\begin{array}{l}0 \\
\end{array}$ & $\begin{array}{l}52.53756 \\
\end{array}$ & $\begin{array}{ll}0 \\
\end{array}$ & "8.49 & $\begin{array}{l}0.07 \\
\end{array}$ & & 0 & "52.83769 & 0 & $\begin{array}{l}8.48 \\
\end{array}$ & $\begin{array}{l}0.07 \\
\end{array}$ \\
\hline $\mathrm{F}$ & 4.013981 & $\mathrm{~F}$ & 0.72 & 0.06 & $\mathrm{Na}$ & 0.343073 & $\mathrm{Na}$ & 0.08 & 0.01 & & $\mathrm{Na}$ & 0.301241 & $\mathrm{Na}$ & 0.07 & 0.01 \\
\hline $\mathrm{Na}$ & 0.101477 & $\mathrm{Na}$ & 0.02 & 0.01 & $\mathrm{Mg}$ & 4.353484 & $\mathrm{Mg}$ & 1.07 & 0.02 & & $\mathrm{Mg}$ & 4.386071 & $\mathrm{Mg}$ & 1.07 & 0.02 \\
\hline $\mathrm{Mg}$ & 0.045101 & $\mathrm{Mg}$ & 0.01 & 0.01 & $\mathrm{Al}$ & 0.236602 & $\mathrm{Al}$ & 0.06 & 0.01 & & $\mathrm{Al}$ & 0.240993 & $\mathrm{Al}$ & 0.07 & 0.01 \\
\hline $\mathrm{Al}$ & 0.045101 & $\mathrm{Al}$ & 0.01 & 0.01 & $\mathrm{Si}$ & 23.36449 & $\mathrm{Si}$ & 6.63 & 0.04 & & $\mathrm{Si}$ & 23.37631 & $\mathrm{Si}$ & 6.59 & 0.04 \\
\hline $\mathrm{Si}$ & 0.338257 & $\mathrm{Si}$ & 0.09 & 0.01 & $\mathrm{P}$ & 0 & $\mathrm{P}$ & 0 & 0 & & $\mathrm{P}$ & 0 & $\mathrm{P}$ & 0 & 0 \\
\hline $\mathrm{P}$ & 17.02559 & $\mathrm{P}$ & 4.97 & 0.04 & $\mathrm{~s}$ & 0 & $\mathrm{~s}$ & 0 & 0 & & $\mathrm{~s}$ & 0 & $\mathrm{~s}$ & 0 & 0 \\
\hline $\mathrm{s}$ & 0 & $\mathrm{~s}$ & 0 & 0 & $\mathrm{~K}$ & 0 & $\mathrm{~K}$ & 0 & 0 & & K & 0 & K & 0 & 0 \\
\hline $\mathrm{Cl}$ & 0.101477 & $\mathrm{Cl}$ & 0.03 & 0.01 & $\mathrm{Ca}$ & 9.499586 & $\mathrm{Ca}$ & 3.85 & 0.04 & & $\mathrm{Ca}$ & 9.48307 & $\mathrm{Ca}$ & 3.81 & 0.04 \\
\hline $\mathrm{K}$ & 0 & K & 0 & 0 & $\mathrm{Ti}$ & 0.165622 & $\mathrm{Ti}$ & 0.08 & 0.02 & & $\mathrm{Ti}$ & 0.120496 & $\mathrm{Ti}$ & 0.06 & 0.02 \\
\hline $\mathrm{Ca}$ & 28.33465 & $\mathrm{Ca}$ & 10.7 & 0.06 & $\mathrm{Cr}$ & 0 & $\mathrm{Cr}$ & 0 & 0 & & $\mathrm{Cr}$ & 0 & $\mathrm{Cr}$ & 0 & 0 \\
\hline $\mathrm{Ti}$ & 0 & $\mathrm{Ti}$ & 0 & 0 & $\mathrm{Mn}$ & 0.816278 & $\mathrm{Mn}$ & 0.45 & 0.03 & & $\mathrm{Mn}$ & 0.819376 & $\mathrm{Mn}$ & 0.45 & 0.03 \\
\hline $\mathrm{Cr}$ & 0 & $\mathrm{Cr}$ & 0 & 0 & $\mathrm{Fe}$ & 8.683308 & $\mathrm{Fe}$ & 4.9 & 0.07 & & $\mathrm{Fe}$ & 8.434751 & $\mathrm{Fe}$ & 4.72 & 0.07 \\
\hline $\mathrm{Mn}$ & 0.056376 & $\mathrm{Mn}$ & 0.03 & 0.03 & $\mathrm{Ni}$ & 0 & $\mathrm{Ni}$ & 0 & 0 & & $\mathrm{Ni}$ & 0 & $\mathrm{Ni}$ & 0 & 0 \\
\hline $\mathrm{Fe}$ & 0.451009 & $\mathrm{Fe}$ & 0.24 & 0.03 & Total & 100 & Total & 25.61 & & & Total & 100 & Total & 25.32 & \\
\hline $\mathrm{Ni}$ & 0 & $\mathrm{Ni}$ & 0 & 0 & & & & & & & & & & & \\
\hline $\mathrm{Ce}$ & 0.157853 & $\mathrm{Ce}$ & 0.2 & 0.05 & & & & & & & & & & & \\
\hline Total & 100 & Total & 25.9 & & & & & & & & & & & & \\
\hline & & Site 5 & & & & & & Sit & te 5 & & & & & & \\
\hline Spectrum 13 & 3 Atomic \% & $\%$ Spectru & um 13 & $\mathbf{W t} \%$ & Vt\% Sigma & Spectrum 1 & 14 Atomic \% & Spec & ctrum 14 & $\mathbf{W t} \%$ & $\mathrm{Wt} \% \mathrm{Si}$ & igma & & & \\
\hline 0 & 52.24778 & 80 & & $\begin{array}{l}8.41 \\
\end{array}$ & 0.07 & 0 & 52.22566 & & 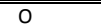 & $\begin{array}{l}8.33 \\
\end{array}$ & $\begin{array}{l}0.07 \\
\end{array}$ & & & & \\
\hline $\mathrm{Na}$ & 0.450711 & $\mathrm{Na}$ & & 0.11 & 0.01 & $\mathrm{Na}$ & 0.377618 & & $\mathrm{Na}$ & 0.09 & 0.01 & & & & \\
\hline $\mathrm{Mg}$ & 4.518664 & $\mathrm{M} \xi$ & & 1.1 & 0.02 & $\mathrm{Mg}$ & 4.382652 & & $\mathrm{Mg}$ & 1.06 & 0.02 & & & & \\
\hline $\mathrm{Al}$ & 0.254247 & Al & & 0.07 & 0.01 & $\mathrm{Al}$ & 0.263188 & & $\mathrm{Al}$ & 0.07 & 0.01 & & & & \\
\hline $\mathrm{Si}$ & 23.49474 & $\mathrm{Si}$ & & 6.64 & 0.04 & $\mathrm{Si}$ & 23.73269 & & $\mathrm{Si}$ & 6.64 & 0.04 & & & & \\
\hline$P$ & 0 & $\mathrm{P}$ & & 0 & 0 & $\mathrm{P}$ & 0 & & $P$ & 0 & 0 & & & & \\
\hline $\mathrm{s}$ & 0 & $\mathrm{~s}$ & & 0 & 0 & $S$ & 0 & & $S$ & 0 & 0 & & & & \\
\hline $\mathrm{K}$ & 0 & $\mathrm{~K}$ & & 0 & 0 & $\mathrm{~K}$ & 0 & & $\mathrm{~K}$ & 0 & 0 & & & & \\
\hline $\mathrm{Ca}$ & 9.511152 & $\mathrm{Ca}$ & & 3.84 & 0.04 & $\mathrm{Ca}$ & 9.52054 & & $\mathrm{Ca}$ & 3.8 & 0.04 & & & & \\
\hline $\mathrm{Ti}$ & 0.115567 & $\mathrm{Ti}$ & & 0.06 & 0.02 & $\mathrm{Ti}$ & 0.160201 & & $\mathrm{Ti}$ & 0.08 & 0.02 & & & & \\
\hline $\mathrm{Cr}$ & 0 & $\mathrm{Cr}$ & & 0 & 0 & $\mathrm{Cr}$ & 0 & & $\mathrm{Cr}$ & 0 & 0 & & & & \\
\hline $\mathrm{Mn}$ & 0.808968 & $\mathrm{Mn}$ & & 0.45 & 0.03 & $\mathrm{Mn}$ & 0.789564 & & $\mathrm{Mn}$ & 0.43 & 0.03 & & & & \\
\hline $\mathrm{Fe}$ & 8.598174 & $\mathrm{Fe}$ & & 4.83 & 0.07 & $\mathrm{Fe}$ & 8.547889 & & $\mathrm{Fe}$ & 4.76 & 0.07 & & & & \\
\hline $\mathrm{Ni}$ & 0 & $\mathrm{Ni}$ & & 0 & 0 & $\mathrm{Ni}$ & 0 & & $\mathrm{Ni}$ & 0 & 0 & & & & \\
\hline Total & 100 & Tot & & 25.51 & & Total & 100 & & Total & 25.26 & & & & & \\
\hline
\end{tabular}




\section{H9. MS-14-06}

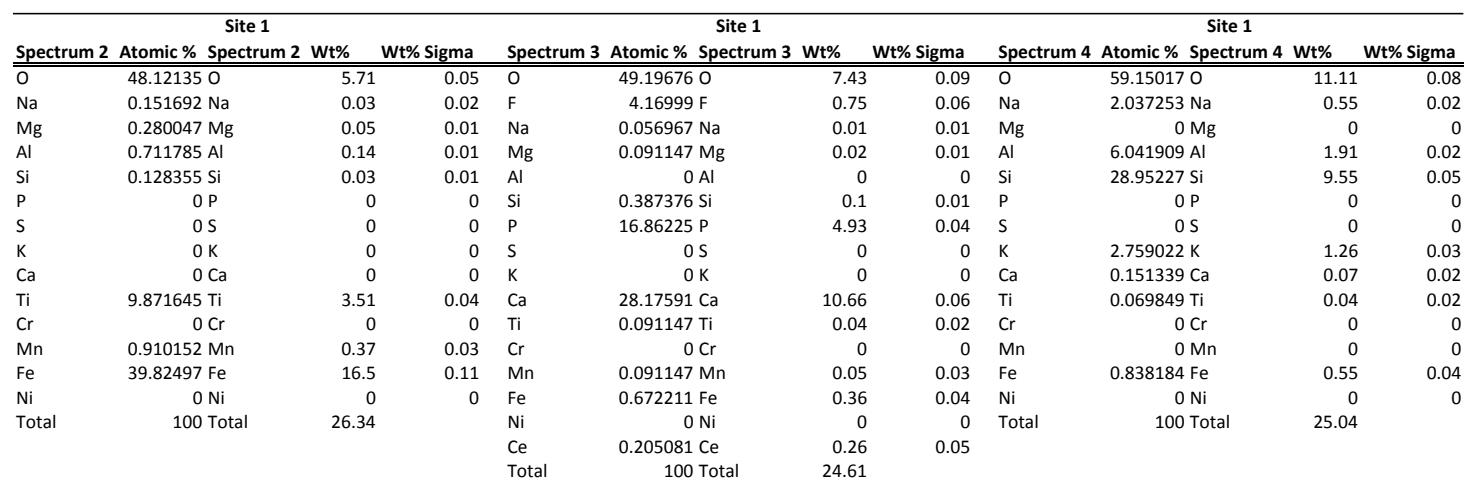

\begin{tabular}{|c|c|c|c|c|c|c|c|c|c|c|c|}
\hline \multicolumn{4}{|c|}{$\begin{array}{l}\text { Site } 2 \\
\end{array}$} & \multicolumn{4}{|c|}{ Site 2} & \multicolumn{4}{|c|}{ Site 2} \\
\hline $\mathrm{Na}$ & $2.51 \mathrm{Na}$ & 0.67 & 0.02 & $\mathrm{Na}$ & $2.415293 \mathrm{Na}$ & 0.66 & 0.02 & $\mathrm{Na}$ & $2.476886 \mathrm{Na}$ & 0.66 & 0.02 \\
\hline $\mathrm{Mg}$ & $0 \mathrm{Mg}$ & 0 & 0 & $\mathrm{Mg}$ & $0 \mathrm{Mg}$ & 0 & 0 & $\mathrm{Mg}$ & $0.057071 \mathrm{Mg}$ & 0.02 & 0.01 \\
\hline $\mathrm{Si}$ & $29.68 \mathrm{Si}$ & 9.67 & 0.05 & $\mathrm{Si}$ & $28.6859 \mathrm{Si}$ & 9.53 & 0.05 & $\mathrm{Si}$ & $29.02637 \mathrm{Si}$ & 9.53 & 0.05 \\
\hline $\mathrm{P}$ & $O P$ & 0 & 0 & $\mathrm{P}$ & $O P$ & 0 & 0 & $\mathrm{P}$ & $O P$ & 0 & 0 \\
\hline $\mathrm{s}$ & os & 0 & 0 & $\mathrm{~s}$ & $0.034341 \mathrm{~s}$ & 0.01 & 0.01 & $\mathrm{~s}$ & $0 \mathrm{~S}$ & 0 & 0 \\
\hline $\mathrm{K}$ & $2.69 \mathrm{~K}$ & 1.22 & 0.02 & $\mathrm{~K}$ & $2.712912 \mathrm{~K}$ & 1.25 & 0.02 & $\mathrm{k}$ & $2.385572 \mathrm{~K}$ & 1.09 & 0.02 \\
\hline $\mathrm{Cr}$ & $0 \mathrm{Cr}$ & 0 & 0 & $\mathrm{Cr}$ & $0 \mathrm{Cr}$ & 0 & 0 & $\mathrm{Cr}$ & $0.034243 \mathrm{Cr}$ & 0.02 & 0.02 \\
\hline $\mathrm{Mn}$ & $0 \mathrm{Mn}$ & 0 & 0 & $\mathrm{Mn}$ & $0.045788 \mathrm{Mn}$ & 0.03 & 0.02 & $\mathrm{Mn}$ & $0.068485 \mathrm{Mn}$ & 0.05 & 0.02 \\
\hline $\mathrm{Fe}$ & $0.59 \mathrm{Fe}$ & 0.38 & 0.03 & $\mathrm{Fe}$ & $0.915751 \mathrm{Fe}$ & 0.6 & 0.04 & $\mathrm{Fe}$ & $0.890309 \mathrm{Fe}$ & 0.58 & 0.04 \\
\hline $\mathrm{Ni}$ & $0 \mathrm{Ni}$ & 0 & 0 & $\mathrm{Ni}$ & $0 \mathrm{Ni}$ & 0 & 0 & $\mathrm{Ni}$ & $0.0799 \mathrm{Ni}$ & 0.06 & 0.04 \\
\hline Total & 100 Total & 24.82 & & Total & 100 Total & 25.31 & & Total & 100 Total & 25.02 & \\
\hline
\end{tabular}

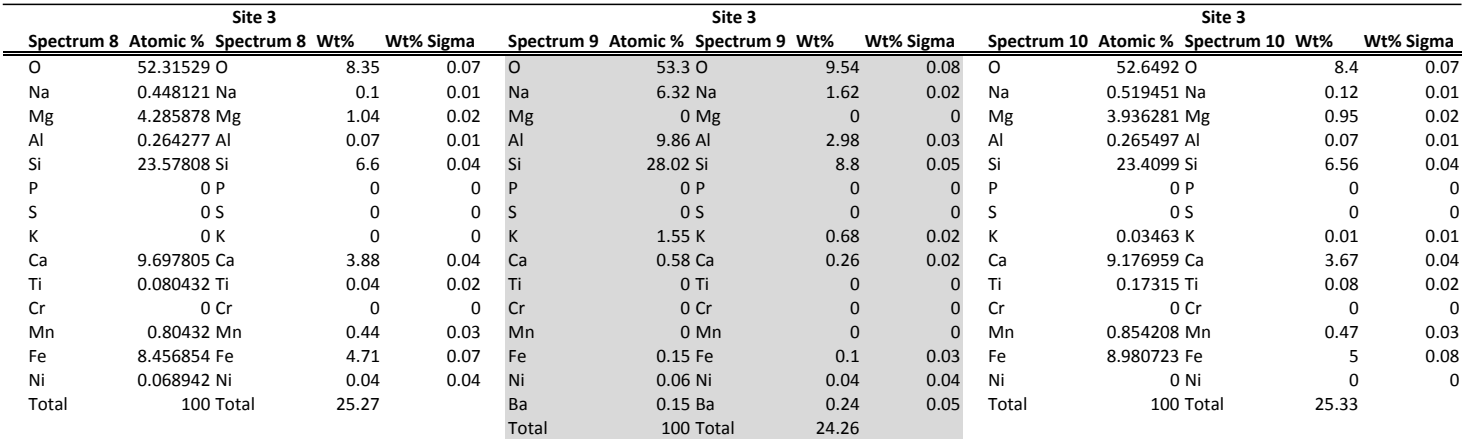

\begin{tabular}{|c|c|c|c|c|c|c|c|c|c|c|c|}
\hline \multicolumn{4}{|c|}{ Site 3} & \multicolumn{4}{|c|}{ Site 3} & \multicolumn{4}{|c|}{ Site 3} \\
\hline $\mathrm{Na}$ & $0.158282 \mathrm{Na}$ & 0.03 & 0.02 & $\mathrm{~F}$ & $2.560907 \mathrm{~F}$ & 0.44 & 0.05 & $\mathrm{Na}$ & $0.355342 \mathrm{Na}$ & 0.08 & 0.01 \\
\hline $\mathrm{Mg}$ & $0.293951 \mathrm{Mg}$ & 0.05 & 0.01 & $\mathrm{Na}$ & $0.090652 \mathrm{Na}$ & 0.02 & 0.01 & $\mathrm{Mg}$ & $4.562127 \mathrm{Mg}$ & 1.11 & 0.02 \\
\hline $\mathrm{Si}$ & $0.13567 \mathrm{Si}$ & 0.03 & 0.01 & Al & $0.090652 \mathrm{Al}$ & 0.02 & 0.01 & $\mathrm{Si}$ & $23.40669 \mathrm{Si}$ & 6.56 & 0.04 \\
\hline $\mathrm{P}$ & $0.101752 \mathrm{P}$ & 0.02 & 0.01 & $\mathrm{Si}$ & $9.053824 \mathrm{Si}$ & 2.32 & 0.02 & $\mathrm{P}$ & $O P$ & 0 & 0 \\
\hline $\mathrm{s}$ & $0 \mathrm{~S}$ & 0 & 0 & $\mathrm{P}$ & $10.5949 \mathrm{P}$ & 2.99 & 0.03 & $\mathrm{~s}$ & $0 \mathrm{~s}$ & 0 & 0 \\
\hline $\mathrm{k}$ & $0 \mathrm{~K}$ & 0 & 0 & $\mathrm{~s}$ & $O S$ & 0 & 0 & $\mathrm{~K}$ & $0 \mathrm{~K}$ & 0 & 0 \\
\hline $\mathrm{Cr}$ & $0 \mathrm{Cr}$ & 0 & 0 & $\mathrm{Ti}$ & $0 \mathrm{Ti}$ & 0 & 0 & $\mathrm{Ti}$ & $0.149014 \mathrm{Ti}$ & 0.07 & 0.02 \\
\hline $\mathrm{Mn}$ & $0.927077 \mathrm{Mn}$ & 0.37 & 0.03 & $\mathrm{Cr}$ & $0 \mathrm{Cr}$ & 0 & 0 & $\mathrm{Cr}$ & $0 \mathrm{Cr}$ & 0 & 0 \\
\hline $\mathrm{Fe}$ & 38.97117 Fe & 16.02 & 0.11 & $\mathrm{Mn}$ & $0.226629 \mathrm{Mn}$ & 0.11 & 0.03 & $\mathrm{Mn}$ & $0.836772 \mathrm{Mn}$ & 0.46 & 0.03 \\
\hline $\mathrm{Ni}$ & $0 \mathrm{Ni}$ & 0 & 0 & $\mathrm{Fe}$ & $2.946176 \mathrm{Fe}$ & 1.5 & 0.05 & $\mathrm{Fe}$ & $8.757451 \mathrm{Fe}$ & 4.88 & 0.07 \\
\hline \multirow[t]{4}{*}{ Total } & 100 Total & 25.87 & & $\mathrm{Ni}$ & $0 \mathrm{Ni}$ & 0 & 0 & $\mathrm{Ni}$ & $0 \mathrm{Ni}$ & 0 & 0 \\
\hline & & & & $\mathrm{Zn}$ & $0.124646 \mathrm{Zn}$ & 0.07 & 0.03 & Total & 100 Total & 25.44 & \\
\hline & & & & $\mathrm{Ce}$ & $0.215297 \mathrm{Ce}$ & 0.27 & 0.05 & & & & \\
\hline & & & & Total & 100 Total & 23.41 & & & & & \\
\hline
\end{tabular}




\begin{tabular}{|c|c|c|c|c|c|c|c|c|c|c|c|}
\hline \multicolumn{4}{|c|}{ Site 4} & \multicolumn{4}{|c|}{ Site 4} & \multicolumn{4}{|c|}{$\begin{array}{ll}\text { Site } 4 \\
\end{array}$} \\
\hline $\mathrm{Na}$ & $3.182693 \mathrm{Na}$ & 0.83 & 0.02 & $\mathrm{Na}$ & $3.143351 \mathrm{Na}$ & 0.82 & 0.02 & $\mathrm{Na}$ & $0 \mathrm{Na}$ & & 0 \\
\hline $\mathrm{Mg}$ & $0.09061 \mathrm{Mg}$ & 0.03 & 0.01 & $\mathrm{Mg}$ & $0.069085 \mathrm{Mg}$ & 0.02 & 0.01 & $\mathrm{Mg}$ & $0.399772 \mathrm{Mg}$ & 0.07 & 0.01 \\
\hline $\mathrm{Si}$ & $22.16559 \mathrm{Si}$ & 7.04 & 0.04 & $\mathrm{Si}$ & $21.72712 \mathrm{Si}$ & 6.91 & 0.04 & $\mathrm{Si}$ & $0.102798 \mathrm{Si}$ & 0.02 & 0.01 \\
\hline $\mathrm{P}$ & $0 \mathrm{P}$ & 0 & 0 & $\mathrm{P}$ & $O P$ & 0 & 0 & $\mathrm{p}$ & $0.068532 \mathrm{P}$ & 0.01 & 0.01 \\
\hline s & OS & 0 & 0 & s & os & 0 & 0 & s & os & & 0 \\
\hline k & $0.147242 \mathrm{~K}$ & 0.07 & 0.01 & $\mathrm{k}$ & $0.126655 \mathrm{~K}$ & 0.06 & 0.01 & $\mathrm{k}$ & $0 \mathrm{~K}$ & & 0 \\
\hline $\mathrm{Cr}$ & $0 \mathrm{Cr}$ & 0 & 0 & $\mathrm{Cr}$ & $0 \mathrm{Cr}$ & 0 & 0 & $\mathrm{Cr}$ & $0 \mathrm{Cr}$ & & 0 \\
\hline $\mathrm{Mn}$ & $0 \mathrm{Mn}$ & 0 & 0 & $\mathrm{Mn}$ & $\mathrm{OMn}$ & 0 & 0 & $\mathrm{Mn}$ & $0.799543 \mathrm{Mn}$ & 0.32 & 0.03 \\
\hline $\mathrm{Fe}$ & $0.237853 \mathrm{Fe}$ & 0.15 & 0.03 & $\mathrm{Fe}$ & $0.218768 \mathrm{Fe}$ & 0.14 & 0.03 & $\mathrm{Fe}$ & $39.47459 \mathrm{Fe}$ & 16.25 & 0.11 \\
\hline $\mathrm{Ni}$ & $0 \mathrm{Ni}$ & 0 & 0 & $\mathrm{Ni}$ & $0 \mathrm{Ni}$ & 0 & 0 & $\mathrm{Ni}$ & $0 \mathrm{Ni}$ & & 0 \\
\hline Total & 100 Total & 24.77 & & Total & 100 Total & 24.73 & & Total & 100 Total & 25.98 & \\
\hline \multicolumn{4}{|c|}{$\begin{array}{ll}\text { Site } 4 \\
\end{array}$} & \multicolumn{4}{|c|}{$\begin{array}{ll}\text { Site } 5 \\
\end{array}$} & \multicolumn{4}{|c|}{$\begin{array}{ll}\text { Site } 5 \\
\end{array}$} \\
\hline $\mathrm{Si}$ & $21.94733 \mathrm{Si}$ & 6.79 & 0.04 & $\mathrm{Si}$ & $23.37633 \mathrm{Si}$ & 6.79 & 0.04 & $\mathrm{Si}$ & $26.60615 \mathrm{Si}$ & 8.98 & 0.05 \\
\hline $\mathrm{P}$ & $0.387641 \mathrm{P}$ & 0.13 & 0.01 & $\mathrm{p}$ & $0 \mathrm{P}$ & 0 & 0 & $\mathrm{p}$ & $0 \mathrm{P}$ & 0 & 0 \\
\hline s & $0.09121 \mathrm{~S}$ & 0.03 & 0.01 & s & $0 \mathrm{~S}$ & 0 & 0 & s & OS & 0 & 0 \\
\hline K & $0.980504 \mathrm{~K}$ & 0.42 & 0.02 & K & $0 \mathrm{~K}$ & 0 & 0 & K & $1.582868 \mathrm{~K}$ & 0.75 & 0.02 \\
\hline $\mathrm{Ca}$ & $3.910615 \mathrm{Ca}$ & 1.73 & 0.03 & $\mathrm{Ca}$ & $8.925922 \mathrm{Ca}$ & 3.7 & 0.04 & $\mathrm{Ca}$ & $0.512104 \mathrm{Ca}$ & 0.25 & 0.02 \\
\hline $\mathrm{Ti}$ & $0.855091 \mathrm{Ti}$ & 0.45 & 0.02 & $\mathrm{Ti}$ & $0.125556 \mathrm{Ti}$ & 0.06 & 0.02 & $\mathrm{Ti}$ & $0 \mathrm{Ti}$ & 0 & 0 \\
\hline $\mathrm{Cr}$ & $0 \mathrm{Cr}$ & 0 & 0 & $\mathrm{Cr}$ & $0 \mathrm{Cr}$ & 0 & 0 & $\mathrm{Cr}$ & $0 \mathrm{Cr}$ & 0 & 0 \\
\hline $\mathrm{Mn}$ & $0.182419 \mathrm{Mn}$ & 0.11 & 0.03 & $\mathrm{Mn}$ & $0.821824 \mathrm{Mn}$ & 0.47 & 0.03 & $\mathrm{Mn}$ & $0 \mathrm{Mn}$ & 0 & 0 \\
\hline $\mathrm{Fe}$ & $4.298256 \mathrm{Fe}$ & 2.65 & 0.06 & $\mathrm{Fe}$ & $8.777537 \mathrm{Fe}$ & 5.07 & 0.08 & $\mathrm{Fe}$ & $0.162942 \mathrm{Fe}$ & 0.11 & 0.03 \\
\hline $\mathrm{Ni}$ & $0 \mathrm{Ni}$ & 0 & 0 & $\mathrm{Ni}$ & $0 \mathrm{Ni}$ & 0 & 0 & $\mathrm{Ni}$ & $0 \mathrm{Ni}$ & 0 & 0 \\
\hline \multirow[t]{2}{*}{ Total } & 100 Total & 25.35 & & Total & 100 Total & 26.13 & & $\mathrm{Ba}$ & $0.174581 \mathrm{Ba}$ & 0.29 & 0.05 \\
\hline & & & & & & & & Total & 100 Total & 25.75 & \\
\hline
\end{tabular}

\begin{tabular}{|c|c|c|c|c|c|c|c|c|c|c|c|}
\hline \multicolumn{4}{|c|}{$\begin{array}{l}\text { Site } 5 \\
\end{array}$} & \multicolumn{4}{|c|}{$\begin{array}{l}\text { Site } 5 \\
\end{array}$} & \multicolumn{4}{|c|}{$\begin{array}{ll}\text { Site } 5 \\
\end{array}$} \\
\hline Spectrum 20 & Atomic \% Spectrum 20 & $\mathbf{W t} \%$ & Wt\% Sigma & \multicolumn{3}{|c|}{ Spectrum 21 Atomic \% Spectrum 21 Wt\% } & Wt\% Sigma & \multirow{2}{*}{$\begin{array}{l}\text { Spectrum 22 } \\
\mathrm{Be}\end{array}$} & \multicolumn{2}{|c|}{ Atomic \% Spectrum $22 \mathrm{wt} \%$} & Wt\% Sigma \\
\hline 0 & 55.064520 & 9.3 & 0.07 & 0 & 62.205250 & 11.84 & 0.09 & & $0 \mathrm{Be}$ & & $\begin{array}{ll}0 & 0\end{array}$ \\
\hline $\mathrm{Na}$ & $6.07514 \mathrm{Na}$ & 1.47 & 0.02 & $\mathrm{Na}$ & $1.628116 \mathrm{Na}$ & 0.45 & 0.02 & $\mathrm{Na}$ & $\mathrm{ONa}$ & & 0 \\
\hline $\mathrm{Mg}$ & $0 \mathrm{Mg}$ & 0 & 0 & $\mathrm{Mg}$ & $0 \mathrm{Mg}$ & 0 & 0 & $\mathrm{Mg}$ & $\mathrm{OMg}$ & 0 & 0 \\
\hline Al & $9.603746 \mathrm{Al}$ & 2.73 & 0.03 & Al & $2.335504 \mathrm{Al}$ & 0.75 & 0.02 & Al & $0 \mathrm{Al}$ & & 0 \\
\hline Si & $26.91561 \mathrm{Si}$ & 7.98 & 0.04 & $\mathrm{Si}$ & $12.25017 \mathrm{Si}$ & 4.09 & 0.03 & Si & $0.169372 \mathrm{Si}$ & 0.03 & 0.01 \\
\hline $\mathrm{P}$ & $O P$ & 0 & 0 & $\mathrm{P}$ & $7.186167 \mathrm{P}$ & 2.65 & 0.03 & $\mathrm{P}$ & $0.169372 \mathrm{P}$ & 0.03 & 0.01 \\
\hline $\mathrm{s}$ & os & 0 & 0 & $\mathrm{~s}$ & OS & 0 & 0 & $\mathrm{~s}$ & $49.69654 \mathrm{~S}$ & 10.05 & 0.05 \\
\hline K & $1.518785 \mathrm{~K}$ & 0.63 & 0.02 & $\mathrm{~K}$ & $0.931956 \mathrm{~K}$ & 0.43 & 0.02 & $\mathrm{~K}$ & $0 \mathrm{~K}$ & & 0 \\
\hline $\mathrm{Ca}$ & $0.593811 \mathrm{Ca}$ & 0.25 & 0.02 & $\mathrm{Ca}$ & $13.21581 \mathrm{Ca}$ & 6.31 & 0.05 & $\mathrm{Ca}$ & $0.112915 \mathrm{Ca}$ & 0.03 & 0.02 \\
\hline $\mathrm{Ti}$ & $0 \mathrm{Ti}$ & 0 & 0 & $\mathrm{Ti}$ & $0 \mathrm{Ti}$ & 0 & 0 & $\mathrm{Ti}$ & $0.084686 \mathrm{Ti}$ & 0.03 & 0.02 \\
\hline $\mathrm{Cr}$ & $0 \mathrm{Cr}$ & 0 & 0 & $\mathrm{Cr}$ & $0 \mathrm{Cr}$ & 0 & 0 & $\mathrm{Cr}$ & $0 \mathrm{Cr}$ & & 0 \\
\hline $\mathrm{Mn}$ & $0 \mathrm{Mn}$ & 0 & 0 & $\mathrm{Mn}$ & $0 \mathrm{Mn}$ & 0 & 0 & $\mathrm{Mn}$ & $0.155258 \mathrm{Mn}$ & 0.05 & 0.03 \\
\hline $\mathrm{Fe}$ & $0.102775 \mathrm{Fe}$ & 0.06 & 0.03 & $\mathrm{Fe}$ & $0.247024 \mathrm{Fe}$ & 0.16 & 0.03 & $\mathrm{Fe}$ & $49.61186 \mathrm{Fe}$ & 17.47 & 0.14 \\
\hline $\mathrm{Ni}$ & $0 \mathrm{Ni}$ & 0 & 0 & $\mathrm{Ni}$ & $0 \mathrm{Ni}$ & 0 & 0 & $\mathrm{Ni}$ & $0 \mathrm{Ni}$ & & 0 \\
\hline Ва & $0.125614 \mathrm{Ba}$ & 0.19 & 0.05 & Total & 100 Total & 26.68 & & Total & 100 Total & 27.69 & \\
\hline Total & 100 Total & 22.61 & & & & & & & & & \\
\hline \multicolumn{4}{|c|}{ Site 6} & \multicolumn{4}{|c|}{ Site 7} & \multicolumn{4}{|c|}{ Site 7} \\
\hline Spectrum 23 & Atomic \% Spectrum 23 & $\mathbf{W t} \%$ & Wt\% Sigma & Spectrum 24 & Atomic \% Spectrum 24 & $\mathbf{W}+\%$ & Wt\% Sigma & Spectrum 25 & Atomic \% Spectrum 25 & $\mathrm{Wt} \%$ & Wt\% Sigma \\
\hline 0 & 55.123670 & 10.26 & 0.08 & 0 & 52.629780 & $\begin{array}{l}8.84 \\
\end{array}$ & 0.07 & 0 & 54.663820 & $\begin{array}{l}9.87 \\
\end{array}$ & 0.08 \\
\hline $\mathrm{Na}$ & $6.200843 \mathrm{Na}$ & 1.66 & 0.02 & $\mathrm{Na}$ & $0.319452 \mathrm{Na}$ & 0.08 & 0.01 & $\mathrm{Na}$ & $2.256145 \mathrm{Na}$ & 0.59 & 0.02 \\
\hline $\mathrm{Mg}$ & $0 \mathrm{Mg}$ & 0 & 0 & $\mathrm{Mg}$ & $9.492299 \mathrm{Mg}$ & 2.42 & 0.02 & Mg & $0.101021 \mathrm{Mg}$ & 0.03 & 0.01 \\
\hline Al & $9.483643 \mathrm{Al}$ & 2.98 & 0.03 & Al & $1.312037 \mathrm{Al}$ & 0.37 & 0.01 & $\mathrm{Al}$ & $15.22056 \mathrm{Al}$ & 4.63 & 0.03 \\
\hline $\mathrm{Si}$ & $26.78673 \mathrm{Si}$ & 8.75 & 0.05 & $\mathrm{Si}$ & $22.76098 \mathrm{Si}$ & 6.71 & 0.04 & $\mathrm{Si}$ & $21.00123 \mathrm{Si}$ & 6.66 & 0.04 \\
\hline $\mathrm{P}$ & $O P$ & 0 & 0 & $\mathrm{P}$ & $O P$ & 0 & 0 & $\mathrm{P}$ & $O P$ & 0 & 0 \\
\hline s & $O S$ & 0 & 0 & $\mathrm{~s}$ & $0 \mathrm{~S}$ & 0 & 0 & $\mathrm{~s}$ & $O S$ & 0 & 0 \\
\hline K & $1.538812 \mathrm{~K}$ & 0.7 & 0.02 & $\mathrm{~K}$ & $0.034227 \mathrm{~K}$ & 0.02 & 0.01 & $\mathrm{~K}$ & $0.044898 \mathrm{~K}$ & 0.02 & 0.01 \\
\hline $\mathrm{Ca}$ & $0.626924 \mathrm{Ca}$ & 0.29 & 0.02 & $\mathrm{Ca}$ & $9.12721 \mathrm{Ca}$ & 3.84 & 0.04 & $\mathrm{Ca}$ & $6.510271 \mathrm{Ca}$ & 2.95 & 0.03 \\
\hline $\mathrm{Ti}$ & $0 \mathrm{Ti}$ & 0 & 0 & $\mathrm{Ti}$ & $0.296634 \mathrm{Ti}$ & 0.15 & 0.02 & $\mathrm{Ti}$ & $0 \mathrm{Ti}$ & 0 & 0 \\
\hline $\mathrm{Cr}$ & $0 \mathrm{Cr}$ & 0 & 0 & $\mathrm{Cr}$ & $0.11409 \mathrm{Cr}$ & 0.06 & 0.02 & $\mathrm{Cr}$ & $0 \mathrm{Cr}$ & 0 & 0 \\
\hline $\mathrm{Mn}$ & $0 \mathrm{Mn}$ & 0 & 0 & $\mathrm{Mn}$ & $0.045636 \mathrm{Mn}$ & 0.03 & 0.03 & $\mathrm{Mn}$ & $0 \mathrm{Mn}$ & 0 & 0 \\
\hline $\mathrm{Fe}$ & $0.102587 \mathrm{Fe}$ & 0.07 & 0.03 & $\mathrm{Fe}$ & $3.867655 \mathrm{Fe}$ & 2.26 & 0.06 & $\mathrm{Fe}$ & $0.202043 \mathrm{Fe}$ & 0.13 & 0.03 \\
\hline $\mathrm{Ni}$ & $0 \mathrm{Ni}$ & 0 & 0 & $\mathrm{Ni}$ & $0 \mathrm{Ni}$ & 0 & 0 & $\mathrm{Ni}$ & $0 \mathrm{Ni}$ & 0 & 0 \\
\hline Ва & $0.136783 \mathrm{Ba}$ & 0.21 & 0.05 & Total & 100 Total & 24.78 & & Total & 100 Total & 24.88 & \\
\hline Total & 100 Total & 24.92 & & & & & & & & & \\
\hline
\end{tabular}




\begin{tabular}{|c|c|c|c|c|c|c|c|c|c|c|c|}
\hline \multicolumn{4}{|c|}{ Site 7} & \multicolumn{4}{|c|}{ Site 7} & \multicolumn{4}{|c|}{ Site 7} \\
\hline $\mathrm{Na}$ & $0.323392 \mathrm{Na}$ & 0.07 & 0.01 & $\mathrm{Na}$ & $0.129397 \mathrm{Na}$ & 0.03 & 0.01 & $\mathrm{Na}$ & $3.271984 \mathrm{Na}$ & 0.84 & $4 \quad 0.02$ \\
\hline $\mathrm{Mg}$ & $2.970416 \mathrm{Mg}$ & 0.65 & 0.02 & $\mathrm{Mg}$ & $9.587107 \mathrm{Mg}$ & 2.44 & 0.03 & $\mathrm{Mg}$ & $0.636219 \mathrm{Mg}$ & 0.17 & 0.01 \\
\hline $\mathrm{Si}$ & $12.73206 \mathrm{Si}$ & 3.22 & 0.03 & $\mathrm{Si}$ & $22.62087 \mathrm{Si}$ & 6.65 & 0.04 & $\mathrm{Si}$ & $22.49489 \mathrm{Si}$ & 7.07 & 0.04 \\
\hline $\mathrm{P}$ & $1.054018 \mathrm{P}$ & 0.29 & 0.01 & $\mathrm{P}$ & $O P$ & 0 & 0 & $\mathrm{P}$ & $O P$ & 0 & 0 \\
\hline $\mathrm{s}$ & $O S$ & 0 & 0 & $\mathrm{~s}$ & $0.058817 \mathrm{~S}$ & 0.02 & 0.01 & $\mathrm{~s}$ & $O S$ & 0 & 0 \\
\hline K & $0.155707 \mathrm{~K}$ & 0.05 & 0.01 & K & $0 \mathrm{~K}$ & 0 & 0 & K & $0.159055 \mathrm{~K}$ & 0.07 & 0.01 \\
\hline $\mathrm{Cr}$ & $0 \mathrm{Cr}$ & 0 & 0 & $\mathrm{Cr}$ & $0 \mathrm{Cr}$ & 0 & 0 & $\mathrm{Cr}$ & $0 \mathrm{Cr}$ & 0 & 0 \\
\hline $\mathrm{Mn}$ & $0.19164 \mathrm{Mn}$ & 0.1 & 0.02 & $\mathrm{Mn}$ & $0.14116 \mathrm{Mn}$ & 0.08 & 0.03 & $\mathrm{Mn}$ & $0 \mathrm{Mn}$ & 0 & 0 \\
\hline $\mathrm{Fe}$ & $8.312373 \mathrm{Fe}$ & 4.17 & 0.06 & $\mathrm{Fe}$ & $4.634749 \mathrm{Fe}$ & 2.71 & 0.06 & $\mathrm{Fe}$ & $0.806635 \mathrm{Fe}$ & 0.5 & 0.04 \\
\hline $\mathrm{Ni}$ & $0 \mathrm{Ni}$ & 0 & 0 & $\mathrm{Ni}$ & $0 \mathrm{Ni}$ & 0 & 0 & $\mathrm{Ni}$ & $0 \mathrm{Ni}$ & 0 & 0 \\
\hline Total & 100 Total & 24.07 & & Total & 100 Total & 24.84 & & Total & 100 Total & 24.63 & \\
\hline \multicolumn{4}{|c|}{$\begin{array}{ll}\text { Site } 8 \\
\end{array}$} & \multicolumn{4}{|c|}{$\begin{array}{ll}\text { Site } 8 \\
\end{array}$} & \multicolumn{4}{|c|}{$\begin{array}{ll}\text { Site } 8 \\
\end{array}$} \\
\hline $\mathrm{Si}$ & $23.65654 \mathrm{Si}$ & 6.62 & 0.04 & $\mathrm{Al}$ & $0.079763 \mathrm{Al}$ & 0.02 & 0.01 & $\mathrm{Si}$ & $23.71315 \mathrm{Si}$ & 7.36 & 0.04 \\
\hline $\mathrm{p}$ & $0 \mathrm{P}$ & & 0 & $\mathrm{Si}$ & $0.535552 \mathrm{Si}$ & 0.14 & 0.01 & $\mathrm{p}$ & $0.222274 \mathrm{P}$ & 0.07 & 0.01 \\
\hline $\mathrm{s}$ & os & & 0 & $\mathrm{p}$ & $16.78441 \mathrm{P}$ & 4.89 & 0.04 & $\mathrm{~s}$ & $0.116986 \mathrm{~S}$ & 0.04 & 0.01 \\
\hline $\mathrm{K}$ & $0.046729 \mathrm{~K}$ & 0.02 & 0.01 & s & os & 0 & 0 & $\mathrm{~K}$ & $1.111371 \mathrm{~K}$ & 0.48 & 0.02 \\
\hline $\mathrm{Ca}$ & $9.509346 \mathrm{Ca}$ & 3.8 & 0.04 & $\mathrm{~K}$ & $0.182315 \mathrm{~K}$ & 0.07 & 0.01 & $\mathrm{Ca}$ & $2.994853 \mathrm{Ca}$ & 1.33 & 0.03 \\
\hline $\mathrm{Ti}$ & $0.116822 \mathrm{Ti}$ & 0.06 & 0.02 & $\mathrm{Ca}$ & $28.2361 \mathrm{Ca}$ & 10.64 & 0.06 & $\mathrm{Ti}$ & $0.701919 \mathrm{Ti}$ & 0.37 & 0.02 \\
\hline $\mathrm{Cr}$ & $0 \mathrm{Cr}$ & & 0 & $\mathrm{Ti}$ & $0 \mathrm{Ti}$ & 0 & 0 & $\mathrm{Cr}$ & $0 \mathrm{Cr}$ & 0 & 0 \\
\hline $\mathrm{Mn}$ & $0.794393 \mathrm{Mn}$ & 0.44 & 0.03 & $\mathrm{Cr}$ & $0 \mathrm{Cr}$ & 0 & 0 & $\mathrm{Mn}$ & $0.093589 \mathrm{Mn}$ & 0.05 & 0.03 \\
\hline $\mathrm{Fe}$ & $8.703271 \mathrm{Fe}$ & 4.85 & 0.07 & $\mathrm{Mn}$ & $0 \mathrm{Mn}$ & 0 & 0 & $\mathrm{Fe}$ & $3.614881 \mathrm{Fe}$ & 2.23 & 0.06 \\
\hline $\mathrm{Ni}$ & $0 \mathrm{Ni}$ & & 0 & $\mathrm{Fe}$ & $0.250684 \mathrm{Fe}$ & 0.13 & 0.03 & $\mathrm{Ni}$ & $0 \mathrm{Ni}$ & 0 & 0 \\
\hline \multirow[t]{3}{*}{ Total } & 100 Total & 25.33 & & $\mathrm{Ni}$ & $0 \mathrm{Ni}$ & 0 & 0 & Total & 100 Total & 24.95 & \\
\hline & & & & $\mathrm{Ce}$ & $0.136737 \mathrm{Ce}$ & 0.17 & 0.05 & & & & \\
\hline & & & & Total & 100 Total & 24.27 & & & & & \\
\hline
\end{tabular}

\begin{tabular}{|c|c|c|c|c|c|c|c|}
\hline \multicolumn{4}{|c|}{ Site 8} & \multicolumn{4}{|c|}{ Site 8} \\
\hline Spectrum 32 & Atomic \% Spectrum 32 & Wt\% & Wt\% Sigma & Spectrum 33 & Atomic \% Spectrum 33 & Wt\% & Wt\% Sigma \\
\hline 0 & 58.582530 & 10.7 & 0.08 & 0 & 58.384150 & 11.09 & 0.08 \\
\hline $\mathrm{Na}$ & $2.307511 \mathrm{Na}$ & 0.61 & 0.02 & $\mathrm{Na}$ & $2.345216 \mathrm{Na}$ & 0.64 & 0.02 \\
\hline $\mathrm{Mg}$ & $1.000706 \mathrm{Mg}$ & 0.28 & 0.01 & $\mathrm{Mg}$ & $0.480769 \mathrm{Mg}$ & 0.14 & 0.01 \\
\hline $\mathrm{Al}$ & $6.604662 \mathrm{Al}$ & 2.03 & 0.02 & $\mathrm{Al}$ & $5.417448 \mathrm{Al}$ & 1.73 & 0.02 \\
\hline $\mathrm{Si}$ & $25.2178 \mathrm{Si}$ & 8.09 & 0.04 & $\mathrm{Si}$ & $27.83771 \mathrm{Si}$ & 9.28 & 0.05 \\
\hline$P$ & $0.153049 \mathrm{P}$ & 0.05 & 0.01 & $P$ & $O P$ & 0 & 0 \\
\hline S & $0.058865 \mathrm{~S}$ & 0.02 & 0.01 & S & $0 \mathrm{~S}$ & 0 & 0 \\
\hline K & $1.554038 \mathrm{~K}$ & 0.7 & 0.02 & K & $1.923077 \mathrm{~K}$ & 0.89 & 0.02 \\
\hline $\mathrm{Ca}$ & $1.895456 \mathrm{Ca}$ & 0.86 & 0.02 & $\mathrm{Ca}$ & $1.371951 \mathrm{Ca}$ & 0.65 & 0.02 \\
\hline $\mathrm{Ti}$ & $0.423829 \mathrm{Ti}$ & 0.23 & 0.02 & $\mathrm{Ti}$ & $0.105535 \mathrm{Ti}$ & 0.06 & 0.02 \\
\hline $\mathrm{Cr}$ & $0 \mathrm{Cr}$ & 0 & 0 & $\mathrm{Cr}$ & $0 \mathrm{Cr}$ & 0 & 0 \\
\hline $\mathrm{Mn}$ & $0.094184 \mathrm{Mn}$ & 0.06 & 0.03 & $\mathrm{Mn}$ & $0.140713 \mathrm{Mn}$ & 0.09 & 0.03 \\
\hline $\mathrm{Fe}$ & $2.10737 \mathrm{Fe}$ & 1.34 & 0.05 & $\mathrm{Fe}$ & $1.993433 \mathrm{Fe}$ & 1.32 & 0.05 \\
\hline $\mathrm{Ni}$ & $0 \mathrm{Ni}$ & 0 & 0 & $\mathrm{Ni}$ & $0 \mathrm{Ni}$ & 0 & 0 \\
\hline Total & 100 Total & 24.97 & & Total & 100 Total & 25.89 & \\
\hline
\end{tabular}


APPENDIX I: SEM and EMP Data for Feldspar Calculations

\begin{tabular}{|c|c|c|c|c|c|c|c|c|c|}
\hline \multicolumn{10}{|c|}{ Compare SEM and EMP Feldspar Info } \\
\hline \multirow[b]{2}{*}{ Sample } & \multirow[b]{2}{*}{ Site } & \multirow{2}{*}{\multicolumn{2}{|c|}{\begin{tabular}{ccc}
\multicolumn{2}{c}{ SEM } \\
(High K) & (High Ca) \\
Or & An \\
\end{tabular}}} & \multirow{2}{*}{$\begin{array}{c}\text { (High Na) } \\
\text { Ab }\end{array}$} & \multirow[b]{2}{*}{ Total } & \multirow[b]{2}{*}{ Site-Location } & \multirow{2}{*}{$\begin{array}{l}\text { EMP } \\
\text { (High K) } \\
\text { Or }\end{array}$} & \multirow{2}{*}{$\begin{array}{c}\text { (High Ca) } \\
\text { An }\end{array}$} & \multirow{2}{*}{$\begin{array}{c}\text { (High Na) } \\
\text { Ab }\end{array}$} \\
\hline & & & & & & & & & \\
\hline HS154A & 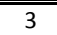 & 18.95 & 5.99 & 75.06 & 100 & "HS-15-4a_site3_ctr-rim & 6.7 & 1818.72 & 747.6 \\
\hline HS154A & 3 & & & & & HS-15-4a_site3_ctr-rim & 17.8 & 6.11 & 76.1 \\
\hline HS154A & 4 & 6.08 & 36.60 & 57.32 & 100 & & & & \\
\hline HS154A & 5 & 8.09 & 17.72 & 74.20 & 100 & HS-15-4a_site5_ctr-rim & 13.9 & 9.47 & 76.6 \\
\hline HS154A & 5 & 21.71 & 6.39 & 71.89 & 100 & HS-15-4a_site5_ctr-rim & 28.2 & 4.07 & 67.8 \\
\hline HS154A & 6 & 18.39 & 6.58 & 75.03 & 100 & HS-15-4a_site6_ctr-rim & 19.1 & 5.92 & 75.0 \\
\hline HS154A & 6 & 18.55 & 6.91 & 74.55 & 100 & HS-15-4a_site6_ctr-rim & 22.3 & 6.78 & 70.9 \\
\hline HS154A & 8 & & & & & HS-15-4a_site8_ctr-rim & 0.9 & 59.93 & 39.2 \\
\hline HS154A & 8 & & & & & HS-15-4a_site8_ctr-rim & 1.1 & 61.81 & 37.1 \\
\hline HS154A & 9 & & & & & HS-15-4a_site9_ctr-rim & 4.6 & 24.48 & 70.9 \\
\hline HS154A & 9 & & & & & HS-15-4a_site9_ctr-rim & 5.7 & 22.36 & 71.9 \\
\hline HS154A & 10 & & & & & HS-15-4a_site10_ctr-rim & 17.6 & 5.66 & 76.8 \\
\hline HS154A & 10 & & & & & HS-15-4a_site10_ctr-rim & 18.4 & 6.60 & 75.0 \\
\hline HS154A & 11 & & & & & HS-15-4a_site11_ctr-rim & 17.1 & 6.51 & 76.4 \\
\hline HS154A & 11 & & & & & HS-15-4a_site11_ctr-rim & 18.7 & 6.67 & 74.6 \\
\hline HS154C & 1 & 20.14 & 7.48 & 72.37 & 100 & & & & \\
\hline HS154C & 1 & 18.87 & 9.86 & 71.27 & 100 & & & & \\
\hline HS154C & 3 & 0.00 & 96.14 & 3.86 & 100 & & & & \\
\hline HS154C & 3 & 17.15 & 8.16 & 74.69 & 100 & & & & \\
\hline HS154C & 4 & 18.26 & 6.60 & 75.14 & 100 & & & & \\
\hline HS154C & 5 & 19.41 & 6.09 & 74.50 & 100 & & & & \\
\hline HS154C & 6 & 2.44 & 39.11 & 58.46 & 100 & & & & \\
\hline HS154C & 6 & 2.12 & 43.24 & 54.64 & 100 & & & & \\
\hline HS154D & 1 & 30.14 & 5.49 & 64.37 & 100 & HS-15-4d_site1_ctr-rim & 28.00 & 4.09 & 67.93 \\
\hline HS154D & 1 & & & & & HS-15-4d_site1_ctr-rim & 28.89 & 4.94 & 66.20 \\
\hline HS154D & 2 & 37.66 & 14.29 & 48.05 & 100 & & & & \\
\hline HS154D & 2 & 62.71 & 3.61 & 33.68 & 100 & & & & \\
\hline HS154D & 3 & 47.54 & 0.00 & 52.46 & 100 & HS-15-4d_site3_ctr-rim & 44.43 & 2.56 & 53.03 \\
\hline HS154D & 3 & & & & & HS-15-4d_site3_ctr-rim & 47.79 & 3.31 & 48.93 \\
\hline HS154D & 4 & 7.69 & 48.72 & 43.59 & 100 & & & & \\
\hline
\end{tabular}




\begin{tabular}{|c|c|c|c|c|c|c|c|c|c|}
\hline \multicolumn{10}{|c|}{ Compare SEM and EMP Feldspar Info (Cont'd) } \\
\hline \multirow[b]{3}{*}{ Sample } & \multirow[b]{3}{*}{ Site } & \multirow{3}{*}{\multicolumn{2}{|c|}{\begin{tabular}{cc}
\multicolumn{2}{c}{ SEM } \\
(High K) & (High Ca) \\
Or & An \\
\end{tabular}}} & \multirow{3}{*}{$\begin{array}{c}\text { (High Na) } \\
\mathrm{Ab}\end{array}$} & \multirow[b]{3}{*}{ Total } & \multirow[b]{3}{*}{ Site-Location } & \multirow{3}{*}{$\begin{array}{l}\text { EMP } \\
\text { (High K) } \\
\text { Or }\end{array}$} & \multirow{3}{*}{$\begin{array}{c}\text { (High Ca) } \\
\text { An }\end{array}$} & \multirow{3}{*}{$\begin{array}{c}\text { (High Na) } \\
\text { Ab }\end{array}$} \\
\hline & & & & & & & & & \\
\hline & & & & & & & & & \\
\hline HS154D & 5 & "51.01 & 0.00 & 48.99 & 100 & "HS-15-4d_site5_ctr-rim & 23.55 & 6.79 & 69.68 \\
\hline HS154D & 5 & & & & & HS-15-4d_site5_ctr-rim & 25.99 & 7.94 & 66.10 \\
\hline HS154D & 6 & 1.78 & 62.19 & 36.03 & 100 & HS-15-4d_site6a_ctr-rim & 0.96 & 60.88 & 38.16 \\
\hline HS154D & 6 & 1.29 & 55.78 & 42.93 & 100 & HS-15-4d_site6a_ctr-rim & 1.08 & 61.78 & 37.14 \\
\hline HS154D & 6 & 1.56 & 56.76 & 41.68 & 100 & HS-15-4d_site6b_ctr-rim & 1.12 & 58.97 & 39.91 \\
\hline HS154D & 6 & 1.63 & 62.42 & 35.96 & 100 & HS-15-4d_site6b_ctr-rim & 1.02 & 60.78 & 38.20 \\
\hline HS154D & 9 & 18.75 & 6.40 & 74.85 & 100 & HS-15-4d_site9_ctr-rim & 18.01 & 6.30 & 75.71 \\
\hline HS154D & 9 & 19.17 & 6.39 & 74.44 & 100 & HS-15-4d_site9_ctr-rim & 23.67 & 7.23 & 69.12 \\
\hline HS154D & 10 & 34.93 & 5.49 & 59.58 & 100 & HS-15-4d_site10_ctr-rim & 31.28 & 4.23 & 64.52 \\
\hline HS154D & 10 & & & & & HS-15-4d_site10_ctr-rim & 33.36 & 5.02 & 61.65 \\
\hline HS154D & 11 & 2.37 & 40.67 & 56.96 & 100 & HS-15-4d_site11_ctr-rim & 2.63 & 37.09 & 60.29 \\
\hline HS154D & 11 & 2.15 & 43.34 & 54.51 & 100 & HS-15-4d_site11_ctr-rim & 2.37 & 42.98 & 54.65 \\
\hline HS154D & 12 & & & & & HS-15-4d_site12_ctr-rim & 1.12 & 61.16 & 37.73 \\
\hline HS154D & 12 & & & & & HS-15-4d_site12_ctr-rim & 1.03 & 61.43 & 37.53 \\
\hline HS154D & 13 & & & & & HS-15-4d_site13_ctr-rim & 27.83 & 3.54 & 68.65 \\
\hline HS154D & 13 & & & & & HS-15-4d_site13_ctr-rim & 31.81 & 5.12 & 63.10 \\
\hline HS154E & 1 & 38.64 & 5.61 & 55.76 & 100 & & & & \\
\hline HS154E & 1 & 43.71 & 4.72 & 51.57 & 100 & & & & \\
\hline HS154E & 2 & 39.00 & 4.43 & 56.57 & 100 & & & & \\
\hline HS154E & 3 & 48.75 & 4.00 & 47.25 & 100 & & & & \\
\hline HS154E & 4 & 26.18 & 8.24 & 65.59 & 100 & & & & \\
\hline HS154E & 5 & 18.23 & 7.10 & 74.66 & 100 & & & & \\
\hline HS154E & 6 & 18.04 & 7.05 & 74.91 & 100 & & & & \\
\hline HS154E & 6 & 66.02 & 6.02 & 27.96 & 100 & & & & \\
\hline HS154E & 7 & 17.36 & 7.99 & 74.66 & 100 & HS-15-4e_site7_ctr-rim & 16.14 & 6.97 & 76.91 \\
\hline HS154E & 7 & & & & & HS-15-4e_site7_ctr-rim & 18.35 & 7.25 & 74.42 \\
\hline HS154E & 8 & 2.65 & 40.14 & 57.21 & 100 & & & & \\
\hline HS154E & 9 & 19.05 & 6.79 & 74.17 & 100 & HS-15-4e_site9_ctr-rim & 17.66 & 5.58 & 76.77 \\
\hline HS154E & 9 & 18.88 & 6.53 & 74.58 & 100 & HS-15-4e_site9_ctr-rim & 16.94 & 5.99 & 77.09 \\
\hline HS154E & 10 & 1.26 & 63.13 & 35.61 & 100 & HS-15-4e_site10_ctr-rim & 1.10 & 60.64 & 38.26 \\
\hline
\end{tabular}




\begin{tabular}{|c|c|c|c|c|c|c|c|c|c|}
\hline \multicolumn{10}{|c|}{ Compare SEM and EMP Feldspar Info (Cont'd) } \\
\hline \multirow[b]{2}{*}{ Sample } & \multirow[b]{2}{*}{ Site } & \multirow{2}{*}{\multicolumn{2}{|c|}{\begin{tabular}{ccc}
\multicolumn{2}{c}{ SEM } \\
(High K) & (High Ca) \\
Or & An \\
\end{tabular}}} & \multirow{2}{*}{$\begin{array}{c}\text { (High Na) } \\
\mathrm{Ab}\end{array}$} & \multirow[b]{2}{*}{ Total } & \multirow[b]{2}{*}{ Site-Location } & \multirow{2}{*}{$\begin{array}{l}\text { EMP } \\
\text { (High K) } \\
\text { Or }\end{array}$} & \multirow{2}{*}{$\begin{array}{c}\text { (High Ca) } \\
\text { An }\end{array}$} & \multirow{2}{*}{$\begin{array}{c}\text { (High Na) } \\
\quad \text { Ab }\end{array}$} \\
\hline & & & & & & & & & \\
\hline$\overline{\mathrm{HSS154E}}$ & 10 & 1.25 & 646.29 & 34.46 & 100 & HS-15-4e_site10_ctr-rim & $\begin{array}{ll}1.06 \\
\end{array}$ & 200.36 & 38.58 \\
\hline HS154E & 12 & & & & & HS-15-4e_site12_ctr-rim & 3.57 & 25.82 & 70.61 \\
\hline HS154E & 12 & & & & & HS-15-4e_site12_ctr-rim & 3.00 & 34.51 & 62.49 \\
\hline HS154E & 13 & & & & & HS-15-4e_site13_ctr-rim & 17.13 & 6.66 & 76.23 \\
\hline HS154E & 13 & & & & & HS-15-4e_site13_ctr-rim & 19.39 & 8.12 & 72.50 \\
\hline MS145 & 2 & 18.21 & 6.30 & 75.49 & 100.00 & MS-14-5_site2_ctr-rim & 5.95 & 77.51 & 16.55 \\
\hline MS145 & 2 & 17.44 & 7.36 & 75.20 & 100.00 & MS-14-5_site2_ctr-rim & 5.72 & 77.77 & 16.53 \\
\hline MS145 & 3 & 0.34 & 95.58 & 4.08 & 100.00 & MS-14-5_site3_ctr-rim & 5.85 & 76.93 & 17.23 \\
\hline MS145 & 3 & 0.00 & 99.64 & 0.36 & 100.00 & MS-14-5_site3_ctr-rim & 6.32 & 76.93 & 16.77 \\
\hline MS145 & 4 & 0.00 & 96.51 & 3.49 & 100.00 & MS-14-5_site4_ctr-rim & 5.21 & 76.17 & 18.64 \\
\hline MS145 & 4 & 0.00 & 96.92 & 3.08 & 100.00 & MS-14-5_site4_ctr-rim & 6.43 & 76.52 & 17.06 \\
\hline MS145 & 6 & & & & & MS-14-5_site6_ctr-rim & 16.22 & 76.14 & 7.65 \\
\hline MS145 & 6 & & & & & MS-14-5_site6_ctr-rim & 7.11 & 77.06 & 15.84 \\
\hline MS145 & 7 & & & & & MS-14-5_site7_ctr-rim & 5.57 & 77.25 & 17.19 \\
\hline MS145 & 7 & & & & & MS-14-5_site7_ctr-rim & 5.63 & 77.44 & 16.94 \\
\hline MS145 & 8 & & & & & MS-14-5_site8_ctr-rim & 5.93 & 77.31 & 16.77 \\
\hline MS145 & 8 & & & & & MS-14-5_site8_ctr-rim & 6.37 & 76.91 & 16.74 \\
\hline MS145 & 9 & & & & & MS-14-5_site9_ctr-rim & 5.97 & 76.32 & 17.73 \\
\hline MS145 & 9 & & & & & MS-14-5_site9_ctr-rim & 6.76 & 77.01 & 16.24 \\
\hline MS145 & 10 & & & & & MS-14-5_site10_ctr-rim & 2.97 & 74.39 & 22.66 \\
\hline MS145 & 10 & & & & & MS-14-5_site10_ctr-rim & 2.91 & 73.88 & 23.23 \\
\hline MS145 & 11 & & & & & MS-14-5_site11_ctr-rim & 6.10 & 76.58 & 17.34 \\
\hline MS145 & 11 & & & & & MS-14-5_site11_ctr-rim & 6.51 & 77.18 & 16.33 \\
\hline MS145 & 12 & & & & & MS-14-5_site12_ctr-rim & 5.99 & 76.70 & 17.33 \\
\hline MS145 & 12 & & & & & MS-14-5_site12_ctr-rim & 6.34 & 77.07 & 16.61 \\
\hline MS145 & 13 & & & & & MS-14-5_site13_ctr-rim & 2.71 & 73.50 & 23.81 \\
\hline MS145 & 13 & & & & & MS-14-5_site13_ctr-rim & 3.04 & 73.70 & 23.28 \\
\hline MS145 & 14 & & & & & MS-14-5_site14_ctr-rim & 5.00 & 77.65 & 17.36 \\
\hline MS145 & 14 & & & & & MS-14-5_site14_ctr-rim & 6.03 & 77.13 & 16.86 \\
\hline MS145 & 15 & & & & & MS-14-5_site15_ctr-rim & 21.39 & 72.93 & 5.68 \\
\hline
\end{tabular}




\begin{tabular}{|c|c|c|c|c|c|c|c|c|c|}
\hline \multicolumn{10}{|c|}{ Compare SEM and EMP Feldspar Info (Cont'd) } \\
\hline \multirow[b]{3}{*}{ Sample } & \multirow[b]{3}{*}{ Site } & \multirow{3}{*}{\multicolumn{2}{|c|}{$\begin{array}{cc} & \text { SEM } \\
\text { (High K) } & \text { (High Ca) } \\
\text { Or } & \text { An }\end{array}$}} & \multirow{3}{*}{$\begin{array}{c}\text { (High Na) } \\
\text { Ab }\end{array}$} & \multirow[b]{3}{*}{ Total } & \multirow{3}{*}{\multicolumn{2}{|c|}{$\begin{array}{l}\text { EMP } \\
\text { (High K) } \\
\text { Or } \\
\end{array}$}} & \multirow{3}{*}{$\begin{array}{c}\text { (High Ca) } \\
\text { An }\end{array}$} & \multirow{3}{*}{$\begin{array}{c}\text { (High Na) } \\
\text { Ab }\end{array}$} \\
\hline & & & & & & & & & \\
\hline & & & & & & & & & \\
\hline MS145 & 15 & & & & & "MS-14-5_site15_ctr-rim & 6.23 & 76.87 & 16.92 \\
\hline MS145 & 16 & & & & & MS-14-5_site16_ctr-rim & 6.04 & 77.05 & 16.93 \\
\hline MS145 & 16 & & & & & MS-14-5_site16_ctr-rim & 6.10 & 76.75 & 17.16 \\
\hline MS145 & 17 & & & & & MS-14-5_site17_ctr-rim & 13.08 & 78.03 & 8.90 \\
\hline MS145 & 17 & & & & & MS-14-5_site17_ctr-rim & 6.04 & 76.36 & 17.62 \\
\hline MS145 & 18 & & & & & MS-14-5_site18_ctr-rim & 66.91 & 31.63 & 1.46 \\
\hline MS145 & 18 & & & & & MS-14-5_site18_ctr-rim & 62.20 & 36.08 & 1.72 \\
\hline MS145 & 19 & & & & & MS-14-5_site19_ctr-rim & 70.61 & 28.55 & 0.84 \\
\hline MS145 & 19 & & & & & MS-14-5_site19_ctr-rim & 70.86 & 28.51 & 0.63 \\
\hline MS145 & 20 & & & & & MS-14-5_site20_ctr-rim & 15.31 & 77.06 & 7.64 \\
\hline MS145 & 20 & & & & & MS-14-5_site20_ctr-rim & 6.06 & 76.78 & 17.17 \\
\hline MS145 & 20 & & & & & MS-14-5_site20_glass1 & 0.44 & 37.30 & 62.30 \\
\hline MS145 & 20 & & & & & MS-14-5_site20_glass1 & 0.74 & 42.37 & 56.92 \\
\hline MS145 & 20 & & & & & MS-14-5_site20_glass1 & 0.54 & 34.78 & 64.71 \\
\hline MS145 & 20 & & & & & MS-14-5_site20_glass2 & 5.90 & 34.85 & 59.28 \\
\hline MS145 & 20 & & & & & MS-14-5_site20_glass2 & 1.06 & 43.91 & 55.06 \\
\hline MS145 & 20 & & & & & MS-14-5_site20_glass2 & 1.12 & 39.76 & 59.15 \\
\hline MS143 & 1 & 35.46 & 3.71 & 60.82 & 100 & & & & \\
\hline MS143 & 2 & 19.01 & 6.87 & 74.12 & 100 & & & & \\
\hline MS143 & 2 & 16.34 & 6.37 & 77.29 & 100 & & & & \\
\hline MS143 & 2 & 18.70 & 6.33 & 74.96 & 100 & & & & \\
\hline MS143 & 3 & 1.02 & 63.82 & 35.16 & 100 & & & & \\
\hline MS143 & 3 & 0.88 & 80.23 & 18.89 & 100 & & & & \\
\hline MS143 & 3 & 1.31 & 64.05 & 34.64 & 100 & & & & \\
\hline MS143 & 3 & 1.04 & 65.76 & 33.20 & 100 & & & & \\
\hline MS143 & 4 & 33.93 & 61.31 & 4.76 & 100 & & & & \\
\hline MS143 & 4 & 14.12 & 70.99 & 14.89 & 100 & & & & \\
\hline MS143 & 5 & 4.29 & 24.38 & 71.33 & 100 & & & & \\
\hline MS143 & 6 & 19.03 & 6.29 & 74.68 & 100 & & & & \\
\hline MS143 & 6 & 18.10 & 7.52 & 74.38 & 100 & & & & \\
\hline
\end{tabular}




\begin{tabular}{|c|c|c|c|c|c|c|c|c|c|}
\hline \multicolumn{10}{|c|}{ Compare SEM and EMP Feldspar Info (Cont'd) } \\
\hline & & (High K) & $\begin{array}{l}\text { SEM } \\
\text { (High Ca) }\end{array}$ & (High Na) & & & $\begin{array}{l}\text { EMP } \\
\text { (High K) }\end{array}$ & (High Ca) & (High Na) \\
\hline Sample & Site & Or & An & $\mathbf{A b}$ & Total & Site-Location & Or & An & $\mathrm{Ab}$ \\
\hline MS143 & 77 & 8.97 & 222.86 & 688.16 & 100 & & & & \\
\hline MS143 & 7 & 8.00 & 25.10 & 66.90 & 100 & & & & \\
\hline MS143 & 7 & 7.63 & 24.97 & 67.41 & 100 & & & & \\
\hline HS1505 & 2 & 3.21 & 35.36 & 61.42 & 100 & & & & \\
\hline HS1505 & 2 & 2.57 & 35.43 & 62.00 & 100 & & & & \\
\hline HS1505 & 3 & 48.13 & 0.00 & 51.88 & 100 & & & & \\
\hline HS1505 & 3 & 15.57 & 5.07 & 79.36 & 100 & & & & \\
\hline HS1505 & 3 & 2.19 & 46.84 & 50.97 & 100 & & & & \\
\hline HS1505 & 4 & 19.09 & 6.12 & 74.79 & 100 & & & & \\
\hline HS1505 & 4 & 18.47 & 6.91 & 74.61 & 100 & & & & \\
\hline HS1505 & 5 & 0.00 & 74.05 & 25.95 & 100 & & & & \\
\hline HS1505 & 5 & 0.00 & 71.01 & 28.99 & 100 & & & & \\
\hline HS1505 & 7 & 8.84 & 22.21 & 68.95 & 100 & HS-15-5_site7_ctr-rim & 6.66 & 25.39 & 67.96 \\
\hline HS1505 & 7 & & & & & HS-15-5_site7_ctr-rim & 10.06 & 19.79 & 70.16 \\
\hline HS1505 & 7 & & & & & HS-15-5_site7_ctr-rim & 7.33 & 22.62 & 70.06 \\
\hline HS1505 & 9 & 19.24 & 6.55 & 74.22 & 100 & & & & \\
\hline HS1505 & 10 & 75.98 & 0.00 & 24.02 & 100 & & & & \\
\hline HS1505 & 11 & 19.52 & 6.06 & 74.43 & 100 & HS-15-5_site11_ctr-rim & 17.61 & 5.46 & 76.94 \\
\hline HS1505 & 11 & 53.67 & 7.91 & 38.42 & 100 & HS-15-5_site11_ctr-rim & 17.52 & 5.95 & 76.55 \\
\hline HS1505 & 14 & & & & & HS-15-5_site14_ctr-rim & 22.95 & 3 & 74.07 \\
\hline HS1505 & 14 & & & & & HS-15-5_site14_ctr-rim & 22.37 & 2.83 & 74.83 \\
\hline HS1505 & 15 & & & & & HS-15-5_site15_ctr-rim & 16.77 & 6.02 & 77.23 \\
\hline HS1505 & 15 & & & & & HS-15-5_site15_ctr-rim & 15.73 & 6.41 & 77.87 \\
\hline HS1505 & 16 & & & & & HS-15-5_site16_ctr-rim & 6.12 & 20.56 & 73.32 \\
\hline HS1505 & 16 & & & & & HS-15-5_site16_ctr-rim & 16.49 & 7.04 & 76.48 \\
\hline HS1505 & 17 & & & & & HS-15-5_site17_ctr-rim & 18.09 & 5.76 & 76.16 \\
\hline HS1505 & 17 & & & & & HS-15-5_site17_ctr-rim & 17.03 & 6.27 & 76.72 \\
\hline HS1505 & 18 & & & & & HS-15-5_site18_ctr-rim & 15.99 & 7.02 & 77.01 \\
\hline HS1505 & 18 & & & & & HS-15-5_site18_ctr-rim & 17.05 & 6.34 & 76.63 \\
\hline HS1505 & 19 & & & & & HS-15-5_site19_ctr-rim & 15.84 & 6.99 & 77.18 \\
\hline
\end{tabular}




\begin{tabular}{|c|c|c|c|c|c|c|c|c|c|}
\hline \multicolumn{10}{|c|}{ Compare SEM and EMP Feldspar Info (Cont'd) } \\
\hline \multirow[b]{3}{*}{ Sample } & \multirow[b]{3}{*}{ Site } & \multirow{3}{*}{$\begin{array}{l}\text { (High K) } \\
\text { Or }\end{array}$} & \multirow{3}{*}{$\begin{array}{l}\text { SEM } \\
\text { (High Ca) } \\
\text { An }\end{array}$} & \multirow{3}{*}{$\begin{array}{c}\text { (High Na) } \\
\text { Ab }\end{array}$} & \multirow[b]{3}{*}{ Total } & & \multirow{3}{*}{$\begin{array}{l}\text { EMP } \\
\text { (High K) } \\
\text { Or }\end{array}$} & \multirow{3}{*}{$\begin{array}{c}\text { (High Ca) } \\
\text { An }\end{array}$} & \multirow{3}{*}{$\begin{array}{c}(\mathrm{High} \mathrm{Na}) \\
\mathrm{Ab}\end{array}$} \\
\hline & & & & & & & & & \\
\hline & & & & & & Site-Location & & & \\
\hline HS1505 & 1919 & & & & & " HS-15-5_site19_ctr-rim & 15.6 & 6.42 & 78 \\
\hline HS1505 & 20 & & & & & HS-15-5_site20_ctr-rim & 16.25 & 6.73 & 77.03 \\
\hline HS1505 & 20 & & & & & HS-15-5_site20_ctr-rim & 15.82 & 5.91 & 78.29 \\
\hline HS1505 & 21 & & & & & HS-15-5_site21_ctr-rim & 16.69 & 6.58 & 76.74 \\
\hline HS1505 & 21 & & & & & HS-15-5_site21_ctr-rim & 16.41 & 6.04 & 77.57 \\
\hline MS137 & 1 & 20.77 & 79.23 & 0.00 & 100 & & & & \\
\hline MS137 & 1 & 19.87 & 80.13 & 0.00 & 100 & & & & \\
\hline MS137 & 1 & 21.48 & 78.52 & 0.00 & 100 & & & & \\
\hline MS137 & 2 & 15.93 & 3.58 & 80.49 & 100 & & & & \\
\hline MS137 & 2 & 9.92 & 11.43 & 78.66 & 100 & & & & \\
\hline MS137 & 2 & 8.75 & 0.00 & 91.25 & 100 & & & & \\
\hline MS137 & 3 & 15.37 & 3.72 & 80.92 & 100 & & & & \\
\hline MS137 & 3 & 15.55 & 3.23 & 81.22 & 100 & & & & \\
\hline MS137 & 3 & 19.86 & 80.14 & 0.00 & 100 & & & & \\
\hline MS137 & 6 & 17.31 & 2.86 & 79.83 & 100 & & & & \\
\hline MS137 & 6 & 17.63 & 2.59 & 79.78 & 100 & & & & \\
\hline MS137 & 7 & 14.16 & 3.88 & 81.95 & 100 & & & & \\
\hline MS137 & 7 & 55.69 & 4.71 & 39.61 & 100 & & & & \\
\hline MS137 & 7 & 15.38 & 3.72 & 80.89 & 100 & & & & \\
\hline MS137 & 8 & 16.58 & 2.97 & 80.45 & 100 & & & & \\
\hline MS137 & 8 & 15.57 & 3.61 & 80.82 & 100 & & & & \\
\hline MS137 & 8 & 14.91 & 3.76 & 81.33 & 100 & & & & \\
\hline MS137 & 9 & 14.06 & 4.07 & 81.87 & 100 & & & & \\
\hline MS146 & 3 & 18.34 & 6.86 & 74.79 & 100 & MS-14-6_site3_ctr-rim & 17.96 & 77.49 & 4.55 \\
\hline MS146 & 3 & & & & & MS-14-6_site3_ctr-rim & 21.35 & 74.18 & 4.48 \\
\hline MS146 & 4 & 1.67 & 62.21 & 36.12 & 100 & MS-14-6_site4_ctr-rim & 60.93 & 38.06 & 1.01 \\
\hline MS146 & 4 & 1.43 & 63.07 & 35.50 & 100 & MS-14-6_site4_ctr-rim & 62.03 & 36.93 & 1.04 \\
\hline MS146 & 4 & 16.83 & 67.12 & 16.05 & 100 & & & & \\
\hline MS146 & 5 & 19.77 & 6.40 & 73.84 & 100 & MS-14-6_site5_ctr-rim & 16.85 & 75.80 & 7.36 \\
\hline MS146 & 5 & 18.55 & 7.25 & 74.20 & 100 & MS-14-6_site5_ctr-rim & 6.52 & 76.75 & 16.74 \\
\hline
\end{tabular}




\begin{tabular}{|c|c|c|c|c|c|c|c|c|c|}
\hline \multicolumn{10}{|c|}{ Compare SEM and EMP Feldspar Info (Cont'd) } \\
\hline \multirow[b]{3}{*}{ Sample } & \multirow[b]{3}{*}{ Site } & \multirow{3}{*}{\multicolumn{2}{|c|}{$\begin{array}{cc} & \text { SEM } \\
\text { (High K) } & \text { (High Ca) } \\
\text { Or } & \text { An } \\
\end{array}$}} & \multirow{3}{*}{$\begin{array}{c}\text { (High Na) } \\
\mathrm{Ab}\end{array}$} & \multirow[b]{3}{*}{ Total } & \multirow{3}{*}{\multicolumn{2}{|c|}{$\begin{array}{l}\text { EMP } \\
\text { (High K) } \\
\text { Or }\end{array}$}} & \multirow{3}{*}{$\begin{array}{c}\text { (High Ca) } \\
\text { An }\end{array}$} & \multirow{3}{*}{$\begin{array}{c}\text { (High Na) } \\
\text { Ab }\end{array}$} \\
\hline & & & & & & & & & \\
\hline & & & & & & & & & \\
\hline MS146 & 5 & 5.91 & 83.77 & 10.32 & 100 & "MS-14-6_site5_ctr-rim & 6.27 & 76.64 & 17.11 \\
\hline MS146 & 5 & & & & & MS-14-6_site5_ctr-rim & 6.18 & 76.30 & 17.53 \\
\hline MS146 & 5 & & & & & MS-14-6_site5_ctr-rim & 2.79 & 45.96 & 51.28 \\
\hline MS146 & 5 & & & & & MS-14-6_site5_ctr-rim & 4.28 & 48.43 & 47.31 \\
\hline MS146 & 6 & 19.07 & 4.10 & 76.84 & 100 & MS-14-6_site6_ctr-rim & 5.93 & 77.25 & 16.83 \\
\hline MS146 & 6 & & & & & MS-14-6_site6_ctr-rim & 6.50 & 76.70 & 16.82 \\
\hline MS146 & 7 & 0.36 & 96.27 & 3.37 & 100 & & & & \\
\hline MS146 & 7 & 0.51 & 73.89 & 25.61 & 100 & & & & \\
\hline MS146 & 7 & 1.85 & 94.30 & 3.85 & 100 & & & & \\
\hline MS146 & 7 & 0.00 & 98.52 & 1.48 & 100 & & & & \\
\hline MS146 & 7 & 1.84 & 60.21 & 37.94 & 100 & & & & \\
\hline MS146 & 8 & 19.83 & 53.44 & 26.72 & 100 & MS-14-6_site8_ctr-rim & 6.12 & 76.82 & 17.07 \\
\hline MS146 & 8 & 26.99 & 32.92 & 40.08 & 100 & MS-14-6_site8_ctr-rim & 6.22 & 76.39 & 17.41 \\
\hline MS146 & 8 & 34.10 & 24.32 & 41.58 & 100 & & & & \\
\hline MS146 & 9 & & & & & MS-14-6_site9_ctr-rim & 6.96 & 76.26 & 16.79 \\
\hline MS146 & 9 & & & & & MS-14-6_site9_ctr-rim & 16.77 & 76.69 & 6.55 \\
\hline MS146 & 10 & & & & & MS-14-6_site10_ctr-rim & 61.75 & 37.21 & 1.04 \\
\hline MS146 & 10 & & & & & MS-14-6_site10_ctr-rim & 63.29 & 35.58 & 1.13 \\
\hline MS146 & 10 & & & & & MS-14-6_site10_mafic glass & 52.86 & 23.28 & 23.86 \\
\hline MS146 & 10 & & & & & MS-14-6_site10_mafic glass & 49.88 & 28.11 & 22.02 \\
\hline MS146 & 10 & & & & & MS-14-6_site10_silicic glass & 3.38 & 55.60 & 41.04 \\
\hline MS146 & 10 & & & & & MS-14-6_site10_silicic glass & 3.96 & 55.11 & 40.96 \\
\hline MS146 & 11 & & & & & MS-14-6_site11_ctr-rim & 18.70 & 75.95 & 5.35 \\
\hline MS146 & 11 & & & & & MS-14-6_site11_ctr-rim & 17.91 & 76.65 & 5.44 \\
\hline MS146 & 11 & & & & & MS-14-6_site11_ctr-rim & 59.40 & 19.87 & 20.73 \\
\hline MS146 & 11 & & & & & MS-14-6_site11_ctr-rim & 49.63 & 26.16 & 24.21 \\
\hline MS146 & 12 & & & & & MS-14-6_site12_ctr-rim & 6.44 & 82.52 & 11.05 \\
\hline MS146 & 12 & & & & & MS-14-6_site12_ctr-rim & 6.44 & 76.95 & 16.63 \\
\hline MS146 & 12 & & & & & MS-14-6_site12_ctr-rim & 4.23 & 55.36 & 40.44 \\
\hline MS146 & 12 & & & & & MS-14-6_site12_ctr-rim & 4.01 & 53.00 & 43.01 \\
\hline
\end{tabular}

\begin{tabular}{|c|c|c|c|c|c|c|c|c|c|}
\hline \multicolumn{10}{|c|}{ Compare SEM and EMP Feldspar Info (Cont'd) } \\
\hline \multirow[b]{3}{*}{ Sample } & \multirow[b]{3}{*}{ Site } & \multirow{3}{*}{\multicolumn{2}{|c|}{$\begin{array}{cc}\text { SEM } \\
\text { (High K) } & \text { (High Ca) } \\
\text { Or } & \text { An } \\
\end{array}$}} & \multirow{3}{*}{$\begin{array}{c}\text { (High Na) } \\
\mathrm{Ab} \\
\end{array}$} & \multirow[b]{3}{*}{ Total } & \multirow{3}{*}{\multicolumn{2}{|c|}{$\begin{array}{l}\text { EMP } \\
\text { (High K) } \\
\text { Or } \\
\end{array}$}} & \multirow{3}{*}{$\begin{array}{c}\text { (High Ca) } \\
\text { An } \\
\end{array}$} & \multirow{3}{*}{$\begin{array}{c}\text { (High } \mathrm{Na} \text { ) } \\
\mathrm{Ab}\end{array}$} \\
\hline & & & & & & & & & \\
\hline & & & & & & & & & \\
\hline MS146 & 12 & & & & & "MS-14-6_site12_ctr-rim & 35.36 & 43.46 & 21.19 \\
\hline MS146 & 12 & & & & & MS-14-6_site12_ctr-rim & 48.24 & 36.03 & 15.74 \\
\hline MS146 & 13 & & & & & MS-14-6_site13_ctr-rim & 83.94 & 0.00 & 16.06 \\
\hline MS146 & 14 & & & & & MS-14-6_site14_ctr-rim & 24.07 & 72.18 & 3.75 \\
\hline MS146 & 14 & & & & & MS-14-6_site14_ctr-rim & 24.35 & 71.61 & 4.05 \\
\hline MS146 & 15 & & & & & MS-14-6_site15_ctr-rim & 60.63 & 38.30 & 1.07 \\
\hline MS146 & 15 & & & & & MS-14-6_site15_ctr-rim & 62.28 & 36.77 & 0.95 \\
\hline MS146 & 16 & & & & & MS-14-6_site16_ctr-rim & 21.84 & 74.11 & 4.06 \\
\hline MS146 & 16 & & & & & MS-14-6_site16_ctr-rim & 24.05 & 72.02 & 3.93 \\
\hline
\end{tabular}




\section{APPENDIX J: SEM and EMP Data for Pyroxene Calculations, Combined}

\begin{tabular}{|c|c|c|c|c|c|c|c|c|c|}
\hline \multicolumn{10}{|c|}{ Compare SEM and EMP Pyroxene Info } \\
\hline \multirow[b]{3}{*}{ Sample } & \multirow{3}{*}{ Site } & \multirow{3}{*}{$\begin{array}{c}\text { (High Ca) } \\
\text { Wo }\end{array}$} & \multirow{3}{*}{$\begin{array}{l}\text { SEM } \\
\text { (High Mg) } \\
\quad \text { En }\end{array}$} & \multirow{3}{*}{$\begin{array}{c}\text { (High Fe) } \\
\text { Fs }\end{array}$} & \multirow[b]{3}{*}{ Total } & \multirow{3}{*}{\multicolumn{2}{|c|}{$\begin{array}{l}\text { EMP } \\
\text { (High Ca) } \\
\text { Wo }\end{array}$}} & \multirow{3}{*}{$\begin{array}{c}\text { (High Mg) } \\
\text { En }\end{array}$} & \multirow{3}{*}{$\begin{array}{c}\text { (High Fe) } \\
\text { Fs }\end{array}$} \\
\hline & & & & & & & & & \\
\hline & & & & & & & & & \\
\hline HS154a & 2 & 38.83 & 40.90 & 20.27 & 100 & & & & \\
\hline HS154a & 3 & 42.02 & 19.88 & 38.10 & 100 & & & & \\
\hline HS154a & 4 & 32.44 & 19.07 & 48.50 & 100 & & & & \\
\hline HS154a & 5 & 42.09 & 19.62 & 38.28 & 100 & & & & \\
\hline HS154a & 5 & 42.03 & 19.54 & 38.43 & 100 & & & & \\
\hline HS154a & 7 & 42.22 & 19.82 & 37.96 & 100 & & & & \\
\hline HS154a & 7 & 41.90 & 19.63 & 38.47 & 100 & & & & \\
\hline HS154c & 2 & 16.70 & 6.79 & 76.52 & 100 & HS-15-4c_P2_ctr-rim & 41.19 & 15.52 & 43.29 \\
\hline HS154c & 2 & 42.58 & 18.46 & 38.96 & 100 & HS-15-4c_P2_ctr-rim & 42.47 & 20.60 & 36.94 \\
\hline HS154c & 3 & 42.58 & 19.12 & 38.30 & 100 & & & & \\
\hline HS154c & & & & & & HS-15-4c_P4_ctr-rim & 42.33 & 20.73 & 36.94 \\
\hline HS154c & & & & & & HS-15-4c_P4_ctr-rim & 42.47 & 20.89 & 36.64 \\
\hline HS154c & & & & & & HS-15-4c_P4_ctr-rim & 42.07 & 20.37 & 37.56 \\
\hline HS154c & & & & & & HS-15-4c_P4_ctr-rim & 95.23 & 0.28 & 4.49 \\
\hline HS154c & & & & & & HS-15-4c_P4_ctr-rim & 0.02 & 1.20 & 98.78 \\
\hline HS154c & & & & & & HS-15-4c_P4_ctr-rim & 0.09 & 1.23 & 98.68 \\
\hline HS154c & & & & & & HS-15-4c_P4_ctr-rim & 0.36 & 1.21 & 98.43 \\
\hline HS154c & & & & & & HS-15-4c_P4_ctr-rim & 0.05 & 1.06 & 98.89 \\
\hline HS154c & 7 & 41.65 & 19.81 & 38.54 & 100 & HS-15-4c_P7ab_ctr-rim & 42.27 & 21.23 & 36.51 \\
\hline HS154c & 7 & 42.12 & 19.70 & 38.19 & 100 & HS-15-4c_P7ab_ctr-rim & 41.76 & 20.95 & 37.29 \\
\hline HS154c & & & & & & HS-15-4c_P7ab_ctr-rim & 0.10 & 1.41 & 98.49 \\
\hline HS154c & & & & & & HS-15-4c_P7ab_ctr-rim & 0.03 & 1.48 & 98.49 \\
\hline HS154c & & & & & & HS-15-4c_P7ab_ctr-rim & 42.31 & 19.98 & 37.71 \\
\hline HS154c & & & & & & HS-15-4c_P7ab_ctr-rim & 42.50 & 20.25 & 37.24 \\
\hline HS154c & & & & & & HS-15-4c_P7ab_ctr-rim & 33.17 & 25.19 & 41.64 \\
\hline HS154c & & & & & & HS-15-4c_P7ab_ctr-rim & 32.44 & 24.20 & 43.36 \\
\hline HS154c & 9 & 42.65 & 19.25 & 38.10 & 100 & HS-15-4c_P9_ctr-rim & 42.96 & 20.09 & 36.95 \\
\hline HS154c & & & & & & HS-15-4c_P9_ctr-rim & 41.97 & 20.43 & 37.60 \\
\hline HS154c & & & & & & HS-15-4c_P9_ctr-rim & 0.00 & 1.27 & 98.73 \\
\hline
\end{tabular}




\begin{tabular}{|c|c|c|c|c|c|c|c|c|c|}
\hline \multicolumn{10}{|c|}{ Compare SEM and EMP Pyroxene Info (Cont'd) } \\
\hline \multirow[b]{2}{*}{ Sample } & & (High Ca) & SEM & (High Fe) & & & $\begin{array}{l}\text { EMP } \\
\text { (High Ca) }\end{array}$ & (High Mg) & (High Fe) \\
\hline & Site & Wo & En & $\mathrm{Fs}$ & Total & Site-Location & Wo & En & $\mathrm{Fs}$ \\
\hline HS154c & 10 & 42.98 & 19.54 & 37.48 & 100 & & & & \\
\hline HS154c & 10 & 42.36 & 19.23 & 38.41 & 100 & & & & \\
\hline HS154c & & & & & & HS-15-4c_P12_ctr-rim & 41.68 & 20.67 & 37.64 \\
\hline HS154c & & & & & & HS-15-4c_P12_ctr-rim & 42.24 & 20.59 & 37.17 \\
\hline HS154c & & & & & & HS-15-4c_P13_ctr-rim & 38.32 & 42.54 & 19.14 \\
\hline HS154c & & & & & & HS-15-4c_P13_ctr-rim & 40.08 & 42.02 & 17.90 \\
\hline HS154c & & & & & & HS-15-4c_P13_ctr-rim & 39.90 & 42.53 & 17.58 \\
\hline HS154c & & & & & & HS-15-4c_P13_ctr-rim & 52.57 & 1.91 & 45.52 \\
\hline HS154c & & & & & & HS-15-4c_P13_ctr-rim & 39.02 & 6.54 & 54.44 \\
\hline HS154c & & & & & & HS-15-4c_P14_ctr-rim & 39.16 & 37.05 & 23.79 \\
\hline HS154c & & & & & & HS-15-4c_P14_ctr-rim & 40.35 & 25.12 & 34.53 \\
\hline HS154c & & & & & & HS-15-4c_P14_ctr-rim & 0.20 & 1.66 & 98.14 \\
\hline HS154c & & & & & & HS-15-4c_P14_ctr-rim & 0.16 & 1.72 & 98.12 \\
\hline HS154c & & & & & & HS-15-4c_P15_ctr-rim & 42.78 & 20.44 & 36.78 \\
\hline HS154c & & & & & & HS-15-4c_P15_ctr-rim & 42.14 & 20.76 & 37.10 \\
\hline HS154c & & & & & & HS-15-4c_P15_ctr-rim & 0.05 & 1.82 & 98.13 \\
\hline HS154c & & & & & & HS-15-4c_P15_ctr-rim & 0.06 & 1.89 & 98.05 \\
\hline HS154c & & & & & & HS-15-4c_P15_ctr-rim & 16.14 & 5.64 & 78.22 \\
\hline HS154c & & & & & & HS-15-4c_P15_ctr-rim & 20.92 & 5.17 & 73.91 \\
\hline HS154c & & & & & & HS-15-4c_P16_ctr-rim & 42.03 & 20.70 & 37.27 \\
\hline HS154c & & & & & & HS-15-4c_P16_ctr-rim & 42.36 & 20.47 & 37.17 \\
\hline HS154c & & & & & & HS-15-4c_P16_ctr-rim & 42.52 & 20.50 & 36.98 \\
\hline HS154c & & & & & & HS-15-4c_P17_ctr-rim & 42.44 & 20.33 & 37.24 \\
\hline HS154c & & & & & & HS-15-4c_P17_ctr-rim & 41.87 & 20.46 & 37.67 \\
\hline HS154c & & & & & & HS-15-4c_P18abc_ctr-rim & 0.58 & 21.27 & 78.15 \\
\hline HS154c & & & & & & HS-15-4c_P18abc_ctr-rim & 0.60 & 20.97 & 78.43 \\
\hline HS154c & & & & & & HS-15-4c_P18abc_ctr-rim & 0.62 & 21.36 & 78.02 \\
\hline HS154c & & & & & & HS-15-4c_P18abc_ctr-rim & 0.57 & 21.09 & 78.34 \\
\hline HS154c & & & & & & HS-15-4c_P18abc_ctr-rim & 0.68 & 20.93 & 78.39 \\
\hline HS154c & & & & & & HS-15-4c_P18abc_ctr-rim & 0.63 & 21.16 & 78.21 \\
\hline
\end{tabular}




\begin{tabular}{|c|c|c|c|c|c|c|c|c|c|}
\hline \multicolumn{10}{|c|}{ Compare SEM and EMP Pyroxene Info (Cont'd) } \\
\hline \multirow[b]{3}{*}{ Sample } & \multirow[b]{3}{*}{ Site } & \multirow{3}{*}{\multicolumn{2}{|c|}{$\begin{array}{cc} & \text { SEM } \\
\text { (High Ca) } & \text { (High Mg) } \\
\text { Wo } & \text { En } \\
\end{array}$}} & \multirow{3}{*}{$\begin{array}{c}\text { (High Fe) } \\
\text { Fs }\end{array}$} & \multirow[b]{3}{*}{ Total } & \multirow{2}{*}{\multicolumn{2}{|c|}{$\begin{array}{l}\text { EMP } \\
\text { (High Ca) }\end{array}$}} & \multirow{3}{*}{$\begin{array}{c}\text { (High Mg) } \\
\text { En }\end{array}$} & \multirow{3}{*}{$\begin{array}{c}\text { (High Fe) } \\
\text { Fs } \\
\end{array}$} \\
\hline & & & & & & & & & \\
\hline & & & & & & Site-Location & Wo & & \\
\hline HS154c & & & & & & "HS-15-4c_P18abc_ctr-rim & 0.83 & 18.82 & 80.36 \\
\hline HS154c & & & & & & HS-15-4c_P18abc_ctr-rim & 0.59 & 21.27 & 78.14 \\
\hline HS154c & & & & & & HS-15-4c_P18abc_ctr-rim & 0.60 & 21.02 & 78.38 \\
\hline HS154c & & & & & & HS-15-4c_P18abc_ctr-rim & 0.66 & 20.44 & 78.90 \\
\hline HS154c & & & & & & HS-15-4c_P18abc_ctr-rim & 95.18 & 1.15 & 3.67 \\
\hline HS154c & & & & & & HS-15-4c_P18abc_ctr-rim & 96.19 & 0.00 & 3.81 \\
\hline HS154c & & & & & & HS-15-4c_P19ab_ctr-rim & 42.24 & 20.60 & 37.16 \\
\hline HS154c & & & & & & HS-15-4c_P19ab_ctr-rim & 42.25 & 20.71 & 37.03 \\
\hline HS154c & & & & & & HS-15-4c_P19ab_ctr-rim & 42.63 & 20.30 & 37.07 \\
\hline HS154c & & & & & & HS-15-4c_P19ab_ctr-rim & 41.97 & 20.53 & 37.50 \\
\hline HS154c & & & & & & HS-15-4c_P20_ctr-rim & 38.26 & 37.40 & 24.34 \\
\hline HS154c & & & & & & HS-15-4c_P20_ctr-rim & 36.03 & 39.57 & 24.40 \\
\hline HS154c & & & & & & HS-15-4c_P20_ctr-rim & 0.02 & 4.36 & 95.62 \\
\hline HS154c & & & & & & HS-15-4c_P20_ctr-rim & 0.03 & 3.98 & 95.99 \\
\hline HS154c & & & & & & HS-15-4c_P20_ctr-rim & 1.40 & 1.03 & 97.57 \\
\hline HS154c & & & & & & HS-15-4c_P20_ctr-rim & 1.84 & 0.99 & 97.17 \\
\hline HS154d & 5 & & & & & HS-15-4d_P5_ctr-rim & 40.59 & 45.87 & 13.54 \\
\hline HS154d & 5 & & & & & HS-15-4d_P5_ctr-rim & 40.38 & 45.96 & 13.65 \\
\hline HS154d & 5 & & & & & HS-15-4d_P5_ctr-rim & 40.74 & 45.64 & 13.61 \\
\hline HS154d & 7 & 42.37 & 19.65 & 37.98 & 100 & HS-15-4d_P7_ctr-rim & 42.49 & 20.83 & 36.69 \\
\hline HS154d & 7 & 42.87 & 19.72 & 37.41 & 100 & HS-15-4d_P7_ctr-rim & 42.49 & 20.35 & 37.16 \\
\hline HS154d & 7 & & & & & HS-15-4d_P7_ctr-rim & 42.25 & 20.61 & 37.13 \\
\hline HS154d & 12 & & & & & HS-15-4d_P12_ctr-rim & 38.17 & 26.53 & 35.30 \\
\hline HS154d & 12 & & & & & HS-15-4d_P12_ctr-rim & 36.77 & 27.00 & 36.23 \\
\hline HS154d & 12 & & & & & HS-15-4d_P12_ctr-rim & 35.39 & 26.91 & 37.69 \\
\hline HS154e & 2 & 37.54 & 5.66 & 56.81 & 100 & & & & \\
\hline HS154e & 4 & 42.23 & 19.85 & 37.92 & 100 & HS-15-4e_P4_ctr-rim & 41.89 & 20.76 & 37.36 \\
\hline HS154e & 4 & 43.23 & 18.40 & 38.38 & 100 & HS-15-4e_P4_ctr-rim & 42.41 & 20.59 & 37.00 \\
\hline HS154e & & & & & & HS-15-4e_P4_ctr-rim & 43.01 & 20.42 & 36.57 \\
\hline HS154e & 5 & 41.81 & 19.45 & 38.74 & 100 & HS-15-4e_P5abc_ctr-rim & 42.10 & 19.78 & 38.12 \\
\hline
\end{tabular}




\begin{tabular}{|c|c|c|c|c|c|c|c|c|c|}
\hline \multicolumn{10}{|c|}{ Compare SEM and EMP Pyroxene Info (Cont'd) } \\
\hline \multirow[b]{3}{*}{ Sample } & \multirow[b]{3}{*}{ Site } & \multirow{3}{*}{$\begin{array}{c}\text { (High Ca) } \\
\text { Wo }\end{array}$} & \multirow{3}{*}{$\begin{array}{l}\text { SEM } \\
\text { (High Mg) } \\
\quad \text { En }\end{array}$} & \multirow{3}{*}{$\begin{array}{c}\text { (High Fe) } \\
\text { Fs }\end{array}$} & \multirow[b]{3}{*}{ Total } & \multirow{3}{*}{\multicolumn{2}{|c|}{$\begin{array}{l}\text { EMP } \\
\text { (High Ca) } \\
\text { Wo } \\
\end{array}$}} & \multirow{3}{*}{$\begin{array}{c}\text { (High Mg) } \\
\text { En }\end{array}$} & \multirow{3}{*}{$\begin{array}{c}\text { (High Fe) } \\
\text { Fs }\end{array}$} \\
\hline & & & & & & & & & \\
\hline & & & & & & & & & \\
\hline HS154e & 5 & 42.08 & 19.09 & 38.84 & 100 & "HS-15-4e_P5abc_ctr-rim & 42.29 & 20.72 & 36.99 \\
\hline HS154e & 5 & 42.39 & 19.68 & 37.93 & 100 & HS-15-4e_P5abc_ctr-rim & 42.32 & 20.68 & 37.01 \\
\hline HS154e & 5 & 43.01 & 19.82 & 37.17 & 100 & HS-15-4e_P5abc_ctr-rim & 41.49 & 20.69 & 37.82 \\
\hline HS154e & & & & & & HS-15-4e_P5abc_ctr-rim & 42.56 & 20.47 & 36.97 \\
\hline HS154e & & & & & & HS-15-4e_P5abc_ctr-rim & 42.22 & 20.47 & 37.30 \\
\hline HS154e & 8 & 41.73 & 17.56 & 40.71 & 100 & & & & \\
\hline HS154e & 11 & 42.67 & 19.64 & 37.70 & 100 & HS-15-4e_P11_ctr-rim & 42.03 & 23.27 & 34.69 \\
\hline HS154e & & & & & & HS-15-4e_P11_ctr-rim & 42.36 & 20.93 & 36.71 \\
\hline HS154e & & & & & & HS-15-4e_P11_ctr-rim & 42.40 & 20.61 & 36.99 \\
\hline HS154e & & & & & & HS-15-4e_P11_ctr-rim & 0.06 & 1.60 & 98.34 \\
\hline HS154e & & & & & & HS-15-4e_P11_ctr-rim & 0.05 & 1.52 & 98.44 \\
\hline HS154e & & & & & & HS-15-4e_P11_ctr-rim & 0.05 & 1.51 & 98.44 \\
\hline HS154e & & & & & & HS-15-4e_P11_ctr-rim & 0.01 & 1.44 & 98.55 \\
\hline HS154e & & & & & & HS-15-4e_P12_ctr-rim & 35.13 & 24.54 & 40.33 \\
\hline HS154e & & & & & & HS-15-4e_P12_ctr-rim & 39.33 & 24.77 & 35.90 \\
\hline HS154e & & & & & & HS-15-4e_P12_ctr-rim & 41.03 & 22.00 & 36.97 \\
\hline HS1505 & 5 & 33.70 & 29.26 & 37.05 & 100 & & & & \\
\hline HS1505 & 6 & 39.59 & 37.14 & 23.27 & 100 & & & & \\
\hline HS1505 & 8 & 6.79 & 80.88 & 12.34 & 100 & & & & \\
\hline HS1505 & 8 & 6.15 & 83.57 & 10.28 & 100 & & & & \\
\hline HS1505 & 8 & 4.62 & 84.94 & 10.44 & 100 & & & & \\
\hline HS1505 & & & & & & HS-15-5_P22_ctr-rim & 43.64 & 42.88 & 13.48 \\
\hline HS1505 & & & & & & HS-15-5_P22_ctr-rim & 43.81 & 42.81 & 13.38 \\
\hline MS137 & 4 & 48.83 & 0.00 & 51.17 & 100 & MS-13-7_P3_ & 95.69 & 2.33 & 1.99 \\
\hline MS137 & & & & & & MS-13-7_P3_ & 9.31 & 20.05 & 70.64 \\
\hline MS137 & & & & & & MS-13-7_P11_ & 12.68 & 15.52 & 71.80 \\
\hline MS137 & & & & & & MS-13-7_P11_ & 16.89 & 14.99 & 68.11 \\
\hline MS137 & & & & & & MS-13-7_P11_ & 0.16 & 0.15 & 99.69 \\
\hline MS137 & & & & & & MS-13-7_P11_ & 0.10 & 0.08 & 99.82 \\
\hline MS137 & & & & & & MS-13-7_P12_ctr-rim & 48.63 & 35.33 & 16.05 \\
\hline
\end{tabular}




\begin{tabular}{|c|c|c|c|c|c|c|c|c|c|}
\hline \multicolumn{10}{|c|}{ Compare SEM and EMP Pyroxene Info (Cont'd) } \\
\hline \multirow[b]{2}{*}{ Sample } & & (High Ca) & $\begin{array}{l}\text { SEM } \\
\text { (High Mg) }\end{array}$ & (High Fe) & & & $\begin{array}{l}\text { EMP } \\
\text { (High Ca) }\end{array}$ & (High Mg) & (High Fe) \\
\hline & Site & Wo & En & Fs & Total & Site-Location & Wo & En & Fs \\
\hline MS137 & & & & & & MS-13-7_P12_ctr-rim & 488.23 & 34.61 & 17.16 \\
\hline MS137 & & & & & & MS-13-7_P12_ctr-rim & 47.08 & 29.28 & 23.64 \\
\hline MS137 & & & & & & MS-13-7_P13_ctr-rim & 39.29 & 42.86 & 17.85 \\
\hline MS137 & & & & & & MS-13-7_P13_ctr-rim & 39.35 & 40.27 & 20.38 \\
\hline MS137 & & & & & & MS-13-7_P13_ctr-rim & 39.07 & 43.53 & 17.40 \\
\hline MS137 & & & & & & MS-13-7_P13_ctr-rim & 0.02 & 8.72 & 91.25 \\
\hline MS137 & & & & & & MS-13-7_P13_ctr-rim & 1.41 & 3.71 & 94.88 \\
\hline MS137 & & & & & & MS-13-7_P13_ctr-rim & 0.08 & 8.35 & 91.57 \\
\hline MS137 & & & & & & MS-13-7_P13_ctr-rim & 2.40 & 1.21 & 96.40 \\
\hline MS137 & & & & & & MS-13-7_P14_ctr-rim & 44.64 & 0.71 & 54.65 \\
\hline MS137 & & & & & & MS-13-7_P14_ctr-rim & 44.63 & 0.66 & 54.71 \\
\hline MS137 & & & & & & MS-13-7_P14_ctr-rim & 44.43 & 0.73 & 54.84 \\
\hline MS137 & & & & & & MS-13-7_P15_ctr-rim & 3.54 & 68.10 & 28.37 \\
\hline MS137 & & & & & & MS-13-7_P15_ctr-rim & 39.92 & 43.54 & 16.55 \\
\hline MS137 & & & & & & MS-13-7_P15_ctr-rim & 39.56 & 43.75 & 16.68 \\
\hline MS137 & & & & & & MS-13-7_P15_ctr-rim & 1.09 & 14.25 & 84.66 \\
\hline MS137 & & & & & & MS-13-7_P15_ctr-rim & 0.12 & 9.99 & 89.89 \\
\hline MS137 & & & & & & MS-13-7_P15_ctr-rim & 2.40 & 1.30 & 96.30 \\
\hline MS137 & & & & & & MS-13-7_P15_ctr-rim & 2.72 & 1.31 & 95.98 \\
\hline MS137 & & & & & & MS-13-7_P15_ctr-rim & 34.80 & 23.00 & 42.21 \\
\hline MS137 & & & & & & MS-13-7_P15_ctr-rim & 34.57 & 22.00 & 43.43 \\
\hline MS137 & & & & & & MS-13-7_P15_ctr-rim & 35.70 & 22.57 & 41.73 \\
\hline MS137 & & & & & & MS-13-7_F16_ctr-rim & 76.21 & 2.28 & 21.50 \\
\hline MS137 & & & & & & MS-13-7_F16_ctr-rim & 84.24 & 0.00 & 15.76 \\
\hline MS137 & & & & & & MS-13-7_F17_ctr-rim & 85.00 & 0.00 & 15.00 \\
\hline MS137 & & & & & & MS-13-7_F17_ctr-rim & 81.11 & 1.88 & 17.01 \\
\hline MS137 & & & & & & MS-13-7_F18_ctr-rim & 84.38 & 0.00 & 15.62 \\
\hline MS137 & & & & & & MS-13-7_F18_ctr-rim & 86.75 & 0.00 & 13.25 \\
\hline MS143 & & & & & & MS-14-3_P1_ctr-rim & 42.58 & 20.37 & 37.05 \\
\hline MS143 & & & & & & MS-14-3_P1_ctr-rim & 42.35 & 20.84 & 36.81 \\
\hline
\end{tabular}




\begin{tabular}{|c|c|c|c|c|c|c|c|c|c|}
\hline \multicolumn{10}{|c|}{ Compare SEM and EMP Pyroxene Info (Cont'd) } \\
\hline \multirow[b]{3}{*}{ Sample } & \multirow[b]{3}{*}{ Site } & \multirow{2}{*}{ (High Ca) } & \multirow{3}{*}{$\begin{array}{l}\text { SEM } \\
\text { (High Mg) } \\
\quad \text { En }\end{array}$} & \multirow{3}{*}{$\begin{array}{c}\text { (High Fe) } \\
\text { Fs }\end{array}$} & \multirow[b]{3}{*}{ Total } & \multirow{3}{*}{\multicolumn{2}{|c|}{$\begin{array}{l}\text { EMP } \\
\text { (High Ca) } \\
\text { Wo }\end{array}$}} & \multirow{3}{*}{$\begin{array}{c}\text { (High Mg) } \\
\text { En }\end{array}$} & \multirow{3}{*}{$\begin{array}{c}\text { (High Fe) } \\
\text { Fs }\end{array}$} \\
\hline & & & & & & & & & \\
\hline & & Wo & & & & & & & \\
\hline MS143 & & & & & & "MS-14-3_P1_ctr-rim & 42.24 & 20.48 & 37.29 \\
\hline MS143 & 3 & 2.09 & 54.69 & 43.22 & 100 & MS-14-3_P3_ctr-rim & 1.57 & 50.39 & 48.05 \\
\hline MS143 & & & & & & MS-14-3_P3_ctr-rim & 1.84 & 46.76 & 51.40 \\
\hline MS143 & & & & & & MS-14-3_P3_ctr-rim & 1.87 & 48.69 & 49.43 \\
\hline MS143 & 4 & 10.12 & 15.52 & 74.36 & 100 & & & & \\
\hline MS143 & 4 & 18.69 & 14.87 & 66.43 & 100 & & & & \\
\hline MS143 & & & & & & MS-14-3_P14_ctr-rim & 32.46 & 29.55 & 37.99 \\
\hline MS143 & & & & & & MS-14-3_P14_ctr-rim & 33.95 & 28.18 & 37.87 \\
\hline MS143 & & & & & & MS-14-3_P14_ctr-rim & 38.72 & 28.43 & 32.85 \\
\hline MS143 & & & & & & MS-14-3_P14_ctr-rim & 0.03 & 1.64 & 98.33 \\
\hline MS143 & & & & & & MS-14-3_P14_ctr-rim & 0.05 & 2.22 & 97.74 \\
\hline MS143 & & & & & & MS-14-3_P14_ctr-rim & 0.07 & 1.30 & 98.63 \\
\hline MS143 & & & & & & MS-14-3_P14_ctr-rim & 0.09 & 1.74 & 98.17 \\
\hline MS143 & & & & & & MS-14-3_P14_ctr-rim & 0.17 & 8.03 & 91.80 \\
\hline MS143 & & & & & & MS-14-3_P14_ctr-rim & 0.19 & 7.59 & 92.22 \\
\hline MS145 & 3 & 42.13 & 19.49 & 38.38 & 100 & & & & \\
\hline MS145 & 4 & 42.15 & 19.32 & 38.53 & 100 & MS-14-5_P4ab_ctr-rim & 41.00 & 18.36 & 40.64 \\
\hline MS145 & 4 & 42.52 & 19.67 & 37.82 & 100 & MS-14-5_P4ab_ctr-rim & 42.47 & 20.14 & 37.40 \\
\hline MS145 & & & & & & MS-14-5_P4ab_ctr-rim & 81.52 & 0.24 & 18.24 \\
\hline MS145 & & & & & & MS-14-5_P4ab_ctr-rim & 42.80 & 20.12 & 37.08 \\
\hline MS145 & & & & & & MS-14-5_P4ab_ctr-rim & 42.59 & 20.43 & 36.98 \\
\hline MS145 & & & & & & MS-14-5_P4ab_ctr-rim & 71.01 & 2.18 & 26.82 \\
\hline MS145 & 5 & 42.03 & 19.97 & 38.00 & 100 & & & & \\
\hline MS145 & 5 & 42.41 & 19.52 & 38.07 & 100 & & & & \\
\hline MS145 & & & & & & MS-14-5_p21_ctr-rim & 42.13 & 20.36 & 37.51 \\
\hline MS145 & & & & & & MS-14-5_p21_ctr-rim & 41.62 & 20.75 & 37.63 \\
\hline MS145 & & & & & & MS-14-5_p21_ctr-rim & 0.03 & 1.13 & 98.84 \\
\hline MS145 & & & & & & MS-14-5_p21_ctr-rim & 0.04 & 0.87 & 99.09 \\
\hline MS145 & & & & & & MS-14-5_P22_ctr-rim & 42.32 & 20.62 & 37.05 \\
\hline MS145 & & & & & & MS-14-5_P22_ctr-rim & 41.82 & 20.06 & 38.12 \\
\hline
\end{tabular}




\begin{tabular}{|c|c|c|c|c|c|c|c|c|c|}
\hline \multicolumn{10}{|c|}{ Compare SEM and EMP Pyroxene Info (Cont'd) } \\
\hline \multirow[b]{2}{*}{ Sample } & & (High Ca) & $\begin{array}{l}\text { SEM } \\
\text { (High Mg) }\end{array}$ & (High Fe) & & & $\begin{array}{l}\text { EMP } \\
\text { (High Ca) }\end{array}$ & (High Mg) & (High Fe) \\
\hline & Site & Wo & En & Fs & Total & Site-Location & Wo & En & Fs \\
\hline MS145 & & & & & & "MS-14-5_P23_ctr-rim & 42.70 & 20.49 & 36.81 \\
\hline MS145 & & & & & & MS-14-5_P23_ctr-rim & 42.60 & 20.14 & 37.25 \\
\hline MS145 & & & & & & MS-14-5_P23_ctr-rim & 41.90 & 20.25 & 37.84 \\
\hline MS145 & & & & & & MS-14-5_P23_ctr-rim & 0.02 & 0.89 & 99.09 \\
\hline MS145 & & & & & & MS-14-5_P23_ctr-rim & 0.03 & 0.95 & 99.03 \\
\hline MS145 & & & & & & MS-14-5_P24_ctr-rim & 43.08 & 20.69 & 36.24 \\
\hline MS145 & & & & & & MS-14-5_P24_ctr-rim & 42.68 & 20.76 & 36.57 \\
\hline MS145 & & & & & & MS-14-5_P25_ctr-rim & 42.38 & 20.66 & 36.96 \\
\hline MS145 & & & & & & MS-14-5_P25_ctr-rim & 42.31 & 20.39 & 37.31 \\
\hline MS145 & & & & & & MS-14-5_P26_ctr-rim & 39.91 & 22.43 & 37.66 \\
\hline MS145 & & & & & & MS-14-5_P26_ctr-rim & 37.74 & 22.99 & 39.27 \\
\hline MS145 & & & & & & MS-14-5_P26_ctr-rim & 41.65 & 20.50 & 37.85 \\
\hline MS145 & & & & & & MS-14-5_P27_ctr-rim & 42.49 & 20.14 & 37.37 \\
\hline MS145 & & & & & & MS-14-5_P27_ctr-rim & 42.92 & 20.24 & 36.84 \\
\hline MS145 & & & & & & MS-14-5_P27_ctr-rim & 42.59 & 20.70 & 36.71 \\
\hline MS145 & & & & & & MS-14-5_P27_ctr-rim & 3.01 & 3.70 & 93.29 \\
\hline MS145 & & & & & & MS-14-5_P27_ctr-rim & 1.95 & 0.25 & 97.80 \\
\hline MS146 & 3 & 43.22 & 19.10 & 37.69 & 100 & MS-14-6_P3ab_ctr-rim & 42.17 & 20.13 & 37.70 \\
\hline MS146 & 3 & 41.54 & 17.82 & 40.65 & 100 & MS-14-6_P3ab_ctr-rim & 42.26 & 20.41 & 37.33 \\
\hline MS146 & 3 & 83.89 & 4.76 & 11.35 & 100 & MS-14-6_P3ab_ctr-rim & 42.59 & 20.33 & 37.08 \\
\hline MS146 & 3 & 41.87 & 19.91 & 38.22 & 100 & MS-14-6_P3ab_ctr-rim & 42.04 & 18.71 & 39.25 \\
\hline MS146 & 5 & 40.14 & 20.38 & 39.48 & 100 & MS-14-6_P3ab_ctr-rim & 33.19 & 24.82 & 42.00 \\
\hline MS146 & 7 & 40.59 & 42.21 & 17.20 & 100 & MS-14-6_P3ab_ctr-rim & 32.28 & 26.24 & 41.48 \\
\hline MS146 & 7 & 41.27 & 15.46 & 43.27 & 100 & & & & \\
\hline MS146 & 7 & 37.65 & 42.03 & 20.32 & 100 & & & & \\
\hline MS146 & 8 & 42.20 & 19.18 & 38.62 & 100 & & & & \\
\hline MS146 & & & & & & MS-14-6_P9_ctr-rim & 42.15 & 20.70 & 37.15 \\
\hline MS146 & & & & & & MS-14-6_P9_ctr-rim & 42.04 & 21.00 & 36.96 \\
\hline MS146 & & & & & & MS-14-6_P9_ctr-rim & 0.01 & 1.06 & 98.93 \\
\hline MS146 & & & & & & MS-14-6_P9_ctr-rim & 0.00 & 1.13 & 98.87 \\
\hline
\end{tabular}




\begin{tabular}{|c|c|c|c|c|c|c|c|c|c|}
\hline \multicolumn{10}{|c|}{ Compare SEM and EMP Pyroxene Info (Cont'd) } \\
\hline \multirow[b]{3}{*}{ Sample } & \multirow{3}{*}{ Site } & \multirow{3}{*}{\multicolumn{2}{|c|}{$\begin{array}{cc}\text { SEM } \\
\text { (High Ca) } & \text { (High Mg) } \\
\text { Wo } & \text { En } \\
\end{array}$}} & \multirow{3}{*}{$\begin{array}{c}\text { (High Fe) } \\
\text { Fs }\end{array}$} & \multirow[b]{3}{*}{ Total } & \multirow{3}{*}{\multicolumn{2}{|c|}{$\begin{array}{l}\text { EMP } \\
\text { (High Ca) } \\
\text { Wo }\end{array}$}} & \multirow{3}{*}{$\begin{array}{c}\text { (High Mg) } \\
\text { En }\end{array}$} & \multirow{3}{*}{$\begin{array}{c}\text { (High Fe) } \\
\text { Fs }\end{array}$} \\
\hline & & & & & & & & & \\
\hline & & & & & & & & & \\
\hline MS146 & & & & & & MS-14-6_P9_ctr-rim & 15.72 & 3.82 & 80.47 \\
\hline MS146 & & & & & & MS-14-6_P9_ctr-rim & 20.60 & 1.60 & 77.80 \\
\hline MS146 & & & & & & MS-14-6_F10_ctr-rim & 95.37 & 0.37 & 4.26 \\
\hline MS146 & & & & & & MS-14-6_F10_ctr-rim & 95.30 & 0.66 & 4.03 \\
\hline MS146 & & & & & & MS-14-6_F10_ctr-rim & 94.67 & 0.72 & 4.61 \\
\hline MS146 & & & & & & MS-14-6_F10_ctr-rim & 84.67 & 0.00 & 15.33 \\
\hline MS146 & & & & & & MS-14-6_P11_ctr-rim & 42.44 & 20.43 & 37.13 \\
\hline MS146 & & & & & & MS-14-6_P11_ctr-rim & 42.32 & 19.99 & 37.69 \\
\hline MS146 & & & & & & MS-14-6_P11_ctr-rim & 21.25 & 3.41 & 75.34 \\
\hline MS146 & & & & & & MS-14-6_P11_ctr-rim & 18.30 & 3.19 & 78.50 \\
\hline MS146 & & & & & & MS-14-6_P11_ctr-rim & 33.90 & 25.11 & 40.99 \\
\hline MS146 & & & & & & MS-14-6_P11_ctr-rim & 34.32 & 24.63 & 41.05 \\
\hline MS146 & & & & & & MS-14-6_P11_ctr-rim & 0.04 & 0.94 & 99.01 \\
\hline MS146 & & & & & & MS-14-6_P11_ctr-rim & 0.23 & 1.15 & 98.62 \\
\hline MS146 & & & & & & MS-14-6_P12_ctr-rim & 42.24 & 20.80 & 36.97 \\
\hline MS146 & & & & & & MS-14-6_P12_ctr-rim & 42.68 & 20.37 & 36.94 \\
\hline MS146 & & & & & & MS-14-6_P12_ctr-rim & 0.10 & 1.12 & 98.78 \\
\hline MS146 & & & & & & MS-14-6_P12_ctr-rim & 0.09 & 1.16 & 98.75 \\
\hline MS146 & & & & & & MS-14-6_P13_ctr-rim & 37.44 & 20.85 & 41.72 \\
\hline MS146 & & & & & & MS-14-6_P13_ctr-rim & 36.85 & 21.29 & 41.86 \\
\hline MS146 & & & & & & MS-14-6_P13_ctr-rim & 32.67 & 25.69 & 41.64 \\
\hline MS146 & & & & & & MS-14-6_P13_ctr-rim & 33.28 & 23.59 & 43.14 \\
\hline MS146 & & & & & & MS-14-6_P14ab_ctr-rim & 42.30 & 20.56 & 37.15 \\
\hline MS146 & & & & & & MS-14-6_P14ab_ctr-rim & 41.91 & 20.48 & 37.62 \\
\hline MS146 & & & & & & MS-14-6_P14ab_ctr-rim & 43.72 & 0.54 & 55.73 \\
\hline MS146 & & & & & & MS-14-6_P14ab_ctr-rim & 0.03 & 0.92 & 99.05 \\
\hline MS146 & & & & & & MS-14-6_P14ab_ctr-rim & 42.56 & 20.25 & 37.19 \\
\hline MS146 & & & & & & MS-14-6_P14ab_ctr-rim & 42.50 & 20.21 & 37.28 \\
\hline MS146 & & & & & & MS-14-6_P14ab_ctr-rim & 32.68 & 22.84 & 44.48 \\
\hline MS146 & & & & & & MS-14-6_P14ab_ctr-rim & 35.40 & 22.57 & 42.02 \\
\hline
\end{tabular}




\begin{tabular}{|c|c|c|c|c|c|c|c|c|c|}
\hline \multicolumn{10}{|c|}{ Compare SEM and EMP Pyroxene Info (Cont'd) } \\
\hline \multirow[b]{2}{*}{ Sample } & \multicolumn{2}{|c|}{ (High Ca) } & \multirow{2}{*}{$\begin{array}{l}\text { SEM } \\
\text { (High Mg) } \\
\text { En }\end{array}$} & \multirow{2}{*}{$\begin{array}{c}\text { (High Fe) } \\
\text { Fs }\end{array}$} & \multirow[b]{2}{*}{ Total } & \multirow{2}{*}{\multicolumn{2}{|c|}{$\begin{array}{l}\text { EMP } \\
\text { (High Ca) } \\
\text { Wo }\end{array}$}} & \multirow{2}{*}{$\begin{array}{c}\text { (High Mg) } \\
\text { En }\end{array}$} & \multirow{2}{*}{$\begin{array}{c}\text { (High Fe) } \\
\text { Fs }\end{array}$} \\
\hline & Site & Wo & & & & & & & \\
\hline MS146 & & & & & & "MS-14-6_P15_ctr-rim & 42.88 & 20.32 & 36.80 \\
\hline MS146 & & & & & & MS-14-6_P15_ctr-rim & 41.87 & 20.52 & 37.61 \\
\hline MS146 & & & & & & MS-14-6_P15_ctr-rim & 1.39 & 1.14 & 97.48 \\
\hline MS146 & & & & & & MS-14-6_P15_ctr-rim & 0.01 & 1.08 & 98.91 \\
\hline MS146 & & & & & & MS-14-6_P15_ctr-rim & 22.35 & 5.35 & 72.30 \\
\hline MS146 & & & & & & MS-14-6_P15_ctr-rim & 26.43 & 6.48 & 67.09 \\
\hline MS146 & & & & & & MS-14-6_P15_ctr-rim & 31.30 & 17.53 & 51.17 \\
\hline MS146 & & & & & & MS-14-6_P15_ctr-rim & 34.49 & 18.18 & 47.33 \\
\hline MS146 & & & & & & MS-14-6_P16_ctr-rim & 36.32 & 23.51 & 40.18 \\
\hline MS146 & & & & & & MS-14-6_P16_ctr-rim & 39.35 & 22.61 & 38.04 \\
\hline MS146 & & & & & & MS-14-6_P17_ctr-rim & 41.92 & 42.05 & 16.03 \\
\hline MS146 & & & & & & MS-14-6_P17_ctr-rim & 41.90 & 42.05 & 16.05 \\
\hline MS146 & & & & & & MS-14-6_P17_ctr-rim & 0.03 & 3.40 & 96.57 \\
\hline MS146 & & & & & & MS-14-6_P17_ctr-rim & 0.05 & 3.27 & 96.68 \\
\hline MS146 & & & & & & MS-14-6_P18_ctr-rim & 32.40 & 41.90 & 25.70 \\
\hline MS146 & & & & & & MS-14-6_P18_ctr-rim & 26.62 & 44.37 & 29.00 \\
\hline MS146 & & & & & & MS-14-6_P18_ctr-rim & 34.09 & 41.25 & 24.67 \\
\hline MS146 & & & & & & MS-14-6_P18_ctr-rim & 28.87 & 23.32 & 47.80 \\
\hline MS146 & & & & & & MS-14-6_P18_ctr-rim & 31.16 & 24.96 & 43.88 \\
\hline MS146 & & & & & & MS-14-6_P19_ctr-rim & 39.41 & 21.47 & 39.12 \\
\hline MS146 & & & & & & MS-14-6_P19_ctr-rim & 42.11 & 21.02 & 36.87 \\
\hline MS146 & & & & & & MS-14-6_glass1-4 & 36.57 & 26.02 & 37.41 \\
\hline MS146 & & & & & & MS-14-6_glass1-4 & 36.38 & 24.93 & 38.70 \\
\hline MS146 & & & & & & MS-14-6_glass1-4 & 34.71 & 24.17 & 41.12 \\
\hline MS146 & & & & & & MS-14-6_glass1-4 & 32.70 & 23.36 & 43.94 \\
\hline MS146 & & & & & & MS-14-6_glass1-4 & 30.35 & 25.36 & 44.29 \\
\hline MS146 & & & & & & MS-14-6_glass1-4 & 32.60 & 25.97 & 41.43 \\
\hline MS146 & & & & & & MS-14-6_glass1-4 & 27.13 & 4.08 & 68.79 \\
\hline MS146 & & & & & & MS-14-6_glass1-4 & 23.08 & 3.43 & 73.48 \\
\hline
\end{tabular}


Appendix K: Major Element Comparison Plots

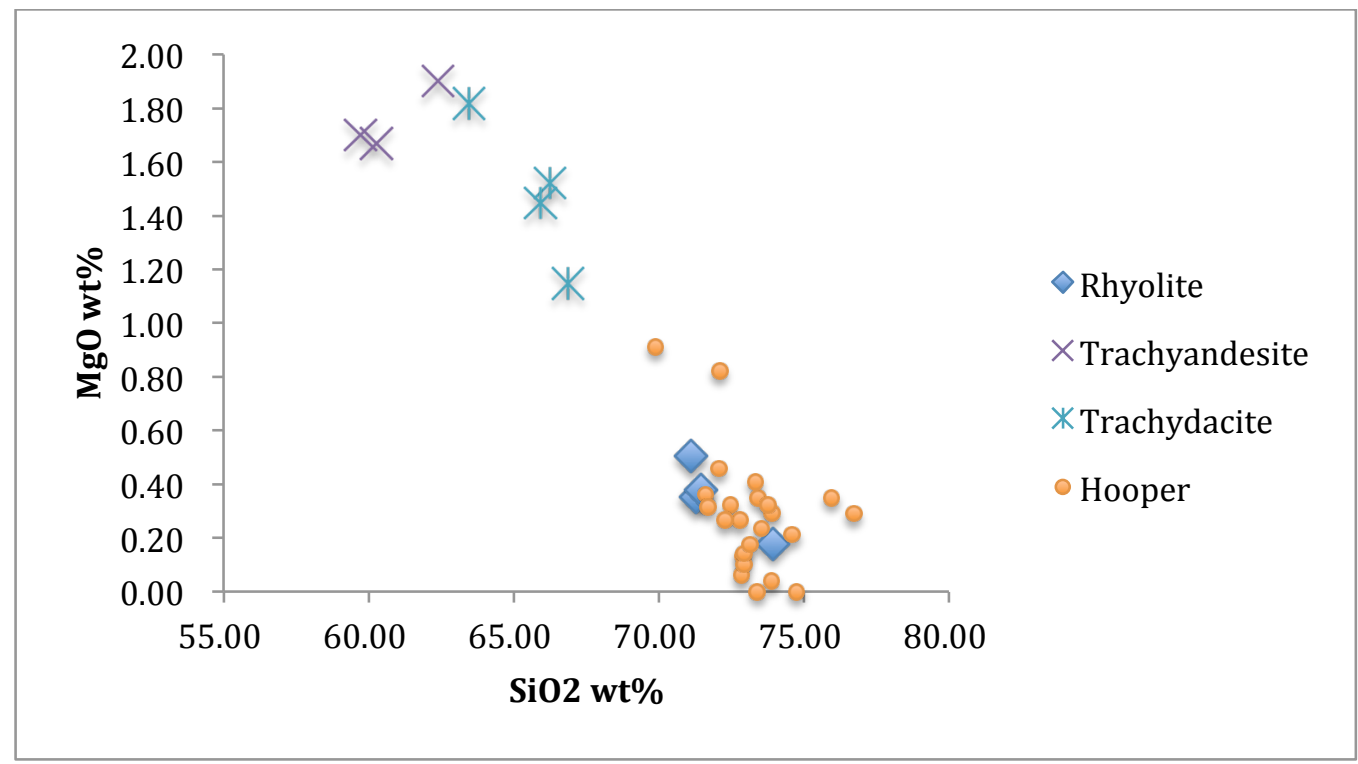

Figure K-1. $\mathrm{SiO}_{2}$ vs. MgO shows a linear pattern ranging from the least silicic samples (trachyandesite) which contain the highest wt\% MgO, to the highest silica samples, rhyolites which have the lowest wt\% MgO.

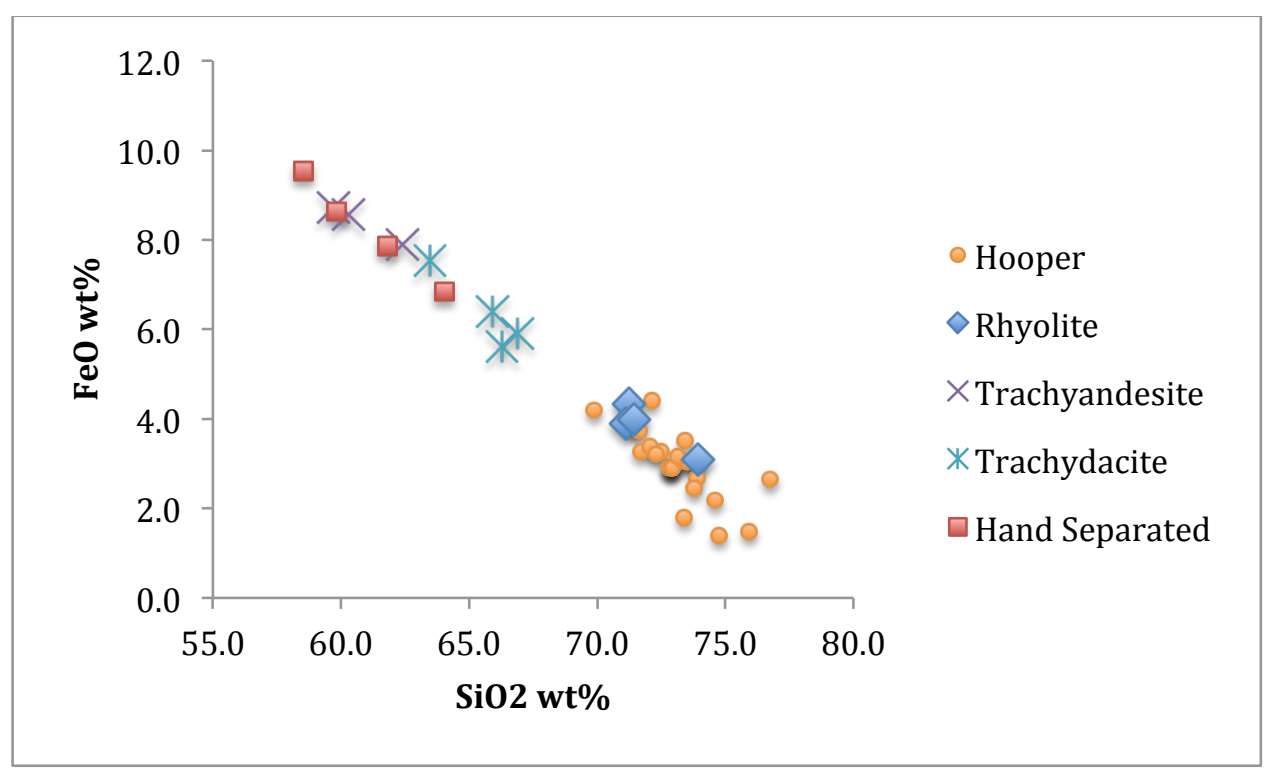

Figure K-2. This major element plot shows $\mathrm{SiO}_{2}$ wt\% vs. FeO wt\%. Again, a clear pattern emerges. The most mafic samples (trachyandesite and the hand-separated mafic materials) have the highest amount of FeO. The most silicic samples, rhyolites, have the lowest amount of FeO. The hand separated mafic minerals were taken from samples HS154D (trachyandesite), HS154E (trachyandesite), MS1307 (rhyolite), and MS1403 (trachydacite). 


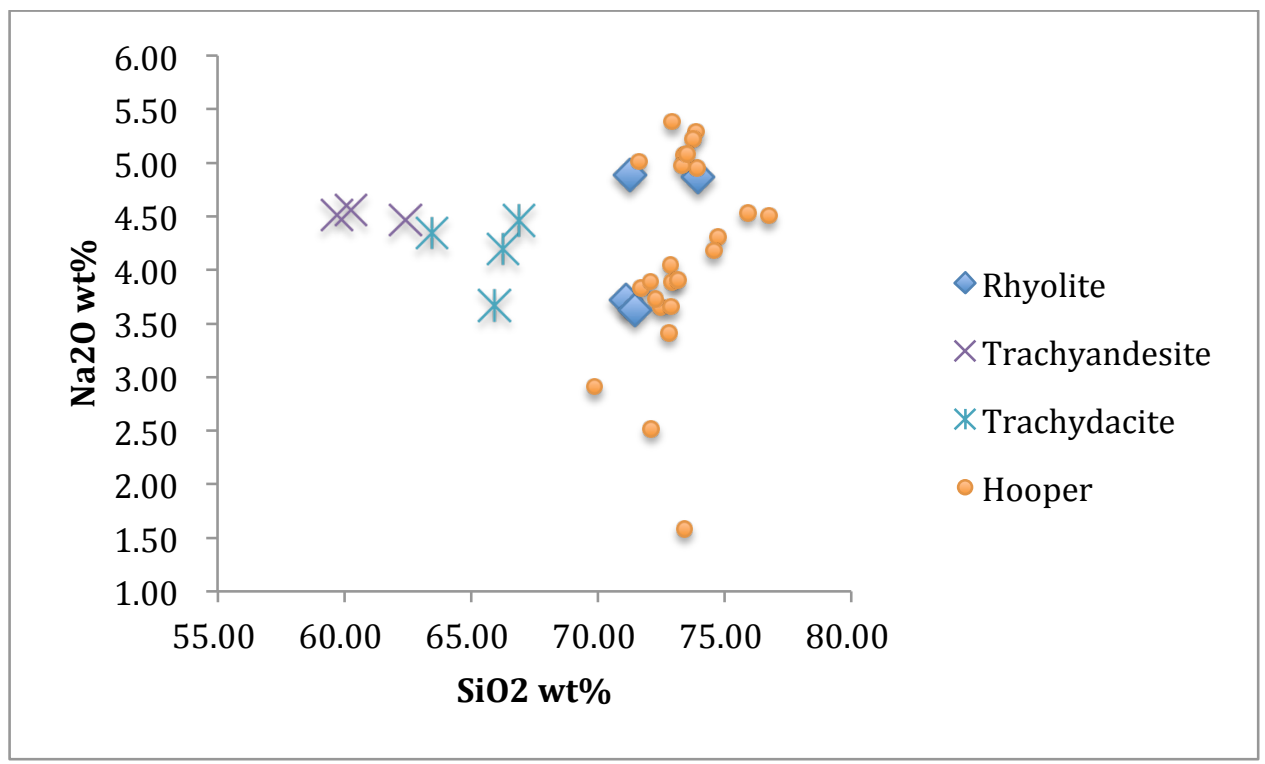

Figure K-3. Major element comparison plot of $\mathrm{SiO}_{2}$ wt\% vs. $\mathrm{Na}_{2} \mathrm{O}$ wt\%. Not much of a pattern is seen in this comparison. A similar amount of $\mathrm{Na}_{2} \mathrm{O}$ is present in each sample despite varying silica compositions.

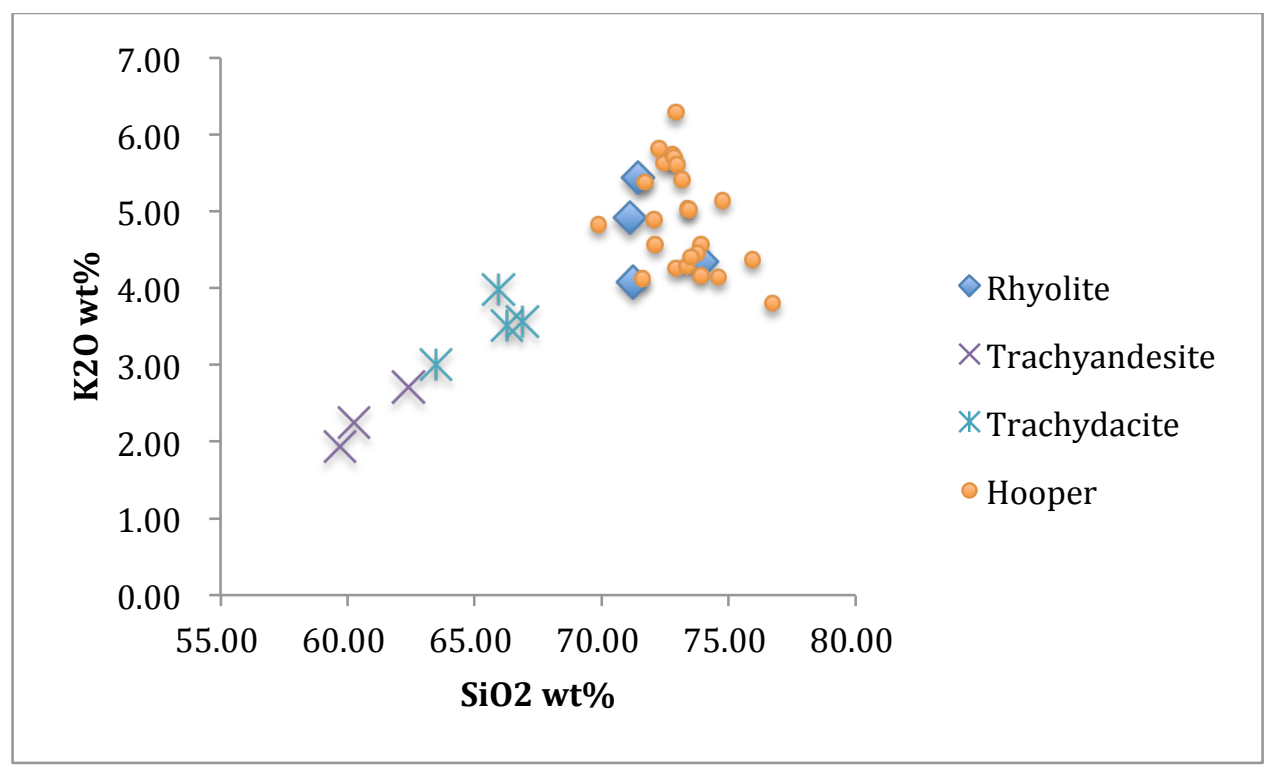

Figure K-4. A pattern of lower $\mathrm{K}_{2} \mathrm{O}$ levels with lower silica content can be seen in this major element plot showing $\mathrm{K}_{2} \mathrm{O}$ vs. $\mathrm{SiO}_{2}$. Trachyandesite samples are the lowest silica samples with the lowest $\mathrm{K}_{2} \mathrm{O}$ content, and rhyolites are the highest silica samples, containing the most $\mathrm{K}_{2} \mathrm{O}$. 


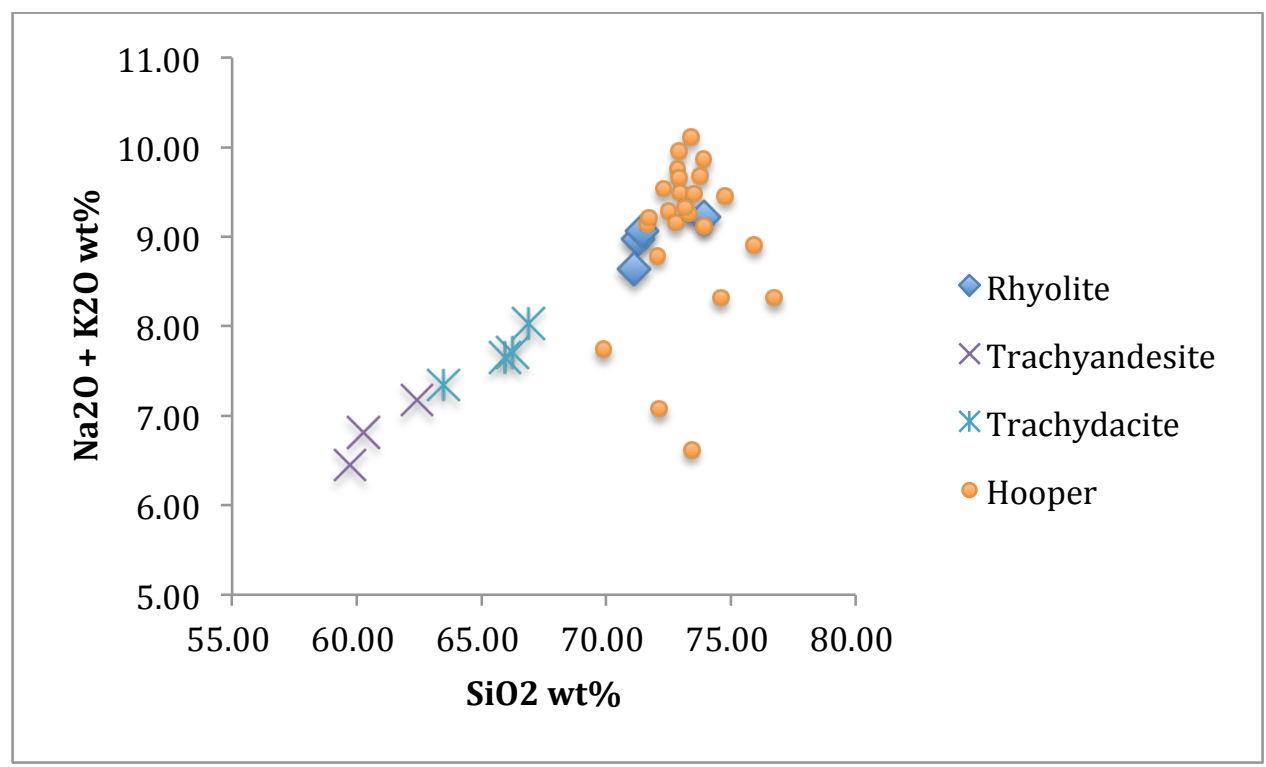

Figure K-5. Although the grouping is not tight, a pattern can be seen in this $\mathrm{SiO}_{2} \mathrm{wt}_{\%}$ vs. $\mathrm{Na}_{2} \mathrm{O}+$ $\mathrm{K}_{2} \mathrm{O}$ wt\% major element comparison plot. Higher silica samples, rhyolites, contain a higher amount of the $\mathrm{Na}_{2} \mathrm{O}+\mathrm{K}_{2} \mathrm{O}$ mixture.

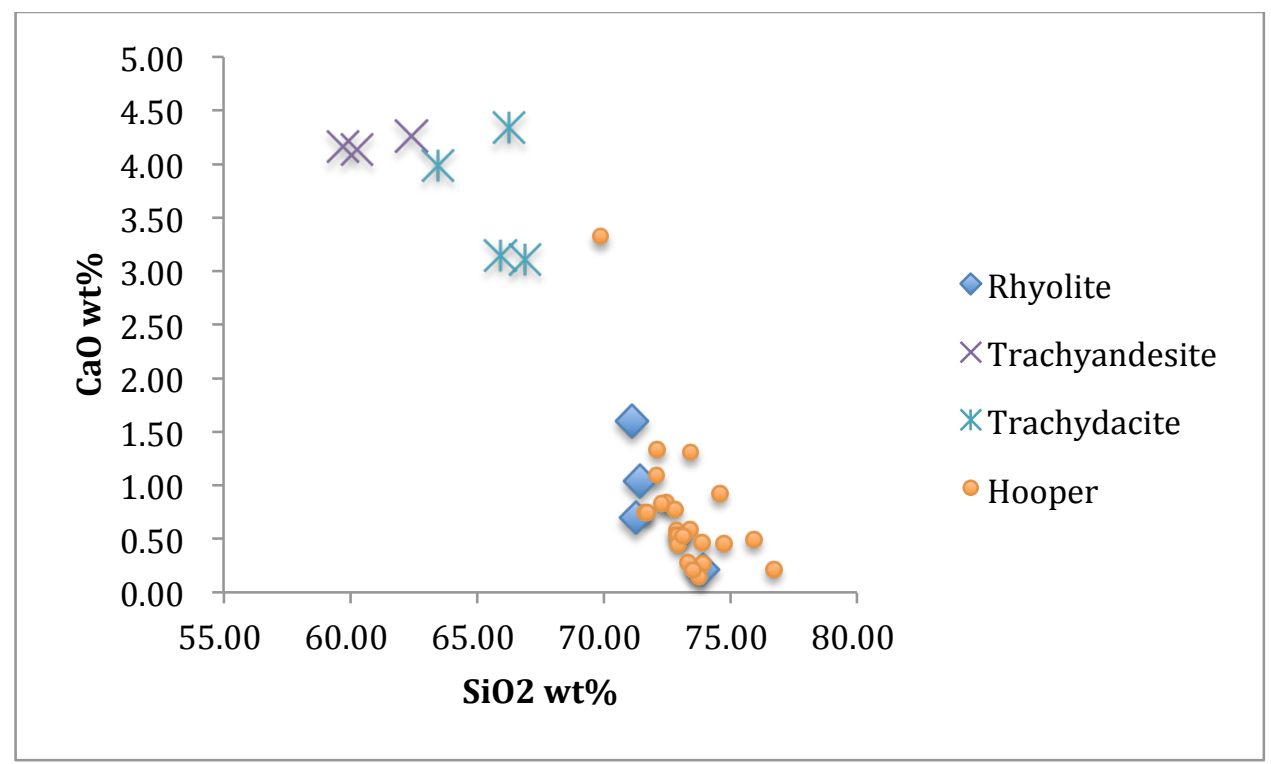

Figure K-6. A slight pattern emerges in this major element comparison plot of $\mathrm{SiO}_{2} \mathrm{wt}_{\%} \mathrm{vs}$. $\mathrm{CaO}$ wt\%. High silica samples contain very little $\mathrm{CaO}$, rarely ranging higher than 2.00 wt\%, while the more mafic samples contain up to $4.5 \mathrm{wt} \% \mathrm{CaO}$. 


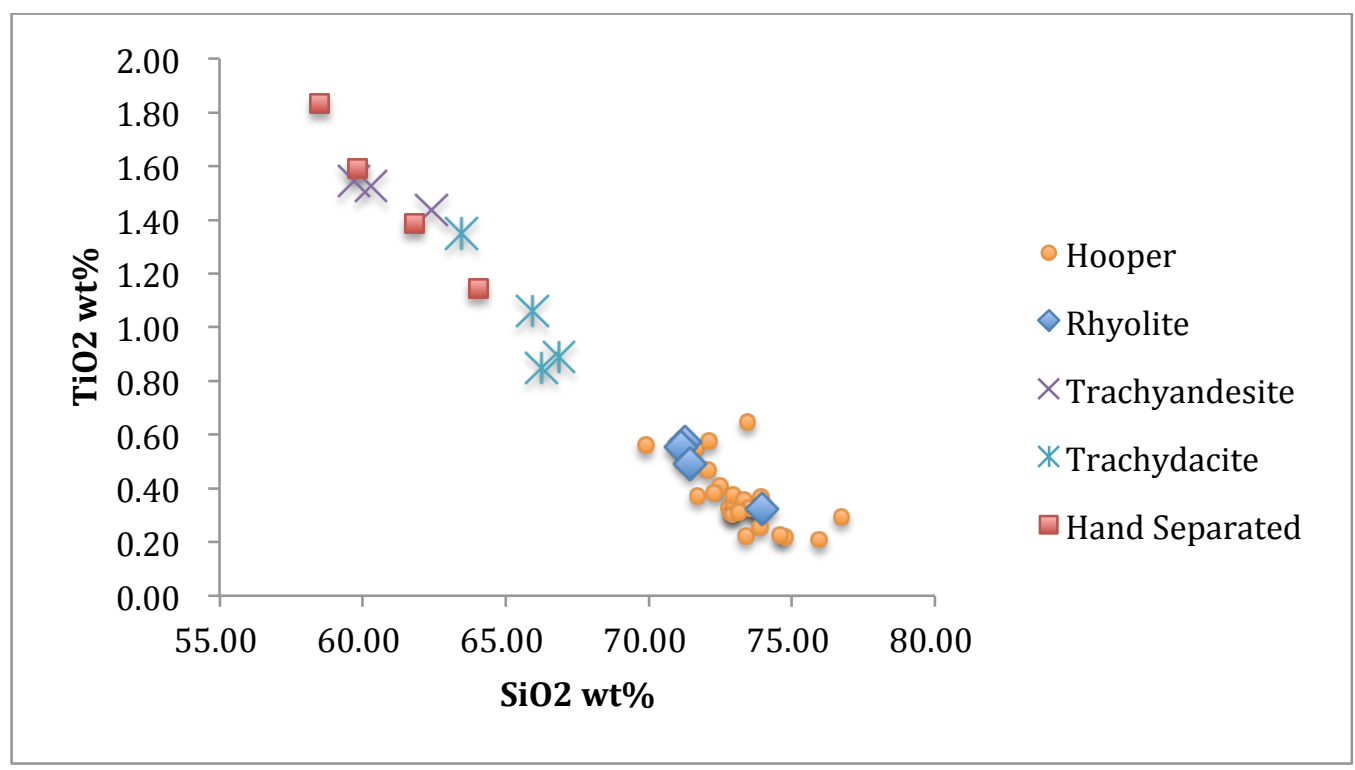

Figure K-7. A clear linear relationship can be seen in the major element comparison plot of $\mathrm{SiO}_{2}$ wt $\%$ vs. $\mathrm{TiO}_{2}$ wt\%. The highest silica samples contain the lowest amount of titanium, where the lower silica samples contain the most. The overall sample set ranges from $0.21 \mathrm{wt} \% \mathrm{TiO}_{2}$ to 1.83 wt\% $\mathrm{TiO}_{2}$. This includes hand separated mafic minerals, taken from samples HS154D (trachyandesite), HS154E (trachyandesite), MS1307 (rhyolite), and MS1403 (trachydacite).

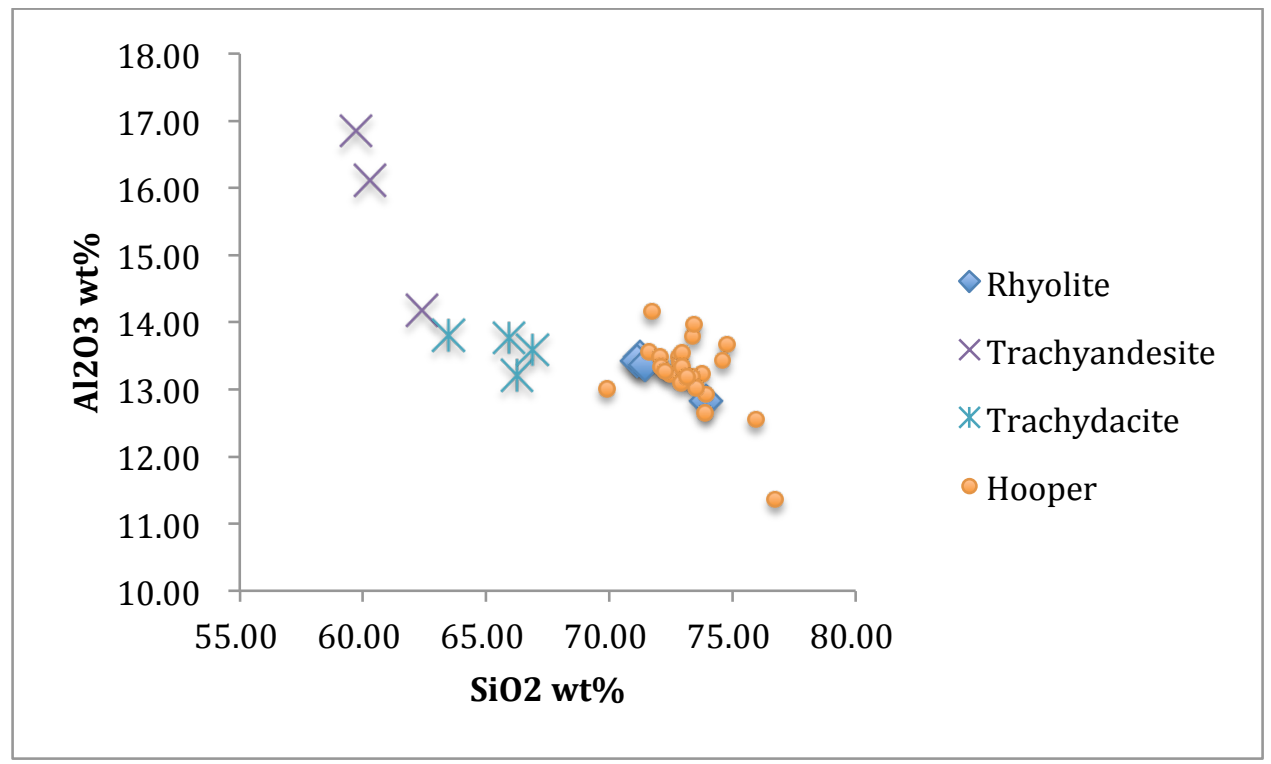

Figure K-8. This major element plot of $\mathrm{SiO}_{2}$ vs. $\mathrm{Al}_{2} \mathrm{O}_{3}$ shows an s-shaped curve. Some of the most felsic samples, the rhyolites in Hooper's data set, have lower amounts of $\mathrm{Al}_{2} \mathrm{O}_{3}$, where some of the most mafic trachyandesite samples have a relatively high wt\% of $\mathrm{Al}_{2} \mathrm{O}_{3}$. The total range is from 11.36 to $16.84 \mathrm{wt} \% \mathrm{Al}_{2} \mathrm{O}_{3}$. Most of the samples fall in the central range of about 13 to $14 \mathrm{wt}_{\mathrm{o}} \mathrm{Al}_{2} \mathrm{O}_{3}$. 


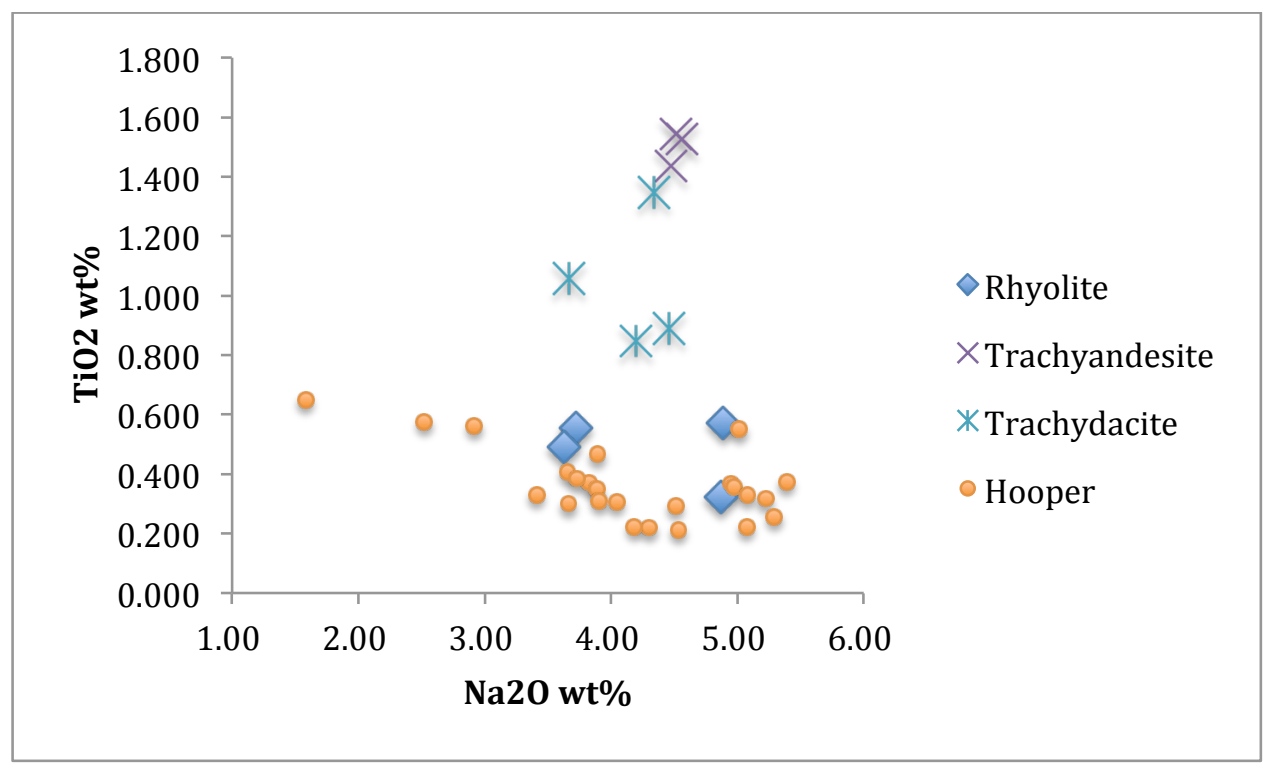

Figure K-9. Although no clear pattern emerges to correlate $\mathrm{Na}_{2} \mathrm{O}$ wt\% vs. $\mathrm{TiO}_{2} \mathrm{wt} \%$, the relationship between $\mathrm{TiO}_{2}$ and silica content is clear. The most mafic samples contain the most $\mathrm{TiO}_{2}$. These are the trachyandesites in the sample set.

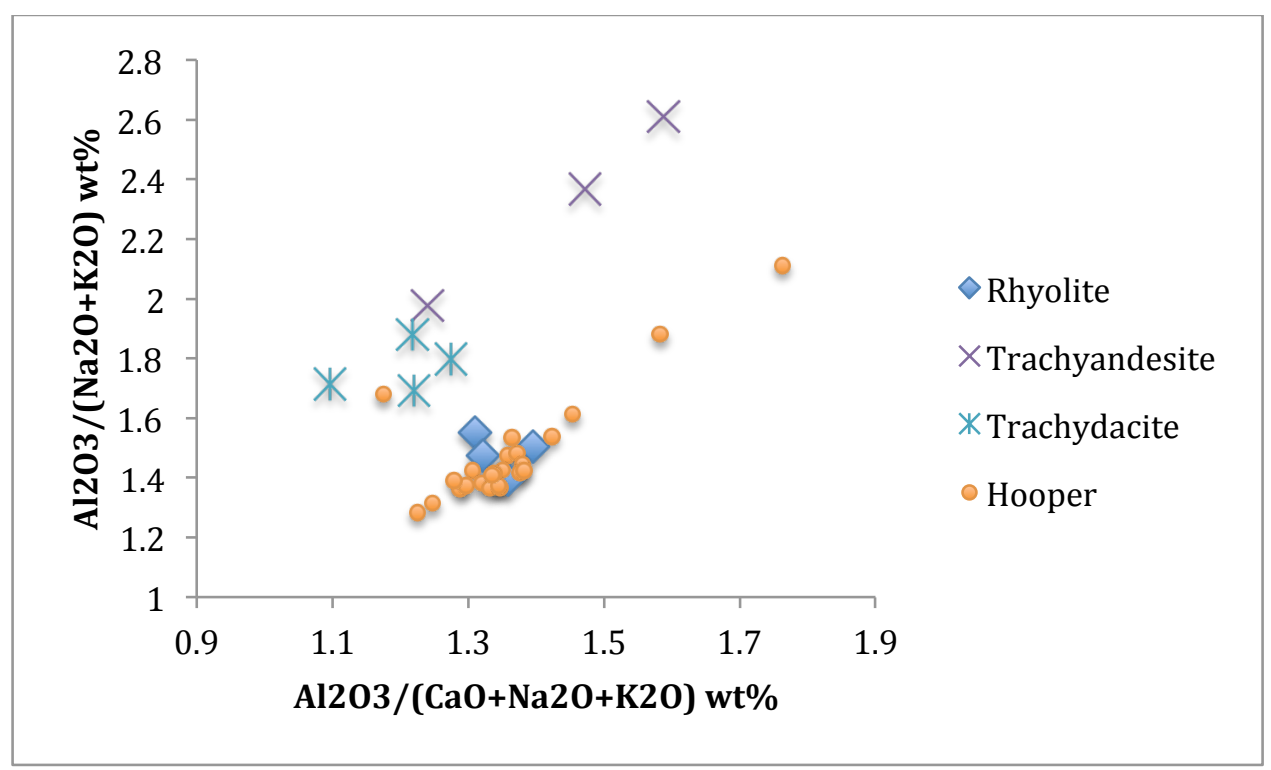

Figure K-10. No true trend can be seen comparing major elements $\mathrm{Al}_{2} \mathrm{O}_{3} /\left(\mathrm{CaO}+\mathrm{Na}_{2} \mathrm{O}+\mathrm{K}_{2} \mathrm{O}\right) \mathrm{wt} \%$ vs. $\mathrm{Al}_{2} \mathrm{O}_{3} /\left(\mathrm{Na}_{2} \mathrm{O}+\mathrm{K}_{2} \mathrm{O}\right) \mathrm{wt} \%$. Overall, Hooper's sample set contains less $\mathrm{Al}_{2} \mathrm{O}_{3} /\left(\mathrm{Na}_{2} \mathrm{O}+\mathrm{K}_{2} \mathrm{O}\right)$ wt\% than the more mafic samples taken in the field. Hooper's data is in line with the rhyolitic samples taken in the field. 


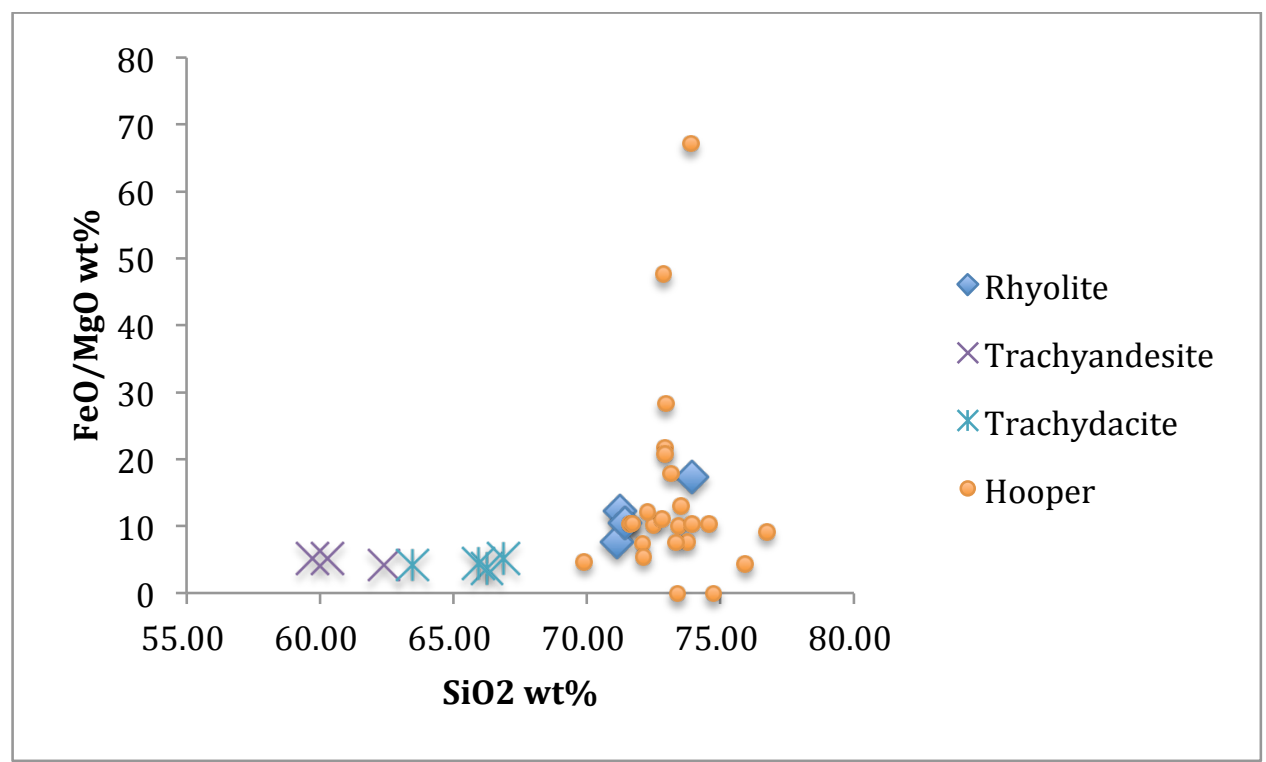

Figure K-11. Most samples contain little-to-no FeO/MgO wt\%. Although the full range is from 0 to $67.25 \mathrm{wt} \% \mathrm{FeO} / \mathrm{MgO}$, most of the samples are below $20 \mathrm{wt} \% \mathrm{FeO} / \mathrm{MgO}$.

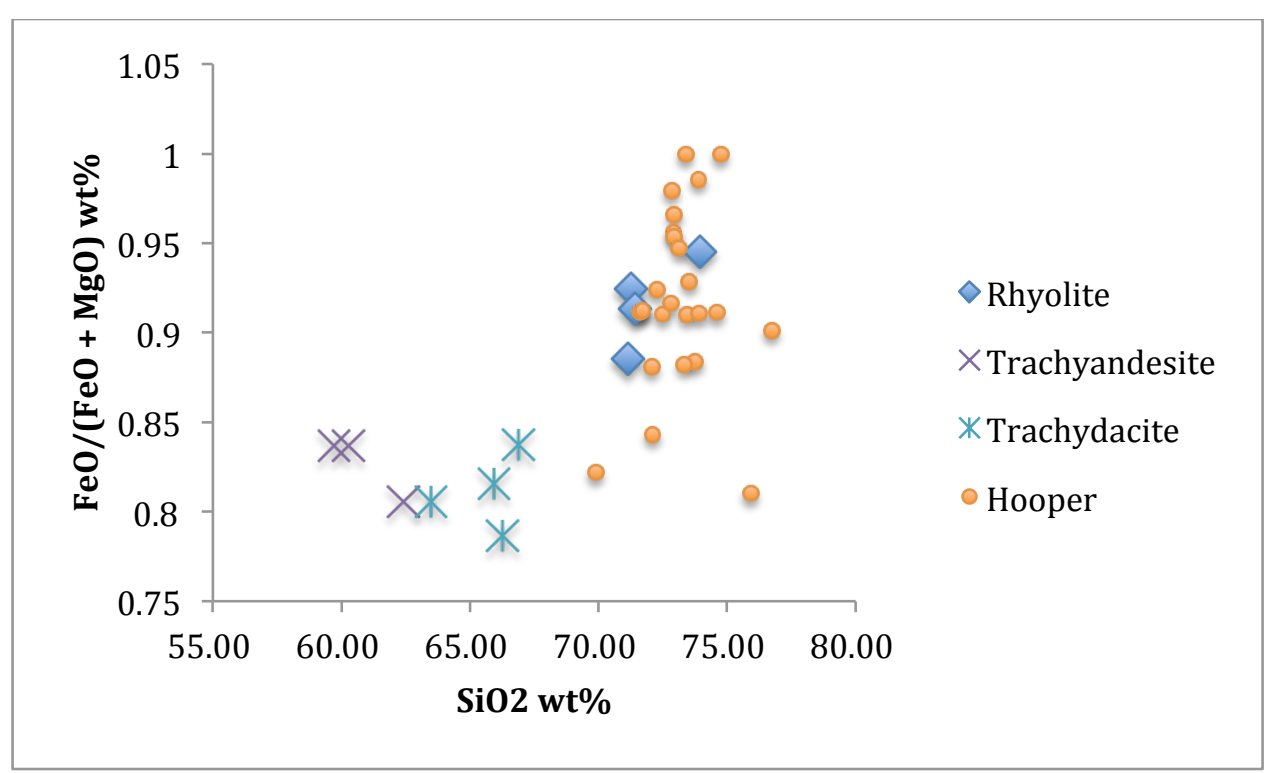

Figure K-12. A general linear trend is seen in this major element comparison diagram. Samples with higher silica levels (rhyolites) contain a higher weight percent of $\mathrm{FeO} /(\mathrm{FeO}+\mathrm{MgO})$. The silicic samples fall between 0.8 and $1.0 \mathrm{wt} \% \mathrm{FeO} /(\mathrm{FeO}+\mathrm{MgO})$, while the mafic samples (trachyandesite and trachydacite) fall between 0.78 and 0.83 wt\% $\mathrm{FeO} /(\mathrm{FeO}+\mathrm{MgO})$. 


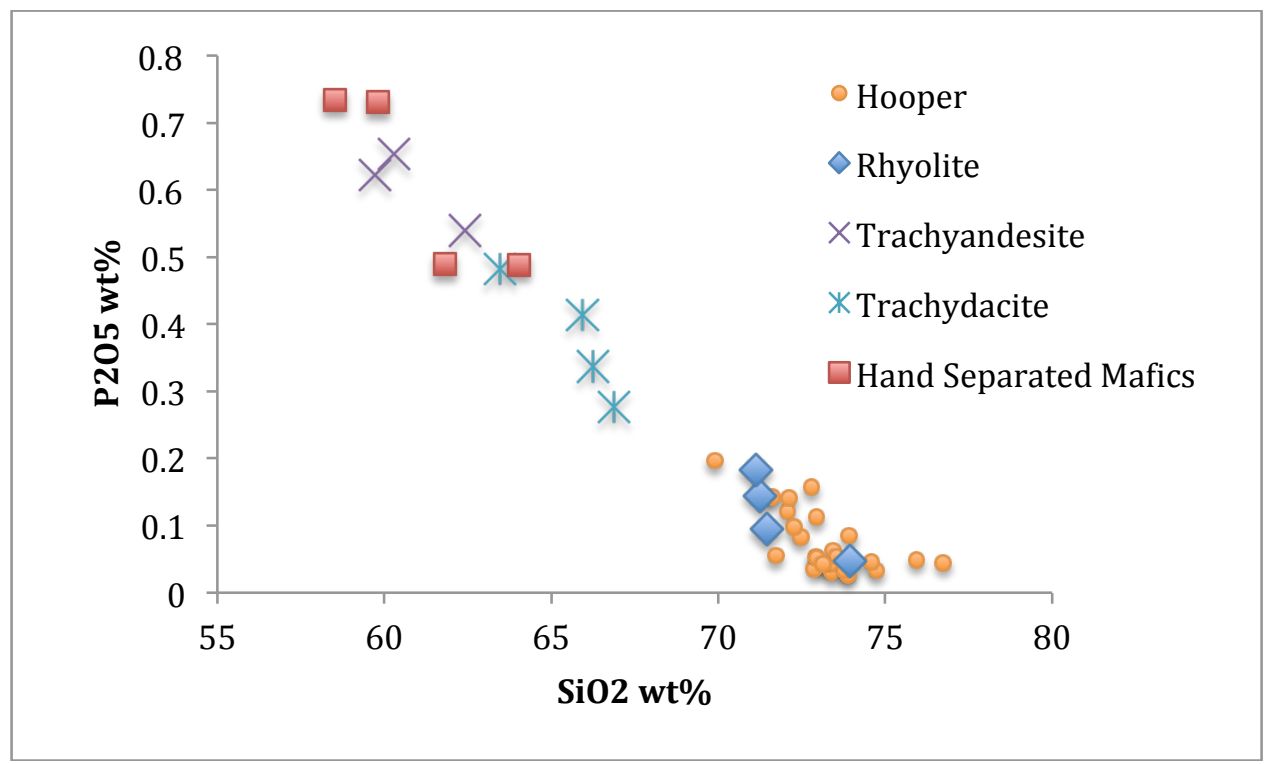

Figure K-13. A clear linear trend is seen in this major element comparison diagram of $\mathrm{SiO}_{2} \mathrm{vss} \mathrm{P}_{2} \mathrm{O}_{5}$.

Samples with lower silica composition contain much higher wt\% $\mathrm{P}_{2} \mathrm{O}_{5}$. This includes hand separated mafic minerals, taken from samples HS154D (trachyandesite), HS154E (trachyandesite), MS1307 (rhyolite), and MS1403 (trachydacite) 
APPENDIX L: Major and Trace Element Comparison Plots

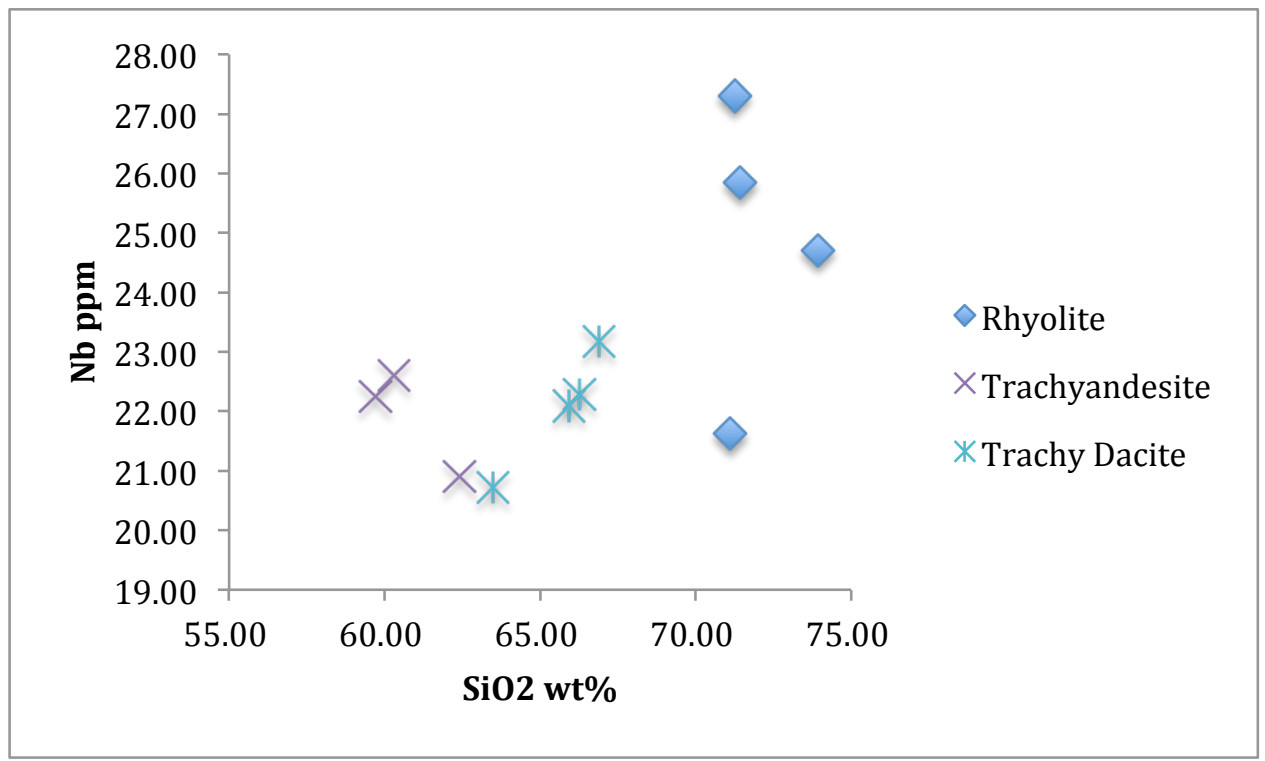

Figure L-1. $\mathrm{SiO}_{2}$ vs. Nb plots without a detectable pattern. The rhyolites typically show a higher ppm value of Nb than the more mafic samples.

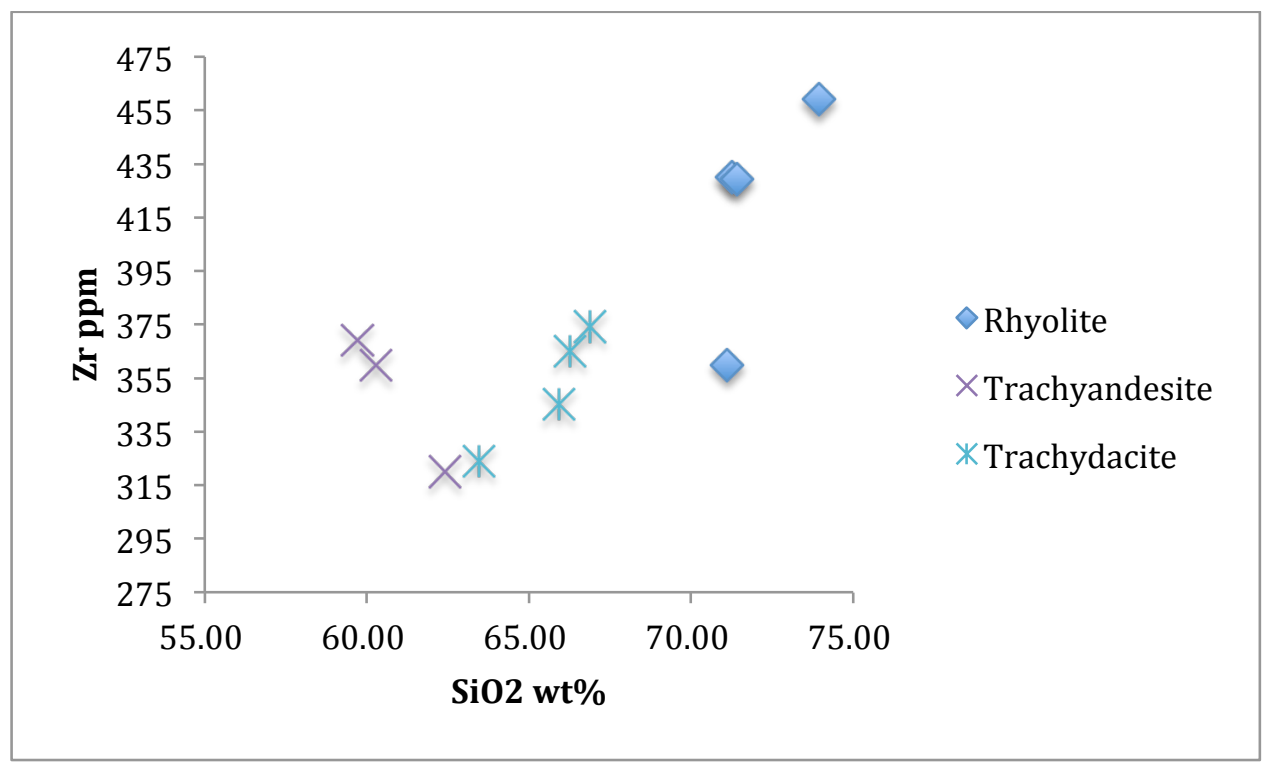

Figure L-2. Major element $\mathrm{SiO}_{2}$ vs. Trace element $\mathrm{Zr}$ shows a slight pattern, as $\mathrm{Zr}$ increases along with silica content. 


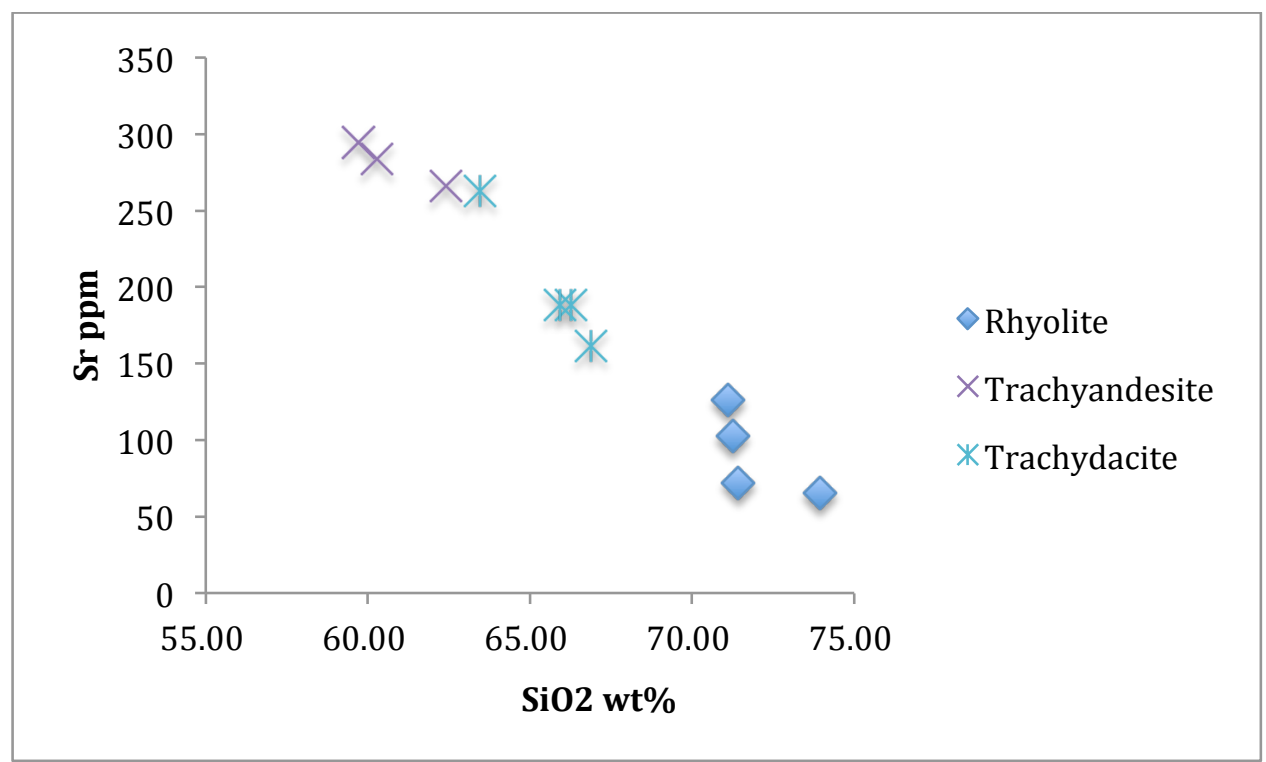

Figure L-3. Major element $\mathrm{SiO}_{2}$ vs. trace element $\mathrm{Sr}$ shows a clear pattern. $\mathrm{Sr}$ decreases as $\mathrm{SiO}_{2}$ increases. The most mafic samples contain around 295ppm Sr, while the rhyolites, the most felsic samples, contain as low as 65pm Sr.

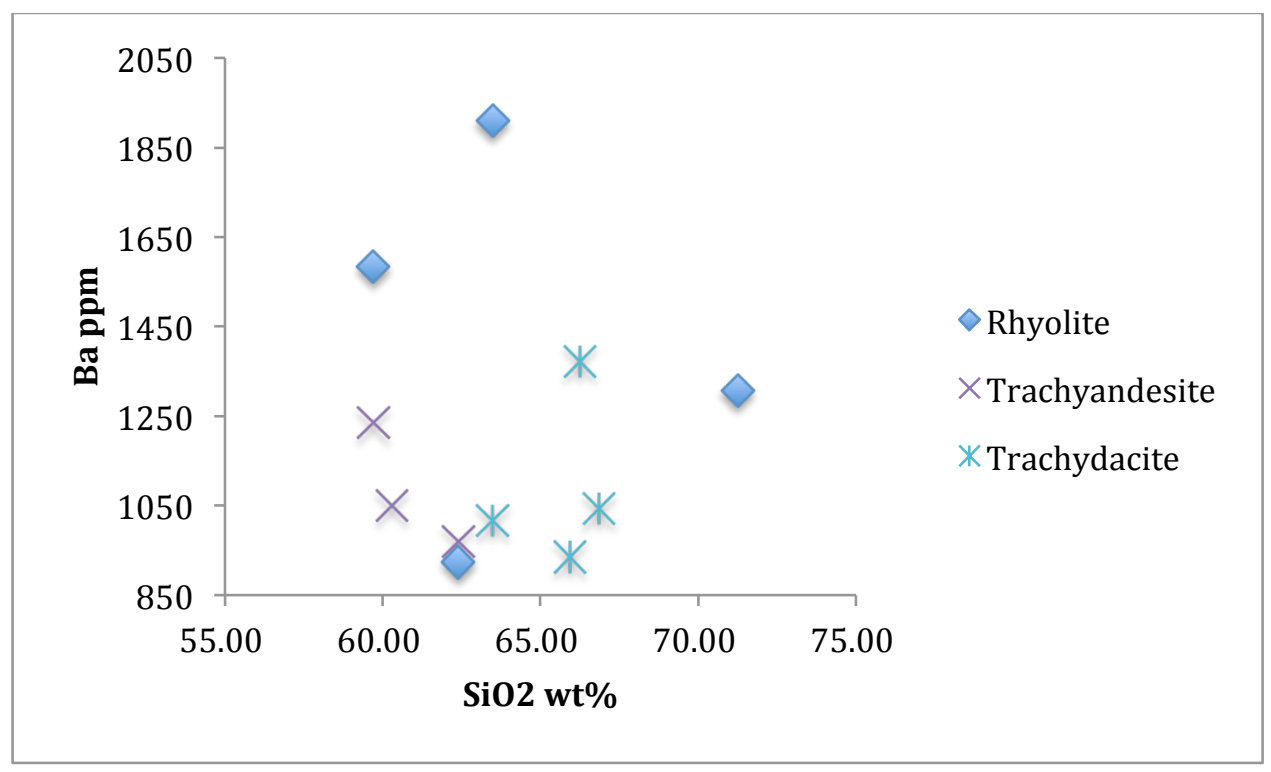

Figure L-4. No clear pattern emerges in this element plot of major element $\mathrm{SiO}_{2}$ vs. trace element $\mathrm{Ba}$.

The total range of barium is from $924 \mathrm{ppm}$ to $1911 \mathrm{ppm}$, with no distinction between silica-rich or silica-poor samples. 
APPENDIX M: Trace Element Comparison Plots

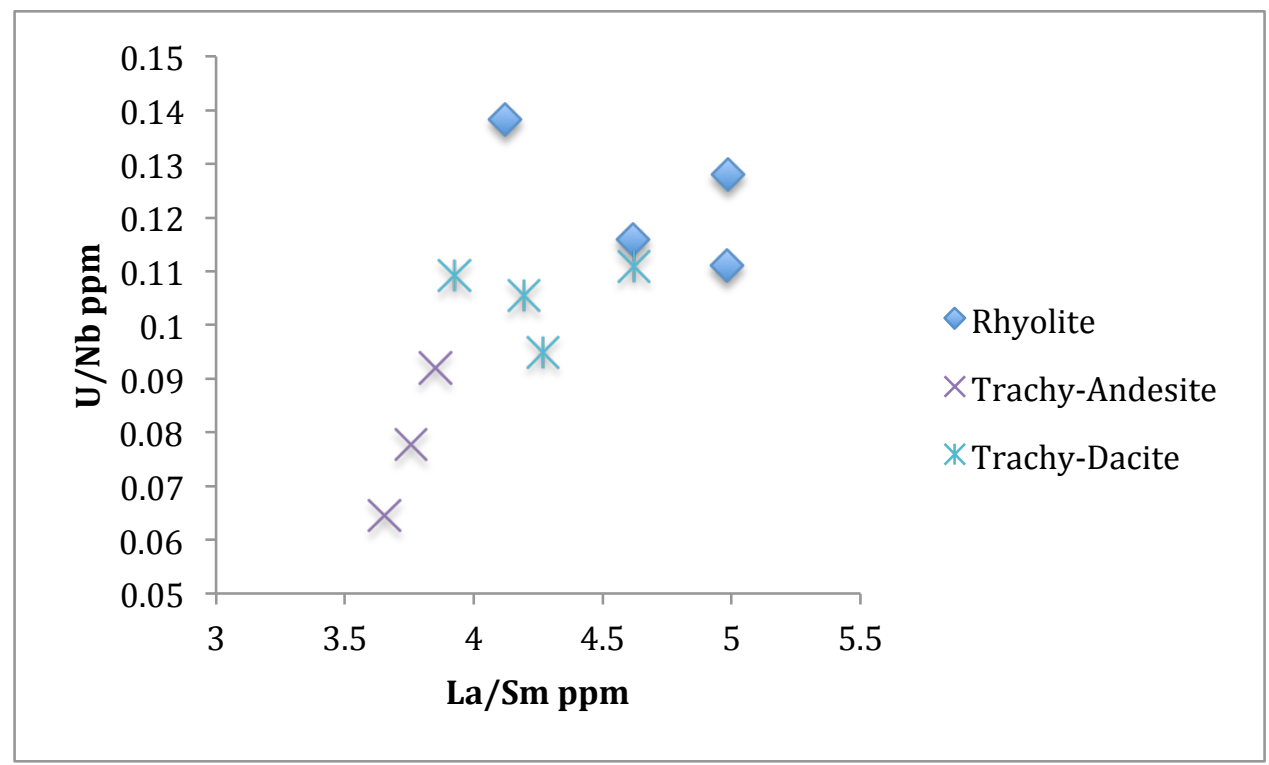

Figure M-1. Trace element plot of La/Sm ppm vs. U/Nb ppm shows a clear pattern. La/Sm is directly proportional with $\mathrm{U} / \mathrm{Nb}$. As silica content increases from trachyandesite to rhyolite, so do the proportions of these trace element ratios.

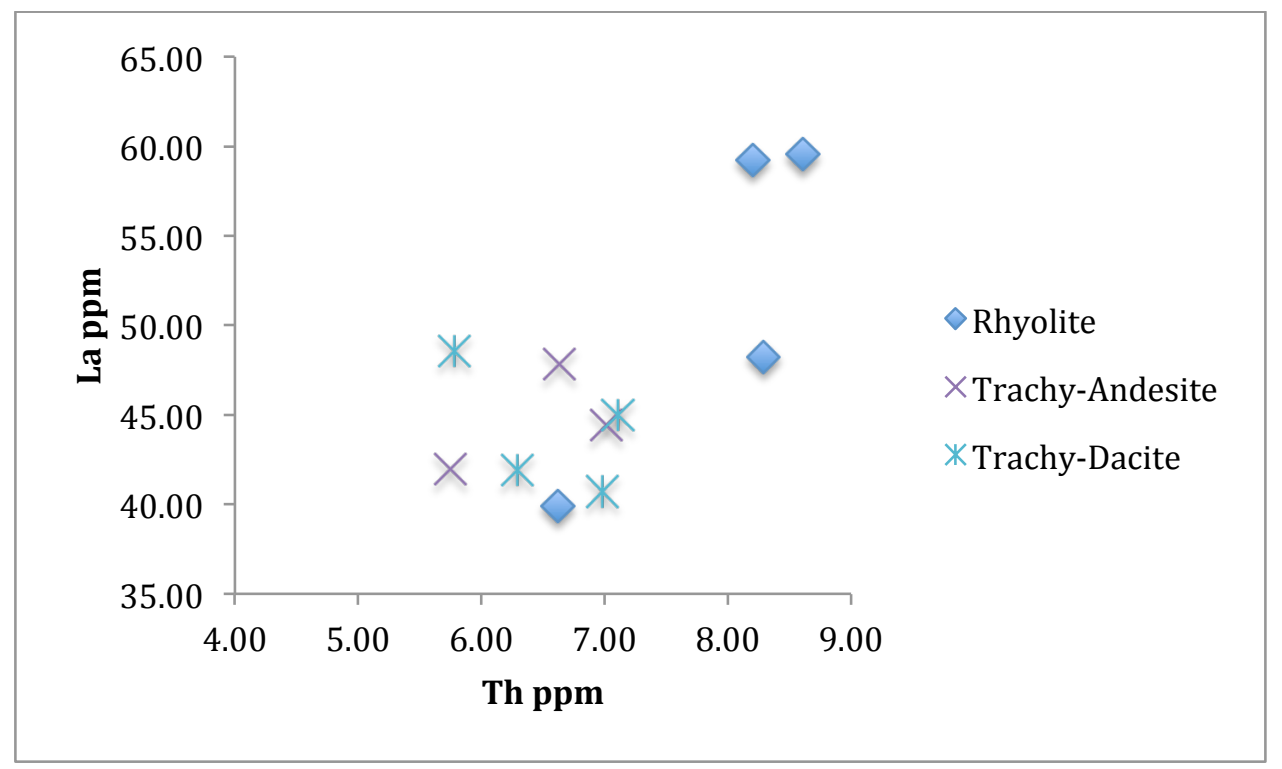

Figure M-2. Trace element diagram of Th ppm vs. La ppm does not show a distinct linear pattern. Instead, the lower silica samples are grouped together in the lower range of $\sim 40$ to $48 p p m$ La and $\sim 6$ to 7ppm Th. Rhyolites are more spread out, ranging from $\sim 6.6 \mathrm{ppm}$ Th to 8.61ppm Th and from 〜0ppm La to as high as $\sim 60$ ppm La. 


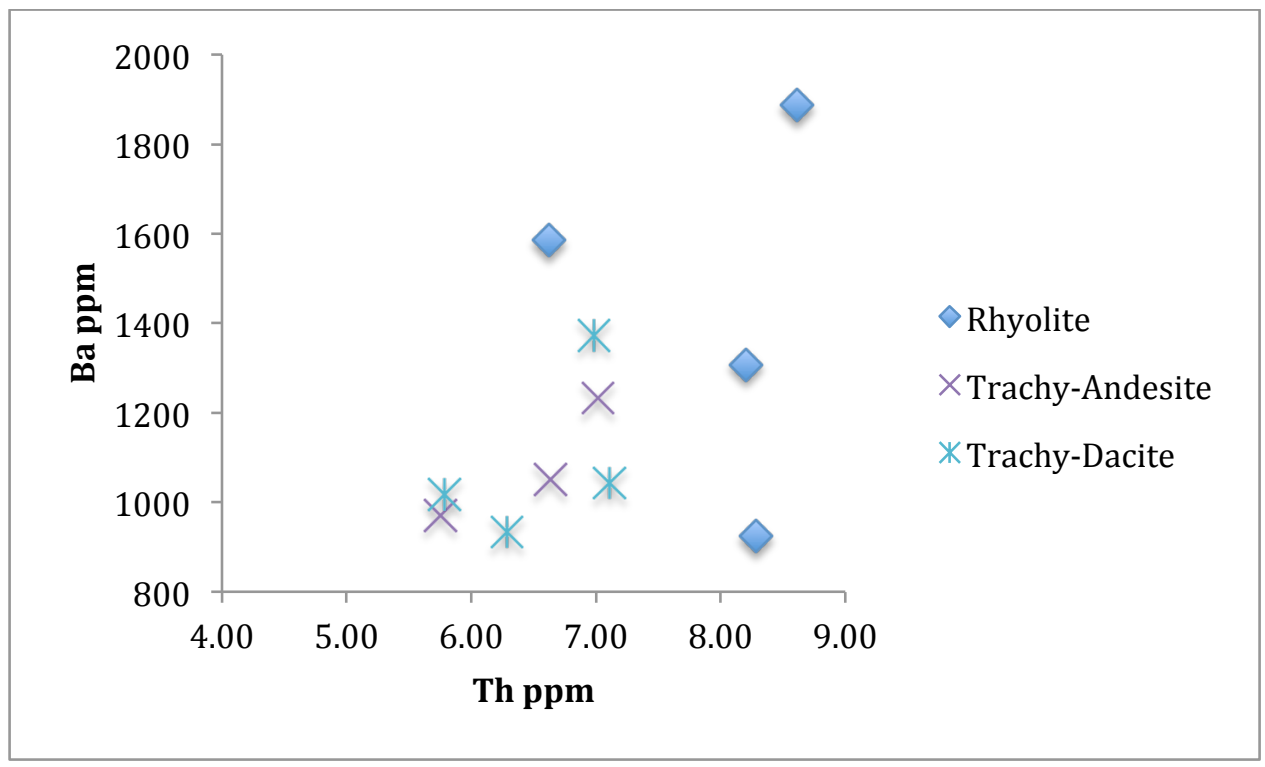

Figure M-3. Again, no clear pattern emerges from the trace element diagram plotting Th ppm vs. Ba ppm. More mafic samples typically show a lower amount of both Ba and $\mathrm{Th}$, while the felsic samples display a higher Th and Ba content. The total range is from 5.79ppm Th to 8.61ppm Th and from 924ppm to $1887 \mathrm{ppm}$ Ba.

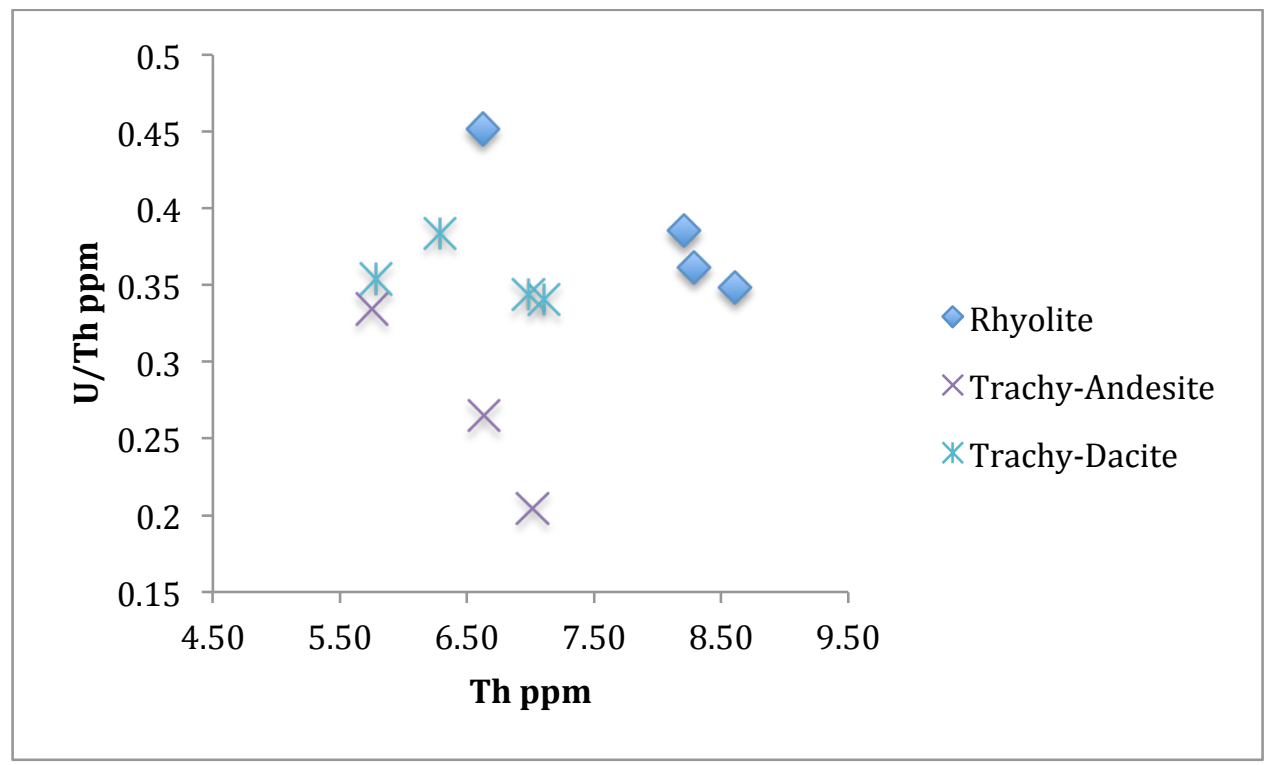

Figure M-4. Though not linear, a pattern is seen in this trace element comparison diagram. U/Th ppm increases with increasing silica content. 


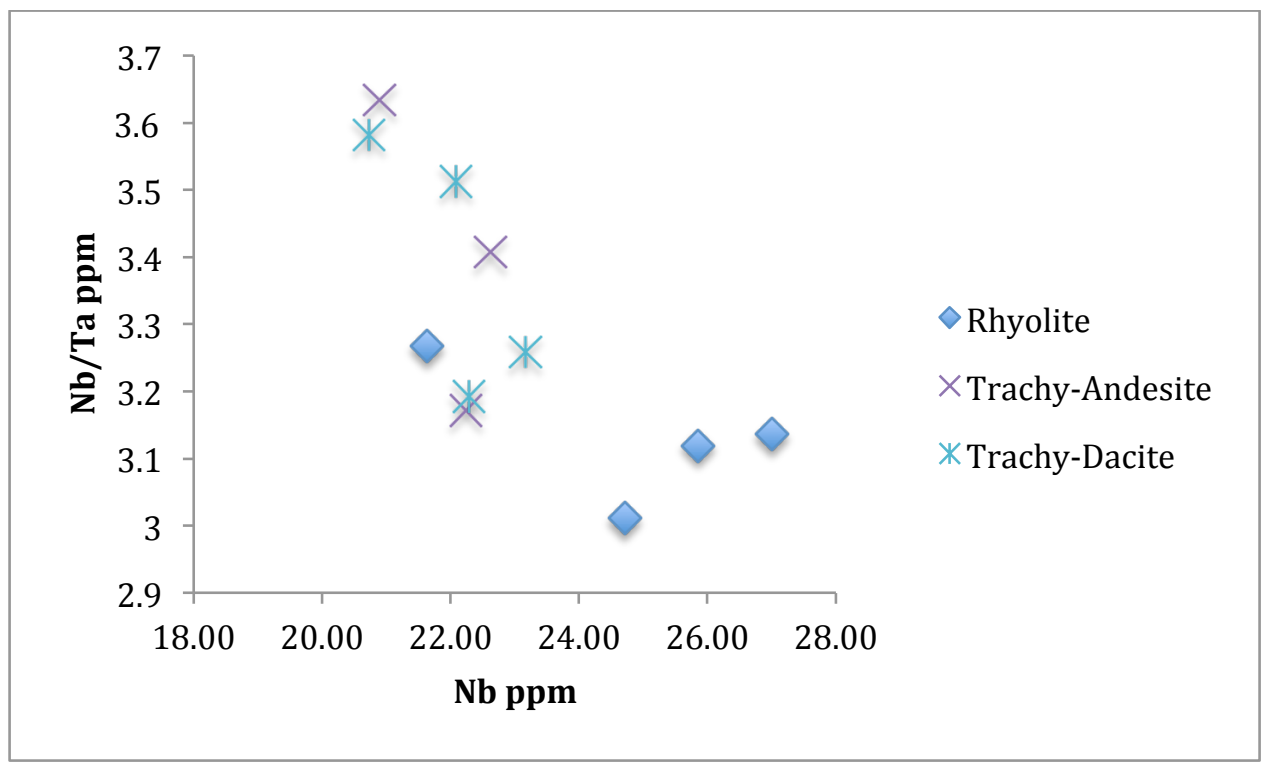

Figure M-5. Trace element plot of $\mathrm{Nb}$ v. $\mathrm{Nb} / \mathrm{Ta}$ shows a generally linear pattern of decreasing $\mathrm{Nb} / \mathrm{Ta}$ with increasing silica. The outlier at $\mathrm{Nb} 21.63 \mathrm{ppm}$, Nb/Ta 3.27ppm is MS1307, a sample of the Buchanan Tuff. The samples range from $\sim 3$ to 3.6ppm $\mathrm{Nb} / \mathrm{Ta}$ and from $\sim 20$ to $27 \mathrm{ppm} \mathrm{Nb}$.

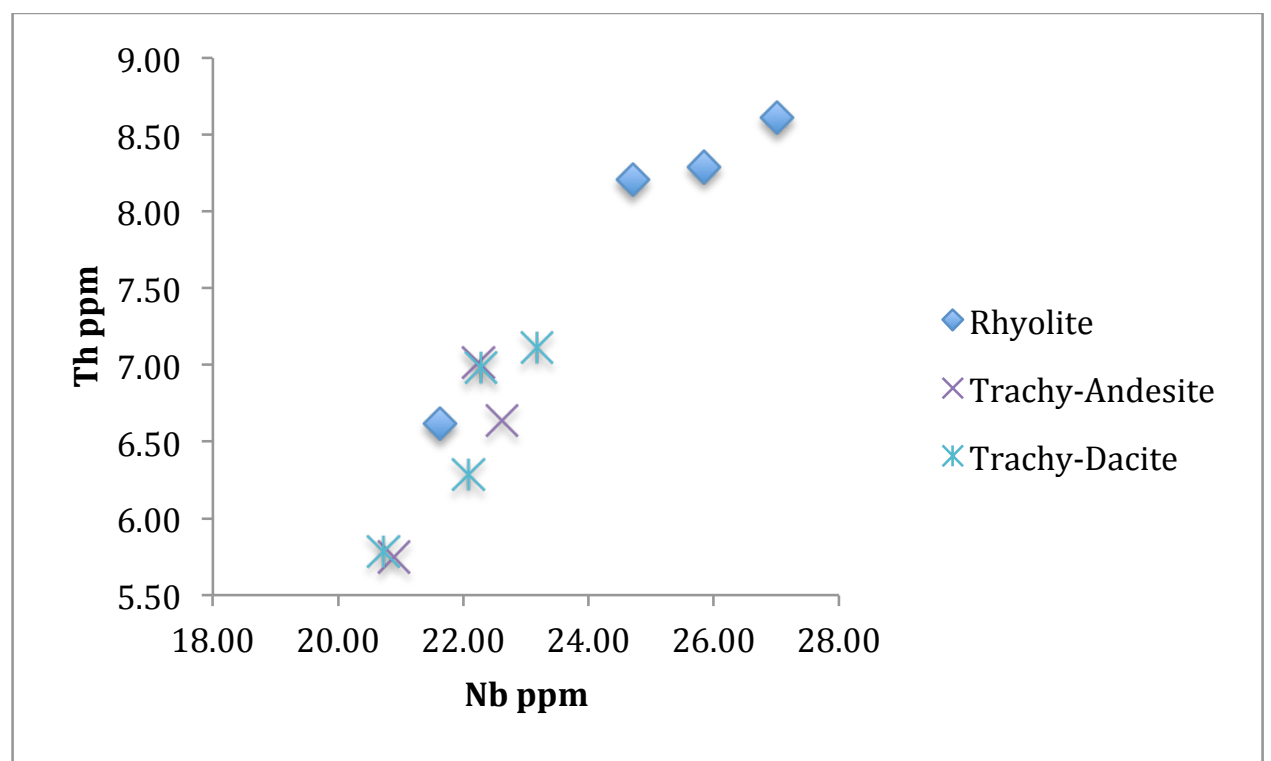

Figure M-6. Again, a linear pattern can be seen in this trace element plot of Nb vs. Th. An increase in silica content shows an increase in both $\mathrm{Nb}$ and Th. The outlier rhyolite is MS1307 from the Buchanan Tuff. 


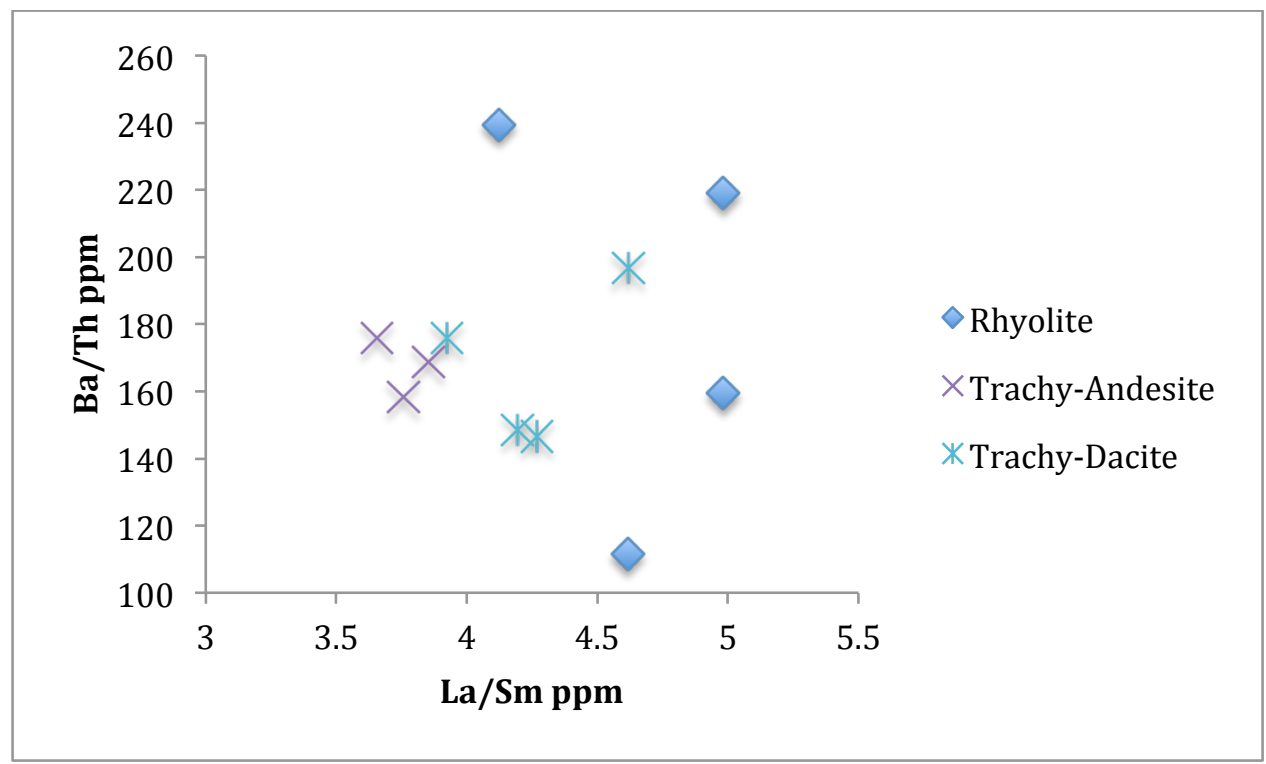

Figure M-7. Trace element plot of $\mathrm{La} / \mathrm{Sm}$ vs. Ba/Th shows no distinct pattern. The trachyandesite samples are grouped tightly together, ranging from 3.65 to $3.92 \mathrm{ppm} \mathrm{La} / \mathrm{Sm}$ and 158 to $175 \mathrm{ppm}$ $\mathrm{Ba} / \mathrm{Th}$. Trachydacite samples are spread out ranging from 3.92 to $4.62 \mathrm{ppm} \mathrm{La} / \mathrm{Sm}$ and 146 to 196 ppm Ba/Th. The rhyolites are the most variable, ranging from 4.1 to $4.98 \mathrm{ppm} \mathrm{La} / \mathrm{Sm}$ and 111 to 239 ppm Ba/Th.

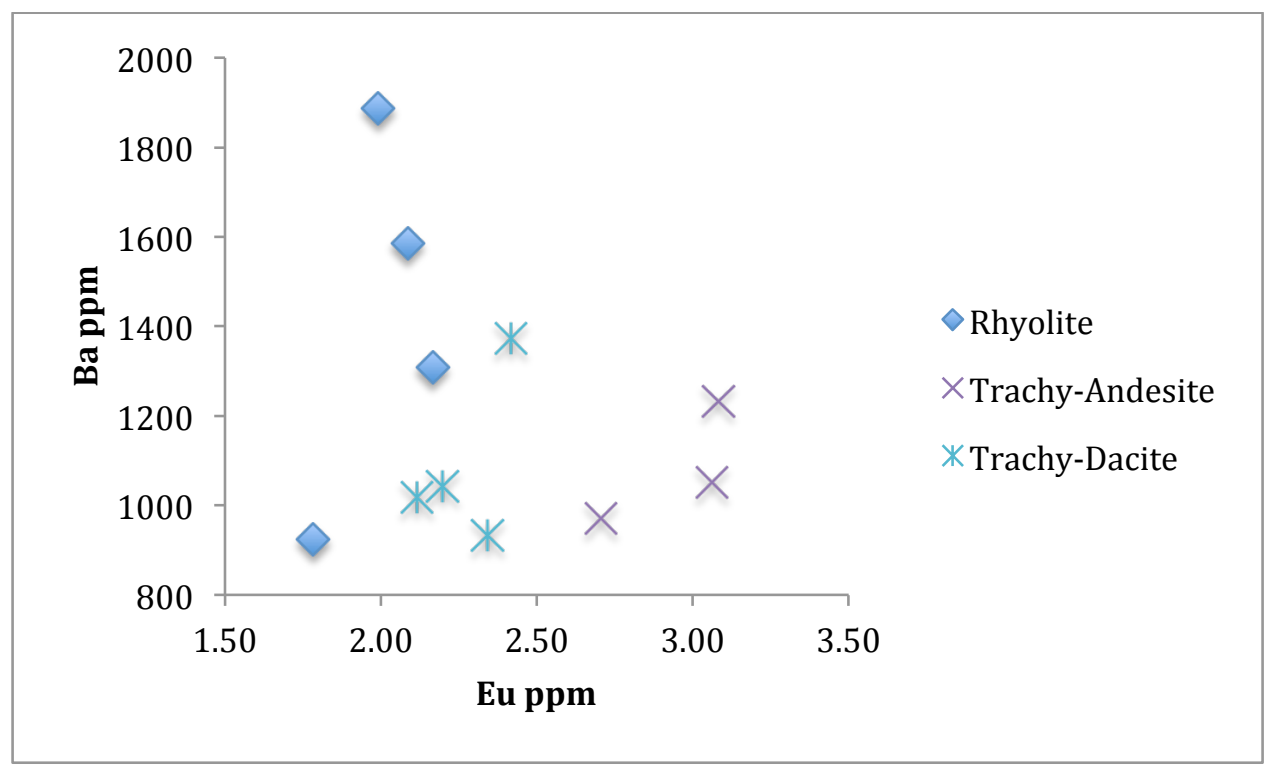

Figure M-8. Although the Ba variations are very large, these samples show a general trend of higher Eu with decreasing silica content. Rhyolites range from 1.78 to $2.17 \mathrm{ppm}$ Eu, while Trachyandesites range from 2.71 to $3.08 \mathrm{ppm}$ Eu. 


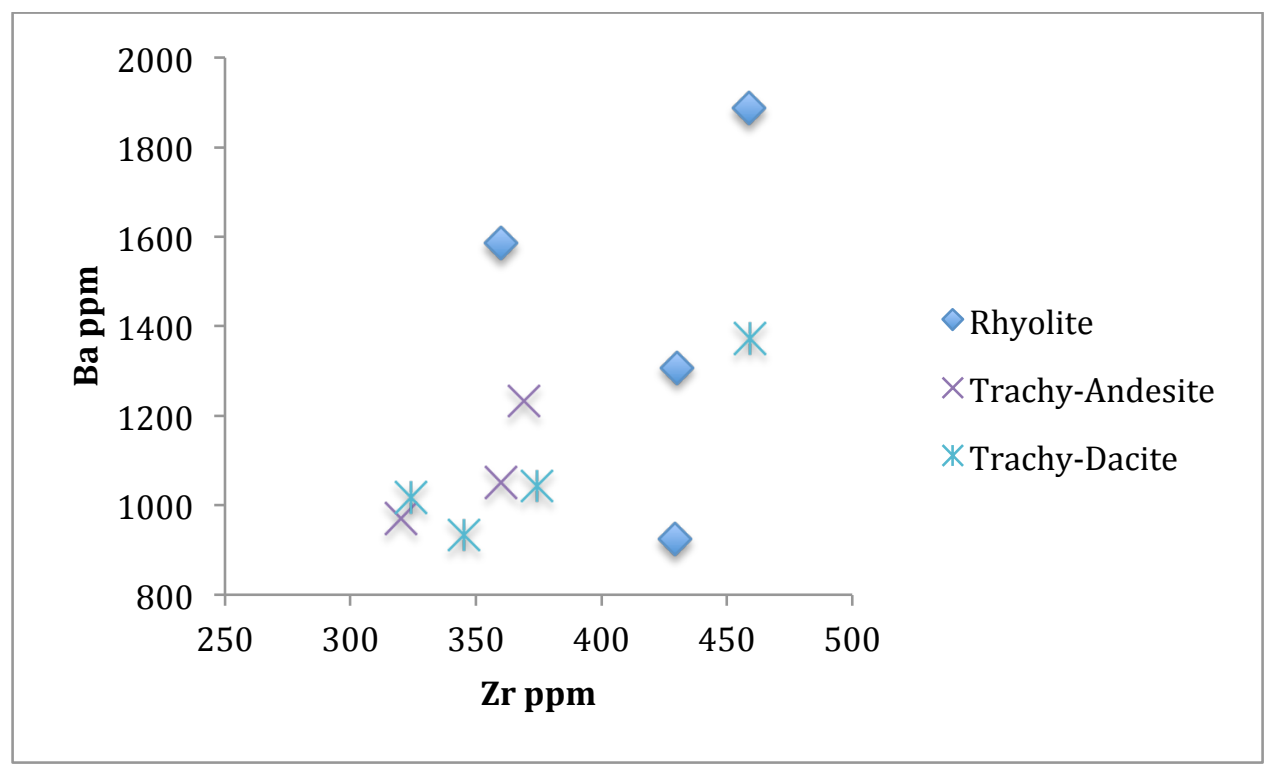

Figure M-9. No clear pattern emerges from this trace element diagram of $\mathrm{Zr}$ vs. Ba. The full range of the Wildcat Creek Tuff samples is from 924 to 1887 ppm Ba, and from 324 to 459 ppm $\mathrm{Zr}$.

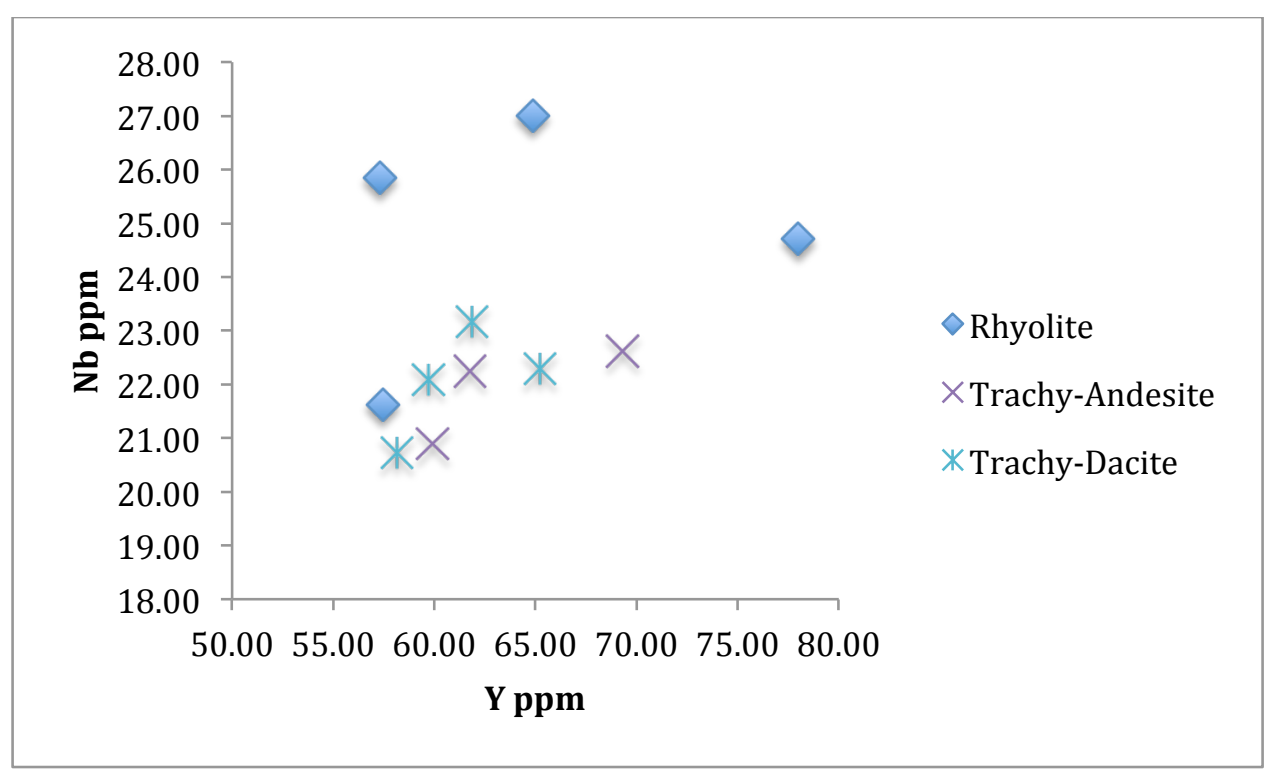

Figure M-10. Trace element plot of $\mathrm{Y}$ vs. Nb shows only a slight pattern of increasing Nb with increasing $\mathrm{SiO}_{2}$ content. With the exception of MS1307 (Buchanan Tuff), the Wildcat Creek Tuff rhyolite samples are highest in $\mathrm{Nb}$ content, ranging from $\sim 25$ to $27 \mathrm{ppm}$. The trachydacite samples are the lowest, containing as low as $20 \mathrm{ppm} \mathrm{Nb}$. The samples range from $\sim 57$ to $78 \mathrm{ppm} \mathrm{Y}$. 


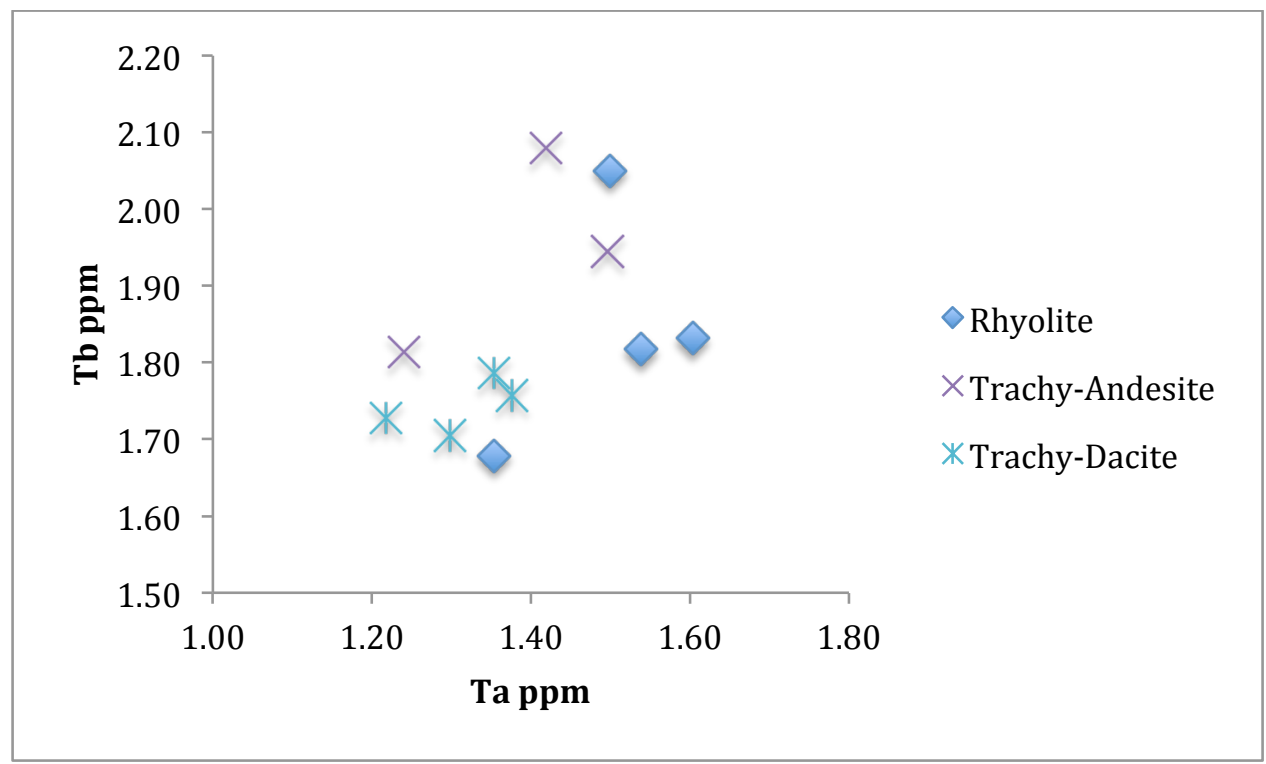

Figure M-11. Trace element plot of Ta vs. Tb. These samples range from 1.22 to $1.60 \mathrm{ppm}$ Ta and from 1.68 to $2.08 \mathrm{ppm}$ Tb. No pattern is truly discernable, though a general trend of higher Ta levels can be observed in more silicic samples.

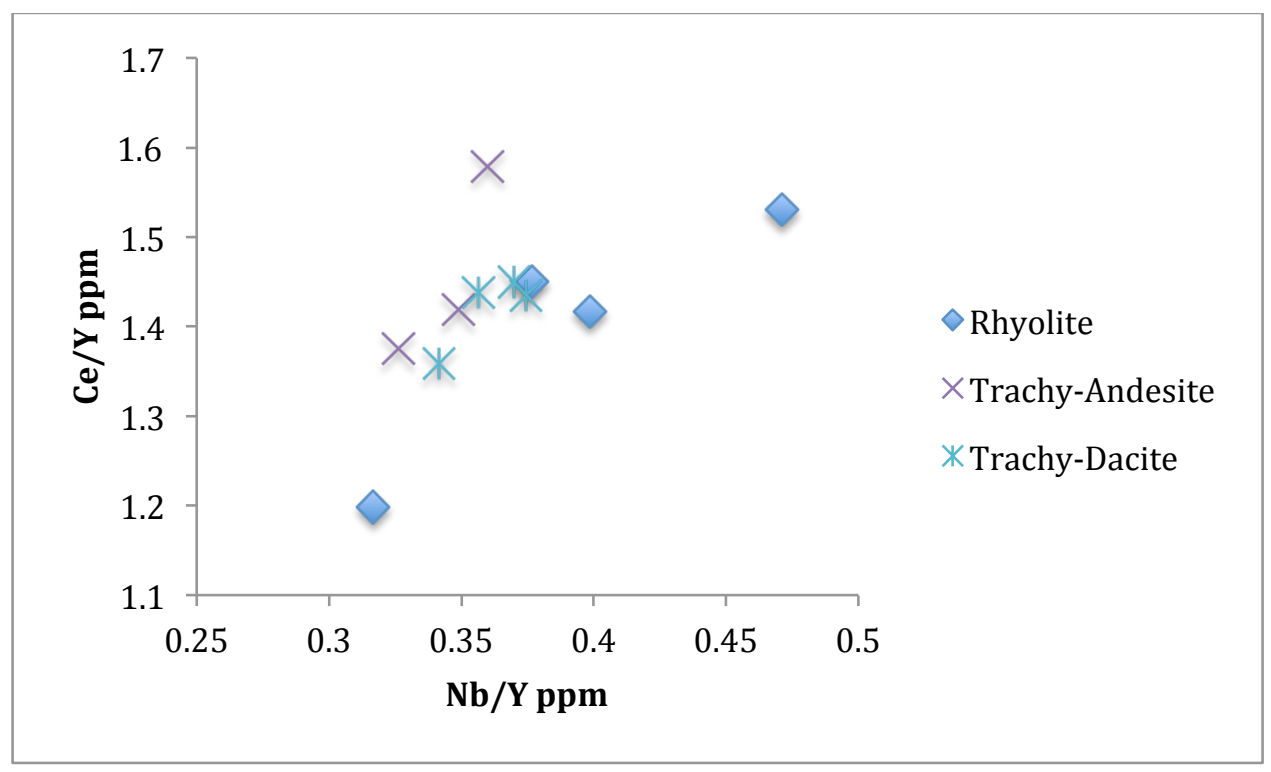

Figure M-12. Trace element chart of $\mathrm{Nb} / \mathrm{Y}$ vs. Ce/Y. Rhyolites range from 0.3 to $0.47 \mathrm{ppm} \mathrm{Nb} / \mathrm{Y}$ and from 1.2 to $1.5 \mathrm{ppm} \mathrm{Ce} / \mathrm{Y}$, while more mafic samples range from only 0.33 to $0.37 \mathrm{ppm} \mathrm{Nb} / \mathrm{Y}$ and 1.36 to $1.58 \mathrm{ppm} \mathrm{Ce} / \mathrm{Y}$. 


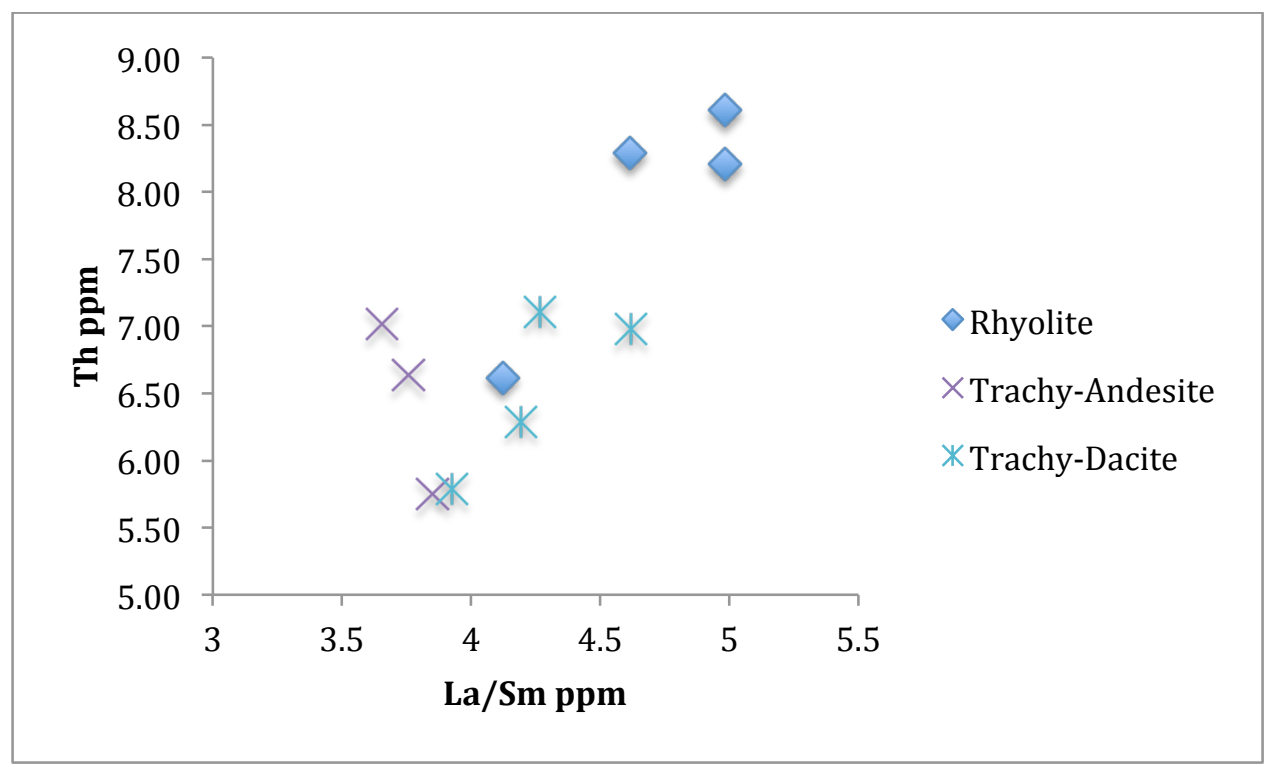

Figure M-13. A slightly linear pattern can be seen in the trace element diagram of La/Sm vs. Th. Mafic samples of the Wildcat Creek Tuff (WCT) contain generally less La/Sm and Th than the rhyolite samples. The exception is sample MS1307, from the Buchanan Tuff, which sits in the middle of the range of mafic samples from the WCT. WCT rhyolites contain 8.2 to $8.1 \mathrm{ppm}$ Th, while the mafic samples contain between 5.7 and 7.1ppm Th.

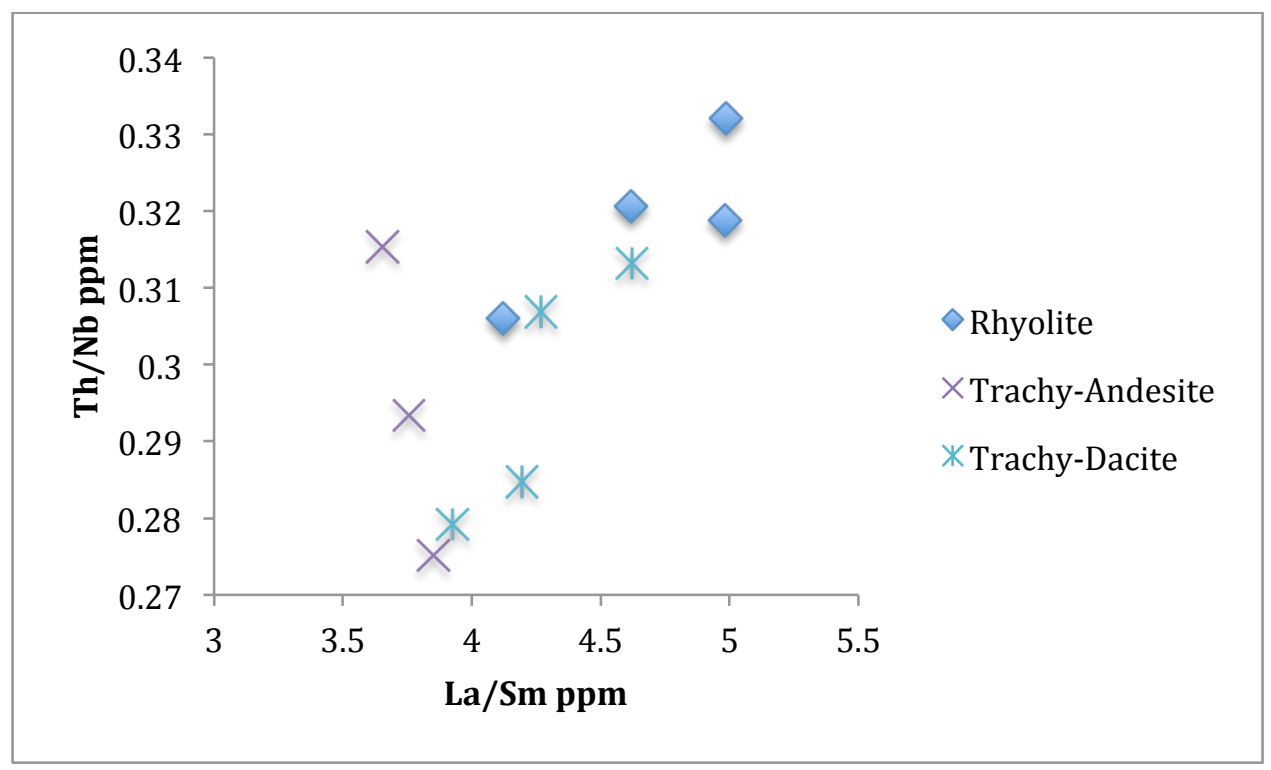

Figure M-14. A loose trend can be seen in this trace element plot of $\mathrm{La} / \mathrm{Sm} \mathrm{vs}$. Th/Nb comparison of the Wildcat Creek Tuff samples. The more felsic rhyolite samples contain higher concentrations of the trace elements, while the more mafic samples contain less. The range of $\mathrm{Th} / \mathrm{Nb}$ is relatively tight, ranging from 0.27 to $0.33 \mathrm{ppm}$ across the entire sample spectrum. The range of $\mathrm{La} / \mathrm{Sm}$ is slightly larger, ranging from 3.7 to $4.9 \mathrm{ppm}$. 


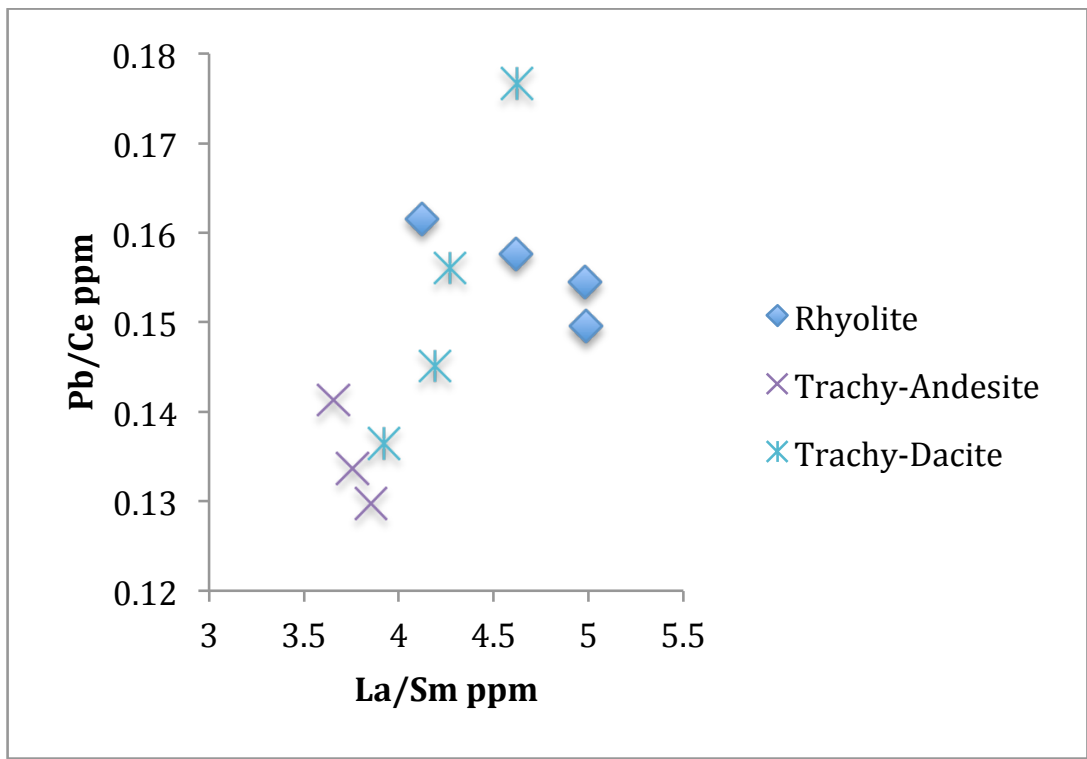

Figure M-15. A general trend of increasing trace element concentrations can be seen with increasing silica values in this trace element plot of $\mathrm{La} / \mathrm{Sm}$ vs. $\mathrm{Pb} / \mathrm{Ce}$. The outlier is $\mathrm{HS1505}$, a trachydacite with a $\mathrm{La} / \mathrm{Sm}$ value of $4.6 \mathrm{ppm}$, and a $\mathrm{Pb} / \mathrm{Ce}$ value of $0.18 \mathrm{ppm}$. 
APPENDIX N: Stratigraphic Column of Site 4

\begin{tabular}{|c|c|c|c|c|}
\hline & Stratigraphic Column & $\begin{array}{l}\text { Corresponding } \\
\text { Thin Section }\end{array}$ & Rock Type & Description \\
\hline $1314 m$ & Figh & HS-15-04d & Trachyandesite & $\begin{array}{l}\text { HS-15-04d: Black mingled } \\
\text { with red, phenocryst } \\
\text { poor. }\end{array}$ \\
\hline $1311 \mathrm{~m}$ & & HS-15-04e & Trachyandesite & $\begin{array}{l}\text { HS-15-04e: dark brown, } \\
\text { large brown pumice }\end{array}$ \\
\hline $1309 \mathrm{~m}$ & & HS-15-04c & Trachyandesite & $\begin{array}{l}\text { HS-15-04c: light } \\
\text { grey/brown, phenocryst } \\
\text { poor, colorful scoria }\end{array}$ \\
\hline $1302 \mathrm{~m}$ & $\begin{array}{l}\text { Low } \\
\text { FeO }\end{array}$ & HS-15-04b & Trachydacite & $\begin{array}{l}\text { HS-15-04b: Highly } \\
\text { welded, large fiamme, } \\
\text { red-brown } \\
\text { HS-15-04a: black pumice, } \\
\text { highly vesicular, low } \\
\text { welding, phenocryst poor }\end{array}$ \\
\hline
\end{tabular}

